Material docente del MOOC:

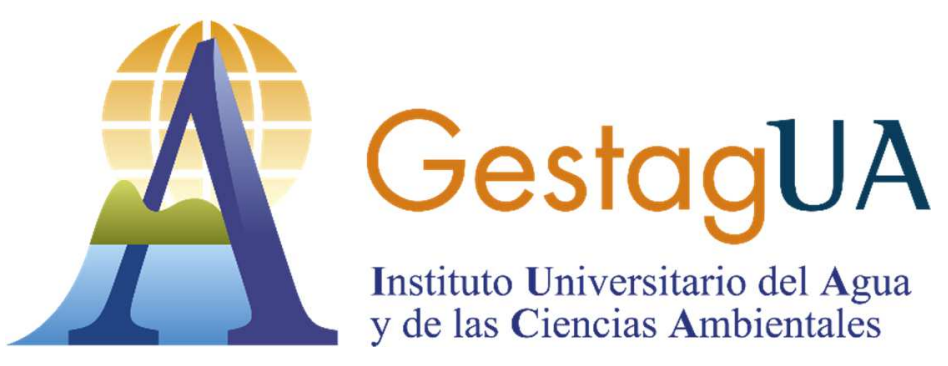

\title{
Herramientas para la gestión territorial sostenible del agua
}

Coordinadores:

Andrés Molina Giménez

Patricia Fernández Aracil

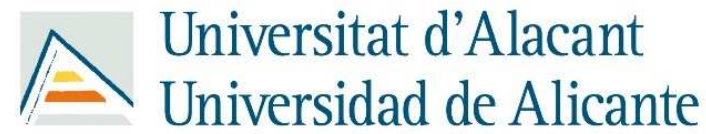




\section{Índice de contenidos}

1. Planificación del recurso 4

1.1. Planificación hidrológica

Joaquín Melgarejo Moreno.

1.2. Recursos y riesgos del agua en la ordenación del territorio

Jorge Olcina Cantos.

1.3. Planificación urbanística

Andrés Molina Giménez

2. Los trasvases de recursos hidráulicos entre cuencas hidrográficas

2.1. Marco legal

Andrés Molina Giménez

2.2. El trasvase Tajo-Segura: reglas de gestión

Joaquín Melgarejo Moreno.

2.3. Funcionamiento económico y financiero

Martín Sevilla Jiménez.

3. La desalación

3.1. Marco legal

Andrés Molina Giménez

3.2. Aspectos técnicos y de gestión

Daniel Prats Rico

3.3. Funcionamiento económico y financiero

Martín Sevilla Jiménez.

4.- La depuración y reutilización de aguas residuales

4.1. Marco legal de la depuración

Andrés Molina Giménez 90

4.2. Marco legal de la reutilización

Andrés Molina Giménez

4.3. Aspectos técnicos y de gestión

Daniel Prats Rico 105

4.4. Eliminación de contaminantes ordinarios y emergentes

María de los Ángeles Bernal Romero del Hombre Bueno

4.5 Funcionamiento económico y financiero

Martín Sevilla Jiménez

5. Gestión de riesgos, sequías e inundaciones.

5.1. Marco legal de los fenómenos hidrológicos extremos

Andrés Molina Giménez

5.2. Instrumentos para la gestión de la escasez

María Hernández Hernández

5.3. Instrumentos de control de las inundaciones

Enrique Alfonso Moltó Mantero. 
6.- El agua urbana

6.1. Gestión del suministro urbano

Andrés Molina Giménez

6.2. Gestión del saneamiento

Arturo Trapote Jaume

6.3. Gestión sostenible del drenaje urbano

Arturo Trapote Jaume

7. Herramientas geográficas 200

7.1. Sistemas de Información Geográfica. Conceptos básicos

Álvaro Francisco Morote Seguido 201

7.2. Tipología de información espacial en los Sistemas de Información Geográfica Antonio Jódar Abellán

7.3. Infraestructura de los datos espaciales en los Sistemas de Información Geográfica

Antonio Jódar Abellán 238

8. Herramientas estadísticas 255

8.1. Conceptos básicos en estadística aplicada a la gestión territorial

Patricia Fernández Aracil 256

8.2. Fuentes estadísticas vinculadas con la gestión territorial

Patricia Fernández Aracil 261

8.3. Fuentes estadísticas relacionadas con el agua

María José Moya Llamas. 273

8.4. Técnicas de análisis

Patricia Fernández Aracil 282

9. La protección ambiental del recurso

9.1. Vertidos indirectos a redes de saneamiento

Irene Sentana Gadea. .288

9.2. Vertidos directos a aguas continentales y marinas

Pedro José Varó Galvañ.

9.3. Contaminación y protección de aguas subterráneas

José Miguel Andreu Rodes

9.4. Los humedales

Carlos Martín Cantarino

10. Evaluación de proyectos .324

10.1. Conceptos básicos

Armando Ortuño Padilla

10.2. Evaluación social, financiera y análisis de riesgos

Armando Ortuño Padilla

10.3. Análisis del impacto social

Antonio José Aledo Tur. 


\section{MODULO 1}

PLANIFICACIÓN DEL RECURSO 


\title{
1.1. PLANIFICACIÓN HIDROLÓGICA
}

\author{
Joaquín Melgarejo Moreno
}

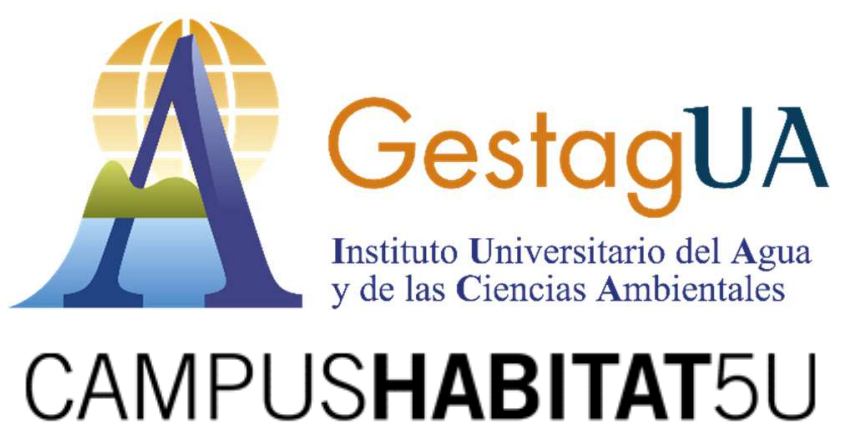




\section{INTRODUCCIÓN}

La planificación hidrológica es la intervención estatal más reciente e incisiva en la gestión de las aguas. Es un concepto que evoca la potestad del Estado sobre los recursos hídricos $y$, en virtud de ella, su competencia para regular su aprovechamiento. Presupone, asimismo, que el Estado debe anticiparse a la iniciativa particular definiendo cuáles son los usos del agua más provechosos para la sociedad $y$, sólo en la medida en que éstos son respetados, pueden los particulares ser acreedores al uso de las aguas. La planificación rompe con la cuenca hidrográfica como marco de la política hidráulica, al tiempo que el regadío deja de ser la preocupación prioritaria, en consonancia con la nueva estructura económica del país, y se introducen, junto a los objetivos tradicionales de equilibrar y ordenar los aprovechamientos, otros nuevos que tratan de dar respuesta a nuevas sensibilidades. Ya no se trata sólo de aumentar las disponibilidades hídricas, sino también de proteger la calidad de las aguas y racionalizar sus usos en armonía con el medio ambiente.

La restauración de la democracia y la promulgación de la Constitución de 1978 dieron lugar a una nueva organización territorial del Estado y a un nuevo régimen de competencias administrativas que incidieron notablemente en el marco legal hidráulico. La Constitución, en su Art. 149, dispone que el Estado tiene competencia exclusiva en las siguientes materias: "legislación, ordenación y concesión de recursos y aprovechamientos hidráulicos cuando las aguas discurran por más de una Comunidad Autónoma". La nueva situación política y territorial aconsejaba elaborar una normativa hidráulica acorde con ella. El resultado fue la promulgación, en 1985, de la Ley de Aguas, en la que se recoge la Planificación Hidrológica de acuerdo con la Constitución, que atribuye al Estado las "Bases y coordinación de la actividad económica", incorporando así al nuevo ordenamiento una dimensión nacional y unitaria de la política hidráulica del país. En la Ley se precisaban dos tipos de planes: los hidrológicos de cuenca -que debían ser aprobados por Decreto- y el hidrológico nacional, que debía ser sancionado por ley en las Cortes.

\section{EL PLAN HIDROLÓGICO NACIONAL (PHN)}

El Plan Hidrológico Nacional (PHN), aprobado por Ley 10/2001 de 5 de julio, es el encargado de regular los criterios de coordinación de los planes hidrológicos de cuenca, de la resolución de las diferentes alternativas que éstos ofrecen, de establecer las modificaciones que se prevean en la planificación del recurso y de la previsión de las condiciones de las transferencias de recursos hidráulicos entre 
ámbitos territoriales de distintos planes hidrológicos de cuenca. Por lo tanto, se limita su competencia a aquellas cuestiones que no han sido tratadas por los planes de cuenca, que lo han sido de manera insuficiente o para las que se han aportado soluciones incoherentes entre sí y que, por ser de interés general, exigen respuestas homogéneas a escala nacional. EI PHN es contemplado por el Estado como un instrumento que debe contribuir a satisfacer las demandas hídricas y al desarrollo económico nacional, en armonía con la protección y el respeto al medio ambiente. Sus objetivos son los siguientes: preservar el buen estado ecológico del dominio público hidráulico, satisfacer las demandas presentes y futuras, lograr el equilibrio interregional, proteger la calidad y economizar los usos. Se trata de un instrumento de ordenación y requilibrio hídrico orientado al uso sostenible del agua y la recuperación medioambiental del dominio público y entorno afectado.

CUADRO 1. PROGRAMA DE INVERSIONES

\begin{tabular}{lrr}
\hline \multicolumn{1}{c}{ Concepto } & \multicolumn{1}{c}{ Millones de } \\
pesetas & \multicolumn{1}{c}{$\%$} \\
\hline Abastecimiento a ciudades & 468.386 & 14,94 \\
Restauración hidrológico-forestal & 309.407 & 9,87 \\
Encauzamientos-Prevención de avenidas & 238.594 & 7,61 \\
$\begin{array}{l}\text { Regulación (presas, desaladoras, espacios de interés } \\
\text { social, laminar avenidas) }\end{array}$ & 452.379 & 14,43 \\
$\begin{array}{l}\text { Control de la calidad (aguas subterráneas y } \\
\text { superficiales) }\end{array}$ & 209.655 & 6,70 \\
Saneamiento y depuración (reutilización) & 433.512 & 13,82 \\
Regadíos (modernización) & 1.023 .345 & 32,64 \\
TOTAL & 3.135 .278 & 100 \\
\hline
\end{tabular}

Fuente: Ministerio de Medio Ambiente (2002) y elaboración propia.

Sin lugar a dudas, el eje central del PHN 2001 lo constituye la regulación de las transferencias de recursos hidráulicos entre ámbitos territoriales de distintos planes de cuenca. Solución por la que optó el legislador para procurar una satisfacción de las demandas en todo el territorio nacional. La propuesta a la que se llegó era la más eficiente tras considerar las diferentes alternativas. Se optó por el trasvase del Ebro estableciendo una previsión máxima de transferencias de 1.050 hm³/año, con 
destino a las cuencas estructuralmente deficitarias, según fueron definidas por el Libro Blanco del Agua, del Júcar (315 hm³/año), Segura (450 hm³/año), Sur (95 $\mathrm{hm}^{3} / \mathrm{año}$ y cuencas internas de Cataluña (190 hm³/año).

Tras las elecciones generales de marzo de 2004 se produce una reorientación profunda de la planificación hidrológica. El nuevo Gobierno emprendió de manera urgente la reforma del PHN de 2001, manteniendo sólo aquellas actuaciones del Anexo de inversiones que en su opinión resultaban coherentes con la carencia de recursos que mostraba la zona de Levante y, en particular, la cuenca del Segura.

Mediante Decreto ley 2/2004, de 18 de junio, se modifica la Ley 10/2001, de 5 de julio del Plan Hidrológico Nacional, eliminando el artículo de la Ley del PHN relativo al trasvase del Ebro y autorizando la urgente ejecución de proyectos sustitutivos del mismo, con la finalidad de mejorar la gestión del agua. Posteriormente, este Decreto se tramitó como ley y su contenido quedó incorporado a la Ley 11/2005, de 22 de junio.

\section{PROGRAMA A.G.U.A.}

Esta nueva estrategia culminó con la aprobación del Programa AGUA (Actuaciones para la Gestión y la Utilización del Agua) que, según la nueva administración supondría "Más agua, a un menor coste y en menos tiempo". Sus objetivos declarados son:

10) Superar definitivamente las carencias existentes en España a través del control público del uso del agua y de su calidad, garantizando el agua necesaria para cada territorio y apostando por la eficiencia en los usos.

2ㅇ) Adecuar la política del agua a la legislación y a los criterios de la Unión Europea, introduciendo mayores exigencias de racionalidad económica, sostenibilidad ambiental y participación pública.

Las actuaciones incluidas en la nueva versión del PHN pueden agruparse en cinco modalidades:

1a) Ahorro y modernización de abastecimientos y regadíos, que contempla la obtención de $231 \mathrm{hm}^{3} /$ año derivados de las medidas de optimización de las infraestructuras de regulación, almacenamiento y distribución existentes, y de la disminución de pérdidas. 
2a) Potenciación de la reutilización de las aguas depuradas, con la que se espera obtener $137 \mathrm{hm}^{3} /$ año adicionales.

3a) Nuevas captaciones y regulaciones que supondrían $74 \mathrm{hm}^{3} /$ año.

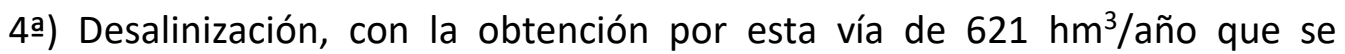
destinarían fundamentalmente al abastecimiento.

5a) Actuaciones ligadas a la prevención de avenidas y a la mejora ambiental; estas últimas no conllevan nuevos aportes.

El resumen de las aportaciones contempladas en el Programa AGUA es como sigue:

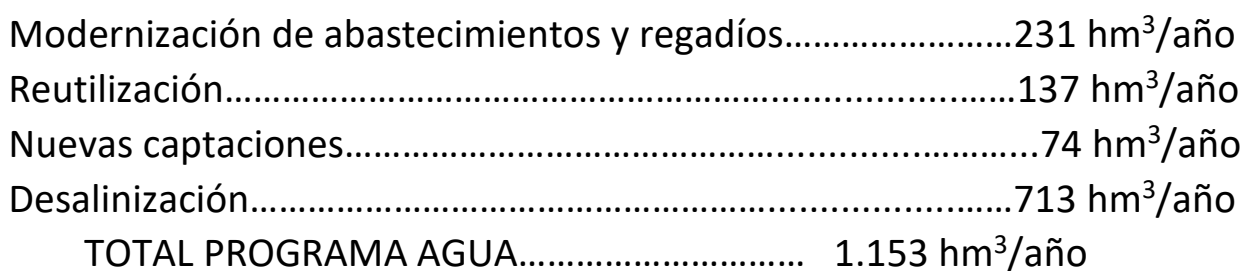

Lo cierto es que no se han cumplido las expectativas: a las cuencas deficitarias del Mediterráneo no han llegado los caudales previstos, el retraso con el que se está aplicando el programa AGUA es considerable, y el precio del agua en estas zonas no sólo no se ha reducido, sino que se ha incrementado como consecuencia de la incorporación del agua desalada.

El principal problema a que se enfrentan las soluciones del programa AGUA se centra fundamentalmente en la sostenibilidad energética y económica. El incremento en los costes de la energía, muy superiores ahora con relación a las previsiones de 2006 con que se diseñó el programa, demuestran la vulnerabilidad de estas estrategias.

Podemos concluir que pasados más de diez años desde la aprobación del programa AGUA, este no ha aportado soluciones ni definitivas ni sostenibles a los problemas de escasez que afectan a las cuencas mediterráneas; sólo las demandas urbanas han experimentado avances en garantía y calidad, especialmente en la costa; continúa la incertidumbre en el interior. Por contra, persisten los graves problemas en la agricultura de regadío y se agudizan los efectos ambientales negativos de la sobreexplotación de acuíferos y de los caudales ambientales de los ríos mediterráneos, que pretendía también resolver el trasvase del Ebro. En definitiva, el slogan "Más agua, a un menor coste y en menos tiempo" ha resultado un auténtico fiasco. 


\section{PLANIFICACIÓN HIDROLÓGICA DE DEMARCACIÓN}

España está estructurada en 17 demarcaciones hidrográficas, cada una de las cuales dispone de un plan hidrológico de demarcación que permite organizar las demandas de agua conforme a la oferta existente, y garantizar la calidad ambiental de las diferentes masas de agua.

Mapa de las Demarcaciones hidrográficas españolas:

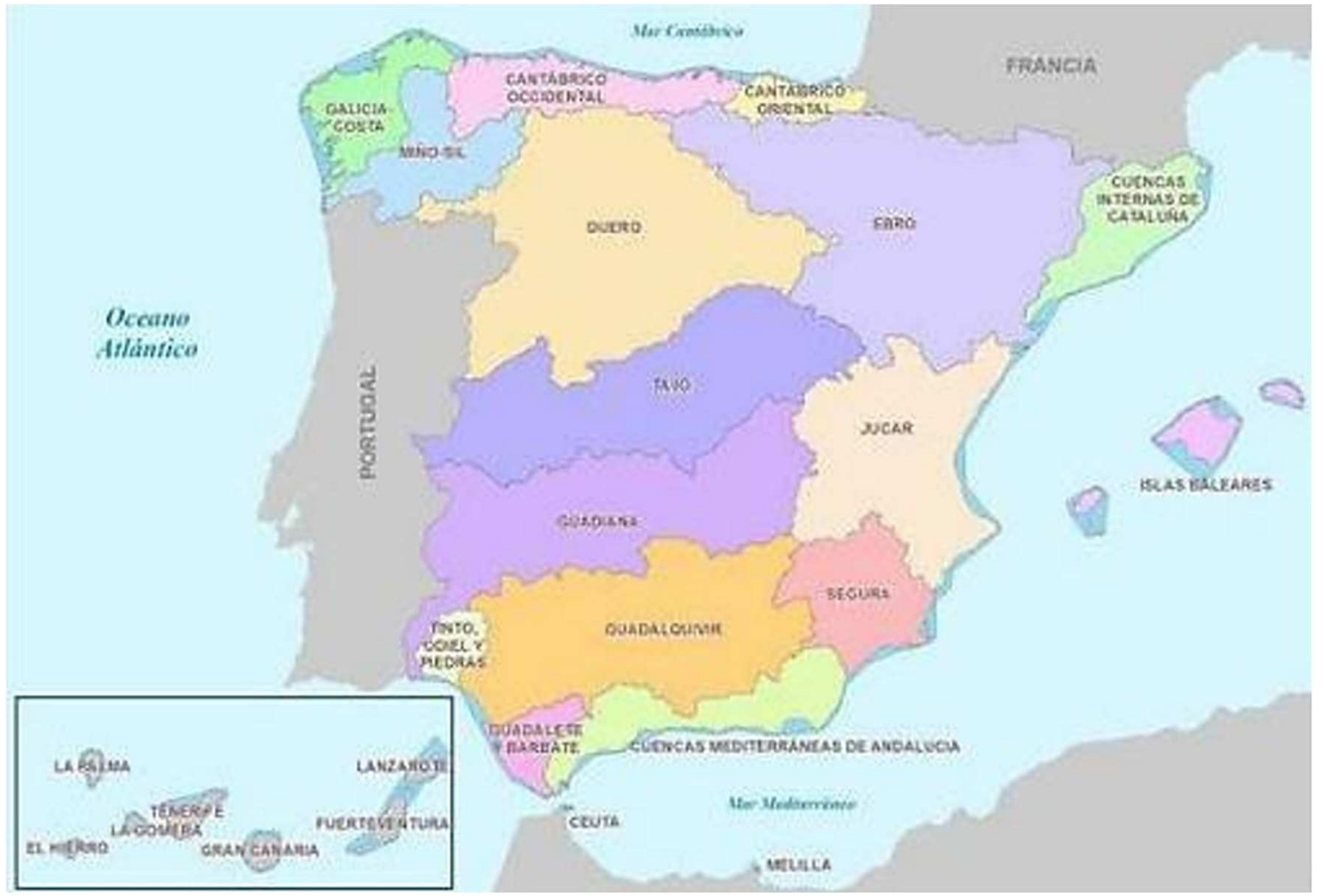

Fuente: http://www.mapama.gob.es/

En 1988, mediante Decreto, se aprobaron los primeros planes hidrológicos de cuenca, los cuales fueron sustituidos por los nuevos planes de demarcación en 2015. Estos instrumentos se elaboraron tras un procedimiento de participación pública y se formalizan en Decretos del Consejo de Ministros, por lo que tienen rango reglamentario. En base a ellos las Confederaciones hidrográficas toman las decisiones más importantes para la gobernanza del recurso.

Los planes establecen las prioridades de uso asignación de recursos (el abastecimiento cuenta con la máxima prioridad). 
Orden de prioridad de usos (TRLA) Dentro de cada uso: de los que introduzcan mejoras técnicas que redunden en un menor consumo de agua y de los que causen menor afección ambiental negativa

Limitaciones: los caudales ecológicos deberán respetarse en todas las concesiones futuras, excepto en las de abastecimiento. En cuanto a los resguardos de embalses para laminación de avenidas, los planes fijan un orden de preferencia de aprovechamientos, situando en primer lugar aquellos de mayor utilidad pública o general, seguidos. Establecen criterios de compatibilidad de usos, máximo aprovechamiento simultáneo o sucesivo del recurso y del propio dominio público hidráulico, favoreciendo la economía del agua.

Los planes caracterizan y estiman las demandas existentes en cada uso.

- Demanda de agua: volumen de agua, en cantidad y calidad, que los usuarios están dispuestos a adquirir para satisfacer un determinado objetivo de producción o consumo. Este volumen será función de factores como el precio de los servicios, el nivel de renta, el tipo de actividad, la tecnología u otros (art. 3 $\mathrm{RPH})$.

- Usos del agua: las distintas clases de utilización del recurso, así como cualquier otra actividad que tenga repercusiones significativas en el estado de las aguas.

Estos datos son fundamentales para que la Confederación hidrográfica pueda tomar decisiones en cuanto a la distribución de los caudales disponibles a través de las concesiones.

En materia de calidad, los planes hidrológicos establecen exigencias de calidad para las diferentes masas de agua superficial y subterránea. En base a dichos objetivos la Confederación hidrográfica determinará las condiciones necesarias para que las empresas puedan emitir vertidos al medio de forma que no queden comprometidos los objetivos de calidad asignados a cada masa.

Los planes de demarcación integran los llamados programas de medidas, donde se definen actuaciones concretas que han de ejecutarse en la cuenca para alcanzar los objetivos de la planificación. 


\section{CONCLUSIONES}

El reciente proceso de planificación hidrológica en España ha estado sujeto a fuertes tensiones y variaciones de diferente índole: ideológicas, técnicas, territoriales y sobre todo políticas. El marco constitucional estableció las pautas de lo que sería el nuevo ordenamiento de agua; pero pronto el desarrollo del Estado de las Autonomías y las tensiones territoriales por el control sobre el agua hizo su aparición, hecho que ha complicado extraordinariamente las propuestas de planificación elaboradas desde la Administración central. Se ha tendido al incremento de la territorialización del agua frente a las competencias estatales recogidas en la Ley de Aguas de 2005.

La unidad de ordenación y gestión en España no es la cuenca hidrográfica en sentido estricto, sino el ámbito de planificación hidrológica, que puede incorporar cuencas de diversa naturaleza.

\section{BIBLIOGRAFÍA}

Del Villar, A. (2014): "El coste energético de la desalinización en el programa A.G.U.A." Investigaciones Geográficas, no 62.

Fanlo Loras, A. (1996): Las confederaciones hidrográficas y otras administraciones hidráulicas, Civitas. Madrid.

Melgarejo, J. (2002): “Consideraciones económicas sobre el PHN”, En Gil Olcina, A. y Morales Gil, A. (Eds.), Insuficiencias hídricas y Plan Hidrológico Nacional. CAM, Alicante.

Melgarejo Moreno, J.; López Ortiz, Mạ I. (2015). Evolución de la planificación hidrológica en la España Democrática, 1978-2014. Agua y Derecho. Retos para el Siglo XXI. pp. 137 - 166. Thomson Aranzadi.

Molina, A.; Melgarejo, J. (2015) Water policy in Spain: seeking a balance between transfers, desalination and wastewater reuse. International Journal of Water Resources Development. 32, pp. 781 - 798.

Rico Amorós, A.M. (2010): "Plan Hidrológico Nacional y Programa AGUA: Repercusión en las regiones de Valencia y Murcia", Investigaciones Geográficas, 54. 


\title{
1.2. RECURSOS y RIESGOS DEL AGUA EN LA ORDENACIÓN DEL TERRITORIO
}

\author{
Jorge Olcina Cantos
}

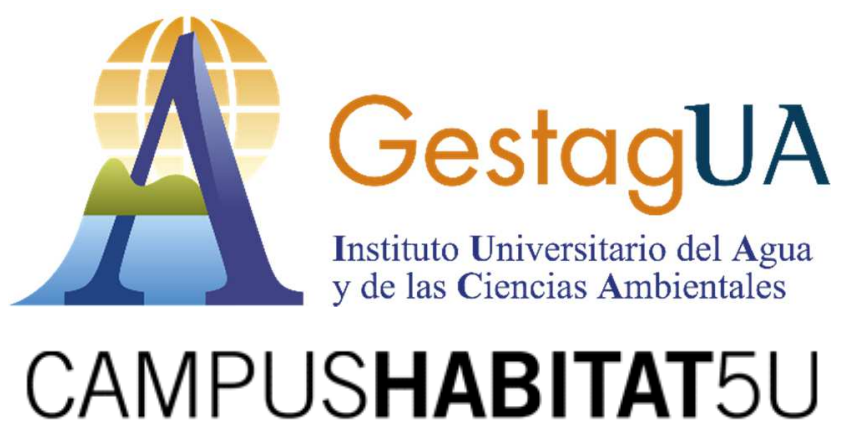




\section{INTRODUCCIÓN: ordenación sostenible de los territorios}

La Carta Europea de Ordenación del Territorio de 1983 propuso una definición que ha sido universalmente aceptada, según la cual, la Ordenación del Territorio es la "expresión espacial de las políticas económicas, sociales, culturales y ecológicas de la sociedad. Es a la vez una disciplina científica, una técnica administrativa y una política concebida como un enfoque multidisciplinario y global, cuyo objetivo es un desarrollo equilibrado de las regiones y la organización física del espacio según un concepto rector". De manera que todo proceso de ordenación del territorio integra una acción administrativa (generalmente pública) que se rige por una normativa legal específica y una reflexión científico-técnica donde se abordan las propuestas para mejorar el estado del territorio. La ordenación del territorio es una acción práctica que comprende un proceso de elección entre diversas alternativas, de manera que es necesaria la existencia de un plan de usos alternativos, justificado a partir de unos criterios (ambientales, socio-económicos), que determinan el nuevo modelo territorial a desarrollar. La puesta en marcha de este nuevo programa de actuación requiere una voluntad política decidida; de ahí que, en gran medida, la ordenación del territorio sea la expresión de una ideología sobre el territorio.

La ordenación del territorio parte del principio de que todo espacio geográfico sobre la superficie terrestre está organizado. Los grupos sociales que se han establecido en él lo han dotado de un sistema de relaciones en el que se fundamenta el propio desarrollo de esa sociedad. Puede -suele- ocurrir que dicha organización requiera modificación en alguno de sus elementos (naturales, sociales, económicos, infraestructurales, etc.) porque requieran adaptación a una nueva realidad. En este momento se pone en marcha un proceso de ordenación del territorio que culmina en la elaboración de un plan (planificación) donde se describe el nuevo modelo territorial.

Los procesos de ordenación del territorio implican tres fases. Una primera, de carácter jurídico que supone la redacción de un texto legal donde se definen los principios, objetivos e instrumentos de la ordenación territorial; a continuación, se lleva a cabo la fase de planificación en sentido estricto que incluye la redacción de un programa o plan territorial con el nuevo modelo a aplicar. Por último, se lleva a cabo dicho plan que culmina, al menos en el plano teórico, con la transformación de la realidad territorial de acuerdo con lo establecido en la fase anterior.

Un aspecto esencial de la ordenación del territorio es su condición de proceso escalar. En España la jerarquía escalar de la planificación territorial comprende las siguientes fases, cada una de las cuales con sus competencias específicas en dicha materia.

-Europa: Existencia de una Estrategia Territorial, aprobada en 1999, donde se recogen los principios básicos que todos los estados miembros deben seguir en materia de 
ordenación territorial para conseguir un desarrollo socio-económico y territorial acorde y respetuoso con el medio ambiente.

-Estado: Elaboración de planes sectoriales (energía, agua, infraestructuras) con incidencia territorial de escala estatal. Elaboración de planes económicos con incidencia territorial de escala nacional o regional. Imposibilidad legal de elaboración de un Plan Nacional de Ordenación del Territorio según sentencia del Tribunal Constitucional de 1997.

-Comunidades Autónomas: Elaboración de planes de ordenación del territorio de escala regional o subregional. Aprobación definitiva del planeamiento municipal.

-Provincia: Sin competencias en materia de ordenación territorial. Elaboración de planes sectoriales (infraestructuras) con incidencia territorial. Redacción, en su caso, de planes estratégicos de finalidad territorial.

-Comarca: En algunas comunidades autónomas se ha dado un protagonismo destacado a la comarca, como escala de intervención administrativa, tanto histórica como funcional, incluso con reconocimiento legal de su existencia y asignación de competencias. A efectos de ordenación del territorio la comarca es el marco territorial de actuación de los denominados "planes sub-regionales" que recoge la legislación de ordenación del territorio de algunas comunidades autónomas como primer escalón entre las figuras de planificación del territorio.

-Municipio: Elaboración de planes de ordenación urbana.

Junto a esta jerarquía escalar, que debe considerarse a la hora de llevar a cabo un proceso de ordenación del territorio, es interesante señalar aquellas competencias que, por mandato constitucional, se ha reservado el Estado central y que afectan a determinadas cuestiones de planificación de usos del suelo en el territorio (costas, planificación hidráulica -excepto en Canarias-, ferrocarriles, carreteras, puertos y aeropuertos del Estado, normas de expropiación). Si en el uso de estas competencias surgen conflictos entre el Gobierno del Estado y los gobiernos autonómicos, deben ser arbitrados a partir de mecanismos de coordinación entre estos dos niveles administrativos.

La ordenación del territorio en España, en virtud de los objetivos que plantean las diferentes leyes autonómicas de ordenación territorial, persigue las siguientes finalidades:

- Garantizar la participación de la población afectada.

- Coordinar las distintas políticas sectoriales.

- Respetar los valores, culturas e intereses de las diversas regiones o comarcas.

- Considerar la situación actual, la tendencia y la evolución a largo plazo de las políticas sobre el territorio.

- Preservar el medio ambiente y conseguir un desarrollo sostenible. 
En España hay una rica tradición en planificación urbana que se remonta, en sentido moderno, al siglo XIX; por el contrario, las actuaciones en materia de ordenación del territorio son muy recientes y se limitan a los tres últimos decenios. La Ley del Suelo del año 1956 inauguró el período moderno de la ordenación de usos del suelo. En un primer momento, la ordenación del territorio se entendió, básicamente, como política sectorial al servicio de la planificación urbana. A partir de los años ochenta, con la transferencia a las Comunidades Autónomas de las competencias en materia del suelo y de ordenación del territorio, empieza a concebirse como política transversal, de carácter integral para los espacios regionales. En efecto, la Constitución de 1978 (art. 148.1, 3ㅇ) introduce un cambio fundamental al establecer la posibilidad de que las competencias en ordenación del territorio y urbanismo sean ejercidas por las Comunidades Autónomas; en todos los casos, estas funciones quedaron recogidas por los estatutos de autonomía y fueron rápidamente transferidas. La promulgación de leyes del suelo y de ordenación del territorio por parte de los gobiernos regionales, donde se contempla la obligada redacción de documentos de Directrices de Ordenación del Territorio de rango regional, no ha ido, sin embargo, acompañada de la elaboración de estos planes con el ritmo que sería deseable. De ahí que, ante la falta de planes de ordenación del territorio de escala regional o subregional, la planificación urbana de escala local siga siendo, en amplias zonas de nuestro país el único procedimiento de "ordenación territorial" que determina la asignación de usos en el suelo.

La incorporación del medio ambiente en los procesos de planificación territorial tuvo un hito fundamental con la aprobación, en 1999, de la Estrategia Territorial Europea. Este documento supone un cambio importante en la consideración del medio ambiente en las políticas territoriales, al establecer la consecución del desarrollo territorial sostenible como principio rector de la ordenación del territorio. La Estrategia Territorial Europea se indica que las políticas de desarrollo territorial pretenden un desarrollo equilibrado y sostenible del territorio de la Unión; para ello es preciso asegurar 3 objetivos fundamentales en la futura política territorial europea: la cohesión económica y social; la conservación y gestión de los recursos naturales y del patrimonio cultural; y la competitividad más equilibrada del territorio europeo.

\section{RECURSOS DE AGUA EN LA ORDENACIÓN DEL TERRITORIO}

Los planes de ordenación del territorio, en cualquier escala, deben incorporar un inventario de los recursos y usos del agua existentes en los territorios objeto de ordenación. Desde la escala regional a la local, la garantía de abastecimiento en los usos del agua es un aspecto fundamental que debe ocupar un espacio principal en los documentos de asignación futura de usos del suelo.

A escala estatal, se da una paradoja geográfica que condiciona actividades y actitudes. Existen recursos de agua suficientes para abastecer los usos existentes, pero 
estos recursos están desigualmente repartidos en el territorio y ello genera actitudes distintas sobre sus posibilidades de aprovechamiento. España tiene una gran cantidad de ríos en todo su territorio. Sólo los ríos principales (Duero, Ebro, Tajo, Guadalquivir...), suman más de 11.000 kilómetros de cauces. Al ser un territorio con una extensión muy grande de montañas, los cauces aprovechan las fracturas, quebradas y valles para dibujar su trazado. Hay diferentes tipos de ríos según la cantidad de agua que llevan a lo largo del año, del comportamiento mensual de sus aguas y del origen de las mismas (lluvia, nieve).

En su conjunto, los recursos de agua existentes en España son suficientes para abastecer las demandas (agrícolas, industriales, urbanas, energéticas, ecológicas) existentes. La cuestión es el desigual reparto territorial de estos recursos, en virtud de los rasgos climáticos de las diferentes regiones españolas y, asimismo, el diferente aprovechamiento del recurso que se lleva a cabo en cada territorio; estos dos factores son los que generan disparidades hídricas y conflictos por el uso del recurso. Esta situación es la clave para entender las políticas hídricas desarrolladas en España en los últimos ciento cincuenta años, basadas en la oferta de recursos de agua allá donde hicieran falta; medida poco respetuosa con el medio ambiente $y$, en particular con los territorios y paisajes del agua, que ha experimentado cambio tras la aprobación de la directiva europea del agua.

Un aspecto importante a tener en cuenta para la planificación de recursos de agua en España es la reducción de aportaciones naturales que se ha observado en los ríos de nuestro país en las dos últimas décadas. En algunas cuencas esta disminución supera el $20 \%$ respecto a los recursos existentes en la serie histórica de caudales $1940-$ 1996. 
Tabla. Reducción de aportaciones medias anuales en la Demarcaciones Hidrográficas de España.

\begin{tabular}{|l|c|c|c|}
\hline Demarcación & $\begin{array}{c}\text { Aportación media, } \\
\text { periodo 1940/41 - } \\
1995 / 96\end{array}$ & $\begin{array}{c}\text { Aportación media, } \\
\text { periodo1995/96- } \\
2005 / 06\end{array}$ & $\begin{array}{c}\text { Reducción de } \\
\text { aportaciones en el } \\
\text { periodo 1996/97- } \\
\text { 2005/06, con } \\
\text { respecto al periodo } \\
\text { 1940/41-1995/96 }\end{array}$ \\
\hline Norte & 43.494 & 38.573 & $-11,3 \%$ \\
\hline Duero & 13.861 & 11.729 & $-15,5 \%$ \\
\hline Tajo & 10.533 & 9.012 & $-14,4 \%$ \\
\hline Guadiana & 5.464 & 4.391 & $-19,6 \%$ \\
\hline Guadalquivir & 8.770 & 8.113 & $-7,5 \%$ \\
\hline C.M.Andalucía & 2.446 & 2.101 & $-14,1 \%$ \\
\hline Segura & 817 & 505 & $-38,2 \%$ \\
\hline Júcar & 3.493 & 3.057 & $-12,5 \%$ \\
\hline Ebro & 17.189 & 13.555 & $-21,1 \%$ \\
\hline C.I. Gataluña & 2.742 & 2.196 & $-19,9 \%$ \\
\hline Total & $\mathbf{1 0 8 . 8 0 9}$ & $\mathbf{9 3 . 2 3 2}$ & $-\mathbf{1 4 , 3} \%$ \\
\hline
\end{tabular}

Fuente: Ministerio de Medio Ambiente. Libro Blanco del Agua y Planes de Demarcación Hidrográfica.

Y esta situación puede agravarse, si se cumplen los escenarios de reducción de la precipitación estimados para gran parte del territorio español hacia final del presente siglo, En efecto, los modelos de reducción de escorrentía elaborados por el CEDEX, para el último tercio del presente siglo, dentro de escenarios de emisión de gases de efecto invernadero moderados, señalan unas menguas significativas, diversas según las cuencas hidrográficas de que se trate, en el agua circulante de los ríos españoles. Y este aspecto debe incorporarse, como un dato importante, en los futuros procesos de planificación del agua en nuestro país.

\section{RIESGOS DEL AGUA EN LA ORDENACIÓN DEL TERRITORIO}

España es un territorio de riesgo en el contexto europeo y mundial. Y ello porque se suman una elevada peligrosidad física y, en algunas áreas, una alta vulnerabilidad y exposición a dichos peligros naturales. Destacan tres "regiones-riesgo" principales: 
litoral mediterráneo entre Girona y Cádiz incluido el archipiélago balear, litoral del País Vasco y archipiélago canario. Aunque, la posibilidad de que ocurran episodios catastróficos en el resto del territorio español no es, en absoluto, descartable. En esas tres regiones-riesgo principales conviven una peligrosidad media-alta (frecuencia de desarrollo de eventos extremos) con un grado elevado de vulnerabilidad y exposición a los peligros naturales y tecnológicos en relación con una ocupación intensa del territorio (núcleos urbanos, infraestructuras y actividades económicas). Sin duda, inundaciones, sequías son los episodios de rango extremo más frecuentes en nuestro país y los que originan mayores daños económicos y pérdida de vidas humanas. La responsabilidad de los daños originados por estos eventos naturales extraordinarios es siempre antrópica. Corresponde al ser humano conocer bien los territorios donde va a implantar usos y actividades y ello supone, como se ha señalado, la obligación de llevar a cabo análisis detallados del riesgo natural existente en ellos. Si no se hace, por desconocimiento o por acción premeditada, los efectos ocasionados por un episodio natural de rango extraordinario no pueden ser imputables a la naturaleza, como ha sido costumbre en España durante décadas. La imprevisibilidad de los peligros naturales, salvo en el caso de los terremotos, es un sofisma que atenta contra la seguridad de las personas.

De manera que los daños económicos y las víctimas humanas que pueda generar una inundación o un temporal de viento y mar son siempre imputables a la mala praxis del ser humano en sus acciones sobre el territorio. Y lo mismo cabe decir de las sequías, un riesgo silencioso pero constante, que manifiesta sus efectos cuando el ser humano no ha entendido que no se pueden llevar a cabo expansiones de áreas de regadío o de zonas urbanizadas por encima de las posibilidades hídricas de un territorio, o cuando no se ha diseñado bien la gestión del agua en áreas urbanas ubicadas en territorios expuestos a este riesgo climático. Eso sí, siempre hay un componente de imprudencia del ser humano ante los eventos de rango extremo que debe tenerse en cuenta a la hora de diseñar las medidas de gestión de las emergencias.

Nuestro país ha conocido inundaciones desde época histórica, tanto en grandes cursos fluviales (inundaciones de desbordamiento masivo) como en pequeños cauces, generalmente secos o con poca agua, que se convierten en torrenteras de crecida súbita y elevado poder destructivo (inundaciones "relámpago"). Estas últimas, son las más frecuentes en las últimas décadas en nuestro país, puesto que en los grandes ríos (Duero, Ebro, Tajo, Guadiana y Guadalquivir) se han implantado medidas de defensa (presas, canalizaciones, sistemas de información hidrológica) que han reducido al mínimo la posibilidad de generación de víctimas humanas. Por el contrario, la invasión de cauces secos, que son indiscutiblemente dominio público hidráulico, por la agricultura o la urbanización, ha incrementado la vulnerabilidad y la exposición al peligro de crecidas fluviales en amplias zonas de nuestro territorio. Se han creado "territorios de riesgo" de inundación por la acción imprudente del ser humano sobre el medio fluvial. 
Las sequías son la otra cara de la moneda del comportamiento irregular de las precipitaciones en nuestro país y especialmente en las regiones con clima de rasgos mediterráneos. Todo el territorio español está expuesto al riesgo de sequías, incluido la fachada cantábrica que, aunque con una frecuencia muy baja, también participa de las denominadas "sequías cantábricas", con efectos ambientales y económicos (problemas de abastecimiento de agua), como ocurrió en 1988-90. Pero sin duda son las grandes sequías ibéricas, las que afecta con intensidad diversa al conjunto de regiones españolas, las que suponen mayores pérdidas económicas por sus efectos en la actividad agraria, producción energética -hidroeléctrica- y en el propio abastecimiento urbano de agua en amplias zonas del centro y sur peninsular. Destacan en las últimas décadas las sequías de 1981-84 y la de comienzos de los años noventa del siglo pasado (1992-95). Estas grandes secuencias secas ibéricas no tienen una periodicidad fija, pero suelen desarrollarse en un intervalo entre 10 y 20 años. Otros territorios peninsulares, en función de su propia ubicación geográfica y del ritmo anual de tipos de tiempo, tienen sus propias modalidades de sequía. Es el caso de Cataluña, el sureste ibérico o Canarias. En España las políticas hidráulicas desarrolladas en los últimos cincuenta años han primado las soluciones al problema de las sequías basadas en la oferta de agua. Ante la demanda de agua de un territorio sometido a condiciones de sequía, se han diseñado siempre medidas de incremento de la oferta hídrica (canales, trasvases, desaladoras). Este tipo de medidas ha dado paso, en los últimos años a prácticas de gestión de la demanda, en áreas agrícolas y urbanas, basadas en el ahorro y en la utilización de recursos hídricos procedentes de depuración de aguas residuales, en una concepción más sostenible de la gestión del agua.

\section{CAMBIO CLIMÁTICO Y SUS EFECTOS EN LOS RECURSOS DE AGUA EN LA ORDENACIÓN DEL TERRITORIO}

Los riesgos vinculados a la manifestación extrema de los elementos climáticos han pasado a ocupar una parcela importante en los estudios de cambio climático. El quinto informe del IPCC (2013), confirmando lo ya adelantado en anteriores ediciones, ha dado carta de naturaleza definitiva a la relación entre estos dos procesos. En el momento actual de investigación de la hipótesis de cambio climático por efecto invernadero se puede señalar que existen evidencias, cada vez más explícitas, de que los fenómenos atmosféricos de rango extremo tienen vinculación con los cambios que se están observando en el funcionamiento de la circulación atmosférica general a escala planetaria. Los riesgos climáticos son un problema para el funcionamiento de las sociedades en la actualidad y lo pueden ser más en las próximas décadas. En efecto, la actual modelización climática señala que algunas regiones del mundo, entre ellas las situadas en latitudes mediterráneas, pueden verse afectadas por un incremento en la frecuencia de aparición de los fenómenos atmosféricos de rango extraordinario, 
especialmente los derivados de extremos pluviométricos y ello puede agravar el grado de riesgo ya existente en los territorios (figura adjunta).

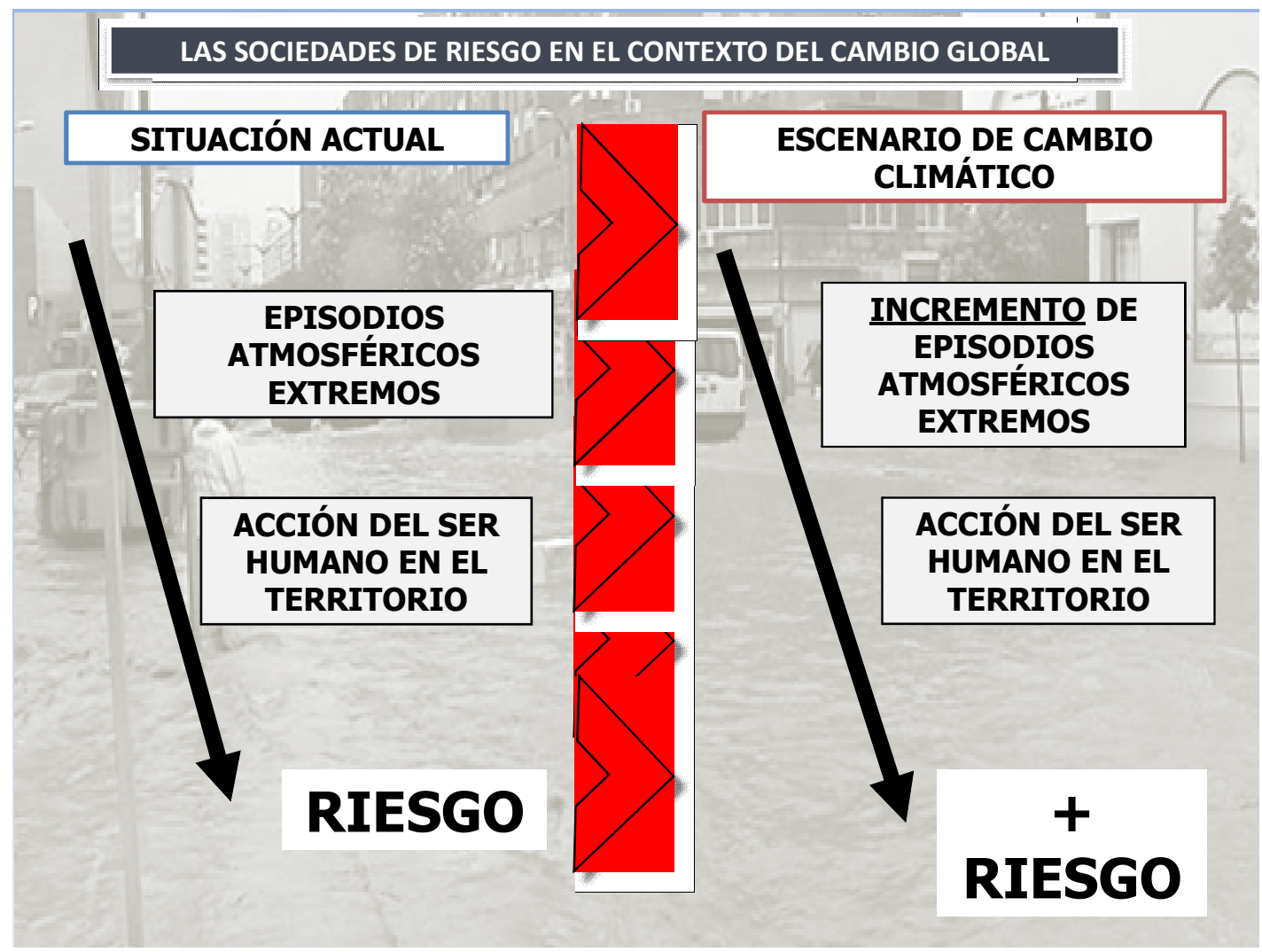

Figura. Sociedades y territorios de riesgo en el contexto del cambio climático. Situación actual y previsión futura. Elaboración propia.

La menor disponibilidad de agua para una población con demandas creciente y el desarrollo frecuente de fenómenos de torrencialidad pluviométrica se presentan como los procesos de causa atmosférica que van a caracterizar el incremento del riesgo en latitudes mediterráneas.

En España se han registrado en las tres últimas décadas los cambios térmicos y de alteración de otros elementos climáticos observados en el resto de la superficie terrestre, en el marco del calentamiento planetario. En efecto, desde los años ochenta del pasado siglo se ha apreciado una subida de las temperaturas, un descenso de la cobertura de hielo y nieve y un ascenso -muy débil- del nivel marino. Así, se indicaba ya en el informe oficial del Ministerio de Medio Ambiente sobre evaluación preliminar de los impactos del cambio climático en nuestro país (MMA, 2005) que fue actualizado en 2007 con la incorporación de los escenarios climáticos regionalizados con horizonte 2100 (INM y OECC, 2007). Desde entonces, se vienen confirmando estos procesos. 
Los modelos climáticos aplicados a escala peninsular, indican un agravamiento de estas condiciones y un aumento de la irregularidad climática, aspecto por otra parte común en los climas de influencia subtropical, como los que se dan en la mayor parte de las tierras ibéricas y los archipiélagos. En esencia, los rasgos más destacados de la evolución climática futura en España se resumen en los siguientes aspectos (INM y OECC, 2007):

- Incremento progresivo de las temperaturas medias.

- Calentamiento más acusado en verano que en invierno.

- Calentamiento estival superior en el interior que en las costas e islas.

- Mayor frecuencia de anomalías térmicas, en especial de las máximas estivales.

- Disminución de la precipitación.

- Mayor reducción pluviométrica en primavera. Probable aumento de la Iluvia invernal en el oeste y otoñal en el noreste.

- Probable aumento de los riesgos climáticos (lluvias torrenciales, olas de calor, sequías, etc.)

De todos los efectos previstos para las condiciones climáticas del territorio español dentro de la actual hipótesis de cambio climático por efecto invernadero, lo más preocupante es justamente el probable incremento de los episodios atmosféricos de rango extremo. Una subida de temperaturas de 3-4 $\mathrm{C}$ o una reducción de precipitaciones entre el 20 y $40 \%$ respecto a los valores actuales son escenarios que implican enormes impactos y que imponen profundos procesos de adaptación. Pero, lo peor para un territorio, sus habitantes y sus actividades económicas puede ser, sin duda, el aumento del carácter "extremo" de sus condiciones climáticas. La posibilidad de ser escenario frecuente de lluvias intensas con efectos de inundación, de sequías agudas, de golpes de calor intensos en verano o de temporales de viento causados por borrascas enérgicas o situaciones de borde de anticiclón en el área mediterránea, supone un escenario de enorme vulnerabilidad socio-económica. Si se cumplen las previsiones establecidas en la modelización climática, el aumento de daños humanos y económicos que se registrarían anualmente será extraordinario.

\section{BIBLIOGRAFÍA}

AYALA CARCEDO, F.J. (2000) La ordenación del territorio en la prevención de catástrofes naturales y tecnológicas. Bases para un procedimiento técnico-administrativo de evaluación de riesgos para la población”, en Boletín de la $A G E, \mathrm{n}-30$. Asociación de Geografía Españoles, pp. 37-49

AYALA-CARCEDO, F. J. (2002) "El sofisma de la imprevisibilidad de las inundaciones y la responsabilidad social de los expertos. Un análisis del caso español y sus 
alternativas", en Boletín de la Asociación de Geógrafos Españoles, no 33, Madrid, Asociación de Geógrafos Españoles, pp. 79-92.

AYALA-CARCEDO, F.J. (2003): "Impactos del cambio climático sobre los recursos hídricos en España y viabilidad física y ecológica del Plan Hidrológico Nacional 2001", en P. ARROJO y L. DEL MORAL (Coords.) La Directiva Marco del Agua. Realidades y futuros, III Congreso Ibérico sobre Gestión y Planificación del Agua. Ponencias, Zaragoza, Institución Fernando el Católico, pp. 253-271.

AYALA-CARCEDO, F. J. y OLCINA CANTOS, J. (coords.) (2002) Riesgos Naturales. Barcelona, Editorial Ariel. Col. Ciencia, 1.512 p.

BECK, U. (2002) La sociedad del riego global. Madrid, Edit. Siglo XXI.

BENITO, G. (2005): "Impacto sobre los riesgos naturales de origen climático. A. Riesgos de crecidas fluviales", en Moreno Rodríguez, J.M. (Coord.) (2005), Evaluación preliminar de los impactos en España por efecto del cambio climático. Proyecto ECCE. Informe final, Ministerio de Medio Ambiente, Universidad de Castilla La Mancha, pp. 527-548.

BURTON, I, R. KATES and G. WHITE $(1978,1993)$ : The Environment as hazard. New York, Oxford University Press.

CALVO GARCÍA-TORNEL, F. (2001) Sociedades y Territorios en riesgo. Barcelona, Ediciones del Serbal.

CEDEX (1997): Estudio sobre el impacto potencial del cambio climático en los recursos hídricos y las demandas de agua de riego en determinadas regiones de España, Informe técnico para el Ministerio de Medio ambiente de España, Madrid.

CEDEX (2010) Evaluación del impacto del cambio climático en los recursos hídricos en régimen natural. Memoria. Encomienda de Gestión de la Dirección General del Agua (MARM) al CEDEX para el estudio del cambio climático en los recursos hídricos y las masas de agua http://www.magrama.gob.es/es/cambioclimatico/publicaciones/publicaciones/Memoria encomienda CEDEX tcm7165767.pdf

DAUPHINÉ, A. (2003) Risques et catastrophes. Observer, spatialiser, comprendre, gérer. París, Armand Colin.

DIEZ HERRERO, A., LAÍN-HUERTA, L. y LLORENTE-ISIDRO, M. (2009) A Handbook on Flood Hazard Mapping Methodologies, IGME, Madrid, 190 pp.

EASTERLING, D. R., G.A. MEEHL, C. PARMESAN, S.A. CHANGNON, T.R. KARL AND L.O. MEARNS (2000): Climate Extremes: Observations, Modeling and Impacts, Science, Vol. 289, 22 september 2000, pp. 2068-2074.

ESPEJO MARÍN, C. y CALVO GARCÍA-TORNEL, F. (2003) "Bibliografía sobre riesgos con origen en procesos naturales publicada en España (1975-2002), en Biblio 3W, Revista Bibliográfica de Geografía y Ciencias Sociales, vol. VIII, no 455, Universidad de Barcelona, $42 \mathrm{p}$.

FIELD, C.B., V. BARROS, T.F. STOCKER, D. QIN, D.J. DOKKEN, K.L. EBI, M.D. MASTRANDREA, K.J. MACH, G.-K. PLATTNER, S.K. ALLEN, M. TIGNOR, AND P.M. MIDGLEY (2012) (Eds.) Managing the Risks of Extreme Events and Disasters to Advance Climate Change Adaptation. http://www.ipcc-wg2.gov/SREX/ 
GREIVING, S., FLEISCHHAUER, M. AND WANCZURA, S. (2007) "Planificación territorial para la gestión de riesgos en Europa", Boletín de la Asociación de Geógrafos Españoles, 45, Madrid, pp.49-78.

HILPERT, K., MANNKE, F and SCHMIDT-THOMÉ, P. (2007) Towards climate change adaptation strategies in the Baltic Sea Region, GTK, Finland, Baltic Sea Region (Interreg III B). Espoo, 55 p.

IGLESIAS, ESTRELA Y GALLART, (2005): en MORENO RODRIGUEZ, J.M. (Coord.) (2005), Evaluación preliminar de los impactos en España por efecto del cambio climático. Proyecto ECCE. Informe final, Ministerio de Medio Ambiente, Universidad de Castilla La Mancha, pp. 303-353.

INM y OECC (2007): Generación de escenarios regionalizados de cambio climático en España. Primera Fase. 145 p.

INTERGOVERNMENTAL PANEL ON CLIMATE CHANGE (IPCC) (1990, 1995, 2001, 2007, 2013) Assessment Reports, Special Reports, Methodology Reports. United Nations Environment Programme. http://www.ipcc.ch/ipccreports/assessmentsreports.htm).

JUDT, T. (2010) Algo va mal. Ed. Taurus, Madrid, 250 p.

LAMARRE, D. (dir.) (2002) Les risques climátiques. Ed. Belin, París, 224 p.

MARM (2008). ORDEN ARM/2656/2008 del Ministerio de Medio Ambiente y Medio Rural y Marino, de 10 de septiembre, por la que se aprueba la instrucción de planificación hidrológica. BOE núm 229, de 22 sept 2008: 38472-38582

MARTín VIDE, J. (coord.) (2007) Aspectos económicos del cambio climático. Estudios Caixa de Cataluña no 4. Barcelona, Caixa Cataluña, 83 pp.

MATA OLMO, R. y Olcina Cantos, J. (2010) "El sistema de espacios libres" en Teoría y Práctica para una ordenación racional del territorio (Luis Galiana y Julio Vinuesa, coords). Ed. Síntesis, Madrid, pp.87-127.

MORENO RODRIGUEZ, J.M. (Coord.) (2005), Evaluación preliminar de los impactos en España por efecto del cambio climático. Proyecto ECCE. Informe final, Ministerio de Medio Ambiente, Universidad de Castilla La Mancha.

OLCINA CANTOS, J. (2007) Riesgo de inundaciones y ordenación del territorio en España. Instututo Euromediterráneo del Agua, Murcia

OLCINA CANTOS, J. (2009) "Hacia una ordenación sostenible de los territorios de riesgo en Europa" en Cohesión e inteligencia territorial. Dinámicas y procesos para una mejor planificación y toma de decisiones (Farinós, J. Romero, J. y Salom. J. (eds.)) Publicaciones de la Universitat de Valencia, Valencia, pp. 153-182.

OLCINA CANTOS, J. (2009): "Cambio climático y riesgos climáticos en España", Investigaciones Geográficas, 49. Universidad de Alicante, pp.197-220.

OLCINA CANTOS, J. (2010) "Cambio climático y riesgos climáticos en España", Investigaciones Geográficas, 49. Instituto Universitario de Geografía. Universidad de Alicante, pp. 197-220.

OLCINA CANTOS, J. (2013) "Experiences in adapting to Climate Change and Climate Risk in Spain", in Climate Change Adaptation in practice: from strategy development to implementation, Wiley-Blackwell, New Jersey, pp. 253-268 
OLCINA CANTOS, J., HERNÁNDEZ HERNÁNDEZ, M., RICO AMORÓS, A.M., MARTÍNEZ IBARRA, E. (2010) "Increased risk of flooding on the coast of Alicante (Region of Valencia, Spain)", Natural Hazards, vol. 10, no 11, pp. 2229-2234.

OLLERO OJEDA, ALFREDO; ASKOA IBISATE GONZÁLEZ DE MATAUCO; ORBANGE ORMAETXEA ARENAZA (2000). "Las inundaciones en la vertiente cantábrica del País Vasco en los últimos veinte años: principales eventos, consecuencias territoriales y sistemas de prevención." Serie geográfica 9 (2000): 177-186.

ONU (2004) Living with Risk: A Global Review of Disaster Reduction Initiatives, Nairobi, ISDR.

PARRY, M., C. PARRY AND M. LIVERMORE (Eds). (2000): Valoración de los efectos potenciales del Cambio Climático en Europa (Informe ACACIA de la Comisión europea, Resumen y Conclusiones), Universidad de Castilla-La Mancha-Iberdrola, Toledo, 29 pp.

PÉREZ MORALES, A. (2012) “Estado actual de la cartografía de los riesgos de inundación y su aplicación en la ordenación del territorio. El caso de la Región de Murcia", Boletín de la Asociación de Geógrafos Españoles, 58:57 -82

PERLES ROSELLÓ M. J. y MERIDA M. (2010) “Patrón territorial y conformación del riesgo en espacios periurbanos. El caso de la periferia este de la ciudad de Málaga, Scripta Nova XIV, (on line).

REGUEIRO, M. (ed.) (2008) Guía Metodológica para la elaboración de cartografías de riesgos naturales en España. Ministerio de Vivienda y Colegio Oficial de Geólogos, Madrid, $187 \mathrm{pp}$.

RIBAS, A. y SAURI, D. (2006) "De la geografía de los riesgos a las geografías de la vulnerabilidad", en NOGUÉ, J. y ROMERO, J., eds. (2006) Las otras Geografías. Ed. Tirant Lo Blanch. Col. Crónica. Valencia, pp. 285-299.

SAURí, D., OLCINA, J., MARCH, H., MARTÍN-VIDE, J., VERA, F., PADILLA, E. AND SERRALLOBET, A. (2011) "Case Study Mediterranean Coast of Spain", in ESPON Climate: Climate Change and Territorial Effects on Regions and Local Economies. Applied research project 2012/1/4. Final Report. Annex 4. Disponible en: www.espon.eu/export/sites/default/Documents/Projects/AppliedResearch/CLIMA TE/ESPON Climate Final Report Annex4 Spain Case Study.pdf.

SCHMIDT-THOMÉ, P. (edit) (2005) The spatial effects and management of natural and technological hazards in Europe. Luxemburgo. ESPON, (thematic project 1.3.1.) (avaliable in www.espon.eu)

VV.AA. (2006) Cambios de ocupación del suelo en España. Implicaciones para la sostenibilidad. Observatorio de la Sostenibilidad e España, Ministerio de Medio Ambiente. Alcalá de Henares, 485 p. 


\section{ENLACES}

-www.ipcc.ch (disponible en V Informe de Cambio Climático on line)

-www.aemet.es (modelización climática para el ámbito español)

-Evaluación del Primer Ciclo de Planificación Hidrológica en España. (Disponible en: http://www.fnca.eu/component/content/article/38-observatorio-dma/483-informeoppa-evaluador-del-primer-ciclo-de-planificacion). Capítulo sobre "riesgos climáticos y cambio climático"

-Consorcio de Compensación de Seguros. Estadística de Riesgos Extraordinarios (19712013). (Disponible en:

http://www.consorseguros.es/web/c/document library/get file?uuid=548d4f59-

b6c5-40dd-b06b-98dbcefd790f\&groupld=10124)

-Informe Global Risk 2014 (disponible en: http://www.weforum.org/reports/globalrisks-2014-report)

-Proyecto ESPON-Climate (Disponible en:

http://www.espon.eu/main/Menu Projects/Menu AppliedResearch/climate.html) 


\title{
1.3. PLANIFICACIÓN URBANÍSTICA
}

\author{
Andrés Molina Giménez
}

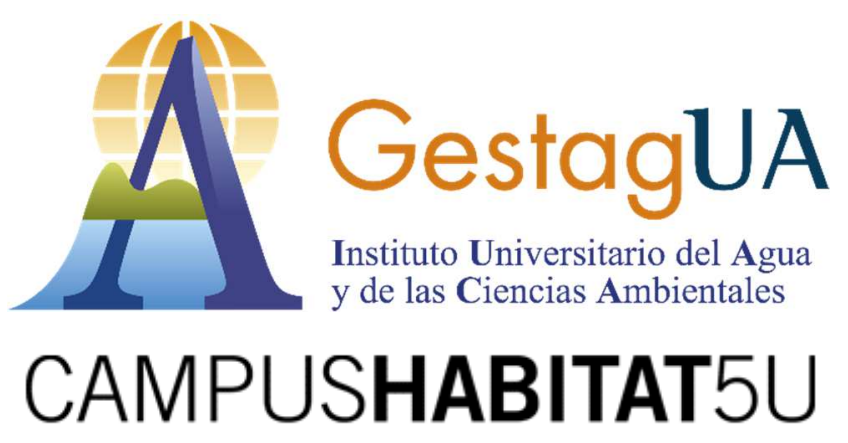




\section{INTRODUCCIÓN}

En la gestión territorial del agua resulta fundamental la variable urbanística, que se desarrolla a nivel más local. Mientras que la ordenación del territorio tiene un alcance regional, e incluso, en ocasiones nacional, el urbanismo pone su foco en lo más próximo, en la ciudad y su entorno inmediato.

El objetivo del urbanismo, por tanto, es ordenar el crecimiento de las ciudades, tratando de que éste sea harmónico en el territorio y compatible con los valores ambientales. A su vez, se preocupa del diseño de la ciudad, de su organización interna, edificabilidades, volúmenes, tipologías, con el objeto de planificar una ciudad más amable para el ciudadano, con mayor calidad de vida, y que permita el desarrollo de todas las actividades urbanas de manera más eficiente (movilidad, zonas verdes, localización de servicios, interacción social, etc.).

Desde la óptica de la gestión del agua, el urbanismo nos aporta aspectos muy importantes. Por ejemplo, las ciudades no deben crecer más allá de lo que permiten los recursos hídricos disponibles. La planificación urbanística debe coordinarse con la territorial para evitar la construcción en zonas inundables, o para definir la ubicación de determinados usos (i.e. localizaciones industriales), para la organización e integración urbana de grandes infraestructuras (vías de comunicación, puertos, aeropuertos, etc.), o para la protección de determinados valores (culturales, protección del litoral, protección de espacios naturales, etc.).

Son por tanto muchas y muy intensas las relaciones entre la planificación urbanística y el resto de planificaciones que inciden en el territorio (de ordenación territorial, espacios naturales, carreteras, etc.), siendo fundamental que entre las Administraciones públicas responsables exista una adecuada coordinación.

\section{PLANIFICACIÓN URBANÍSTICA}

En España, la planificación urbanística es competencia de las regiones (Comunidades Autónomas), por lo que el Estado sólo establece las reglas básicas que cada Comunidad debe seguir. Esto se realiza mediante el Real Decreto Legislativo $7 / 2015$, de 30 de octubre, por el que se aprueba el texto refundido de la Ley de Suelo y Rehabilitación Urbana. Cada Comunidad, por tanto, ha creado su legislación específica, creando modelos urbanísticos bastante diferentes en las diferentes regiones españolas. No obstante, hay algunos elementos comunes que destaremos en este tema. 
Todas las Comunidades crean un esquema de planes urbanísticos para ordenar el desarrollo de la ciudad. Los tipos generales de planes serían:

a.- El plan general. Es el instrumento más importante, porque permite regular el crecimiento de la ciudad en su conjunto. Contiene por tanto la ordenación estructural, que regula las grandes decisiones. Entre sus determinaciones más importantes está la Clasificación del suelo (distribución del territorio municipal en grandes tipologías de suelo según su idoneidad para incorporarse al proceso edificatorio: suelos urbanos: aptos por estar ya urbanizados, suelos urbanizables: aptos pero precisan planificación diferida y obra urbanizadora, y suelos no urbanizables: aquellos que quedan fuera del proceso edificatorio por sus características naturales, ambientales, o por su dedicación a determinadas actividades económicas incompatibles con la urbanización como los usos agrarios). También forma parte de su contenido fundamental la calificación del suelo, que permite determinar, dentro de cada tipología de suelo, los usos y aprovechamientos de que éste es susceptible (edificación residencial, densa, mixta, baja densidad, usos terciarios, usos comerciales). El Plan general también regula el viario principal y los equipamientos generales (hospitales, sedes de entidades públicas, etc.).

b.- Planificación de desarrollo o diferida. Existen numerosos tipos de planes que vienen a completar al general, y que tienen una posición jerárquica inferior. Es decir, no pueden contradecir sus determinaciones. Destacamos los más importantes:

-Planes parciales: permiten especificar las regulaciones, mucho más amplias, del plan general, para los suelos urbanizables. Estos suelos, que no están urbanizados, necesitan completar su urbanización para convertirse en suelos urbanos, solares ya edificables. Para eso, dado que el plan general no puede ordenar de forma pormenorizada todos estos suelos, porque ello resultaría muy costoso y porque, además, estos suelos pueden incorporarse al proceso urbanizador-edificatorio a muchos años vista, se necesitan estos planes para poder regular el proceso una vez se quiera poner en marcha.

-Planes de reforma interior: este tipo de planes se utilizan para completar la ordenación de espacios ya clasificados como suelos urbanos pero para los que es necesario completar la ordenación establecida por el plan general. Se trata de realizar operaciones de cirugía urbana en zonas consolidadas o de convertir en suelos urbanizados áreas clasificadas como suelos urbanos con urbanización inexistente o insuficiente. 
-Planes especiales. Este tipo de planes tienen un objetivo concreto, cuya importancia hace que incluso puedan modificar al propio plan general. Se utilizan para facilitar la integración de grandes infraestructuras en la ciudad (puertos, vías de comunicación, etc.), así como para la protección de determinados bienes de interés cultural, entre otros supuestos. Cada legislación autonómica determina específicamente su objeto.

-Estudios de detalle: sirven para definir volúmenes, alineaciones de edificios y rasantes. Son un plan de menor entidad, complementario de alguno de los planes diferidos antes considerados.

-Proyectos de urbanización: no son planes propiamente dichos, sino proyectos de obra necesarios para ejecutar las determinaciones de los planes sobre el terreno.

c.- Catálogos de bienes y espacios protegidos. Esta figura es de gran interés, suele incorporarse a los planes generales, como documento específico, o bien, en ausencia de aquellos, se puede tramitar de manera separada. Sirve para identificar bienes de interés cultural o catalogados, y establecer su régimen concreto de protección a través de fichas individualizadas que establecen su protección integral, ambiental, etc. También se incluyen los espacios con interés ambiental que merecen ser específicamente protegidos por el planeamiento urbanístico.

\section{PLANIFICACIÓN URBANÍSTICA Y PLANIFICACIÓN HIDROLÓGICA}

Vamos a destacar dos aspectos en los que la relación entre la planificación hidrológica y urbanística es más relevante, indicando, con carácter previo, que la planificación hidrológica (planes hidrológicos de demarcación) es siempre prevalente con respecto a la urbanística, de modo que en caso de conflicto la hidrológica prevalecerá.

a.- El informe de la Confederación hidrográfica en los procesos de planeamiento urbanístico. Esta es la primera relación de importancia, toda vez que la Administración hidráulica, es decir, las Confederaciones u organismos autonómicos equivalentes, deben emitir un informe preceptivo en todos los procesos de aprobación del planeamiento urbanístico general. De este modo se garantiza que no se desarrollen nuevos usos urbanísticos si la Administración hidráulica no asegura que existirán recursos hidráulicos suficientes en la 
demarcación para atender las nuevas demandas. Dicho informe, según las legislaciones urbanísticas autonómicas, es calificado como vinculante o determinante, lo que, en este segundo caso, ha dado lugar a conflictos.

b.- Los planes hidrológicos determinan la distribución de los recursos disponibles entre las diferentes demandas de la demarcación. Deben atender, por tanto, en la medida de lo posible, las demandas que generen los desarrollos urbanísticos. Para ello los planes establecen sistemas de explotación diferenciados y asignan dotaciones por habitante y día para cada uno de ellos. El abastecimiento a poblaciones es siempre prioritario al resto de usos (agricultura, industria, etc), lo que no significa que los planes hidrológicos estén obligados a atender todas las demandas potenciales que se planteen en los procesos de planeamiento. Deberán atender, eso sí, las actuales, así como un incremento previsible, racional y derivado de parámetros objetivos, como el crecimiento vegetativo esperado de la población.

\section{PLANIFICACIÓN URBANÍSTICA Y PLANIFICACIÓN TERRITORIAL: EN PARTICULAR, CONTROL DE INUNDACIONES}

Los planes de ordenación del territorio, aprobados por las Comunidades Autónomas, son jerárquicamente superiores a los planes urbanísticos, y por tanto, estos últimos deben aprobarse atendiendo a sus determinaciones. De ahí que los planes urbanísticos más importantes tengan un proceso de aprobación en dos fases, una municipal (aprobación provisional) y otra autonómica (aprobación definitiva), momento en el que se comprueba, entre otros aspectos, que el plan urbanístico provisionalmente aprobado se ajusta a la planificación territorial.

Existen numerosos planes territoriales que inciden en diferentes aspectos de la gestión del territorio, pero aquí nos centramos en los que tienen que ver con una problemática específica, relacionada con el agua, como son las inundaciones. La Comunidad Autónoma que primero aprobó planificación territorial en esta materia fue la Valenciana. La última versión del documento fue aprobada por el DECRETO 201/2015, de 29 de octubre, del Consell, por el que se aprueba el Plan de acción territorial sobre prevención del riesgo de inundación en la Comunitat Valenciana.

Este plan realiza una cartografía de toda la Comunidad Valenciana, gracias a la que ésta puede sectorializarse en áreas con diferente nivel de riesgo de inundación. Aquellas áreas con mayor riesgo quedan fuera de todo proceso urbanizador, de modo que ningún plan urbanístico puede aprobarse si afecta a una de estas zonas. En el resto de áreas, la urbanización si es posible, pero siempre que se apliquen las 
medidas correctoras que establece el plan y se redacte un estudio de inundabilidad. La tramitación de estos estudios, mucho más detallados que el PATRICOVA, al centrarse en un área más concreta y poder utilizar cartografías de menor escala, puede permitir la recalificación del nivel de riesgo inicialmente declarado por el PATRICOVA, reduciendo así las obligaciones del promotor.

\section{CONCLUSIONES}

La planificación urbanística es un instrumento fundamental para la gestión del territorio, y su relación con la gestión de los recursos hídricos es directa. Así se pone de manifiesto en la necesidad de que los planes urbanísticos cuenten con un informe favorable de la Confederación hidrográfica competente, el cual se realizará atendiendo a lo que los planes hidrológicos de demarcación establezcan en cuanto a la disponibilidad de recursos hídricos. También se observa en otros ámbitos, como la gestión de inundaciones, de modo que ningún plan de este tipo puede aprobarse si no se ajusta a lo establecido en la planificación territorial relativa a estos riesgos.

Se observa, en definitiva, que sobre el territorio inciden numerosos aspectos y agentes administrativos, siendo necesario una elevada coordinación entre todos ellos, especialmente en los diferentes niveles de planificación.

\section{BIBLIOGRAFÍA}

AA.VV. (2016) Paisaje, cultura territorial y vivencia de la Geografía. Libro homenaje al profesor Alfredo Morales Gil. http://rua.ua.es/dspace/handle/10045/58747

Fernández, T.R. (2016) Manual de Derecho Urbanístico. 24 ed. Civitas, Madrid.

Diez Sanchez, J.J (2016) Comentarios a la Ley de Ordenación del Territorio, Urbanismo y Paisaje de la Comunitat Valenciana, Tirant lo Blanch, Valencia. 


\section{ENLACES}

https://www.boe.es/boe/dias/2015/10/31/pdfs/BOE-A-2015-11723.pdf

http://www.habitatge.gva.es/web/planificacion-territorial-e-infraestructuraverde/patricova-plan-de-accion-territorial-de-caracter-sectorial-sobre-prevenciondel-riesgo-de-inundacion-en-la-comunitat-valenciana 


\section{MÓDULO 2}

\section{LOS TRASVASES DE RECURSOS HIDRÁULICOS ENTRE CUENCAS HIDROGRÁFICAS}




\title{
2.1. MARCO LEGAL
}

\author{
Andrés Molina Giménez
}

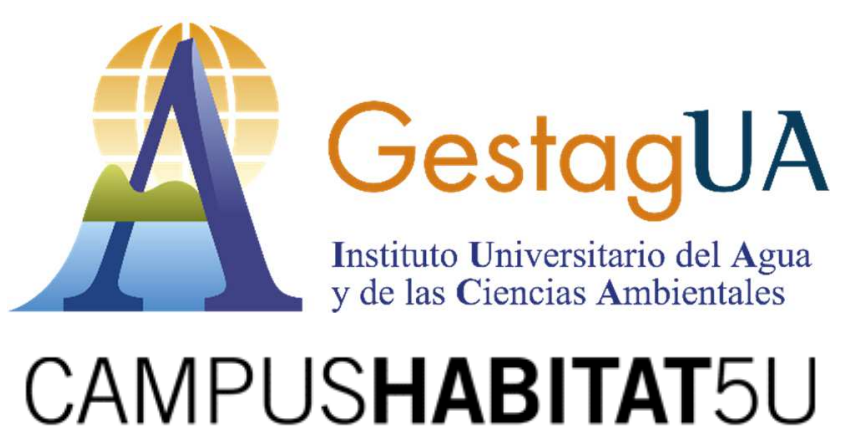




\section{INTRODUCCIÓN}

En este tema queremos clarificar conceptos básicos sobre el marco legal de los trasvases en España. España tiene en materia hidráulica un doble desequilibrio: la irregularidad temporal de las precipitaciones, que afecta a gran parte del país, y la irregularidad de su distribución geográfica.

La necesidad de afrontar la escasez estructural de muchas cuencas hidrográficas llevó pronto a concebir la conveniencia de proveer al país de obras hidráulicas de gran porte. Primero fueron las obras de regulación, que abordan el problema temporal, reservan aguas durante los periodos de lluvias, y permiten la laminación de avenidas. Luego vinieron las obras de transferencia o trasvase, destinadas a paliar la desigualdad territorial.

Los trasvases presentan ciertamente dificultades tanto en términos ambientales como sociales y territoriales. Así lo reconoce el Preámbulo de la Ley 10/2001 de 5 de julio, del Plan Hidrológico Nacional (PHN), que los califica como «la opción última y más comprometida para solucionar los déficits hídricos estructurales». Ahora bien, en ocasiones, ésta es la solución más sostenible en términos económicos, ya que otras opciones, como la desalación de agua marina, presentan unos precios muy elevados por su consumo energético, que a su vez puede generar importantes efectos adversos en el medio ambiente si la energía utilizada no es renovable; el precio del agua desalada no es competitivo para determinados usos, especialmente si se necesita trasladar el producto a lugares alejados de la planta o a cotas superiores.

\section{CONCEPTO DE TRASVASE}

Es preciso indicar que trasvase, en términos jurídicos, no es todo tipo de transferencia o cesión de caudales entre dos cuencas hidrográficas. Según su definición legal, trasvase sólo es aquella cesión de caudales que se realiza entre dos ámbitos de planificación hidrológica o, dicho de otra manera, entre dos demarcaciones hidrográficas.

Los trasvases, así definidos, sólo pueden ser autorizados mediante una ley específica que, a partir de la Ley de Aguas de 1985, es el Plan hidrológico Nacional (art. 45.c del Real Decreto Legislativo 1/2001, de 20 de julio, por el que se aprueba el texto refundido de la Ley de Aguas, en adelante TRLA). 


\section{TRASVASES EN ESPAÑA}

Existen numerosos trasvases en funcionamiento en España, aunque el mayor y más importante de todos ellos es el trasvase Tajo-Segura.

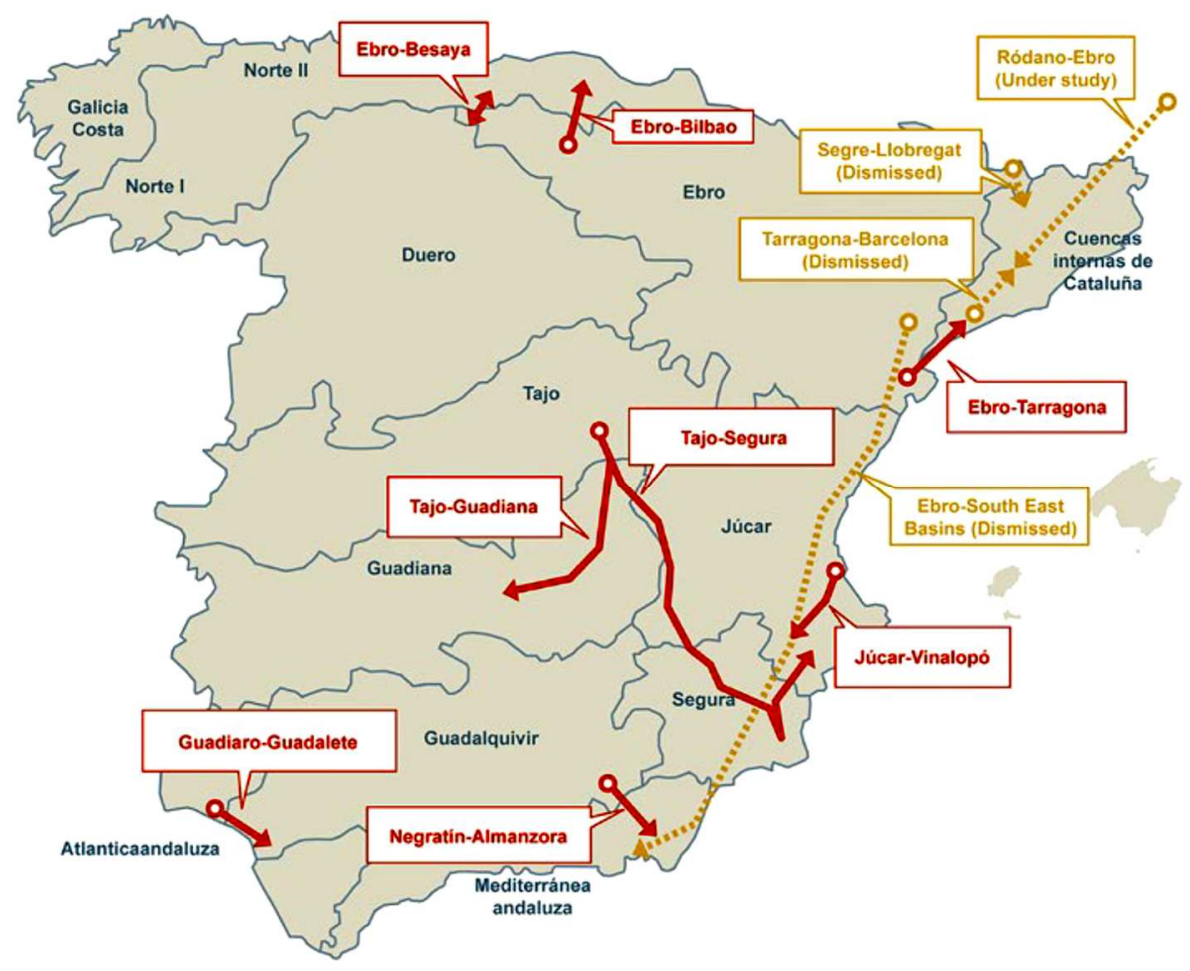

Fuente: CEDEX (2008) Elaboración propia.

1. Trasvases del Ebro anteriores a la Ley de Aguas de 1985 (Ebro-cuencas cántabras, vascas y catalanas)

Antes de la entrada en vigor de la Ley de Aguas en 1985 se realizaron varios trasvases desde la demarcación del Ebro a otras demarcaciones. El PHN garantiza en su disposición adicional primera la continuidad de los trasvases amparados en títulos concesionales o legales otorgados con anterioridad al 1 de enero de 1986, y remite su régimen de funcionamiento a lo dispuesto en su título concesional o legal vigente.

En la actualidad, desde el río Ebro se realizan con esta cobertura jurídica hasta siete trasvases que permiten extraer aproximadamente 300 hm³/año. El Trasvase CiuranaRiudecueñas, con $55 \mathrm{hm}^{3}$ anuales, tiene fines agrícolas y urbanos, y destino la comarca de Reus. El área metropolitana de Bilbao se beneficia de los ríos Cerneja (10 hm³/año) y Zahorra (180 hm³/año), ambos del sistema Ebro. 
En Guipúzcoa tenemos un pequeño trasvase Alzania-Oria de $2.5 \mathrm{hm}^{3} /$ año para producción de hidroelectricidad. En la cabecera del Ebro funcionan dos trasvases hacia Cantabria, alguno de ellos reversible, como son el trasvase Ebro-Besaya, pare mejora del abastecimiento de Torrelavega, y el trasvase del Alto de Tornos, ambos de escasa entidad. Finalmente, Francia también se beneficia de un trasvase a través del Canal Carol-Ariège para producir hidroelectricidad (MELGAREJO: 2008)

\section{Trasvase del Ebro a Tarragona (Minitrasvase)}

Desde los años setenta se evidenció que la provincia de Tarragona, con fuerte crecimiento demográfico y turístico, experimentaba una creciente escasez y deterioro en sus disponibilidades hídricas. Se hacía necesario sustituir las precarias extracciones de aguas subterráneas, afectadas por procesos de intrusión marina. La solución pasó por traer caudales de la desembocadura del Ebro.

La Ley 18/1981 de 1 de julio, sobre actuaciones en materia de Aguas en Tarragona, reformada por el PHN, autorizó trasvasar agua desde el Ebro a las comarcas de Tarragona, situadas en el ámbito de las cuencas internas catalanas. A este trasvase se le conoce comúnmente como el "Minitrasvase del Ebro», y está destinado a riegos, usos urbanos e industriales. El volumen máximo de las transferencias es de $4 \mathrm{~m}^{3}$ por segundo, lo que supone aproximadamente unos $120 \mathrm{hm}^{3}$ anuales, de los que se consumen entre 70 y 80 ; existe por ello un remanente de unos 40-50 hm³/año (MELGAREJO: 2008).

\section{Trasvase Negratín-Almanzora}

Este trasvase, concebido a finales de la década de los noventa, conecta la cuenca alta del río Guadalquivir con la cuenca del Sur, en la provincia de Almería. El RDL 9/1998, de 28 de agosto, por el que se aprueban y declaran de interés general determinadas obras hidráulicas, justificó en la demora del PHN la necesidad utilizar una norma específica con rango de Ley para poner en marcha esta actuación hidráulica. La Ley 55/1999, de 29 de diciembre, autorizó la transferencia de recursos entre ambas cuencas para usos de riego y abastecimiento, bajo determinadas condiciones. El volumen anual transferido no puede superar los $50 \mathrm{hm}^{3}$ anuales.

\section{La «tubería manchega» (Trasvase Tajo-Guadiana)}

Mediante Real Decreto Ley 8/1995 de 4 de agosto, por el que se adoptan medidas urgentes para la mejora del sistema Tajo-Segura, se consolidó la posibilidad de trasvasar caudales de la cuenca alta del Tajo al Guadiana, para usos ambientales y de abastecimiento urbano. Anteriormente, se había autorizado un trasvase puntual con destino a las Tablas de Daimiel, experiencia que se repitió posteriormente a través de diversos Decretos Leyes; estas medidas coyunturales pasaron por tanto a tener un carácter estructural. 
El límite máximo del trasvase es de $50 \mathrm{hm}^{3}$ anuales, parte de los cuales pueden ser destinados al parque nacional de las Tablas de Daimiel y otros a abastecimientos urbanos y aprovechamientos hidroeléctricos. Además, se reservan $3 \mathrm{hm}^{3}$ cada año para su asignación a abastecimientos urbanos inmediatos al trazado del acueducto Tajo-Segura, en las cuencas de los ríos Guadiana y Júcar.

\section{EL TRASVASE TAJO-SEGURA}

Se trata del trasvase más importante por su longitud, infraestructuras asociadas, y relevancia socioeconómica. Permite transferir hasta $600 \mathrm{hm}^{3}$ anuales entre las cuencas del río Tajo y el Segura. Ha sido utilizado también para derivar caudales a la cuenca del río Guadiana, así como a la cuenca del Júcar (transferencias internas dentro de dicha demarcación).

El primer instrumento normativo que regula el Trasvase es la L 21/1971, de 19 de junio, vigente en la actualidad. El Trasvase se configura en dos fases, una primera en la que se sitúa un techo de $600 \mathrm{hm}^{3}$ anuales de transferencia, y una segunda con un máximo de $1000 \mathrm{hm}^{3}$ anuales, diferida a la ejecución de obras necesarias en cabecera del Tajo. El 31 de marzo de 1979 se da por finalizada la obra con la llegada de los primeros caudales a la cuenca del Segura.

La Ley 52/1980, de 16 de octubre, de regulación del régimen económico del acueducto, que establece un sistema tarifario complejo que elimina las subvenciones estatales y asigna parte de la tarifa a la financiación de obras hidráulicas en la cuenca cedente.

Tanto la redacción inicial del PHN como su reforma de 2005 refieren algunos aspectos sobre el Trasvase. Incorpora disposiciones adicionales específicas destinadas a agilizar obras y optimizar aprovechamientos vinculados al trasvase en La Mancha, e incluye la posible revisión en el futuro de los volúmenes trasvasables. El DL 15/2005, de 16 de diciembre, permite usar el acueducto para circular caudales procedentes de contratos de cesión, y legitima a los usuarios con título legal a utilizar dicha fórmula.

El principal problema legal que ha soportado el trasvase, sobre todo en los últimos años, es la falta de certidumbre de los usuarios sobre si recibirían caudales en cada momento. Las cesiones concretas se autorizan mediante una Regla de Explotación bastante compleja, cuya aplicación ha sido muy controvertida. Por ejemplo, era imposible trasvasar caudales cuando en los macroembalses de cabecera: Entrepeñas y Buendía, no existieran más de 240 hm3 embalsados, siendo 
que a partir de ahí se abrían varios escenarios en los que la Administración podía, o no, autorizar trasvases en función de dicha Regla.

Ley $21 / 2013$, de 9 de diciembre, de evaluación ambiental, ha modificado sustancialmente dicha Regla, otorgando una mayor seguridad jurídica a los usuarios. En resumen, el mínimo no trasvasable se eleva ahora a $400 \mathrm{hm}^{3}$, en beneficio de la cuenca cedente, pero a cambio, en los siguientes tramos (mayores caudales embalsados) se reconoce un derecho subjetivo de los usuarios del trasvase a obtener caudales (diferentes volúmenes según estado de los embalses).

Este reconocimiento de un derecho a recibir los caudales es una novedad extraordinaria en el marco regulador del trasvase, que hasta entonces siempre se había movido en el terreno de la discrecionalidad y de la incertidumbre.

\section{TRASVASES Y MERCADOS DEL AGUA}

Las infraestructuras de un trasvase pueden utilizarse para la cesión de caudales a través tanto de los contratos de cesión de derechos de aprovechamiento como mediante los centros de intercambio de derechos. La Dirección General del Agua es la competente para autorizar específicamente tanto los contratos como el uso de las infraestructuras (art. 72 TRLA).

Los contratos de cesión de derechos de aprovechamiento son acuerdos entre concesionarios o usuarios legales de agua que permiten movilizar caudales entre concesionarios que disponen de un excedente y otros cuyas dotaciones reales son inferiores a las concedidas. Entre las partes se realiza un contrato y se pacta un precio, y es la Confederación hidrográfica a la que pertenezcan ambos usuarios la que autoriza el contrato. Si la cesión implica un trasvase, la competencia es, como hemos dicho, de la Dirección General del Agua. Existen condiciones legales que ambas partes deben cumplir que en ocasiones dificultan dichas autorizaciones.

El centro de intercambio de derechos es un mecanismo de intercambio completamente diferente. En este caso es el Consejo de Ministros, a propuesta del Ministro de Medio Ambiente, quien autoriza la creación de un centro, que realizará ofertas de adquisición de caudales a concesionarios interesados en ceder sus caudales, para luego cederlos a un precio determinado a potenciales concesionarios interesados en adquirirlos. La Dirección General del Agua podrá autorizar la utilización de infraestructuras de trasvase para realizar estos intercambios. 


\section{CONCLUSIONES}

Los trasvases en España ayudan a reequilibrar los balances hídricos de algunas demarcaciones españolas, y son fundamentales para mantener los aprovechamientos agrícolas, así como los abastecimientos urbanos, sobre todo en el Sudeste de España. No están exentos, no obstante, de tensiones territoriales y políticas que es preciso resolver. El marco legal actual es bastante amplio, aunque está pendiente la aprobación de un nuevo Plan Hidrológico Nacional que regule de manera definitiva el funcionamiento de estas infraestructuras estratégicas.

\section{BIBLIOGRAFÍA}

CEDEX. (2008).

http://hispagua.cedex.es/sites/default/files/especiales/Trasvases\%20Africa/espan a1.html

Melgarejo, J., Molina, A., \& Del Villar, A. (2010). El Valor socioeconómico del Trasvase Tajo-Segura: análisis jurídico y económico ante la hipótesis de su reducción o cancelación. Confederación Empresarial de la Provincia de Alicante \& Fundación Agua y Progreso, Alicante.

Melgarejo, J., Molina, A., Lopez, M.I. (2014) El memorándum sobre el Trasvase Tajo-Segura. Modelo de resolución de conflictos hídricos, Revista Aranzadi de Derecho Ambiental, no 29.

Melgarejo, J., Molina, A. (2012) La gestión territorial de los recursos hídricos españoles: tensiones entre las fronteras físicas y administrativas, Revista Aranzadi de Derecho Ambiental, n 21.

Molina Giménez A. (2010) Derecho de los trasvases en España. Diario la Ley. http://diariolaley.laley.es/content/Documento.aspx?params=H4sIAAAAAAAEAMt MSbF1CTEAAkNjc0tTU7Wy1KLizPw8WyMDQwMDYwMLkEBmWqVLfnJIZUGqbVpi TnEqAKTosgM1AAAAWKE

Moreu, J. L. (1993). Los trasvases de recursos hidráulicos entre cuencas y el caso particular de los trasvases del Ebro Revista Jurídica de Navarra, 15.

Navarro, T. M. (2008). Las transacciones de derechos al uso del agua y su transferencia a las cuencas receptoras del Trasvase Tajo-Segura En: A. Fanlo (coord). La ordenación jurídica del trasvase Tajo-Segura, Murcia: Instituto Euromediterráneo del Agua. 


\section{ENLACES}

http://www.magrama.gob.es/es/agua/legislacion/

http://www.scrats.es/

https://www.mct.es/

https://www.chsegura.es/chs/cuenca/infraestructuras/postrasvaseTajoSegur

a/legislacion.html 


\subsection{EL TRASVASE TAJO-SEGURA: REGLAS DE GESTIÓN}

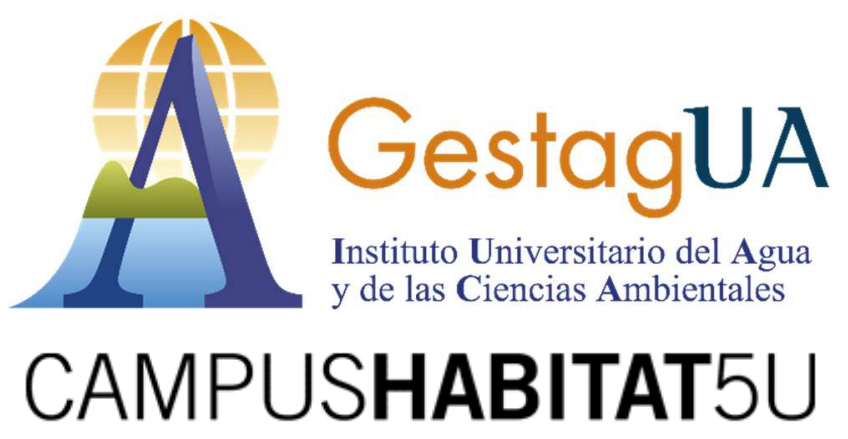




\section{INTRODUCCIÓN}

El Acueducto Tajo-Segura se ha convertido, en sus años de funcionamiento, en un instrumento vertebrador del territorio, puesto que esta vital infraestructura interconecta las cuencas del Tajo, Júcar, Segura, Guadiana y cuencas mediterráneas andaluzas, lo que facilita el transporte y distribución de los recursos. Además, ha permitido ampliar los objetivos originarios a otros fines. Es el caso del trasvase para socorro ambiental de las Tablas de Daimiel (cuenca del Guadiana).

\section{Trazado y tramos del ATS}
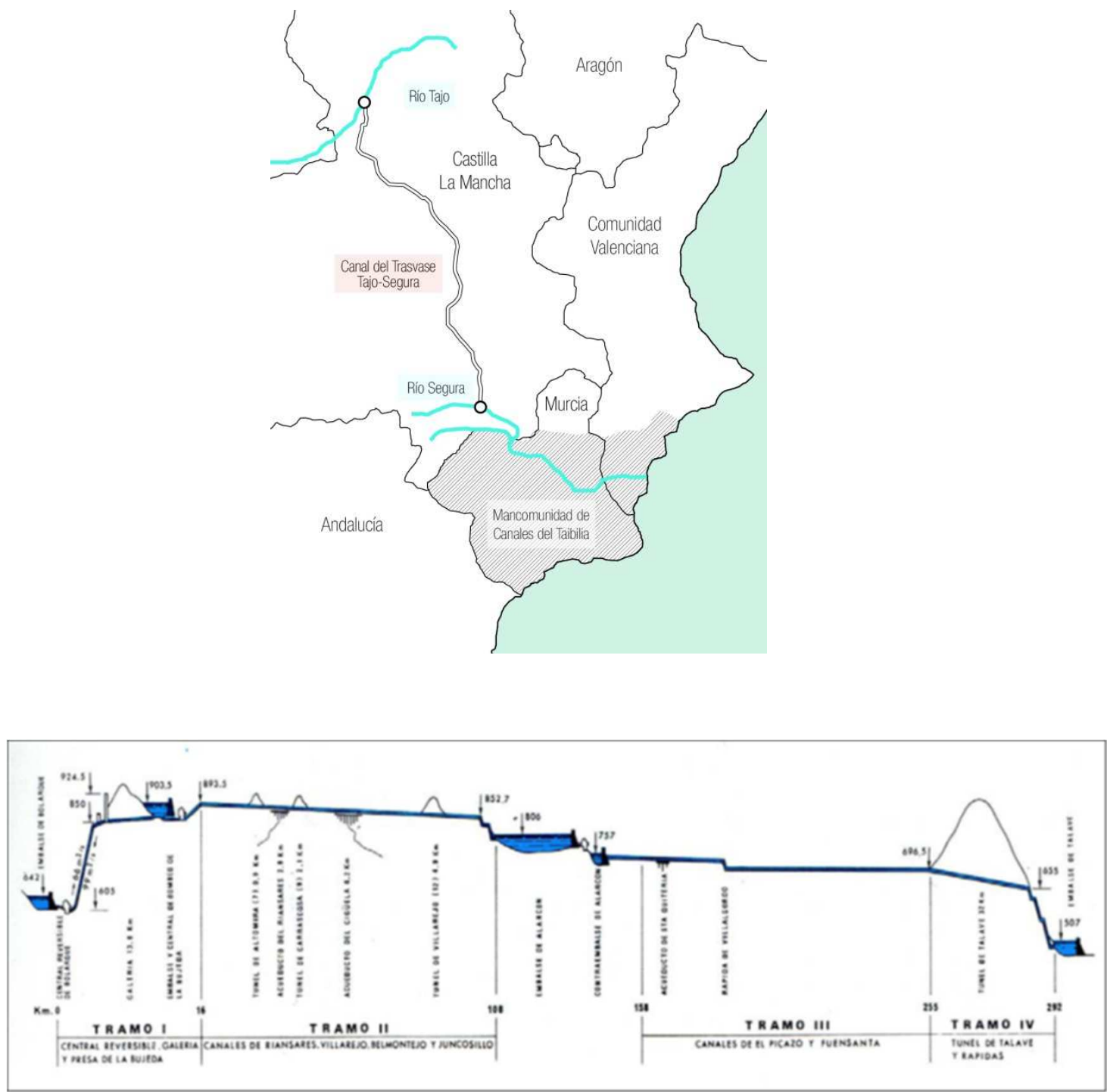


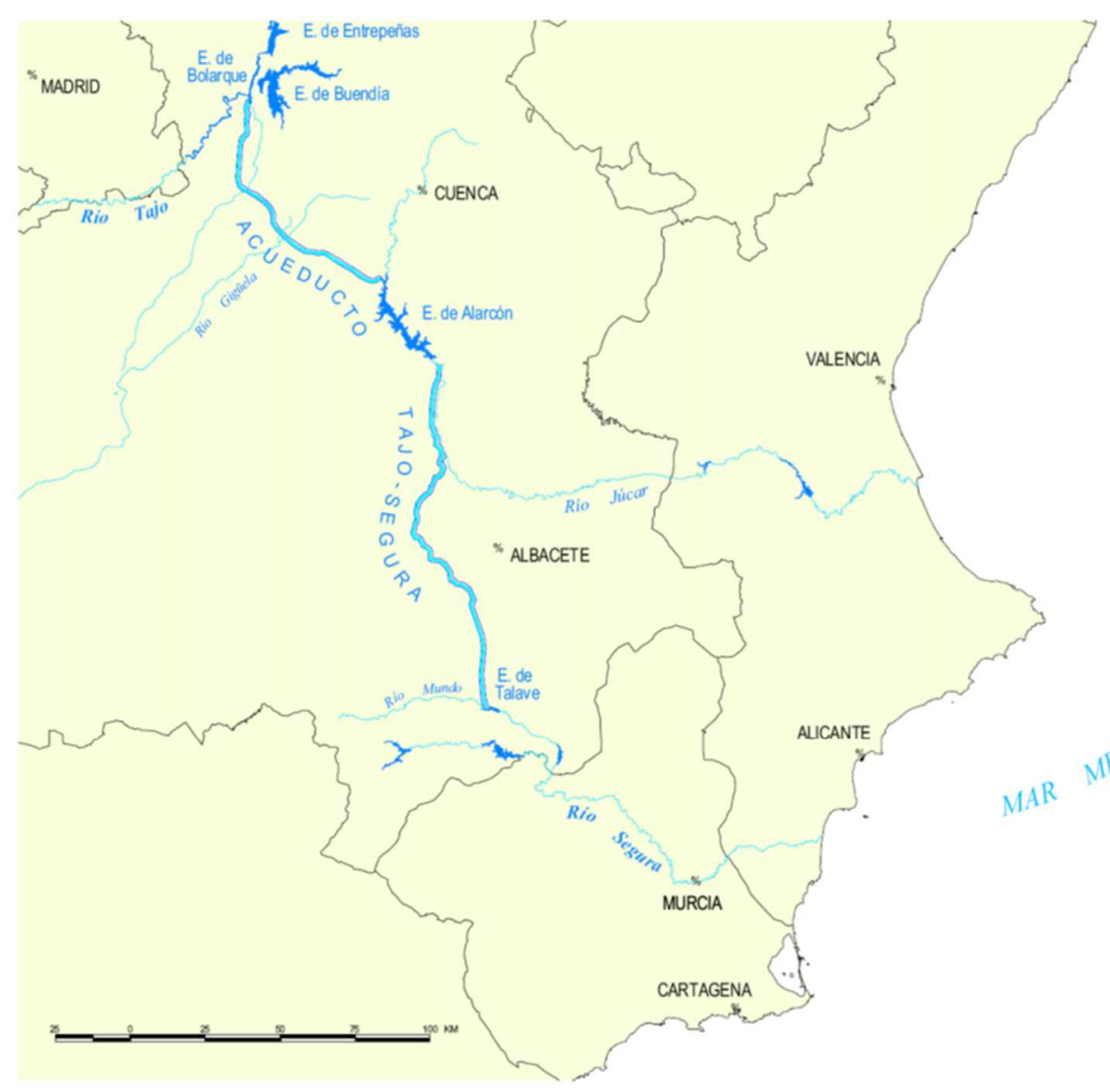

\section{REGLAS DE GESTIÓN DEL TRAVASE TAJO-SEGURA}

Las reglas de explotación se crearon con el objetivo de proporcionar pautas para reducir la discrecionalidad en la toma de decisiones sobre los desembalses. Sin embargo, su indefinición fue fuente de continuas controversias. En la figura se muestra la Regla de Explotación en su versión de 1997, que estuvo vigente hasta el 30 de septiembre de 2014. 


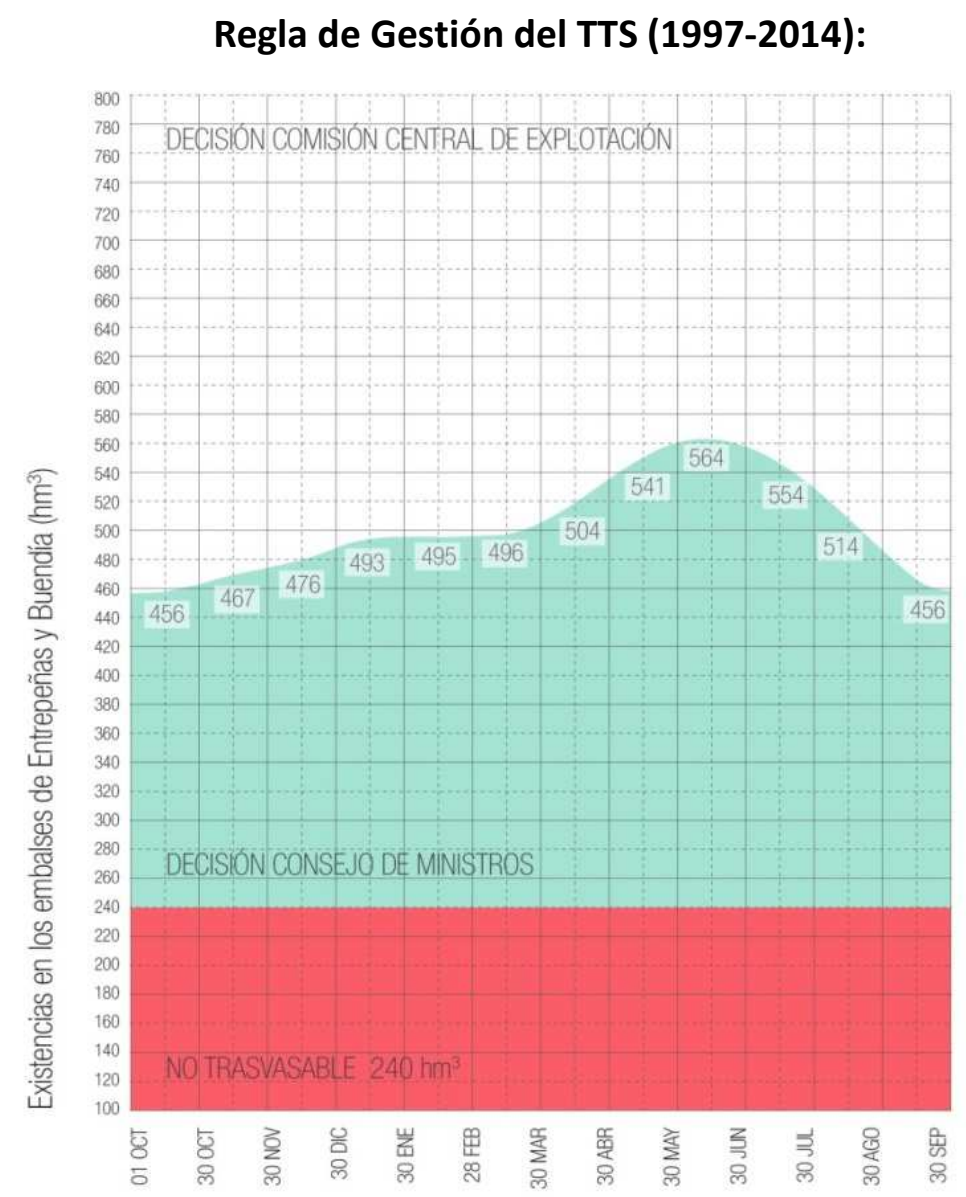

Fuente: Melgarejo, 2009. Elaboración propia.

Ante la inseguridad jurídica y técnica que atenazaba al TTS, el Gobierno introdujo a través de la Ley de Evaluación Ambiental (LEA), una serie de modificaciones en la legislación de aguas con el objeto de establecer un régimen de garantías de funcionamiento futuro de la infraestructura. La iniciativa parte del llamado Memorándum del trasvase Tajo-Segura, documento acordado entre el Gobierno de la Nación y el de las comunidades autónomas de Murcia y Valencia, y al que en una fase posterior se adhirieron las comunidades de Castilla-La Mancha, Madrid y Extremadura.

En la LEA, los antiguos tres niveles de decisión quedan redistribuidos en cuatro, con importantes modificaciones, y siempre atendiendo al máximo total trasvasable en cada año hidrológico de $650 \mathrm{hm}^{3}$ (600 para el Segura y 50 para el Guadiana). Se contempla asimismo la posibilidad de que mediante real decreto se puedan modificar los volúmenes de existencias y de aportaciones del Nivel 1, los volúmenes de trasvase mensual de los Niveles 1,2 y 3, así como los volúmenes de existencias 
para el Nivel 3. Todo ello al objeto de facilitar la posible modificación de estos valores si en el futuro se estimara necesario técnicamente, y sin tener que acudir para ello a una más complicada modificación legal. De hecho, así ha sido, ya que estos niveles fueron reestructurados por el Real Decreto 773/2014, de 12 de septiembre. En el artículo 1 del Decreto se recogen las nuevas Reglas de explotación del Trasvase.

\section{Reglas de Explotación del trasvase Tajo-Segura (2014):}

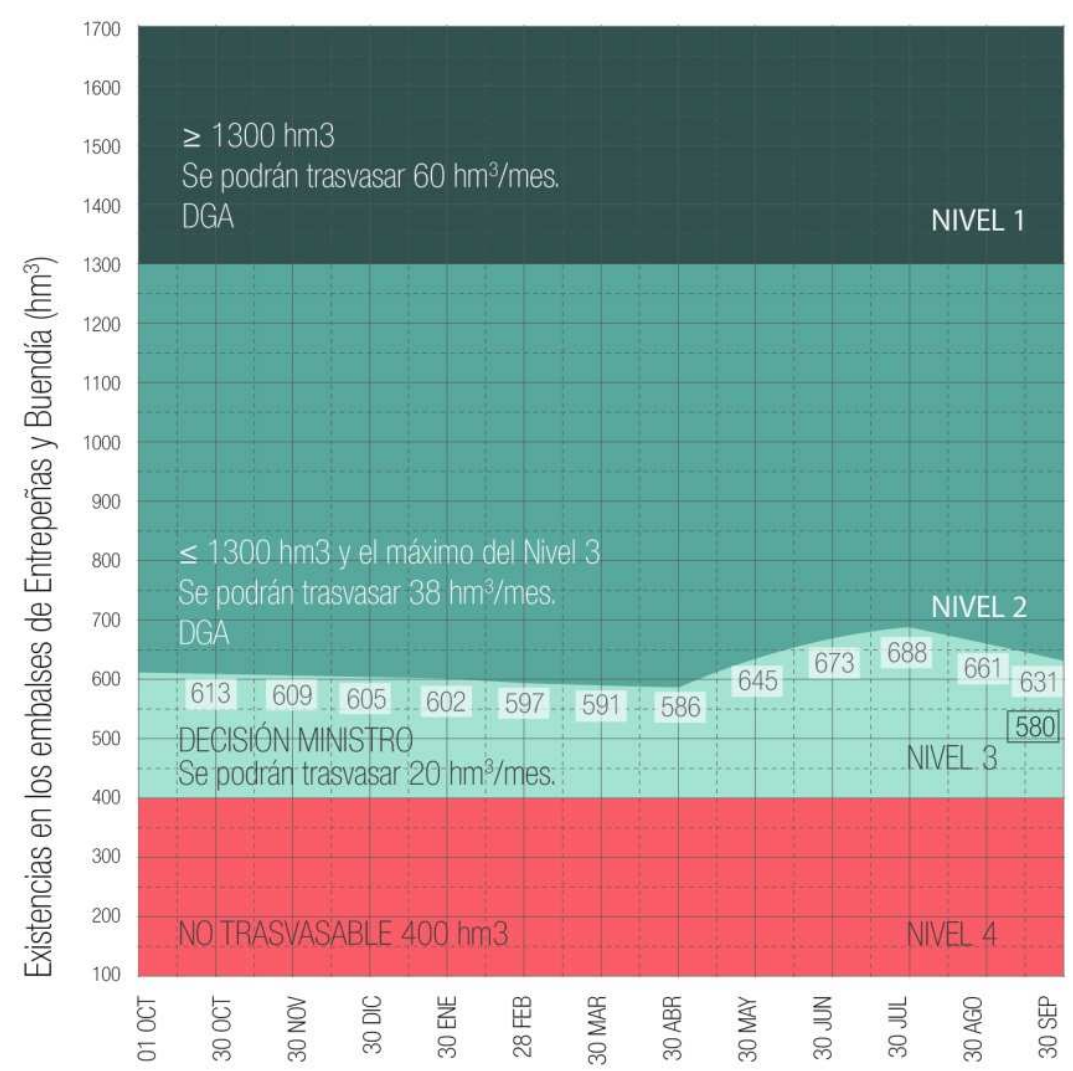

Fuente: Melgarejo et al., 2014. Elaboración propia.

En la nueva Regla se observan algunas diferencias entre los volúmenes previstos a trasvasar para los distintos niveles aprobados en la LEA y el Real Decreto 773/2014. En primer término, tanto en el Nivel 1 como 2 hay alteraciones en el volumen de existencias conjuntas en los embalses de cabecera y el volumen de las entradas. Respecto a las existencias, de $1.500 \mathrm{hm}^{3}$ pasamos a $1.300 \mathrm{hm}^{3}$, lo que resulta más favorecedor del trasvase. Sin embargo, las aportaciones requeridas para que se den ambos niveles suben desde los $1.000 \mathrm{hm}^{3}$ de la Ley a los $1.200 \mathrm{hm}^{3}$ 
del Decreto, lo que resulta algo más restrictivo. En cuanto a las cantidades a trasvasar en cada nivel, se opta por reducir en el Nivel 1 los $68 \mathrm{hm}^{3}$ mensuales previstos en la LEA hasta los $60 \mathrm{hm}^{3}$, manteniéndose la misma cantidad $\left(38 \mathrm{hm}^{3}\right)$ en el nivel 2. El agua que se puede trasvasar en cada Nivel no sólo no ha aumentado, sino más bien se ha reducido en uno de los niveles, aunque sin demasiada trascendencia práctica.

En ningún caso, además, se pueden superar los $650 \mathrm{hm}^{3}$ en cada año hidrológico (600 para el Segura y 50 para el Guadiana). Para mayor claridad, veamos con detalle cómo quedan definidos ambos niveles:

Nivel 1. Se dará cuando las existencias conjuntas en Entrepeñas y Buendía sean iguales o mayores que $1.300 \mathrm{hm}^{3}$, o cuando las aportaciones conjuntas entrantes a estos embalses en los últimos doce meses sean iguales o mayores que $1.200 \mathrm{hm}^{3}$. En este caso el órgano competente autorizará un trasvase mensual de $60 \mathrm{hm}^{3}$, hasta el máximo anual antes referido.

Nivel 2. Se dará cuando las existencias conjuntas de Entrepeñas y Buendía sean inferiores a $1.300 \mathrm{hm}^{3}$, sin llegar a los volúmenes previstos en el Nivel 3, y las aportaciones conjuntas registradas en los últimos doce meses sean inferiores a $1.200 \mathrm{hm}^{3}$. En este caso el órgano competente autorizará un trasvase mensual de $38 \mathrm{hm}^{3}$, hasta el máximo anual antes referido.

En la concreción de los volúmenes a trasvasar en este segundo nivel fue donde se vivieron los momentos más tensos de la negociación. Se preveía en un principio una reducción de 38 a $32 \mathrm{hm}^{3} /$ mes con respecto a lo previsto en la LEA, es decir un descenso anual de $72 \mathrm{hm}^{3}$, cantidad inaceptable para la cuenca receptora en su conjunto, que hizo que las negociaciones estuvieran a punto de fracasar. Finalmente fue rectificado en las horas previas a su aprobación por el Consejo Nacional del Agua manteniendo las cantidades previstas en la Ley, y por tanto el envío de $38 \mathrm{hm}^{3} /$ mes para el Nivel 2 .

Se consagra en los Niveles 1 y 2 un auténtico derecho al trasvase, lo que presenta una gran trascendencia y un cambio radical en la situación jurídica de los usuarios, al establecerse que, cuando concurran las condiciones hidrológicas fijadas para cada uno de ellos, deberá trasvasarse un volumen mensual determinado para los niveles 1 y 2 siempre con el máximo de los 600 $\mathrm{hm}^{3}$ anuales. El envío de esos recursos es imperativo en la Ley, a diferencia de lo que ocurría en las anteriores Reglas de Explotación, donde la expresión utilizada: "se podrá autorizar", llevó al Tribunal Supremo a negar un auténtico derecho al trasvase (STS 27-01-2009), quedando el mismo como una simple expectativa a merced de la discrecionalidad del órgano decisorio. 
Nivel 3. Se dará cuando las existencias conjuntas en Entrepeñas y Buendía no superen, a comienzos de cada mes, los valores mostrados en la siguiente tabla (valores en $\mathrm{hm}^{3}$ ):

\begin{tabular}{|c|c|c|c|c|c|c|c|c|c|c|c|}
\hline Oct. & Nov. & Dic. & Ene. & Feb. & Mar. & Abr. & May. & Jun. & Jul. & Ago. & Sep. \\
\hline 613 & 609 & 605 & 602 & 597 & 591 & 586 & 645 & 673 & 688 & 661 & 631 \\
\hline
\end{tabular}

Este segmento es calificado por la ley bajo el rótulo de "situaciones hidrológicas excepcionales", y tendrá lugar cuando las existencias conjuntas en los embalses de Entrepeñas y Buendía no superen, a comienzos de cada mes, los valores que se determinen por el Plan Hidrológico del Tajo vigente (2014). En este nivel, el órgano competente podrá autorizar discrecionalmente y de forma motivada un trasvase de hasta $20 \mathrm{hm}^{3} /$ mes. La concreción de una cantidad máxima contribuye a reducir la discrecionalidad en este segmento. Sin embargo, aquí se ha producido una diferencia significativa, ya que de acuerdo con la LEA se podía llegar a trasvasar hasta $23 \mathrm{hm}^{3} /$ mes, mientras que el Decreto reduce esta cantidad en $3 \mathrm{hm}^{3} /$ mes, lo que supone una reducción total de $36 \mathrm{hm}^{3} /$ año.

El órgano competente para decidir los trasvases en esta situación ya no será, como hasta ahora, el Consejo de Ministros, sino el Ministro de Agricultura, o el que en el futuro tenga la competencia sobre aguas. Además, podrá actuar con un amplio margen de discrecionalidad, mediante una decisión motivada y fundada en los informes técnicos correspondientes, dada la situación excepcional de las reservas. Los acuerdos de trasvase, en el caso de los Niveles 1 y 2 , se realizarán preferentemente por semestres, mientras que en el caso del Nivel 3 lo serán preferentemente por trimestres, salvo que el órgano competente justifique la utilización de plazos distintos. Con ello se ha pretendido lograr una mayor previsibilidad en la planificación.

Nivel 4. Se dará esta situación cuando las existencias conjuntas en Entrepeñas y Buendía sean inferiores a $400 \mathrm{hm}^{3}$, en cuyo caso no cabe aprobar trasvase alguno salvo que una norma legal de urgencia, un real decreto-ley, lo autorizase de forma excepcional, como ya ha ocurrió en 1995. El nuevo umbral de aguas no trasvasables pretende garantizar, en el horizonte temporal de la planificación hidrológica, las demandas actuales y futuras de todos los usos y aprovechamientos de la cuenca cedente, incluidos los requerimientos y restricciones medioambientales, dependientes del sistema de la cabecera del Tajo. La garantía es extensible a los caudales ambientales que deben asegurar el buen estado de las aguas en cumplimiento de la Directiva Marco del Agua.

Los volúmenes cuyo trasvase haya sido autorizado se distribuirán entre abastecimientos y regadíos, en la proporción de un $25 \%$ para abastecimiento y 
el 75\% restante para regadío, hasta el máximo de sus dotaciones anuales, y asegurando siempre al menos $7,5 \mathrm{hm}^{3} /$ mes (90 $\mathrm{hm}^{3} /$ año) para los abastecimientos urbanos. Esta medida da satisfacción al apartado 30 de la cláusula segunda del Memorándum: "revisión de la cuestión de las menores pérdidas y de su regulación jurídica, considerando su posible asignación parcial o total a los regadíos ante las nuevas circunstancias de abastecimiento urbano, y la posible proporcionalidad en la asignación a los usos". Se trata de una conquista de los regantes, ya que hasta este momento la MCT percibía en cualquier caso $110 \mathrm{hm}^{3} /$ año del Trasvase, como mínimo, como consecuencia de que el abastecimiento es prioritario en nuestro ordenamiento (Melgarejo et al., 2014).

\section{CONCLUSIONES}

Ante la inseguridad jurídica y técnica que atenazaba al TTS, el Gobierno ha introducido a través de la Ley de Evaluación Ambiental (LEA), una serie de modificaciones en la legislación de aguas con el objeto de establecer un régimen de garantías de funcionamiento futuro de la infraestructura. El Memorándum sobre el TTS, ejemplo muy destacable de gobernanza del agua, es un pacto político que pretende impulsar la planificación hidrológica del Tajo y de las demarcaciones del Júcar y Segura, dando con ello seguridad jurídica y estabilidad institucional a los regadíos y abastecimientos que actualmente dependen del Trasvase, y respetando en todo caso la prevalencia de las demandas en la cuenca cedente que tienen lógicamente carácter prioritario. El Memorándum recoge expresamente que el mantenimiento del trasvase Tajo-Segura y de una actividad agraria segura y sostenible constituye un objetivo estratégico y socioeconómico fundamental para el Estado, cuya permanencia debe quedar garantizada.

La tramitación de la Ley 21/2013, de 9 de diciembre, de Evaluación Ambiental (LEA) sirvió de vehículo para la adopción de parte de las observaciones y recomendaciones que se habían elaborado a partir del Memorándum. Como resultado de estas enmiendas, se introducen en la LEA una serie de modificaciones relativas a los trasvases intercuencas en general, y particularmente, al funcionamiento del trasvase Tajo-Segura. En definitiva, el Memorándum ha sido un ejercicio de consenso y buena gobernanza del agua entre las Administraciones y actores implicados, superando una larga etapa de confrontación. Con este acuerdo se avanza en la pretensión de regular las relaciones en materia de agua desde el rigor, la transparencia y la información recíproca entre las Comunidades 
Autónomas, suponiendo por ello un importante impulso para alcanzar la necesaria planificación hidrológica nacional.

\section{BIBLIOGRAFÍA}

Embid Irujo, A. (Dir.) (2007) "Los nuevos estatutos de autonomía y el reparto de competencias sobre el agua y las obras hidráulicas entre el Estado y las Comunidades Autónomas", en Agua y territorio, Thomson-Civitas, Cizur Menor.

Melgarejo J. y López, M.I. (2009): "Historia del trasvase Tajo-Segura”, en Melgarejo J. (Dir.), El trasvase Tajo-Segura: repercusiones económicas, sociales, y ambientales en la cuenca del Segura. Ed. CAM. Alicante.

Melgarejo, J. y Molina, A. (2012): “La gestión territorial de los recursos hídricos españoles. Tensiones entre las fronteras físicas y administrativas". Revista Aranzadi de Derecho Ambiental, no 21.

Melgarejo, J. y Molina, A. y López Mạ. I. (2014): “El Memorándum sobre el trasvase Tajo Segura. Modelo de resolución de conflictos hídricos". Revista Aranzadi de Derecho Ambiental, no 29.

Melgarejo Moreno, J.; López Ortiz, Mạ I. (2015). Evolución de la planificación hidrológica en la España Democrática, 1978-2014. Agua y Derecho. Retos para el Siglo XXI. pp. 137 - 166. Thomson Aranzadi. 


\title{
2.3. FUNCIONAMIENTO ECONÓMICO Y FINANCIERO
}

\author{
Martín Sevilla Jiménez
}

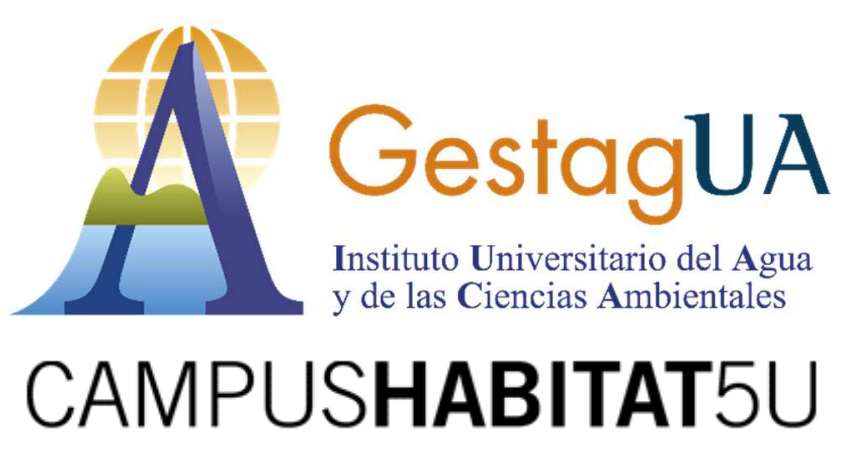




\section{INTRODUCCIÓN}

La actual Planificación Hidrológica española del agua está basada fundamentalmente en los denominados Planes de Cuenca correspondientes a cada Demarcación Hidrográfica donde se trata de equilibrar las demandas actuales y futuras de cada demarcación con los recursos de que dispone. Sin embargo, la solución a los déficits de recursos que puedan presentar algunos de estos Planes de Cuenca están encomendados al Plan Hidrológico Nacional que, según el art. 45 de la actual Ley de Aguas de 1985, debe ser aprobado por Ley. A este respecto, la Ley aplicable a esta cuestión es la Ley 10/2001 de 5 de julio del Plan Hidrológico Nacional, con las modificaciones posteriores introducidas.

Si bien el Plan Hidrológico Nacional elude la palabra "trasvase" (solamente aparece en la mención que se hace al "Trasvase Tajo-Segura"), utilizando la posiblemente menos conflictiva de "transferencias", este concepto es esencial para entender la solución adoptada sobre el equilibrio hídrico en España especialmente para las zonas deficitarias.

Una cuestión clave para entender el papel encomendado al Plan Hidrológico Nacional es la del concepto de "déficit". En la gestión de las aguas, este concepto está referido a los desequilibrios que se han ido generando entre las disponibilidades reales o potenciales de aguas (tanto superficiales, subterráneas o de otra índole) y los derechos otorgados por los responsables de la Administración Hidráulica a los distintos usuarios. El desconocimiento histórico sobre la capacidad real que tenían los distintos sistemas hidráulicos para atender a todas las demandas que se producían tanto para el regadío como para el abastecimiento de las poblaciones o para su utilización en la generación de hidroelectricidad, posibilitó que, antes de la Ley de Aguas de 1985 se pudiera dar un mayor volumen de derechos que las disponibilidades de recursos.

La solución a esta problemática solo puede darse mediante tres alternativas: o bien la disminución de los derechos otorgados, mediante la correspondiente indemnización a los usuarios (con la correspondiente conflictividad sobre su aplicación y efectos económicos y sociales), o bien mediante la transferencia de recursos entre las distintas Demarcaciones Hidrográficas o, por último, mediante las aportaciones de recursos no convencionales, como se ha hecho mediante el Plan Agua y la construcción de desalinizadoras. 
Es evidente que cada una de las distintas alternativas presentas costes diferentes, aunque ahora vamos a referirnos solamente a la alternativa de las "transferencias" de recursos entre las distintas Cuencas.

\section{EL MARCO NORMATIVO DE LAS TRANSFERENCIAS DE RECURSOS HÍDRICOS A LOS EFECTOS DE SU FUNCIONAMIENTO ECONÓMICO-FINANCIERO}

Las disposiciones generales acerca del tratamiento económico de las transferencias de los recursos hídricos están recogidas en el artículo 12.3 de la Ley 10/2001 del Plan Hidrológico Nacional que precisa que: "Las transferencias previstas en esta Ley deberán someterse igualmente al principio de recuperación de costes, de acuerdo con los principios de la Ley de Aguas y de la normativa comunitaria."

Se puede deducir de esta redacción que el tratamiento que se le da a la cuestión de las transferencias de recursos hídricos respecto a su funcionamiento económicofinanciero no difieren de las que se aplican a otros aspectos de las inversiones y gestión de los recursos hídricos, (mediante las tarifas y cánones recogidos en el artículo 114 de la Ley de Aguas), por lo que no se deberían de dar mayores problemas.

Sin embargo, como se recoge en el Libro Blanco del Agua (apartado 3.7.3, p.408 y sig.), en la actualidad existen numerosas transferencias de recursos entre distintas cuencas con regímenes específicos en cada caso desde el punto de vista económicofinanciero. En este caso se mencionan los relativos al Trasvase Guadiaro-Guadalete, Tajo-Guadiana, Campo de Tarragona, o abastecimiento a Mallorca, aunque hay algunos más, con un tratamiento singular en cada caso respecto a los costes que se recuperan y los cánones y tarifas que aplican. En el propio Libro Blanco se planteó esta cuestión, llegándose a la conclusión de que "no existe una denominación común para los pagos por las transferencias de agua (tarifa de conducción del agua, canon de trasvase, canon), lo que induce una indeterminación nominal y jurídica que puede ser obviada mediante la planificación nacional” (p. 411).

Como hemos señalado con anterioridad, la Ley del Plan Hidrológico Nacional (posterior al Libro Blanco), no ha entrado en esta cuestión por lo que los distintos regímenes siguen funcionando con sus normas específicas. 
Directiva Marco del Agua (2000): artículo 9, recuperación de los costes de los servicios relacionados con el agua.

1. Los Estados miembros tendrán en cuenta el principio de la recuperación de los costes de los servicios relacionados con el agua, incluidos los costes medioambientales y los relativos a los recursos, a la vista del análisis económico efectuado con arreglo al anexo III, y en particular de conformidad con el principio de que quien contamina paga.

\section{EL FUNCIONAMIENTO ECONÓMICO-FINANCIERO DEL TRASVASE TAJO-SEGURA}

La mayor transferencia de aguas de España es la relacionada con el Trasvase Tajo-Segura que, a diferencia del resto dispone de una Ley específica sobre su sistema económico-Financiero: Ley 52/1980, de 16 de octubre, de Regulación del Régimen Económico de la Explotación del Acueducto Tajo-Segura.

Podemos considerar en este caso que nos encontramos ante una disposición que se adelantó a la propia DEA, al contener aspectos como las compensaciones a las cuencas cedentes que no han sido tenidas en cuenta en otros casos.

La Ley crea una tarifa concreta para esta transferencia y en su artículo 1 especifica que "La tarifa de conducción de las aguas que por excedentarias sean trasvasadas desde la cuenca del Tajo a la del Segura, según lo dispuesto en la Ley veintiuno/mil novecientos setenta y uno, de diecinueve de junio, a través del acueducto construido a este efecto, se regirá por lo dispuesto en la presente Ley y disposiciones complementarias."

Y en su artículo 7 determina cuáles son los costes a incluir, así como distribuir los mismos entre los consumos de regadíos y los de abastecimiento:

"Uno. La tarifa incluirá las aportaciones motivadas por los siguientes conceptos:

a) El coste de las obras.

b) Los gastos fijos de funcionamiento.

c) Los gastos variables de funcionamiento.

Dos. La tarifa comprende los tres valores siguientes:

a) El obtenido de repartir el coste total de las obras entre la dotación total anual definitiva asignada al conjunto de usos del agua conducida, afectado por un coeficiente [...]

b) El obtenido de repartir la previsión anual de los gastos de funcionamiento necesarios para efectuar la explotación de las obras del acueducto Tajo-Segura [...] 
c) El valor unitario obtenido en la previsión de los gastos de funcionamiento necesarios para realizar la explotación de las obras del acueducto Tajo-Segura, de carácter proporcional al volumen de agua suministrada. Dichos gastos incluyen los de adquisición del agua, consumo de energía, servidumbres de peso establecidas y cualquier otro de naturaleza análoga.

Tres. La liquidación correspondiente a cada usuario se calculará por adición de los tres valores fijados en el epígrafe anterior aplicados:

a) A la dotación concesional o comprometida, los correspondientes al coste de las obras.

b) A la dotación concesional o comprometida, los correspondientes a los gastos de funcionamiento independientes del volumen de agua suministrada.

c) Al consumo realmente producido, los correspondientes a los gastos de funcionamiento proporcionales al volumen de agua suministrada."

Si bien la determinación de estas tarifas ha estado sujeta a varios litigios respecto a los montantes a considerar, su aplicación ha estado vigente hasta la actualidad.

Esta tarifa, ingresada por la Confederación Hidrográfica del Segura, también ha posibilitado las compensaciones hacia la cuenca cedente que se ha repartido entre las Comunidades Autónomas por las que discurre el río Tajo que han supuesto desde 1980 un valor actualizado de 418 millones de euros desde aquella fecha hasta la actualidad.

\section{LAS TARIFAS ACTUALES DEL TRASVASE TAJO-SEGURA}

La existencia de esta infraestructura ha posibilitado adicionalmente que varias zonas y abastecimientos que originalmente no estaban incluidos en el mismo (como el caso de los abastecimientos urbanos a Albacete), se hayan incorporado, dando lugar a su inclusión, así como también al transporte de aguas de uno a otro lugar de las concesiones (las denominadas "aguas de peaje"), con lo que el nuevo Cuadro de Tarifas es mucho más amplio que el inicial.

En el cuadro siguiente se incluyen las tarifas aplicadas del Trasvase para los usuarios del Acueducto Tajo-Segura, aplicadas durante los ejercicios de 2013 y 2014, cuya fuente es la memoria 2014 del Sindicato Central de Regantes del Acueducto Tajo-Segura (SCRATS): 


\begin{tabular}{|c|c|c|}
\hline ANO & 2013 & 2014 \\
\hline \multirow[t]{2}{*}{ Perlodo de Vigencia } & $\begin{array}{c}29 / 11 / 2013 a \\
28 / 11 / 2014\end{array}$ & $29 / 11 / 2014$ \\
\hline & $\operatorname{ctm} . \epsilon / \mathrm{m}^{3}$ & $\operatorname{ctm} . \epsilon / \mathrm{m}^{3}$ \\
\hline \multicolumn{3}{|l|}{ TARIFA TRASVASE RIEGOS } \\
\hline Coste Obra & 1,4774 & 1,5388 \\
\hline Gastos fijos & 1,8707 & 1,2130 \\
\hline Gastos Variables & 6,4964 & 6,9800 \\
\hline Total Tarifa Trasvase $\left(\mathrm{ctm} . \in / \mathrm{m}^{3}\right) \ldots$ & 9,8445 & 9,7318 \\
\hline \multicolumn{3}{|c|}{ TARIFA TRASVASE ABASTECIMIENTOS } \\
\hline Coste Obra & 4,1568 & 4,2796 \\
\hline Gastos fijos & 1,2354 & 0,0628 \\
\hline Gastos Variables & 6,1846 & 5,5739 \\
\hline Total $\left(\mathrm{ctm}, \mathrm{e} / \mathrm{m}^{2}\right)$.......................... & 11,5768 & 9,9163 \\
\hline \multicolumn{3}{|l|}{ TARIFA PEAJE RIEGOS } \\
\hline Coste Obra & 0,5611 & 0.5597 \\
\hline Gastos fijos & 0,0000 & 0,4481 \\
\hline Gas tos Variables & 4,4142 & 0,9786 \\
\hline Total Peaje $\left(\mathrm{ctm}, \mathrm{C} / \mathrm{m}^{3}\right) \ldots \ldots \ldots \ldots \ldots \ldots . . . . . . .$. & 4,9753 & 1,9864 \\
\hline \multicolumn{3}{|l|}{ TARIFA PEAJE AB ASTECIMIENTO } \\
\hline Coste Obra & 2,3242 & 2,3214 \\
\hline Gastos fijos & 0,0000 & 0,0000 \\
\hline Gastos Variables & 2,6882 & 3,1314 \\
\hline Total $\left(\mathrm{ctm}, \mathrm{E} / \mathrm{m}^{3}\right)^{2} \ldots \ldots \ldots \ldots \ldots \ldots \ldots \ldots \ldots$ & 5,0124 & 5,4528 \\
\hline \multicolumn{3}{|l|}{ TABLAS DE DAIMIEL } \\
\hline Coste Obra & 0,0000 & 0,0000 \\
\hline Gastos fijos & 0,2724 & 1,3959 \\
\hline Gastos Variables & 6,2743 & 5,7915 \\
\hline Total $\left(\mathrm{ctm}, \in / \mathrm{m}^{3}\right) \ldots \ldots \ldots \ldots \ldots \ldots \ldots \ldots$ & 6,5467 & 7,1874 \\
\hline \multicolumn{3}{|l|}{ ABASTECIMIENTOS GUADIANA } \\
\hline Coste Obra & 2,0851 & 2,1369 \\
\hline Gastos fijos & 0,1114 & 0,1118 \\
\hline Gastos Variables & 6,2743 & 5,7915 \\
\hline Total $\left(\mathrm{ctm}, \mathrm{C} / \mathrm{m}^{3}\right) \ldots$ & 8,4708 & 8,0402 \\
\hline \multicolumn{3}{|c|}{ LLANOS DE ALBACETE (COMPENSACION.) } \\
\hline Coste Obra & 0,0000 & 0,0000 \\
\hline Gastos fijos & 0,0911 & 0,0402 \\
\hline Gastos Variables & 0,0000 & 0.0000 \\
\hline Total $\left(\operatorname{ctm}, \in / \mathrm{m}^{3}\right) \ldots \ldots \ldots \ldots \ldots \ldots \ldots \ldots$ & 0,0911 & 0.0402 \\
\hline \multicolumn{3}{|c|}{ LLANOS DE ALB ACETE (SUMINISTRO.) } \\
\hline Coste Obra & 0,3113 & 0,3337 \\
\hline Gastos fijos & 0,4180 & 0,6269 \\
\hline Gastos Variables & 0,0000 & 0,0000 \\
\hline Total $\left(\mathrm{ctm}, \mathrm{e} / \mathrm{m}^{3}\right) \ldots \ldots \ldots \ldots \ldots \ldots \ldots \ldots$ & 0,7293 & 0,9606 \\
\hline \multicolumn{3}{|c|}{ AB ASTECIMIENTOS JUCAR A ALB ACETE } \\
\hline Coste Obra & 1,8246 & 1,8694 \\
\hline Gastos fijos & 0,0000 & 0,0000 \\
\hline Gas tos Variables & 0,0000 & 0,0000 \\
\hline Total $\left(\operatorname{ctm}, \epsilon / \mathrm{m}^{3}\right) \ldots \ldots \ldots \ldots \ldots \ldots \ldots \ldots \ldots$ & 1,8246 & 1,8694 \\
\hline \multicolumn{3}{|c|}{ AB ASTECIMIENTO DEL JUCAR AL SUDESTE } \\
\hline Coste Obra & 3,2886 & 3,3560 \\
\hline Gastos fijos & 2,9754 & 3,3589 \\
\hline Gastos Variables & 1,9730 & 2,2039 \\
\hline Total $\left(\mathrm{ctm}, \in / \mathrm{m}^{3}\right) \ldots \ldots \ldots$ & 8,2370 & 8,9188 \\
\hline
\end{tabular}


En el Libro Blanco del Agua se planteaba una de las consecuencias de la aplicación de estas Tarifas del Trasvase Tajo-Segura en el año 2000: “...puede concluirse que este sistema -que moviliza menos del 3\% del agua consumida en España- genera aproximadamente la quinta parte de la suma de todos los ingresos económicos que se producen en todas las Confederaciones por todos los conceptos vigentes. Tal desequilibrio no resulta en modo alguno razonable, y exige, como veremos, una profunda y radical reconsideración del problema" (p. 405). Esa reflexión no se ha tenido en cuenta posteriormente, estando en la actualidad en una situación a la descrita en el Libro Blanco.

\section{CONCLUSIONES}

La legislación española de aguas, si bien no recoge la denominación de "trasvase" (esta denominación la conserva en el caso del "Trasvase Tajo-Segura"), contempla la transferencia de aguas de una a otra Cuenca Hidrográfica a través de la Ley del Plan Hidrológico Nacional.

A pesar de la existencia de numerosas "transferencias" de agua entre las distintas Cuencas españolas, no existe una normativa específica y homogénea sobre los aspectos económico-financieros de las mismas, encontrándonos con que el mismo hecho es tratado de una forma diferente en cada caso, presentándose situaciones de trato desigual respecto a la recuperación de costes o la compensación a las cuencas cedentes que producen un trato desigual a los usuarios según su localización.

La "transferencia" que ha desarrollado con mayor precisión los conceptos de recuperación de costes y compensación a las cuencas cedentes ha sido el Trasvase Tajo-Segura que representa el $20 \%$ de los ingresos totales de las Confederaciones Hidrográficas españolas, aunque transfiere solo el $3 \%$ del agua utilizada.

\section{BIBLIOGRAFÍA}

Ministerio de Medio Ambiente (2000); Libro Blanco Del Agua. MMA

Ley 29/1985 de Aguas

Ley 10/2001 del Plan Hidrológico Nacional 
Herramientas para la gestión territorial sostenible del agua || MOOC UA

\section{ENLACES}

https://www.chsegura.es/chs/cuenca/infraestructuras/postrasvaseTajoSegur a/infraestructura01.html

http://www.scrats.es/ 


\section{MÓDULO 3}

\section{LA DESALACIÓN}




\title{
3.1. MARCO LEGAL
}

\author{
Andrés Molina Giménez
}

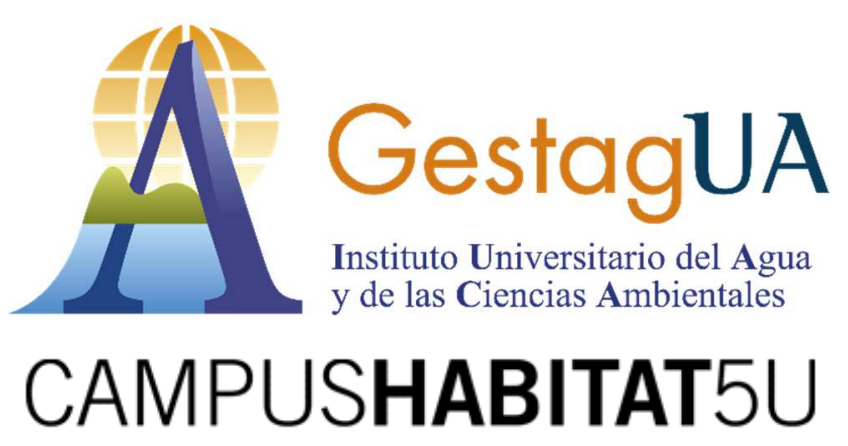




\section{INTRODUCCIÓN}

En este tema queremos clarificar conceptos básicos sobre el marco legal de la desalación en España. Esta actividad se ha desarrollado exponencialmente en España gracias a la derogación del PHN de 2001, en particular en los aspectos relacionados con el trasvase del Ebro, y la aprobación del plan AGUA, basado en la sustitución de los trasvases por desaladoras.

No cabe duda de que las desaladoras son una importante garantía en el suministro hídrico, puesto que son instalaciones que pueden funcionar durante todo el año y, cuando son de agua de mar, manejan un recurso prácticamente inagotable. Permiten también a cada cuenca ayudar a resolver sus propios déficits sin necesidad de acudir a otras demarcaciones mediante trasvases, lo que siempre genera grandes tensiones territoriales y políticas. Sin embargo, por otro lado, presentan todavía importantes retos, ya que el elevado consumo energético y el precio de la energía hacen que el metro cúbico de agua producto sea caro e inasumible para determinados usos, fundamentalmente agrarios. En el contexto del abastecimiento urbano, además, la utilización de estas aguas puede generar importantes alzas en la tarifa.

No hay un marco legal específico que regule esta actividad, a diferencia de lo que ocurre, sin embargo, con las aguas regeneradas. Sin embargo, sí que existen importantes referencias normativas que es preciso analizar.

\section{MARCO JURÍDICO DE LA DESALACIÓN}

El TRLA establece que las aguas de mar desaladas forman parte del dominio público hidráulico del Estado desde el momento en que se incorporan al continente. Es decir, una vez transformadas, las aguas de mar quedan sujetas, al igual que el resto de recursos continentales, al régimen legal común que regula el agua, es decir, la Ley de Aguas.

Artículo 2 TRLA: "Constituyen el dominio público hidráulico del Estado, con las salvedades expresamente establecidas en esta Ley: (...) e) Las aguas procedentes de la desalación de agua de mar". 
Eso determina, por ejemplo, que cualquier interesado en utilizar estas aguas deberá obtener la correspondiente concesión administrativa, conforme a los procedimientos ordinarios del TRLA (arts. 59 y ss).

Tratándose de agua subterránea salobre, toda vez que el TRLA determina que todas las aguas superficiales o subterráneas, dulces o salobres, continuas o discontinuas, son dominio público hidráulico, la captación y utilización de estas aguas, tras su desalación, quedará sujeta al régimen concesional como cualquier otro recurso continental.

Al margen de lo anterior, es importante indicar que la actividad industrial de desalación genera un subproducto, un residuo, que es la salmuera. Es decir, un porcentaje apreciable del agua originaria no se transforma en agua producto, sino que se rechaza por la planta con mucho mayor contenido en sales. Es decir, tenemos un efluente más concentrado en sales que puede ser perjudicial para el medio ambiente.

Cuando dicho efluente se vierte a aguas continentales es preciso que la planta cuente con una autorización de vertido, que debe ser otorgada por la Confederación hidrográfica en cuya demarcación se sitúe el vertido (arts. 100 y ss TRLA). En el caso de que la planta emita la salmuera directamente al mar, teniendo en cuenta que los vertidos de tierra a mar son de competencia autonómica, deberá obtenerse la autorización de vertido correspondiente ante dicha Administración.

Por otra parte, la planta en sí misma es una instalación industrial, por lo que deberá contar con los permisos preceptivos de la Administración con competencias en industria, así como las correspondientes licencias municipales de obra y actividad o ambientales. Las plantas de mayor entidad quedarán sujetas a los procedimientos de evaluación de impacto ambiental de proyectos, o autorización ambiental integrada según el caso.

A todo lo anterior habría que añadir que la planta deberá contar con todas las autorizaciones y concesiones demaniales que sean precisas de acuerdo con la Ley $22 / 1988$, de 28 de julio, de Costas, y las demás que procedan conforme a la legislación sectorial aplicable. Téngase en cuenta que las plantas de agua marina deben estar situadas cerca de la costa y disponer sus colectores tanto de captación como de vertido sobre ella o en sus proximidades, por lo que es preciso obtener las concesiones de ocupación y autorizaciones sectoriales que sean precisas con arreglo ad dicha normativa. 


\section{OTROS ASPECTOS DE SU REGULACIÓN}

El artículo 13 del TRLA regula la actividad de manera pormenorizada. Fue redactado por la disposición final tercera de la Ley 42/2007, de 13 de diciembre, del Patrimonio Natural y de la Biodiversidad. Destacamos a continuación los aspectos principales:

Las obras e instalaciones de desalación declaradas de interés general del Estado podrán ser explotadas directamente por los órganos del Ministerio de Medio Ambiente, por las Confederaciones Hidrográficas o por las sociedades estatales a las que se refiere el capítulo II del título VIII de esta Ley. Toda esta casuística se produce de hecho, ya que buena parte de las infraestructuras de desalación del programa AGUA han sido construidas y gestionadas por Acuamed.

Con la aprobación del Programa A.G.U.A., el Ministerio de Medio Ambiente cambió totalmente la política hidráulica española, optando por abandonar la política de trasvases, e incrementar el peso de las desalinizadoras. Fruto de ello, será la construcción por Acuamed, entre otras, de la desalinizadora más grande de Europa, la de Torrevieja $\left(80 \mathrm{hm}^{3}\right)$.

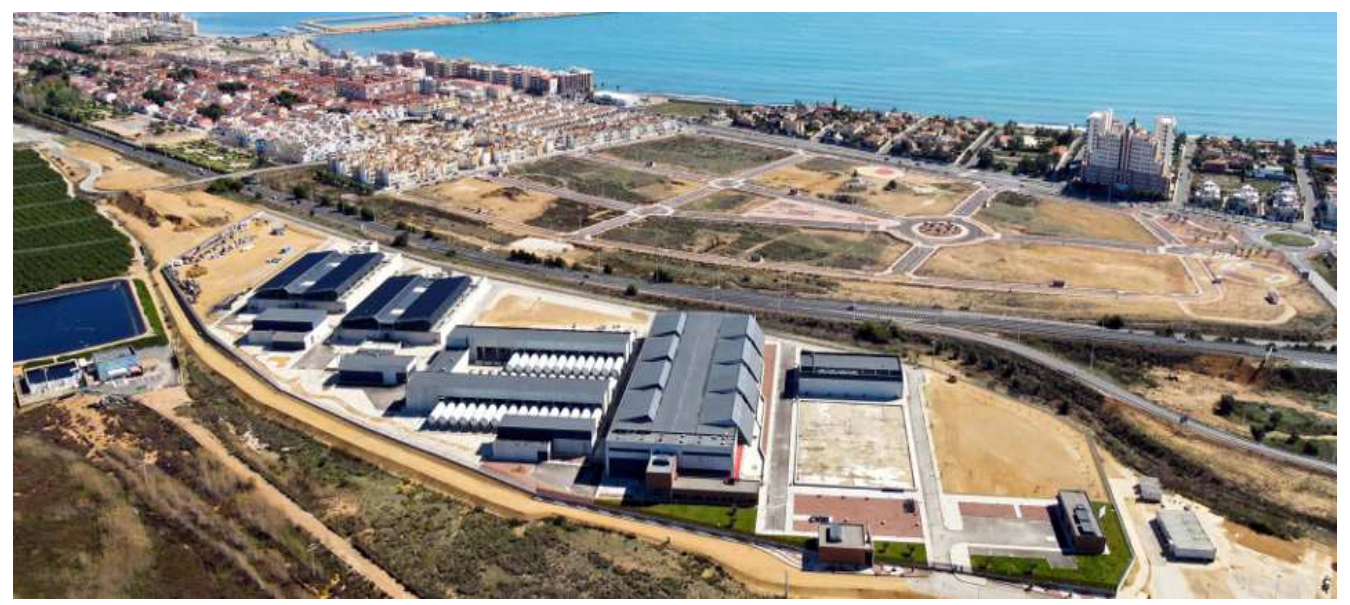

Desaladora de Torrevieja. Fuente: Acciona-Agua.

Un caso significativo es el de la Mancomunidad de Canales del Taibilla, que se encarga del suministro en alta de localidades como Murcia, Cartagena, Alicante, Elche, Orihuela o Torrevieja, entre otras (más de 2.400 .000 hab), que dispone de 4 plantas de desalación. 


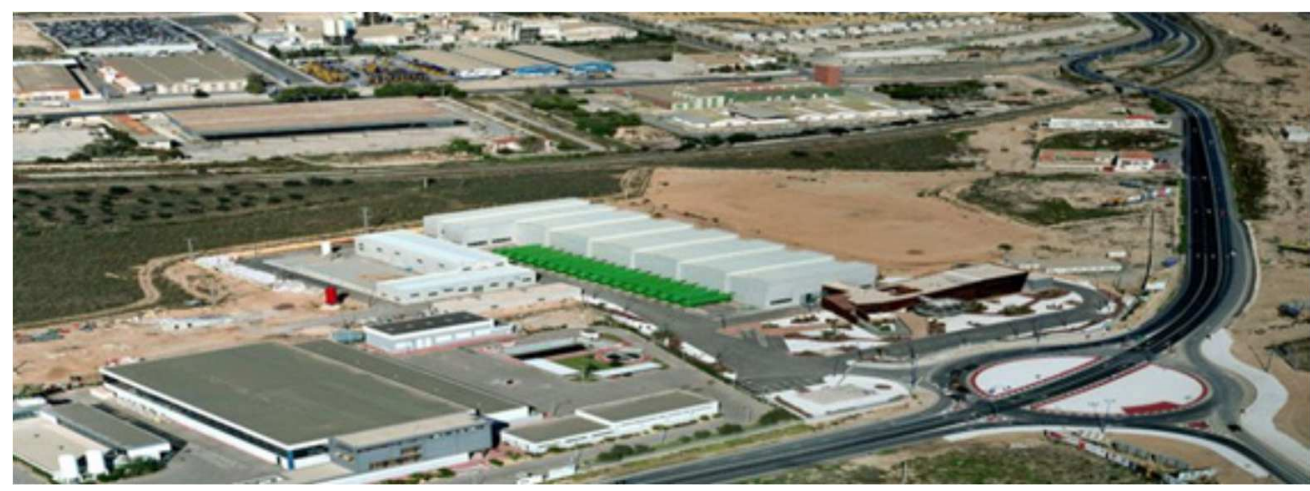

Desaladoras Alicante I y II de la MCT. Fuente: MCT.

Las aguas generadas por estas instalaciones pueden destinarse a los abastecimientos urbanos, como ocurre en gran parte de los casos, pero las comunidades de usuarios o las juntas centrales de usuarios pueden, mediante la suscripción de convenios específicos con los entes mencionados, ser beneficiarios directos de las obras e instalaciones de desalación para riego u otros usos. Estas entidades deben contar, eso sí, con la preceptiva concesión de aprovechamiento de estas aguas que debe conceder la Confederación Hidrográfica en cuyo territorio esté situada la planta.

Un aspecto muy importante es que sobre estas aguas pueden operar los centros de intercambio de derechos de agua. En concreto, el apartado 6 del precepto señala: "Los concesionarios de la actividad de desalación y de aguas desaladas que tengan inscritos sus derechos en el Registro de Aguas podrán participar en las operaciones de los centros de intercambio de derechos de uso del agua a los que se refiere el artículo 71 de esta Ley". La Ley no menciona la posibilidad de que sobre dichas aguas operen los contratos de cesión entre concesionarios, lo que supone una importante limitación.

\section{CONCLUSIONES}

La desalación es una actividad con gran potencial en España. El número y dimensión de las plantas desaladoras construidas hasta ahora convierten a este país en uno de los más importantes del mundo en estas infraestructuras. Su marco legal no presenta excesivas particularidades, al presentarse las aguas desaladas como un recurso más entre los que forman parte del dominio público hidráulico del Estado. Ello supone, sin embargo, que su titularidad sea siempre pública y que el derecho a su aprovechamiento se articule mediante concesiones a otorgar por la Administración hidráulica. El vertido de las salmueras, a su vez, precisa la autorización correspondiente. 
Herramientas para la gestión territorial sostenible del agua || MOOC UA

\section{ENLACES}

http://hispagua.cedex.es/node/61332

http://www.aedyr.com/ 


\title{
3.2. ASPECTOS TÉCNICOS Y DE GESTIÓN
}

\author{
Daniel Prats Rico
}

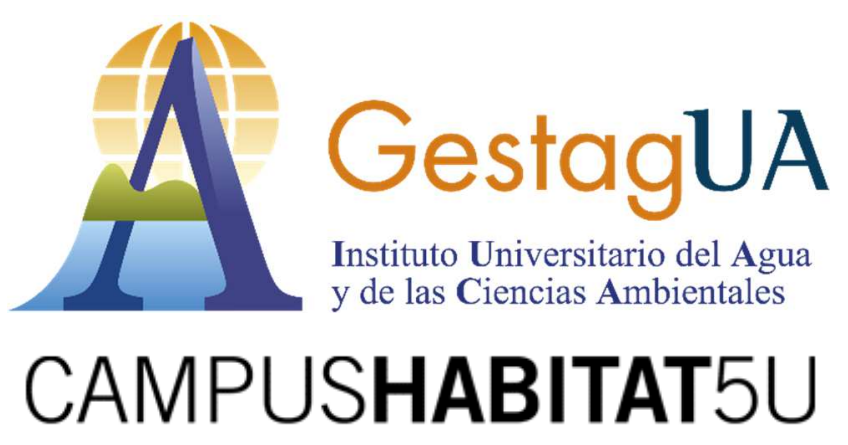


1. INTRODUCCIÓN. CONCEPTO DE DESALINIZAR (DESALAR)

Según la 23a Ed. (2014) del diccionario de la Real Academia Española, desalinización es "La acción y efecto de desalinizar" y desalinizar (desalar) es "Quitar la sal del agua del mar o de las aguas salobres, para hacerlas potables o útiles para otros fines."

Así pues, con la desalación se pretende conseguir, a partir de aguas salobres no utilizables o de agua de mar, un agua con una cantidad de sales inferior a la inicial que posibilite su utilización. Los procesos industriales, que no buscan la obtención por separado de las sales, se pueden esquematizar como se muestra en la figura 1.

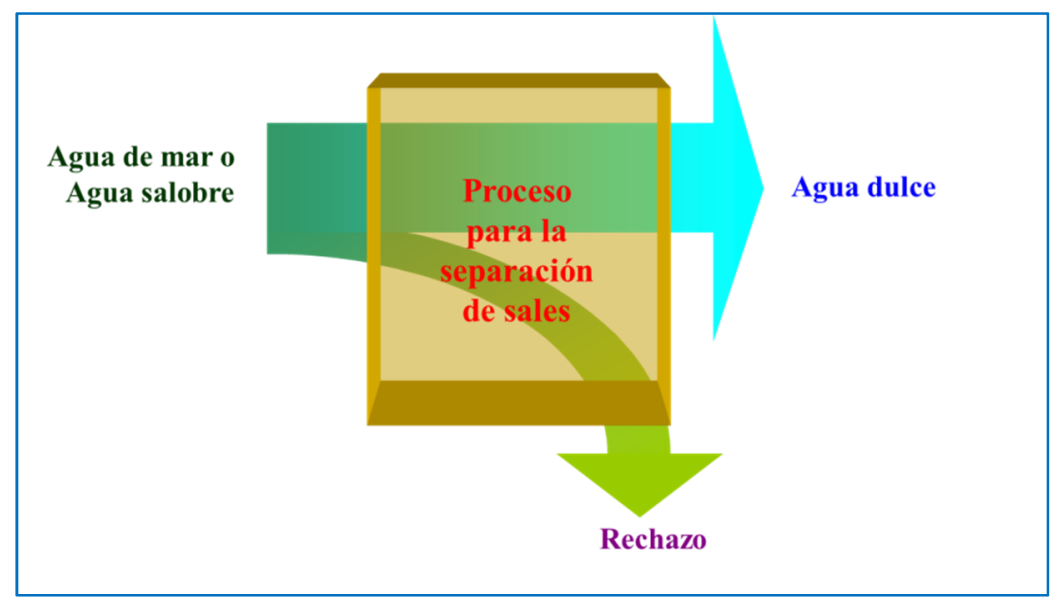

Figura 1. Esquema simplificado del proceso de desalación (fuente: elaboración propia)

Tal como se observa en la figura, a partir de una corriente de agua de mar o agua salobre se obtienen dos corrientes, una de ellas de agua dulce utilizable y otra de rechazo o salmuera, que contiene la mayoría de las sales de la corriente original

\section{PROCEDIMIENTOS PARA REALIZAR LA DESALINIZACIÓN}

Es muy importante señalar que para separar las sales que están disueltas en una solución salina es imprescindible aportar una cierta cantidad de energía, que, al menos, debe ser equivalente a la energía mínima que se desprende al disolver dichas sales en agua pura. Los consumos mínimos son del orden de $0,88 \mathrm{kWh} / \mathrm{m}^{3}$ para agua de mar de $35 \mathrm{~g} / \mathrm{L}$ de sales, y de $0,30 \mathrm{kWh} / \mathrm{m}^{3}$ para aguas salobres de 15 g/L. En la práctica los consumos son mucho mayores, de 3 a 20 veces, según la 
técnica y diseño aplicado. Aunque estos consumos energéticos se han reducido sustancialmente en los últimos años, siguen representando actualmente el principal problema con el que se enfrenta la desalación.

La necesidad de aproximar los consumos reales a los mínimos teóricos ha sido una de las principales motivaciones para los avances tecnológicos que se han experimentado en este campo desde el inicio de la desalación a gran escala industrial, hace unos 50 años. Se debe indicar que el avance científico en las técnicas empleadas y el constante incremento de instalaciones en todo el mundo, permiten que cada vez sea más fiable y económicamente atractivo la obtención de caudales de agua dulce mediante desalación.

Actualmente se emplean varias tecnologías para la separación de las sales, basadas en dos formas distintas de realizar dicha separación:

- Los procesos de evaporación en los que la separación de las sales se realiza mediante evaporación y condensación del agua, imitando el ciclo del agua en la naturaleza.

- Los procesos de membrana que emplean membranas semipermeables que actúan como barreras selectivas a las sales disueltas, o membranas intercambiadoras de iones.

En la figura 2 se muestran esquemáticamente estos procesos

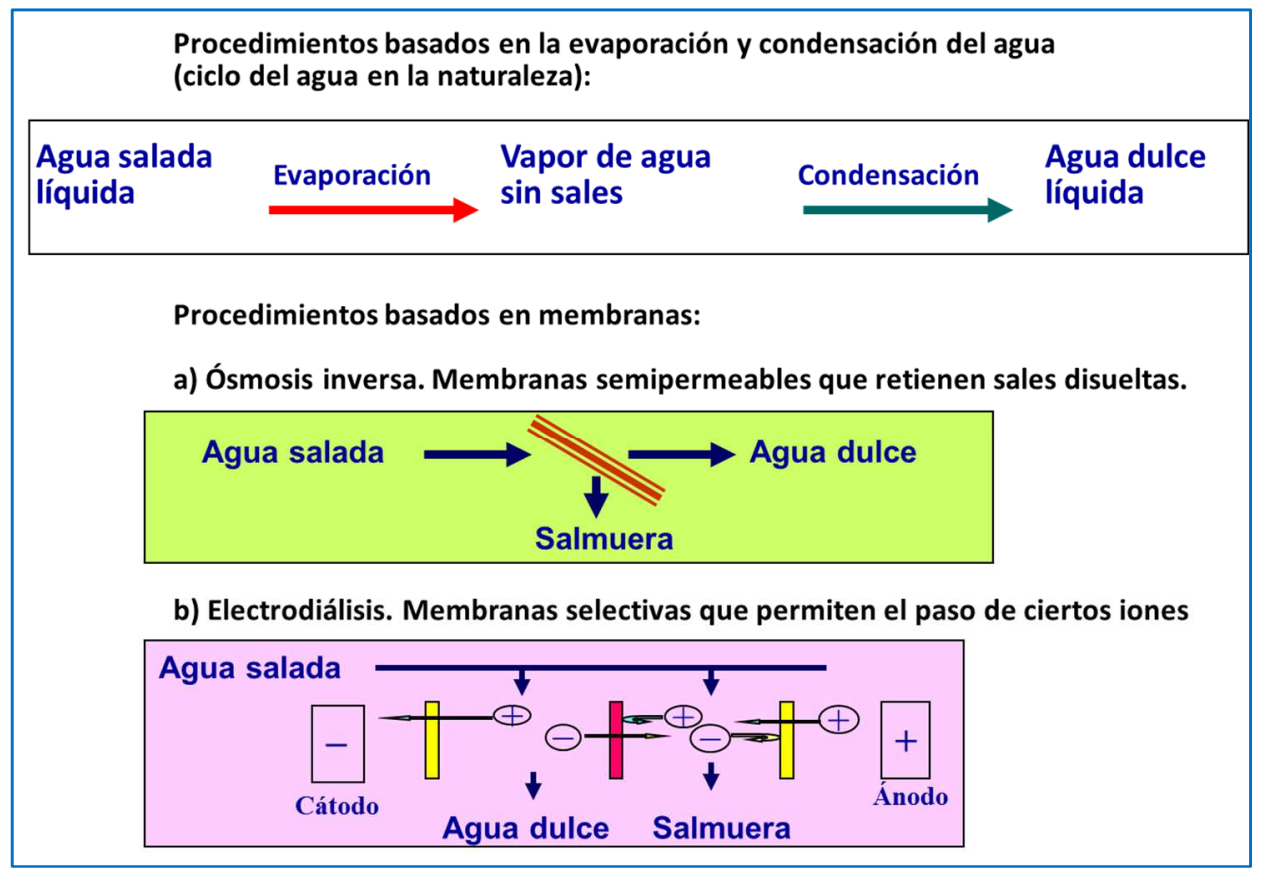

Figura 2. Procedimientos para la desalinización (fuente: elaboración propia) 
Las técnicas de evaporación consisten en evaporar agua de la solución con sales y condensar el vapor resultante como agua dulce producto. Existen diversas técnicas que se diferencian fundamentalmente en la forma de recuperar la energía que se emplea para la evaporación. Las principales son evaporación súbita multietapa, destilación de múltiple efecto (MED) y destilación con compresión de vapor (VC). Además, cabe mencionar la destilación solar, cuya fuente de energía es exclusivamente la radiación solar.

Las técnicas de membrana son la ósmosis inversa, que emplea membranas semipermeables que retienen sales disueltas, y la electrodiálisis, que emplea membranas selectivas que retienen o permiten el paso de iones en función de su carga electrostática.

El consumo energético de los procesos de membranas es significativamente menor que el necesario en los de evaporación, por lo que en esta lección nos referiremos exclusivamente a la tecnología más empleada, que es la ósmosis inversa.

\section{PROCESO DE DESALINIZACIÓN POR ÓSMOSIS INVERSA}

Se entiende por ósmosis natural el fenómeno por el cual se produce el paso de disolvente pero no de soluto entre dos disoluciones de distinta concentración separadas por una membrana semipermeable (membranas que permiten el paso de agua a su través del agua y limitan el paso de las sales disueltas), sin consumo de energía exterior. Este flujo de difusión es debido a la diferencia de concentraciones del soluto a ambos lados de la membrana, que provoca una diferencia de potencial químico.

El fundamento de la ósmosis se puede entender observando la figura 3, en la que un recipiente con agua dulce se pone en contacto a través de una membrana semipermeable con otro recipiente que contiene una solución concentrada en sales. 


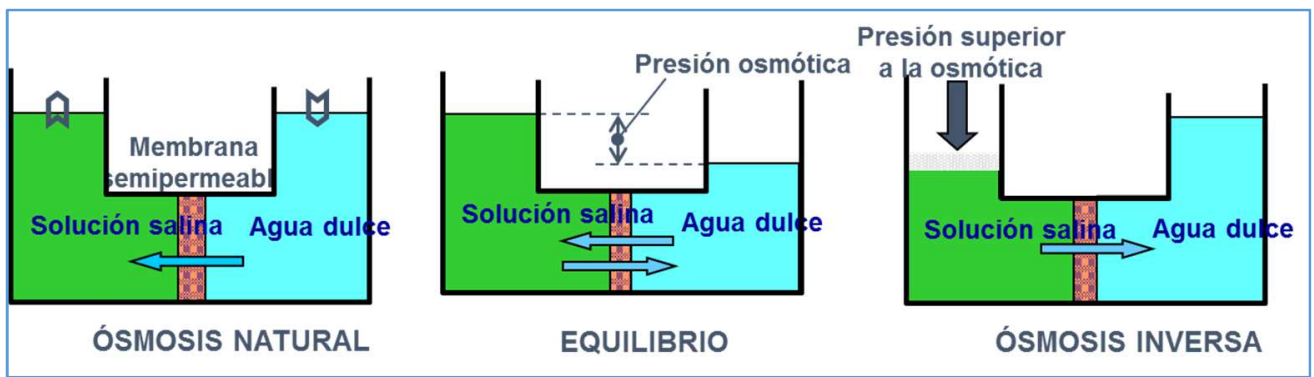

Figura 3. Ósmosis inversa (fuente: elaboración propia)

Inicialmente el potencial químico (que es una medida de la energía interna de un sistema) del agua dulce es mayor que el de la solución salina, por lo que el agua tenderá a pasar hacia la solución con sales, produciéndose el fenómeno de ósmosis natural (figura izquierda), diluyéndola, y aumentando su potencial químico. Las alturas en cada recipiente se van desequilibrando, la presión hidrostática de la solución salina aumenta y la presión hidrostática del lado del agua dulce disminuye, con lo que los potenciales químicos se van igualando. El flujo neto entre ambas soluciones se hace igual a cero cuando se alcanza el equilibrio osmótico, es decir, cuando se igualan los potenciales químicos de ambas soluciones. A partir de entonces se producirá un transporte de agua hacia los dos lados de la membrana de forma equilibrada (figura central). A la diferencia de presión hidrostática que se establece entre ambos compartimentos se conoce como presión osmótica de la solución concentrada en cuestión.

Lo que se pretende con el proceso de desalinización de ósmosis inversa es que este fenómeno de ósmosis natural se realice en sentido contrario. Si queremos que el agua de una solución salina fluya hacia el lado del agua dulce para separarla de las sales, debemos aumentar suficientemente su potencial químico. Esto se puede realizar aplicando en el lado de la solución salina una presión superior a la presión osmótica. De esta forma se conseguirá que pase agua a través de la membrana en sentido inverso al descrito anteriormente (figura derecha).

Así pues, para que sea posible un flujo continuo de agua a través de las membranas en el sentido desde el agua salada hasta el agua dulce, se debe aplicar una presión superior a la presión osmótica de la solución salada (figura 4). Esta presión depende de la concentración de sales (el potencial químico depende del tipo y la concentración de sales disueltas). Las instalaciones de ósmosis inversa para aguas salobres con un contenido en sales de unos $5 \mathrm{~g} / \mathrm{L}$, pueden necesitar presiones del orden de $12 \mathrm{~kg} / \mathrm{cm}^{2}$, mientras que las de agua de mar, con $28-30 \mathrm{~g} / \mathrm{L}$ de sales, pueden requerir hasta los 70 $\mathrm{kg} / \mathrm{cm}^{2}$. 


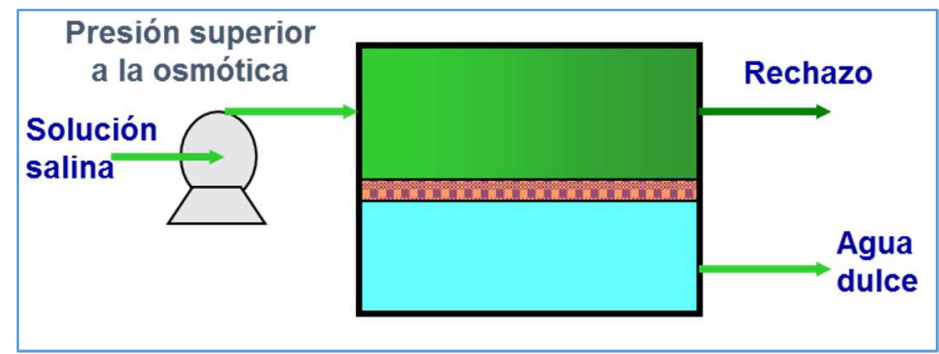

Figura 4. Esquema de proceso continuo de osmosis inversa (fuente: elaboración propia)

La membrana semipermeable es un film que actúa permitiendo el paso de algunos componentes presentes en la corriente alimento y dificulta o impide el paso de otros. Como consecuencia de esta operación se obtiene una corriente de permeado con baja concentración o libre de ciertos componentes y una corriente de rechazo concentrada en esos componentes. En la figura 5 se esquematiza el efecto de la membrana, que rechaza totalmente algunas sustancias y permite el paso del agua y de algunas sustancias disueltas.

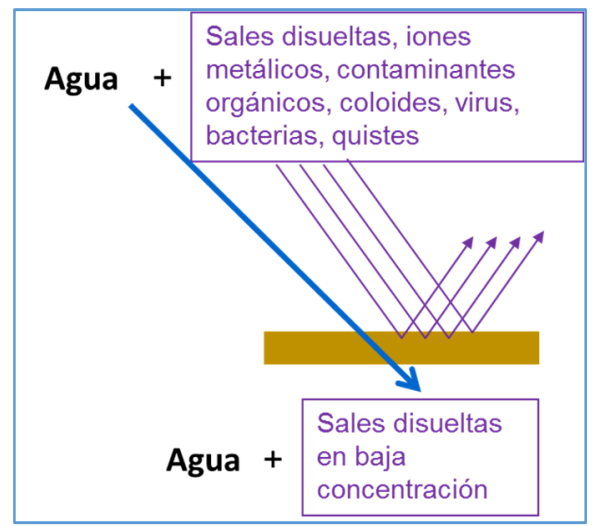

Figura 5. Efecto de membrana semipermeable de ósmosis inversa (fuente: elaboración propia)

La estructura de las membranas semipermeables que se emplean en ósmosis inversa es asimétrica y está compuesta por varias capas. La capa en contacto con el agua salobre o agua de mar tiene una estructura densa (sin poros) que es la responsable de la separación de las sales disueltas en el agua. Como esta capa debe ser muy fina tiene muy poca resistencia mecánica y no sería capaz de soportar las altas presiones a que debe ser sometida, por lo que se fabrica con otra u otras capas adicionales porosas, que no inciden en la separación pero que aportan la resistencia necesaria. En la figura 6 se muestra un esquema de una membrana compuesta. 


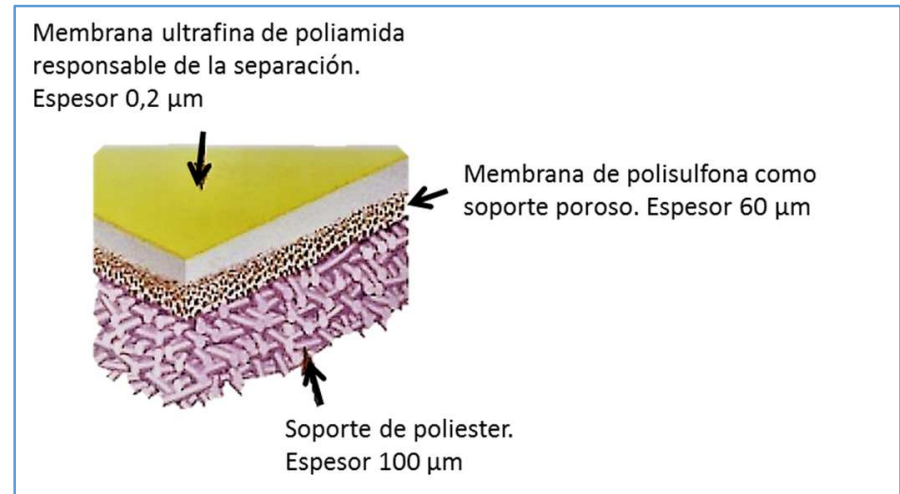

Figura 6. Ejemplo esquemático de una membrana asimétrica compuesta

Para las operaciones con membranas es necesario disponerlas en un dispositivo en el que se puedan poner en contacto con la corriente alimento para obtener las corrientes de permeado y rechazo. Este dispositivo se denomina módulo y debe cumplir una serie de características como soportar las presiones de trabajo, facilitar la limpieza o reposición de membranas, resistir agentes de limpieza química, etc. En el caso de ósmosis inversa se emplea el módulo de arrollamiento en espiral, que es una especie de sándwich formado por dos membranas planas más un elemento por el que circula el flujo de agua a tratar y otro elemento colector de permeado. Este sándwich se envuelve en forma espiral de tal modo que la parte interior del elemento colector de permeado conduce el agua tratada hacia un tubo central a través de unos orificios practicados en el mismo. El sistema se sella externamente. El agua a tratar se introduce en sentido axial. En la figura 7 se presenta un esquema del funcionamiento.

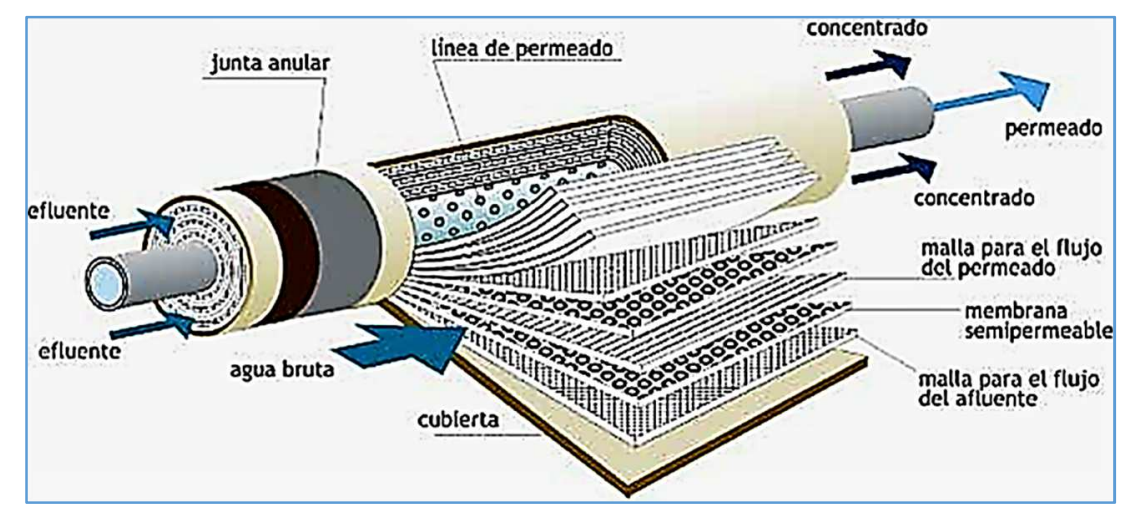

Figura 7. Representación esquemática del módulo de arrollamiento en espiral

En la práctica estas membranas arrolladas se introducen en el interior de tubos a presión con una entrada para el agua salada y dos salidas, una para el agua dulce y otra para el rechazo. Los tubos tienen medidas estandarizadas y contienen varias 
membranas. Los más habituales son de 8 pulgadas de diámetro nominal y contienen 7 membranas cada uno.

Como las membranas son elementos muy sensibles al ensuciamiento, el proceso industrial de ósmosis inversa incluye una serie de operaciones previas, denominadas pretratamiento, cuyo objetivo es reducir al máximo o eliminar todas las sustancias que no sean sales disueltas. Además, tras la etapa de ósmosis puede ser necesario acondicionar la calidad del agua en función de su uso previsto. También resulta imprescindible recuperar al máximo la energía que se aplica para realizar la ósmosis. En la figura 8 se muestran las fases del proceso industrial de ósmosis inversa.

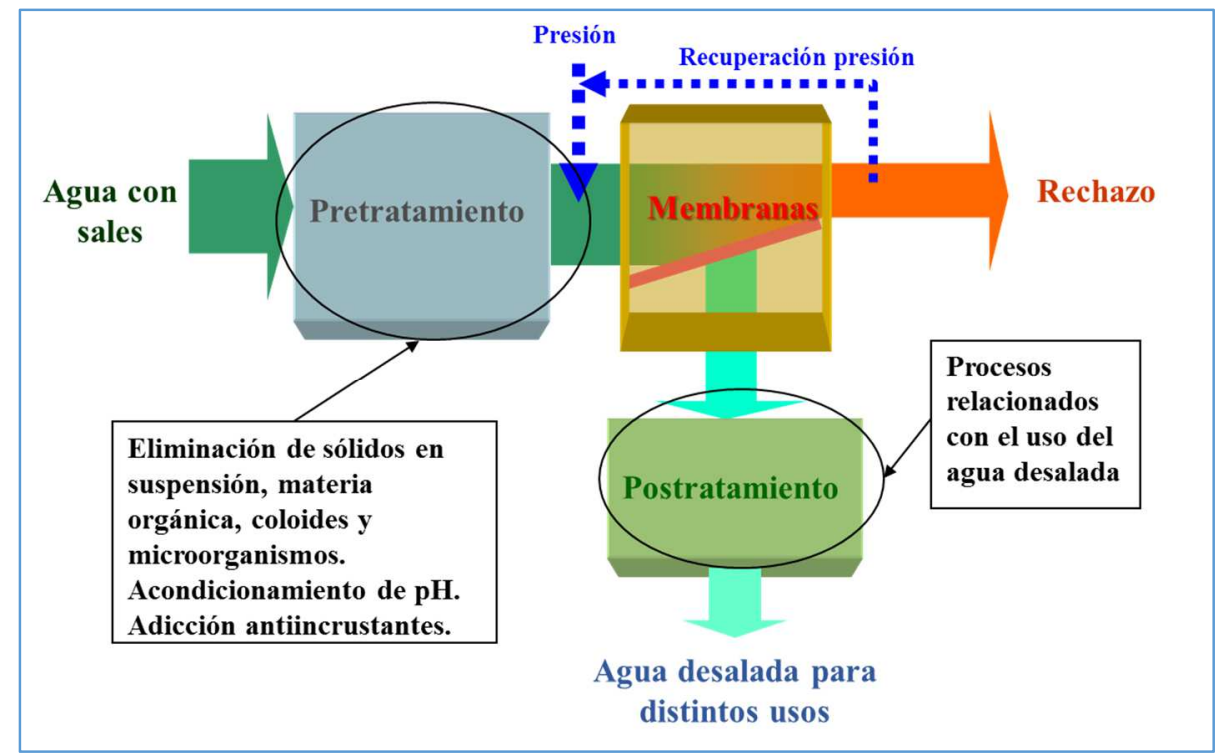

Figura 8. Fases de un proceso de ósmosis inversa (FUENTE: ELABORACIÓN PREVIA)

\section{PRETRATAMIENTO}

El pretratamiento trata de evitar que las partículas de tamaño pequeño, como algas, sólidos en suspensión, compuestos orgánicos o minerales lleguen a las membranas y tengan efectos negativos sobre su funcionamiento. También se pretende eliminar microorganismos, para evitar que formen colonias sobre las membranas, y acondicionar el $\mathrm{pH}$ del agua en valores óptimos. Aunque puede variar en función de la calidad del agua a tratar, el pretratamiento suele incorporar etapas de filtración, de desinfección y de acondicionamiento químico, para evitar precipitaciones. En la figura 9 se puede observar una secuencia de operaciones de pretatamiento. 


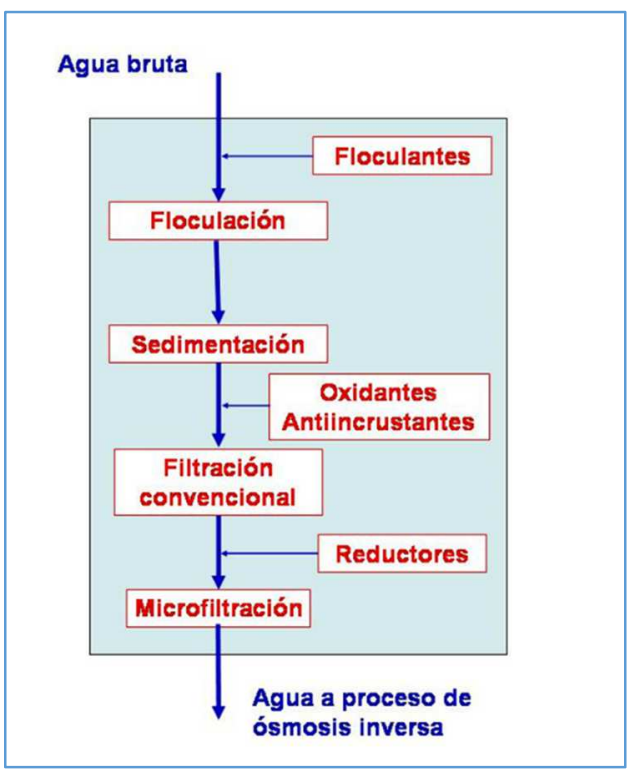

Figura 9. Esquema de pretratamiento convencional (fuente: elaboración propia)

\section{OPERACIÓN DE ÓSMOSIS INVERSA}

La forma de realizar la operación de ósmosis inversa depende del tipo de agua que se quiera desalinizar y de la calidad final que se busque para el agua producto. En función de ello la operación de ósmosis inversa puede tener diferentes pasos y etapas. Se habla de un paso cuando el permeado (agua dulce) obtenido en las membranas no se hace pasar por otro módulo de membranas para reducir su salinidad en otro paso. Por otra parte, cuando el rechazo de un módulo de membranas se emplea como alimento de otro módulo de membranas se dice que el primer módulo es la primera etapa y el segundo módulo la segunda etapa. Las configuraciones más habituales suelen ser en una sola etapa, en dos etapas o en dos pasos.

La operación en una sola etapa se realiza como se esquematiza en la figura 10. El agua procedente del pretratamiento se introduce en los módulos de presión que contienen las membranas y salen dos corrientes, el permeado que se lleva, en su caso, a postratamiento, y el rechazo que se evacúa normalmente al mar. Dependiendo del caudal de agua que se esté tratando, se utilizan uno o varios módulos en paralelo. La cantidad de tubos de presión en paralelo puede ser muy grande en plantas de gran capacidad de producción. 


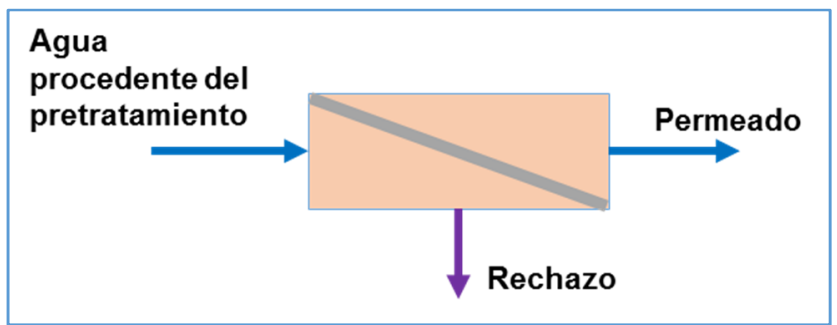

Figura 10. Operación de ósmosis inversa en una sola etapa (fuente: elaboración propia)

La operación en dos etapas se realiza como se esquematiza en la figura 11. El agua procedente del pretratamiento se introduce el primer módulo de presión. El rechazo sirve de alimento a otro módulo de membranas que constituye la segunda etapa. Esta forma de operar es habitual para tratar aguas salobres de baja o media salinidad.

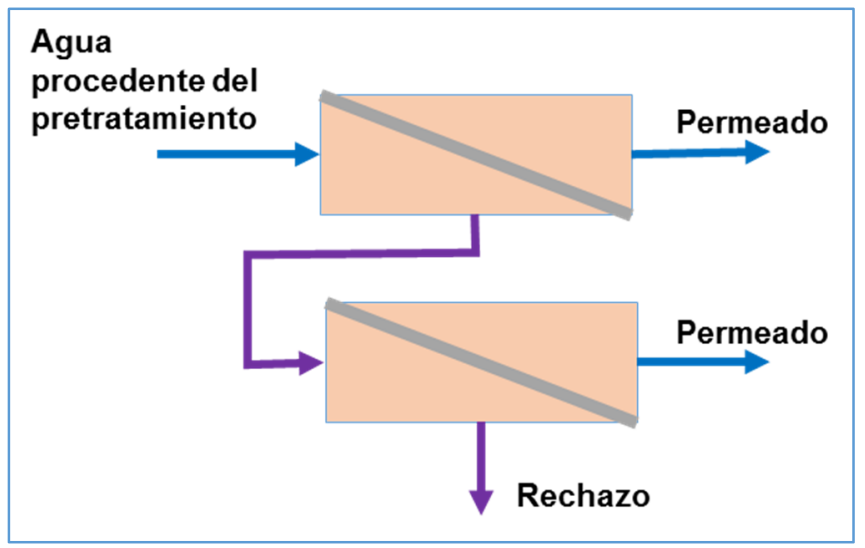

Figura 11. Operación en dos etapas (fuente: elaboración propia)

A modo de ejemplo, en la figura 12 se muestra una fotografía de los tubos de presión de la desalinizadora de la Universidad de Alicante, que trata aguas salobres con una concentración de sales de 4,5 g/L. Hay tres tubos en primera etapa (color azul) y dos en segunda etapa (color blanco). 


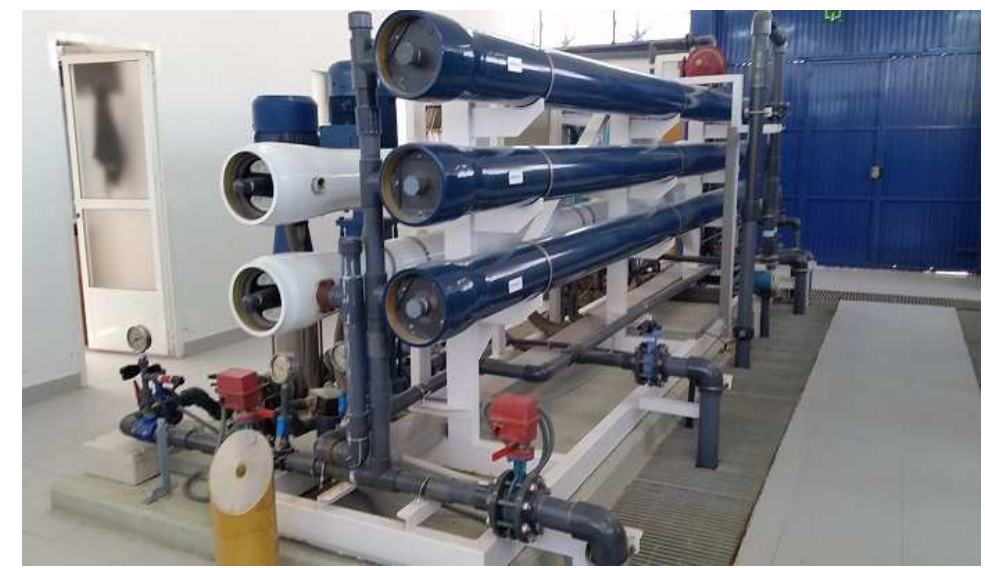

Figura 12. Tubos de presión de la desalinizadora de la Universidad de Alicante

La operación en dos pasos se realiza cuando se quiere reducir la salinidad del permeado de la primera etapa, para lo que se hace pasar por otro módulo de membranas que constituye el segundo paso. En la figura 13 se muestra esta disposición, que se emplea para obtener aguas de alta calidad o para reducir contaminantes específicos cambiando las condiciones de operación en el segundo paso.

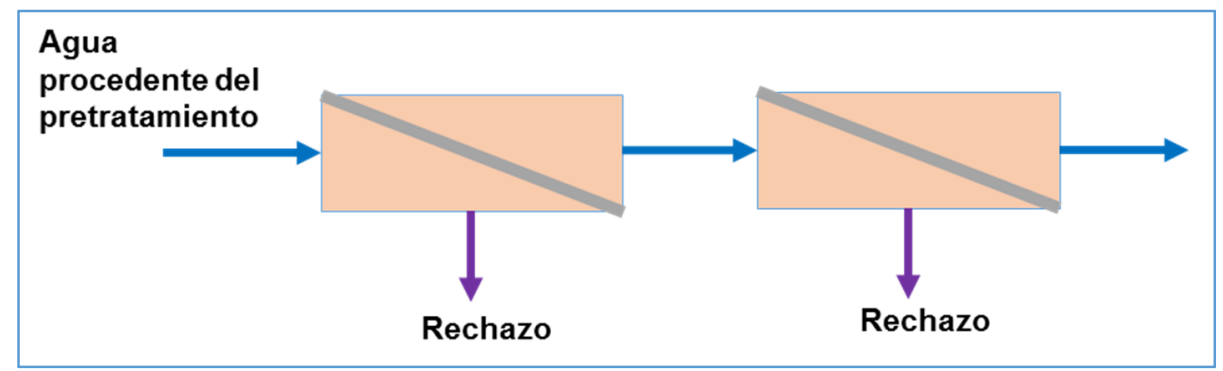

Figura 13. Operación en dos pasos (fuente: elaboración propia)

Un aspecto muy importante en la operación de ósmosis inversa es la recuperación de energía del rechazo. Como ya se ha comentado, el agua que se alimenta a los tubos de presión debe ser presurizada para que se produzca el paso a través de la membrana (ósmosis inversa). El permeado pierde la presión al atravesar la membrana, en cambio la corriente de rechazo mantiene casi toda la presión inicial del alimento cuando abandona el módulo.

En consecuencia resulta de gran interés recuperar la energía en forma de presión de la corriente de rechazo. Para ello se suelen utilizar actualmente dos dispositivos, las turbinas tipo Pelton (figura 14), que impulsan la corriente de rechazo sobre los 
alabes de una turbina para generar un movimiento de rotación, y los intercambiadores de presión rotatorios (figura 15), que intercambian directamente la presión del rechazo para presurizar el alimento. Con turbinas Pelton se alcanzan recuperaciones del orden del $90 \%$, mientras que con los intercambiadores de presión se puede llegar al 98\%, permitiendo que los consumos de la etapa de ósmosis inversa en instalaciones modernas sean inferiores a $2,5 \mathrm{kWh} / \mathrm{m}^{3}$.

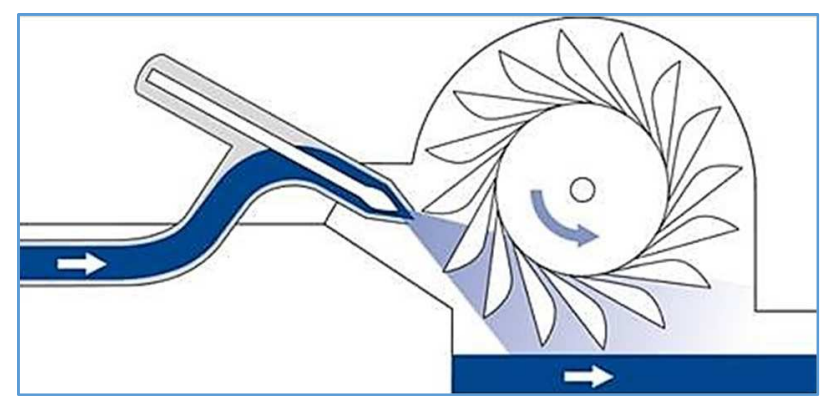

Figura 14. Esquema de funcionamiento de turbina tipo Pelton

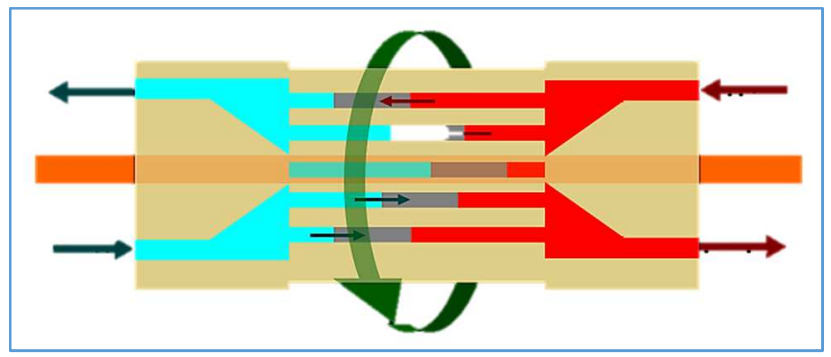

Figura 15. Esquema de funcionamiento de intercambiador de presión rotatorio

\section{POSTRATAMIENTO}

Dependiendo del uso final que vaya a tener el agua desalinizada, se suele someter a un postratamiento para acondicionar su calidad. Cuando se emplea para abastecimiento urbano se ajusta el pH y el índice de saturación de Langelier a los valores que marca la normativa. Esto se realiza remineralizando. Además, se añade cloro que garantiza la presencia de un desinfectante residual en las conducciones y depósitos.

En caso de que el agua vaya a ser empleada para riego generalmente no se realiza postratamiento ya que el agua desalada suele ser mezclada con aguas de otras procedencias. 


\section{EVACUACIÓN DE RECHAZOS}

El rechazo o salmuera que contiene las sales que se han separado debe ser convenientemente evacuado, lo que mayoritariamente se hace en el mar. En el caso de desalinización de agua de mar esta corriente puede contener hasta $70 \mathrm{~g} / \mathrm{L}$ de sales (el agua de mar contiene 35-38 g/L). Para aguas salobres las concentraciones son menores. Hay que indicar que se trata de las mismas sales que hay en el mar, no de otros agentes tóxicos o contaminantes, como puede ser el caso de vertidos de efluentes de aguas residuales.

En la actualidad el impacto ambiental de estos vertidos es mínimo y está muy controlado. Se conoce cuáles son las concentraciones que causan problemas a especies sensibles, por lo que se evita que se alcancen tales concentraciones. Para ello se puede realizar una o varias de las siguientes actuaciones:

- Distribuir el vertido a través de varios difusores convenientemente diseñados.

- Seleccionar zonas con hidrodinamismo apropiado.

- Alejar el vertido de especies sensibles.

- Diluir el vertido con agua de mar.

- Mezclar con agua residual depurada. 


\title{
3.3. FUNCIONAMIENTO ECONÓMICO Y FINANCIERO
}

\author{
Martín Sevilla Jiménez
}

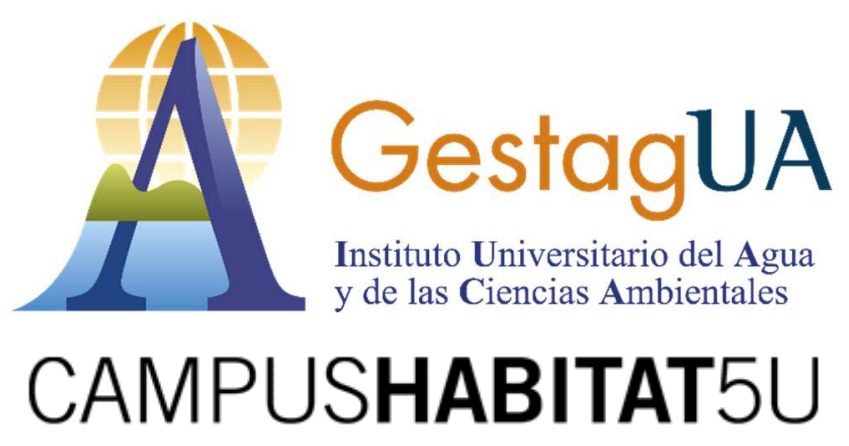




\section{INTRODUCCIÓN}

La insuficiencia de recursos hídricos (superficiales o subterráneos), para atender a las demandas de distintos usos en algunas zonas áridas o semiáridas españolas, ha planteado desde siempre la necesidad de estudiar alternativas que no supongan el estancamiento económico de las mismas. Si bien primeramente se han buscado alternativas con los menores costes económicos posibles (que no medioambientales) a través del agotamiento de los recursos subterráneos o las transferencias de recursos entre cuencas, las exigencias medioambientales y los enfrentamientos territoriales por el agua han exigido la búsqueda de lo que se llaman los recursos no convencionales: aguas desalinizadas y reutilizadas. Debemos tener en cuenta que también a través de la mejora de la gestión de estos recursos se ha tratado y se trata de disminuir la demanda y aumentar la eficacia de sus usos (la ampliación de los sistemas de riego localizado a través de las inversiones de la SEIASA, ejemplifica estos procedimientos).

La disponibilidad casi ilimitada de agua de mar en las zonas costeras o las aguas salobres del interior se han considerado como una fuente posible de uso siempre que se pudieran desalinizar a unos costes razonables. Durante años se han experimentado con diversas técnicas de desalinización, aunque los costes incorporados por las exigencias energéticas de este proceso han limitado bastante su desarrollo. Los procesos de ósmosis inversa, si bien han avanzado mucho en la reducción de los costes económicos de transformación, siguen presentando todavía muchas restricciones sobre el acceso de los usuarios distintos a los abastecimientos urbanos o industriales, debido a los costes energéticos del proceso.

En España, a través del denominado Programa Agua (Real Decreto Ley 2/2004, de 18 de junio, por el que se modifica la Ley 10/2001, de 5 de julio, del Plan Hidrológico Nacional), a partir de 2004 se puso en marcha una gran iniciativa pública de construcción de desalinizadoras en la costa mediterránea que ha supuesto que nos convirtamos en uno de los principales países en estos procesos.

\section{LA EVOLUCIÓN DE LA DESALINIZACIÓN EN ESPAÑA Y A NIVEL INTERNACIONAL}

Las primeras plantas desalinizadoras en España se localizaron en las Islas Canarias a principios de los años 70, ante la carencia de otras alternativas que sí se plantearon en la península (los trasvases, p.e.). Estas instalaciones de tipo térmico (MSF, MED y CV) utilizaban técnicas poco eficientes en la producción de agua y un gran consumo de energía que podía suponer que para producir un metro cúbico de agua fueran necesarios más de $50 \mathrm{kWh}$. 
A partir de los años 80 aparecen las primeras instalaciones de ósmosis inversa que van a suponer una auténtica revolución en los procesos de desalinización, al reducir los consumos necesarios de energía que, para primeros de esta década se sitúan en unos $3 \mathrm{kWh} / \mathrm{m}^{3}$. Este descenso del consumo de energía (y de los costes que lleva aparejados), ha ido parejo al incremento de los volúmenes de agua desalinizados que para 2010 alcanzaban una capacidad instalada de cerca de 3 $\mathrm{hm}^{3} /$ día (ver gráfico siguiente).

Evolución de la relación capacidad instalada/consumo específico en España, para el período 1970-2010.

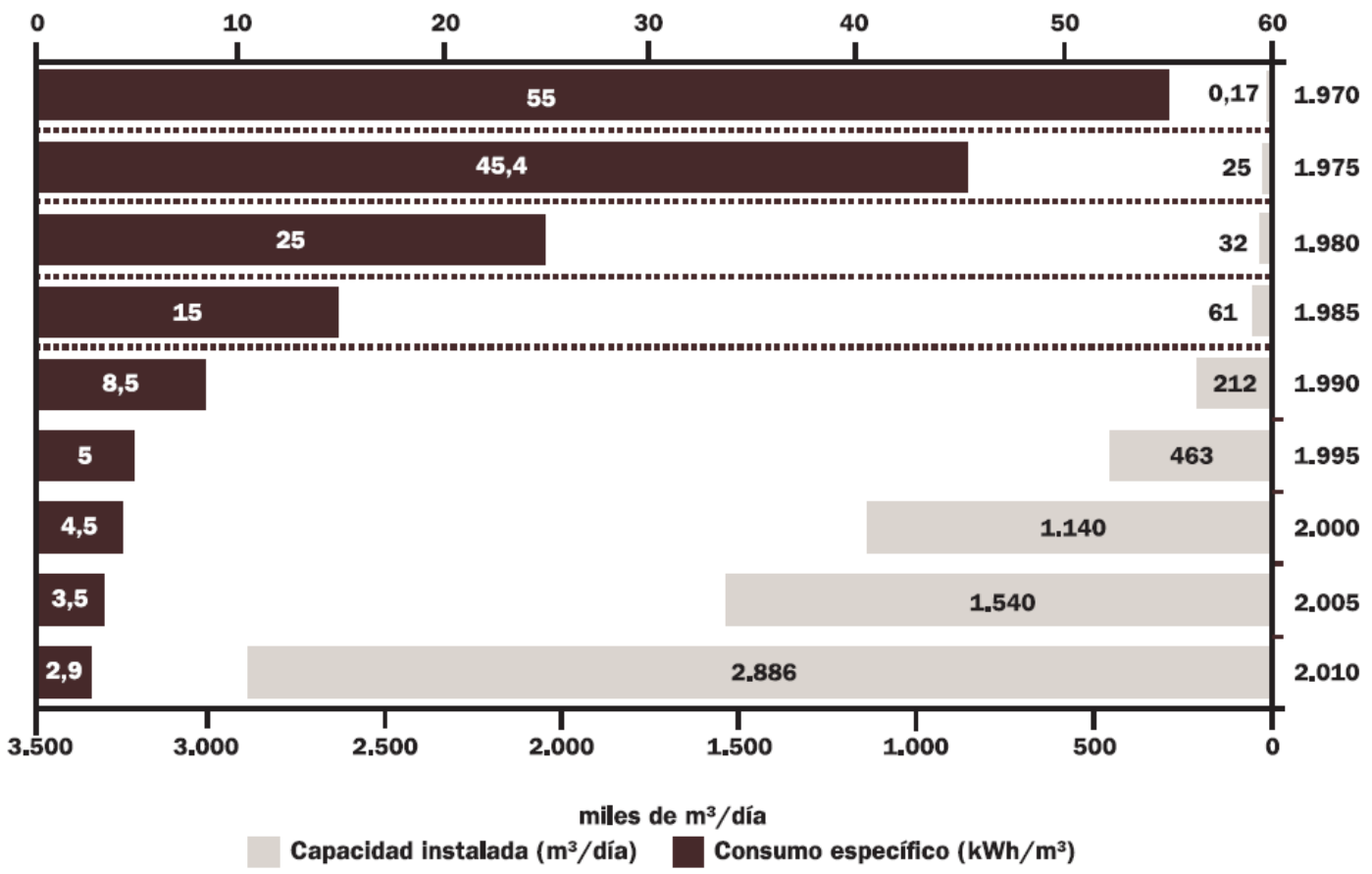

Fuente CEDEX

Citado por ACUAMED, p. 5.

Este proceso recibió un fuerte apoyo con la puesta en marcha del denominado Programa Agua que introdujo el Gobierno español a partir de la modificación de la Ley de Aguas y el Plan Hidrológico Nacional en 2004. A través del mismo se han realizado una gran cantidad de instalaciones en la costa mediterránea española que han convertido a España en uno de los países donde mayores volúmenes de agua se producen, siendo además obtenida con la tecnología más eficiente en términos de consumo energético. Estas inversiones se vieron favorecidas por disponer todavía en esas fechas de los Fondos de Cohesión de la Unión Europea, con cuantiosas subvenciones aplicadas en todas las plantas desalinizadoras. 
Capacidad instalada en la actualidad (por países y tecnología)

口MSF

DME

- HYBRID

口OTHER

EDY

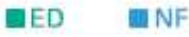

ERO

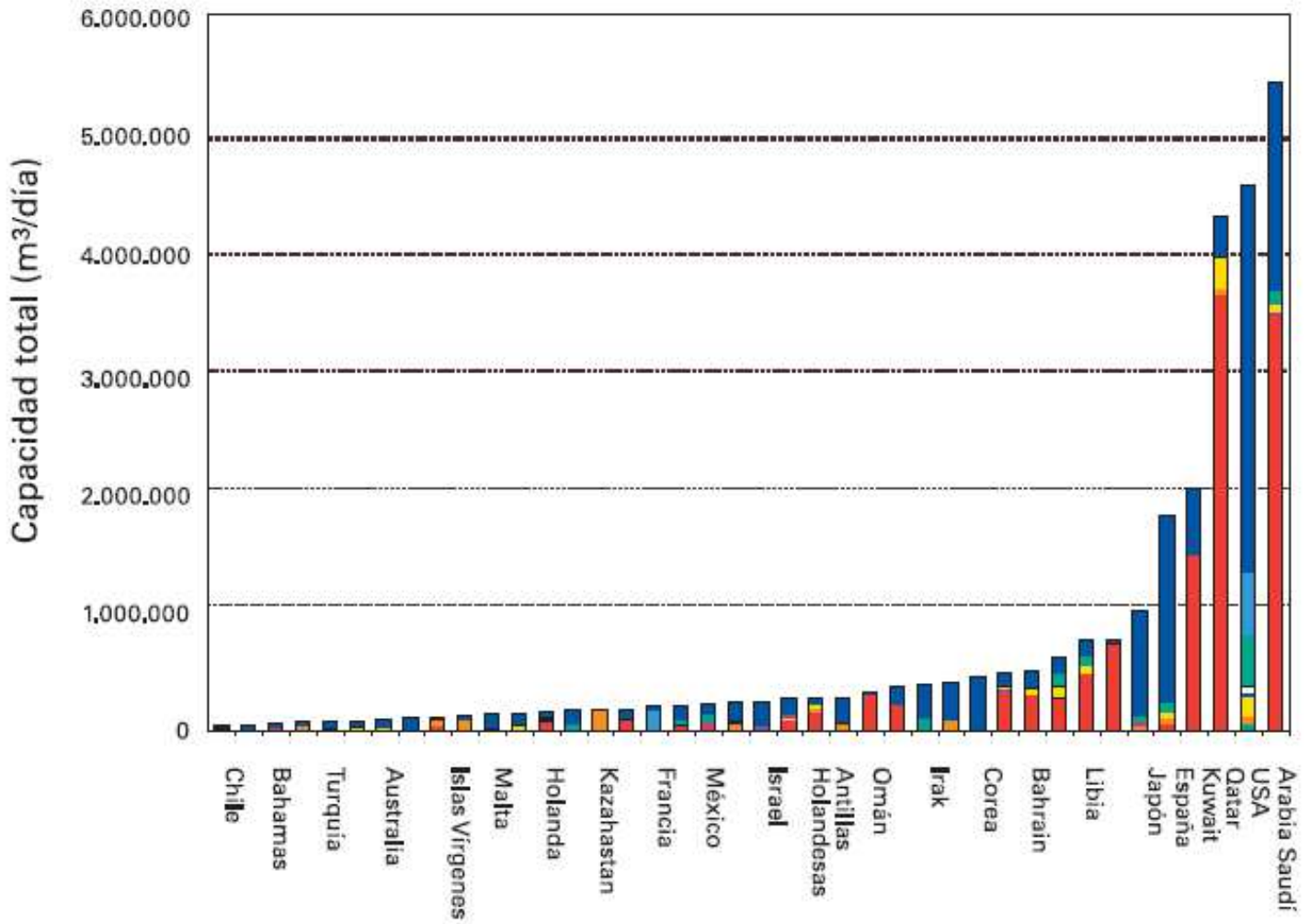

Fuente: IDA desalting plant inventory/Wangnick

Citado por: ACUAMED, p. 9.

\section{LOS COSTES DE LA DESALINIZACIÓN}

Se ha mencionado anteriormente el gran avance que supuso la introducción de las técnicas de ósmosis inversa en los procesos de desalinización, al reducir los consumos de energía necesarios hasta los $3 \mathrm{kWh} / \mathrm{m}^{3}$. Evidentemente, cada país ha articulado su estrategia para la obtención de agua desalinizada en función de los propios costes de la energía, por lo que los países de Oriente Medio, con grandes disponibilidades de petróleo, todavía no han incorporado las nuevas tecnologías.

Sin embargo, en España y en otros países que tienen en cuenta los precios internacionales de la energía y la eficiencia económica en las instalaciones, los costes de la desalinización, a pesar de su gran descenso, siguen todavía siendo una importante barrera para su uso. 
Las componentes de los costes de la desalinización vienen a estar representados aproximadamente por un $40 \%$ correspondiente a la amortización del capital y los intereses, un $40 \%$ a la energía necesaria para la producción y un $20 \%$ otros costes. Si consideramos que el coste de la energía en España puede ser de unos $0,12 € / \mathrm{kWh}$, el coste final de la producción de agua desalinizada podría rondar $\operatorname{los} 0,90 € / \mathrm{m}^{3}$.

Ante la gran variedad de situaciones respecto a las inversiones en la construcción de las plantas desalinizadoras, es difícil considerar que esa cifra sea común a todas ellas.

Las dos grandes empresas que han llevado a cabo las inversiones han sido la MCT y Acuamed S.A., pero a pesar de que ambas tienen varias instalaciones, no han elaborado informes públicos sobre los costes de cada una de ellas, siendo los disponibles contradictorios con estas cifras (los referentes a 2013 publicados por la MCT vienen a duplicar las cifras anteriores).

Debido a la importancia que suponen estos nuevos suministros se echa en falta una mayor trasparencia para conocer los costes de la forma más detallada posible, máxime cuando estas aportaciones van a convivir con las procedentes de otras fuentes y, además, en Planes Hidrológicos distintos.

\section{EL FUNCIONAMIENTO ECONÓMICO-FINANCIERO DE LA DESALINIZACIÓN}

La incorporación de los procesos de desalinización a los recursos hídricos de los distintos sistemas y cuencas supone un cambio notable en el funcionamiento económico-financiero en las mismas. Si tenemos en cuenta que los costes de estos procesos son mucho más elevados que los aplicados a las aguas de otras procedencias, se hace evidente que los mismos solamente se van a poder utilizar si los usos que se le dan pueden soportar esos costes (especialmente los de abastecimiento urbano) o bien, si estos pueden ser aplicados con importantes subvenciones. Por otro lado, la demanda de agua desalinizada en cada momento no es autónoma, en el sentido de que depende de la disposición de otras fuentes que pueden ser más baratas si están disponibles, por lo que la estrategia sobre cómo incorporar los costes fijos y variables debería ser un objetivo preferente en estos momentos.

Como se ha dicho anteriormente, las dos empresas titulares de casi la totalidad de las desalinizadoras en la Península tienen estrategias diferentes. Por parte de 
Acuamed S.A., prácticamente está iniciando la producción y venta de agua a usuarios tanto urbanos como agrícolas, sin un protocolo claro a medio plazo acerca de cuáles son las subvenciones que debe aplicar en cada caso.

La Mancomunidad de Canales del Taibilla viene desde hace algunos años utilizando el agua desalinizada para el abastecimiento urbano. En este caso el procedimiento está relativamente claro. La MCT ha realizado la construcción de varias plantas en Alicante y Murcia que actúan como garantizadoras de completar la demanda de consumo en todo el territorio que abarcan sus servicios. La MCT, en función de las disponibilidades de agua en el río Taibilla (a las que accede desde sus instalaciones a un coste 0 ), las procedentes del Trasvase Tajo-Segura (a un coste de $0,1861 € / \mathrm{m}^{3}$ ) o incluso mediante compras procedentes de otras cuencas (del Tajo a un coste de $0,20 € / \mathrm{m}^{3}$ ) completa los recursos totales con la producción del agua desalinizada (de un coste solo de explotación mucho mayor).

Se puede ver esta estrategia durante los años 2012-13:

\begin{tabular}{|c|c|c|c|c|}
\hline PROCEDENCIA & $\begin{array}{l}\text { Año Hidrológico } \\
\text { 2011-2012 }\end{array}$ & $\begin{array}{l}\text { Año Hidrológico } \\
2012-2013\end{array}$ & $\Delta \mathrm{hm}^{3}$ & $\Delta \%$ \\
\hline Rio Taibilla & 53,0 & 69,5 & $+16,5$ & $+31,1$ \\
\hline Desalación & 44,3 & 12,8 & $-31,5$ & $-71,1$ \\
\hline Trasvase y Extraordinarios & 98,9 & 101,3 & $+2,4$ & $+2,4$ \\
\hline TOTAL & 196,2 & 183,6 & $-12,6$ & $-6,4$ \\
\hline
\end{tabular}

Fuente: Memoria MCT 2013, p. 15. 


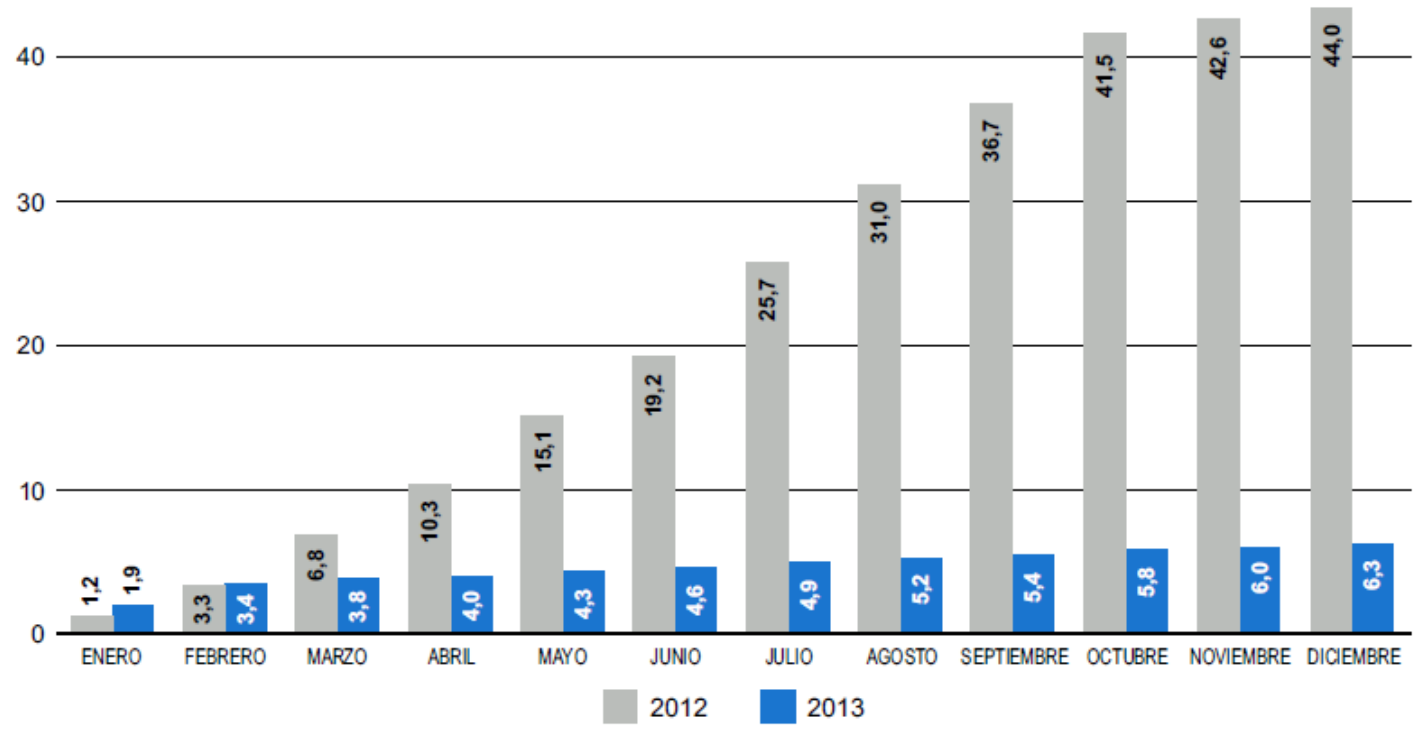

Fuente: Memoria MCT 2013, p. 19.

La utilización del agua desalinizada actúa así como un seguro, por lo que la puesta en funcionamiento de las plantas va a depender en los próximos años del régimen de lluvias en el río Taibilla, las posibilidades de trasvase de aguas desde el Tajo o la flexibilización del mercado de aguas, siendo las desalinizadoras el suministro de último recurso. 


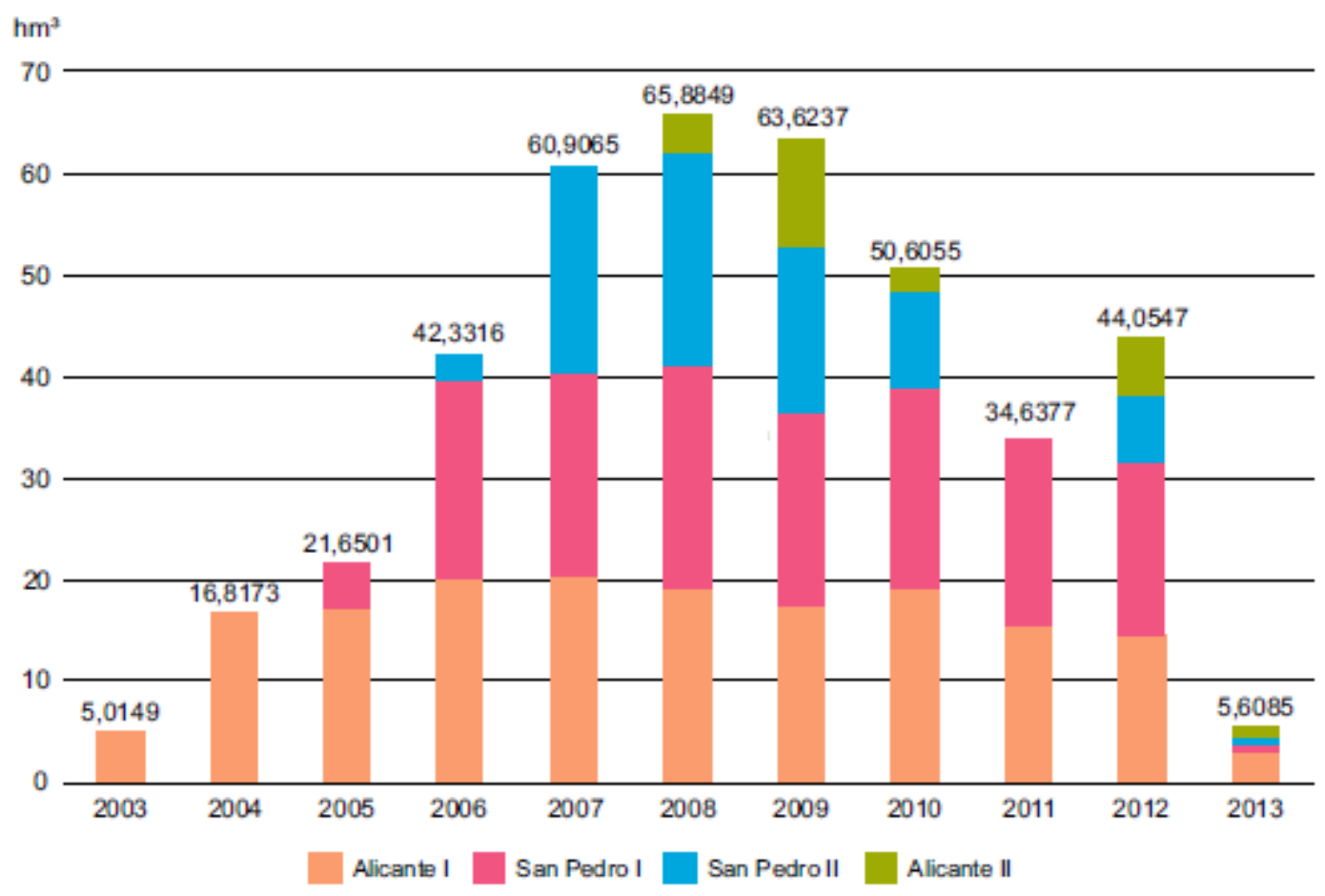

Fuente: Memoria MCT 2013, p. 35.

Evidentemente esto plantea la necesidad de incorporar algunos costes a estos procesos, aunque las desalinizadoras estén paradas, si bien estos al ser repercutidos en los abastecimientos urbanos no presentan tanta tensión como en los referidos a los regadíos.

\section{CONCLUSIONES}

El gran desarrollo que han adquirido en los últimos años las construcciones de plantas desalinizadoras en España ha tenido en cuenta tanto las facilidades financieras de la UE, las necesidades hídricas de nuestras zonas semiáridas y los avances técnicos procedentes de la ósmosis inversa.

A pesar de este avance, los costes de producción de agua desalinizada todavía son muy superiores a los procedentes de otras fuentes (superficiales y subterráneas), por lo que plantean no pocas dudas acerca del procedimiento de recuperación de costes que se deben tener en cuenta en cada caso.

Especialmente es reseñable este proceso en la utilización de esta agua para regadío (donde también son necesarias investigaciones acerca de sus efectos en la 
agricultura), donde la disparidad de costes con los de otras fuentes son muy considerables y solo soportables por un muy reducido tipo de plantaciones.

En la utilización para el abastecimiento urbano se presentan menos problemas, especialmente en las zonas costeras, ya que este recurso se utiliza mezclado con las aguas procedentes de otras fuentes a unos precios inferiores, con los precios medios pueden ser más soportables para los usuarios urbanos. No obstante, con independencia del funcionamiento o no de las plantas desalinizadoras es necesario plantear quien debe soportar los costes fijos de las mismas.

\section{BIBLIOGRAFÍA}

Real Decreto Ley 2/2004, de 18 de junio, por el que se modifica la Ley 10/2001, de 5 de julio, del Plan Hidrológico Nacional.

Acuamed (2007). La desalación en España.

Acuamed (2016). Informe Anual 2015.

MCT (2014). Gestión del Servicio 2013.

\section{ENLACES}

http://www.acuamed.es/media/publicaciones/desalinizacion-en-espana.pdf https://www.mct.es/documents/74411/74817/Gestion+del+servicio+2013.pd f/320d0159-ebce-4eb8-85ba-d6f4b8407847 


\section{MÓDULO 4}

\section{LA DEPURACIÓN Y REUTILIZACIÓN DE AGUAS RESIDUALES}




\title{
4.1. MARCO LEGAL DE LA DEPURACIÓN
}

\author{
Andrés Molina Giménez
}

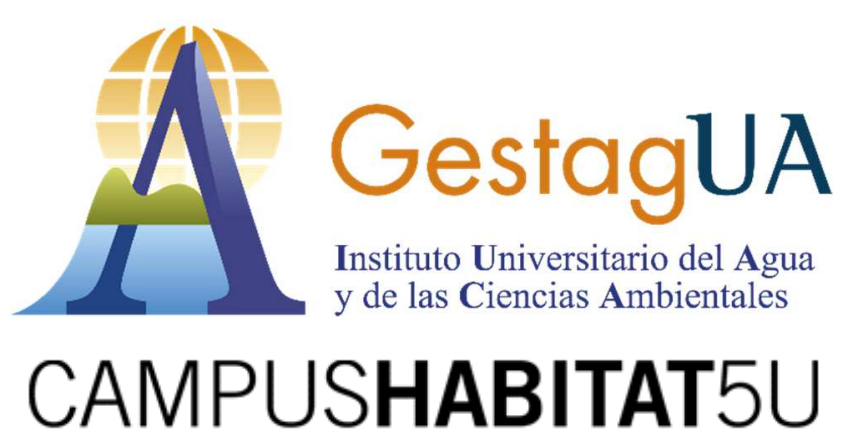




\section{INTRODUCCIÓN}

En este tema estudiaremos los fundamentos del marco legal que regula la depuración de las aguas residuales. Uno de los retos socio-ambientales más importantes a nivel mundial es garantizar la adecuada depuración de las aguas residuales urbanas. El saneamiento básico ha sido uno de los grandes avances de la humanidad, que ha permitido superar las históricas enfermedades y epidemias que han diezmado la población mundial a lo largo de la historia. Allí donde todavía no llega este servicio, fundamentalmente en el tercer mundo, aparecen episodios de enfermedades hídricas como el cólera que causan una elevada mortandad.

En las sociedades desarrolladas no aparecen dichos problemas sanitarios, pero todavía experimentan problemas ambientales derivados de la deficiente o incluso inexistente depuración de las aguas residuales, que se canalizan a las masas de agua. Estas masas se contaminan y, según el grado que alcancen, pueden comprometer la supervivencia de las especies de peces más sensibles a la contaminación.

En España, la situación de la depuración es bastante satisfactoria, gracias fundamentalmente a la aplicación durante estos últimos años de la normativa comunitaria. La depuración a gran escala se inicia con el Plan Nacional de Saneamiento y Depuración 1995-2005 (PNSD), que tenía como principal objetivo cumplir la Directiva 91/271CEE, que establecía calidades de vertido de aguas residuales tratadas en función de la zona de vertido.

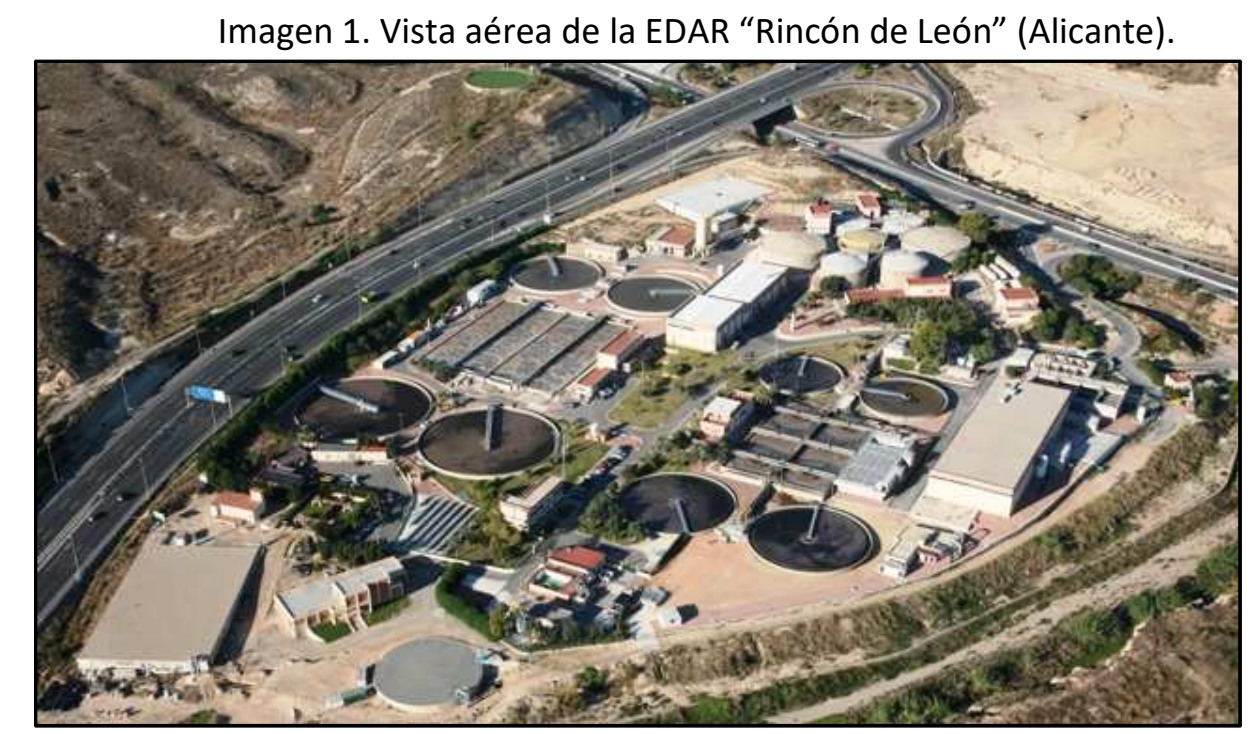

Fuente: Entidad Publica de Saneamiento de Aguas Residuales de la Comunidad Valenciana (EPSAR). 
Durante su período de implantación, se pasó de un volumen de 0,13 m3/habitante/día de aguas residuales tratadas en 1996 a 0,31 en 2006. El dato más reciente, del año 2011, cifra el volumen de aguas residuales tratadas en $13,5 \mathrm{hm} 3 /$ día, y principalmente se producen en Andalucía, Cataluña, Madrid y Valencia (MAGRAMA, 2014).

Figura 1. Grado de conformidad de la Directiva 91/271/CEE, 1995-2010 en España.

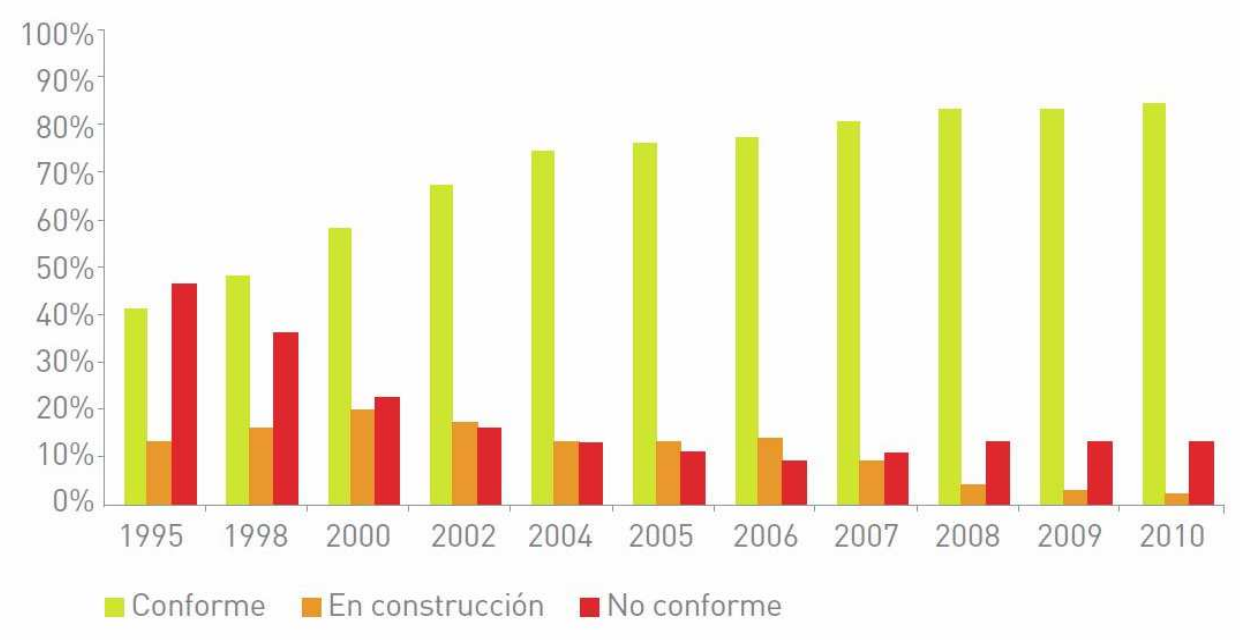

Fuente: Elaboración OSE a partir del MAGRAMA, 2012.

En la siguiente figura se muestra la situación por CCAA en 2010. 
Figura 2. Grado de conformidad con la Directiva 91/271/CEE por Comunidades Autónomas, 2010.

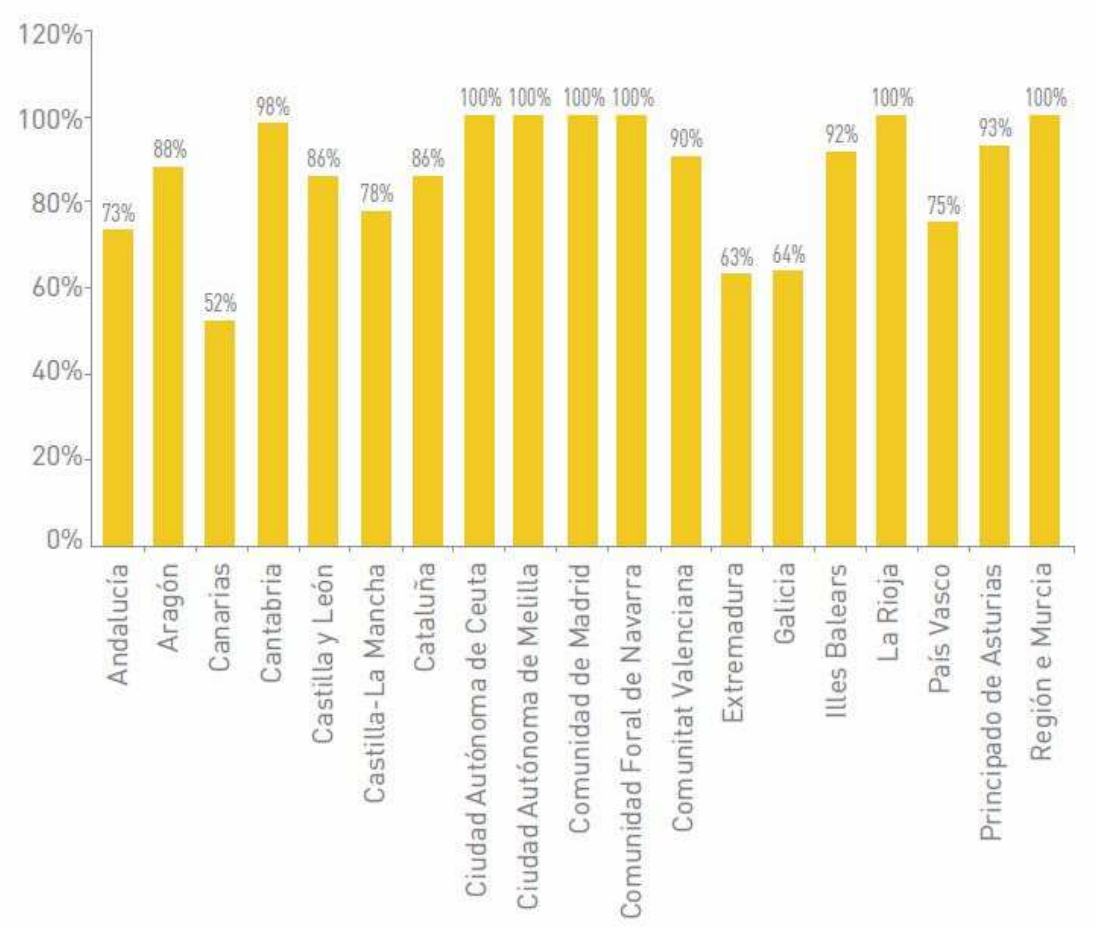

Fuente: Elaboración OSE a partir del MAGRAMA, 2012.

Sin embargo, existen cuestiones que es necesario analizar, como la operativa de los Ayuntamientos en cuanto al control de vertidos indirectos a redes de saneamiento, o la posibilidad de implantar tratamientos terciarios asociados a la reutilización.

\section{DERECHO COMUNITARIO}

La norma de referencia en el Derecho comunitario es, como hemos indicado la Directiva 91/271/CEE sobre el tratamiento de las aguas residuales urbanas. La transposición de la Directiva al Derecho español, está contenida en el Real Decreto-Ley 11/1995, de 28 de diciembre (BOE núm. 312, de 30 de diciembre), por el que se establecen las normas aplicables al tratamiento de las aguas residuales urbanas. el Real Decreto 509/1996, de 15 de marzo (BOE núm. 77, de 29 de marzo) desarrolló su contenido mediante la incorporación de los Anexos contenidos en la Directiva.

Según esta normativa, corresponde a las Comunidades Autónomas (CC.AA.) la delimitación de las aglomeraciones urbanas, la declaración de las zonas sensibles y zonas menos sensibles de acuerdo con las directrices marcadas en el Anexo II, y la elaboración de programas que permitan alcanzar los objetivos de la Directiva. 
En la Tabla № 1, se especifican los niveles de tratamiento establecidos en la Directiva 91/271/CEE, cuya intensidad depende de la zona en que se realice el vertido de las aguas una vez depuradas, (normal, sensible o menos sensible) y del número de habitantes equivalentes de la aglomeración urbana. El tratamiento requerido deberá estar en funcionamiento en la fecha indicada en la tabla.

\begin{tabular}{|c|c|c|c|c|c|c|}
\hline \multicolumn{7}{|c|}{ TABLA 1. REQUERIMIENTOS DE LA DIRECTIVA 91/271/CEE } \\
\hline \multirow{2}{*}{ NORMALES } & $\begin{array}{l}\text { Aguas dulces y } \\
\text { estuarios }\end{array}$ & $\begin{array}{l}\text { T. adecuado } \\
\text { dic-05 } \\
\text { ant.7 }\end{array}$ & $\begin{array}{c}\text { T. secundario } \\
\text { dit } 0.06 \\
\text { art } 2.1 . \\
\end{array}$ & $\begin{array}{c}\text { T. secundario } \\
\text { dic-05 } \\
\text { 3r.4.1. }\end{array}$ & $\begin{array}{c}\text { T. secundario } \\
\text { dio-00 } \\
\text { art.4.1. }\end{array}$ & $\begin{array}{c}\text { T. secundario } 11 \\
\text { dic00 } \\
\text { ant.4. }\end{array}$ \\
\hline & Aguas costeras & $\begin{array}{c}\text { T. adecuado } \\
\text { dio- } 05 \\
\text { ant } 7 \\
\end{array}$ & $\begin{array}{c}\text { T. adecuado } \\
\text { dio- } 05 \\
\text { ant } 7 \\
\end{array}$ & $\begin{array}{c}\text { T. secundario } \\
\text { dic-05 } \\
\text { an.41. }\end{array}$ & $\begin{array}{c}\text { T. secundario } \\
\text { dio-00 } \\
\text { art } 11 \\
\end{array}$ & $\begin{array}{c}\text { T. secundario } \\
\text { dic-100 } \\
\text { art } 11\end{array}$ \\
\hline \multirow{2}{*}{ SENSIBLES } & $\begin{array}{l}\text { Aguas dulces y } \\
\text { estuarios }\end{array}$ & $\begin{array}{c}\text { T. adecuado } \\
\text { dio-05 } \\
\text { ant? }\end{array}$ & $\begin{array}{c}\text { T. secundario }{ }^{\text {II }} \\
\text { dio-05 } \\
\text { at.1. }\end{array}$ & $\begin{array}{c}\text { T. más riguroso }{ }^{\text {IIt }} \\
\text { dic- } 68 \\
3 n_{1.52} \\
\end{array}$ & $\begin{array}{c}\text { T. más riguroso } \\
\text { dic- } \theta 8 \\
\text { 3it.52 }\end{array}$ & $\begin{array}{c}\text { T. más riguroso } \\
\text { dic- }-98 \\
\text { art } 52 .\end{array}$ \\
\hline & Aguas costeras & $\begin{array}{c}\text { T. adecuado } \\
\text { dic-05 } \\
\text { ant } 7\end{array}$ & $\begin{array}{c}\text { T. adecuado } \\
\text { dic-05 } \\
\text { an.7 } \\
\end{array}$ & $\begin{array}{c}\text { T. más riguroso } \\
\text { dio- } 98 \\
3 \text { m.5.2 } \\
\end{array}$ & $\begin{array}{c}\text { T. más riguroso } \\
\text { dic- } 88 \\
3 \text {.52. } \\
\end{array}$ & $\begin{array}{c}\text { T. más riguroso } \\
\text { do- } 88 \\
\text { ant.2. } \\
\end{array}$ \\
\hline \multirow{2}{*}{$\begin{array}{l}\text { MENOS } \\
\text { SENSIBLES }\end{array}$} & Estuarios & $\begin{array}{c}\text { T. adecuado } \\
\text { dic-05 } \\
\text { ant } 7\end{array}$ & $\begin{array}{c}\text { T. menos riguroso (2) } \\
\text { dic-05 } \\
\text { at } 6.2 \\
\end{array}$ & $\begin{array}{c}\text { T. secundario } \\
\text { dic-05 } \\
\text { art } 4.1 . \\
\end{array}$ & $\begin{array}{c}\text { T. secundario } \\
\text { dio-00 } \\
\text { at } 1.1\end{array}$ & $\begin{array}{c}\text { T. secundario } \\
\text { dia.00 } \\
\text { ar. } 41 .\end{array}$ \\
\hline & Aguas costeras & $\begin{array}{c}\text { T. adecuado } \\
\text { dic-05 } \\
\text { an. } 7 \\
\end{array}$ & $\begin{array}{c}\text { T. adecuado } \\
\text { dio-05 } \\
\text { ant.7 } \\
\end{array}$ & $\begin{array}{c}\text { T. menos riguroso (2) } \\
\text { dic-05 } \\
3152.52 \\
\end{array}$ & $\begin{array}{c}\text { T. menos riguroso (2) } \\
\text { dic-05 } \\
\text { 3!6.2. } \\
\end{array}$ & $\begin{array}{c}\text { T. secundario } \\
\text { dio-00 } \\
\text { at.t.t. } \\
\end{array}$ \\
\hline
\end{tabular}

MAPAMA (Manual de interpretación y elaboración de informes Directiva 91/271/CEE)

Los programas de aplicación de la Directiva 91/271/CEE, en España, se introdujeron mediante la aprobación del Plan Nacional de Saneamiento y Depuración de Aguas Residuales (1995-2005). La articulación del Plan se realizó mediante Convenios de Colaboración entre el MOPTMA y las diferentes CC.AA., suscritos a lo largo de los años 1995 y 1996.

Al margen de lo anterior, es importante tener en cuenta que las CCAA han venido aprobando legislación propia, así como planes de saneamiento autonómicos, que han establecido el marco jurídico más importante que regula esta actividad.

\section{INSTRUMENTOS REGULADORES DE LA DEPURACIÓN}

La legislación española de régimen local sitúa el saneamiento y la depuración como una competencia municipal mínima, de prestación obligatoria, y reservada, es decir, es un servicio público de titularidad local. Ahora bien, la competencia 
regulatoria y de ejecución de este servicio es compartida con las CCAA, quienes han legislado sobre esta cuestión y desarrollado actuaciones concretas de depuración en colaboración con los municipios.

En la legislación autonómica se siguen unas pautas comunes, aunque cada Comunidad Autónoma presenta sus propias particularidades. Reseñamos a continuación algunos de los instrumentos más destacados que pueden observarse en dichas leyes.

a.- Las leyes autonómicas suelen precisar el alcance de las competencias municipales y autonómicas y los mecanismos de coordinación.

b.- Regulan los planes directores y zonales de saneamiento. Estos instrumentos sirven para determinar los criterios de implantación, financiación, gestión y explotación de las infraestructuras de saneamiento y depuración necesarias. La elaboración y aprobación de estos planes, así como la del planeamiento territorial y urbanístico, se basarán en la necesidad de garantizar la coherencia entre las determinaciones de dichos tipos de planes.

c.- Creación de entidades de gestión. Un modelo de interés es el valenciano, seguido por otras comunidades, como la Región de Murcia. Se trata de crear una entidad descentralizada, con personalidad jurídica propia y funcionamiento autónomo (EPSAR, Entidad Pública de Saneamiento de Aguas Residuales de la Comunidad Valenciana, ESAMUR, Entidad de Saneamiento de la Región de Murcia, etc.). Esto permite encargar todas las tareas relativas a la construcción, mantenimiento y operación de estaciones depuradoras a un organismo específico, de carácter público, centrado exclusivamente en esta actividad.

d.- Creación de una figura tributaria (canon, tasa, etc.) destinada a la financiación tanto de la construcción como del mantenimiento de las instalaciones. Este elemento es una de las claves más importantes del éxito de las políticas de depuración, puesto que permite generar un flujo financiero continuo para sostener económicamente esta actividad. Se supera así lo que a menudo ocurría en el pasado, donde se realizaban inversiones en depuradoras gracias a una financiación pública puntual, que luego dejaban de funcionar al cabo de unos pocos años por falta de financiación.

e.- Establecimiento de criterios de calidad de las aguas depuradas, de acuerdo con las disposiciones de la Directiva y normativa estatal de transposición. 


\section{CONCLUSIONES}

El saneamiento y depuración de las aguas residuales es un elemento esencial en el desarrollo socio-sanitario de las poblaciones. Se trata de un servicio público al que todos los ciudadanos tienen derecho, y a su vez, obligación de sostener. Este servicio es prestado por los Municipios y las CCAA, y presenta un marco regulador bastante desarrollado en el que a nuestro juicio hay dos pilares básicos que fundamental el éxito, la presencia de una entidad pública específica, centrada en exclusiva en la prestación del servicio, y la existencia de un instrumento financiero que grave el consumo de agua debido a que todo consumo genera contaminación del agua y, por tanto, la necesidad de su depuración.

\section{BIBLIOGRAFÍA}

Cajigas Delgado, Á. (2012): La evolución de la depuración de las aguas residuales urbanas en España. Ingeniería Civil 168/2012.

COMISIÓN EUROPEA (2013). Informe de la Comisión al Parlamento Europeo, al Consejo, al Comité Económico y Social Europeo y al Comité de las Regiones. Séptimo informe de la Comisión sobre la aplicación de la Directiva sobre el tratamiento de las aguas residuales urbanas (91/271/CEE).

ESAMUR (2014). Memoria de actividades. Murcia.

INE (2015). Encuesta sobre el Suministro y Saneamiento del Agua. Año 2013

MAGRAMA (2007). Plan Nacional de Calidad de las Aguas: Saneamiento y Depuración (2007-2015) PNCA.

Melgarejo, J. y López, M.I. (2016) Depuración y reutilización de aguas en España, en prensa.

Molina Giménez, A. (2016) La protección jurídica del estado químico de las masas de agua subterránea. Pesticidas y nitratos. En: Desafíos del Derecho de Aguas, Navarro, T.M. (dir), Aranzadi, monográfico Revista Aranzadi de Derecho Ambiental, $\mathrm{n}$ 은. 
Torres Sánchez, G. (2014). Situación de la depuración de las aguas urbanas en España. MAPAMA.

\section{ENLACES}

http://www.mapama.gob.es/es/agua/planes-yestrategias/PlanNacionalCalidadAguas tcm7-29339.pdf

https://www.boe.es/buscar/doc.php?id=DOUE-L-1991-80646

http://eur-lex.europa.eu/resource.html?uri=cellar:9bf48961-b030-11e3-86f901aa75ed71a1.0005.04/DOC 1\&format=PDF

http://www.coiaanpv.org/recursos/files/web/el colegio/comisiones de trab ajo/comision agua/blueprint spanish.pdf 


\title{
4.2. MARCO LEGAL DE LA REUTILIZACIÓN
}

\author{
Andrés Molina Giménez
}

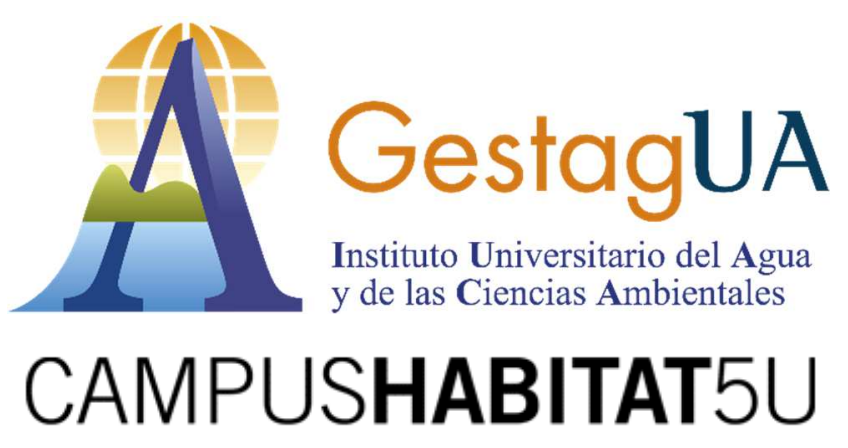




\section{INTRODUCCIÓN}

En este tema estudiaremos los fundamentos del marco legal que regula las aguas regeneradas. Para ello, resulta preciso definirlas. No debe confundirse las aguas depuradas con las regeneradas.

Las primeras son aquellas que una vez tratadas en la EDAR resultan legalmente admisibles para el medio al que van a dirigirse (cauce, lago o laguna, mar), y por tanto pueden obtener una autorización de vertido. Deben para ello cumplir los niveles paramétricos exigidos por el RDPH, y tener unas condiciones de calidad suficiente para no alterar el buen estado ecológico de la masa de agua, de conformidad con lo establecido en el plan hidrológico de la demarcación.

Las aguas regeneradas, sin embargo, son aquellas que obtienen un tratamiento adicional al que resulta obligado para las aguas depuradas, de modo que se convierten en aguas aptas para otros usos. La mayor calidad exigida para estas aguas, en función del uso para el que van destinadas, se deduce de lo establecido en el Real Decreto 1620/2007, de 7 de diciembre, por el que se establece el régimen jurídico de la reutilización de las aguas depuradas. Los requisitos de calidad que exige esta reglamentación obligan a realizar tratamientos terciarios de distinto tipo, dependiendo de las características del efluente de cada EDAR, y del uso pretendido. Un tratamiento secundario no sería suficiente.

Las principales dudas que plantea la regulación de esta actividad pasan por determinar quién la puede realizar, es decir, quién se beneficiará de estos caudales, y bajo qué cobertura formal (concesión, autorización, etc.), así como todos los aspectos relacionados con la calidad del agua regenerada y los posibles usos a los que puede ir dirigida.

La utilización de estas aguas está resultando de una extraordinaria utilidad en España, sobre todo en el sudeste peninsular, lo que permite el sostenimiento de numerosos cultivos, liberar fuentes de recursos de mayor calidad para otros usos, y suministrar agua a proyectos para los que el uso de aguas limpias supondría un despilfarro, como los campos de golf.

\section{DERECHO COMUNITARIO}

En el Derecho Comunitario no existe ninguna Directiva que regule específicamente la reutilización de las aguas regeneradas. Sin embargo, muchas de las Directivas que abordan la protección de los recursos hidráulicos, inciden directa o indirectamente en este ámbito desde diferentes perspectivas. En primer término, es necesario tener en cuenta lo establecido en la Directiva 60/2000/CE Marco del 
Agua, toda vez que esta normativa establece los principios fundamentales del Derecho de aguas en Europa. De sus normas y principios se puede inferir que la utilización de las aguas regeneradas debe realizarse de manera coherente con la planificación hidrológica, no hacer peligrar el buen estado ecológico de las masas de agua superficial o subterránea, y cumplir con el principio de recuperación de costes.

También debe tenerse en cuenta que la Directiva 2006/118/CE, de 12 de diciembre, relativa a la protección de las aguas subterráneas contra la contaminación y el deterioro. En ella encontramos importantes instrumentos como la fijación de normas de calidad y valores umbral para estas masas de agua, la identificación de tendencias sostenidas de deterioro, o el establecimiento de medidas correctoras a través de la programación de actuaciones en los planes hidrológicos de demarcación. La Directiva 2008/105/CE relativa a las normas de calidad ambiental en el ámbito de la política de aguas, aplicable a las superficiales, merece también atención.

En otro orden de cosas, si las aguas regeneradas están en disposición de afectar a un espacio natural protegido, resultaría aplicable la Directiva 92/43/CE de 21 de mayo de 1992, relativa a la conservación de los hábitats naturales y de la fauna y flora silvestres, así como la Directiva 2009/147/CE de 30 de noviembre, sobre conservación de las aves silvestres. Las aguas regeneradas podrían también afectar a masas destinadas a la captación de aguas potables, en cuyo caso habría que tener en cuenta la Directiva 98/83/CE del Consejo, de 3 de noviembre de 1998, relativa a la calidad de las aguas destinadas al consumo humano, en la que se establece, entre otros aspectos, la posible delimitación de perímetros de protección.

La reutilización, por otra parte, es una actividad que la Directiva 91/271/CEE, sobre tratamiento de aguas residuales urbanas, recoge y fomenta en su artículo 12.1. Dicho precepto determina que el agua tratada deberá ser reutilizada cuando resulte apropiado, minimizando los efectos adversos en el medio ambiente. El uso será apropiado cuando se cumplan los estándares de calidad para cada tipo de uso que prevé la reglamentación.

Finalmente, es importante mencionar que algunos proyectos de reutilización, en cuanto supongan la transformación a regadío de terrenos rústicos, así como los planes y programas que los prevean, pueden estar sujetos a evaluación de impacto ambiental de proyectos, y a evaluación estratégica de planes y programas. Así se desprende de la Directiva 2011/92/UE de 13 de diciembre, relativa a la evaluación de las repercusiones de determinados proyectos públicos y privados sobre el medio 
ambiente, y de la Directiva 2001/42/CE del de 27 de junio relativa a la evaluación de los efectos de determinados planes y programas en el medio ambiente.

\section{EL REAL DECRETO 1620/2007, DE 7 DE DICIEMBRE, POR EL QUE SE ESTABLECE EL RÉGIMEN JURÍDICO DE LA REUTILIZACIÓN DE LAS AGUAS DEPURADAS}

El artículo 109 del TRLA, que regula el uso de las aguas regeneradas, resulta por sí solo insuficiente para abordar todos los temas que resultan de la utilización de las aguas regeneradas. Además, tras la nueva redacción del PHN, quedó prácticamente sin contenido. Por ello, vamos a centrarnos en la regulación del Real Decreto de 2007, que regula pormenorizadamente esta cuestión.

\section{1. ¿Quién puede utilizar estas aguas?}

El agua regenerada es considerada en el ordenamiento español como cualquier agua continental y, por tanto, tiene naturaleza demanial. El recurso no pertenece a nadie, ni siquiera a quien lo depura. Atendiendo a esta naturaleza, quien quiera utilizarlo necesita obtener un título de aprovechamiento del organismo de cuenca, o de la autoridad autonómica equivalente en las cuencas internas.

La normativa distingue los siguientes supuestos:

a) Terceros. Todas las personas físicas o jurídicas que desean utilizar aguas regeneradas, deben obtener una concesión administrativa bajo las reglas generales establecidas en el TRLA. Por tanto, cuando una persona o entidad que ni es el concesionario del agua natural originaria, ni tampoco es titular de la autorización de vertido, desea obtener agua regenerada, deberá obtener una concesión ordinaria, en competencia de proyectos con otros potenciales interesados.

b) Primer usuario. Se trata de la persona física o jurídica que dispone de una concesión administrativa de aprovechamiento de aguas. Estamos por tanto ante un particular, una empresa, o una Administración pública, a quien el Organismo de cuenca ha otorgado una concesión en competencia de proyectos para un uso determinado (agricultura, industria, lúdicos, abastecimiento a poblaciones, etc.).

Una vez realizado ese uso, esta misma persona o entidad podría estar interesada en utilizar el agua depurada para otro propósito. En este caso, es necesario determinar si ya es titular de la autorización de vertido o carece de ella. 
- Cuando coincidan en la misma persona ambas condiciones (concesionario y vertedor autorizado), estaríamos en el supuesto que comentamos en el apartado (c). Por tanto, el interesado deberá tramitar una autorización de reutilización, que se califica en el RDR como una autorización complementaria a la autorización de vertido, contando con prioridad frente a terceros.

- En otro caso, es decir, cuando el concesionario no es titular de la autorización de vertido, deberá obtener una concesión de reutilización, que se tramitará, eso sí, sin competencia de proyectos. Con ello se garantiza para este usuario preferencia en relación con terceros eventualmente interesados. También puede optar por tramitar una autorización de vertido, de manera conjunta a la autorización complementaria.

c) Titular de la autorización de vertido. En muchas ocasiones la entidad que realiza el vertido del agua residual, una vez utilizada el agua para los usos correspondientes, es la misma que en su momento obtuvo la concesión. Se trata no obstante de una ecuación que no siempre se cumple. Por ejemplo, en el caso de las "empresas de vertido" (art. 108 TRLA), o de la mayoría de las EDAR urbanas.

Pues bien, con el objetivo de incentivar la inversión en tecnologías de regeneración, el RDR otorga preferencia para obtener las aguas regeneradas a quienes ya están depurando las aguas de manera que, si solicitan su utilización, cualquiera que vaya a ser el uso pretendido, pueden tramitarlo a través de una simple autorización administrativa complementaria a la autorización de vertido.

Con ello se reducen, al menos en parte, las cargas burocráticas que conlleva la tramitación de una concesión sin competencia de proyectos (primer usuario), así como las incertidumbres derivadas de la tramitación ordinaria de las concesiones (tercero). Esta configuración atribuye a estos sujetos la máxima prioridad en la obtención de estas aguas.

d) Adquirentes de agua regenerada mediante contratos de cesión o centros de intercambio de derechos de agua.

Según el RDR, las aguas regeneradas están sujetas a las mismas reglas que se establecen en el TRLA sobre contratos de cesión y centros de intercambio. Sobre este punto volveremos con mayor profundidad en el apartado 3.4. de este trabajo. 


\section{2. ¿Qué calidad debe tener el agua regenerada y para qué usos es posible?}

El agua regenerada no es apta para uso de boca, pero al margen de esta limitación, el agua regenerada puede utilizarse para muchos propósitos (agrarios, industriales, riego urbano, baldeos, lúdicos, etc.). Cada uno de estos usos precisa un tipo diferente de agua regenerada, con condiciones de calidad variables.

El Anexo IA del Real Decreto de 2007 especifica la calidad exigible en el punto de entrega del agua regenerada en función del tipo de uso. Si van a ser varios usos, siempre se exigirá el nivel de calidad más estricto asignado a cualquiera de ellos. Estos valores deben ser especificados por la Confederación en las concesiones y autorizaciones complementarias. Se trata de valores paramétricos mínimos, que pueden ser incrementados si la Confederación, de forma razonada, así lo decide. Nunca puede reducirse el nivel de protección, por el contrario.

Los valores pueden verse alterados también por el efecto de normativas más rigurosas como la que regula los espacios naturales protegidos, (i.e. un humedal protegido, al que pudieran llegar parte de las aguas regeneradas), o a partir de las exigencias de la evaluación de impacto ambiental a que se someta el proyecto.

El responsable de mantener la calidad del agua regenerada en el punto de entrega es el titular de la concesión o autorización de reutilización. A partir de ese momento, el responsable es el usuario final del agua.

\section{CONCLUSIONES}

En un contexto de escasez de recursos hidráulicos, la utilización de recursos no convencionales como son las aguas regeneradas es un factor estratégico.

Los proyectos de reutilización deben contribuir a alcanzar el buen estado ecológico de las masas de agua, así como favorecer su equilibrio cuantitativo. Deben servir a su vez para reducir los vertidos de aguas residuales tratadas en secundario al medio, aportando caudales de mayor calidad para usos deficitarios. La derivación de estos caudales deberá realizarse de manera que no comprometa el caudal ecológico de los cursos de agua a los que accederían las aguas depuradas. También pueden ayudar a reducir los vertidos de aguas residuales al mar.

El marco jurídico actual proporciona seguridad jurídica a los actores implicados, así como introduce garantías para proteger tanto la salud como el medio ambiente. 


\section{BIBLIOGRAFÍA}

Molina, A. (2015) "La contaminación difusa del agua por actividades agrarias. Especial referencia al riego con aguas regeneradas", en: Benito, M.A. (dir), et al. Agua y Derecho. Retos para el Siglo XXI. Aranzadi, Pamplona.

Molina Giménez, A. (2016) La protección jurídica del estado químico de las masas de agua subterránea. Pesticidas y nitratos. En: Desafíos del Derecho de Aguas, Navarro, T.M. (dir), Aranzadi, monográfico Revista Aranzadi de Derecho Ambiental, $\mathrm{n}$ ㅇ 25 .

Molina, A. y Melgarejo, J. (2015): Water policy in Spain: seeking a peaceful balance between transfers, desalination and wastewater reuse. International Journal of Water Resources Development.

Navarro, T. M. (2013). "La utilización de los recursos hídricos no convencionales. Carencias y disonancias de un régimen jurídico inconcluso". Embid, A. (dir.), Usos del Agua (Concesiones, Autorizaciones y Mercados del Agua). Civitas, Navarra.

Navarro, T. M. (2012). "Cuestiones jurídico-ambientales de la reutilización de aguas regeneradas". Embid, A. (dir.), Agua y Ciudades. Civitas, Navarra.

\section{ENLACES}

http://www.boe.es/buscar/doc.php?id=BOE-A-2007-21092

http://www.mapama.gob.es/es/agua/publicaciones/GUIA RD 16202007 t cm7-178027.pdf 


\title{
4.3. ASPECTOS TÉCNICOS Y DE GESTIÓN
}

\author{
Daniel Prats Rico
}

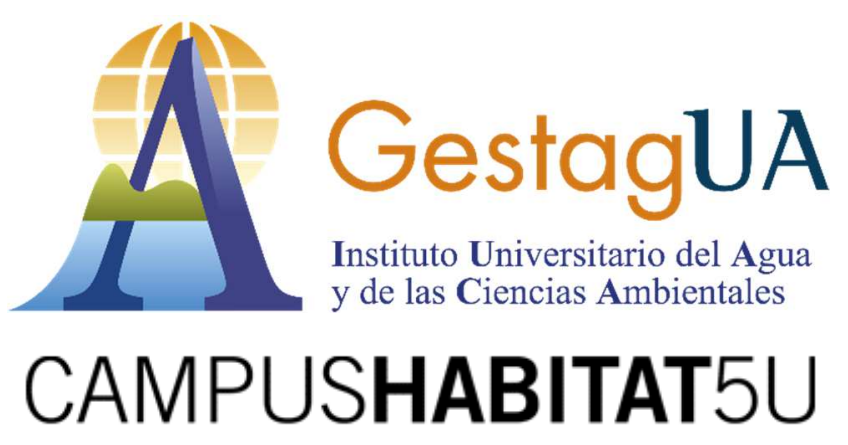




\section{INTRODUCCIÓN. CONTAMINACIÓN DE LAS AGUAS DEBIDO A SU USO}

El uso del agua en cualquier aplicación urbana, agrícola o industrial, hace que el agua incorpore en forma disuelta o en suspensión, muchas de las sustancias con las que se pone en contacto. Muchas de estas sustancias son contaminantes. En la figura 1 se muestran algunos de los contaminantes típicos derivados de cada uso:

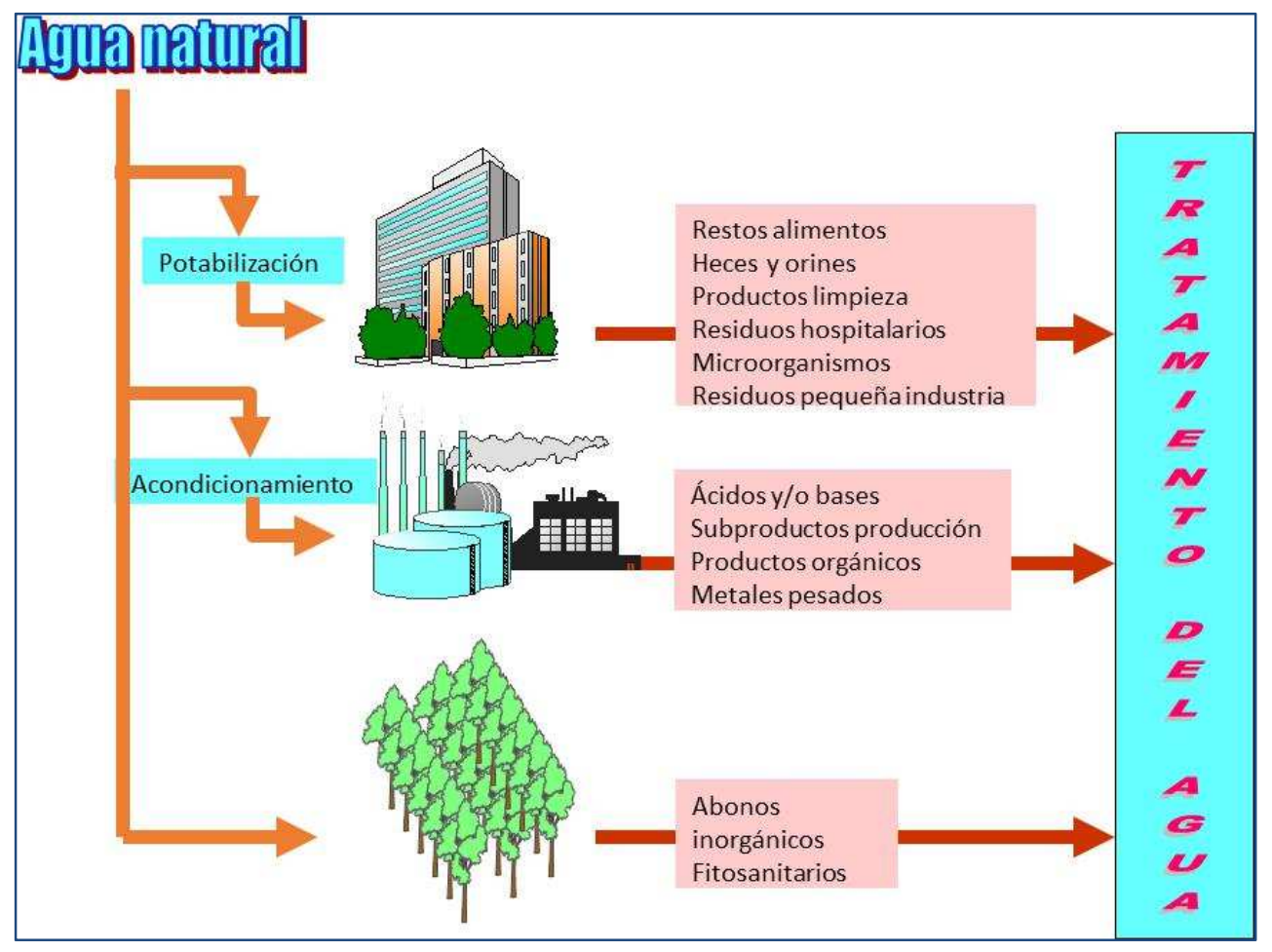

Figura 1. Contaminación de las aguas debido a su uso (elaboración propia)

\section{OBJETIVOS DEL TRATAMIENTO O DEPURACIÓ DE LAS AGUAS}

El objetivo del tratamiento de aguas es eliminar los componentes indeseables para su aplicación a un uso determinado o para su vertido al medio ambiente, intentando ajustarse a las especificaciones deseadas con el coste más bajo posible.

Para conseguir los objetivos de calidad el agua residual debe someterse a tratamiento de depuración mediante una serie de procesos de carácter físico, químico o biológico. Una planta depuradora es una instalación industrial en la que 
partiendo del agua contaminada se obtiene como producto agua tratada, generándose lodos como subproductos, tal como se muestra en la figura 2.

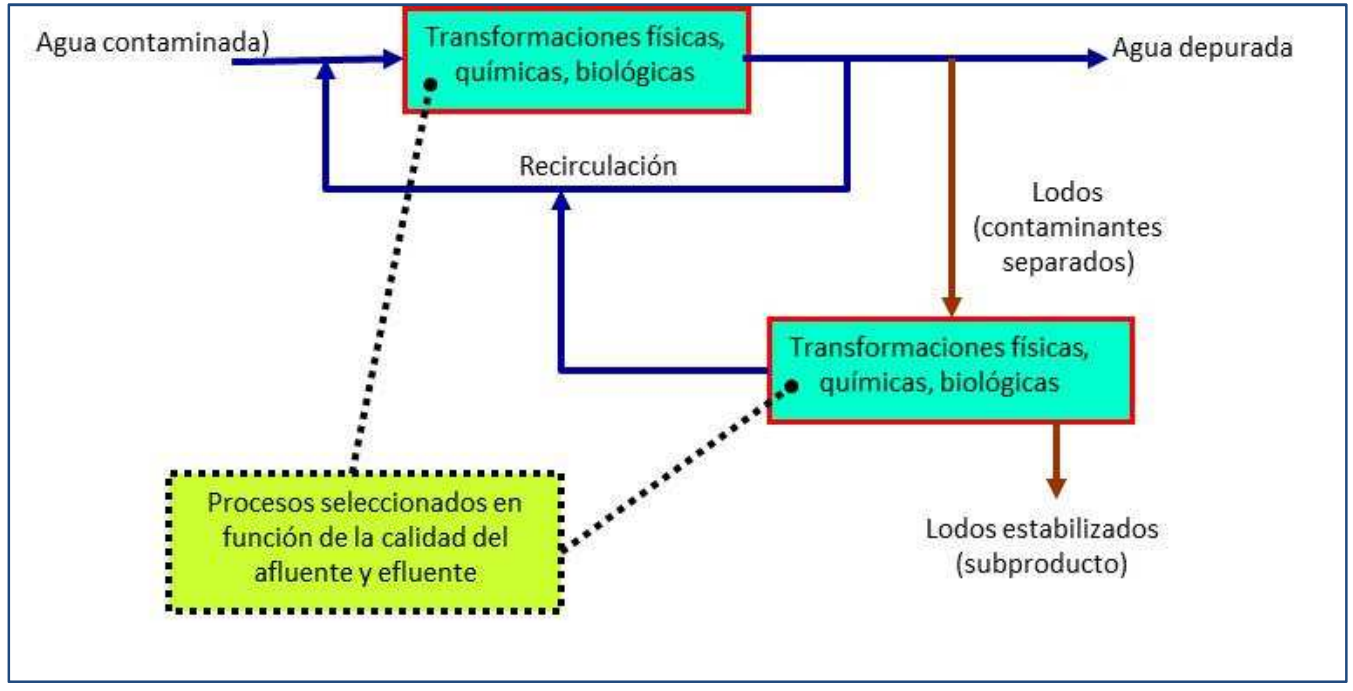

Figura 2. Esquema simplificado del tratamiento de aguas (elaboración propia)

Todos los países de la UE están obligados a depurar sus aguas hasta unos ciertos niveles de calidad para minimizar su impacto ambiental cuando se produzca el vertido, según establece la Directiva 91/271/CEE. La depuración no se consigue en una sola etapa o proceso, sino en una serie de tratamientos en los que se va reduciendo la concentración de los distintos contaminantes presentes, llevando el agua al nivel de calidad deseado. El número e intensidad de los tratamientos dependerá de los contaminantes que se pretenda reducir o eliminar. Tradicionalmente se suelen agrupar los procesos en una serie de etapas denominadas pretratamiento, tratamiento primario, tratamiento secundario $y$ tratamiento terciario, tal como se muestra en la figura 3. 


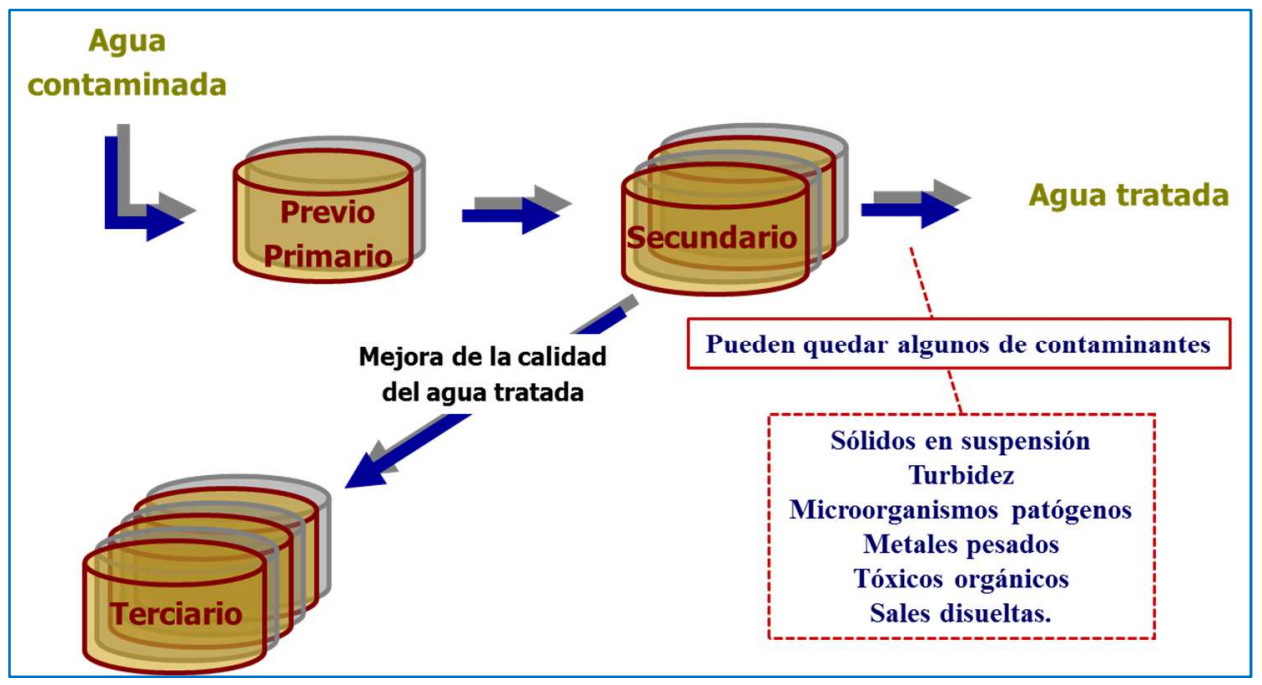

Figura 3. Tratamientos que se aplican al agua residual (elaboración propia)

Los tratamientos previos tienen como objetivo eliminar o reducir sólidos groseros, arenas, grasas y aceites, el tratamiento primario busca la eliminación de materia en suspensión, flotantes y espumas, el tratamiento secundario se centra en la eliminación de materia orgánica disuelta o coloidal. En muchas ocasiones el agua tratada todavía puede contener algunos contaminantes, por tanto, si su destino es el vertido en zonas sensibles o la reutilización, debe ser adicionalmente tratada con tratamientos terciarios orientados a la eliminación de estos contaminantes.

\section{PROCESOS EMPLEADOS}

Las tecnologías son muy diversas y aplican procesos físicos, químicos y/o biológicos en función de los contaminantes que se pretenda eliminar. En la figura 4 se indican los procesos más habituales en las distintas etapas del proceso. 


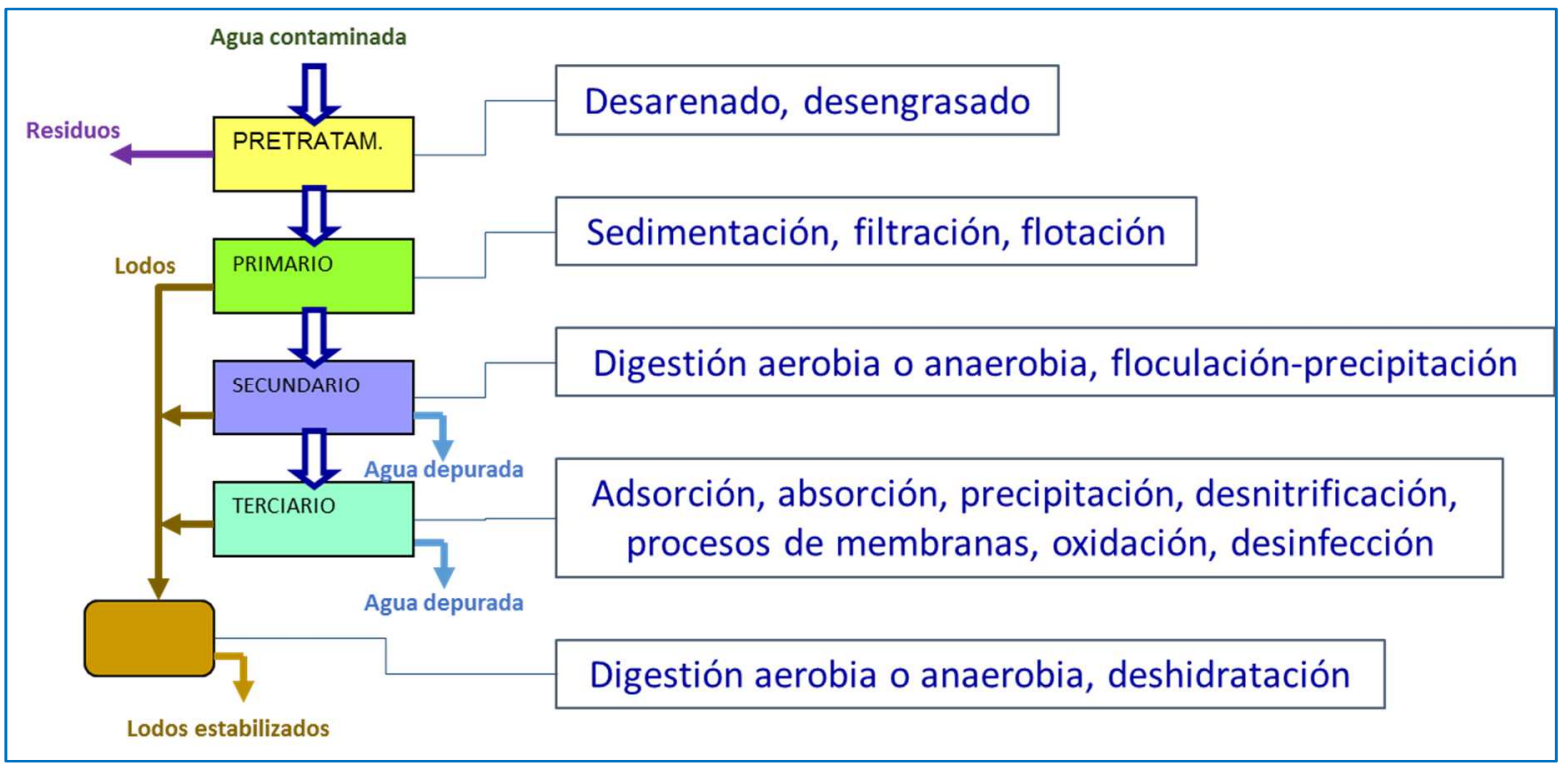

Figura 4. Procesos habitualmente utilizados en el tratamiento de aguas (elaboración propia)

\section{ESTACIÓN DEPURADORA DE AGUAS RESIDUALES}

Una estación depuradora de aguas residuales (EDAR) es una instalación en la que se combinan diferentes procesos y tecnologías para depurar las aguas residuales. Pueden ser pocos o muchos los distintos procesos implicados para realizar el tratamiento en función de la contaminación del agua a tratar y del objetivo de calidad que se pretenda conseguir. A modo de ejemplo en las figuras 5 y 6 se muestra respectivamente una fotografía y el diagrama de flujo de la depuradora de El Verger-Els Poblets, en la provincia de Alicante, que trata una población de 1.800 he1 y tiene únicamente los procesos de desbaste, reactor biológico y decantación en la línea de agua y espesado y deshidratación mecánica en la línea de fangos.

\footnotetext{
${ }^{1}$ he: habitante equivalente. El término he se utiliza para evaluar la carga orgánica biodegradable que llega a una EDAR o la que se puede generar en una determinada población. Aproximadamente se puede asimilar a la contaminación que puede generar una persona de forma individual.
} 


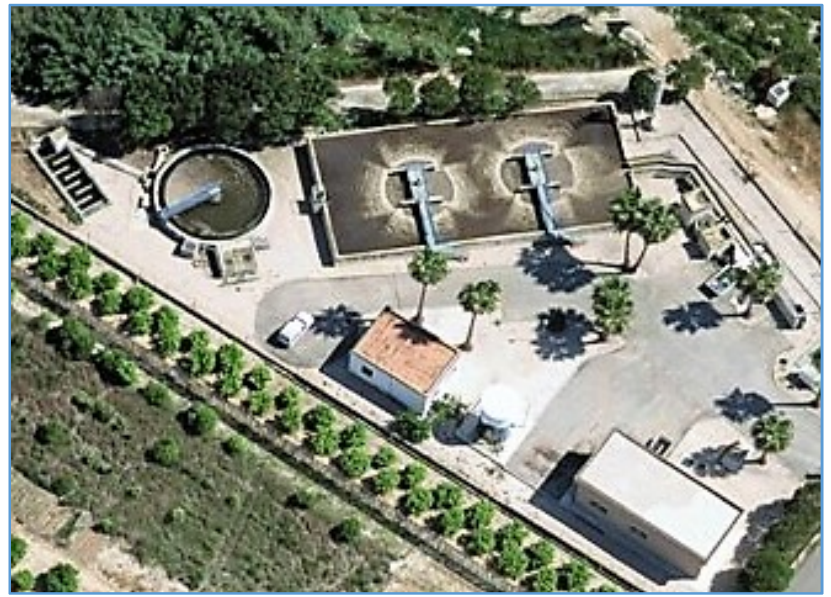

Figura 5. EDAR de El Verger-Els Poblets (fuente: EPSAR)

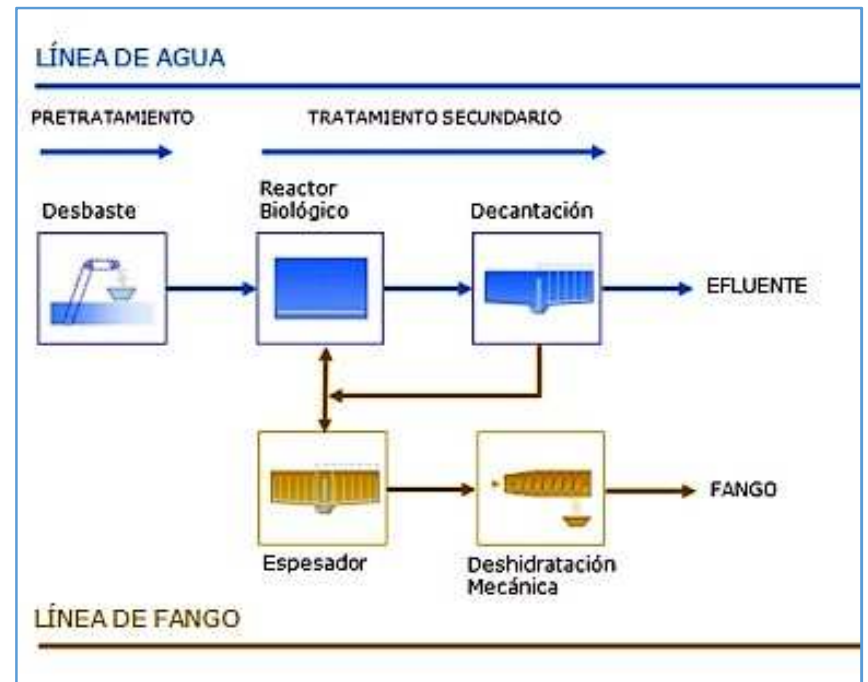

Figura 6. Diagrama de flujo esquemático de la EDAR de El Verger-Els Poblets (fuente: EPSAR)

Otro ejemplo más complejo se muestra en las figuras 7 y 8 , donde se muestra, respectivamente, una fotografía de la depuradora de Benidorm (Alicante) y su diagrama de flujo. 


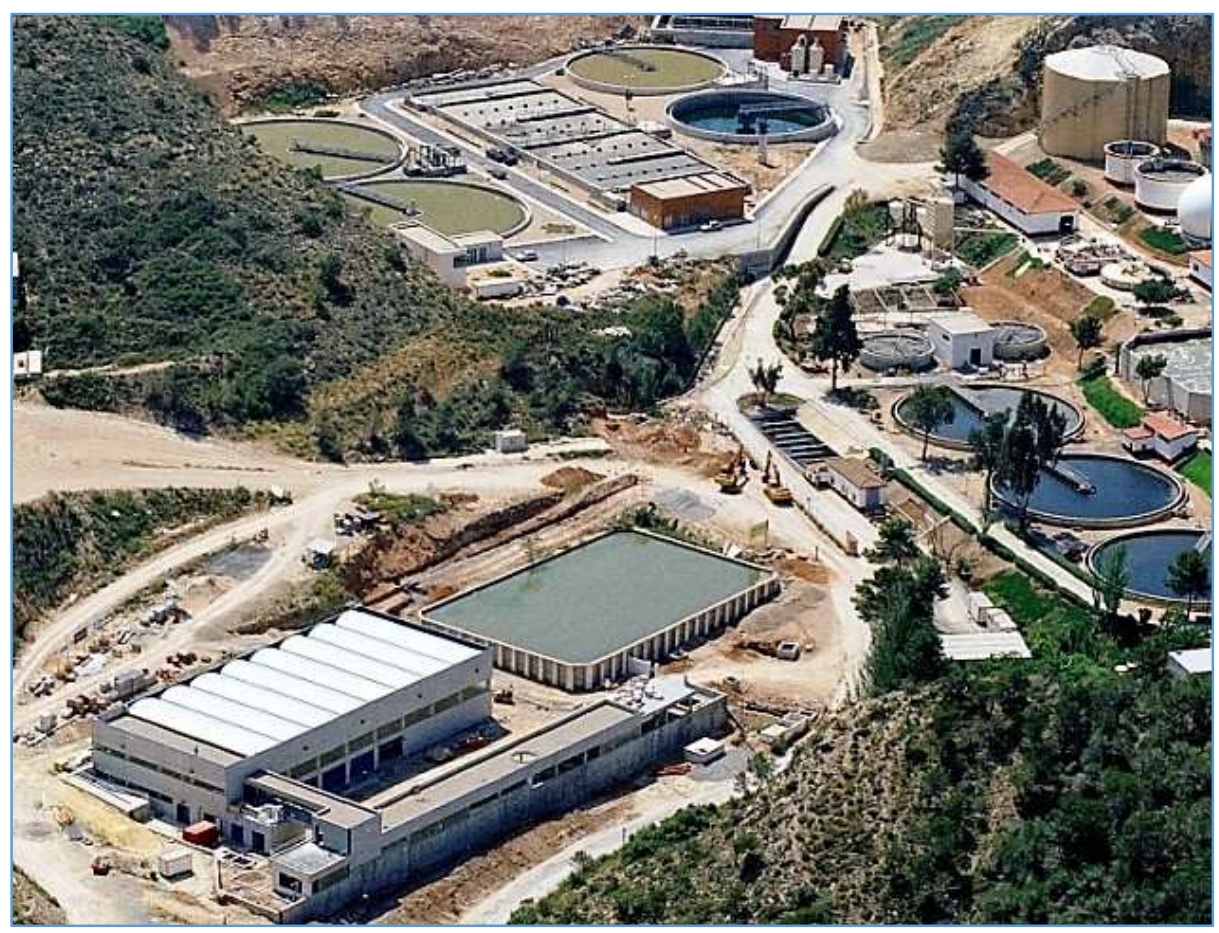

Figura 7. EDAR de Benidorm (Alicante) (fuente: EPSAR)

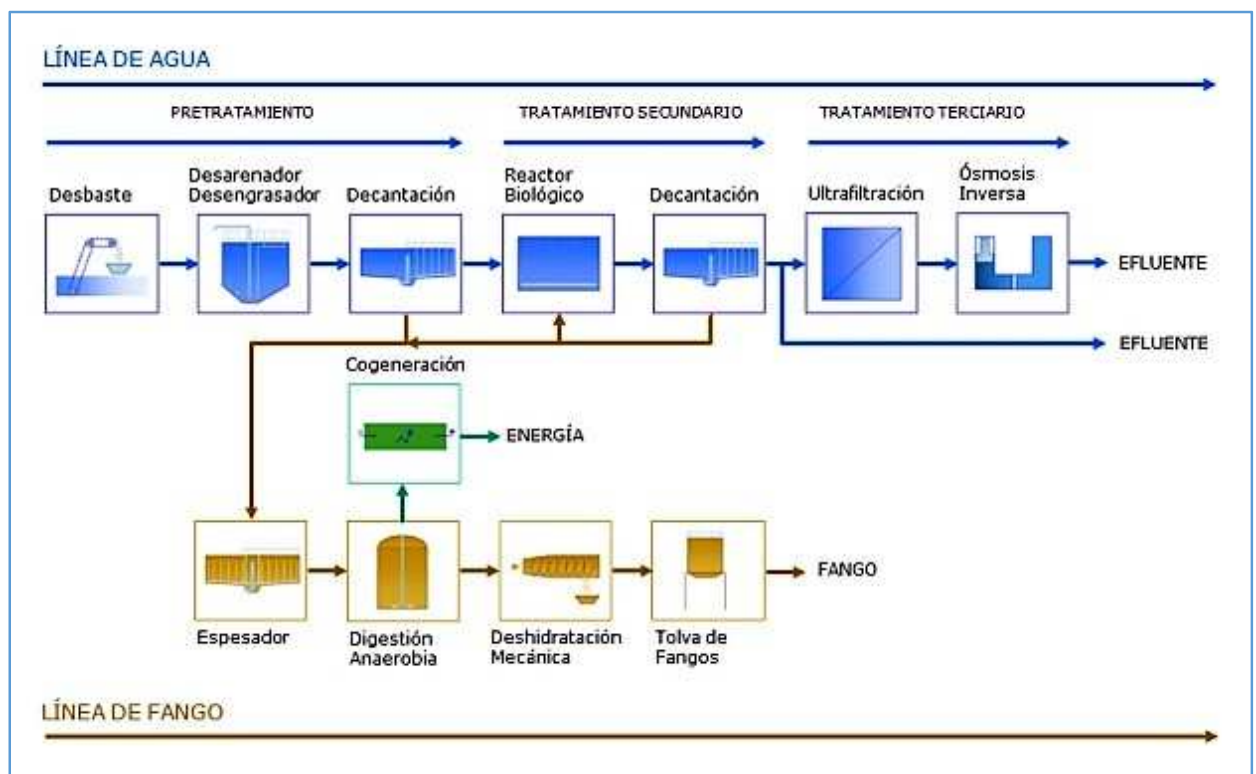

Figura 8. Diagrama de flujo esquemático de la EDAR de Benidorm (fuente: EPSAR)

En este caso se trata una población de 255.000 he y tiene los procesos de desbaste, desarenador, desengrasador y decantación como tratamiento previo y 
primario, reactor biológico y decantación como tratamiento secundario, y además incorpora un tratamiento terciario con ultrafiltración y ósmosis inversa. Por otra parte, los lodos o fangos son espesados, sometidos a digestión anaerobia y deshidratados. Además, mediante un proceso de cogeneración se genera energía.

\section{REUTILIZACIÓN DE AGUAS RESIDUALES}

Los desequilibrios hídricos tienden a acentuarse a escala mundial (crecimiento de la población, inapropiada gestión, desarrollo, contaminación, deforestación, cambio climático). Como ya se ha comentado las aguas se contaminan durante su uso, inhabilitándose generalmente para ser directamente empleadas nuevamente en el mismo u otros usos. No obstante, cuando los usos se producen lejos de litoral, la dinámica de los flujos residuales puede permitir que las aguas sobrantes retornen a cauces $y$, diluidas con las propias aguas del cauce, emplearse nuevamente para otros usos. En estos casos se puede producir una progresiva contaminación. Este tipo de reutilización indirecta derivada de la dinámica de uso del agua se muestra en la figura 9 y constituye una reutilización indirecta de aguas residuales, tratadas o no.

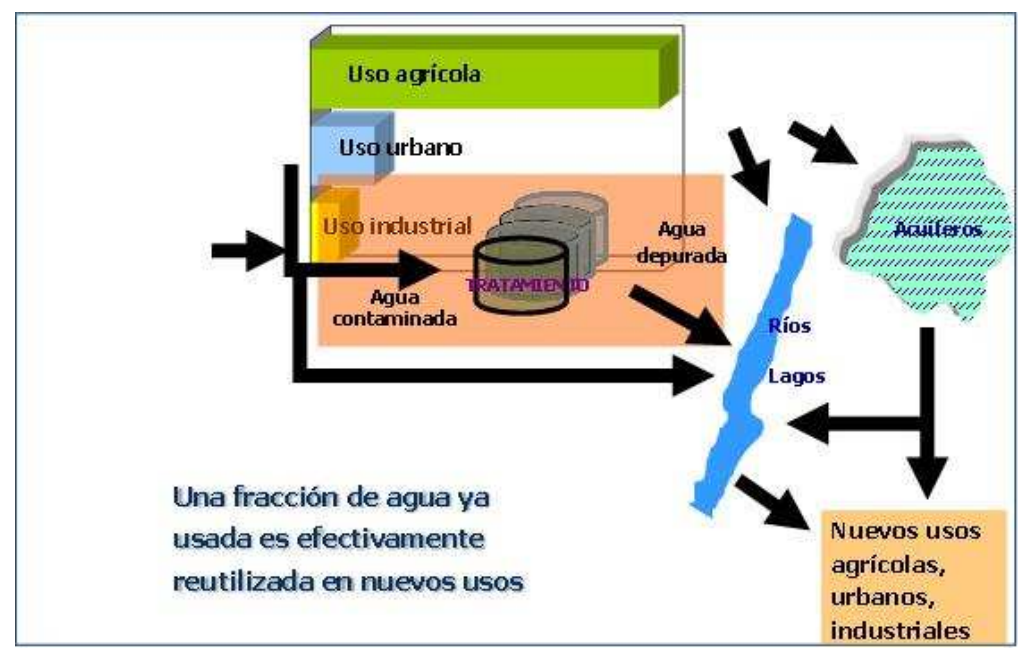

Figura 9. Reutilización indirecta de aguas residuales (elaboración propia)

En general, cuando se habla de reutilización de aguas residuales, los términos se refieren a reutilización directa planificada, cuyo esquema se muestra en la figura 10. 


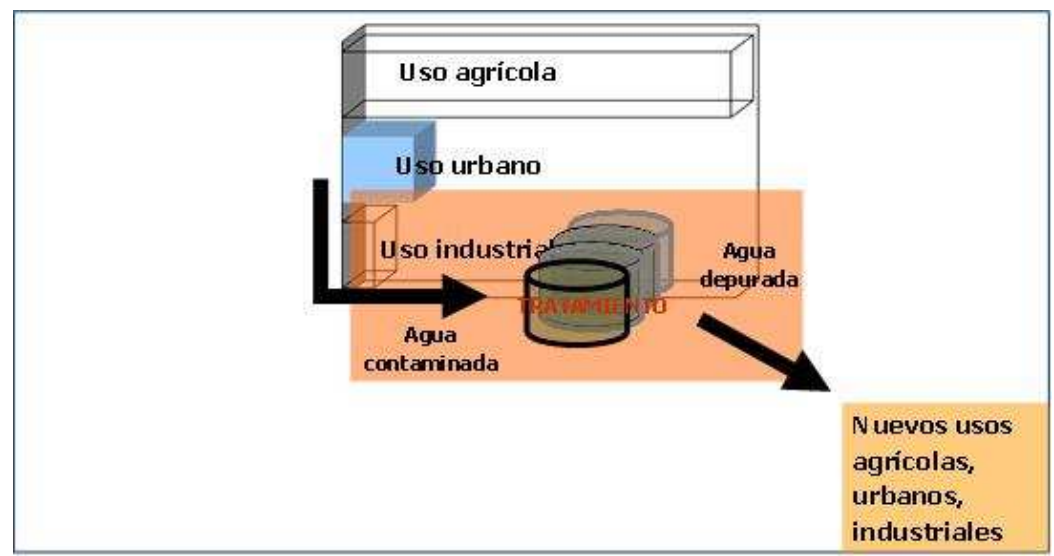

Figura 10. Reutilización directa planificada de aguas residuales (elaboración propia)

Resulta evidente que con la reutilización del agua una vez usada se conseguirá un ahorro para el nuevo uso en un caudal equivalente al reciclado. Si la reutilización es total prácticamente se duplicará el caudal inicial del recurso. Además, se reducirá el riesgo de contaminación del medio receptor al eliminar del agua las sustancias contaminantes. Complementariamente sería también posible recuperar parte de los costes de la depuración si se revierten sobre el nuevo uso del agua.

\section{USOS DEL AGUA REUTILIZADA}

Los usos posibles del agua residual pueden ser muy variados: municipales (riego de parques públicos, instalaciones deportivas, jardines privados, bordes de carreteras; limpieza de las calles; sistemas de protección contra incendios; ...), agrícolas (riego de cultivos, pastos para los animales de ordeño, forraje, fibra, cultivos de flores, ...) industriales (agua de refrigeración; agua de lavado, lavado, control del polvo, ...), recreativos (riego del campo de golf, embalses recreativos, nieve artificial, ...), ambientales, (recarga de acuíferos, humedales, pantanos; caudales ecológicos, ...) uso como potable (recarga de acuíferos para agua potable, mezcla con los suministros de agua potable de superficie, uso directo como agua potable).

Se reutiliza agua residual con distintos grados de depuración. En algunos casos se usa sin depurar o con una depuración muy deficiente, sobre todo en países poco desarrollados de América latina, Asia y África subsahariana. 
En países desarrollados y para aguas con calidad de tratamiento secundario o superior, se estima que los usos a escala mundial se distribuyen, como se indica en la figura 12.

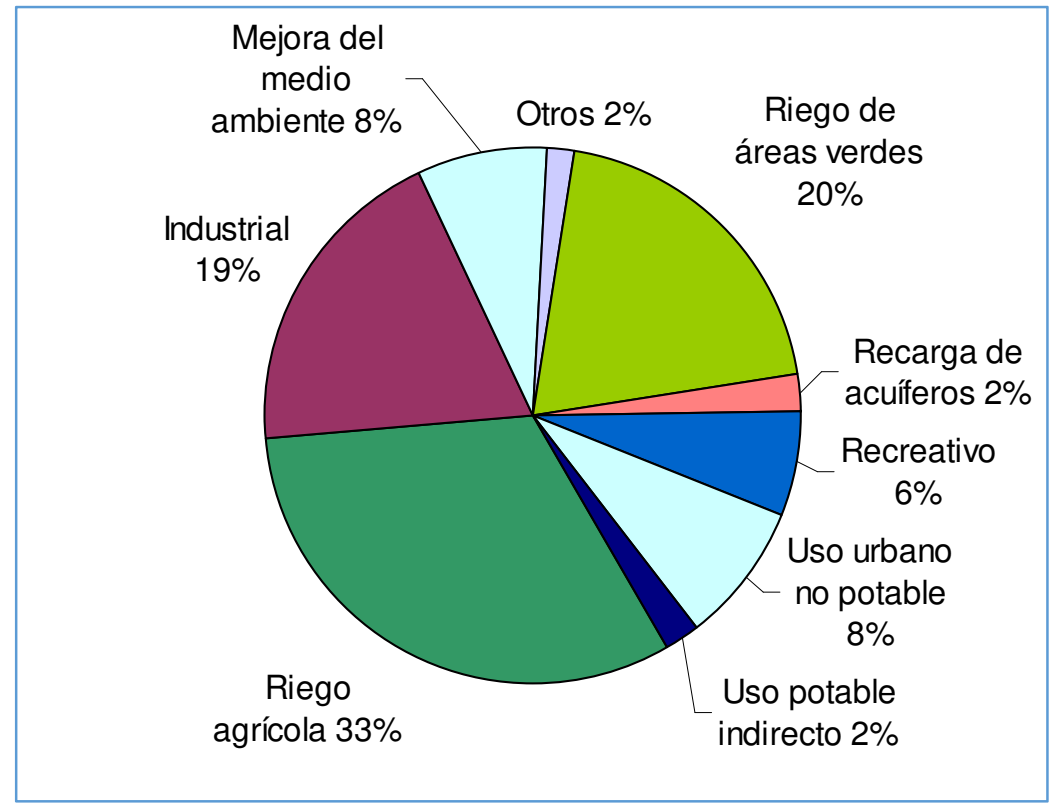

Figura 11. Usos del agua reutilizada a escala mundial (adaptado de Municipal Water Reuse Markets 2010²).

\footnotetext{
${ }^{2}$ Municipal Water Reuse Markets 2010. Analysis forecasts and inventory. Global Water Intelligence. Media Analytics Ltd., Oxford, Reino Unido, 2009
} 
En España los usos se muestran en la figura 12:

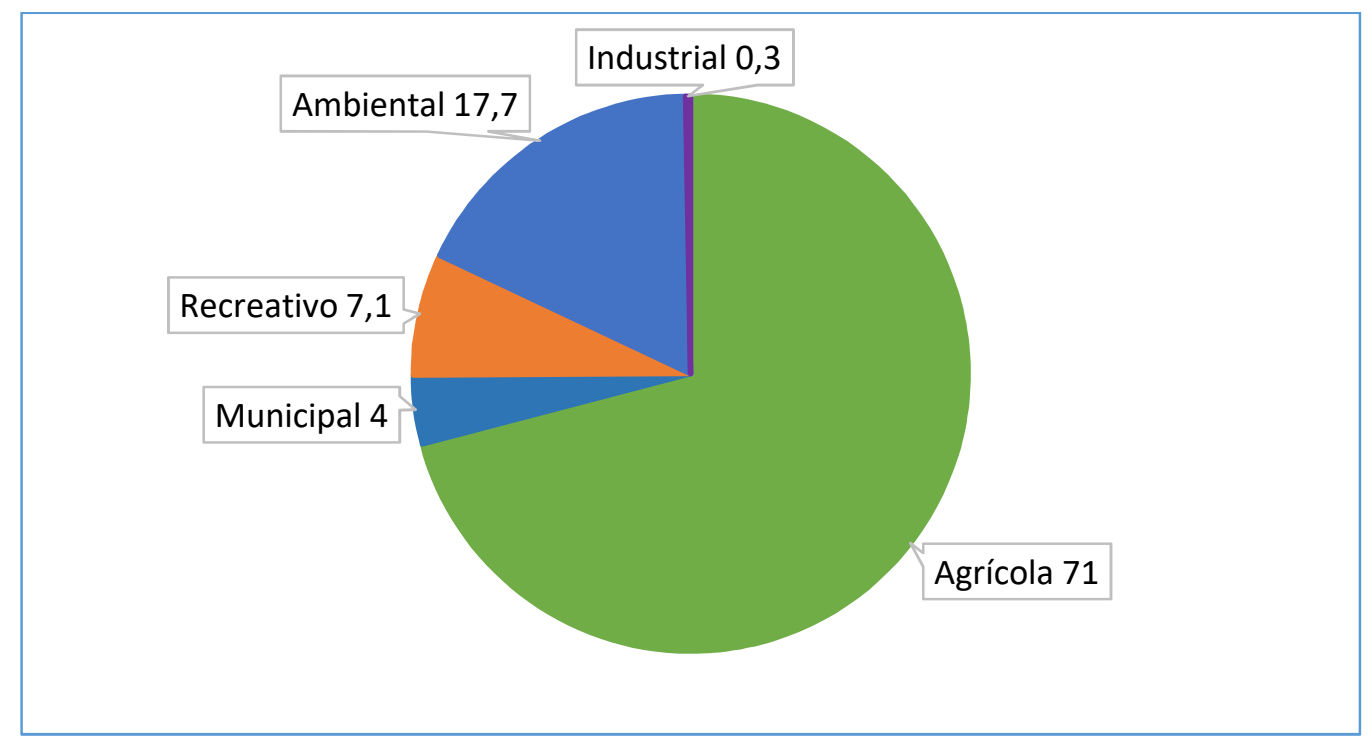

Figura 12. Porcentajes de uso del agua residual en España (elaboración propia con datos de Ortega de Miguel, 2008³)

Como se puede observar, los usos principales van orientados al regadío, siendo pequeño el porcentaje de uso urbano. Este hecho está relacionado con los usos de las aguas dulces, ya que la demanda y consumo de agua para uso agrícola es, con gran diferencia, el sector que más agua demanda.

\section{REGENERACIÓN DE AGUAS RESIDUALES Y COSTES ASOCIADOS}

Los tratamientos de regeneración de aguas residuales suelen combinar una serie de operaciones cuyo objetivo es eliminar contaminantes todavía presentes en el agua tratada como sólidos en suspensión, materia coloidal (turbidez), contaminantes disueltos, sales solubles y microorganismos patógenos. La casuística es muy variable ya que depende de la calidad de las aguas que se deban regenerar y de la calidad que se precise para el agua tratada. Los procesos que se aplican pueden incluir tratamiento físico-químico (para eliminación de materia orgánica y contaminantes específicos) filtración (para sólidos suspendidos), membranas (para sales disueltas y otros contaminantes y desinfección (para microorganismos patógenos). En la figura 13 se muestra el esquema de un tratamiento terciario convencional.

\footnotetext{
${ }^{3}$ Ortega de Miguel, E., 2008. La reutilización de las aguas residuales depuradas en España. Perspectivas, oportunidades y barreras. Jornada sobre reutilización de aguas depuradas. Pamplona
} 


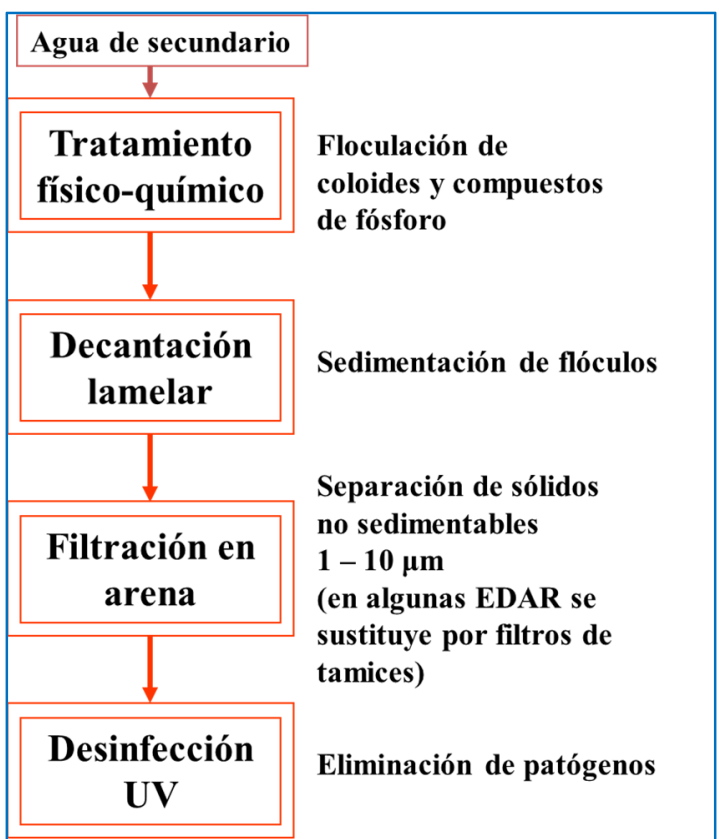

Figura 13. Tratamiento terciario convencional para la regeneración de aguas residuales (elaboración propia)

Respecto a los costes hay que distinguir entre costes de implantación y costes de operación. Los costes de implantación dependen de la tecnología, tamaño, ubicación, materiales, etc. Los costes de operación dependen de la necesidad de reactivos, energía, mano de obra, etc. A modo de ejemplo, en la tabla 1 se indican los intervalos típicos de costes de implantación y operación para una serie de tratamientos.

Tabla 1. Costes de implantación y operación de una serie de tratamientos (datos de Iglesias, 20164)

\begin{tabular}{|l|c|c|}
\hline \multicolumn{1}{|c|}{ Tratamiento } & $\begin{array}{c}\text { Implantación } \\
\left(€ / \mathrm{m}^{3} \cdot \text { día }\right)\end{array}$ & $\begin{array}{c}\text { Operación }\left(€ / \mathrm{m}^{3}\right. \\
\text { producido) }\end{array}$ \\
\hline Físico-químico con decantación & $18-25$ & $0,01-0,02$ \\
\hline Filtración por gravedad con arena & $5-11$ & $0,04-0,07$ \\
\hline Doble filtración de arena & $62-80$ & $0,07-0,08$ \\
\hline Ultrafiltración & $158-315$ & $0,08-0,10$ \\
\hline
\end{tabular}

${ }^{4}$ Iglesias Esteban, Raquel, 2016. La reutilización de efluentes depurados en España: retrospectiva, desarrollo del marco normativo, estudio de las tecnologías de regeneración frente a los biorreactores de membrana y sus costes en función del uso. Tesis doctoral. Universidad Politécnica de Madrid. 
Herramientas para la gestión territorial sostenible del agua || MOOC UA

\begin{tabular}{|l|c|c|}
\hline Ósmosis inversa & $153-173$ & $0,20-0,25$ \\
\hline Electrodiálisis por radiación & $208-366$ & $0,25-0,35$ \\
\hline $\begin{array}{l}\text { Desinfección } \\
\text { ultravioleta }\end{array}$ & $5-11$ & $0,002-0,003$ \\
\hline
\end{tabular}




\subsection{ELIMINACIÓN DE CONTAMINANTES ORDINARIOS Y EMERGENTES}

María de los Ángeles Bernal Romero del Hombre Bueno

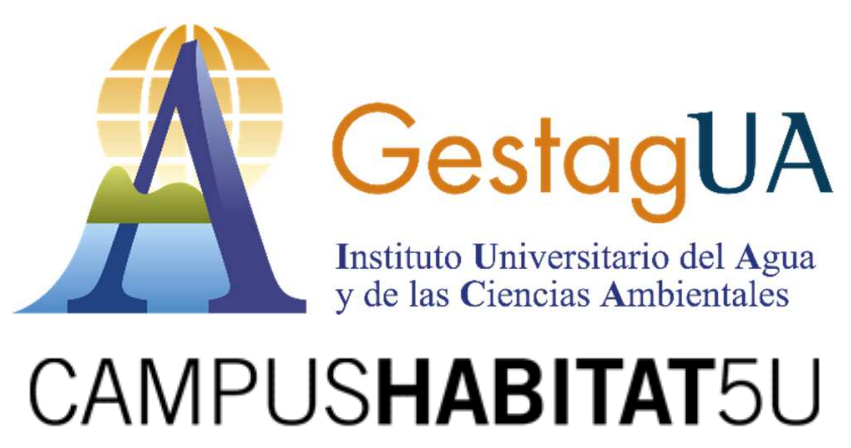




\section{INTRODUCCIÓN}

El agua posee una serie de propiedades físicas, químicas y biológicas que la hacen esencial para la vida. El Texto Refundido de la Ley de Aguas (artículo 93) define contaminación del agua como "la acción y el efecto de introducir materias o formas de energía, o inducir condiciones en el agua que, de modo directo o indirecto, impliquen una alteración perjudicial de su calidad en relación con los usos posteriores, con la salud humana, o con los ecosistemas acuáticos o terrestres directamente asociados a los acuáticos; causen daños a los bienes; y deterioren 0 dificulten el disfrute y los usos del medio ambiente" (artículo 93).

Las causas de la contaminación de las aguas esencialmente son:

- Contaminación de origen natural

Se debe a la presencia de determinadas sustancias en el agua sin que intervenga la acción humana. Por lo general, los residuos naturales (ej. partículas sólidas y gases atmosféricos arrastrados por la lluvia, residuos vegetales y animales, etc.) suelen ser eliminados mediante procesos químicobiológicos que permiten la capacidad autodepuradora del agua.

- Vertidos urbanos, industriales y agrícolas-ganaderos Las aguas residuales de origen urbano (resultado del uso del agua en viviendas, actividades comerciales y servicios) contienen sustancias principalmente generadas por el metabolismo urbano, así como productos químicos de uso doméstico (detergentes, cosméticos, etc.). Las aguas de origen industrial

- Contaminación difusa (las aguas de lluvia o de regadío arrastran contaminantes de origen agrícola, pesticidas, detergentes, etc.).

- Salinización de acuíferos por intrusión marina debido a la sobreexplotación de éstos.

- Contaminación accidental.

\section{CONTAMINANTES ORDINARIOS PRESENTES EN LAS AGUAS}

Según su naturaleza, los contaminantes presentes en las aguas se pueden clasificar en físicos, químicos y biológicos (figura 1).

Entre los contaminantes físicos cabe destacar el efecto de la temperatura, las partículas radiactivas y los sólidos en suspensión, tanto de origen inorgánico (ej. lodos, arenas finas y gruesas, gravas) como orgánico (restos de animales y vegetales). 
Entre los contaminantes químicos es necesario distinguir entre contaminantes de origen orgánico (ej. grasas animales y aceites, carbohidratos, proteínas), inorgánico (ej. nitrógeno y sus formas oxidados como $\mathrm{NO}_{2}$ y NO $\mathrm{N}_{3}$ y reducida como $\mathrm{NH}_{4}{ }^{+}$, fósforo y derivados, azufre, cloruros, metales pesados, $\mathrm{pH}$ ) y gases (ej. oxígeno, sulfuro de hidrógeno, metano).

Entre los contaminantes biológicos cabe destacar: bacterias (ej. escherichia coli, salmonela), protozoos y helmintos, virus (ej. enterovirus, rotavirus) y algas.

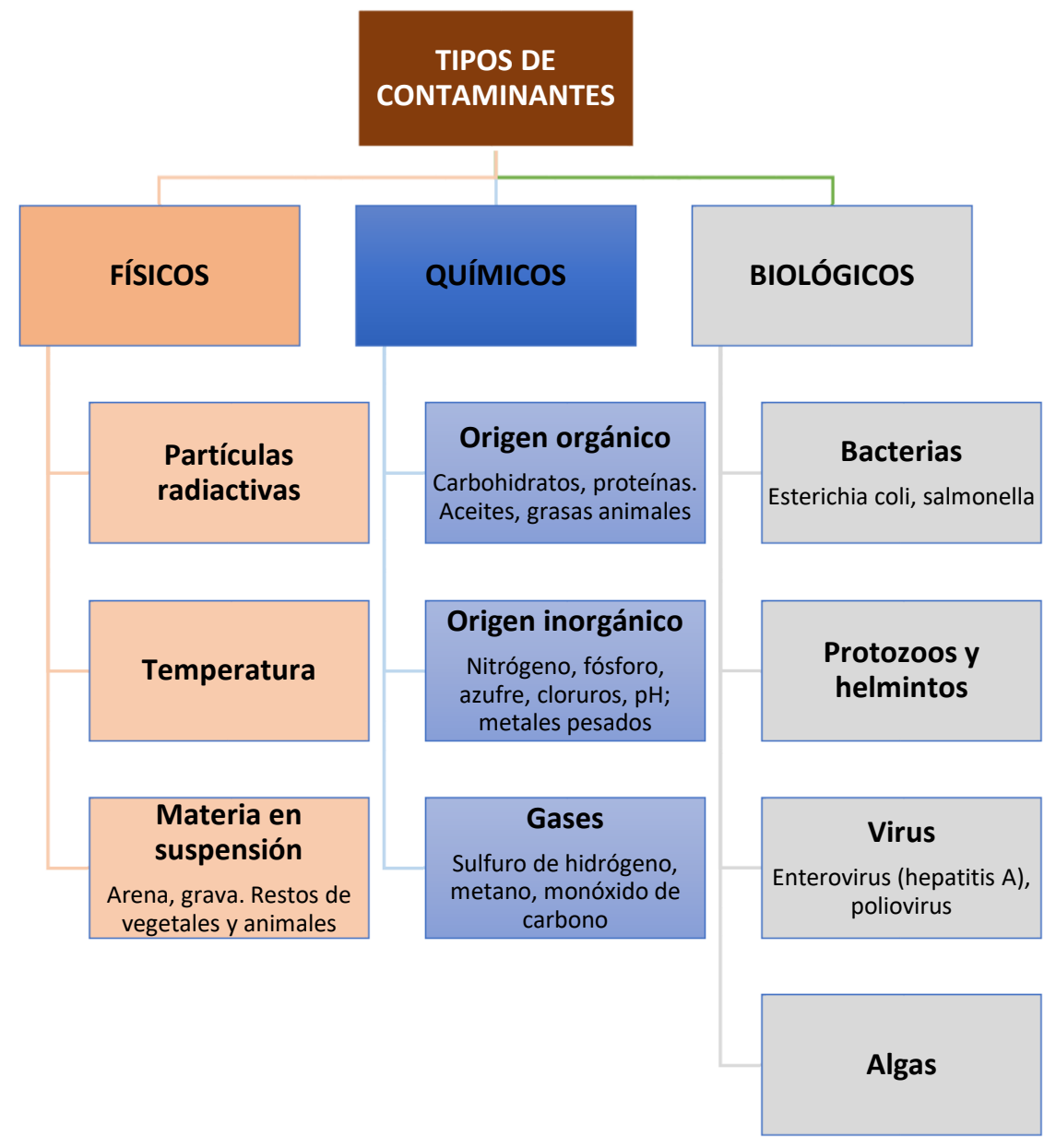

Figura 1 Tipos de contaminantes presentes en las aguas.

Las aguas superficiales y las aguas subterráneas pueden contener algunos de estos contaminantes. Las estaciones de tratamiento de agua potable (ETAP) son las encargadas de recoger el agua bruta captada y someterla a una serie de procesos físico-químicos para adecuarlas a los valores de calidad que establece la legislación vigente para su consumo. 
La presente lección se centra en el estudio de las aguas residuales. Se entiende por aguas residuales urbanas a las aguas residuales domésticas o la mezcla de las mismas con aguas residuales industriales y/o aguas de correntía pluvial (Directiva 91/271/CEE).

En la tabla 1 se definen algunos parámetros físicos, químicos y biológicos habitualmente empleados en las estaciones depuradoras de aguas residuales (EDAR).

Tabla 1 Parámetros físicos, químicos y biológicos importantes en aguas residuales.

\begin{tabular}{|c|c|c|c|}
\hline Tipo & Parámetro & Unidad & Descripción \\
\hline \multirow{4}{*}{ FÍSICO } & Turbidez & NTU & $\begin{array}{l}\text { La turbidez mide la reducción de la intensidad de la } \\
\text { luz que pasa a través de una muestra de agua por } \\
\text { efecto de la materia suspendida y coloidal. } \\
\text { Es importante su control sobre todo para la } \\
\text { desinfección del agua y para su regeneración. }\end{array}$ \\
\hline & $\begin{array}{c}\text { Propiedades } \\
\text { organolépticas }\end{array}$ & & $\begin{array}{l}\text { La variación en las propiedades organolépticas (color, } \\
\text { sabor y olor) permiten evidenciar agentes } \\
\text { contaminantes. }\end{array}$ \\
\hline & Temperatura & ${ }^{\circ} \mathrm{C}$ & $\begin{array}{l}\text { La temperatura condiciona los procesos de depuración } \\
\text { biológica. Con el aumento de la temperatura, la } \\
\text { solubilidad del oxígeno disuelto en agua disminuye. } \\
\text { El descenso de la temperatura ralentiza los procesos } \\
\text { biológicos. }\end{array}$ \\
\hline & $\begin{array}{c}\text { Sólidos en } \\
\text { suspensión (SS) }\end{array}$ & $\mathrm{mg} \cdot \mathrm{L}^{-1}$ & $\begin{array}{l}\text { Los sólidos presentes en las aguas residuales se } \\
\text { clasifican en: sólidos totales (ST), sólidos en } \\
\text { suspensión (SS), sólidos totales disueltos (STD), } \\
\text { sólidos totales volátiles (STV) y sólidos volátiles en } \\
\text { suspensión (SSV). } \\
\text { Los SS representan la cantidad de lodo removible por } \\
\text { sedimentación simple. }\end{array}$ \\
\hline \multirow{4}{*}{ QUÍMICO } & $\begin{array}{c}\text { Demanda } \\
\text { bioquímica de } \\
\text { oxígeno }(\mathrm{DBO})\end{array}$ & $\mathrm{mg} \cdot \mathrm{L}^{-1}$ & $\begin{array}{l}\text { La DBO es una medida de la cantidad de } \mathrm{O}_{2} \\
\text { consumida durante la oxidación bioquímica de la } \\
\text { materia orgánica presente en el agua. } \\
\text { Se suele indicar el valor de este parámetro para un } \\
\text { tiempo de incubación de } 5 \text { días a } 20^{\circ} \mathrm{C}\left(\mathrm{DBO}_{5}\right) \text {. }\end{array}$ \\
\hline & $\begin{array}{l}\text { Demanda química } \\
\text { de oxígeno (DQO) }\end{array}$ & $\mathrm{mg} \cdot \mathrm{L}^{-1}$ & $\begin{array}{l}\text { La DQO es una medida de la cantidad de } \mathrm{O}_{2} \\
\text { consumida durante la oxidación química de la materia } \\
\text { orgánica presente en el agua. Se cumple que la DQO } \\
\geq \mathrm{DBO}_{5} \text {. } \\
\mathrm{La} \text { relación DBO/DQO indica el tipo de } \\
\text { contaminación que hay en las aguas residuales: } \\
\text { - } \mathrm{DBO} / \mathrm{DQO}<0.2 \text { Vertido de tipo inorgánico } \\
-\mathrm{DBO} / \mathrm{DQO}>0.6 \text { Vertido de tipo orgánico }\end{array}$ \\
\hline & $\begin{array}{l}\text { Carbono orgánico } \\
\text { total (COT) }\end{array}$ & $\mathrm{mg} \cdot \mathrm{L}^{-1}$ & $\begin{array}{l}\text { El COT es la medida de la cantidad de carbono } \\
\text { orgánico presente en el agua. }\end{array}$ \\
\hline & $\begin{array}{l}\text { Amonio } \\
\left(\mathrm{NH}_{4}^{+}\right)\end{array}$ & $\mathrm{mg} \cdot \mathrm{L}^{-1}$ & $\begin{array}{l}\text { La urea se transforma rápidamente en } \mathrm{NH}_{4}^{+} \text {y los } \\
\text { compuestos de nitrógeno orgánico }\left(\mathrm{N}_{\text {org }}\right) \text { son } \\
\text { hidrolizados por bacterias y convertidos también en } \\
\mathrm{NH}_{4}^{+} \text {. }\end{array}$ \\
\hline
\end{tabular}




\begin{tabular}{|c|c|c|c|}
\hline Tipo & Parámetro & Unidad & Descripción \\
\hline & $\begin{array}{l}\text { Nitrógeno total } \\
\text { Kjeldahl (NTK) }\end{array}$ & $\mathrm{mg} \cdot \mathrm{L}^{-1}$ & $\begin{array}{l}\text { El nitrógeno total Kjeldahl es la cantidad total } \\
\text { de nitrógeno presente en el agua, suma de la } \\
\text { concentración Norg en sus diversas formas } \\
\text { (proteínas,ácidos nucleicos, urea, etc.) y el nitrógeno } \\
\text { amoniacal }\left(\mathrm{NH}_{4}^{+}\right) \text {. }\end{array}$ \\
\hline & Nitritos $\left(\mathrm{NO}_{2}^{-}\right)$ & $\mathrm{mg} \cdot \mathrm{L}^{-1}$ & $\begin{array}{l}\text { Los nitritos son indicadores de contaminación por } \\
\text { descomposición orgánica en el agua. Son tóxicos. }\end{array}$ \\
\hline & Nitratos $\left(\mathrm{NO}_{3}{ }^{-}\right)$ & $\mathrm{mg} \cdot \mathrm{L}^{-1}$ & $\begin{array}{l}\text { La reducción de nitratos a nitritos (compuestos } \\
\text { tóxicos) puede suponer un problema de salud. }\end{array}$ \\
\hline & Fósforo $\left(\mathrm{PO}_{4}^{-3}\right)$ & $\mathrm{mg} \cdot \mathrm{L}^{-1}$ & $\begin{array}{l}\text { El fósforo se encuentra en las aguas residuales en } \\
\text { forma de orto-fosfato }\left(\mathrm{PO}_{4}^{-3}\right) \text { o polifosfato }\left(\mathrm{P}_{2} \mathrm{O}_{7}\right) \text {. }\end{array}$ \\
\hline & $\mathrm{pH}$ & - & $\begin{array}{l}\text { El pH es un parámetro de medida de la acidez o } \\
\text { basicidad del agua. } \\
\text { La actividad biológica se desarrolla con normalidad } \\
\text { cuando el pH del agua están entre } 6.5-8.5 \text {, rango } \\
\text { habitual en las aguas residuales urbanas. }\end{array}$ \\
\hline & Alcalinidad & $\mathrm{mg} \cdot \mathrm{L}^{-1}$ & $\begin{array}{l}\text { Es la capacidad del agua para neutralizar ácidos o } \\
\text { aceptar protones. Se determina en términos de } \\
\text { bicarbonatos. }\end{array}$ \\
\hline & $\begin{array}{c}\text { Sólidos } \\
\text { inorgánicos } \\
\text { disueltos }\end{array}$ & $\mathrm{mg} \cdot \mathrm{L}^{-1}$ & $\begin{array}{l}\text { Sulfatos }\left(\mathrm{SO}_{4}^{-2}\right) \text {, cloruros }\left(\mathrm{Cl}^{-}\right) \text {, calcio }\left(\mathrm{Ca}^{+2}\right) \text {, sodio } \\
\left(\mathrm{Na}^{+}\right)\end{array}$ \\
\hline & Metales & $\mathrm{mg} \cdot \mathrm{L}^{-1}$ & Manganeso, hierro, etc. \\
\hline & $\begin{array}{l}\text { Materia orgánica } \\
\text { refractaria }\end{array}$ & $\mathrm{mg} \cdot \mathrm{L}^{-1}$ & $\begin{array}{l}\text { Son contaminantes tipo: surfactantes, pesticidas } \\
\text { orgánicos, fenoles, etc. }\end{array}$ \\
\hline & Grasas y aceites & $\mathrm{mg} \cdot \mathrm{L}^{-1}$ & $\begin{array}{l}\text { Son escasamente solubles. Ensucian las tuberías y } \\
\text { dificultan los procesos de eliminación de } \\
\text { contaminantes. }\end{array}$ \\
\hline BIOLÓGICO & Coliformes totales & $\begin{array}{l}\mathrm{UD} / 100 \\
\mathrm{~mL}\end{array}$ & $\begin{array}{l}\text { Se suelen emplear las bacterias coliformes } \\
\text { (escherichia y aerobacter) como indicadoras de la } \\
\text { calidad del agua. Son organismos patógenos. }\end{array}$ \\
\hline
\end{tabular}

Las aguas residuales urbanas están contaminadas principalmente por materia orgánica (medida en términos de $\mathrm{DQO} \mathrm{DBO}_{5} \mathrm{y} / \mathrm{O} \mathrm{COT}$ ), materia en suspensión (SS) y nutrientes (nitrógeno y fósforo y sus derivados), entre otros contaminantes.

\section{ELIMINACIÓN DE CONTAMINANTES ORDINARIOS PRESENTES EN AGUAS RESIDUALES}

Para obtener la Autorización de Vertido a cauce público, las aguas tras su paso por las EDAR han de cumplir lo dispuesto en la Directiva 91/271/CEE y sus posteriores modificaciones (traspuesta en España por el Real Decreto 509/1996). En ésta, se considera explícitamente los parámetros $\mathrm{SS}_{1} \mathrm{DBO}_{5}$ y $\mathrm{DQO}$ (tabla 2), así 
como nitrógeno y fósforo cuando el vertido depurado se realice en zonas sensibles cuyas aguas sean eutróficas o tengan tendencia a serlo en un futuro próximo (tabla 3).

Tabla 2 Requisitos para los vertidos procedentes de instalaciones de depuración de aguas residuales urbanas mediante tratamiento secundario (a) (Fuente: Manual Directiva 91/271/CEE sobre el tratamiento de aguas residuales urbanas).

\begin{tabular}{|c|c|c|}
\hline Parámetros & Concentración & Porcentaje mínimo de reducción (b) \\
\hline $\mathrm{DBO}_{5}$ (c) (a 20 $0^{\circ} \mathrm{C}$ sin nitrificación) & $25 \mathrm{mg} / \mathrm{L} \mathrm{_{2 }}$ & $70-90 \%$ \\
\hline DQO & $125 \mathrm{mg} / \mathrm{L} \mathrm{O}_{2}$ & $75 \%$ \\
\hline Total sólidos en suspensión & $35 \mathrm{mg} / \mathrm{L}$ (d) & $90 \%$ (d) \\
\hline
\end{tabular}

(a) O proceso equivalente. Se aplicará el valor de concentración o el porcentaje de reducción.

(b) Reducción relacionada con la carga del caudal de entrada.

(c) Este parámetro phede sustituirse por otro: carbono orgánico total (COT) o demanda total de oxigeno (DTO), si puede establecerse una correlación entre la $\mathrm{DBO}_{5}$ y el parámetro sustituto.

(d) Este requisito es optativo. Los análisis de vertidos procedentes de sistemas de depuración por lagunaje se llevarân a cabo sobre muestras filtradas; no obstante, la concentración de sólidos en suspensión en las muestras de agua sin filtrar no deberá superar los $150 \mathrm{mg} / \mathrm{L}$.

Tabla 3 Requisitos para los vertidos procedentes de instalaciones de depuración de aguas residuales urbanas mediante tratamiento más riguroso (a) (Fuente: Manual Directiva 91/271/CEE sobre el tratamiento de aguas residuales urbanas).

\begin{tabular}{|c|c|c|c|}
\hline \multirow{2}{*}{ Parámetros } & \multicolumn{2}{|c|}{ Concentración } & \multirow{2}{*}{$\begin{array}{c}\text { Porcentaje minimo } \\
\text { de reducción (b) }\end{array}$} \\
\cline { 2 - 3 } & 10.000 a $100.000 \mathrm{~h}-\mathrm{e}$ & $>100.000 \mathrm{~h}-\mathbf{e}$ & $80 \%$ \\
\hline Fósforo total & $2 \mathrm{mg} / \mathrm{L} \mathrm{P}$ & $1 \mathrm{mg} / \mathrm{L} \mathrm{P}$ & $70-80 \%$ \\
\hline Nitrógeno total $(\mathrm{c})(\mathrm{mg} / \mathrm{L} \mathrm{N})$ & $15 \mathrm{mg} / \mathrm{L} \mathrm{N}(\mathrm{d})$ & $10 \mathrm{mg} / \mathrm{L} \mathrm{N}$ & \\
\hline
\end{tabular}

(a) Según la situación local se podrá aplicar uno o los dos parámetros. Se aplicará el valor de concentración o el porcentaje de reducción

(b) Reducción relacionada con la carga del caudal de entrada

(c) Nitrógeno total equivalente a la suma del nitrógeno Kjeldahl total ( $\mathrm{N}$ orgánico y amoniacal), nitrógeno en forma de nitrato $\left(\mathrm{NO}_{3}\right)$ y nitrógeno en forma de nitrito $\left(\mathrm{NO}_{2}\right)$

(d) Estos valores de concentración constituyen medias anuales según el punto $3^{\circ}$ del apartado A) 2 del Anexo III del RD. 509/96. No obstante, los requisitos relativos al nitrogeno pueden comprobarse mediante medias diarias cuando se demuestre, que de conformidad con el apartado A)1 del Anexo III se obtiene el mismo nivel de protección. En ese caso la media diaria no deberá superar los $20 \mathrm{mg} / \mathrm{L}$ de Nitrógeno total para todas las muestras, cuando la temperatura del efluente del reactor biológico sea superior o igual a $12{ }^{\circ} \mathrm{C}$. En sustitución del requisito relativo a la temperatura, se podrá aplicar una limitación del tiempo de funcionamiento que tenga en cuenta las condiciones climáticas regionales

Además, se deberán cumplir los objetivos medioambientales establecidos en los planes de cuenca, para los usos que normativamente establezca el medio receptor, de acuerdo con el Real Decreto 817/2015. La relación de sustancias contaminantes de acuerdo con este real decreto son: 
1. Compuestos organohalogenados y sustancias que puedan dar origen a compuestos de esta clase en el medio acuático.

2. Compuestos organofosforados.

3. Compuestos organoestánnicos.

4. Sustancias y preparados, o productos derivados de ellos, cuyas propiedades cancerígenas, mutágenas o que puedan afectar a la tiroides, esteroidogénica, a la reproducción o a otras funciones endocrinas en el medio acuático o a través del medio acuático estén demostradas.

5. Hidrocarburos persistentes y sustancias orgánicas tóxicas persistentes y bioacumulables.

6. Cianuros.

7. Metales y sus compuestos.

8. Arsénico y sus compuestos.

9. Biocidas y productos fitosanitarios.

10. Materias en suspensión.

11. Sustancias que contribuyen a la eutrofización (en particular nitratos y fosfatos).

12. Sustancias que ejercen una influencia desfavorable sobre el balance de oxígeno (y computables mediante parámetros tales como DBO o DQO).

En la línea de aguas de una EDAR se lleva a un conjunto de operaciones unitarias en serie (procesos físicos, químicos y biológicos) con el objetivo de reducir ciertos contaminantes que contiene el agua residual a unos niveles aceptables. En la línea de fangos, se realizan operaciones unitarias para tratar y acondicionar los fangos o lodos producidos durante la depuración del agua.

Por lo general, las EDAR urbanas están diseñadas principalmente para eliminar carga biodegradable y sólidos en suspensión. Los rendimientos de eliminación de otro tipo de contaminantes (ej. contaminantes prioritarios) es variable y depende en gran medida de las propiedades de éstos. En la figura 2 se muestra el esquema de una EDAR urbana convencional. 


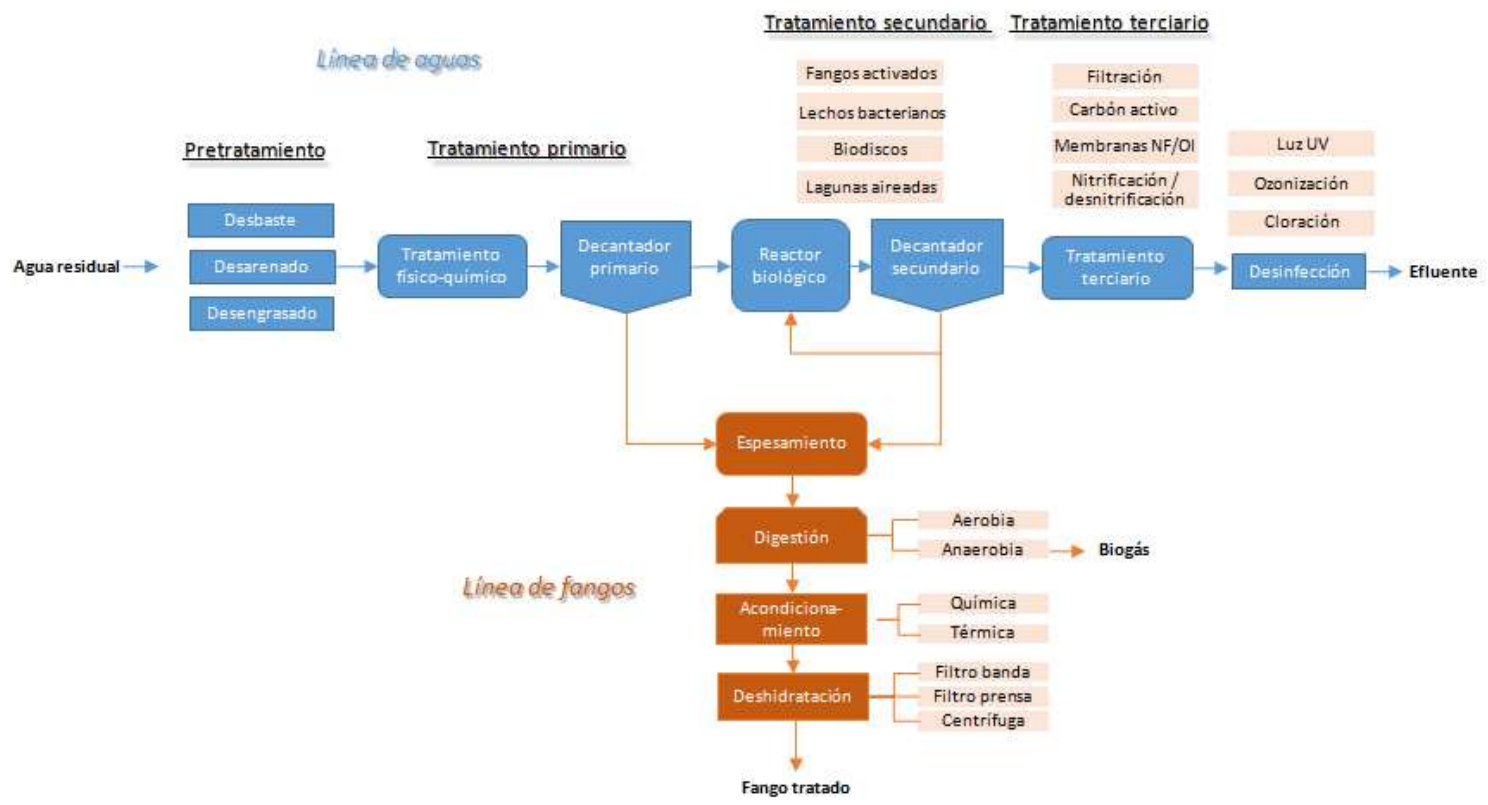

Figura 2 Esquema de una EDAR urbana convencional.

En función del grado de depuración alcanzado, los tratamientos que constituyen la línea de agua son:

\section{Pretratamiento}

En esta primera etapa de la línea de aguas se realizan operaciones unitarias de:

- desbaste (grueso y fino): su objetivo es separar el agua de materias/sólidos flotantes de gran tamaño (trapos, palos, plásticos, etc.) que podrían dañar los equipos u obstruir las conducciones. Se hace pasar el agua residual a través de una serie de rejas de distinto tamaño de paso.

- desarenado: su objetivo es extraer del agua los elementos con una velocidad de sedimentación superior a las de la materia orgánica en suspensión, tales como arenas, gravas y partículas minerales, para proteger los equipos mecánicos contra la abrasión y desgaste;

- desengrasado: su objetivo es eliminar las grasas, espumas y materias flotantes sólidas más ligeras que el agua.

\section{Tratamiento primario}

En esta etapa se realizan operaciones unitarias de:

- decantación o sedimentación primaria: su objetivo es separar sólidos en suspensión (insolubles) y sólidos sedimentables por gravedad. Se lleva a cabo 
en tanques de forma circular o rectangular, con mecanismos de arrastre y extracción de grasas y fangos denominados decantadores primarios.

- flotación: su objetivo es la eliminación de sólidos en suspensión con densidad similar a la del agua, así como aceites y grasas no eliminados en el pretratamiento;

- tratamiento físico-químico: su objetivo es la eliminación de partículas coloidales (procesos de coagulación-floculación), así como el ajuste de $\mathrm{pH}$ para las etapas posteriores.

\section{Tratamiento secundario o biológico}

Es la etapa que permite la depuración biológica de las aguas residuales. En esta etapa se realizan operaciones unitarias de:

- reactor biológico y/o tratamiento biológico: su objetivo es la eliminación de la materia orgánica e inorgánica, suspendida y coloidal presente en el agua residual por la acción de los microorganismos (generalmente de tipo aerobiooxidación biológica).

- Decantación secundaria: su objetivo es separar los fangos floculados (agregados formados por los microorganismos) del agua depurada para obtener el efluente.

Algunos procesos biológicos empleados son: fangos activados, lechos activados, biodiscos y lagunas aireadas. El proceso biológico más utilizado es el de fangos activados.

\section{Tratamiento terciario (complementario)}

El tratamiento terciario se aplica en algunas EDAR de manera complementaria al tratamiento secundario para adaptar la calidad de las aguas residuales a las normas establecidas según el uso o destino del medio receptor (eliminar nutrientes, reducir la concentración de otros contaminantes, etc.).

Entre los tratamientos terciarios cabe destacar:

- Eliminación de nutrientes (nitrógeno y fósforo) para evitar la eutrofización;

- Eliminación de compuestos nitrogenados $\left(\mathrm{NO}_{2}\right.$ y $\left.\mathrm{NO}_{3}\right)$ mediante procesos de nitrificación/desnitrificación.

- Adsorción sobre carbón activo.

- Uso de membranas de filtración (ósmosis inversa, nanofiltración). 


\section{Desinfección y vertido del efluente}

El objetivo de esta etapa es la destrucción de los microorganismos patógenos mediante procesos físicos (ej. radiación ultravioleta) o químicos (cloración, ozonización), antes de su vertido a un medio receptor.

En la tabla 4 se recopilan los objetivos principales de cada una de las etapas de la línea de aguas.

Tabla 4 Objetivo principal de cada una de las etapas de la línea de aguas.

\begin{tabular}{|l|l|}
\hline Etapas línea de aguas & \multicolumn{1}{|c|}{ Objetivo } \\
\hline Pretratamiento & Eliminación de gruesos y grasas \\
\hline Tratamiento primario & $\begin{array}{l}\text { Eliminación SS: } 50-70 \% \\
\text { Reducción DBO }: 25-40 \%\end{array}$ \\
\hline Tratamiento secundario & $\begin{array}{l}\text { Eliminación SS: } 80-95 \% \\
\text { Reducción DBO5: } 85-95 \%\end{array}$ \\
\hline Tratamiento terciario & $\begin{array}{l}\text { Eliminación SS: 95-96\% } \\
\text { Reducción DBO }: 95-98 \%\end{array}$ \\
\hline Desinfección & Eliminación de patógenos \\
\hline
\end{tabular}

Los fangos producidos en el tratamiento del agua poseen más de un $95 \%$ de agua, por lo que ocupan grandes volúmenes. Por otra parte, son de naturaleza putrescible, debido a su contenido en materia orgánica biodegradable.

Los tratamientos que constituyen la línea de fangos en una EDAR son:

\section{Espesamiento}

Los objetivos de esta etapa son:

- Mezclar y homogenizar los fangos procedentes de los decantadores primarios y de los decantadores secundarios;

- Concentrar los fangos, eliminando parte del agua que contienen, antes de su entrada a la digestión.

Se emplean espesadores que se basan en mecanismos de gravedad o flotación. Se alcanza un lodo con un contenido de sólidos de hasta un $4 \%$.

\section{Estabilización}

El objetivo de esta etapa es la eliminación controlada de una parte o de la totalidad de la materia orgánica contenida en el fango, sobre todo de la materia que se descompone más rápidamente y que puede generar problemas de emisión de olores. Se reduce la presencia de patógenos. 
Los procesos de estabilización más habituales son:

- digestión aerobia / anaerobia: se alcanza una degradación del 40-50\% de la materia orgánica. En la digestión aerobia, el fango es aireado continuamente hasta conseguir la destrucción de la materia orgánica más volátil y obtener un fango razonablemente estable; se suele emplear en poblaciones de hasta 20000 habitantes equivalentes. En la digestión anaerobia, la descomposición de la materia orgánica se produce en ausencia de oxígeno, obteniéndose como subproducto biogás, constituyendo otra línea de tratamiento en una EDAR, la línea de gas;

- Estabilización química: se reduce la concentración de patógenos mediante la modificación del $\mathrm{pH}$ por encima de 12 durante un tiempo suficiente por adición de cal;

- Otros: térmica, compostaje, pasteurización, etc.

\section{Acondicionamiento}

El objetivo de esta etapa es facilitar la separación de los sólidos del agua en la siguiente etapa. Se puede realizar mediante:

- Acondicionamiento químico: se desestabiliza la suspensión que forma el fango con el agua mediante la adición de coagulantes (polielectrolitos, cal, cloruro férrico, sulfato de alúmina).

- Acondicionamiento térmico: mediante tratamiento a 160-210ㄷ se reduce la afinidad de los sólidos residuales por el agua.

\section{Deshidratación}

La finalidad de esta etapa es eliminar el agua del fango para convertirlo en un sólido manejable con entre un $20-40 \%$ de materia seca. Se lleva a cabo en:

- filtros mecánicos (centrífugas, filtros banda, filtros prensa), en los que se logra una sequedad de hasta un $40 \%$;

- eras de secado: se hace pasar el fango sobre una serie de capas drenantes (grava o arena) dispuestas de forma vertical produciéndose el filtrado y la deshidratación de los lodos por evaporación, en función de las condiciones climáticas de la zona, los días de exposición y las características del lodo.

En función de la calidad final del fango obtenido (contenido en metales, nutrientes, contaminantes orgánicos, etc.) y de condicionantes de tipo técnico, económico, legal y medioambiental, su destino puede ser: uso agrícola (compostaje), fuente energética (incineración), descarga en vertederos, etc. 


\section{CONTAMINANTES EMERGENTES}

La Directiva 2000/60/CE dispuso una estrategia para luchar contra la contaminación de las aguas. Esta estrategia implica la identificación de sustancias prioritarias entre aquellas que suponen un riesgo significativo en la Unión para el medio acuático o a través de éste. En la Decisión no 2455/2001/CE del Parlamento Europeo, se estableció una lista de 33 sustancias prioritarias en el ámbito de la política de aguas. Esta lista se sometió a revisión y en la Directiva 2013/39/UE del Parlamento Europeo y del Consejo de 12 de agosto de 2013, se recogen las modificaciones en cuanto a las sustancias prioritarias recogidas en las Directivas 2000/60/CE y 2008/105/CE. La lista actual incluye 45 sustancias prioritarias. La Decisión no 2015/495/CE estableció una primera lista de observación de 10 sustancias a efectos de seguimiento a nivel de la Unión Europea en el ámbito de la política de aguas.

De acuerdo con la Directiva 2013/39/UE (Artículo 26 Introducción Directiva $2013 / 39 / \mathrm{UE}$ ), los contaminantes emergentes son "contaminantes que en la actualidad no están incluidos en los programas de seguimiento sistemático de la Unión, pero que suponen un importante riesgo, lo cual exige su regulación, dependiendo de los efectos ecotoxicológicos y toxicológicos, y de sus niveles en el medio acuático."

Los contaminantes emergentes (CEs) son compuestos cuya presencia en el medioambiente no es necesariamente nueva pero sí la preocupación por las posibles consecuencias de la misma. La mayoría de estos compuestos no están regulados. Sus características generales se resumen en la figura 3. 


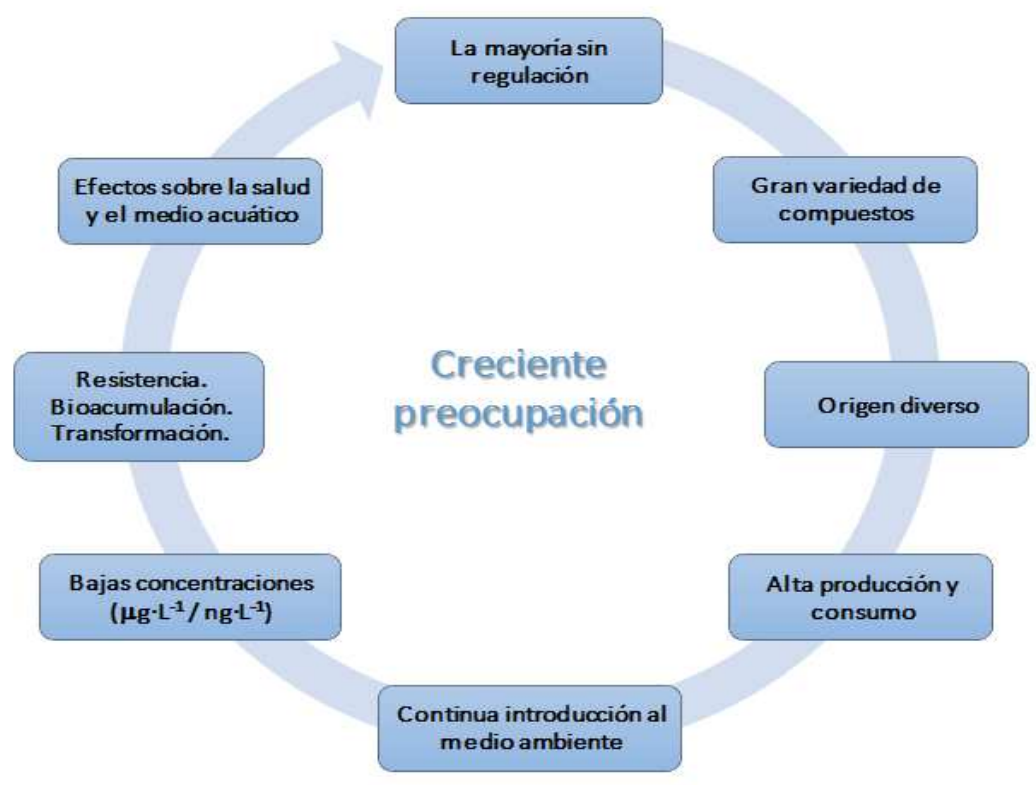

Figura 3 Características de los contaminantes emergentes.

Los CEs tienen una elevada producción y consumo. Su origen es diverso, tanto industrial, agrícola como urbano, existiendo una gran variedad de compuestos (tabla 5), entre los que se pueden encontrar: fármacos, productos de higiene y cuidado personal, pesticidas, retardadores de llama, surfactantes, etc.

Tabla 5 Contaminantes emergentes y sustancias prioritarias

\begin{tabular}{|c|c|}
\hline Tipo & Ejemplos \\
\hline Pesticidas & $\begin{array}{r}\text { trifluralina, endosulfán, o,p-DDD, p,p-DDD, alacloro, atrazina, simazina, } \\
\text { terbutilazina, ametrin, diclorvós, malatión, bromofós }\end{array}$ \\
\hline Fármacos & $\begin{array}{r}\text { ibuprofeno, acetaminofeno, ácido acetilsalicílico, diclofenaco, } \\
\text { naproxeno, diazepam, eritromicina, azitromicina, trimetoprima, cafeína }\end{array}$ \\
\hline Esteroides y hormonas & 17-b-estradiol, estrona, 17-a-etinilestradiol, testosterona, nandrolona \\
\hline Surfactantes & 4-octilfenol, 4-nonilfenol, alquilfenoles etoxilados \\
\hline Retardantes de llama & difenil éteres polibromados (PBDEs), tetrabromo bisfenol A \\
\hline Aditivos de la gasolina & metil-ter-butil éter (MTBE), dialquil éteres \\
\hline $\begin{array}{c}\text { Productos de higiene y } \\
\text { cuidado personal }\end{array}$ & parabenos, triclosán, triclorocarbono, benzofenona \\
\hline Aditivos industriales & agentes quelantes (EDTA), sulfonados aromáticos \\
\hline
\end{tabular}

Generalmente, estos compuestos se encuentran a bajas concentraciones en el medioambiente (orden de $\mu \mathrm{g} \cdot \mathrm{L}^{-1}-\mathrm{ng} \cdot \mathrm{L}^{-1}$ ), requiriéndose técnicas analíticas más sensibles para su análisis, como cromatografía líquida/gaseosa acoplada a espectrometría masas-masas (GC-MS/MS o LC-MS/MS). La mejora en las técnicas 
de análisis ha permitido detectar la presencia de estos contaminantes en las aguas incluso a niveles traza.

La presencia de CEs en las aguas puede conllevar riesgos ecológicos y sobre la salud, debido, entre otras características, a que muchos son resistentes a la degradación biológica (ej. fármacos); tienden a bioacumularse introduciéndose en los organismos vivos a través de la cadena alimentaria; y algunos se transforman en metabolitos más nocivos. Algunos compuestos como los disruptores endocrinos (ej. estrógenos, pesticidas, alquilfenoles, etc.) interfieren con las funciones del sistema endocrino (hormonal) produciendo efectos tales como: disminución de la fertilidad, disfunciones tiroidales, alteraciones sexuales; y pueden estar relacionados con diversos tipos de cáncer (ej. próstata, mama).

La red científica NORMAN "Network of reference laboratories, research centres and related organisations for monitoring of emerging environmental substances", además de compartir información sobre investigaciones y participar en la creación de protocolos de análisis, elabora y actualiza una lista de las sustancias y contaminantes emergentes más frecuentemente discutidas (1036 sustancias incluidas en la lista actualizada en febrero de 2016). Esta comunidad científica va más allá y distingue entre:

- Sustancias emergentes: son sustancias que han sido detectadas en el medio ambiente, pero que actualmente no están incluidas en los programas de seguimiento rutinario de la Unión Europea y cuyo estado, comportamiento y efectos (eco)toxicológicos se desconocen.

- Contaminantes emergentes: son contaminantes que actualmente no están incluidos en los programas de seguimiento rutinario de la Unión Europea, pero, que en función de las investigaciones sobre su (eco)toxicidad, efectos potenciales sobre la salud, percepción pública y presencia en las diversas matrices ambientales pueden ser candidatos para futuras regulaciones.

\subsection{Eliminación de contaminantes emergentes}

Las EDAR urbanas están diseñadas principalmente para eliminar carga biodegradable y SS, siendo variables los rendimientos de eliminación de otros contaminantes, entre los que se pueden citar los contaminantes emergentes.

Las investigaciones centradas en la aplicación de un postratamiento (tabla 6) al efluente del tratamiento secundario de una EDAR han permitido observar que los rendimientos de eliminación varían, entre otros factores, en función de:

- las propiedades (naturaleza) de los compuestos (hidrofobicidad, biodegradabilidad, polaridad, tamaño molecular, solubilidad...); 
- las condiciones de operación de los procesos (tiempo de retención hidráulico-TRH, tiempo de retención celular-TRC, dosis de adsorbente, dosis de agente químico, etc.);

- el tipo de microorganismos (en procesos biológicos): aerobio/anaerobio;

Tabla 6 Tratamientos de eliminación de CEs

\begin{tabular}{|l|}
\hline \multicolumn{1}{|c|}{ Procesos } \\
\hline Tratamiento biológico (fangos activos, biorreactor de membrana, UASB...) \\
\hline Adsorción en carbón activado (polvo-PAC; granular- GAC) \\
\hline Tratamientos físico-químicos (coagulación - floculación) \\
\hline Oxidación química \\
\hline Fotólisis y radiación UV \\
\hline Membranas (nanofiltracion, ósmosis inversa, etc.) \\
\hline Interacción suelo-acuífero \\
\hline
\end{tabular}

No existe un único proceso capaz de eliminar todos los CEs presentes en las aguas residuales, por lo que las investigaciones actuales tienden hacia la combinación de tratamientos.

A modo de ejemplo, las membranas de ósmosis inversa permiten reducir la concentración de CEs en las aguas, pero generan un rechazo donde se concentran estos contaminantes. Los rechazos pueden ser tratados mediante procesos de oxidación avanzada que operan mejor con efluentes concentrados. Otras posibilidades son: la combinación de la ozonización con adsorción en carbón activado; tratamiento biológico combinado con membrana y/o carbón activado, etc.

\section{BIBLIOGRAFÍA}

Trapote Jaume, Arturo. Depuración y regeneración de aguas residuales urbanas. Publicaciones de la Universidad de Alicante (2013). ISBN 978-84-9717-264-6.

Real Decreto Legislativo 1/2001, de 20 de julio, por el que se aprueba el texto refundido de la Ley de Aguas.

Directiva 91 del Consejo, de 21 de Mayo de 1991, sobre el tratamiento de las aguas residuales urbanas.

MAGRAMA. Manual Directiva 91/271/CEE sobre el tratamiento de aguas residuales urbanas. 
Real Decreto 509/1996, de 15 de marzo, de desarrollo del Real Decreto-ley 11/1995, de 28 de diciembre, por el que se establecen las normas aplicables al tratamiento de las aguas residuales urbanas.

Real Decreto 817/2015, de 11 de septiembre, por el que se establecen los criterios de seguimiento y evaluación del estado de las aguas superficiales y las normas de calidad ambiental.

Directiva 2000/60/CE del Parlamento Europeo y del Consejo, de 23 de octubre de 2000 establece un marco comunitario de actuación en el ámbito de la política de aguas.

Directiva 2008/105/CE del Parlamento Europeo y del Consejo, de 16 de diciembre de 2008, relativa a las normas de calidad ambiental en el ámbito de la política de aguas, por la que se modifican y derogan ulteriormente las Directivas 82/176/CEE, 83/513/CEE, 84/156/CEE, 84/491/CEE y 86/280/CEE del Consejo, y por la que se modifica la Directiva 2000/60/CE.

Directiva 2013/39/UE del Parlamento Europeo y del Consejo, de 12 de agosto de 2013 por la que se modifican las Directivas 2000/60/CE y 2008/105/CE en cuanto a las sustancias prioritarias en el ámbito de la política de aguas.

Decisión de ejecución (UE) 2015/495 de la Comisión de 20 de marzo de 2015 por la que se establece una lista de observación de sustancias a efectos de seguimiento a nivel de la Unión en el ámbito de la política de aguas, de conformidad con la Directiva 2008/105/CE del Parlamento Europeo y del Consejo.

NORMAN: Network of reference laboratories, research centres and related organisations for monitoring of emerging environmental substances.

\section{ENLACES}

European Environment Agency

http://www.eea.europa.eu/themes

United States Environmental Protection Agency

https://www3.epa.gov/

NORMAN: Network of reference laboratories, research centres and related organisations for monitoring of emerging environmental substances.

http://www.norman-network.net/ 


\title{
4.5. FUNCIONAMIENTO ECONÓMICO Y FINANCIERO
}

\author{
Martín Sevilla Jiménez
}

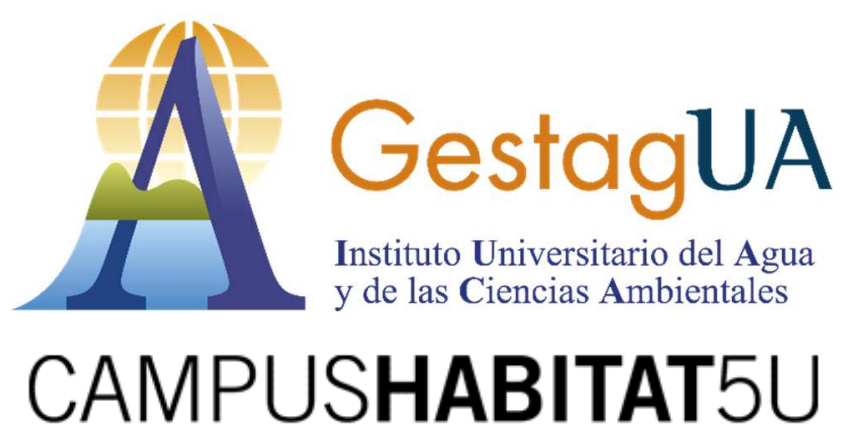




\section{INTRODUCCIÓN}

La utilización de las aguas por parte de los distintos usuarios consuntivos (teóricamente, los usuarios no consuntivos, como las empresas hidroeléctricas, no presentan problemas en este aspecto, aunque sí en lo relativo a la regulación de los cursos de agua), tales como los abastecimientos urbanos, las industrias o la agricultura, adicionan productos químicos y orgánicos a las mismas que pueden hacer que estas no reúnan las características necesarias para su uso posterior en el ciclo del agua. La contaminación de los ríos y de los suelos es una consecuencia directa de estos procesos que, debido al intenso proceso de industrialización y utilización de productos contaminantes como los detergentes, abonos etc. suponen una amenaza grave para la salud humana, animal y vegetal.

Los procesos de depuración de las aguas han sido incorporados en todos los países desarrollados como una forma de cortar con estos procesos, especialmente con respecto a las aguas procedentes de los usos urbanos y de la industria (la agricultura reacciona de una forma distinta al introducir por filtración los contaminantes procedentes de los abonos, por lo que la prevención pasa por limitar el uso de estos), contribuyendo de esta forma a una mejora notable de nuestros cursos de agua.

Lamentablemente, las inversiones económicas necesarias para llevar a cabo el proceso de depuración son muy cuantiosas, por lo que los países en desarrollo más atrasados todavía presentan enormes carencias en la lucha contra esta contaminación de las aguas, por lo que se requiere de tiempo, apoyo económico y decisiones políticas adecuadas para hacer frente al problema de una forma seria, ante el impacto que tiene sobre la vida humana, animal y vegetal a corto, medio y largo plazo.

En España, si bien las competencias para realizar la depuración de las aguas se atribuyen a los Ayuntamientos preferentemente, debido a la necesidad de grandes instalaciones que pueden generar economías de escala y a las externalidades que pueden soportar otros usuarios, el tratamiento de las aguas servidas suele ser de carácter supramunicipal con notables ayudas públicas procedentes de la Comunidad Europea, el Estado español o las Comunidades Autónomas. Este hecho plantea numerosos problemas a la hora de conocer los costes reales del proceso, así como su repercusión entre los distintos usuarios. 


\section{EL MARCO ESPAÑOL SOBRE LA CALIDAD DEL AGUA}

La trasposición de la Directiva Europea Directiva 91/271/CEE sobre el tratamiento de aguas residuales a la legislación española tuvo lugar a través del RD Ley $11 / 1995$, normas aplicables al tratamiento de aguas residuales urbanas. Si bien anteriormente se habían realizado inversiones en instalaciones de depuración, el Estado español impulsó los dos Planes sobre Calidad de las aguas que han estado vigentes hasta ahora. En estos Planes, aparte de fijar los parámetros específicos que debían requerirse en la depuración de las aguas, se adoptó un sistema de financiación peculiar que está vigente hasta la actualidad. Los costes de las infraestructuras contaban con una aportación del $25 \%$ procedentes de los fondos estatales y el resto se atribuía a las CCAA y ayuntamientos, condicionándose las subvenciones a la existencia de una normativa autonómica que tuviera en cuenta la recuperación de costes de estos servicios y plasmándose a través de un convenio específico entre cada CCAA y el Estado.

La disposición de Fondos Europeos (FEDER y Fondos de Cohesión) hizo que dichas subvenciones se ampliaran en muchos casos hasta cifras cercanas al $80 \%$ de las inversiones, sin existir un proceso claro y trasparente acerca de esas decisiones.

Por otro lado, tampoco se precisaban las distinciones entre los costes de las inversiones y de la gestión y mantenimiento de las instalaciones, originando muchas dudas acerca de quienes debían soportar los costes de las mismas. Mientras que son los Ayuntamientos los competentes en esta materia en virtud de la legislación de régimen local, su participación en este proceso ha sido casi inexistente, originando problemas sobre la financiación ordinaria de estos servicios.

\section{LA NORMATIVA VALENCIANA SOBRE DEPURACIÓN}

La distribución de competencias en España ha originado que no exista una normativa única en materia de depuración de las aguas y han sido las Comunidades Autónomas las que han dictado normativas específicas dirigidas a hacer frente a estos problemas.

En el caso de la Comunidad Valenciana, desde el año 1992 existe la LEY 2/1992,

de 26 de marzo, del Gobierno Valenciano, de saneamiento de las aguas residuales de la Comunidad Valenciana, mediante la cual se regula todo lo referente a los aspectos de esta materia, especialmente los referidos a cómo financiar los elevados costes de este proceso. 
"Artículo 1. Objeto

1. La presente ley tiene por objeto garantizar una actuación coordinada y eficaz entre las distintas Administraciones Públicas en materia de evacuación y tratamiento, y, en su caso, reutilización de las aguas residuales en el ámbito territorial de la Comunidad Valenciana.

A estos efectos, se entienden comprendidas en el ámbito de la ley:

a) La gestión y explotación de instalaciones públicas de evacuación, tratamiento, depuración y, en su caso, reutilización de aguas residuales procedentes de las redes de alcantarillado de titularidad local.

b) La realización de obras de infraestructura para abastecimiento de aguas de carácter general y de construcción de instalaciones públicas de depuración de aguas residuales procedentes de las redes de alcantarillado de titularidad local así como de colectores generales que unan las redes de alcantarillado de titularidad local a dichas instalaciones.

2. Asimismo la ley regula el régimen económico financiero preciso para asegurar el funcionamiento de las instalaciones de evacuación, tratamiento y depuración de aguas residuales, así como, en su caso, para su ejecución, mediante la aplicación de un canon específico de saneamiento y depuración.

3. Esta actuación se desarrolla en el ámbito de la política de la Generalitat definitoria del marco de protección del medio ambiente."

La evolución de los volúmenes de agua tratada ha sido creciente hasta 2005, siguiéndose un descenso desde esa fecha hasta ahora, aunque ha habido un pequeño rebote en el año 2015. En la actualidad, prácticamente todo el territorio de la Comunidad Valenciana dispone de estas instalaciones, aunque muchas de ellas precisan de inversiones de actualización y mejora. 
VOLUMEN DE AGUA DEPURADA

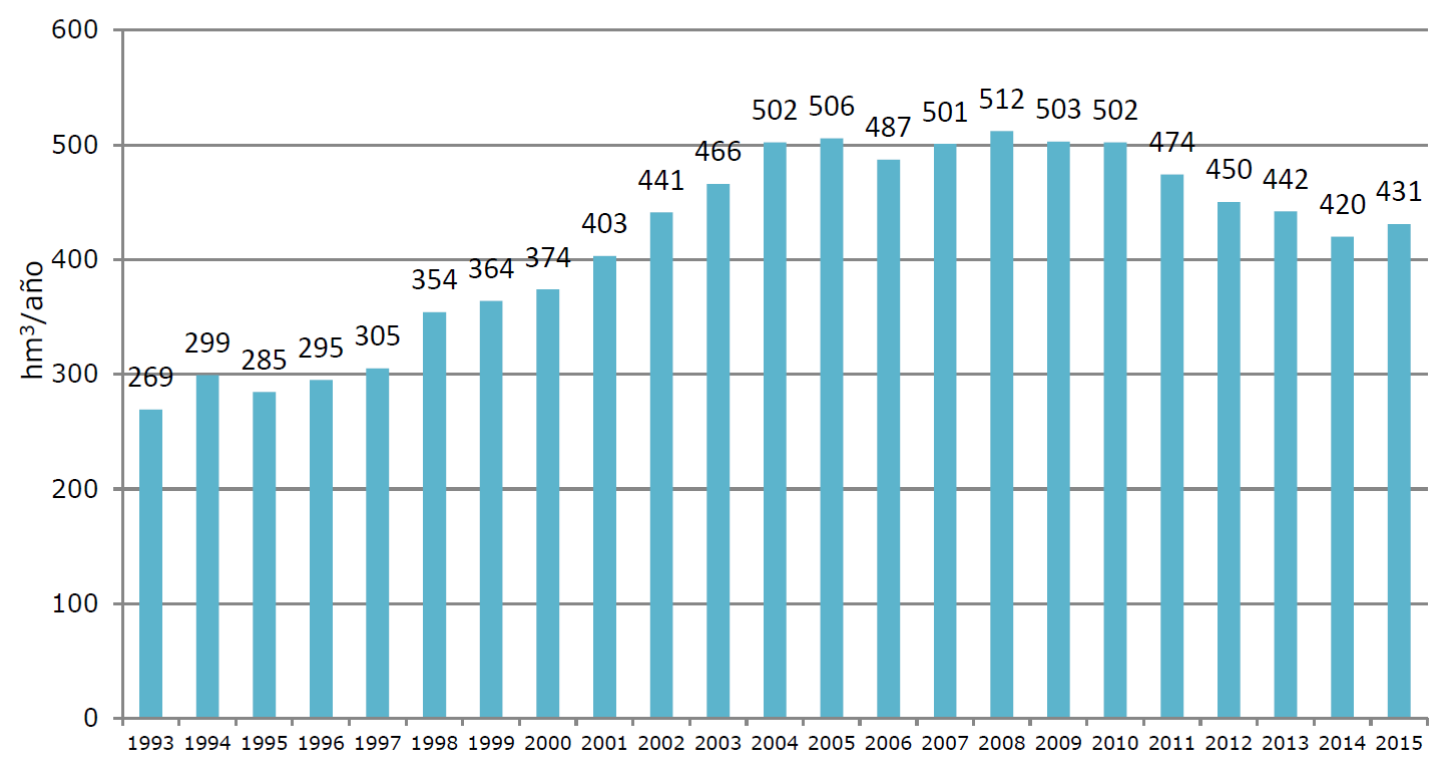

Fuente: EPSAR

\section{LA FINANCIACIÓN DE LA DEPURACIÓN: EL CANON DE SANEAMIENTO}

Buena parte del éxito de tener todo el territorio de la Comunidad Valenciana con los servicios de depuración ha radicado en la creación del denominado "canon de saneamiento". Éste, creado desde el mismo momento de la entrada en vigor de la Ley ha permitido financiar las inversiones necesarias, así como contemplar desde fecha tan temprana como 1992 el proceso de recuperación de costes en estas operaciones.

Según la Ley:

\section{"Artículo 19. Disposición general}

1. La financiación de los gastos de gestión y explotación de las instalaciones de evacuación, tratamiento y depuración a que se refiere esta ley, así como, en su caso, de las obras de construcción de las mismas, se llevará a cabo con los recursos que se obtengan por aplicación del presente régimen económicofinanciero.

2. Las Administraciones y Entidades competentes para la gestión de las instalaciones y la ejecución de las obras, podrán solicitar, asimismo, ayudas económicas provenientes de otras Administraciones Públicas, así como contraer los créditos necesarios con entidades oficiales o privadas.

3. El pago de intereses y la amortización de créditos podrán garantizarse con cargo a la recaudación a obtener con el canon de saneamiento. 


\section{Artículo 20. Canon de saneamiento}

1. A los efectos previstos en el artículo anterior, se exigirá un canon de saneamiento, que tendrá la naturaleza de impuesto y la consideración de ingreso específico del régimen económico-financiero de la Entidad Pública de Saneamiento de las Aguas Residuales de la Comunidad Valenciana, debiéndose destinar su recaudación, exclusivamente, a la realización de los fines recogidos en la presente ley.

2. Su hecho imponible lo constituye la producción de aguas residuales, manifestada a través del consumo de agua de cualquier procedencia. El canon será exigible desde la entrada en vigor de la ley y vendrá referido al volumen de agua consumida para usos domésticos o industriales, pudiendo diferenciarse en su determinación atendiendo a la clase de consumo, a la población y la carga contaminante incorporada al agua. Su aplicación afectará tanto al consumo de agua suministrada por los Ayuntamientos o por las empresas de abastecimiento, como a los consumos no medidos por contadores o no facturados."

El canon de saneamiento distingue entre las aguas vertidas por los usuarios domésticos y los industriales. En ambos casos las cuotas aplicadas están relacionadas con la denominada "cuota de consumo", que es única para los usos industriales y que en 2016 asciende a $0,57 € / \mathrm{m}^{3}$; mientras que para los usos urbanos oscila entre $0,321 € / \mathrm{m}^{3}$ aplicados a los municipios de entre 500 y 3.000 habitantes y los $0,441 € / \mathrm{m}^{3}$ a los de más de 50.000 habitantes.

Por su parte, la denominada "cuota de servicio" varía en el caso de los usos domésticos en función del número de habitantes entre 32,43 €/año para los de menor tamaño hasta los 44,83 €/año los mayores. En el caso de los usos industriales, la "cuota de servicio" se asocia al tamaño del contador oscilando entre los 116,39 €/año para los contadores de hasta $13 \mathrm{~mm}$ hasta los 4.071,50 €/año para los de diámetro mayor de $80 \mathrm{~mm}$. 
Tarifas del Canon de 2016 Comunidad valenciana

\begin{tabular}{|l|r|r|r|r|}
\hline \multirow{2}{*}{$\begin{array}{c}\text { Tramos de } \\
\text { población }\end{array}$} & \multicolumn{2}{|c|}{ Usos domésticos } & \multicolumn{2}{c|}{ Usos industriales } \\
\cline { 2 - 5 } & $\begin{array}{c}\text { Cuota de } \\
\text { consumo } \\
\text { T/m3 }\end{array}$ & Cuota Servicio $€ /$ año & Cuota de consumo $€ / m 3$ & $\begin{array}{c}\text { Cuota } \\
\text { Servicio } \\
€ / \text { año }\end{array}$ \\
\hline $500-3.000$ & 0,321 & 32,43 & & \\
\hline $3.001-10.000$ & 0,376 & 39,75 & & \\
\hline $10.001-50.000$ & 0,412 & 43,81 & & \\
\hline Más de 50.000 & 0,441 & 44,83 & & \\
\hline & & & & \\
\hline Calibre & & & & 116,39 \\
\hline contador & & & & 174,48 \\
\hline hasta $13 \mathrm{~mm}$ & & & & 290,65 \\
\hline Hasta $15 \mathrm{~mm}$ & & & & 407,05 \\
\hline Hasta $20 \mathrm{~mm}$ & & & & 581,67 \\
\hline Hasta $25 \mathrm{~mm}$ & & & & $1.163,34$ \\
\hline Hasta $30 \mathrm{~mm}$ & & & & $1.745,02$ \\
\hline Hasta $40 \mathrm{~mm}$ & & & & $2.326,47$ \\
\hline Hasta $50 \mathrm{~mm}$ & & & & $2.908,34$ \\
\hline Hasta $65 \mathrm{~mm}$ & & & & $4.071,50$ \\
\hline Hasta $80 \mathrm{~mm}$ & & & & \\
\hline Más de $80 \mathrm{~mm}$ & & & & \\
\hline
\end{tabular}

Fuente: EPSAR

Este canon es recaudado conjuntamente con las tarifas de abastecimiento de agua en cada municipio, lo que permite que la gestión del mismo sea relativamente simple, por lo que se puede considerar que ha sido un instrumento muy eficaz para hacer frente a las necesarias inversiones para la depuración del agua en la Comunidad Valenciana. En el Gráfico adjunto puede verse la evolución de estos ingresos entre 2005 y 2015. 
CANON DE SANEAMIENTO

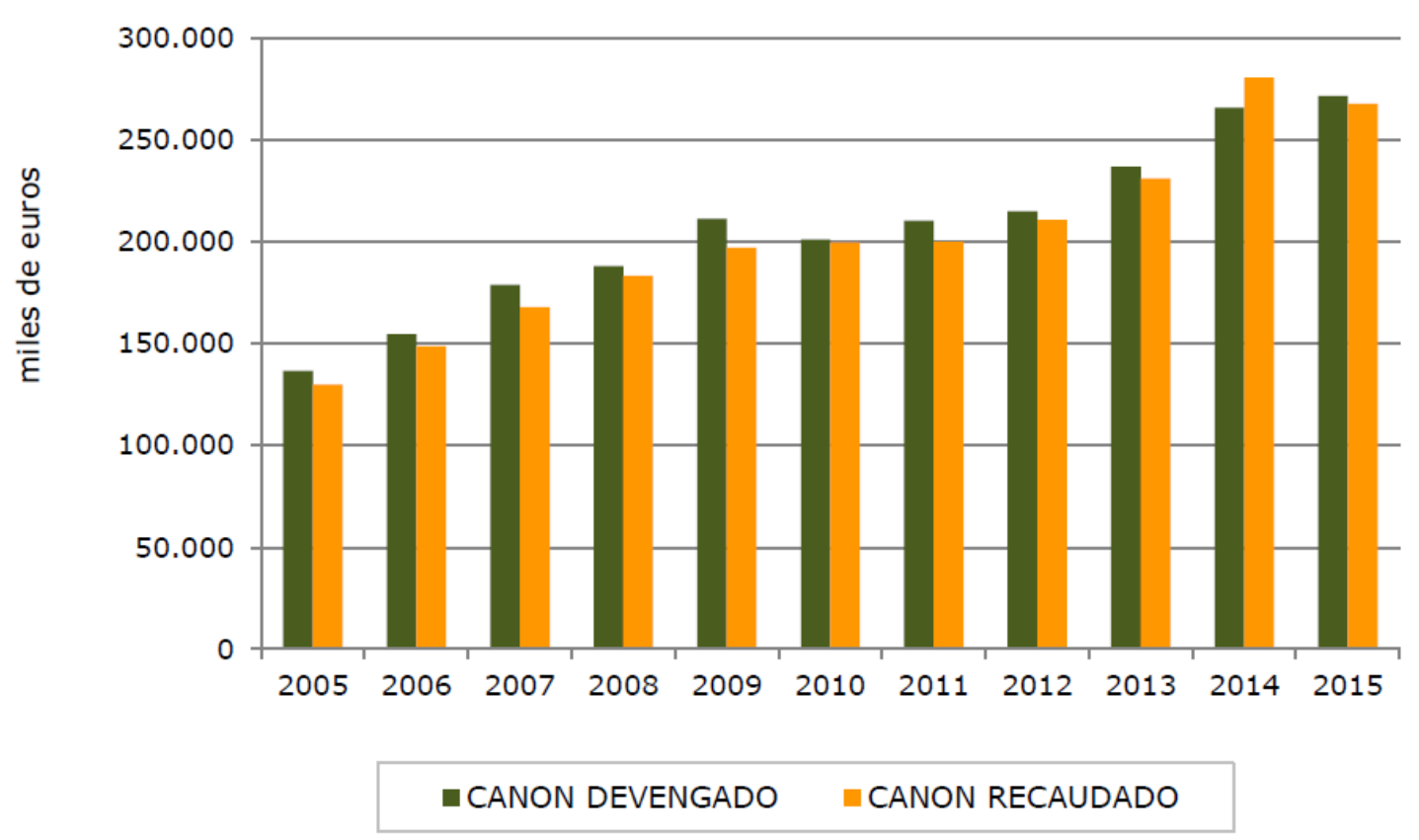

Fuente: EPSAR

\section{LA REUTILIZACIÓN DEL AGUA}

La mayor parte de las aguas utilizadas en los procesos de abastecimiento urbano o en la industria han sido tradicionalmente reutilizadas, ya que los vertidos de éstas en los cauces, hace que las mismas sean de nuevo utilizadas por los usuarios que se encuentran en el curso más bajo de los ríos, salvo los cercanos al mar que suelen utilizar en algunos casos "emisarios" para verterlos por ese procedimiento en el interior del mar a cierta distancia de la costa.

Sin embargo, en las zonas más áridas, ante las necesidades crecientes de las demandas de agua para los regadíos o bien para los usos urbanos no humanos (riegos de parques y jardines, baldeo de calles, campos de golf, etc.), se ha planteado la necesidad de dictar normas específicas que tuvieran en cuenta las calidades de estas aguas para su aplicación directa, sin ser vertidas a los cauces públicos (REAL DECRETO 1620/2007, de 7 de diciembre, por el que se establece el régimen jurídico de la reutilización de las aguas depuradas). Mientras que el tratamiento de la depuración de las aguas destinadas a ser vertidas en los cauces es menos exigente, las destinadas a su uso inmediato requieren de tratamientos específicos (el "terciario") que suponen costes adicionales a estos procesos. 
Desde el punto de vista del principio de "recuperación de costes", los procesos de depuración y regeneración de las aguas son distintos. Mientras que en el primer caso nos encontramos con que los responsables de soportar los costes de depuración son esencialmente los usuarios urbanos o industriales que han utilizado y contaminado las aguas, en el segundo caso, quien debería de soportar los costes de la regeneración de esas aguas deberían ser los nuevos usuarios de las mismas.

En la práctica, muchas veces esta distinción no se da (son los propios titulares de las depuradoras los que realizan los procesos de regeneración a través de subvenciones públicas), por lo que los usuarios de las aguas regeneradas no contabilizan los costes de esa transformación.

Las desiguales situaciones del territorio español en cuanto a necesidades hídricas también se pueden ver en lo relativo a la utilización de las aguas regeneradas, ya que las mismas se concentran en las Demarcaciones del Júcar y del Segura, siendo las Comunidades Autónomas de Valencia y Murcia las que consumen mayores cantidades de estas aguas.

En el caso de la Comunidad Valenciana, según la EPSAR, en 2015 "se ha realizado durante este ejercicio el aprovechamiento directo de los caudales depurados en 111 instalaciones, habiéndose reutilizado de forma directa en el ejercicio de 2015 un total de 133,01 $\mathrm{hm}^{3}$ que representa el 30,86\% del volumen depurado" (p. 26). El uso preferente, como se puede ver en el Gráfico adjunto ha sido la agricultura.

\section{Distribución del aprovechamiento de las aguas regeneradas en la Comunidad Valenciana por usos}

$0,5 \%$

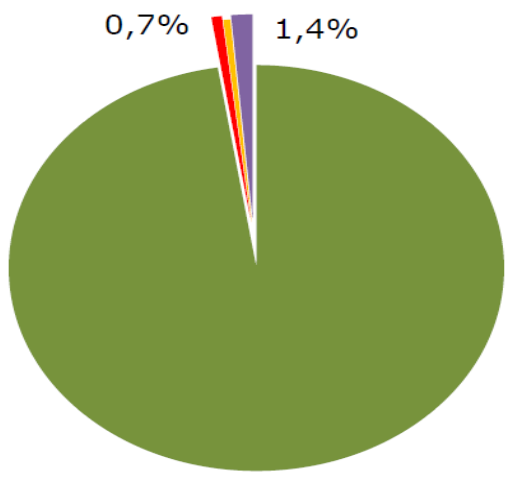

AGRÍCOLA

- RECREATIVO

INDUSTRIAL

- URBANO

$97,5 \%$

Fuente: EPSAR 
Si bien los datos globales acerca de los volúmenes de aguas residuales tratadas en España se acercan a los $5.000 \mathrm{Hm} 3$ /anuales, poco más del 10\% se reutiliza (muy inferiores a los porcentajes valencianos) según los datos del INE, por lo que todavía queda un margen de actuación para incrementar este uso.

Recogida y tratamiento de las aguas residuales en España

\begin{tabular}{|lll|l|l|l|l|l|l|l|}
\hline & & $\mathbf{2 0 1 4}$ & $\mathbf{2 0 1 3}$ & $\mathbf{2 0 1 2}$ & $\mathbf{2 0 1 1}$ & $\mathbf{2 0 1 0}$ & $\mathbf{2 0 0 9}$ & $\mathbf{2 0 0 8}$ \\
\hline Volumen de aguas residuales tratadas & $\mathbf{H m}^{3}$ & 4.942 & 4.998 & 4.961 & 4.927 & 4.864 & 4.672 & 4.516 \\
\hline Volumen total de agua reutilizada & $\mathbf{H m}^{3}$ & 531 & 531 & 548 & 608 & 491 & 534 & 526 \\
\hline
\end{tabular}

Fuente: INE. Estadística sobre el suministro y saneamiento del agua. Serie 2000-2014

\section{CONCLUSIONES}

Los procesos de depuración y reutilización de las aguas son distintos ya que, mientras en el primer caso nos encontramos con que los responsables de proceder a la depuración de las mismas y a soportar los costes de estos procesos son los usuarios domésticos e industriales, en el segundo caso deberían ser los nuevos consumidores los que soportaran los costes la puesta en servicio de estas aguas. En la práctica esta distinción muchas veces no se lleva a cabo, ya que son las propias instalaciones de depuración las que llevan a cabo los procesos de regeneración sin aplicar el coste soportado a los nuevos usuarios.

Al estar las competencias en materia de depuración de las aguas (medio ambiente) atribuidas a las CCAA en España, no existen muchos datos homogeneizados sobre los mismos, por lo que hemos utilizado la normativa valenciana y el canon de saneamiento para poner en evidencia cómo la financiación de estos procesos se ha puesto en marcha en esta comunidad de una forma bastante exitosa.

\section{BIBLIOGRAFÍA}

Entidad Pública de Saneamiento de Aguas Residuales de la Comunidad Valenciana (2016): Memoria de Gestión 2015

INE. Estadística sobre el suministro y saneamiento del agua. Serie 2000-2014 
LEY 2/1992, de 26 de marzo, del Gobierno Valenciano, de saneamiento de las aguas residuales de la Comunidad Valenciana

Puig Infante, A. (2012): Reutilización de las Aguas Residuales. SG de Gestión Integrada del DPH Dirección General del Agua. Ministerio de Agricultura.

REAL DECRETO 1620/2007, de 7 de diciembre, por el que se establece el régimen jurídico de la reutilización de las aguas depuradas.

\section{ENLACES}

http://www.ine.es/jaxi/Tabla.htm?path=/t26/p067/p01/serie/l0/\&file=01005.p $\underline{x \& L=0}$

http://www.epsar.gva.es/sanejament/quienes-somos/INFORME-DE-

GESTION.pdf 


\section{MÓDULO 5}

\section{GESTIÓN DE RIESGOS, SEQUÍAS E INUNDACIONES}




\title{
5.1. MARCO LEGAL DE LOS FENÓMENOS HIDROLÓGICOS EXTREMOS
}

\author{
Andrés Molina Giménez
}

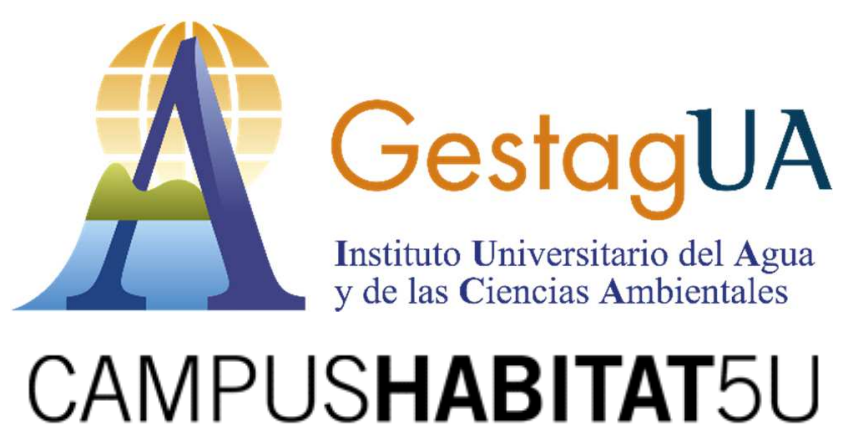




\section{INTRODUCCIÓN}

Los fenómenos hidrológicos extremos, sequías e inundaciones, se sitúan en los márgenes de la gestión del agua. Son situaciones excepcionales que precisan de mecanismos reguladores especiales, donde la gestión de las dinámicas territoriales es especialmente importante.

Si pensamos en las sequías, es cierto que existe una regulación en el marco del Derecho de Aguas que habilita un conjunto de instrumentos (planes y decretos de sequía) que permiten abordar las consecuencias derivadas de estos episodios. Pero junto a ello, la ordenación del territorio tiene también un componente regulador importante, toda vez que la previsión de usos en el territorio, de mayor o menor consumo de agua, debe acompasarse con la presencia de periodos recurrentes de sequía.

Todavía es mayor la importancia de la ordenación territorial en la gestión de los riesgos de inundación. De hecho, el Derecho de Aguas no contiene los instrumentos más importantes para abordar estos retos. Encontraremos en ese marco regulador la previsión de espacios junto a los cursos fluviales, las llamadas "zonas inundables", es decir, terrenos que puedan resultar inundados durante las crecidas no ordinarias de los lagos, lagunas, embalses, ríos o arroyos. Pero dicha legislación únicamente determina que dichos espacios deben conservar la calificación jurídica y la titularidad dominical que tuvieren, pública o privada, y remite a la ordenación del territorio y urbanismo su regulación. Las Confederaciones hidrográficas únicamente suministrarán los datos y estudios disponibles sobre avenidas, al objeto de que se tengan en cuenta en la planificación del suelo y, en particular, en las autorizaciones de usos que se acuerden en las zonas inundables.

Donde está la regulación más importante en este terreno es por tanto en la ordenación del territorio y el urbanismo, ambos aspectos de competencia autonómica en España. La legislación de ordenación del territorio determinará la necesidad de aprobar planes de gestión territorial de inundaciones, y la ordenación urbanística fijará las condiciones y limitaciones necesarias para evitar que las nuevas urbanizaciones ocupen zonas inundables. Lo fundamental, por tanto, es evitar el riesgo, es decir, evitar que se siga construyendo en zonas susceptibles de inundación, y en caso de que sea imprescindible, que se haga con aplicación de las medidas correctoras necesarias.

Al margen de lo anterior, es necesario destacar la política de laminación de avenidas que es clásica en España mediante la construcción de grandes embalses. 
Esto nos sitúa en el terreno de la planificación de obras de interés general, así como en la normativa sobre embalses y presas, lo que no puede ser abordado en este tema.

\section{LOS FENÓMENOS HIDROLÓGICOS EXTREMOS. CONCEPTOS.}

a.- Sequía.

Es preciso distinguir entre sequía y escasez. La primera es una situación excepcional que debe abordarse a través de medidas también excepcionales. La escasez, sin embargo, tiene que ver con el balance hídrico de las cuencas, y puede ser estructural. Precisa por ello medidas a más largo plazo que deben aparecer en los planes hidrológicos de demarcación y en el plan hidrológico nacional.

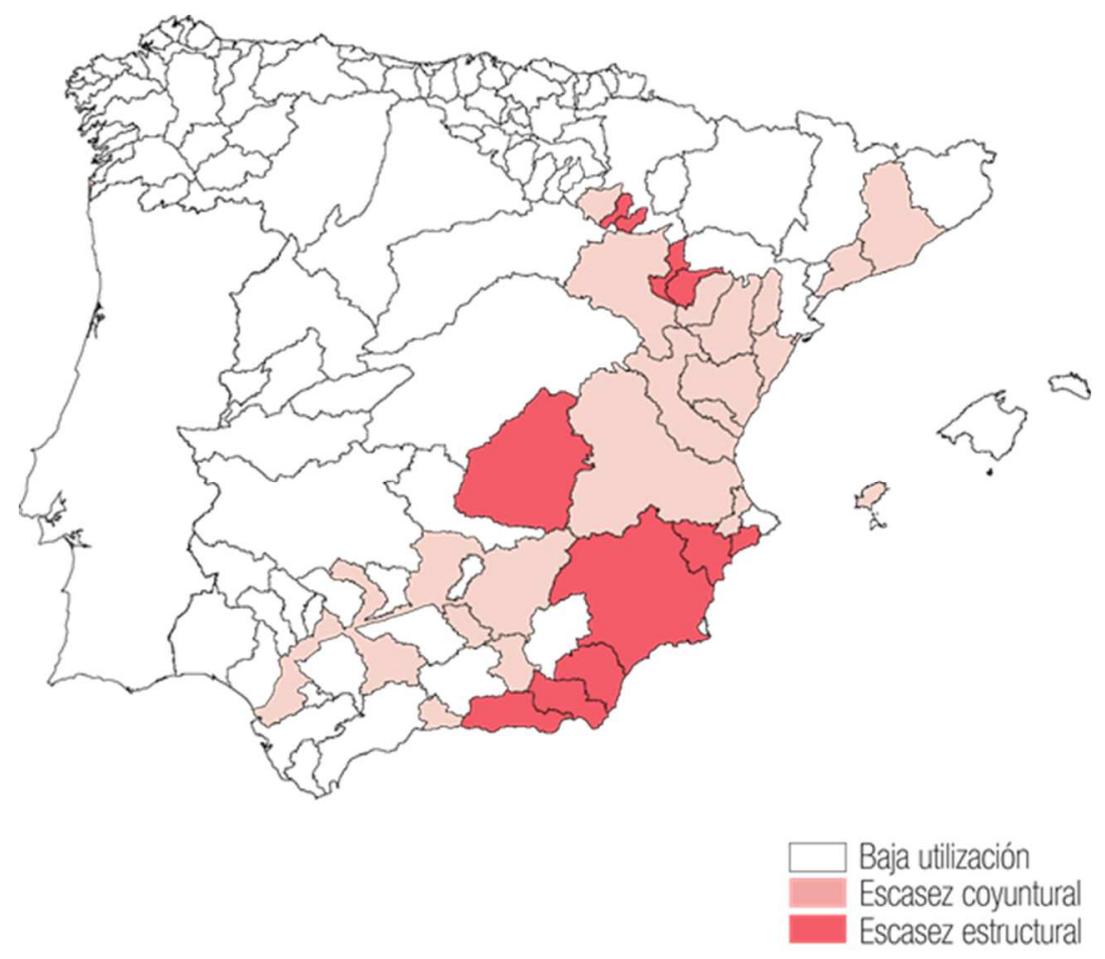

Sistemas de escasez estructural y coyuntural por subcuencas hidrográficas (Libro blanco del Agua, 2000) 
b.- Inundaciones.

Como señala el MAGRAMA, las inundaciones son las catástrofes naturales que más daños generan en España. Según el Consorcio de Compensación de Seguros y el Instituto Geológico y Minero de España, en nuestro país, los daños por inundaciones se estiman en total en una media de 800 millones de euros anuales.

Estamos ante precipitaciones extraordinarias, concentradas en un espacio y tiempo limitado, que generan escorrentías incontroladas que provocan daños en los bienes públicos y privados, con riesgo incluso para la vida e integridad de las personas.

\section{MARCO LEGAL DE LAS SEQUÍAS}

Existen dos respuestas del ordenamiento jurídico frente a la sequía:

a.- Como situación de emergencia: considerando que es una situación de crisis, a la que hay que hacer frente movilizando recursos de carácter extraordinario.

Artículo 58 TRLA: "En circunstancias de sequías extraordinarias, de sobreexplotación grave de acuíferos, o en similares estados de necesidad, urgencia o concurrencia de situaciones anómalas o excepcionales, el Gobierno, mediante Decreto acordado en Consejo de Ministros, oído el organismo de cuenca, podrá adoptar, para la superación de dichas situaciones, las medidas que sean precisas en relación con la utilización del dominio público hidráulico, aun cuando hubiese sido objeto de concesión. La aprobación de dichas medidas llevará implícita la declaración de utilidad pública de las obras, sondeos y estudios necesarios para desarrollarlos, a efectos de la ocupación temporal y expropiación forzosa de bienes y derechos, así como la de urgente necesidad de la ocupación."

b.- En el marco de la planificación: haciendo un análisis del riesgo existente, e introduciendo la sequía en la planificación general como un escenario distinto.

Los Planes se enfrentan a las situaciones de sequía hidrológica definiendo una serie de normas para las situaciones de emergencia, fundamentalmente la existencia de una Reserva de Usos de agua y un Programa de Actuaciones que permitan una adecuada gestión crítica de los recursos. En estas situaciones extremas se establecerán en los embalses, con carácter prioritario, las reservas mínimas necesarias para garantizar el abastecimiento a las poblaciones. Además, se 
desarrollarán nomas concretas de actuación, tales como reducción de horas de servicio, reducción de la presión de servicio, prohibición de determinados usos, así como los adecuados sistemas de control de todo ello.

La Directiva Marco del Agua nos da un nuevo enfoque para la gestión de las sequías. En particular, establece que los efectos de las sequías sobre las masas de agua pueden quedar fuera del régimen sancionador de la Directiva. El deterioro temporal de las masas de agua no constituirá infracción si se debe a causas naturales o de fuerza mayor, que sean excepcionales o que no hayan podido preverse razonablemente, en particular sequías prolongadas (Art. 4 DMA). El estado miembro podrá determinar que no es factible adoptar medidas adicionales de protección en situación de sequía.

La Comunicación de la Comisión 414/2007, de 18 de julio: afrontar el desafío de la escasez de agua y la sequía en la UE, pretende potenciar el control de las demandas frente a la ejecución de infraestructuras de oferta. Para ello recomienda medidas como el control sistemático de las captaciones de agua (Programas obligatorios de medición), asignar el agua de forma más eficiente, potenciar la evaluación ambiental estratégica, los programas de ahorro voluntario o medidas obligatorias (Programas de medidas), eliminar políticas ineficaces de tarificación del agua (el usuario paga), o planificar los usos del suelo de manera eficaz entre otras. En cuanto a la creación de infraestructuras adicionales de suministro (embalses, trasvases, desalación y reutilización, etc., la Comisión las condiciona a la previa aplicación de las medidas preventivas indicadas.

Ya en el ordenamiento jurídico interno español, el TRLA (versión 2003), en su artículo 55 faculta a Organismos de Cuenca para:

- Fijar el régimen de explotación de los embalses y de los acufferos subterráneos, cuando as包 lo exija la disponibilidad del recurso. La utilización coordinada de los aprovechamientos existentes deberá de adaptarse al régimen as?establecido.

- Igualmente, los Organismos de Cuenca podrán fijar el régimen de explotación conjunta de las aguas superficiales y de los acufiferos subterráneos.

- El uso del dominio público hidráulico podrá igualmente ser condicionado o limitado para garantizar su explotación racional. Cuando por ello se ocasione una modificación de caudales que genere perjuicios a unos 
aprovechamientos en favor de otros. Los titulares beneficiados deberán satisfacer la oportuna indemnización.

El Plan Hidrológico Nacional de 2001 (art. 21) exige que el Ministerio de Medio Ambiente establezca un sistema global de indicadores hidrológicos que permita prever las situaciones de sequía y que sirva de referencia general a los Organismos de cuenca para la declaración formal de situaciones de alerta y eventual sequía.

Dicha declaración implica la entrada en vigor de los PLANES ESPECIALES DE ACTUACIÓN EN SITUACIONES DE ALERTA Y EVENTUAL SEQUÍA, que permiten fijar lasr eglas de explotación de los sistemas y aplicar medidas en relación con el uso del dominio público hidráulico. La Orden MAM/698/2007, de 21 de marzo, aprobó los planes especiales de actuación en situaciones de alerta y eventual sequía en los ámbitos de los planes hidrológicos de cuencas intercomunitarias.

Estos planes permiten resolver tres cuestiones fundamentales:

- ¿Cuándo actuar?

- Anticiparse a la sequía es el modo más eficiente de mitigar sus efectos. Se definen así diferentes estadios de sequía. Estos estados son de NORMALIDAD, PREALERTA, ALERTA Y

EMERGENCIA, y dependen del índice de estado hidrológico (IEH), que se obtiene a partir del volumen de las existencias de los embalses, el caudal circulante en ríos, y el nivel de los acuíferos.

- ¿Cómo actuar?

- El Plan establece la secuencia de activación de las medidas de mitigación, según el estado de los recursos en la cuenca y las previsiones sobre su evolución.

- ¿Quiénes son los responsables de la gestión?

- El plan atribuye responsabilidades de acción, es decir, indica quienes han de ser los responsables de implantación y seguimiento de tales medidas, para garantizar su adopción y la coordinación entre instituciones y entidades públicas o privadas vinculadas al problema.

El instrumento operativo más importante, que se pone en marcha cuando se dan las condiciones fijadas en el PES, son los DECRETOS DEL SEQUÍA. Se activan en 
situación de prealerta, y permiten adoptar medidas sobre el régimen de explotación de embalses y acuíferos, e incluso reasignar temporalmente concesiones.

Las Administraciones titulares del servicio de abastecimiento en poblaciones de más de 20.000 habitantes deberán además disponer de un PLAN DE EMERGENCIA ANTE SITUACIONES DE SEQUÍA (plazo: 2005).

\section{MARCO LEGAL DE LAS INUNDACIONES}

La prevención y control de las inundaciones es una materia preferentemente de ordenación del territorio. Como se ha señalado, la legislación de aguas sólo determina que en las llamadas "zonas inundables" las autoridades correspondientes deben ordenar la actividad edificatoria. No existe una prohibición absoluta de edificar en estas zonas, lo que haría que muchos municipios no tuvieran ninguna opción para crecer. No son pocos los que tienen prácticamente todo su término municipal en zonas susceptibles de algún grado de inundación.

En consecuencia, corresponde a los planes de ordenación territorial, y por extensión a los planes urbanísticos, clasificar los niveles de riesgo de inundación de las diferentes áreas del municipio y establecer las decisiones correspondientes. La clasificación de riesgos que realice en estos planes la Comunidad Autónoma vinculará a los planes urbanísticos que deseen aprobar los municipios.

La Comunidad Autónoma pionera en planificar los riesgos de inundación fue la Comunidad Valenciana, que aprobó en 2003 el PATRICOVA, cuya redacción actual está recogida en el Decreto 201/2015, de 29 de octubre, del Consell, por el que se aprueba el Plan de acción territorial sobre prevención del riesgo de inundación en la Comunitat Valenciana. El contenido de este plan resulta un modelo de interés para otras Comunidades Autónomas.

En lo sustancial, este modelo supone la realización de una cartografía (inicialmente a 1:50000) donde se clasifica todo el terreno de la Región en diferentes niveles de riesgo de inundación. Estos niveles permiten establecer una gradación en función de la cual los suelos se clasifican según su aptitud para acoger procesos urbanísticos y edificaciones. En el nivel de máximo riesgo se prohíbe toda actuación, pero a partir de ahí, es posible realizar actuaciones con medidas correctoras. 
Dado que esta cartografía no permite descender al detalle, se crean los denominados "estudios de inundabilidad" que pueden acompañar a los planes urbanísticos, con el objetivo de alterar la clasificación de riesgo de inundación si procede (atendiendo a información más precisa), así como establecer los condicionantes y medidas correctoras necesarias.

\section{CONCLUSIONES}

Los fenómenos hidrológicos extremos se abordan a través de instrumentos que no necesariamente están integrados en la legislación de aguas. Por su elevado impacto territorial, cobran gran protagonismo los planes de ordenación del territorio y urbanísticos.

En el caso de las sequías, el ordenamiento jurídico reacciona mediante una planificación especial para afrontar estos riesgos, donde el instrumento operativo fundamental pasa a ser el Decreto de Sequía. Este Decreto permite poner en uso nuevos recursos, sobre todo subterráneos, elimina o reduce cargas burocráticas para tramitar procedimientos que permitan adoptar medidas frente a la sequía (por ejemplo, agilizando los contratos de cesión de aprovechamientos de agua y centros de intercambio de derechos, o reduciendo los plazos para tramitar evaluaciones ambientales en el caso de poner en funcionamiento pozos de emergencia, etc). Permite además aportar recursos financieros para ayudar a los afectados, por ejemplo, por los mayores costes de adquisición de agua (compra de agua en desaladoras de mar). En definitiva, son medidas no estructurales que no afrontan la escasez, sino que tratan de reaccionar frente a episodios concretos de sequía.

En relación con las inundaciones, sólo se pueden afrontar, una vez el problema está ya creado (preexistencias: usos, edificaciones, ya situados en zona inundable), mediante medidas de defensa, laminación, y corrección de cauces (grandes y costosas obras). El ordenamiento legal, sin embargo, proporciona instrumentos para evitar nuevos riesgos, es decir, evitar que se siga construyendo en zonas inundables y reorientar los desarrollos hacia zonas sin riesgo o con riesgo bajo. Para ello es fundamental que las Comunidades Autónomas aprueben un Plan de riesgo de inundaciones, vinculante para los municipios, y en él se clasifiquen los suelos según su nivel de riesgo. De esa clasificación dependerán los usos admisibles y medidas correctoras requeridas. El uso de cartografías de escala no muy detallada obligará a la realización de estudios de inundabilidad que especifiquen, a escala local, para cada proyecto, el riesgo de inundación. 


\section{BIBLIOGRAFÍA}

Brufao Curiel, P. (2012) El régimen jurídico de las sequías: crítica a la regulación extraordinaria y urgente de un fenómeno natural y cíclico propio del clima. Revista de Administración Pública, no 187.

Molina Giménez, A. (2010) La disciplina territorial del riesgo de inundaciones en el ordenamiento jurídico español. Revista Aranzadi de Derecho Ambiental, no 18.

\section{ENLACES}

http://www.magrama.gob.es/es/agua/legislacion/

http://www.scrats.es/

https://www.mct.es/

https://www.chsegura.es/chs/cuenca/infraestructuras/postrasvaseTajoSegura/legisl acion.html

http://www.habitatge.gva.es/documents/20551069/162377494/00+Decreto+2012015\%2C\%20de+29+de+octubre\%2C\%20del+Consell\%2C\%20por+el+que+se+aprueba+el+ PATRICOVA/e40d2967-979e-49f9-ba70-6fb5e0b5e3fb

http://www.habitatge.gva.es/web/planificacion-territorial-e-infraestructuraverde/patricova-docs 


\title{
5.2. INSTRUMENTOS PARA LA GESTIÓN DE LA ESCASEZ
}

\author{
María Hernández Hernández
}

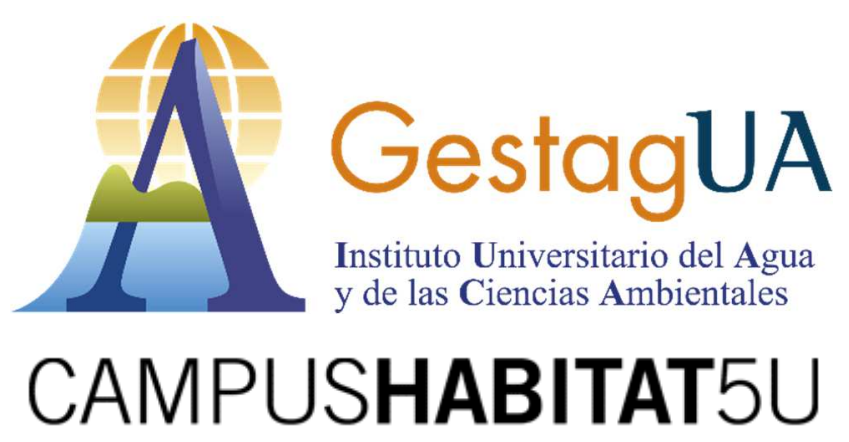




\section{INTRODUCCIÓN: los conceptos de aridez, sequía, escasez hídrica y déficit hídrico)}

Aridez y sequía, por un lado, y escasez hídrica y déficit hídrico, por otro, son conceptos que se utilizan frecuentemente al tratar la gestión territorial del agua y que, en ocasiones se utilizan como sinónimos, cuando no lo son. Explicar, aunque sea brevemente, estos conceptos resulta fundamental para entender los conceptos desarrollados en esta unidad.

Sequía y aridez son rasgos físicos asociados a la falta de precipitaciones que caracterizan a unos territorios, por ejemplo, el sector litoral sur de la provincia de Alicante. La aridez se define como la relación entre la evapotranspiración, la precipitación y la absorción del suelo. Un territorio será árido si las precipitaciones recibidas no compensan las pérdidas de agua debidas a los demás factores. Se considera que una región es semiárida si tiene más de cuatro meses secos, y árida si éstos son más de siete. La aridez es una característica natural permanente (estructural).

La sequía es una situación de déficit hídrico del suelo tal que las necesidades hídricas de la población, los animales y las plantas no pueden ser satisfechas. Se habla de sequía cuando esta situación de falta de precipitación o su duración no forma parte de las características del clima de la zona. Es una anomalía natural transitoria. Se diferencian tres tipos de sequía: sequía meteorológica, sequía hidrológica y sequía socioeconómica. Se dice que se está en sequía meteorológica cuando se produce una baja precipitación durante un período de tiempo suficientemente largo, respecto a los valores medios. Es la sequía que da origen a los otros tipos de sequía. El origen de la escasez de precipitaciones está relacionado con el comportamiento global del sistema océano-atmósfera, donde influyen tanto factores naturales como factores antrópicos (deforestación o el incremento de los gases de efecto invernadero, por ejemplo). Por sequía hidrológica se entiende la disminución en las disponibilidades de aguas superficiales y subterráneas en un sistema de gestión durante un plazo temporal dado, respecto a los valores medios, que puede impedir cubrir las demandas de agua. La sequía socioeconómica es la afección de la escasez de agua a las personas y a la actividad económica. Esta afectación se traduce en pérdidas económicas (Rinamed). La creciente presión de la actividad humana sobre el recurso agua hace que cada vez sea mayor la incidencia de la sequía socioeconómica.

Frente a estos dos conceptos de carácter más físico (natural), los términos escasez hídrica y déficit hídrico incorporarán elementos vinculados al uso del agua (factor antrópico). La escasez representa una situación de déficit en relación con la demanda de agua en un sistema de recursos de ámbito regional, caracterizado, bien por un clima árido o bien por un rápido crecimiento de las demandas consuntivas. El déficit hídrico es aquella situación en la que el agua disponible no es suficiente para satisfacer la demanda. Puede ser coyuntural o estructural (permanente). 
2. DE LA ARIDEZ CLIMATICA AL DÉFICIT HÍDRICO ESTRUCTURAL: el ejemplo de la provincia de Alicante

La relación entre factores climáticos y demandas hídricas puede determinar que en una determinada sociedad se pase de situaciones donde la aridez determina unos recursos hídricos escasos a otras donde ese déficit pasa a ser estructural, es decir, permanente. Los territorios de las provincias de Alicante, Murcia o Almería son representativos de este proceso.

La provincia de Alicante, y más concretamente su sector litoral centro y sur, se caracteriza unas precipitaciones que se sitúan alrededor de los $300 \mathrm{~mm}$. La aridez determinó que hasta mediados de 1950 la sociedad, eminentemente rural, hubiese adoptado una serie de prácticas adaptadas a esas precipitaciones entre las que cabe citar el predominio de los cultivos de secano, el uso de aguas pluviales dando lugar a un particular ordenación denominada como regadío de turbias y el predominio de núcleos urbanos de tipologías compactas y con módulos de consumo bajos (no superiores a 50 I/hab/día). Esta ordenación adaptada a las condiciones climáticas determina que se hable de escasez naturalizada (Morales, Olcina y Rico, 2000).

A partir de 1950, estas relaciones van a ir cambiando como consecuencia de las transformaciones socioeconómicas que registra el país, lo que va a traducirse en un aumento notable de las demandas hídricas, que va a conducir, a su vez, a una desnaturalización de la escasez (Rico y Hernández, 2008). Este aumento se relaciona con la expansión de la agricultura de regadío basada en cultivos hortofrutícolas orientados a la exportación, la difusión de los usos turísticos y residenciales y la adopción de nuevas tipologías urbanas más extensivas caracterizadas por la presencia de usos exteriores (jardines y piscinas). El aumento de esas demandas va a traducirse en un hecho relevante como es que, en condiciones climáticas normales, los recursos hídricos resultan insuficientes para cubrir las demandas y sea necesario recurrir a recursos externos. Ello determina que empiece a hablarse de sequía estructural o de déficit hídrico estructural.

\section{INSTRUMENTOS PARA LA GESTIÓN DE LA ESCASEZ: DE LAS INICIATIVAS ORIENTADAS AL INCREMENTO DE LA OFERTA DE RECURSOS HÍDRICOS A LAS ORIENTADAS A LA PLANIFICACIÓN DE LA DEMANDA}

Una demanda creciente y superior a los recursos hídricos disponibles va a traducirse en la adopción de actuaciones orientadas a gestionar la escasez. Los instrumentos que se han adoptado se vinculan a dos grandes líneas de actuación. Por un lado, las orientadas a incrementar la oferta de recursos convencionales y por otro, 
las vinculadas a la gestión de la demanda y recursos no convencionales. En los últimos años, se ha incorporado un tercer instrumento orientado al aprovechamiento de recursos no convencionales asociados, a su vez a la mitigación de riesgos.

La primera de las iniciativas (incremento de la oferta) se inserta en el denominado paradigma hidráulico. Este paradigma formulado a finales del siglo XIX consistía en proporcionar agua suficiente para todos aquellos agentes sociales dispuestos a utilizarla en el desarrollo de la producción (Sauri y Del Moral, 2001). La disponibilidad de mayores recursos hídricos sería la herramienta que permitiría el desarrollo económico de muchos territorios. El instrumento para su consecución serán las obras hidráulicas; concretamente la construcción de embalses (en gran medida entre 1940 y 1970) y los trasvases entre cuencas, como por ejemplo el del Tajo al Segura o el del Ebro a Tarragona.

En los últimos veinte cinco años este paradigma, aún vigente, ha sido objeto de numerosas críticas que son resultado de una reorientación de objetivos, metodologías, aproximaciones conceptuales y de cambios institucionales (agentes implicados y marco normativo). Este nuevo paradigma (Nueva Cultura del Agua), si bien se viene aplicando de manera cada vez más generalizada, ha generado resistencias y críticas desde planteamientos anteriores (Saurí y del Moral, 2001). La aprobación de la Directiva Marco del Agua (DMA 2000/60/CE), que incorpora valores ambientales y culturales al agua más allá de los de los estrictamente económicos, va a dar lugar a nuevas iniciativas orientada a satisfacer las demandas hídricas (Pita et al., 2014):

- Apuesta por recursos no convencionales (desalación) frente a los trasvases. El ejemplo es el programa A.G.U.A. (RDL 2/2004) aprobado tras la derogación del trasvase del Ebro, que apostó por la desalación para incrementar la oferta de recursos hídricos de manera sostenible en el litoral mediterráneo y cubrir las demandas presentes no satisfechas y las nuevas demandas asociadas a la expansión turística-residencial. Iniciativa que se inserta en un paradigma de satisfacción de la demanda, si bien con recursos propios de la cuenca (agua de mar), garantizando las aportaciones en periodos de sequía y reduciendo la presión sobre recursos convencionales (subterráneos y procedentes de trasvases).

- Gestión de la demanda mediante la integración de las políticas sectoriales (por ejemplo, la planificación hidrológica) en los instrumentos de la ordenación del territorio (por ejemplo, ley del suelo). La planificación hidrológica tiene que entenderse como un instrumento al servicio de las políticas territoriales, es decir, las demandas y disponibilidades de agua de cada cuenca sólo pueden fundamentarse en el diagnóstico y la consiguiente formulación de estrategias de utilización del territorio. Ejemplo: la Ley 5/2014, de ordenación del territorio, urbanismo y paisaje de la Comunidad Valenciana. En el apartado "recursos hídricos y su relación con los 
usos del suelo" indica: "se fomentará la implantación de modelos diversos y eficientes desde el punto de vista del consumo de recursos" (art.7) y "adaptará los nuevos desarrollos territoriales a la disponibilidad de recursos, previendo medidas de reasignación de recursos o de construcción de infraestructuras que permitan obtenerlos" (art.9). La aplicación de este instrumento, si bien, ha mejorado notablemente en los últimos años presenta déficits de ejecución que tienen que ver con la debilidad que presenta la ordenación del territorio con respecto a la política hidráulica y otras políticas sectoriales y que se evidencia en la inexistencia de un modelo territorial a escala nacional (normativas diversas) o la existencia de organismos con niveles competenciales diversos a la hora de la planificación hidrológica y la ordenación del territorio (Rico y Hernández, 2008; Del Moral, 2009).

En los últimos años y relacionado con la gestión sostenible de los recursos, se están incorporado nuevos recursos (no convencionales) asociados a la minimización de riesgos ambientales (inundación y contaminación) (Hernández, Sauri y Moltó, 2016). Ante los escenarios que apuntan por una mayor irregularidad pluviométrica en la cuenca mediterránea, la evaluación y eventual movilización de todos los recursos hídricos disponibles se erige como un objetivo territorial prioritario. Entre éstos, la incorporación de aguas depuradas regeneradas y pluviales bajo el principio del "fit for purpose" (recursos adecuados a usos específicos) se considera prioritario ya que pueden contribuir decisivamente a aumentar la resiliencia territorial a episodios de incertidumbre hídrica. Ejemplo: uso de los caudales obtenidos a partir del tanque anticontaminación y del parque inundable la Marjal, ambos en Alicante. Tanto para las aguas pluviales como para las residuales, la literatura científica apunta hacia un cambio de paradigma ya que, de ser consideradas bajo la óptica del riesgo ambiental, han pasado a ser tratadas como flujos que se pueden valorizar (Sedlak, 2014).

\section{GESTIÓN PLANIFICADA DE LA SEQUÍA}

Junto a las medidas orientadas a incrementar los recursos hídricos y, recientemente, a aumentar la resiliencia territorial ante episodios de incertidumbre hídrica, se han desarrollado actuaciones que tienen como finalidad mitigar los efectos socio-económicos de las sequías. La anticipación en la aplicación de las medidas de mitigación es un elemento clave en la reducción de los efectos socioeconómicos de la sequía; de ahí la importancia de establecer umbrales de alerta. Las principales herramientas con las que cuenta la administración general del estado para la planificación y gestión de sequías son:

- Sistemas de indicadores de estado hidrológico. Desarrollados por los organismos de cuenca permiten prever situaciones de sequía y valorar la gravedad con que se presenta. Su finalidad es caracterizar la sequía hidrológica, lo que facilita la toma de 
decisiones relativas a la gestión de los recursos hídricos. Esta caracterización se realiza a partir de la identificación de los recursos (pluviometría, aportaciones de los ríos, volumen almacenado en embalses y niveles piezométricos de los acuíferos) asociados a las unidades de demanda. Los indicadores adoptan valores comprendidos entre 0 y 1 , correspondiendo los valores bajos a situaciones de sequía y el valor de 0,5 a la situación media. Con estos valores, clasifican los estados hidrológicos de los sistemas de explotación en cuatro categorías (normalidad, prealerta, alerta, emergencia) que a su vez determinan el riesgo de restricciones.

- Planes Especiales de Sequía de los Organismos de cuenca (PES). Elaborados por los organismos de cuenca, su objetivo general es, según lo establecido en el artículo 27.1 de la Ley 10/2001, minimizar los aspectos ambientales, económicos y sociales de eventuales situaciones de sequía. Concretamente: a) Garantizar la disponibilidad de agua requerida para asegurar la salud y la vida de la población; b) Evitar o minimizar los efectos negativos de la sequía sobre el estado ecológico de las masas de agua, en especial sobre el régimen de caudales ecológicos; c) Minimizar los efectos negativos sobre el abastecimiento urbano; y d) Minimizar los efectos negativos sobre las actividades económicas, según la priorización de usos establecidos en la legislación de aguas y en los planes hidrológicos. Estos planes se articulan en torno a 3 ejes: a) Diagnóstico, donde se identifican y caracterizan los elementos territoriales y ambientales (recursos y demandas), se analizan las sequías históricas y se definen indicadores, umbrales y fases de sequía; b) Programa de medidas, donde se definen una serie de medidas (desde la planificación y gestión de los recursos a la restricción de usos) para cada una de las fases de la sequía en relación al estado hidrológico; c) Sistemas de gestión y seguimiento del plan.

- Planes de emergencia para los abastecimientos urbanos mayores de 20.000 habitantes. El artículo 3.3 de la Ley 10/2001 dispone que las Administraciones públicas responsables de sistemas de abastecimiento urbano a población igual o superior a 20.000 habitantes deberán disponer de una Plan de Emergencia ante situaciones de sequía. Dichos Planes, que serán informados por el organismo de cuenca, deberán tener en cuenta las medidas previstas en los Planes Especiales de actuación en situaciones de alerta y eventual sequía (PES). La Asociación Española de Abastecimientos de Agua y Saneamiento en colaboración con la Federación Española de Municipios y Provincias y el Ministerio de Medio Ambiente elaboró una "Guía para la elaboración de planes de emergencia por sequía en sistemas de abastecimiento" cuyo objetivo era asegurar que todos los planes respondiesen a un criterio unificado y homogéneo para que la identificación de las situaciones de insuficiencia o incapacidad de los sistemas respondan con los mismos principios y criterios. Ejemplos: plan de emergencia en Madrid (Canal de Isabel II), el de Málaga (EMASA), Sevilla (EMASESA) y Barcelona (Aguas Ter-Llobregat). 


\section{BIBLIOGRAFÍA}

Del Moral Ituarte, L. (2009): “Nuevas tendencias en gestión del agua, ordenación del territorio e integración de políticas sectoriales", Scripta Nova, 13, pp. 281-309.

Hernández Hernández, M.; Pujol Sauri, D. y Moltó Mantero, E. (2016): “Las aguas pluviales y de tormenta: del abandono de un recurso hídrico con finalidad agrícola a su implantación como recurso no convencional en ámbitos urbanos", en: Paisaje, cultura territorial y vivencia de la Geografía. Libro homenaje al profesor Alfredo Morales Gil. San Vicente del Raspeig, Publicaciones de la Universidad de Alicante, pp. 1.099-1.120.

Morales Gil, A.; Olcina Cantos, J. y Rico Amorós, A.M. (2000): “Diferentes percepciones de la sequía en España: adaptación, catastrofismo e intentos de corrección", Investigaciones Geográficas, 23, pp. 5-46.

Pita, Ma. F.; Del Moral, L.; Pedregal, B.; Limones, N. y Hernández-Mora, N. (2014): "Nuevos paradigmas en la gestión de recursos y riesgos hídricos: datos e información necesarios para una gestión integrada del agua", Boletín de la Asociación de Geógrafos Españoles, 69, pp.519-542.

Rico Amorós, A.M. y Hernández Hernández, M. (2008): “Ordenación del territorio, escasez de recursos hídricos, competencia de usos e intensificación de las demandas urbano-turísticas en la Comunidad Valenciana", Documents d'Anàlisi Geogràfica, 51, pp.79-109.

Saurí Pujol, D. y Del Moral Ituarte, L. (2001): "Recent development in Spanish water policy. Alternatives and conflicts at the end of the hydraulic age", Geoforum, 32(3), pp. 351-362.

Sedlak, D. (2014) Water 4.0. The past, present and future of the World's most vital resource. New Haven, Yale University Press.

\section{ENLACES}

Guía para la elaboración de Planes de emergencia por sequía en sistemas de abastecimiento urbano: http://www.magrama.gob.es/es/agua/temas/observatorionacional-de-la-sequia/guia elaboraci\%C3\%B3n planes emergencia tcm7-197482.pdf

Sistema de indicadores de estado hidrológico: http://www.magrama.gob.es/es/agua/temas/observatorio-nacional-de-la-sequia/planificaciongestion-sequias/Observatorio Nacional Sequia 32 sistemas indicadores.aspx

Planes especiales de sequía de los organismos de cuenca (MAGRAMA): http://www.magrama.gob.es/es/agua/temas/observatorio-nacional-de-la-sequia/planificaciongestion-sequias/Observatorio Nacional Sequia 31 planes especiales sequia.aspx

RINAMED, Les risques naturels de l'Arc Mediterranéen Occidental: http://www.rinamed.net/es/es ris clim sequia.htm 


\title{
5.3. INSTRUMENTOS DE CONTROL DE LAS INUNDACIONES
}

\author{
Enrique Moltó Mantero
}

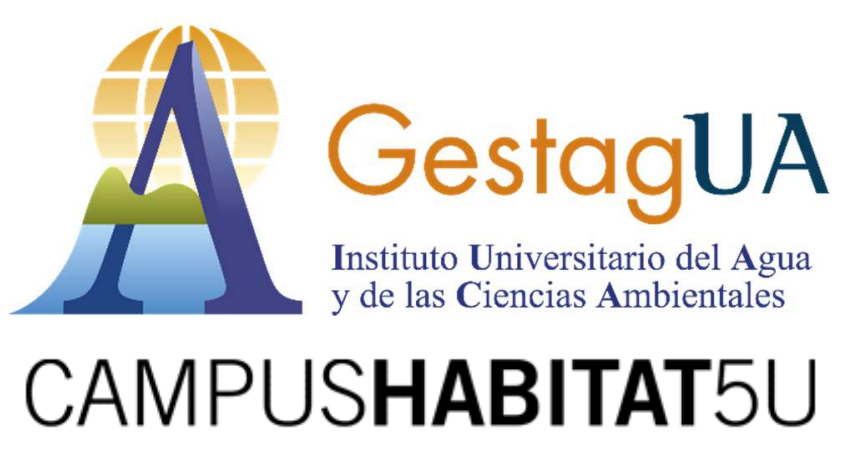




\section{INTRODUCCIÓN}

El aumento de las inundaciones está más ligado al aumento de la exposición que al de la peligrosidad natural. Las herramientas contra estos eventos están vinculadas a reducir la exposición, con la adecuada ordenación del territorio, y la vulnerabilidad, con acciones estructurales y coyunturales. Cada contexto geográfico requiere, como se irá apuntando, actuaciones distintas.

\section{INSTRUMENTOS PARA LA REDUCCIÓN DEL RIESGO}

Es fundamental la investigación de los diversos elementos que deben interactuar. Es fundamental profundizar en las causas de los riesgos y en la mejor forma de reducirlos. Apoyada en esa investigación debe haber una legislación que, entre otras cosas, pueda actuar apoyando la ejecución de obra civil. Por otra parte, como todo esto no es suficiente, es fundamental la educación que acabe con falsas creencias y la correcta comunicación de estos riesgos.

\section{LA ORDENACIÓN DEL TERRITORIO COMO MEDIDA DE REDUCCIÓN DE INUNDACIONES}

- En el cauce en área urbana se debe conseguir mediante la planificación urbanística, en áreas no ocupadas con la declaración de suelo no urbanizable rural, y en las ya ocupadas con medidas estructurales contempladas en los PGOU y en los planes especiales.

- En el cauce en área natural-rural se debe actuar con planificación hidrológica, con planes específicos anti-inundaciones o con restauraciones fluviales.

- En ambos casos es esencial una buena cartografía.

- La planificación sectorial y territorial, regional y subregional debe ser tenida en cuenta.

\section{ENFOQUES EN EL ANÁLISIS DEL RIESGO}

Si enfocamos que la naturaleza es el problema, sólo nos centraremos en que los episodios naturales de rango extraordinario son imprevisibles, en que los 
desastres naturales van a más y en que la única solución procede de medidas curativas estructurales, casi siempre post-desastre.

Si advertimos que el problema es la acción del ser humano, nos daremos cuenta de la creciente ocupación humana de espacios de riesgo, que aumenta su vulnerabilidad ante los mismos, así como el riesgo, y que, en ese contexto, la única acción posible es la ordenación racional del territorio.

\section{TIPOS DE INUNDACIONES}

Podemos tipificar los siguientes modelos de inundaciones:

- Inundaciones por lluvias abundantes y continuas como las acaecidas en grandes cuencas hidrográficas que suponen subidas paulatinas de los espacios inundados, grandes extensiones y perdurabilidad de la lámina de agua. Suponen más daños económicos que personales porque hay tiempo para las evacuaciones.

- Inundaciones por lluvias intensas (50-100 mm/1 hora). Son los típicos fenómenos de "flash flood" o inundaciones relámpago, con lluvias muy concentradas en el tiempo y en el territorio, que afectan a una pequeña cuenca, a veces de régimen espasmódico, con repercusiones muy graves si se encuentran exposición humana y vulnerabilidad alta porque no hay tiempo a evacuaciones. El mejor ejemplo en España es el del Camping Las Nieves de Biescas.

- Inundaciones por lluvias torrenciales (>200 mm/24 h). Son las típicas situaciones del otoño mediterráneo español, aunque pueden presentarse en otras estaciones, con una combinación de torrencialidad prolongada en el tiempo indicado y extensiones afectadas más amplias que en el caso anterior, pero más reducidas que en el primero. El ejemplo del Riu Girona en octubre de 2007, en el norte de la provincia de Alicante resulta paradigmático.

- Inundaciones por deshielo rápido. En ocasiones se combinan con el primero de los casos indicados, debido a una súbita subida de la cota de nieve con lluvias, justo después de haberse producido una nevada en cotas medias e incluso bajas. 
- Inundaciones por rotura de presas. Se suelen vincular especialmente a las situaciones descritas en segundo lugar donde la torrencialidad impide un desagüe progresivo y ello puede suponer que la presa no aguante y ceda. La "pantanada" de Tous en octubre de 1982 es uno de los mejores ejemplos.

- Inundaciones por avalanchas. En algunos casos un deslizamiento puede ir a parar al cauce de un río y suponer una súbita subida del caudal, especialmente si se produce en el vaso de una presa llena o casi llena.

\section{TIPOS DE INTERVENCIONES}

La construcción de presas ha sido una de las intervenciones más usuales, sobre todo en cursos y cuencas de cierta envergadura porque, además, sobre todo en espacios semiáridos o con sequías frecuentes, tiene también una gran utilidad en el control de las sequías.

Las canalizaciones, como en el caso anterior, son el otro gran ejemplo de acción de obra dura de las más empleadas, sobre todo en el paso por zonas urbanas de algunos de los ríos, tanto de caudal más regular como más espasmódico, ya que dan la falsa tranquilidad de saber exactamente la cantidad de agua que puede pasar por un punto y permite hacer cálculo de períodos de retorno, que no siempre se cumplen. Los más "duros" han sido muy criticados, por suponer una pérdida de biodiversidad y calidad ambiental, aparte de por los problemas que pueden generar aguas abajo, por el aumento del coeficiente de escorrentía.

En el caso de cursos alóctonos a la zona urbana, las desviaciones de cursos parecen la mejor elección, porque "sacan" el problema del territorio afectado y evitan la exposición al mismo. El crecimiento urbano puede dejar inservibles estas desviaciones.

Las restauraciones de cuenca y de cursos son un ejemplo de solución integral, son la solución idónea pero no tienen efectos inmediatos y requieren de grandes inversiones y de soluciones poco tradicionales y poco empleadoras de empresas constructoras.

Los depósitos subterráneos de retención son una buena solución en núcleos urbanos en los que los barrancos susceptibles de desbordarse se originan cerca o, en algunos casos, tienen una buena parte de las cuencas en el entramado urbano. 
Los parques inundables son una interesante solución en zonas urbanas como las descritas en el caso anterior, ya que permiten dotar de una zona verde y de recreo y, a la vez, de forma puntual y regulada, como lo son de hecho las inundaciones para las que se disponen, permitir una acumulación de agua durante un tiempo que frene la inundación de zonas residenciales.

La ordenación del territorio es el resumen de lo que debería primar como defensa integral. Podemos resumirla como la forma de planificar las infraestructuras y los usos del suelo para hacer compatible el desarrollo urbanístico.

\section{GRANDES EPISODIOS DE INUNDACIÓN Y PUESTA EN MARCHA DE ACTUACIONES ESTRUCTURALES DE DEFENSA DESDE 1950}

En el siguiente cuadro se muestran diversos ejemplos de cómo diversos episodios de lluvias extraordinarias de consecuencias catastróficas han dado lugar a respuestas estructurales de diversos tipos en función de las tipologías de inundaciones antes descritas y de las características geográficas de cada territorio, así como de la época en la que fueron ejecutados. Queda clara la política de "acción a golpe de desastre" que ha primado en España, en la que también se puede ver una evolución desde las obras más duras a las más integradas y respetuosas con el medio ambiente. 


\begin{tabular}{|l|l|}
\hline \multicolumn{1}{|c|}{ ACTUACIÓN ESTRUCTURAL } & \multicolumn{1}{c|}{ EPISODIO CATASTRÓFICO } \\
\hline Plan “Sur" en el río Turia (Valencia) & Inundación octubre de 1957 \\
\hline Encauzamiento del Llobregat & Inundación septiembre de 1962 \\
\hline Nueva presa de Tous & Inundación octubre de 1982 \\
\hline Actuaciones en cauces del País Vasco & Inundación agosto de 1983 \\
\hline $\begin{array}{l}\text { Plan de defensa de avenidas en la } \\
\text { cuenca del Segura }\end{array}$ & $\begin{array}{l}\text { Inundación octubre de 1973 y } \\
\text { noviembre de 1987 }\end{array}$ \\
\hline $\begin{array}{l}\text { Actuaciones en cauces de Almería y } \\
\text { Málaga }\end{array}$ & $\begin{array}{l}\text { Inundaciones de septiembre V } \\
\text { noviembre de 1989 }\end{array}$ \\
\hline $\begin{array}{l}\text { Actuaciones en cauces de Santa Cruz } \\
\text { de Tenerife }\end{array}$ & Inundaciones de marzo de 2002 \\
\hline $\begin{array}{l}\text { Plan de depositos pluviales de la } \\
\text { ciudad de Barcelona }\end{array}$ & $\begin{array}{l}\text { Tormentas otoñales diversas años } \\
\text { noventa del siglo XX }\end{array}$ \\
\hline $\begin{array}{l}\text { Plan anti-inundaciones en la ciudad } \\
\text { de Alicante }\end{array}$ & Inundación septiembre de 1997 \\
\hline
\end{tabular}

\section{RIESGOS CLIMÁTICOS Y CAMBIO CLIMÁTICO EN EL PRIMER CICLO DE PLANIFICACIÓN HIDROLÓGICA (2009-2015)}

En el primer ciclo de la planificación hidrológica entre 2009 y 2015, en la interacción entre sequias, inundaciones y el contexto general del Cambio Climático podemos contemplar los siguientes instrumentos, variables y a la vez integrados en función de los contextos de actuación.

a) En las sequías el artículo 27 de la Ley del Plan Hidrológico Nacional

Artículo 27. Gestión de las sequías.

1. El Ministerio de Medio Ambiente, para las cuencas intercomunitarias, con el fin de minimizar los impactos ambientales, económicos y sociales de eventuales situaciones de sequía, establecerá un sistema global de indicadores hidrológicos que permita prever estas situaciones y que sirva de referencia general a los Organismos de cuenca para la declaración formal de situaciones de alerta y eventual sequía, siempre sin perjuicio de lo establecido en los artículos 12.2 y 16.2 de la presente Ley. 
Dicha declaración implicará la entrada en vigor del Plan especial a que se refiere el apartado siguiente.

2. Los Organismos de cuenca elaborarán en los ámbitos de los Planes Hidrológicos de cuenca correspondientes, en el plazo máximo de dos años desde la entrada en vigor de la presente Ley, planes especiales de actuación en situaciones de alerta y eventual sequía, incluyendo las reglas de explotación de los sistemas y las medidas a aplicar en relación con el uso del dominio público hidráulico. Los citados planes, previo informe del Consejo de Agua de cada cuenca, se remitirán al Ministerio de Medio Ambiente para su aprobación.

3. Las Administraciones públicas responsables de sistemas de abastecimiento urbano que atiendan, singular o mancomunadamente, a una población igual o superior a $\mathbf{2 0 . 0 0 0}$ habitantes deberán disponer de un Plan de Emergencia ante situaciones de sequía. Dichos Planes, que serán informados por el Organismo de cuenca o Administración hidráulica correspondiente, deberán tener en cuenta las reglas y medidas previstas en los Planes especiales a que se refiere el apartado 2, y deberán encontrarse operativos en el plazo máximo de cuatro años.

4. Las medidas previstas en los apartados 1 y 2 del presente artículo podrán ser adoptadas por la Administración hidráulica de la Comunidad Autónoma, en el caso de cuencas intracomunitarias.

También en el caso de las sequías, los Planes de Sequía que serán adoptados por las confederaciones hidrográficas.

b) En el caso de las inundaciones

- El artículo 28 del Plan Hidrológico Nacional que dice:

Artículo 28. Protección del dominio público hidráulico y actuaciones en zonas inundables.

1. En el dominio público hidráulico se adoptarán las medidas necesarias para corregir las situaciones que afecten a su protección, incluyendo la eliminación de construcciones y demás instalaciones situadas en el mismo. El Ministerio de Medio Ambiente impulsará la tramitación de los expedientes de deslinde del dominio público hidráulico en aquellos tramos de ríos, arroyos y ramblas que se 
considere necesario para prevenir, controlar y proteger dicho dominio.

2. Las Administraciones competentes delimitarán las zonas inundables teniendo en cuenta los estudios y datos disponibles que los Organismos de cuenca deben trasladar a las mismas, de acuerdo con lo previsto en el artículo 11.2 de la Ley de Aguas. Para ello contarán con el apoyo técnico de estos Organismos y, en particular, con la información relativa a caudales máximos en la red fluvial, que la Administración hidráulica deberá facilitar.

3. El Ministerio de Medio Ambiente promoverá convenios de colaboración con las Administraciones Autonómicas y Locales que tengan por finalidad eliminar las construcciones y demás instalaciones situadas en dominio público hidráulico y en zonas inundables que pudieran implicar un grave riesgo para las personas y los bienes y la protección del mencionado dominio.

4. Las actuaciones en cauces públicos situados en zonas urbanas corresponderán a las Administraciones competentes en materia de ordenación del territorio y urbanismo, sin perjuicio de las competencias de la Administración hidráulica sobre el dominio público hidráulico.

El Ministerio de Medio Ambiente y las Administraciones Autonómicas y Locales podrán suscribir convenios para la financiación de estas actuaciones.

- Planes Autonómicos de Gestión del Riesgo de Inundaciones

- Directiva $60 / 2007$

(http://www.unirioja.es/dptos/dd/administrativo/seminarioaguas2 012/bibliografia/Berga inundaciones 2011.pdf)

- Evaluación Preliminar Riesgo Inundaciones

- Sistema Nacional de Cartografía de Zonas Inundables

c) En el contexto del Cambio climático

- -Trabajos del CEDEX, AEMET y Oficina Española de Cambio Climático (adaptación de modelización al territorio español)

- -Planes y Estrategias Autonómicas de adaptación al Cambio Climático 
- Instrucción de Planificación Hidrológica

- Informes IPCC

\section{MEDIDAS LEGALES EFECTIVAS DE REDUCCIÓN DE EXTREMOS HIDROLóGICOS}

1.-Elaboración de cartografía de riesgo y su observancia en procesos de ordenación territorial

-Directiva 60/2007 (SNCZI)

- Cartografías regionales de riesgo

-Ley Suelo 2008 (mapas de riesgo escala local)

2.-Riesgo en la planificación territorial y urbanística

-Planes autonómicos de ordenación territorial

-Ley Suelo 2008 (y adaptación autonómica de la misma)

3.-Planes de infraestructura (aprobados por ley)

-Reducción de inundaciones (Planes demarcación hidrográfica, PHN. Planes estatales y regionales de obras)

\section{BIBLIOGRAFÍA}

AYALA CARCEDO, Francisco Javier; OLCINA CANTOS, Jorge (coords.). Riesgos naturales. Barcelona: Ariel, 2002.

DíEZ HERRERO, Andrés; LAÍN HUERTA, Luis; LLORENTE ISIDRO, Miguel. Mapas de peligrosidad por avenidas e inundaciones: guía metodológica para su elaboración. Madrid: Instituto Geológico y Minero de España, 2008.

GIL OLCINA, Antonio; OLCINA CANTOS, Jorge; RICO AMORÓS, Antonio M. Aguaceros, aguaduchos e inundaciones en áreas urbanas alicantinas. San Vicente del Raspeig: Universidad de Alicante, 2004.

OLCINA CANTOS, Jorge. Riesgos climáticos en la Península Ibérica. Madrid: Acción divulgativa, 1994.

José Chacón Montero y Clemente Irigaray (Eds). Riesgos naturales, ordenación del territorio y medio ambiente (Natural hazards, land-use planning and environment). Sexto Congreso Nacional y Conferencia Internacional de Geología Ambiental y 
Ordenación del Territorio (6th Spanish Congress and International Conference on Environmental Geology and Land-use Planning). Madrid: [s.n.], 1996.

\section{ENLACES}

http://aeclim.org/images/stories/articulos pdf/LIBRO\%20METEOROLOGIA\%20ESP A\%C3\%910L.pdf

http://rua.ua.es/dspace/bitstream/10045/4735/1/RHM 23 07.pdf

http://video.google.com/videoplay?docid=-7147978718716554578\#docid=$\underline{2854769162279936349}$

http://www.aemet.es

http://www.ceamet.es

http://www.inforiesgos.es

http://www.meteoclimatic.com

http://www.meteored.com

http://www.meteosat.com

http://www.meteosim.com

http://www.puertos.es/es/index.html

http://www.rinamed.es

http://www.wetterzentrale.de

http://www.wmo.int/pages/index es.html 


\section{MÓDULO 6}

\section{EL AGUA URBANA}




\title{
6.1. GESTIÓN DEL SUMINISTRO URBANO
}

\author{
Andrés Molina Giménez
}

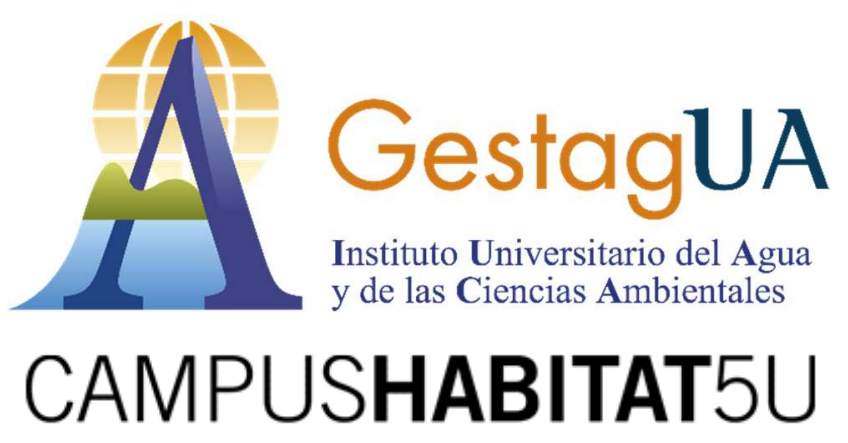




\section{INTRODUCCIÓN}

El abastecimiento urbano de agua potable es un factor decisivo en el desarrollo territorial. Disponer de agua potable domiciliaria es un logro histórico de las sociedades desarrolladas. Para ello es necesario captar el agua de su fuente en el medio, a veces en localizaciones alejadas del punto de uso, transportar ese recurso, potabilizarlo y finalmente distribuirlo a través de redes jerarquizadas hasta el usuario final. El agua, además, debe tener la calidad sanitaria requerida, y el servicio debe ser continuo, prestado con regularidad, universal y a un coste razonable.

Por otra parte, el desarrollo socioeconómico del territorio depende en buena medida de la disponibilidad y calidad del agua. No nos referimos aquí al desarrollo de grandes industrias o a las actividades agrícolas, puesto que éstas resuelven su suministro mediante aprovechamientos específicos que se otorgan mediante concesiones; pero al margen de ello, existen numerosas actividades económicas de carácter urbano o periurbano que dependen de un suministro adecuado de agua potable. Así ocurre con la actividad industrial vinculada a la trama urbana (polígonos industriales, industrias ubicadas en la ciudad, etc), o con actividades tales como el turismo, el turismo residencial, o incluso determinadas actividades comerciales. Todo ello depende de un abastecimiento urbano de agua garantizado.

Dado que estamos ante un servicio esencial para la vida de las personas y para la actividad económica, desde pronto fue considerado en nuestra legislación como un servicio público, reconociendo a las personas y empresas el derecho al establecimiento del servicio (cuando no se disponía de redes de suministro), el derecho al acceso al servicio (altas en el suministro), y el derecho a un suministro de calidad.

Todo lo anterior se sustenta en una estructura financiera adecuada que permita cumplir con los objetivos previstos. Para ello existen diferentes sistemas tarifarios que trasladan al usuario los costes de la actividad.

\section{REGULACIÓN DEL ABASTECIMIENTO DE AGUA EN POBLACIONES}

\section{a. Fases de la actividad}

El suministro urbano se desarrolla a partir de dos fases claramente diferenciadas: 
a.- Fase de alta.

Esta fase comprende la captación del recurso del medio natural donde se encuentra, el transporte del agua hasta las instalaciones de potabilización, y su conducción hasta los depósitos de cabecera de distribución municipal. A veces son los propios municipios los que asumen la gestión de estas actividades, sin embargo, en suministros más complejos, podemos encontrar entidades de ámbito superior. Algunos municipios optan por crear mancomunidades para organizar estas actividades, y en ocasiones, cuando participan otras Administraciones (Comunidades Autónomas, Diputaciones, etc), se crean consorcios.

Al margen de estas modalidades asociativas, existen entidades de ámbito autonómico (Canal de Isabel II) o estatal (Mancomunidad de Canales del Taibilla) que asumen estas fases en situaciones de especial complejidad.

Un caso especial es precisamente el de la Mancomunidad de Canales del Taibilla, un organismo autónomo estatal que se creó en 1923 para dar suministro a la base naval de Cartagena. Desde entonces y hasta la actualidad ha extendido su actividad a numerosos municipios del sudeste de España, incluyendo las ciudades de Cartagena, Murcia, Orihuela, Torrevieja, Elche y Alicante, entre otras, con una población abastecida superior a los 2.400 .000 de habitantes. Lo más característico de este sistema es que en la actualidad se utilizan prácticamente todas las fuentes de suministro posibles: aguas superficiales del río Taibilla, aguas subterráneas, aguas procedentes del Trasvase Tajo-Segura, y últimamente aguas procedentes de la desalación de agua de mar.

Junto a la fase de alta, en baja las responsabilidades se atribuyen a los municipios, ya que estos son los titulares del servicio público de abastecimiento de agua en poblaciones según la legislación de régimen local española. Los municipios organizarán la gestión del suministro desde los depósitos de cabecera hasta el usuario final, para lo que existen diferentes opciones tal como veremos en el apartado siguiente.

b. El abastecimiento urbano de agua potable como servicio público de titularidad municipal y modalidades de gestión

Como ya se ha adelantado, el abastecimiento urbano de agua potable es un servicio público de titularidad municipal. Esto significa que la actividad sólo puede ser prestada, en régimen de monopolio, por parte de los Ayuntamientos. Las 
empresas privadas no pueden iniciar esta actividad por su cuenta y riesgo, sólo pueden participar en su gestión en la forma que indicaremos a continuación.

Por otro lado, la legislación de régimen local establece que es un servicio público mínimo y obligatorio para todo municipio con independencia de su población. En otros casos, como los servicios culturales, bibliotecas, etc., su obligatoriedad para los municipios depende de su población; no es así en el caso del abastecimiento de agua, que deben prestar todos los ayuntamientos sin excepción. Los pequeños municipios podrán resolver la prestación con la asistencia de Administraciones con mayores capacidades financieras y operativas, para lo que las Diputaciones provinciales o las CCAA allí donde éstas no existen entran en juego.

Pero una cosa es la titularidad del servicio y otra muy distinta es su gestión o prestación efectiva. Si decíamos que las empresas privadas no podían crear este servicio, esto no concurre cuando se trata de gestionar la actividad. El Ayuntamiento puede optar por gestionar la actividad bajo una de las siguientes modalidades:

-Mediante una gestión directa: (no interviene la empresa privada):

-De manera centralizada: con sus propios funcionarios y medios.

-De manera desconcentrada: con sus propios funcionarios, pero creando una estructura administrativa específica con este cometido.

-De manera descentralizada: creando una entidad con personalidad jurídica propia para gestionar el servicio (normalmente una empresa de capital íntegramente público)

-Mediante gestión indirecta (dando entrada a empresas privadas):

-A través de una empresa mixta (el ayuntamiento crea una empresa y suscribe el $51 \%$ de su capital social, e invita a empresas privadas a participar en la empresa hasta el $49 \%$ de su capital).

-A través de una empresa privada mediante concesión (el ayuntamiento regula el servicio pero es la empresa la que realiza íntegramente la actividad).

\section{FINANCIACIÓN}

El servicio de abastecimiento urbano en baja se financia mediante tarifas. La tarifa es una tasa (cuando la gestión es directa centralizada o desconcentrada), sin 
embargo, existen dudas en cuanto a su naturaleza en el resto de los casos. La jurisprudencia es un tanto fluctuante, puesto que hasta una reciente sentencia de 2015 se consideraba que estas tarifas eran precios privados, mientras que ésta última resolución las vuelve a considerar tasas, al menos cuando el servicio se presta mediante una empresa pública.

Las tarifas se establecen por parte del Municipio mediante su ordenanza fiscal, y son autorizadas por la Comunidad Autónoma a través de su Comisión de Precios. Pueden adoptar estructuras diferentes, las menos eficientes son las proporcionales, mientras que las más eficientes son aquellas que introducen alguna forma de progresividad. Es decir, los usuarios que consumen poco se situarán en los tramos más bajos de la escala de progresividad, mientras que los usos más suntuarios se verán mucho más gravados por la tarifa. Estas tarifas incentivan el ahorro y el consumo responsable.

\section{INSTRUMENTOS PARA UNA GESTION EFICIENTE DEL AGUA URBANA}

Para que un servicio de abastecimiento resulte eficiente son importantes algunos aspectos:

-Tecnificación: existen sistemas tecnológicos que permiten controlar las presiones de las redes casi de manera instantánea, localizando fugas con rapidez para poder actuar frente a ello.

-Diseño mallado de la red. Es importante para poder intervenir en el caso de fugas y obras sin necesidad de cortar el servicio.

-Seguimiento adecuado: el servicio debe contar con una financiación suficiente y un seguimiento continuo del gestor, sustituyendo y modernizando las redes obsoletas. Para ello es muy importante, si la gestión es indirecta, que los pliegos de condiciones de los contratos establezcan con claridad las obligaciones del gestor, las actuaciones de seguimiento, y los procedimientos de resolución de controversias.

-Tarifas progresivas que incentiven el ahorro. Estas tarifas presuponen un diseño escalonado, en el que en los tramos más bajos de consumo los precios son bajos. Sin embargo, se definen tramos sucesivos de consumo en el que los precios crecen no de manera proporcional, sino exponencial. De esa manera se penalizan 
los consumos suntuarios o excesivos, premiando a quienes consumen de manera más eficiente y responsable.

\section{CONCLUSIONES}

Afortunadamente, el servicio de abastecimiento de agua está bien resuelto en España. No existen problemas sanitarios significativos, aunque en algunos suministros pueden existir deficiencias (i.e. presencia de nitratos en zonas agrícolas). Tampoco se dan, de manera generalizada, problemas de falta de continuidad, regularidad, o universalidad en la prestación. Las incidencias negativas suelen ser puntuales. Sin embargo, como consecuencia del cambio climático, el crecimiento de las demandas, y la irregular distribución temporal y espacial del recurso, es previsible que en los próximos años aparezcan tensiones en algunas zonas geográficas, obligando al uso de fuentes alternativas como la desalación de agua de mar. Esto puede repercutir en los precios del servicio, que pueden experimentar un incremento significativo en algunas localidades.

La selección de la forma de prestación del servicio es, a nuestro juicio, una cuestión técnica. Es decir, al margen de planteamientos ideológicos, deberá optarse por la forma de gestión, pública o privada, más eficiente. La primera suele ser más oportuna en suministros pequeños o medianos, mientras que la gestión privada o mixta lo puede ser en suministros más complejos donde se persiga el know-how del gestor.

A favor de la gestión pública se aduce lo siguiente:

- Una pretendida defensa de lo público. No hacer negocio con bienes públicos.

- Entregar la gestión a una empresa privada es una forma de "Privatización del agua".

- El beneficio industrial de la empresa encarece el servicio

- Posible corrupción en las licitaciones.

- Mayor transparencia cuando es pública la gestión. Mayor participación ciudadana.

- Desequilibrio de poder entre las grandes multinacionales del agua y las autoridades públicas.

- Situación oligopolística en el sector (pocas empresas que en realidad no compiten entre sí).

- Ahorro de los costes de licitación y posterior monitorización. 
- Menor calidad del empleo en empresas privadas.

- La gestión privada no es necesariamente más eficiente y es más cara (Informe de fiscalización del sector público local del Tribunal de Cuentas ejercicio 2011: 9 euros por habitante menos cuando gestión pública). Problema, los costes suministrados no son comparables (directos: personal y corrientes) vs (directos, indirectos y amortización).

- Ahorro del 21\% IVA (no es cierto si es tarifa, pero si en el caso de las tasas)

- Escaso interés del sector privado en reducir la tarifa y los costes del servicio (Reduce su negocio).

- Falta de medios en los entes locales para monitorizar el servicio

A favor de la gestión privada se plantea:

- Mayor eficacia y know how del gestor privado. Especialización. (Principio constitucional de eficacia).

- Marco laboral más flexible y gestión más eficiente del personal.

- Economías de escala (grandes empresas: adquisición de bienes a menor precio, etc).

- Mayor capacidad de inversión que no computa como déficit o gasto corriente.

- Posibilidad de cobro a través de precios en vez de tasas.

- Politización de los órganos directivos de las organizaciones públicas.

- Favorece el equilibrio presupuestario al no incrementar las inversiones la deuda de la Corporación.

\section{BIBLIOGRAFÍA}

Molina Giménez, A. (2001) El servicio público de abastecimiento de agua en poblaciones. El Contexto liberalizador. Tirant lo Blanch, Valencia.

\section{ENLACES}

http://www.aeas.es/servlet/mgc 


\title{
6.2. GESTIÓN DEL SANEAMIENTO
}

\author{
Arturo Trapote Jaume
}

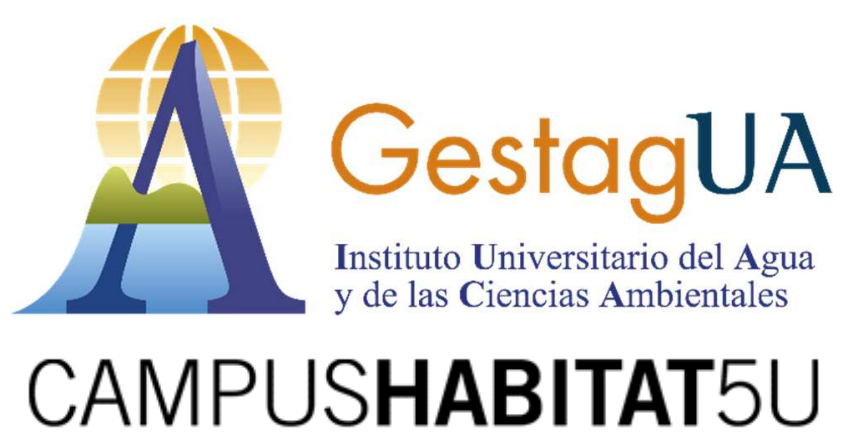




\section{INTRODUCCIÓN}

Durante siglos, las comunidades humanas han venido teniendo el problema de deshacerse de sus aguas residuales, de las aguas de lluvia y de otras, cuyas molestias y peligrosidad sanitaria las hacen indeseables. Al principio, fue la calle el único cauce de evacuación de los residuos líquidos de los pueblos y ciudades. Sin embargo, esta situación originaba notables inconvenientes, como malos olores y la rápida propagación de las epidemias.

Con el progreso de la civilización surgieron los pozos negros en el terreno contiguo a las casas. Pero estos pozos requerían medios de limpieza, siendo la extracción poco higiénica. Después comenzaron a establecerse canales centrales en los empedrados de las calles que constituían simples conductos apenas enterrados y de sección indefinida, que significaron los primeros intentos de alcantarillados y cuya única finalidad era recoger los residuos líquidos que se arrojaban a la calle, conservando ésta relativamente transitable. En estos inicios, los alcantarillados carecían de conexión alguna con las casas.

Con la aparición de las grandes civilizaciones puede hablarse ya de redes de alcantarillado propiamente dichas. Es, por ejemplo, el caso de Roma, en donde aún hoy día están en uso algunos de los grandes colectores que construyeron, como la Cloaca Máxima (Figuras 1 y 2).

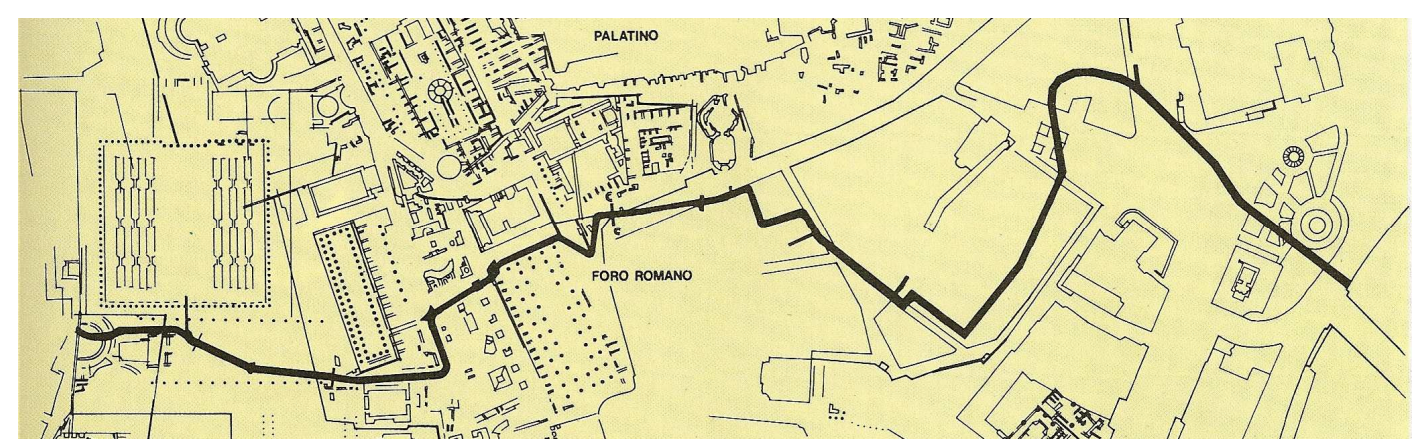

Figura 1. Trazado de la Cloaca Máxima (Ajuntament de Barcelona-CICCP de Catalunya, 1991). 

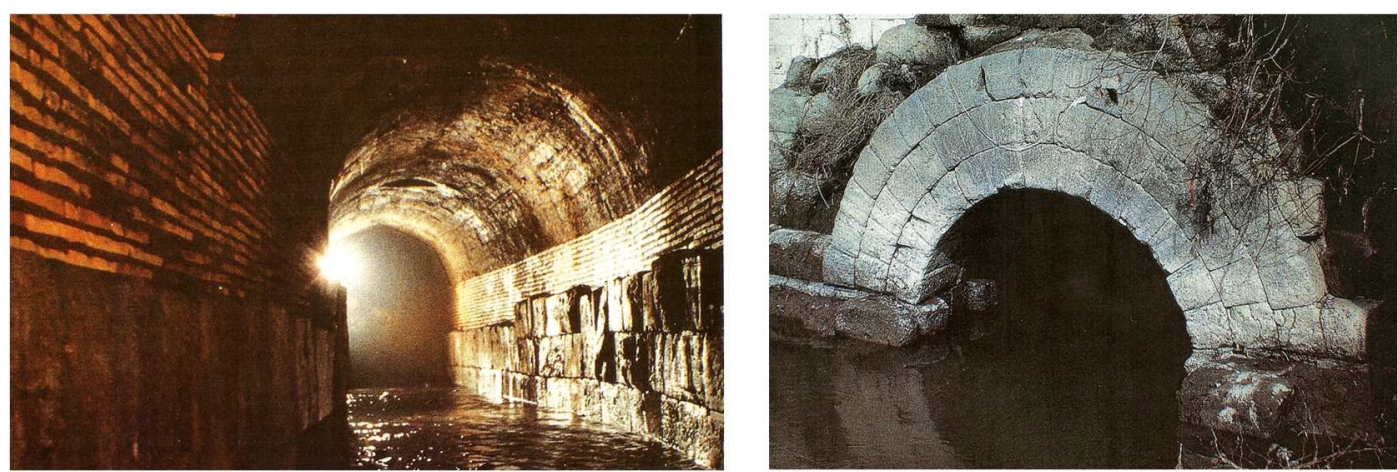

Figura 2. Izquierda: interior de la Cloaca Máxima; derecha: desembocadura (Ajuntament de Barcelona-CICCP de Catalunya, 1991).

En Roma, se fijan una filosofía y unos elementos de alcantarillado que, en lo esencial, son los utilizados en nuestros días. Esta filosofía consiste, por una parte, en la extensión de la red a toda la ciudad, convirtiéndose a su vez la red en factor generador de suelo urbano; y, por otra, en el carácter unitario de la misma, siendo útil tanto para la evacuación de aguas residuales, que, procedentes de las viviendas, entraban en la alcantarilla a través de las acometidas domiciliarias, como la de pluviales, que, procedentes de los tejados y de las calles, ingresaban en la red a través de imbornales (buzones), situados junto a las aceras (Figuras 3 y 4 ).
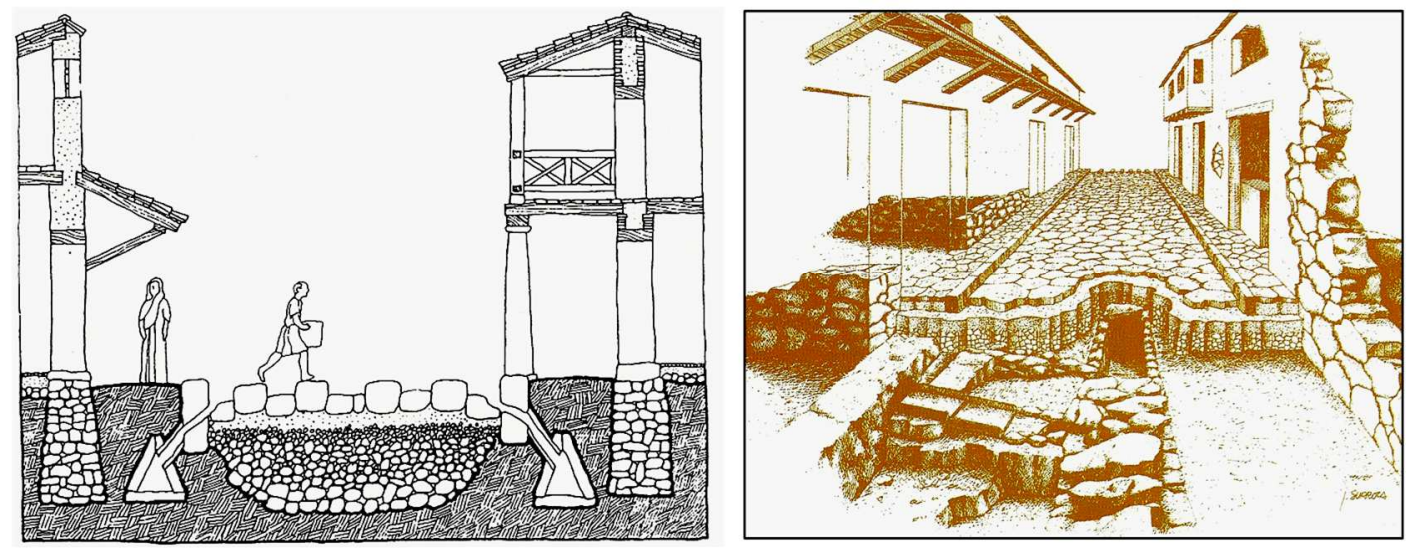

Figura 3. Izquierda: sección transversal de una calle romana; derecha: alcantarilla y acometida en una calle romana (Ajuntament de Barcelona-CICCP de Catalunya, 1991). 


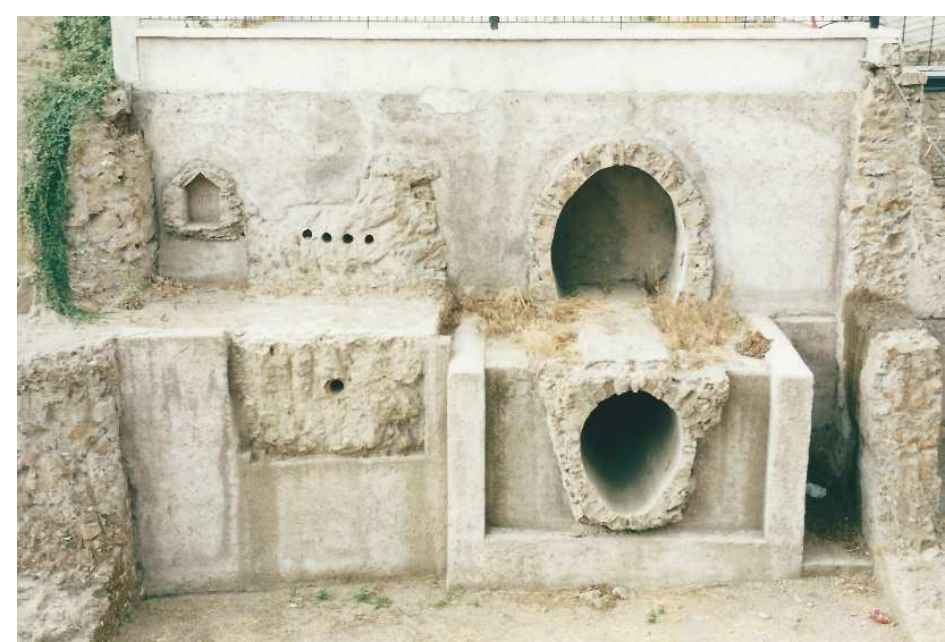

Figura 4. Sección transversal de una calle romana con distintos tipos de alcantarillas.

En la actualidad, las aglomeraciones urbanas resuelven el problema de la evacuación de sus aguas residuales mediante un conjunto de obras y técnicas denominado saneamiento o, en términos más coloquiales, alcantarillado.

Así pues, los principales objetivos del saneamiento son dos:

1. Evacuar las aguas residuales de las áreas urbanas, protegiéndolas contra inundaciones y $\sin$ ocasionar molestias, peligros sanitarios ni inconvenientes organolépticos a sus habitantes.

2. Realizar esta evacuación con los mínimos perjuicios, económicamente asequibles, para el medio ambiente $y$, especialmente, sin perjuicio para los futuros usuarios de las aguas que se están utilizando.

Por consiguiente, el saneamiento urbano tiene, en general, dos finalidades fundamentales:

1) La protección de la ciudad y de sus habitantes contra inundaciones.

2) La protección higiénica de estos habitantes y de los medios receptores.

\section{ESTRUCTURA DE UM SISTEMA DE SANEAMIENTO}

El sistema de saneamiento forma parte de otro de mayor rango, o suprasistema, que podemos denominar Sistema Integral Hidráulico-Sanitario (Figura 5). 


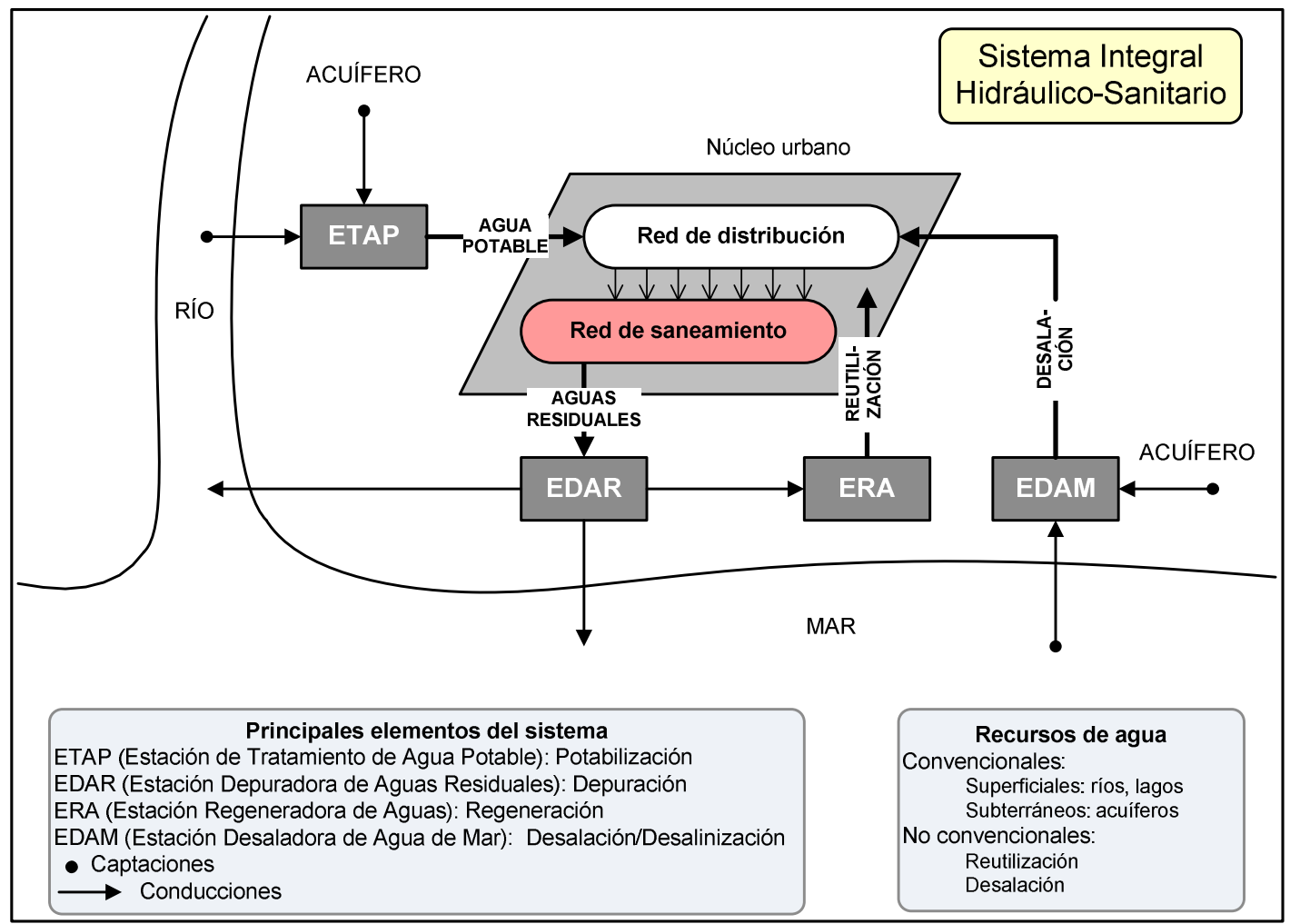

Figura 5. Esquema del Sistema Integral Hidráulico-Sanitario.

De acuerdo con este esquema y conforme con lo anteriormente expuesto, se deduce que un sistema de saneamiento debe constar de las siguientes partes (Figura 6):

a) Red de saneamiento, o alcantarillado, que permite recoger las aguas residuales y concentrarlas en un punto o en un reducido número de ellos, en las adecuadas condiciones sanitarias.

b) Emisario o conducción que transporta las aguas residuales generadas en el núcleo urbano hasta la estación depuradora de aguas residuales.

c) Estación depuradora de aguas residuales (EDAR), elemento indispensable del saneamiento, donde se consigue el grado de calidad necesario, bien para su vertido al medio receptor (tratamientos secundarios), bien para ser sometidas a posteriores tratamientos de regeneración (tratamientos terciarios), con vistas a su reutilización. 


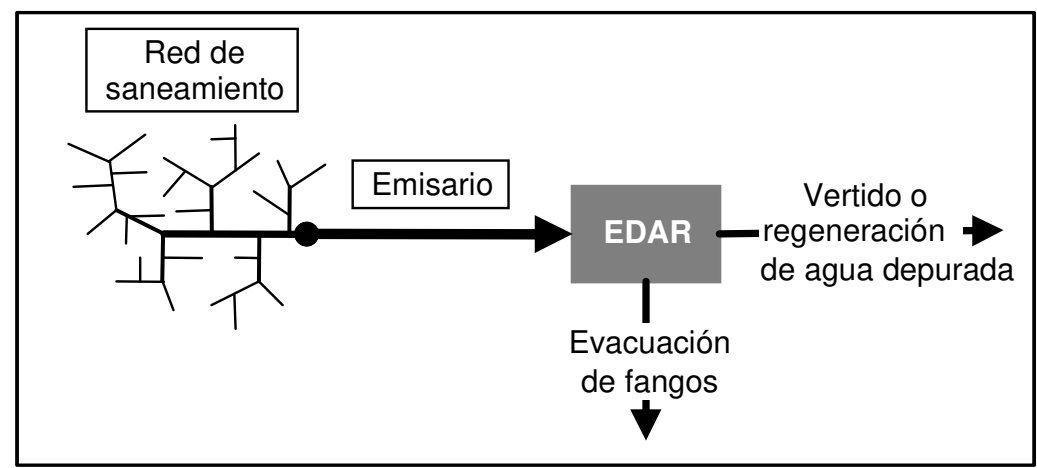

Figura 6. Estructura de un sistema de saneamiento.

\section{TIPOLOGÍA DE REDES DE SANEAMIENTO}

Las redes de saneamiento en los sistemas de saneamiento y drenaje urbano tienen una función análoga a la de las redes de distribución en los abastecimientos de agua. Sin embargo, ambas se diferencian en un punto básico: mientras que las redes de distribución tienen como misión fundamental el reparto de un cierto caudal entre múltiples usuarios, las redes de saneamiento se encargan de recoger o captar las aportaciones de estos mismos usuarios (y las de la precipitación), transportarlas y reunirlas en un punto o en un número reducido de ellos, desde donde resulte fácil su devolución a la naturaleza previo su tratamiento final.

Así pues, una red de saneamiento es, básicamente, un conjunto de tuberías enterradas en el subsuelo urbano, cuyas misiones fundamentales son:

1) La evacuación de las aguas residuales y pluviales que se producen en un cierto entorno, fuera de la vista de sus habitantes. En ocasiones, estas aguas residuales se reducen únicamente a aquellas cuya contaminación estética, peligrosidad sanitaria o características organolépticas así lo exijan (aguas negras), dejándose discurrir en superficie las restantes (aguas blancas).

2) La concentración de estas aguas, dispersas en origen, en puntos tales que puedan ser devueltas a la naturaleza sin perjuicios apreciables, o donde puedan ser adecuadamente tratadas antes de su vertido final al medio natural, requisito que en la actualidad se considera indispensable.

Según el tipo de agua a transportar, las redes de saneamiento pueden ser unitarias o separativas. 
a) Redes unitarias.

Redes unitarias son aquellas que conducen de forma conjunta las aguas residuales y las pluviales o de escorrentía (Figura 7). Por consiguiente, la red se dimensiona con capacidad suficiente para absorber en un mismo conducto las aguas residuales y las pluviales generadas en la cuenca o zona objeto de proyecto.

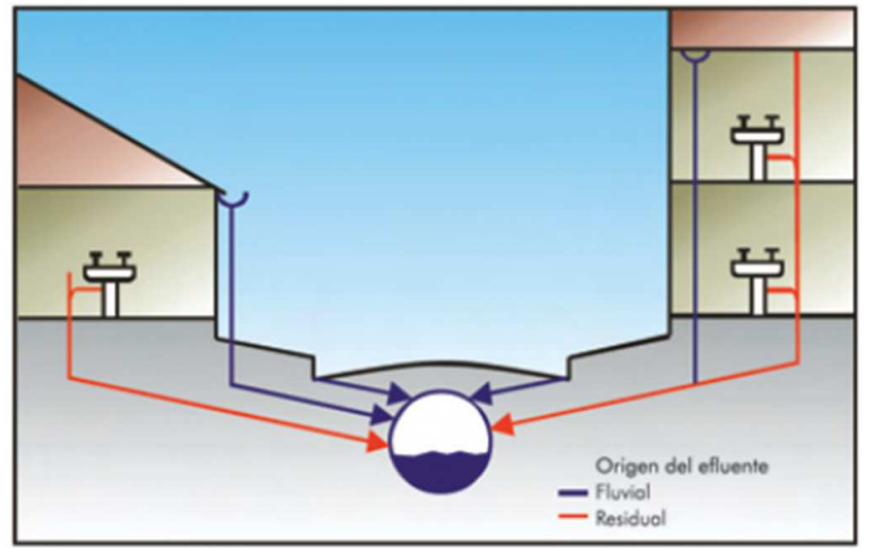

Figura 7. Esquema de acometidas en una red de saneamiento unitaria (AseTUB, 2007).

b) Redes separativas.

La red consta de dos canalizaciones independientes (Figura 8): una de ellas transporta las aguas residuales de origen doméstico, comercial o industrial hasta la EDAR, y la otra conduce las aguas pluviales hasta el medio receptor.

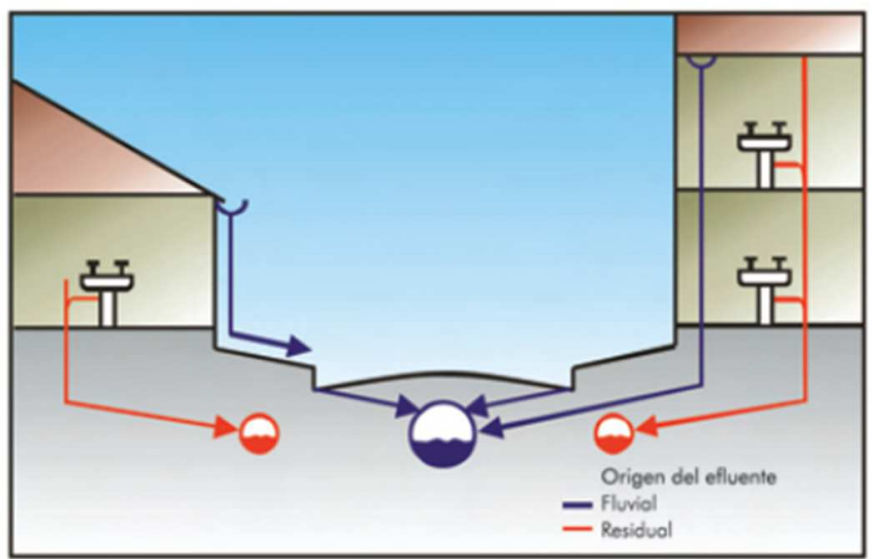

Figura 8. Esquema de acometidas en una red de saneamiento separativa (AseTUB, 2007).

\section{VENTAJAS E INCONVENIENTES DE LAS REDES UNITARIAS DE SANEAMIENTO}

Las redes unitarias tienen como principal ventaja frente a las separativas el que con una sola red se recoge la totalidad de las aguas a evacuar, con secciones de paso 
iguales o ligeramente mayores que las que corresponden a la red de drenaje del sistema separativo, lo que redunda en una mayor economía de construcción y de primer establecimiento, pues el coste de las dos tuberías, hidráulicamente equivalentes en conjunto a la única, es del orden de 1,5 a 2 veces mayor, además de tener que sumar a esto el doble coste de las acometidas. Asimismo, los gastos de levantamiento y reposición de pavimentos son de 1,5 a 2 veces mayores en el tipo separativo.

No obstante, las redes unitarias presentan importantes inconvenientes, como son:

1. Una gran dispersión entre los caudales mínimos (en tiempo seco y en horas valle) y los máximos (fuertes aguaceros), que dificultan su funcionamiento en la gama de velocidades adecuada.

2. Obligan a proyectar la planta depuradora para caudales muy superiores a los estrictamente necesarios, aunque puede atenuarse este inconveniente mediante la implantación de aliviaderos en los colectores que permiten el vertido directo a los cauces del caudal excedente, cuando se alcanza el grado de dilución adecuado.

\section{VENTAJAS E INCONVENIENTES DE LAS REDES SEPARATIVAS DE SANEAMIENTO}

La ventaja más importante de los sistemas separativos ante los unitarios radica en el hecho de que las aguas negras, con fuerte carga contaminante, se transportan por la red de saneamiento hasta la EDAR, la cual se diseñará para el caudal punta de aguas negras. Las aguas blancas, con mucha menor carga contaminante, se podrán conducir por la red de drenaje directamente a un cauce receptor, sin ningún tipo de tratamiento previo.

No obstante, en este caso, las primeras aguas de lluvia (first flush) se deben recoger en un depósito de retención desde el que, posteriormente (cuando cesse la precipitación), irán pasando a la estación depuradora para ser depuradas junto con el caudal normal de aguas negras.

El principal inconveniente de las redes separativas -además de los mayores costes de implantación frente a las redes unitarias- es que la conservación y explotación de una red separativa exige gastos muy superiores a los de una red unitaria. Sin embargo, los gastos de limpieza son menores en las redes separativas, por ser menores las variaciones del caudal circulante por las alcantarillas de aguas negras, y menor, consecuentemente, la variación de la velocidad, lo que reduce las 
sedimentaciones en los tubos. Las conduciones de aguas blancas sólo requieren limpiezas de forma esporádica.

En definitiva, las ventajas de las redes separativas se corresponden, por contraposición, con los inconvenientes de las redes unitarias anteriormente mencionados, es decir:

1) Una gama de caudales más restringida en la red de aguas negras, lo que facilita respetar las velocidades mínimas de sedimentación.

2) Una reducción de caudales en la estación depuradora, lo que supone un abaratamiento de estas últimas al ajustarse a las necesidades reales de agua a depurar.

Las redes unitarias son las más comúnmente utilizadas, debido fundamentalmente a ser las existentes desde hace largo tiempo en la mayor parte de las ciudades, y no ser fácil o resultar excesivamente costosa su transformación o sustitución por otro tipo de red. Sin embargo, hoy en día hay una tendencia generalizada a que las nuevas redes de saneamiento sean de tipo separativo.

En el caso de análisis conjunto de red de saneamiento y depuración final, se considera más económico el tipo separativo, pues en el unitario, aun estableciendo un aliviadero de entrada, será preciso un sobredimensionado de la depuradora.

Por consiguiente, en cada caso particular habrá que sopesar estas ventajas e inconvenientes, a la vista de las condiciones topográficas y geográficas, y de las características sociales, económicas y normativas locales, para elegir uno u otro tipo.

\section{BIBLIOGRAFÍA}

ASOCIACIÓN ESPAÑOLA DE FABRICANTES DE TUBOS Y ACCESORIOS PLÁSTICOS (AseTUB), Tuberías de poliéster reforzado con fibra de vidrio. Guía Técnica, AseTUB (2008).

CENTRO DE ESTUDIOS HIDROGRÁFICOS DEL CEDEX, Guía Técnica sobre redes de saneamiento y drenaje urbano, CEDEX (2007).

CENTRO DE ESTUDIOS HIDROGRÁFICOS DEL CEDEX, Gestión de las aguas pluviales, CEDEX (2008).

HERNÁNDEZ MUÑOZ, A., Saneamiento y Alcantarillado. Vertidos residuales, Colegio de Ingenieros de Caminos, Canales y Puertos (2007).

TRAPOTE JAUME, A., Infraestructuras Hidráulico-Sanitarias II: Saneamiento y Drenaje Urbano, Publicaciones de la Universidad de Alicante (2013). 


\section{ENLACES}

http://www.aguasresiduales.info/

http://www.iagua.es/

http://www.tecnoaqua.es/

http://www.asetub.es/

http://www.cedex.es/CEDEX/LANG_CASTELLANO/FORMACION_EVENTOS/FORMA

CION/CURPRESEN/

http://www.adecagua.es/ 


\title{
6.3. GESTIÓN SOSTENIBLE DEL DRENAJE URBANO
}

\author{
Arturo Trapote Jaume
}

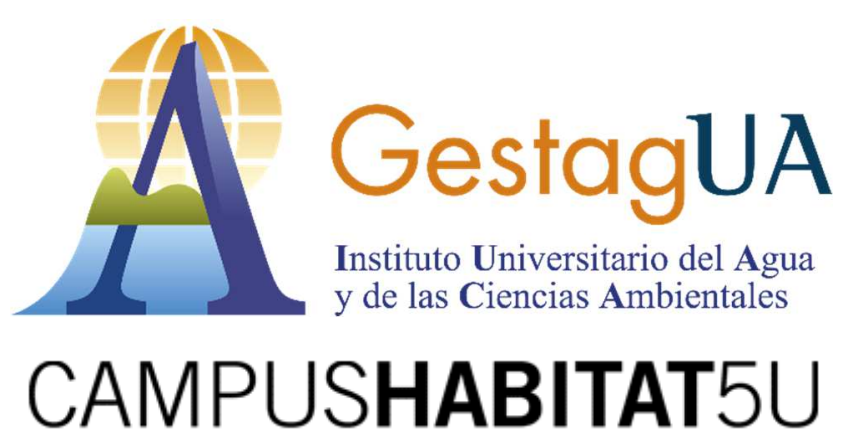




\section{INTRODUCCIÓN}

El desarrollo urbano provoca cambios significativos en los usos del suelo, que alteran el ciclo hidrológico natural y agravan los problemas relacionados con el drenaje y la gestión de las aguas pluviales. El aumento de la cantidad de escorrentía superficial (surface runoff), junto con la disminución de su calidad y la desnaturalización del ambiente urbano son algunas de las más importantes consecuencias adversas del proceso de urbanización.

En el proceso de urbanización las superficies naturales van siendo progresivamente sustituidas por edificaciones, viarios y otras superficies impermeables que impiden o reducen significativamente los procesos hidrológicos naturales de infiltración, interceptación, detención, retención y evapotranspiración (Figura 1). Al disminuir estas abstracciones aumenta la escorrentía neta.

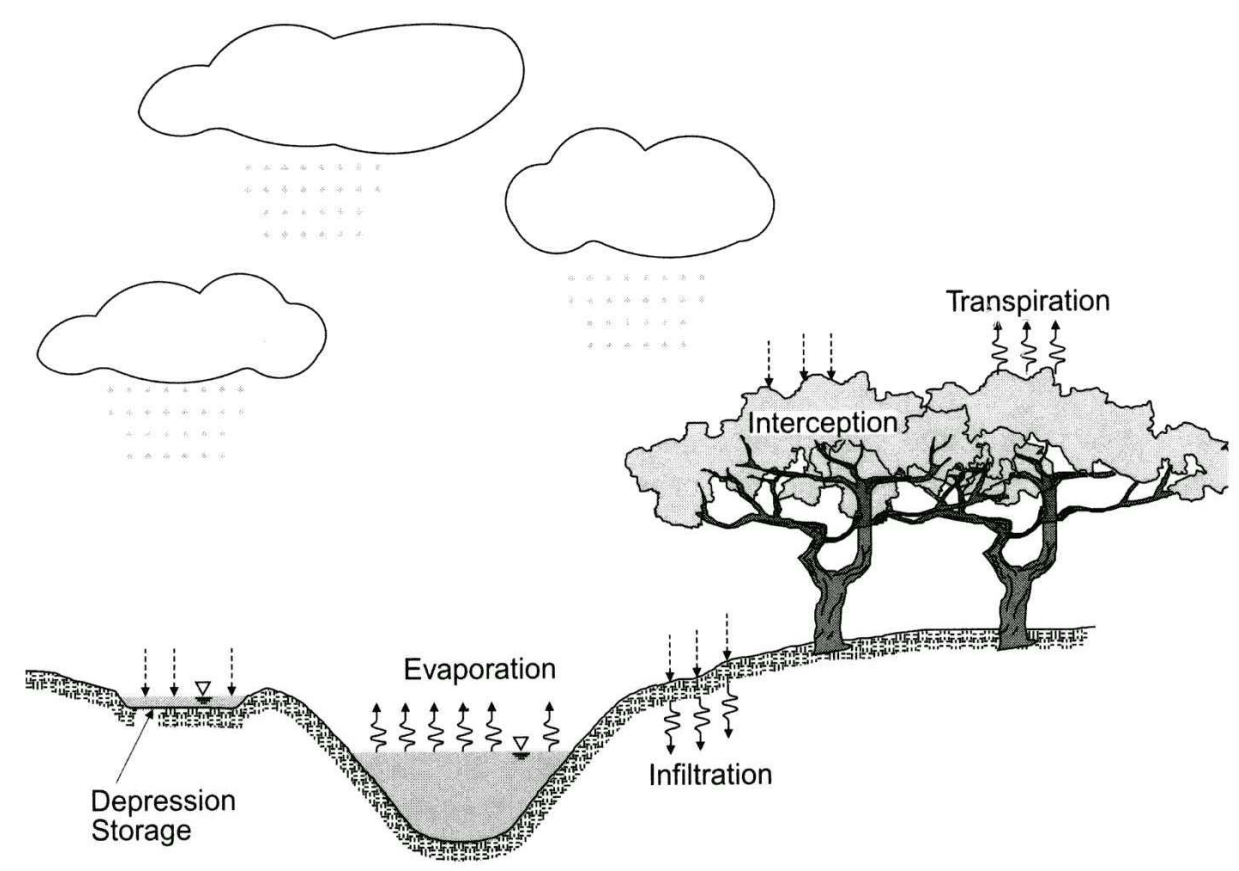

Figura 1. Abstracciones que tienen lugar en el ciclo hidrológico natural (Haested, 2003).

La impermeabilización del suelo tiene una singular incidencia en el balance infiltración-escorrentía, de manera que en un área natural la infiltración representa entre el 80 y el $90 \%$ del agua precipitada y la escorrentía entre el 10 y el $20 \%$, en un área residencial (densidad media-baja) la infiltración puede suponer entre el 50 y el $60 \%$ y la escorrentía entre el 40 y el $50 \%$, mientras que en un área altamente urbanizada la infiltración es del 0 al10\% y la escorrentía aumenta hasta el $90-100 \%$ (GSMM, 2016). La Figura 2 muestra esquemáticamente los efectos de la progresiva 
impermeabilización de un suelo en la escorrentía y en la infiltración, a medida que avanza el proceso de urbanización.

SUELO NATURAL

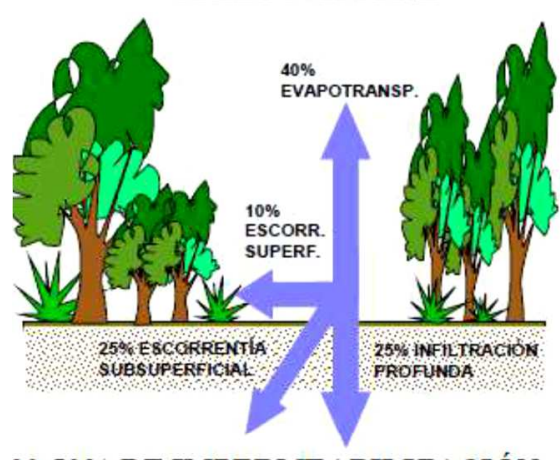

30-50\% DE IMPERMEABILIZACIÓN

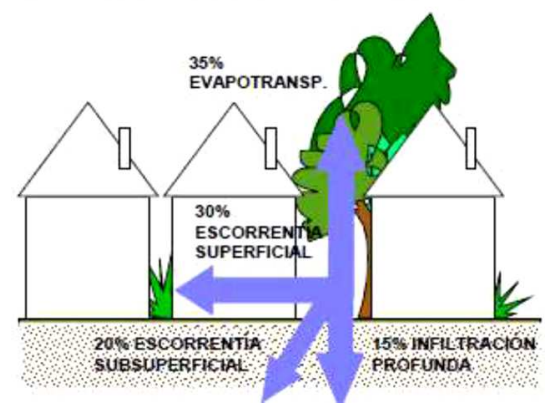

10-20\% DE IMPERMEABILIZACION

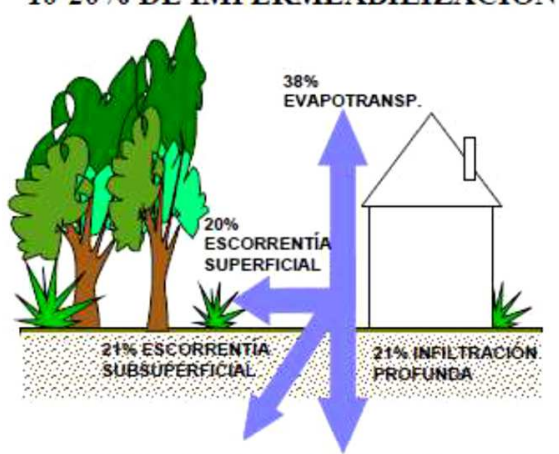

75-100\% DE IMPERMEABILIZACIÓN

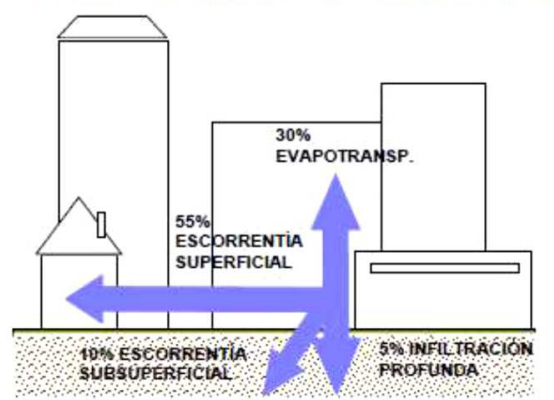

Figura 2. Efectos de la impermeabilización del suelo sobre la escorrentía y la infiltración (adaptado de Arnold y Gibbons, 1996, por Del Río, 2011).

En términos hidrológicos, con la impermeabilización del suelo se incrementa el volumen de la escorrentía y se modifica sustancialmente el hidrograma de tormenta, al redistribuirse la escorrentía pluvial. Esta circunstancia se muestra gráficamente en la Figura 3, en donde se representa el hidrograma de respuesta de una cuenca, antes y después de ser urbanizada, ante un evento de precipitación de duración $\mathrm{D}$ e intensidad I variable (pluviograma de la parte superior de la figura). 


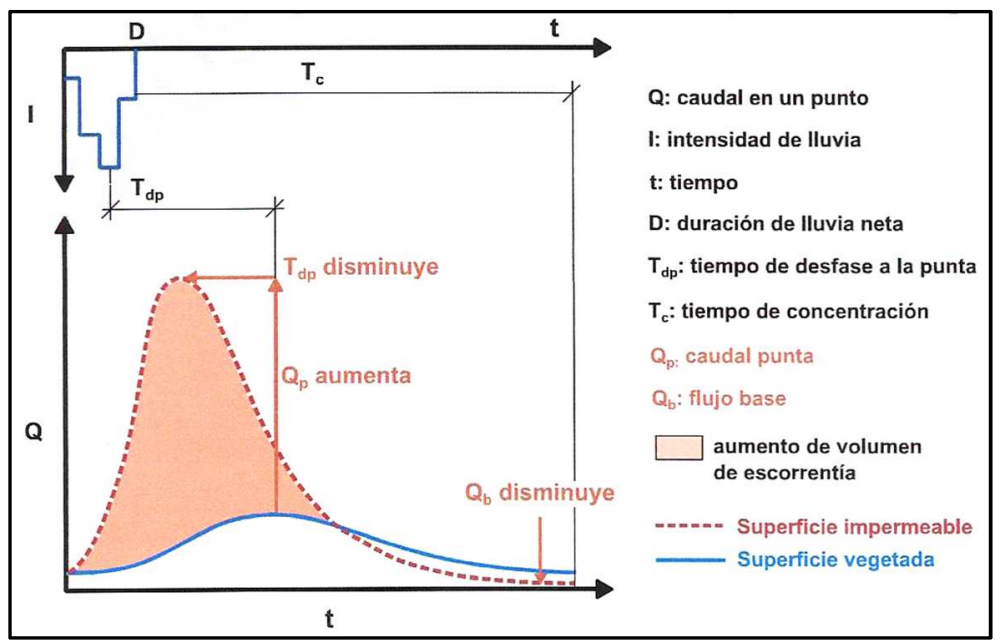

Figura 3. Cambios inducidos por el desarrollo urbano en la transformación lluvia-escorrentía (Perales, 2014)

Por su parte, la disminución de la calidad de la escorrentía deriva de los diversos contaminantes (sedimentos, materia orgánica, nutrientes -principalmente nitrógeno y fósforo-, microorganismos patógenos, metales, etc.), depositados sobre las superficies urbanas (pavimentos, tejados, etc.) durante los periodos de tiempo seco y que con los eventos de precipitación son arrastrados por la escorrentía. Esta carga contaminante, al desembocar en los cuerpos hídricos receptores -ya sea de forma directa o de forma indirecta por vertidos de los aliviaderos de los sistemas unitarios de saneamiento unitario (DSU)-, ocasiona impactos ambientales muy negativos y altera gravemente el estado ecológico del medio.

La desnaturalización del entorno urbano es otra de las consecuencias del desarrollo urbano. Al reducirse las zonas verdes de las ciudades se deteriora el paisaje urbano, se impide la recarga de acuíferos y se induce el efecto "isla de calor", fenómeno este último que caracteriza el incremento térmico en el interior de la ciudad, de forma especialmente acusada en verano, y que, entre otras cosas, potencia las reacciones de los gases de efecto invernadero (Fig. 4). 
Isla de calor urbana

Perfil referencial de temperaturas urbanas en comparación con área rural

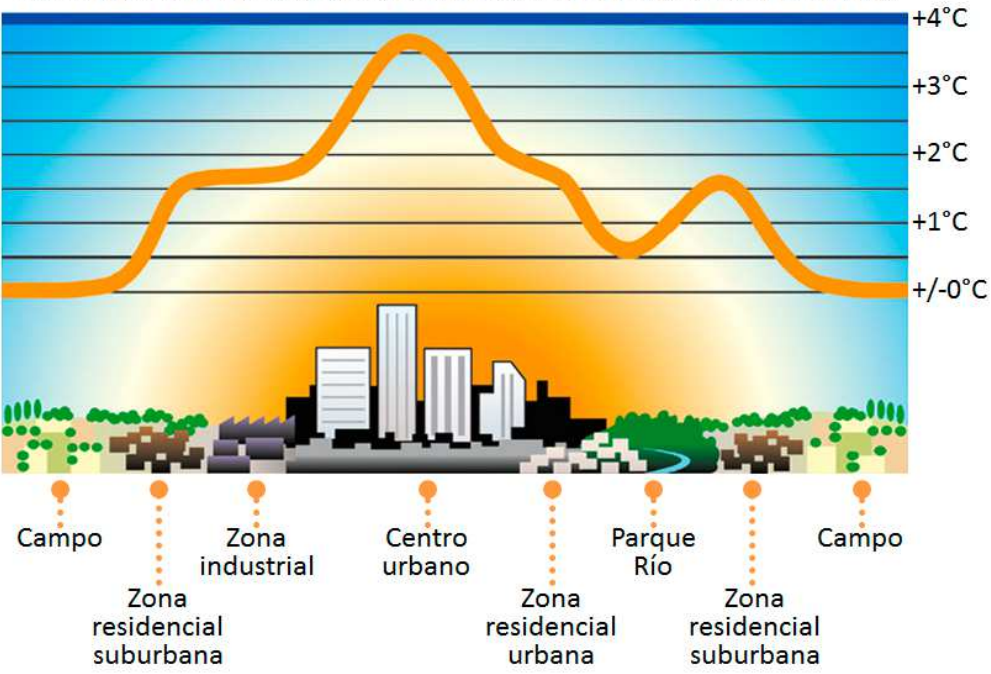

Figura 4. Isla de calor urbana (Arquitectura \& Energía: http://www.arquitecturayenergia.cl/home/isla-de-calor-urbana/).

Ante esta situación, puede actuarse de tres maneras diferentes: no hacer nada (y asumir inundaciones más frecuentes), aumentar la capacidad de la red de drenaje convencional (con el consiguiente coste económico) o implantar técnicas alternativas de drenaje. Entre estas últimas se encuadran las conocidas, en general, como Técnicas de Drenaje Urbano Sostenible (TDUS) o Sistemas Urbanos de Drenaje Sostenible (SUDS) (Best Management Practices, BMP, o Low Impact Development, LID, en USA; Sustainable Drainage System, SuDS, en el Reino Unido, etc.).

\section{SISTEMAS URBANOS DE DRENAJE SOSTENIBLE (SUDS)}

Con la implantación de SUDS en entornos urbanos se pretende minimizar la necesidad de construir y mantener grandes infraestructuras de detención y retención de escorrentía, lograr un tratamiento eficiente del agua y disminuir el riesgo de inundaciones de origen pluvial, suponiendo, además, un ahorro en los costes globales derivados de la gestión del agua de lluvia.

La filosofía de los SUDS es, en definitiva, reproducir, de la manera más fiel posible, el ciclo hidrológico natural previo a la urbanización o actuación humana, con la finalidad de minimizar los impactos del desarrollo urbanístico en cuanto a la cantidad y la calidad de la escorrentía (en origen, durante su transporte y en 
destino), así como maximizar la integración paisajística y el valor social y ambiental de la actuación (Perales, 2014).

En relación con las consecuencias adversas del proceso de urbanización, los principales objetivos de los SUDS son (CIRIA) (Figura 5):

1) Disminuir la cantidad de escorrentía de lluvia, tanto en términos de volumen como de caudal punta

2) Mejorar la calidad del agua de escorrentía para preservar los cuerpos receptores

3) Provocar beneficios al entorno en términos de calidad ambiental y mejora del paisaje

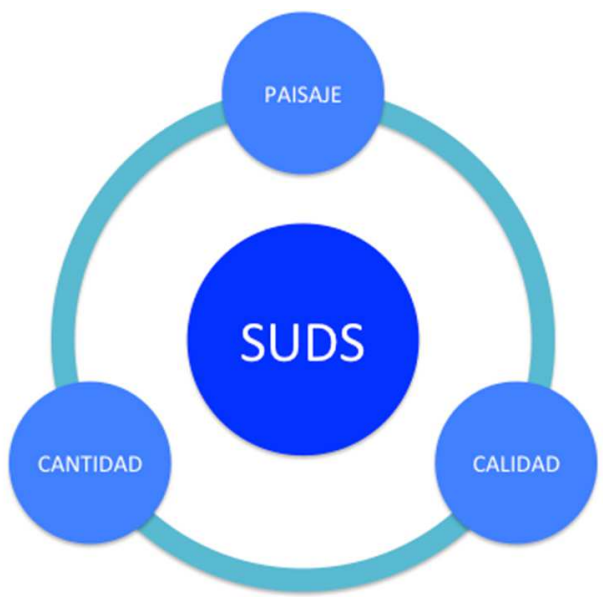

Figura 5. Ideograma de los objetivos de los SUDS (CIRIA; Perales, 2014).

\section{TIPOLOGÍA DE SUDS}

Según el tipo de actuación, los SUDS comprenden medidas no estructurales y medidas estructurales. Las primeras, previenen, por una parte, la contaminación del agua reduciendo las fuentes potenciales de contaminantes $y$, por otra, evitan parcialmente el tránsito de las escorrentías hacia aguas abajo y su contacto con contaminantes. No requieren proceso constructivo alguno. Las segundas, gestionan la escorrentía contaminada mediante actuaciones que contienen en mayor o menor grado algún elemento constructivo o supongan la adopción de criterios urbanísticos ad hoc. Entre las principales medidas no estructurales pueden citarse: educación, adecuada planificación urbanística, diseño adecuado, prácticas de mantenimiento y prevención, y política económica y normativa (Perales, 2014). 
Las medidas estructurales incluyen una amplia gama de actuaciones, que pueden implementarse de forma aislada o combinada. Las principales son las siguientes (Woods-Ballard et al., 2007; SFPUC, 2010; CIRIA, 2015): instalaciones de aprovechamiento del agua de lluvia, aljibes, cubiertas vegetadas (green roofs o vegetated roofs), plantación de árboles, superficies permeables, pozos y zanjas de infiltración, sistemas geocelulares, zonas de biorretención, franjas y drenes filtrantes, cunetas vegetadas, depósitos de infiltración, depósitos de detención, estanques de retención y humedales artificiales (constructed wetlands). Se trata, en su mayoría, de medidas para reducir de forma significativa la escorrentía generada mediante la desconexión de zonas impermeables (Pitt et al., 1994, citado por García, 2011). La Figura 6 muestra algunos ejemplos de medidas estructurales.

b)

a)
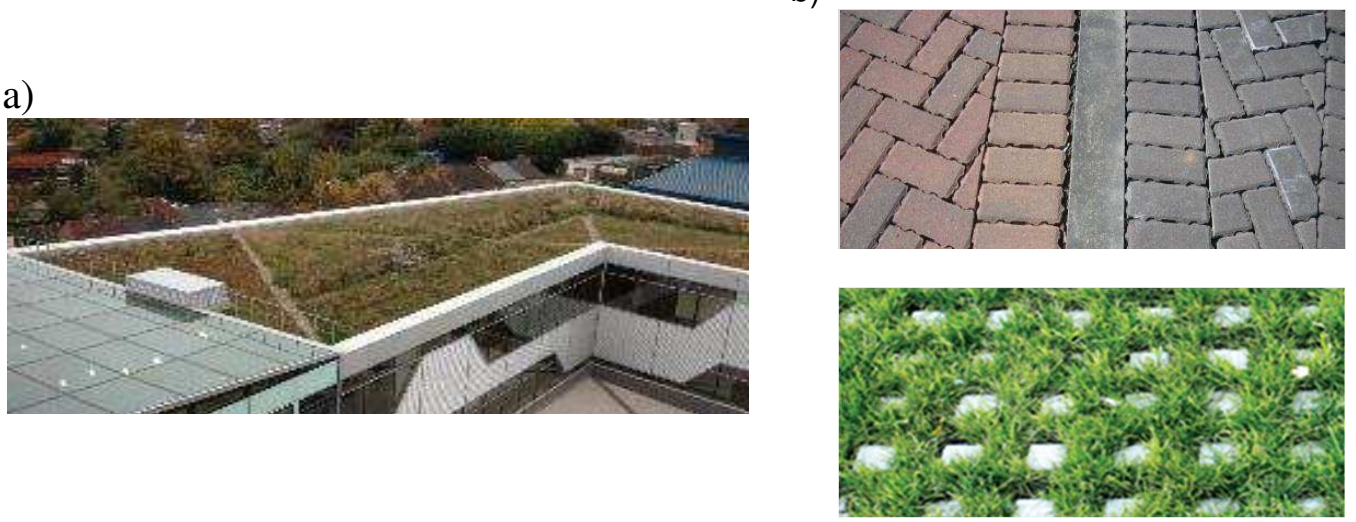

c)

d)
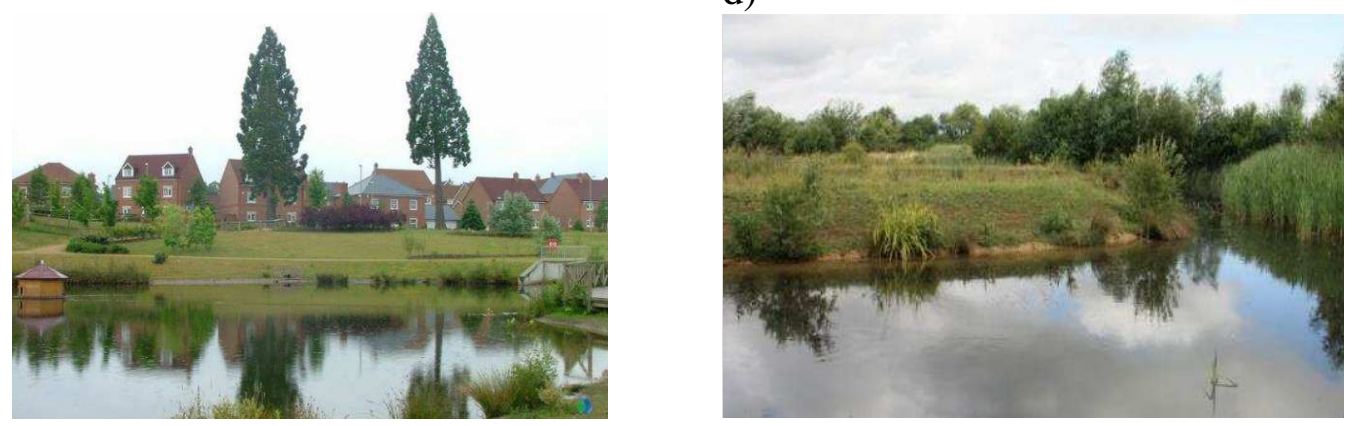

Figura 6. Ejemplos de SUDS estructurales: a) Cubierta vegetada; b) Superficies permeables; c) Estanque de retención; d) Humedal artificial.

\section{GESTIÓN DE LOS SUDS}

Cuando lo que se pretende es imitar el comportamiento natural de una cuenca urbana, para que ésta se comporte de la forma más parecida posible a como lo hacía antes de ser urbanizada, es necesario comprender el concepto de "cadena de 
gestión" ("management train"). Se trata de usar técnicas de drenaje en serie para poco a poco incrementar la eliminación de contaminantes, reducir el caudal de escorrentía y el volumen de almacenamiento necesario (Woods-Ballard et al., 2007).

A tal fin, se establece una jerarquía en las técnicas de drenaje que tendrá los siguientes niveles (Figura 6 y Tabla 1):

1. Prevención. Este es el eslabón más alto de la cadena. Algunos ejemplos serían los siguientes: un buen planeamiento urbanístico, buenas prácticas domésticas (p.ej. no tirar residuos por el desagüe, barrer la superficie impermeable, etc.), reutilización del agua de lluvia, políticas de educación y la sensibilización social.

2. Gestión en origen. Es el control de la escorrentía lo más cerca posible del lugar donde se genera, por ejemplo, mediante pozos de infiltración, cubiertas vegetadas, superficies impermeables, etc.

3. Gestión en entorno urbano. Es la gestión de la escorrentía abarcando ámbitos mayores, esto es, más lejanos en relación al lugar donde precipita la lluvia, como son barrios o pequeñas ciudades, aunque sin limitarse a estos, pudiendo no tratarse de áreas urbanas. Entre las técnicas destacables en este nivel cabe citar el direccionar el agua de los tejados o de los aparcamientos hacia grandes pozos de infiltración o lagunas de detención.

4. Gestión en cuencas. Son las técnicas que requieren de un mayor espacio para ponerlas en práctica. Es el caso de los estanques de retención o detención y de los humedales artificiales.

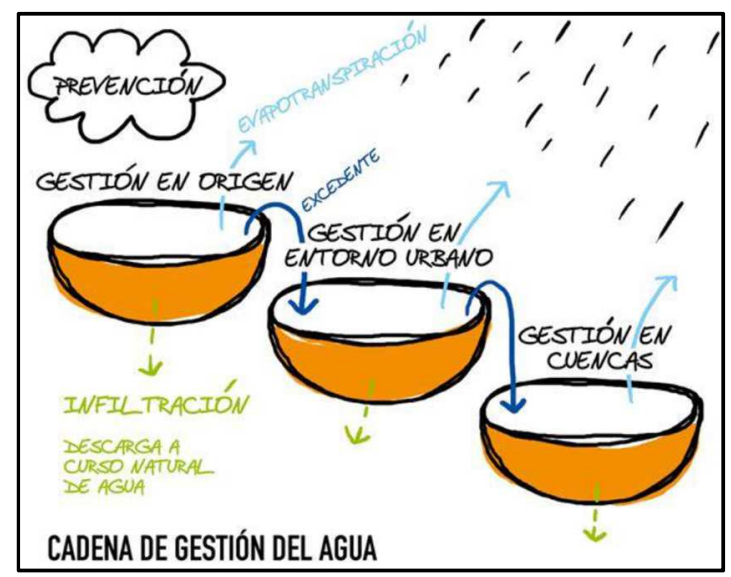

Figura 6. Cadena de gestión del agua de lluvia (Perales, S., 2014). 


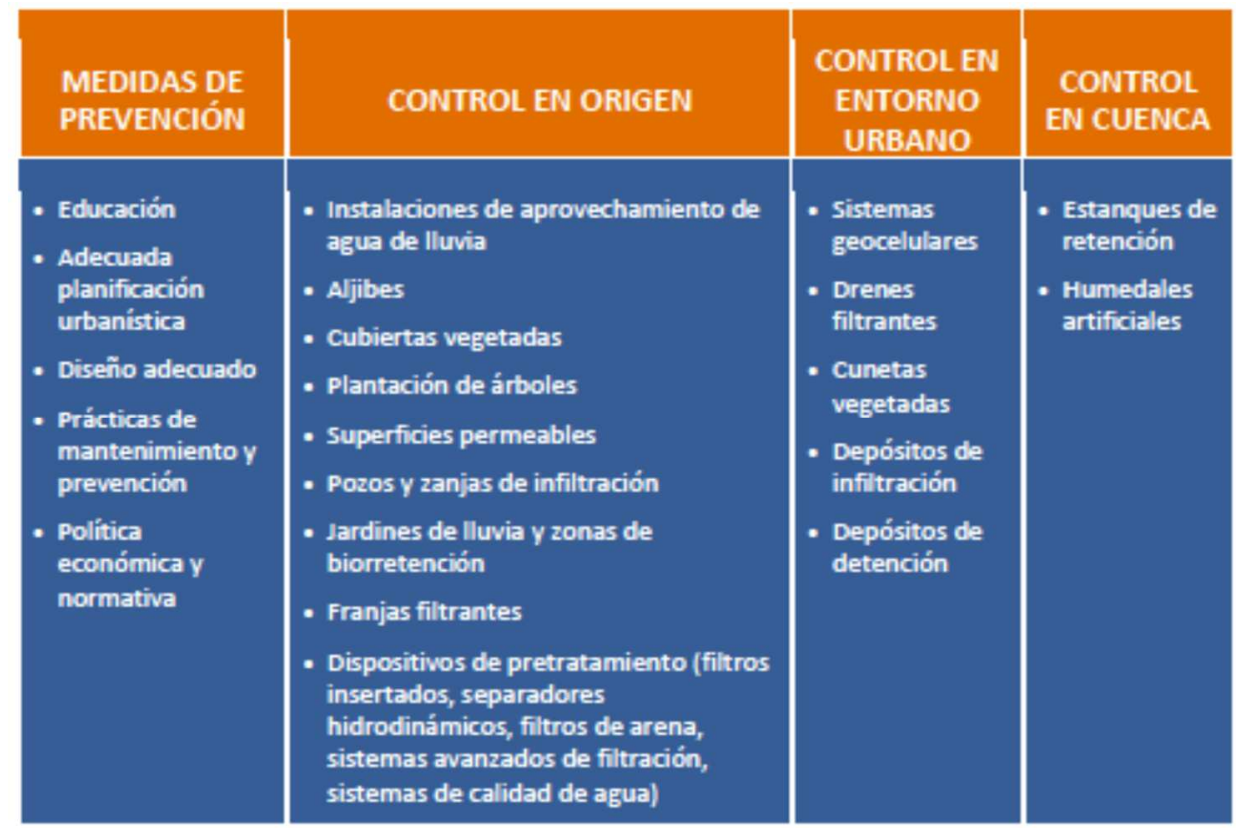

Tabla 1. Tipos de SUDS según su ubicación en la cadena de gestión (Perales, S., 2014).

Será preferible utilizar técnicas ubicadas en los eslabones más altos de la cadena, y en el caso de que no sea posible, emplear las técnicas correspondientes a los niveles más bajos en el orden jerárquico. El agua sólo deberá ser transportada en el caso de que no pueda ser gestionada en el lugar de origen.

Siempre que sea posible, la transición del agua de unos niveles jerárquicos a otros se debe realizar a través de cauces naturales (p.ej. cunetas vegetadas, drenes filtrantes, etc.), para favorecer la evapotranspiración, sedimentación de contaminantes, infiltración, etc. No obstante, los métodos convencionales continuarán siendo utilizados cuando por motivos de espacio disponible no puedan aplicarse otras técnicas.

Por otro lado, deberán existir cauces alternativos para conducir el agua de lluvia cuando tengan lugar los fenómenos extremos. Estos cauces tendrán que transportar las avenidas de agua de forma segura. En general, cuantas más técnicas sean utilizadas en serie, más probable será que el funcionamiento conjunto del sistema sea óptimo y menos probable que se produzca un fallo general en el mismo.

En los nuevos desarrollos urbanos debe estudiarse una aproximación al drenaje urbano mediante SUDS. Cuanto antes se plantee durante la fase de planeamiento la incorporación de SUDS como alternativa de drenaje, mejores serán los resultados. En esta fase se definirán los usos y modelos de ocupación del territorio y quedarán definidas cuáles son las áreas que estarán gestionadas mediante SUDS. Para que la 
implementación de los SUDS tenga éxito será imprescindible la colaboración e implicación de todos los agentes involucrados en el desarrollo urbano (planificadores, constructores, empresas explotadoras, usuarios, etc.) (Perales, 2014).

\section{BIBLIOGRAFÍA}

Atlanta Regional Commission 2016. Georgia Stormwater Management Manual, Vol. 2 (GSMM), Atlanta, GA, USA.

Centro de Estudios y Experimentación de Obras Públicas (CEDEX) 2008. Gestión de las aguas pluviales. Implicaciones en el diseño de los sistemas de saneamiento y drenaje urbano. Madrid, España.

Construction Industry Research and Information Association (CIRIA) (2015). The SUDS Manual, London, UK.

García, E. 2011. Control de escorrentías urbanas mediante pavimentos permeables: aplicación en climas mediterráneos. Trabajo Fin de Máster, Universidad Politécnica de Valencia. Valencia, España.

Perales, S. 2014. Curso de Gestión Integral del agua de lluvia en entornos urbanos: Sistemas de Drenaje Sostenible (SUDS), Instituto Didactia, Almería, España.

San Francisco Public Utilities Commission (SFPUC) 2009. San Francisco Stormwater Design Guidelines, San Francisco, CA, USA.

Woods-Ballard, P., Kellagher, R., Martin, P., Jefferies, C., Bray, R. y Shaffer, P. 2007. CIRIA: The SUDS Manual, Construction Industry Research and Information Association, London, UK.

\section{ENLACES}

http://drenajeurbanosostenible.org/

http://drenajesostenible.com/

http://www.portlandoregon.gov/bes/64040

http://www.sfwater.org/Modules/ShowDocument.aspx?documentID=2779

http://www.aquavalproject.eu/

http://www.ciria.org/Memberships/The_SuDs_Manual_C753_Chapters.aspx

http://www.susdrain.org/resources/SuDS_Manual.html

http://atlantaregional.com/environment/georgia-stormwater-manual

http://udfcd.org/criteria-manual

http://www.melbournewater.com.au/Planning-and-building/Stormwatermanagement/Water-Sensitive-Urban-Design/Pages/wsud.aspx 


\section{MÓDULO 7}

\section{HERRAMIENTAS GEOGRÁFICAS}




\title{
7.1. SISTEMAS DE INFORMACIÓN GEOGRÁFICA. CONCEPTOS BÁSICOS
}

\author{
Álvaro Francisco Morote Seguido
}

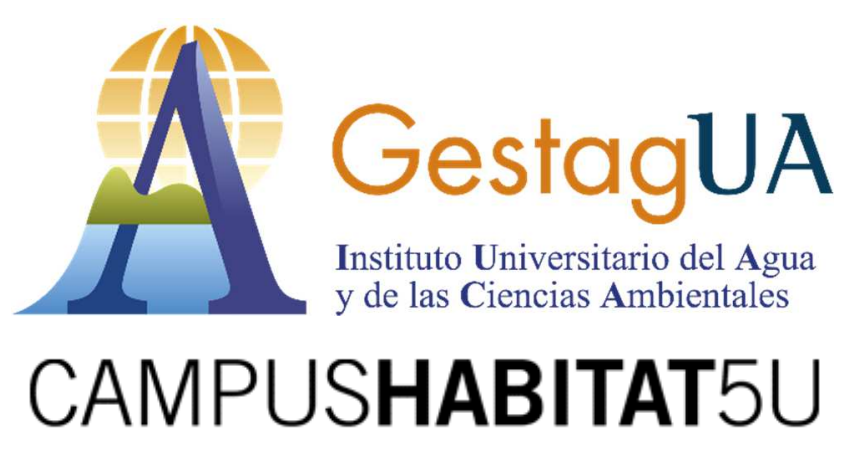




\section{INTRODUCCIÓN A LOS SIG}

Un Sistema de Información Geográfica (SIG) es una herramienta que permite trabajar con información georreferenciada (con coordenadas). En este sentido, cabe indicar que la mayor parte de la de la información que se maneja en cualquier tipo de disciplina está georreferenciada, es decir, se trata de información a la cual puede asignarse una posición geográfica $y$, por tanto, información que viene acompañada de otra información adicional relativa a su localización. Un SIG consiste en información de naturaleza diversa sobre un determinado territorio, almacenada en un conjunto de bases de datos tanto gráficas como alfanuméricas, cuya relación con el territorio se realiza a través de un sistema de referencia geográfico y se gestiona a través de uno o varios programas informáticos específicos.

Un SIG es un sistema que permite la realización de las siguientes operaciones:

$>$ Lectura, edición, almacenamiento y gestión de datos espaciales.

$>$ Análisis de datos. Esto puede incluir desde consultas sencillas a la elaboración de complejos modelos, y puede llevarse a cabo tanto sobre la componente espacial de los datos (la localización de cada valor o elemento) como sobre la componente temática (el valor o el elemento en sí).

$>$ Generación de documentos tales como mapas, informes, gráficos, etc.

Tabla 1. Definiciones de SIG

\begin{tabular}{|c|c|}
\hline Autor & Definición de SIG \\
\hline Aronoff (1989) & $\begin{array}{l}\text { Algo manual o computarizado basado en un conjunto de procedimientos } \\
\text { usados para almacenar y manipular datos referenciados geográficamente. }\end{array}$ \\
\hline Dueker (1979) & $\begin{array}{l}\text { Un caso especial de sistemas de información en el que la base de datos consiste en las } \\
\text { observaciones de atributos, actividades o eventos distribuidos espacialmente representados } \\
\text { mediante puntos, líneas o poligonos. }\end{array}$ \\
\hline Burrough (1986) & $\begin{array}{l}\text { Un poderoso conjunto de herramientas para recolectar, almacenar, recuperar, transformar y } \\
\text { desplegar datos espaciales del mundo real. }\end{array}$ \\
\hline Devine y Field (1986) & $\begin{array}{l}\text { Una forma de sistema de administración de la información que permite desplegar mapas de la } \\
\text { información general. }\end{array}$ \\
\hline NCGIA (1990) & $\begin{array}{l}\text { Sistema compuesto por hardware, software y procedimientos para capturar, manejar, manipular, } \\
\text { analizar, modelizar y representar datos georreferenciados, con el objetivo de resolver problemas } \\
\text { de gestión y planificación. }\end{array}$ \\
\hline $\begin{array}{l}\text { Cebrián y Mark } \\
\text { (1992) }\end{array}$ & Base de datos computarizada que contiene información espacial. \\
\hline Bosque (2000) & $\begin{array}{l}\text { Conjunto de mapas de la misma porción del territorio, donde un lugar concreto [...] tiene la misma } \\
\text { localización (mismas coordenadas) en todos los mapas incluidos en el sistema de información. } \\
\text { De este modo, resulta posible realizar análisis de sus características espaciales y temáticas para } \\
\text { obtener un mejor conocimiento de esa zona. }\end{array}$ \\
\hline
\end{tabular}

Fuente: Goodchild y Rhind, 1991. 
Un SIG representa un paso más allá de los mapas clásicos. Mientras que un mapa es una representación de un conjunto de datos espaciales, y aunque esta representación resulta de enorme importancia, un SIG permite operaciones que pueden hacerse sobre el mapa. Un SIG es una herramienta versátil y de amplio alcance, y actualmente, la gran mayoría de disciplinas se benefician de esta herramienta.

Un SIG puede considerarse compuesto de cinco bloques fundamentales:

1. Datos: Los datos son necesarios para hacer que el resto de componentes de un SIG cobre sentido y puedan ejercer su papel en el sistema. La información geográfica, la verdadera razón de ser de los SIG, reside en los datos, y es por ello que el conocimiento exhaustivo de éstos, su naturaleza, su procedencia, su calidad, así como su gestión y almacenamiento, resulta obligado para una buena comprensión de esta herramienta.

2. Análisis: El análisis es una las funcionalidades básicas de los SIG, y una de las razones fundamentales que llevaron al desarrollo de éstos. Un ordenador es una herramienta con enorme capacidad de cálculo, y esta puede aplicarse a los datos espaciales para obtener resultados de muy diversa índole. En este sentido, en mayor o menor medida, un SIG siempre incorpora una serie de formulaciones que permiten la obtención de resultados y el análisis de los datos espaciales. Las ventajas de la incorporación de todos estos procesos en una única herramienta van desde la automatización de tareas a la aparición de nuevos procesos que producen resultados que no podrían ser obtenidos de otro modo.

3. Visualización: Cualquier tipo de información puede ser representada de forma gráfica, lo cual facilita la interpretación de dicha información. En el caso particular de la información geográfica, la visualización no sólo es una forma más de trabajar con esa información, sino que resulta la forma principal, por ser aquélla a la que estamos más acostumbrados gracias al uso de los mapas. Al contrario que un mapa, que de por sí es de naturaleza gráfica, en un SIG se trabajan con datos de tipo puramente numérico. Para poder presentar una utilidad similar a la de un mapa, un SIG debe incluir capacidades que generen representaciones visuales a partir de esos datos numéricos. La visualización de la información geográfica se rige por los mismos conceptos y principios que se emplean para la confección de cartografía impresa, y estos deben ser conocidos por los usuarios de SIG, ya que una de las tareas de éste es el diseño cartográfico y la preparación de los elementos de visualización para poder realizar su trabajo sobre las representaciones creadas.

4. Tecnología. Se incluyen en este elemento tanto el hardware sobre el que se ejecutan las aplicaciones SIG, como dichas aplicaciones, es decir el software SIG. Además de la propia plataforma, el hardware incluye una serie de periféricos habituales en el trabajo con SIG, como son los periféricos para entrada de datos geográficos y creación de cartografía.

5. Factor organizativo. Engloba los elementos relativos a la coordinación entre personas, datos y tecnología, o la comunicación entre ellos, entre otros aspectos. 
Tabla 2. Preguntas que responde un SIG

\begin{tabular}{|c|c|}
\hline Preguntas de... & Descripción \\
\hline LOCALIZACIÓN & $\begin{array}{l}\text { ¿Qué hay en...? } \\
\text { Siempre se consulta en un mapa o en una base de datos } \\
\text { digital donde está un objeto. } \\
\text { Ejemplo: ¿Qué hay en el poligono seleccionado? }\end{array}$ \\
\hline CONDICIÓN & $\begin{array}{l}\text { ¿Dónde sucede que? } \\
\text { Ejemplo: ¿dónde se ubican las escuelas rurales de un municipio? }\end{array}$ \\
\hline EVOLUCIÓN & $\begin{array}{l}\text { ¿Qué ha cambiado desde? } \\
\text { El análisis a través del tiempo permite pronosticar lo que sucederá en el futuro }\end{array}$ \\
\hline PATRONES & $\begin{array}{l}\text { ¿Qué patrones espaciales existen en? } \\
\text { Los fenómenos repetitivos son manejables por este tipo de sistemas, } \\
\text { cada vez que existe algo que se repite, es porque siempre existe una causa. } \\
\text { Ejemplo: ¿Dónde y a qué hora existe alta congestión vehicular? }\end{array}$ \\
\hline MODELAMIENTO & $\begin{array}{l}\text { ¿Qué ocurriria si ? } \\
\text { Planteamiento de posibles escenarios modificando variables. }\end{array}$ \\
\hline RUTAS & $\begin{array}{l}\text { ¿Cuál es el camino óptimo? } \\
\text { (el más corto, más barato, más rápido) entre dos puntos a través de una red. }\end{array}$ \\
\hline
\end{tabular}

\section{LOS SIG A LO LARGO DE LA HISTORIA. UNA NUEVA FORMA DE CARTOGRAFIAR EL TERRITORIO}

El origen de los SIG puede encuadrarse en el inicio de la década de los sesenta por varios factores: la necesidad creciente de tener una información geográfica y de una gestión y uso óptimo de ésta, y la aparición de los primeros ordenadores. Las bases para la futura aparición de los SIG ya aparecen algunos años antes de los sesenta, con el desarrollo de nuevos enfoques en cartografía como fue la Geografía Cuantitativa. La primera experiencia relevante en la que se combinan Geografía e Informática se produjo en 1959, cuando Waldo Tobler (Geógrafo y Cartógrafo) definió los principios de un sistema denominado MIMO (map in-map out) con la finalidad de aplicar los ordenadores al campo de la Cartografía. En él, se establecen los principios básicos para la creación de datos geográficos, su codificación, análisis y representación dentro de un sistema informatizado.

El primer SIG formalmente desarrollado aparece en Canadá. Este sistema, denominado CGIS (Canadian Geographical Information Systems), fue desarrollado a principios de los años sesenta por Roger Tomlinson (Geógrafo), popularmente conocido como el "padre del SIG". A mediados de los sesenta, las aplicaciones SYMAP y GRID sientan respectivamente las bases de los dos principales enfoques a la hora de manejar 
información geográfica: el enfoque "ráster" y el enfoque "vectorial". Los conceptos básicos para el análisis dentro del SIG ráster los establece poco después Dana Tomlin, desarrollando lo que se conoce como álgebra de mapas.

Durante los años sesenta, se produjo un gran desarrollo de los SIG a partir de esos elementos iniciales, y el SIG comenzó a incorporarse a la comunidad cartográfica, dejando de ser una mera herramienta experimental. La evolución de los SIG, desde entonces recorre sucesivas etapas, avanzando muy rápidamente ante la influencia de numerosos factores externos. Esta evolución tiene lugar en el propio SIG como disciplina, en las tecnologías que lo sustentan, en los datos, así como en las técnicas y formulaciones.

\section{a. La evolución de los SIG como disciplina}

Los SIG eran en origen una mera combinación de elementos de cartografía cuantitativa, enlazados con los sistemas informáticos de la época. Se trataba de un campo de trabajo propio de Cartógrafos y Geógrafos que intentaban adaptar sus conocimientos y necesidades a las tecnologías que en aquella época comenzaban a surgir. No obstante, desde aquellos orígenes, los cambios han sido notables, y se han incorporado al ámbito de los SIG un gran número de otras disciplinas cuya aportación e influencia puede ser equivalente o incluso superior a la de la Cartografía o la Geografía. Coincidiendo con la etapa inicial del desarrollo de los SIG, empezó a aparecer una preocupación por el entorno que tenía consecuencias muy favorables para el desarrollo de todas las ciencias relacionadas, la gran mayoría de las cuales son o serán usuarias directas de SIG. EI SIG comenzó a integrarse paulatinamente en las tareas de gestión del medio, como un apoyo imprescindible a la hora de analizar éste.

Al principio de la década de los setenta, aparecieron no solo los esfuerzos de desarrollo y estabilización de la disciplina, sino todos los restantes que dieron entidad propia a la prometedora ciencia de la información geográfica con base informática. Comenzaron a celebrarse conferencias y simposios sobre SIG, y estos pasaron a formar parte de los curricula universitarios. En el aspecto comercial, la industria del SIG se consolidó también en los años 70. ESRI (Environmental Systems Research Institute), empresa pionera y líder del sector hasta el día de hoy, se funda en 1969, y sus productos tienen gran importancia a la hora de convertir los SIG en un elemento de consumo.

Una década posterior, se consolidaron las revistas y foros especializados. En 1985 aparece el primer SIG de código abierto, GRASS (Geographic Resources Analysis Support System). El mayor avance en la incorporación de los SIG a entornos no profesionales tiene lugar en la primera década del siglo XXI, con la aparición de servicios de cartografía como Google Maps. La popularización de los navegadores GPS, que incorporan tanto elementos de representación como de análisis propios de los SIG, son otro buen ejemplo de la proliferación de esta herramienta entre un público no especializado. 


\section{b. La evolución de la tecnología}

Tres son los bloques principales del desarrollo informático con una influencia más marcada en el campo de los SIG:

$>$ Salidas gráficas. La evolución de las capacidades gráficas, intensa desde sus inicios hasta nuestros días y aún muy activa, ha sido seguida de cerca por los SIG, que progresivamente han ido incorporando mejoras tanto en la representación en pantalla como en la generación de mapas impresos.

$>$ Almacenamiento y acceso de datos. El aumento en el tamaño de los datos manejados en el SIG ha debido acompañarse de mejoras en la capacidad de almacenamiento, así como en la de lectura, para poder garantizar un uso fluido.

$>$ Entrada de datos. Los datos geográficos utilizados en los primeros años de los SIG eran datos en papel que se digitalizaban y almacenaban mecánicamente en tarjetas perforadas en un único proceso mecánico.

Desde esos sistemas mecánicos de tarjetas hasta los modernos equipos, la aparición de scanners de gran precisión y técnicas de digitalización automáticas, entre otros, ha cambiado completamente el ámbito de la entrada de datos para su uso en un SIG. Además del avance de estos elementos, la evolución general de los ordenadores afecta a todos los elementos de software que se ejecutan sobre ellos. De las grandes computadoras se pasa a los ordenadores personales, y programas como los SIG, además, realizan esa transición de una a otra plataforma. La elaboración y análisis de cartografía se convierte a finales de los años ochenta en una tarea que podía realizarse en equipos personales de bajo coste, lejos de las grandes máquinas y equipos de alto coste.

Las tendencias actuales apuntan a llevar los SIG de forma genérica a plataformas móviles tales como teléfonos o tabletas, especialmente indicadas para la toma de datos en campo. La combinación de estos últimos con las tecnologías de posicionamiento global como el GPS se demuestra altamente práctica en este aspecto. La aparición de Internet es un hecho que ha modificado todos los aspectos de la sociedad actual, estén relacionados o no con ámbito científico. El primer uso relacionado con el SIG o la distribución de cartografía lo encontramos en 1993, con la aparición de Xerox PARC, el primer servidor de mapas. El primer atlas digital en línea, el Atlas Nacional de Canadá, se encuentra disponible desde 1994. Más recientemente, ya en el siglo XXI, los conceptos de la Web 2.0 se adaptan al ámbito de los SIG y facilitan la aparición de lo que se conoce como el Web Mapping.

\section{c. La evolución de los datos}

Las primeras bases de datos geográficos contenían mapas escaneados y elementos digitalizados en base a éstos. A partir de este punto, van apareciendo nuevas fuentes de datos cuya estructura es más adecuada para su tratamiento informatizado, y al tiempo que los SIG se adaptan a estas, surge una relación bidireccional que resulta beneficiosa para ambos. Un avance primordial en este sentido lo constituye el lanzamiento de los 
primeros satélites de observación terrestre. Las técnicas existentes para la toma de fotografías aéreas, desarrolladas principalmente con fines militares durante la Primera Guerra Mundial (aunque iniciadas a mitad del siglo XIX con la toma de fotografías desde globos aerostáticos), pasan a aplicarse a escala global con la aparición de satélites destinados a estos efectos. En 1980 se funda SPOT, la primera compañía mundial en ofrecer con carácter comercial imágenes procedentes de satélite para toda la superficie terrestre.

Las tecnologías de posicionamiento y localización son otra fuente de datos de primer orden. En 1981, el sistema GPS pasa a ser plenamente operativo, y en 2000 se amplía la precisión de este para uso civil. Al igual que las aplicaciones, los distintos tipos de datos geográficos digitales se van asentando y popularizando, recibiendo progresivamente más atención y medios. El Servicio Geográfico Estadounidense (USGS) publicó en 1976 los primeros Modelos Digitales de Elevaciones (MDE), en respuesta a la gran importancia que este tipo de dato tiene dentro del nuevo contexto del análisis geográfico. En el año 2000 se publicaron los datos de la Shuttle Radar Topographic Mission (SRTM), con información altitudinal de un $80 \%$ de la superficie terrestre a una resolución de un segundo de arco (aproximadamente, 30 metros).

La aparición de nuevas técnicas tales como el LiDAR abre nuevos caminos en cuanto a la precisión que puede obtenerse en la caracterización del terreno, posibilitando nuevos usos y análisis antes no planteados. La evolución de los datos no es solo una evolución técnica, sino también de carácter social y organizativo. En este sentido, se empezó a entender que resultaba necesario formular estrategias adecuadas para la gestión de los datos espaciales, y se desarrollaron las denominadas Infraestructuras de Datos Espaciales (IDE). El ejemplo más destacado de éstas fue la IDE Nacional de los Estados Unidos (NSDI), de 1994. En Europa, la directiva INSPIRE, de 2007, pretende la creación de una infraestructura similar. Muchos de estos desarrollos y actividades se adhieren a las especificaciones establecidas por el Open GIS Consortium (OGC), que se trata de un consorcio internacional fundado en 1994 para homogeneizar el empleo y difusión de los datos geográficos.

\section{d. La evolución de las técnicas y formulaciones}

Una vez que se implementaron los primeros SIG y se suplieron las necesidades del análisis y gestión de los datos espaciales que motivaron su aparición, comenzó el proceso de desarrollo de nuevas técnicas y planteamientos que permitieron ir más allá en dicho análisis.

En 1854 John Snow (Médico inglés precursor de la epidemiología) realizó la que puede considerarse como una de las primeras experiencias cartográficas analíticas, al utilizar mapas de puntos para efectuar sus deducciones y localizar en Inglaterra la fuente de un brote de cólera (Figura 1). En su libro Design with Nature (1969), Ian McHarg (Arquietecto) definió los elementos básicos de la superposición y combinación de mapas que se aplican tanto en el análisis como en la visualización de las distintas capas de datos geográficos en un SIG. Un desarrollo especialmente relevante es el experimentado por 
el análisis del relieve, una disciplina que con la aparición de los SIG sufrió un salto cualitativo muy importante. La orografía clásica, con un enfoque tradicionalmente sustentado en la Geología y el análisis geomorfológico, va dando lugar a una ciencia cada vez más cuantitativa centrada en el análisis morfométrico del relieve. Junto con la componente analítica, otros elementos de la práctica cartográfica evolucionaron de forma similar.

Figura 1. Variante del mapa original del Dr. John Snow. Los puntos son casos de cólera durante la epidemia en Londres de 1854 y Las cruces la ubicación de las bombas de agua

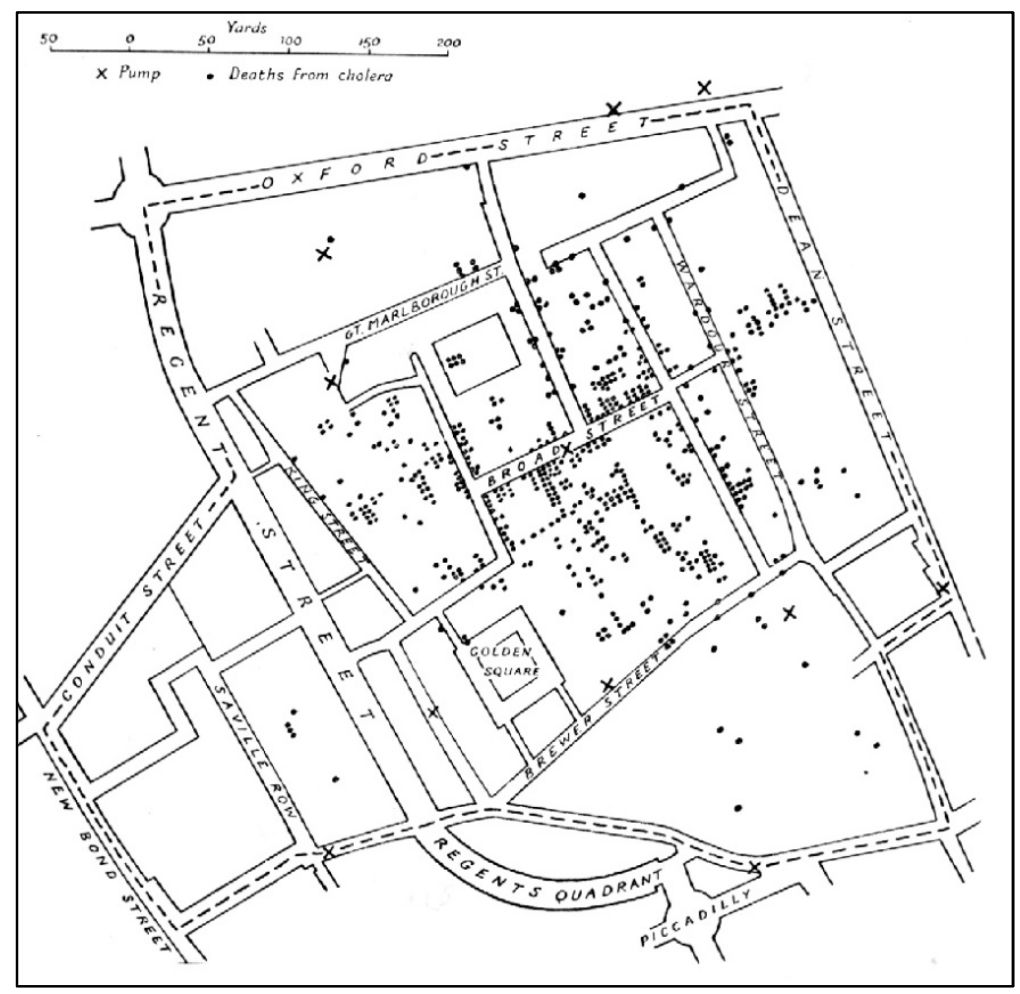

Fuente: https://es.wikipedia.org/wiki/John_Snow

En 1819, Pierre Charles Dupin (Estadista) creó el primer mapa de coropletas (Figura 2). Con la llegada de los SIG, este tipo de mapas se convertirán en una forma de representación muy popular. El avance en el desarrollo de las aplicaciones de diseño asistido por ordenador (CAD), y en general de las representaciones gráficas por ordenador, impulsó igualmente la aparición y evolución posterior de una nueva disciplina: la Geometría Computacional. Sobre esta se fundamenta el análisis vectorial dentro de un SIG, y también parte de los mecanismos que este usa para la representación gráfica de elementos. 
Figura 2. Mapa de coropletas de Pierre Charles Dupin (1826)

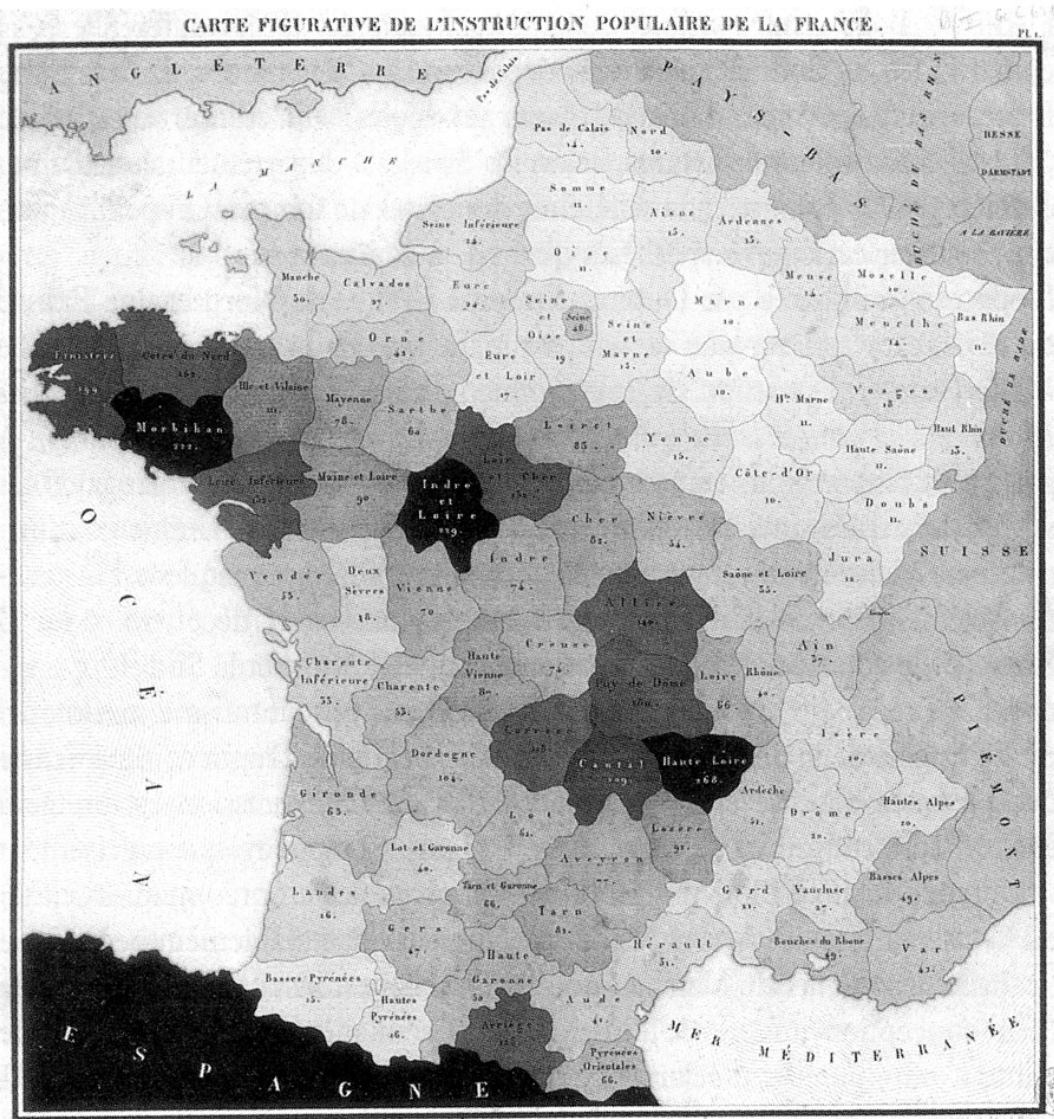

Fuente: https://en.wikipedia.org/wiki/Charles Dupin

\section{CONCEPTOS CARTOGRÁFICOS BÁSICOS}

De entre los conceptos fundamentales de la Cartografía que todo usuario de SIG debe conocer, destaca el de escala. La escala es la relación de tamaño existente entre el mapa que se obtiene al desarrollar nuestra superficie de proyección (de tamaño acorde con el objeto proyectado, esto es la Tierra) y el que finalmente se maneja (de tamaño más reducido). Conociendo esta relación se pueden conocer las verdaderas magnitudes de los elementos que se ven en un mapa, ya que se pueden convertir las medidas hechas sobre el mapa en medidas reales. Es importante recordar que esas medidas no son tan "reales", debido a que la propia proyección las ha distorsionado, pero sí que son medidas en la escala original del objeto cartografiado.

La escala se expresa habitualmente como un denominador que relaciona una distancia medida en un mapa y la distancia que esta medida representa en la realidad. Por ejemplo, una escala 1:50.000 quiere decir que 1 centímetro en un mapa equivale a 
50.000 centímetros en la realidad, es decir a 500 metros. Este valor se conoce como escala numérica.

Independientemente del tipo de proyección, la escala es completamente cierta únicamente en determinadas partes del mapa. En otros puntos de este, la escala varía. La relación entre la escala en esos puntos y la escala numérica se conoce como factor de escala. Aunque tradicionalmente se entiende la escala como un concepto asociado a la representación, los datos geográficos tienen una escala inherente que no es función de dicha representación, sino del detalle con que han sido tomados. En este sentido es más conveniente entender la escala como un elemento relacionado con la resolución de los datos, es decir, con el tamaño mínimo cartografiado. Esta concepción no es en absoluto propia de los SIG, ya que deriva de las representaciones clásicas y los mapas impresos. Se sabe que el tamaño mínimo que el ojo humano es capaz de diferenciar es del orden de $0,2 \mathrm{~mm}$. Aplicando a este valor la escala con la que se quiere crear un mapa, se obtendrá la mínima distancia sobre el terreno que debe medirse.

Es importante considerar la escala a la hora de la toma de datos (conocida como escala operacional), especialmente en el contexto de un SIG. En un SIG, se puede aumentar el tamaño en pantalla de una cierta información geográfica, variando la escala de representación (también conocida como escala cartográfica), pero ello no modifica la escala operacional. Por mucho que se amplié, no se van a ver más detalles, ya que para ello sería necesario tomar más datos. Un tipo de datos particulares con los que se trabaja en un SIG (los datos ráster), tienen a su vez un parámetro de resolución (el tamaño de celda) ligado a la escala. Relacionado con el concepto de escala se encuentra la denominada generalización cartográfica. Generalizar implicar expresar alguna idea o información de forma más resumida, de tal modo que esta sea comprensible y pueda aprovecharse de la mejor manera posible. La generalización es necesaria en un SIG para representar datos a una escala menor que su escala operacional, ya que a las limitaciones de la visión humana han de sumarse las limitaciones de resolución que los dispositivos presentan. Por ejemplo, no tiene sentido representar el callejero de una ciudad a una escala pequeña como la que se utilizaría para representar un mapa mundial, ya que cada pequeño punto de la pantalla contendría un gran número de calles. Además de obtener un resultado inservible, se consumirían recursos en efectuar todos los cálculos necesarios para producir esa representación.

En ocasiones, el proceso de generalización es necesario por razones distintas a las anteriores, y requiere operaciones también distintas. Por ejemplo, se puede crear un mapa del mundo que contenga cursos fluviales, pero no todos, sino sólo los principales ríos de cada país (Figura 3). En este caso, no se van a encontrar problemas con distintos cursos fluviales que se solapan en la representación, ni tampoco un volumen excesivo 
de datos, pero cabe "adaptar" la representación a la escala, es decir, efectuar algún tipo de generalización. En este caso, se representarían los ríos con un ancho mayor del real, ya que, de otro modo, no serían apenas visibles si las representamos con su ancho correspondiente.

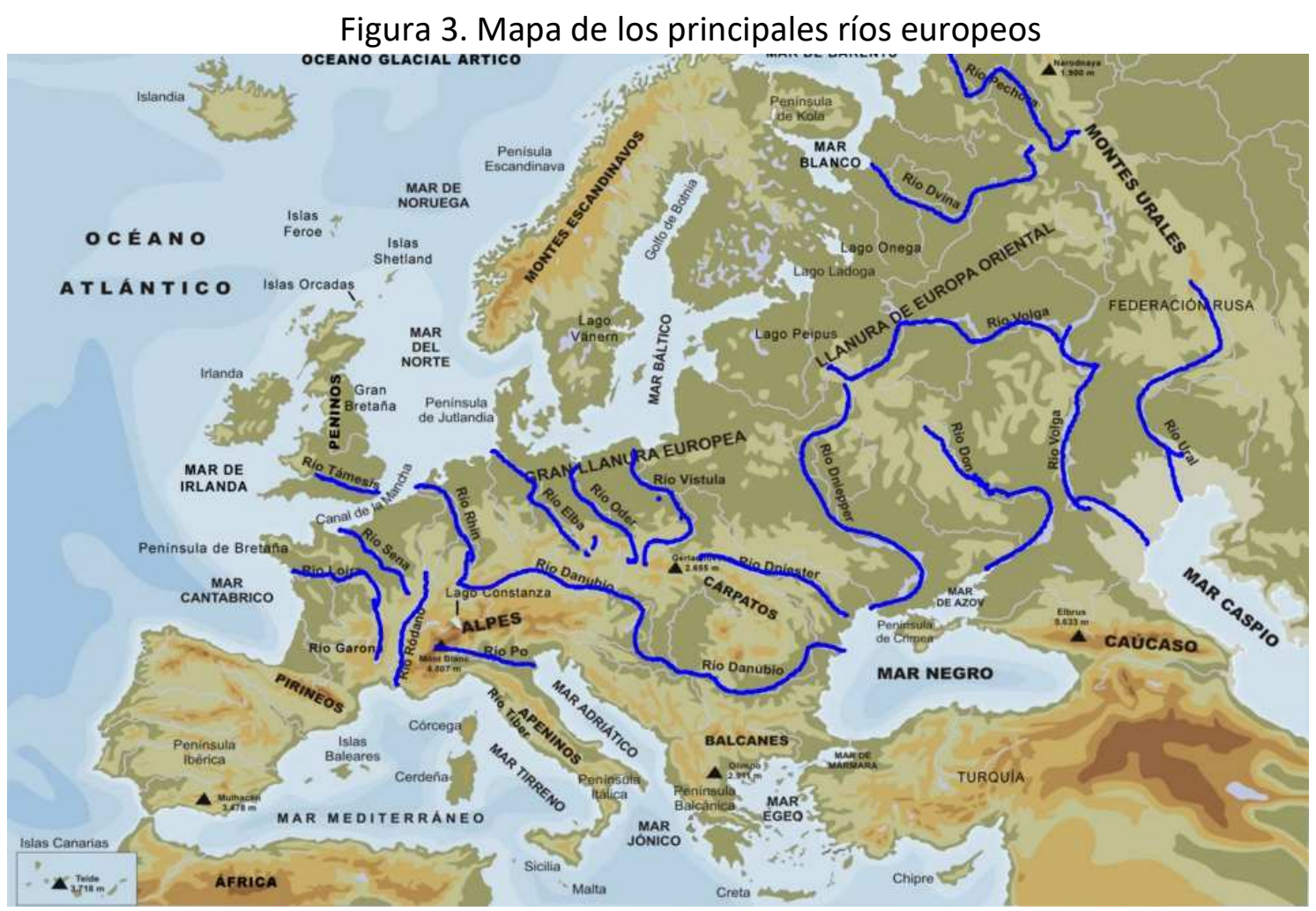

Fuente: http://segundociclobellas.blogspot.com.es/2015/10/rios-de-europa.html

La generalización, por tanto, es un proceso que tiene como objetivo la producción de una imagen cartográfica legible y expresiva, reduciendo el contenido del mapa a aquello que sea posible y necesario representar. Para ello, se enfatiza lo que resulta de importancia y se suprime lo que carece de ella. Existen diversas operaciones que se emplean en el proceso de generalización. Algunas de las más relevantes son: la simplificación (representar un elemento menos complejo), la agregación (representar varios elementos como uno solo), la exageración (representar elementos con mayor tamaño del que les corresponde) y el desplazamiento (representar en una posición modificada, para garantizar la legibilidad). En un SIG, la generalización puede incorporarse como parte de los propios mecanismos de representación, aplicándose las transformaciones correspondientes en tiempo real. A partir de un juego de datos, se elaboran las representaciones según la escala a la que se estén representando. Esta solución tiene el inconveniente de producir resultados que no resultan óptimos, por ser la generalización un proceso complejo y difícil de automatizar, y, sobre todo, el de consumir gran cantidad de recursos. La generalización en este caso tiene un objetivo 
cartográfico, pero en lugar de hacer más fluido el trabajo con datos de gran volumen, lo hace más lento.

Figura 4. Distintas capas de información en un mapa

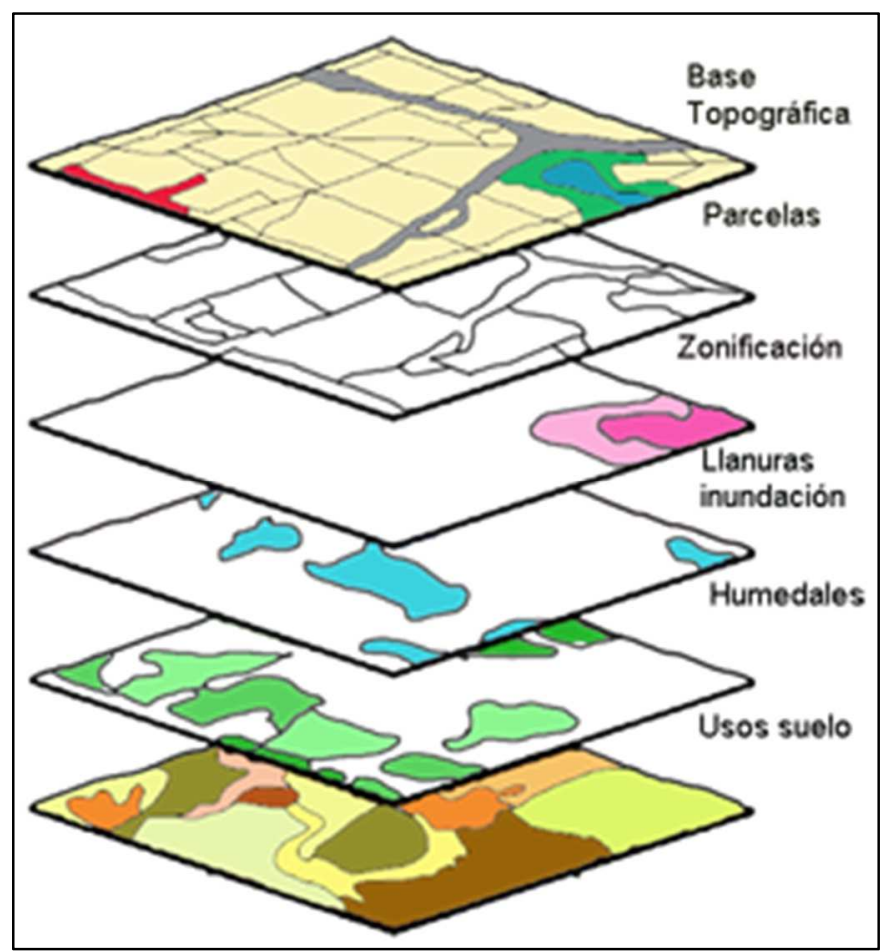

Fuente: http://www.stig.usal.es/quehacemos.php

Una solución alternativa y más adecuada de incorporar la generalización dentro de un SIG suele basarse en un enfoque multiescalar, en el cual se maneja información de una misma zona de estudio a diferentes escalas, y se usa en cada momento aquella que resulte más conveniente. Si se trabajara con cartografía en papel, sería equivalente a tener varios mapas de una zona a diferentes escalas. El concepto de "capa", y que es vital para la idea actual de un SIG, permite este manejo simultáneo de información a distintas escalas (Figura 4). En el caso de imágenes, este enfoque multiescalar implica la creación de las denominadas pirámides. En lugar de una imagen con una determinada resolución, se tiene una colección de estas con distintas resoluciones, y en función de la escala necesaria para la representación, se emplea la más adecuada.

\section{BIBLIOGRAFÍA}

Anon (2005): La iniciativa inspire de la comisión europea: Su evolución y situación actual. Boletín Informático del Instituto Geográfico Nacional, 22. Disponible en http://www.fomento.es/MFOM/LANG CASTELLANO/DIRECCIONES GENERALE 
S/ INSTITUTO_GEOGRAFICO/_INFORMACION/BOLETIN_INFORMATIVO/boletin_22 .htm.

Anselin, L (1992): Spatial data analysis with gis: an introduction to application in the social sciences, technical report 92-10. Technical report, NCGIA. Disponible en http://citeseerx.ist.psu.edu/viewdoc/download?doi=10.1.1.75.9557\&rep=rep1 \&type=pdf.

Asenjo, L (1997): Fundamentos para la realización de levantamientos mediante el sistema GPS. E.T.S.C.G.T. Universidad Politécnica de Valencia.

Bertin, J., (1987): Cartes et gures de la Terre. Ed. G. Pompidou.

Chuvieco, E. (1996): Fundamentos de teledetecci_on espacial 3 ed. Ediciones Rialp, 1996.

Goodchild, M. and R. Haining, R (2003): Gis and spatial data analysis: Converging perspectives. Journal of Economics, 83(1):363\{385, October 2003. Disponible en http://ideas.repec.org/a/kap/jeczfn/v83y2003i1p363-385.html.

D. Greenlee, D. (1987): Raster and vector processing for scanned line work. Photogrammetric Engineering and Remote Sensing, 53(10):1383\{1387.

Guting, RH. (1994): An introduction to spatial database systems. VLDB Journal, 3(4), Disponible en http://ksuseer1.ist.psu.edu/viewdoc/summary?doi=10.1. 1.62.1867.

Olaya, V. (2011): Sistemas de Información Geográfica. Disponible en: http://wiki.osgeo.org/wiki/Libro_SIG.

\section{ENLACES}

http://www.gis.com/whatisgis/index.html

http://gislounge.com/the-components-of-gis-evolve

http://www.pucp.edu.pe/biblioteca/docs/elibros_pucp/medina_hugo/Medina_Fisica2 _Cap3.pdf.

https://es.wikipedia.org/wiki/John_Snow

https://en.wikipedia.org/wiki/Charles_Dupin

http://segundociclobellas.blogspot.com.es/2015/10/rios-de-europa.html

http://www.stig.usal.es/quehacemos.php 


\title{
LECCIÓN 7.2: TRATAMIENTO DE LA INFORMACIÓN ESPACIAL EN SISTEMAS DE INFORMACIÓN GEOGRÁFICA
}

\author{
Antonio Jódar Abellán
}

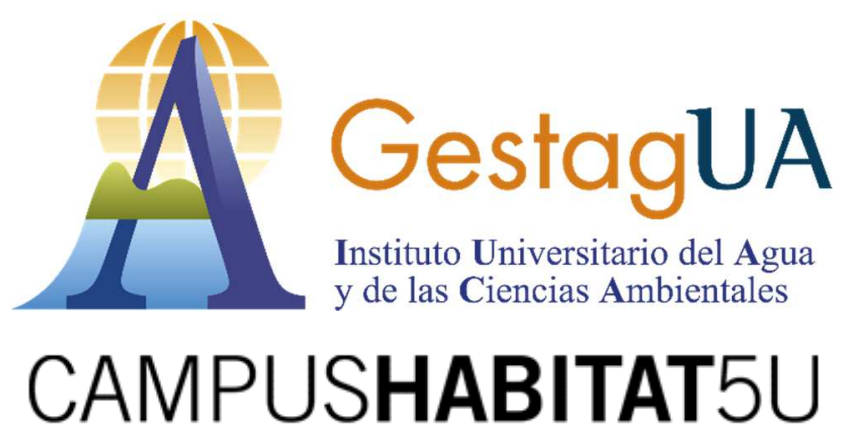




\section{INTRODUCCIÓN}

Tal y como se mencionó en la Lección 7.1-Sistemas de Información Geográfica. Conceptos Básicos, se considera Sistema de Información Geográfica, en adelante SIG, a cualquier sistema de información capaz de integrar, gestionar, almacenar, editar, analizar, compartir y visualizar información espacial geográficamente referenciada (georreferenciada). Desde una perspectiva más práctica, los SIG son herramientas que permiten a los usuarios crear consultas interactivas, analizar la información espacial, editar datos, y presentar los resultados de todas estas operaciones mediante la creación de mapas (UAM, 2011a).

Los SIG almacenan la información espacial (datos) en forma de capas temáticas (layers), las cuales pueden ser activadas y desactivadas por el usuario para que éste realice consultas (superposiciones) acorde a sus necesidades. Debido a la diferente tipología de la información espacial existente en la realidad, la representación de la misma en los SIG se ha realizado tradicionalmente en dos grandes formatos (modelos): capas con información en formato ráster y capas con información en formato vectorial:

Modelo Ráster: divide el espacio en celdas regulares en el que cada una de ellas presenta un único valor. De este modo, posee formato ráster cualquier tipo de imagen digital representada en mallas (pixels). Algunos formatos muy utilizados son: jpeg, png, tiff, etc. (UAM, 2011a; Alonso-Sarría, 2014).

> Modelo Vectorial: la representación vectorial de los datos geográficos implica la utilización de los tres tipos de elementos espaciales, de carácter geométrico, en los que pueden ser interpretados los objetos geográficos: puntos, líneas y polígonos. Los atributos temáticos, que corresponden a las unidades espaciales, se manejan, habitualmente, desde tablas de datos (tablas de atributos).

En la Figura 1, se muestran diferentes tipos de objetos del mundo real clasificados en formato vectorial y raster en función de la naturaleza de los mismos. 


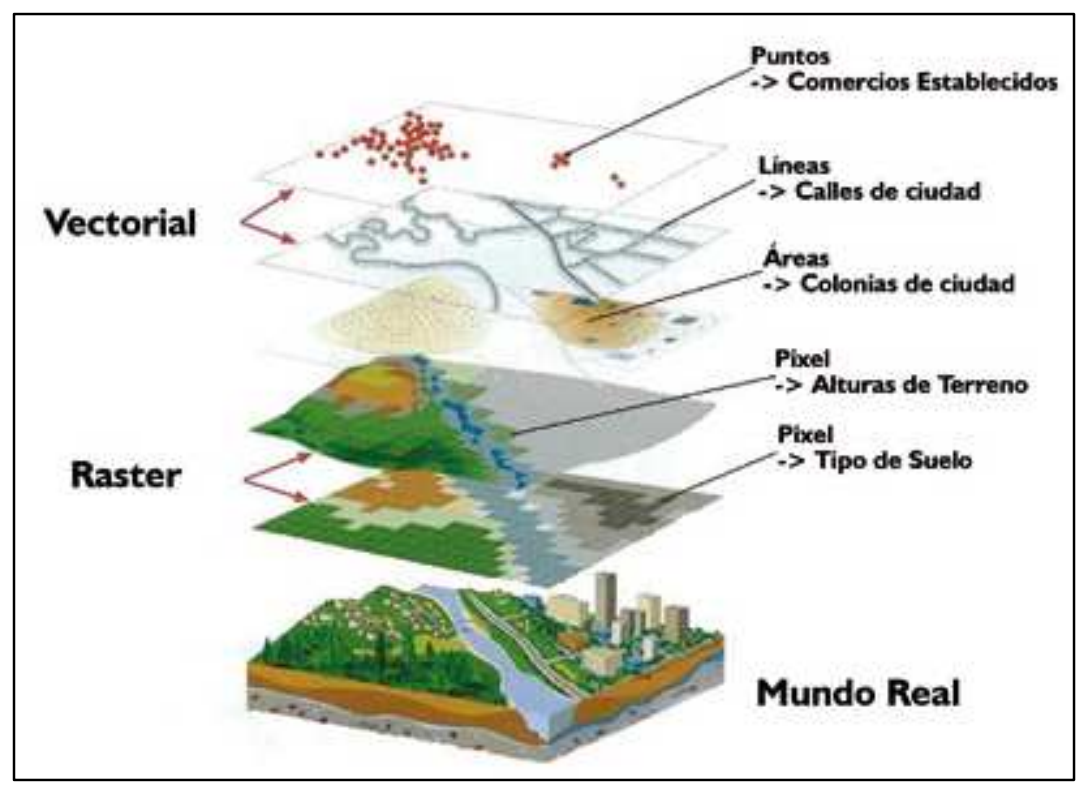

Figura 1. Agrupación de información espacial en formato raster y vectorial. Fuente: http://geoservice.igac.gov.co/contenidos_telecentro/fundamentos_sig/cursos/sem_2/uni2/index. php?id=2

La presente lección queda dividida en dos grandes bloques. En el primero se abordarán los conceptos básicos de los modelos ráster y vectorial, junto con los servicios de visualización (WMS, WMTS, etc.). En el segundo, se indicarán los principales software utilizados actualmente en los Sistemas de Información Geográfica (ArcGIS, QGIS, GRASS, etc.).

\section{FORMATOS RÁSTER, VECTORIAL Y SERVICIOS WEB}

\section{1-Modelo Ráster}

La representación de la superficie del terreno se ha realizado tradicionalmente por medio de cinco modelos principales: Malla regular de puntos, Red Irregular de Triángulos (TIN), Isolineas, Teselación irregular y Modelo ráster. No obstante, dado que éste último ha sido el más ampliamente utilizado a continuación se detallan las características del mismo.

En el formato ráster se divide el espacio en un conjunto regular de celdillas. Cada una de estas celdillas contiene un número que puede ser: el valor de una variable cuantitativa (si la capa contiene esta variable), un identificador de una variable cualitativa o el identificador de un objeto (si la capa contiene objetos). 
De este modo, en su forma más simple, un ráster consta de una matriz de celdas (o píxels) organizadas en filas y columnas, es decir una cuadrícula (Figura 2), en la que cada celda contiene un valor que representa información, como por ejemplo la temperatura. Por ello, a menudo los ráster son fotografías aéreas digitales (ortofotos), imágenes de satélite, imágenes digitales o incluso mapas escaneados.

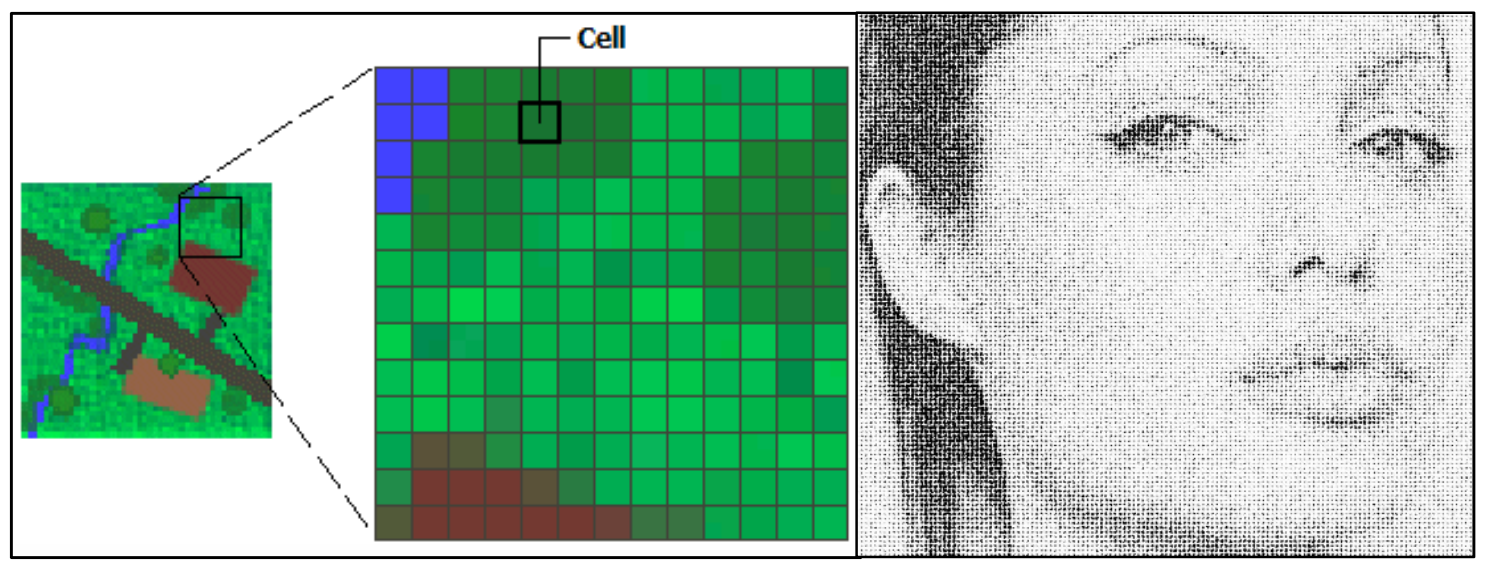

Figura 2. Matriz de celdas (cuadrícula) de un ráster. Fuente:

http://desktop.arcgis.com/es/arcmap/10.3/manage-data/raster-and-images/what-is-raster-data.htm

Una capa en formato ráster se compone esencialmente de cuatro elementos:

$>$ La matriz de datos, que a su vez puede contener tres tipos de datos:

- Valores numéricos en caso de que la variable representada sea cuantitativa (elevaciones, precipitación, etc.).

- Identificadores numéricos si se trata de una variable cualitativa (litología, usos del suelo, etc.).

- Identificadores numéricos únicos para cada uno de los posibles valores en caso de que la capa raster contenga variables cualitativas o entidades (puntos, líneas y/o polígonos como por ejemplo parcelas de terreno, núcleos urbanos, pozos, carreteras, etc.).

Información geométrica acerca de la matriz y de su posición en el espacio para que los programas puedan leerla adecuadamente, como:

- Número de columnas (nc).

- Número de filas (nf).

- Coordenadas de las esquinas de la capa (e, w, s, n).

- Resolución o tamaño de pixel en latitud ( $r y$ ) y en longitud ( $r x$ ).

Sistema de referencia espacial utilizado para georreferenciar la capa.

$>$ Una paleta de colores que permita decidir de qué color se pintará cada celdilla en la interfaz del SIG. 
- En caso de que la capa ráster represente una variable cualitativa, o que se representen entidades, una tabla que haga corresponder a cada identificador numérico una etiqueta de texto descriptiva (Figura 3).

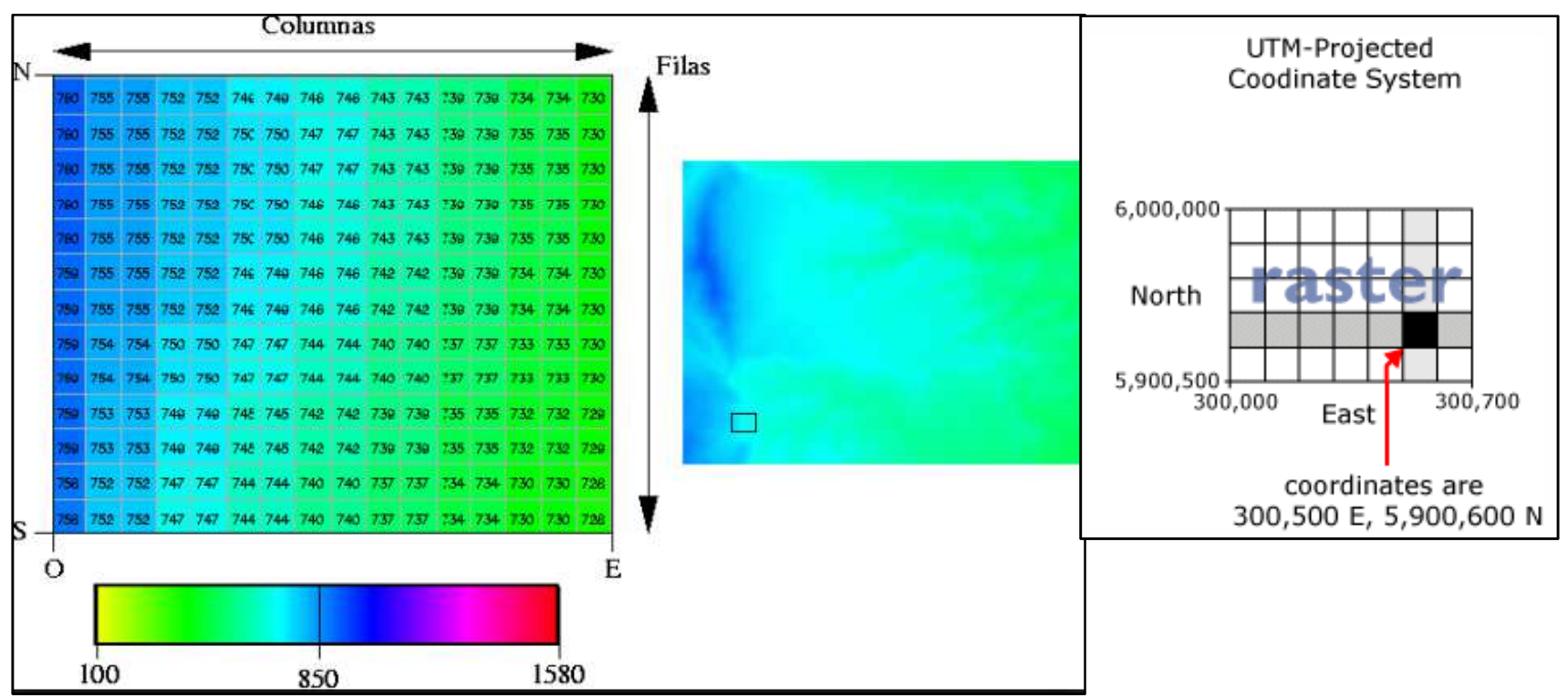

Figura 3. Elementos habituales de una capa ráster. Fuente: https://www.google.es/search?q= imagen+raster\&source=Inms\&tbm=isch\&sa=X\&ved=0ahUKEwj_8-b43oXQAhVFvBoKHT4dCXYQ_AUICCg B\&biw=1366\&bih=662\#imgrc=jXK5-3lso6HvRM\%3A (imagen izquierda). http://desktop.arcgis.com/es/ arcmap/10.3/manage-data/raster-and-images/what-is-raster-data.htm (imagen derecha).

Por último, destacar que los archivos con formato ráster normalmente suelen codificarse con una extensión de fichero Geotiff (un fichero Tiff que incluye el sistema de referencia espacial utilizado y la información necesaria para asignar un par de coordenadas a cada uno de los píxeles que lo forman). Además del .tif, también son habituales en los ráster extensiones de ficheros comprimidos del tipo .ecw, .sid y .jpg (Sastre-Olmos, 2010; Alonso-Sarría, 2014; Olaya, 2014).

\section{2-Modelo Vectorial}

En el formato vectorial los diferentes objetos espaciales se muestran como puntos, líneas o polígonos. Concretamente la representación de puntos o líneas es sencilla, mientras que la representación de polígonos resulta ser más compleja. Las propiedades de dichos objetos se recopilan en tablas enlazadas (Figura 4). 


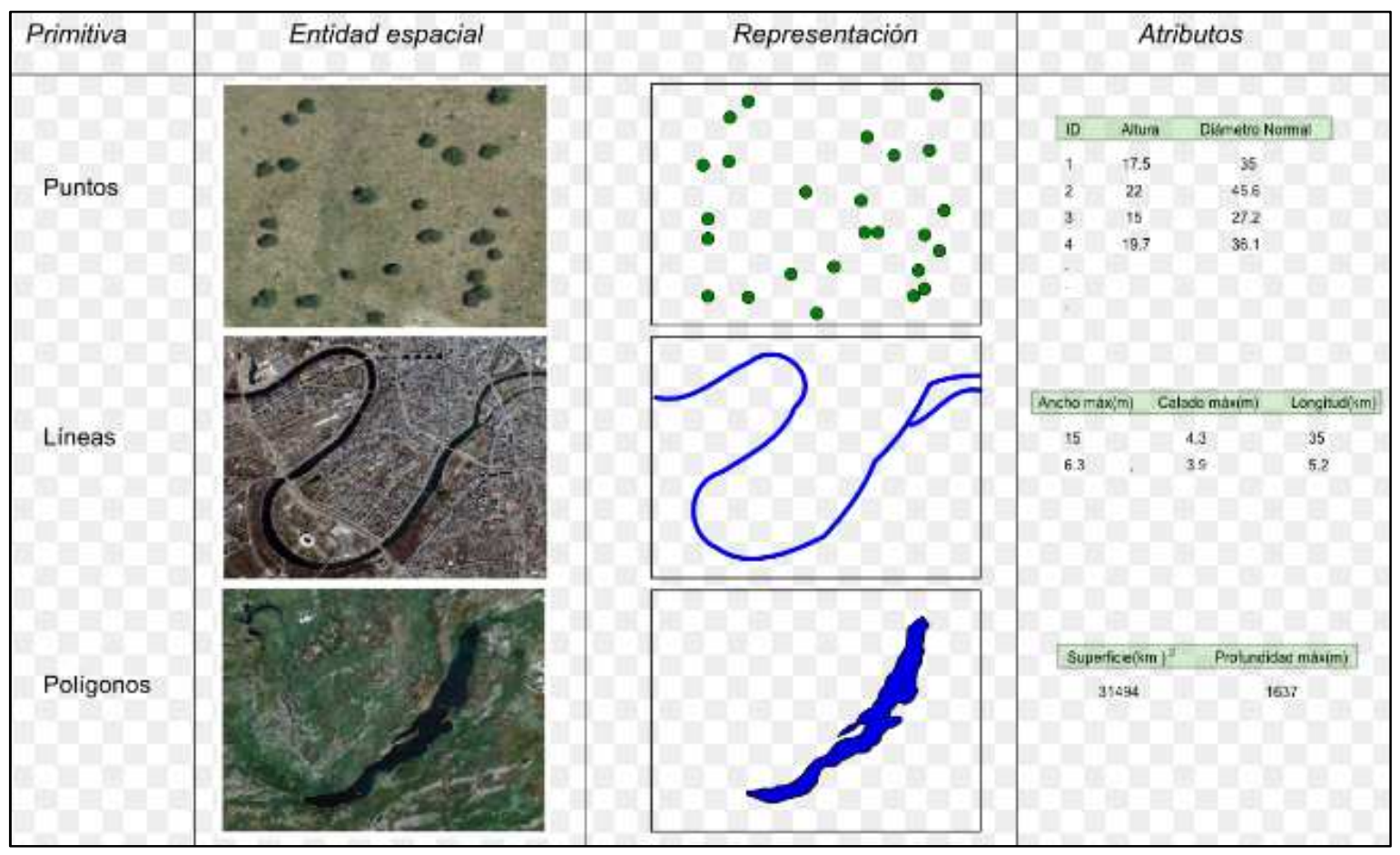

Figura 4. Modelo de representación vectorial y ejemplos de capas con atributos asociados. Fuente: Olaya (2014).

En formato vectorial, la posición de los mencionados objetos geométricos (puntos, líneas o polígonos) se almacena a partir de las coordenadas de los mismos:

Un punto se registra con un par de coordenadas.

$>$ Una línea se recoge como una sucesión de pares de coordenadas (vértices), denominándose a los vértices inicial y final nodos. Cuanto mayor sea el número de vértices/unidad de longitud de la línea mayor será la exactitud en la codificación de la línea.

$>$ Un polígono se almacena como una línea o conjunto de líneas cerradas. Estas líneas, que no corresponden a entidades lineales, sino que definen el perímetro de un polígono, se denominan arcos.

Al igual que sucede en la generalización cartográfica, la elección de un tipo de objeto u otro para representar un elemento de la realidad dependerá en gran medida de la escala de trabajo (escala cartográfica) y del tipo de análisis (genérico o bien más localizado) que se pretenda realizar. Por ejemplo, una ciudad, en función de la escala, puede representarse con un punto o un polígono, o incluso dividirse en varios polígonos (manzanas) en estudios de planificación urbana a gran escala. En otros casos, en cambio, la elección del tipo de objeto no tiene por qué variar significativamente con la escala. Así, por ejemplo, en hidrología, los cauces suelen representarse como líneas, mientras que su anchura y profundidad se codifican como propiedades espaciales. 
Los identificadores y propiedades espaciales y no espaciales, y en ocasiones la topología, de los objetos se almacenan en tablas enlazadas (tablas de atributos) al mapa vectorial gracias a la inclusión en la tabla del identificador único de cada entidad. Así, a partir de éste puede obtenerse tanto el objeto en la base de datos espacial como sus propiedades no espaciales (Figura 5). Este tipo de almacenamiento de datos se denomina Geo-relacional.

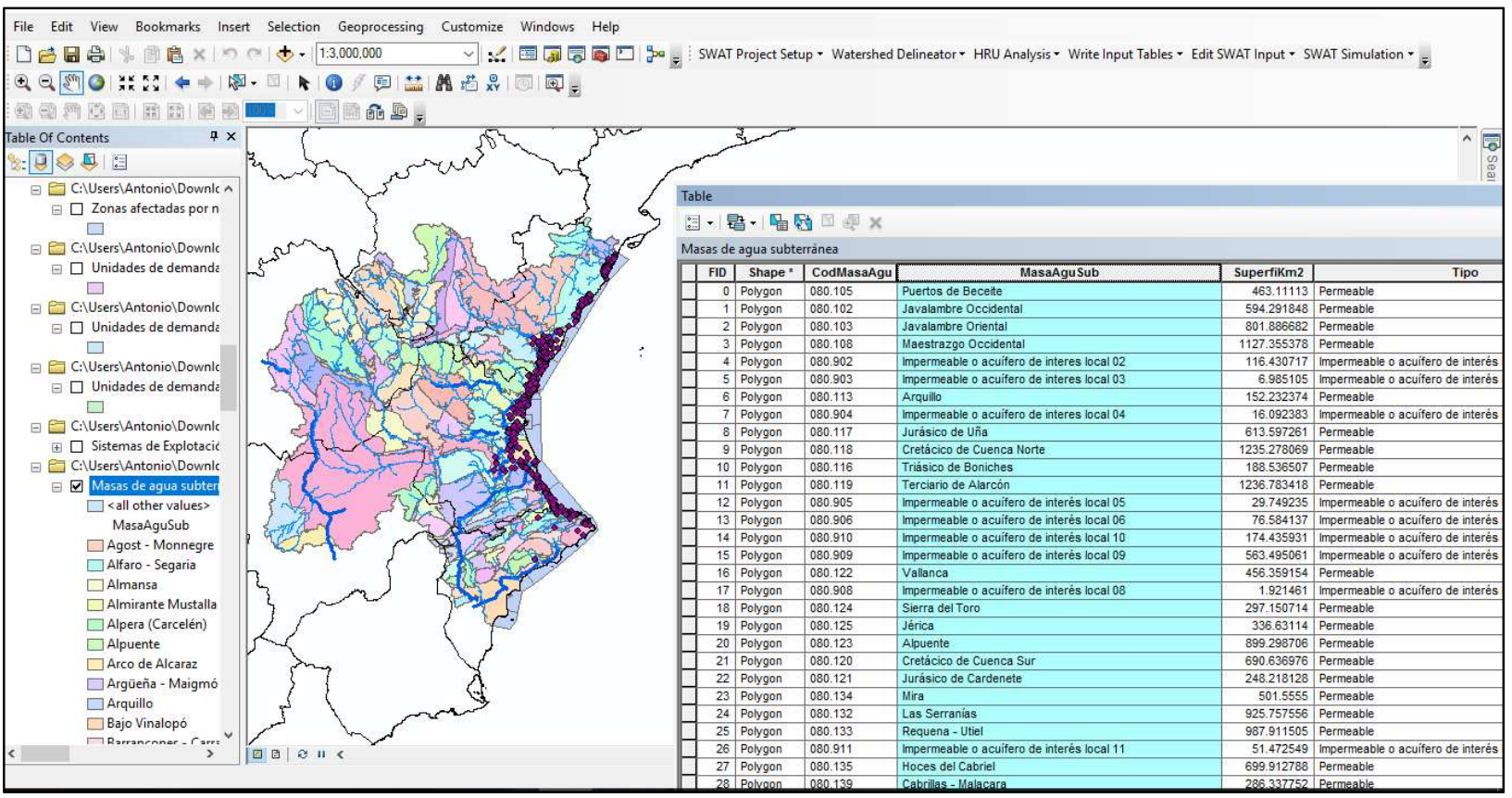

Figura 5. Interfaz de un SIG mostrando la tabla de atributos de la capa, en formato vectorial, denominada "Masas de Agua Subterránea" (propiedad de la Confederación Hidrográfica del Júcar). Fuente: elaboración propia.

Por último, destacar que los archivos con formato vectorial normalmente suelen codificarse con una extensión .shp (archivos shapefile). Los shapefile almacenan además sus atributos temáticos en un fichero con extensión .dbf. Otros ficheros asociados son:

$>$ Fichero .shx guarda un índice espacial para garantizar el acceso aleatorio a los datos almacenados en el fichero .shp.

$>$ Ficheros .sbx, .sbn y .qix contienen otros índices alternativos (no siempre aparecen al descargar un shapefile de la web).

$>$ Fichero .prj incluye información del sistema de referencia espacial que usa el fichero .shp. Tampoco se origina obligatoriamente, aunque es conveniente que aparezca si se quiere integrar la capa en otro sistema (Sastre-Olmos, 2010; UAM, 2011a; Alonso-Sarría, 2014; Olaya, 2014). 


\section{3-Ventajas y desventajas de los modelos Ráster y Vectorial}

En la Tabla 1 se indican las principales diferencias entre los modelos ráster y vectorial.

Tabla 1. Ventajas y desventajas de la información Ráster y Vectorial. Fuente: elaborado a partir de Paruelo (2007), Sastre-Olmos (2010) y UAM (2011a).

\begin{tabular}{|c|c|}
\hline FORMATO RÁSTER & FORMATO VECTORIAL \\
\hline Ventajas & Ventajas \\
\hline Estructura de datos simple & Elevada precisión \\
\hline $\begin{array}{c}\text { Facilidad para la representación de entidades } \\
\text { espaciales continuas }\end{array}$ & Facilidad de integración con CAD vectoriales \\
\hline $\begin{array}{c}\text { Elevada capacidad para la superposición y } \\
\text { combinación de capas }\end{array}$ & Mapas de elevada calidad \\
\hline $\begin{array}{c}\text { Capacidad para la realización de análisis } \\
\text { geoestadísticos }\end{array}$ & Capacidad para realizar análisis de redes \\
\hline $\begin{array}{c}\text { Capacidad para integrar datos de satélite } \\
\text { Eficiente capacidad de incorporación y } \\
\text { procesamiento de imágenes }\end{array}$ & $\begin{array}{c}\text { Estructuras de datos con topología y } \\
\text { representación eficiente de la misma }\end{array}$ \\
\cline { 2 - 2 } Desventajas & Ficheros de poco tamaño \\
\hline Estructura de datos menos compacta & Estructura de datos compacta \\
\hline Dificultades para representar la topología & Ineficiente para procesamiento de imágenes \\
\hline
\end{tabular}

\section{4-Servicios de Visualización: ¿el tercer formato?}

El principal inconveniente de los SIG radica, probablemente, en los elevados costes de adquisición, mantenimiento y actualización de la información espacial. Para paliar dicha problemática numerosas organizaciones han potenciado la creación de las denominadas "Infraestructuras de Datos Espaciales (IDE)" mediante las cuales se ha facilitado la explotación e intercambio de datos espaciales. Estas infraestructuras definen un conjunto de normas y estándares que los productores de datos espaciales (habitualmente organismos públicos) deben seguir.

Tal y como se mencionó en la lección "7.1-Sistemas de Información Geográfica. Conceptos Básicos" han sido varias las iniciativas llevadas a cabo en este sentido destacando la IDE Nacional de los Estados Unidos (NSDI), la Infraestructura para la Información Espacial en Europa (INSPIRE), la Infraestructura de Datos Espaciales de España (IDEE), etc.

La utilidad y estructura de las IDE se pueden inferir fácilmente a partir de los servicios de información geográfica que éstas suelen proporcionar al usuario. En la Tabla 2 se relacionan los servicios genéricos que la mayoría de IDE a menudo ofrecen. 
Tabla 2. Servicios de Información Geográfica de las IDE. Fuente: elaborado a partir de Iniesto y Núñez (2014).

\begin{tabular}{|c|c|c|}
\hline Tipo de Servicio & Denominación del Servicio & Función del Servicio \\
\hline De localización & $\begin{array}{c}\text { Servicios Web de Catálogo } \\
(\mathrm{CSW})\end{array}$ & $\begin{array}{c}\text { Permite buscar qué datos y } \\
\text { servicios hay disponibles en la } \\
\text { IDE }\end{array}$ \\
\hline \multirow{3}{*}{ De descarga } & $\begin{array}{c}\text { Servicio de Fenómenos en la } \\
\text { Web (WFS) }\end{array}$ & $\begin{array}{l}\text { Descargar y analizar datos } \\
\text { vectoriales }\end{array}$ \\
\hline & $\begin{array}{c}\text { Servicio de Coberturas en la } \\
\text { Web (WCS) }\end{array}$ & $\begin{array}{l}\text { Descargar y analizar datos } \\
\text { ráster } \\
\end{array}$ \\
\hline & $\begin{array}{l}\text { Servicio de Descarga de } \\
\text { ficheros (FTP o similar) }\end{array}$ & $\begin{array}{l}\text { Descargar ficheros } \\
\text { predefinidos }\end{array}$ \\
\hline De transformación & $\begin{array}{c}\text { Servicios de Transformación } \\
\text { de Coordenadas (WCTS) }\end{array}$ & $\begin{array}{c}\text { Transformar coordenadas y } \\
\text { Sistemas de referencia }\end{array}$ \\
\hline \multirow{2}{*}{ De visualización } & $\begin{array}{l}\text { Servicio de Mapas en la Web } \\
\text { (WMS) }\end{array}$ & $\begin{array}{c}\text { Visualizar datos } \\
\text { vectoriales y ráster en la web, } \\
\text { etc }\end{array}$ \\
\hline & $\begin{array}{c}\text { Servicios Web de Teselas de } \\
\text { Mapa (WMTS) }\end{array}$ & $\begin{array}{c}\text { Define teselas regulares de } \\
\text { imágenes devueltas por un } \\
\text { WMS }\end{array}$ \\
\hline \multirow{4}{*}{ Otros } & $\begin{array}{c}\text { Servicio de Nomenclátor } \\
\text { (Gazetteer) }\end{array}$ & $\begin{array}{l}\text { Localizar la posición } \\
\text { geográfica de un topónimo }\end{array}$ \\
\hline & $\begin{array}{c}\text { Servicios Web de } \\
\text { Procesamiento (WPS) }\end{array}$ & Ejecutar una aplicación \\
\hline & Web Map Context (WMC) & $\begin{array}{l}\text { Guardar una situación activa y } \\
\text { reproducirla }\end{array}$ \\
\hline & Styled Layer Descriptor (SLD) & $\begin{array}{c}\text { Cambiar la simbología de un } \\
\text { WMS }\end{array}$ \\
\hline
\end{tabular}

Como se puede observar en la Tabla 2, en definitiva la información espacial contenida en las IDE suele estar disponible tanto en formato ráster como vectorial. No obstante, debido principalmente a la dificultad conceptual de ambos modelos, al elevado tamaño de sus ficheros, etc. se han desarrollado, en el entorno de las IDE, los denominados "Servicios de Visualización". Estos servicios permiten visualizar y superponer información geográfica "georreferenciada" (es decir, mapas con sistema de coordenadas, etc.), tanto ráster como vectorial, mostrando una imagen a través de un navegador o visor web (cliente ligero) o a través de nuestro propio programa SIG instalado en el ordenador (cliente pesado) y, opcionalmente, consultar los atributos de los datos geográficos en un punto. En el caso del cliente pesado, el usuario debe "copiar y pegar" la dirección URL procedente de la IDE en la interfaz de su propio programa SIG (Figura 6). 

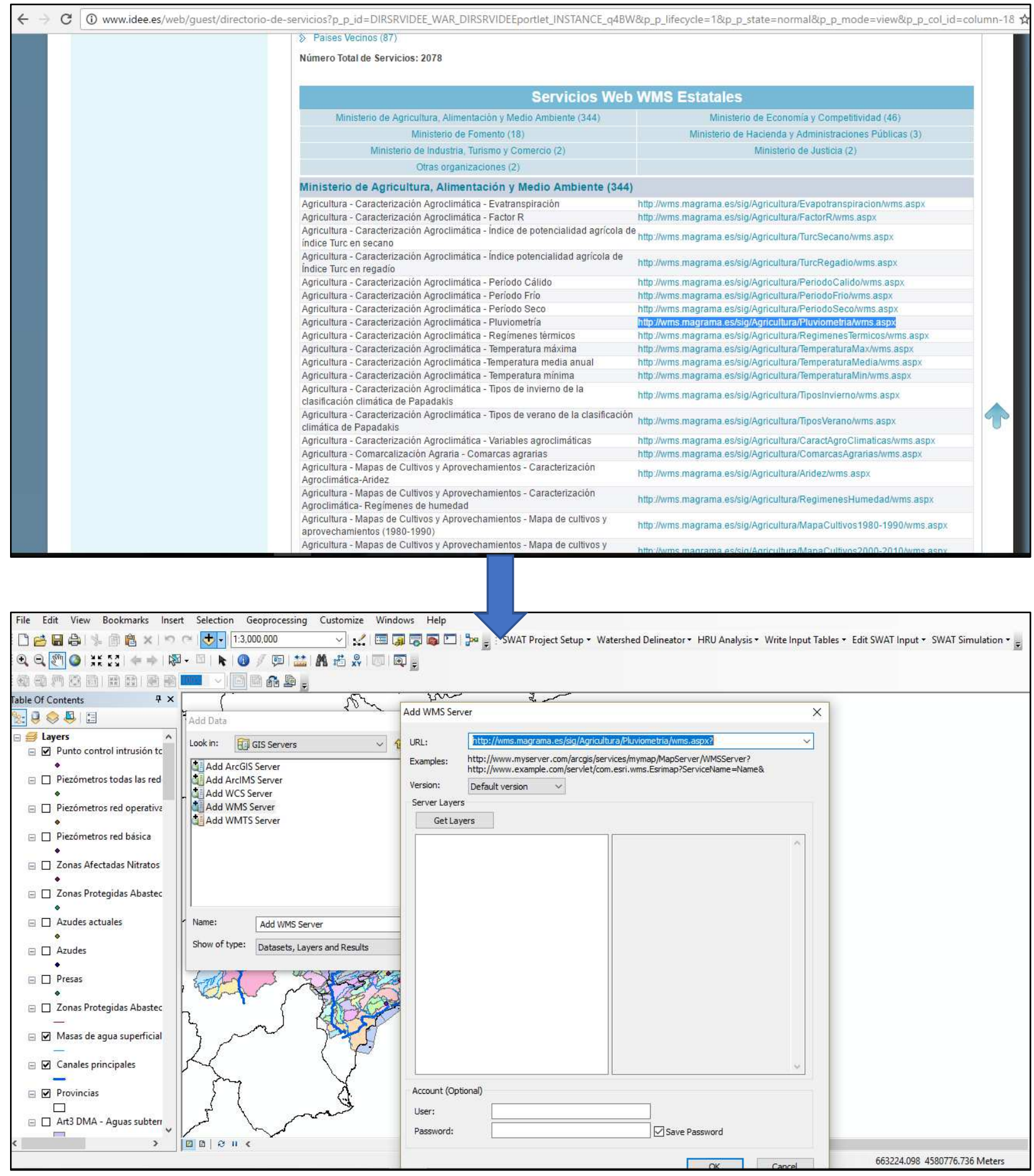

Figura 6. Procedimiento para visualizar un mapa WMS en un programa SIG. Fuente: elaboración propia.

Actualmente, los servicios de visualización se dividen en dos grandes grupos:

Servicio de Mapas en la Web (WMS - Web Map Service), el más extendido.

$>$ Servicios Web de Teselas de Mapa (WMTS -Web Map Tile Service), menos comercializado. 
Cabe destacar que en los mencionados servicios de visualización no se accede a los datos originales, es decir a las capas ráster y/o vectoriales. Simplemente se obtiene una representación gráfica de los mismos, una imagen digital generada normalmente en formato PNG, GIF o JPEG (Ballari, 2006; UAM, 2011b; Alonso-Sarría, 2014; Olaya, 2014; Iniesto y Núñez, 2014).

En la práctica, la información espacial se visualiza habitualmente con ficheros ráster, vectoriales y direcciones URL de los Web Map Service, razón por la que en ocasiones tienden a considerarse como un tercer formato. Sin embargo, debe tenerse en cuenta que los servicios de visualización son simplemente imágenes, no modelos o capas de información a partir de las cuales poder obtener nuevas capas. Por ejemplo, a partir del mapa ráster de elevación del terreno (Modelo Digital de Elevaciones o MDE) el usuario puede generar el mapa ráster de pendientes. Dicho procedimiento resultaría inviable en caso de que el MDE procediera de un servidor WMS.

\section{5-Ejemplos de mapas combinando ficheros Ráster, Vectorial y WMS}

A continuación, se relacionan, a modo de ejemplo, algunos mapas elaborados, para diferentes lugares de España, con un SIG en el que se combinan capas en formato ráster y vectorial, así como imágenes procedentes de servidores WMS. En los siguientes mapas además se han aplicado herramientas básicas en el manejo de los SIG.

\section{- Información proporcionada por un SIG en un caso práctico}

En la Figura 7 se muestra un mapa realizado en la Provincia de Alicante (Demarcación Hidrográfica del Júcar). Dicho mapa es resultado de la superposición de capas en diferentes formatos. En este caso se utilizaron servidores WMS (ortofoto del PNOA máxima actualidad $)^{5}$ y capas SHP de la web de la Demarcación Hidrográfica del Júcar 6 .

\footnotetext{
${ }^{5}$ Plan Nacional de Ortofotografía Aérea (PNOA): http://www.idee.es/wms/PNOA/PNOA?

${ }^{6}$ Ministerio de Agricultura, Alimentación y Medio Ambiente. Confederación Hidrográfica del Júcar (CHJ). Descarga de Datos y Cartografía http://aps.chj.es/down/html/descargas.html
} 


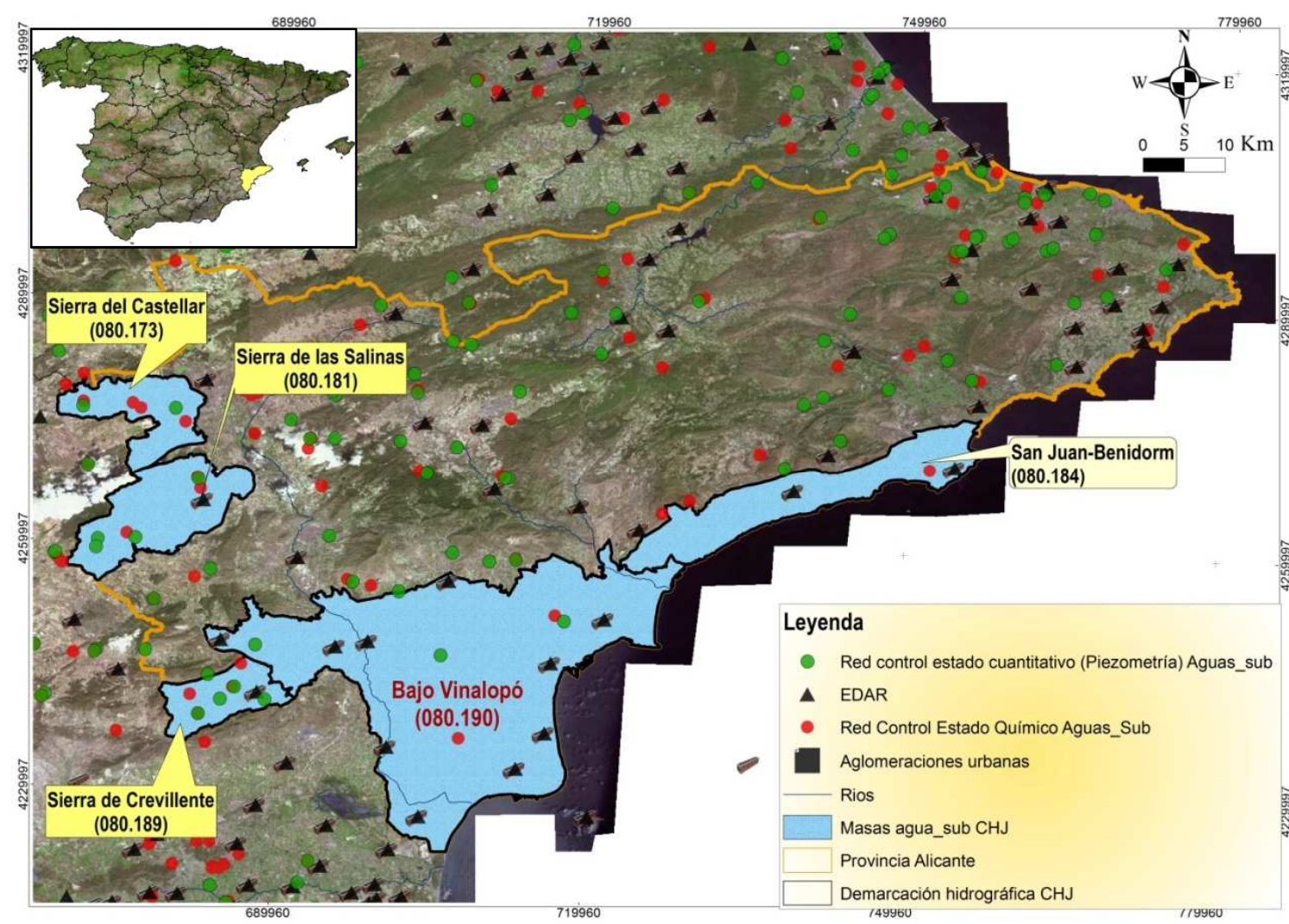

Figura 7. Masas de Agua Subterránea en mal estado cuantitativo y cualitativo en la Provincia de Alicante (España) y posible relación de las mismas con EDAR y núcleos urbanos. Escala cartográfica o de representación 1:250.000. Fuente: elaboración propia con capas de PNOA max.actualidad y CHJ.

Gracias a la superposición de las citadas capas en el mismo sistema de referencia (Proyección ETRS-89/UTM Zone 30N), en el mapa se puede observar la ubicación de determinadas agrupaciones urbanas cuyas aguas residuales son actualmente tratadas en Estaciones Depuradoras de Aguas Residuales (EDARs) y las posibles relaciones (depuración de aguas, reutilización, recarga artificial, etc.) de éstas con Masas de Agua Subterránea en mal estado cuantitativo (sobreexplotación) y cualitativo (contaminación química por nitratos) en la provincia alicantina. Además, tal y como se mencionó en apartados anteriores, las capas en formato vectorial cargadas en este proyecto GIS tienen asociadas tablas de datos (tablas de atributos) con las que poner cifras a las afirmaciones enunciadas.

\section{- Georreferenciación en un SIG}

En la rutina de trabajo con un SIG es habitual que el usuario encuentre archivos que no contienen un sistema de coordenadas establecido. Dicha situación es común por ejemplo en las láminas y anejos de los proyectos donde se muestran imágenes (en .jpeg, .png, etc.) sin referenciar. En caso de que dichas imágenes sean cargadas en un SIG no 
será posible realizar la superposición de las mismas con el resto de capas del proyecto sig. En esta situación resulta necesario realizar la georreferenciación de la capa (imagen) recién cargada, es decir, asignar a dicha capa el sistema de coordenadas con el que el usuario esté trabajando en el proyecto sig.

En la Figura 8, se muestra la superficie del Parque Nacional de las Tablas de Daimiel y la ampliación del mismo realizada en BOE (2014). Esta resolución contiene una imagen (formato pdf) con la superficie ampliada en el mencionado parque nacional. Para trabajar con la nueva superficie fue necesario realizar la georreferenciación de la imagen contenida en BOE (2014) generando a partir de la misma una nueva capa (en formato shapefile).

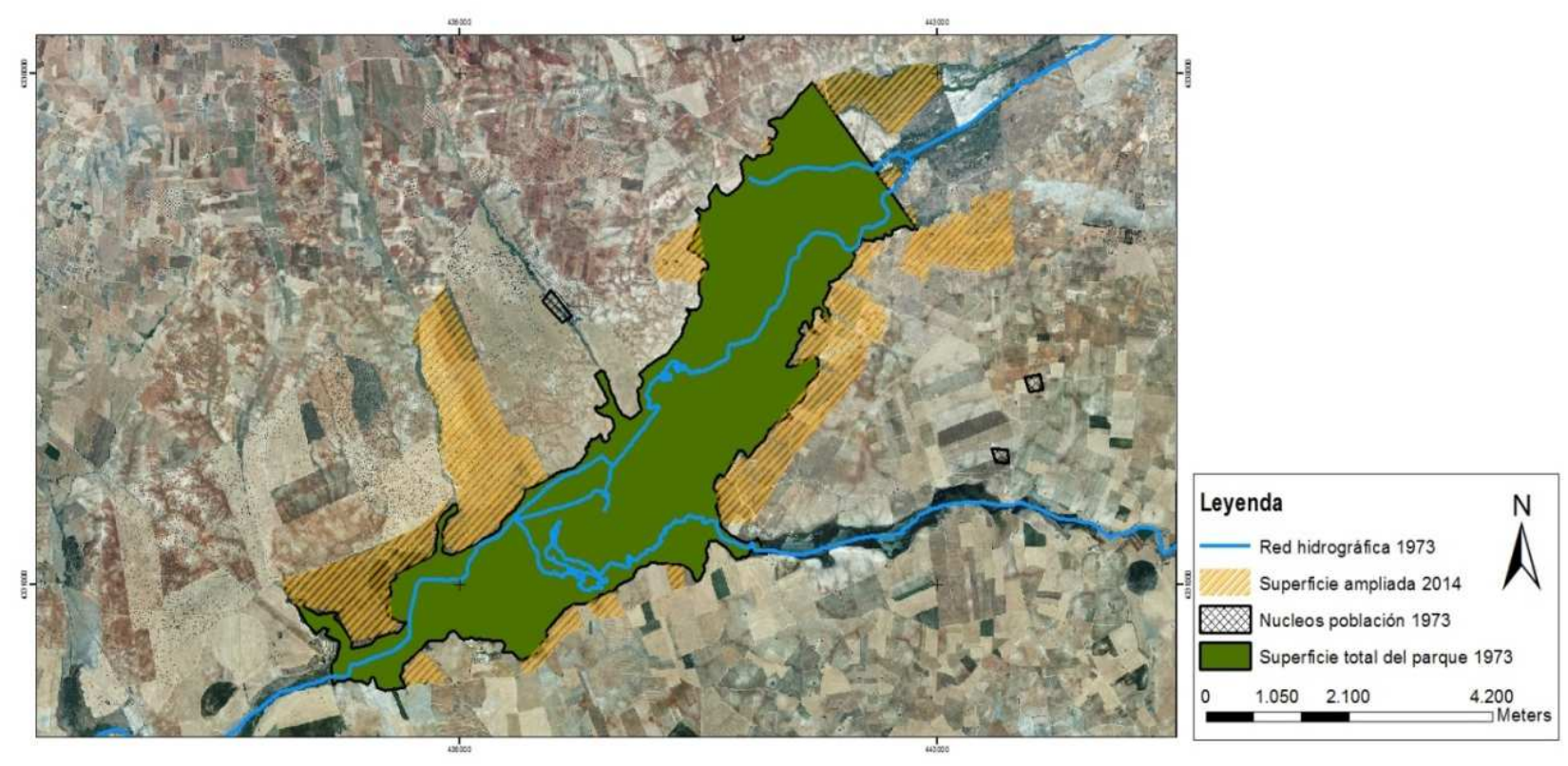

Figura 8. Superficie original y superficie ampliada en 2014 en el Parque Nacional de Las Tablas de Daimiel. Escala de representación 1:50.000. Fuente: Jódar-Abellán et al (2016).

\section{- BUFFER en un SIG}

En el manejo de los SIG en la práctica, y en especial en estudios de Impacto Ambiental y de Ordenación del Territorio, es frecuente la delimitación de zonas de influencia, áreas críticas, zonas de policía, zonas de servidumbre, etc. alrededor de la zona del proyecto en cuestión. Se trata simplemente de franjas de territorio en las que la actividad a realizar se encuentra limitada, por ejemplo, al prohibir la construcción de viviendas en una franja de territorio de $500 \mathrm{~m}$ alrededor de una porción de la línea de costa declarada de Dominio Público Marítimo Terrestre. Estas denominadas franjas de territorio se calculan en un SIG gracias a la herramienta BUFFER. Con dicha herramienta, a partir de la capa original (la zona de estudio), se generan nuevas capas en formato 
shapefile en las que simplemente se establece la franja de territorio a ocupar (100 m, $200 \mathrm{~m}$, etc.).

En la Figura 9, se muestra a modo de ejemplo la fijación de áreas críticas en cuanto al ruido ambiental derivado de una actividad extractiva a cielo abierto.

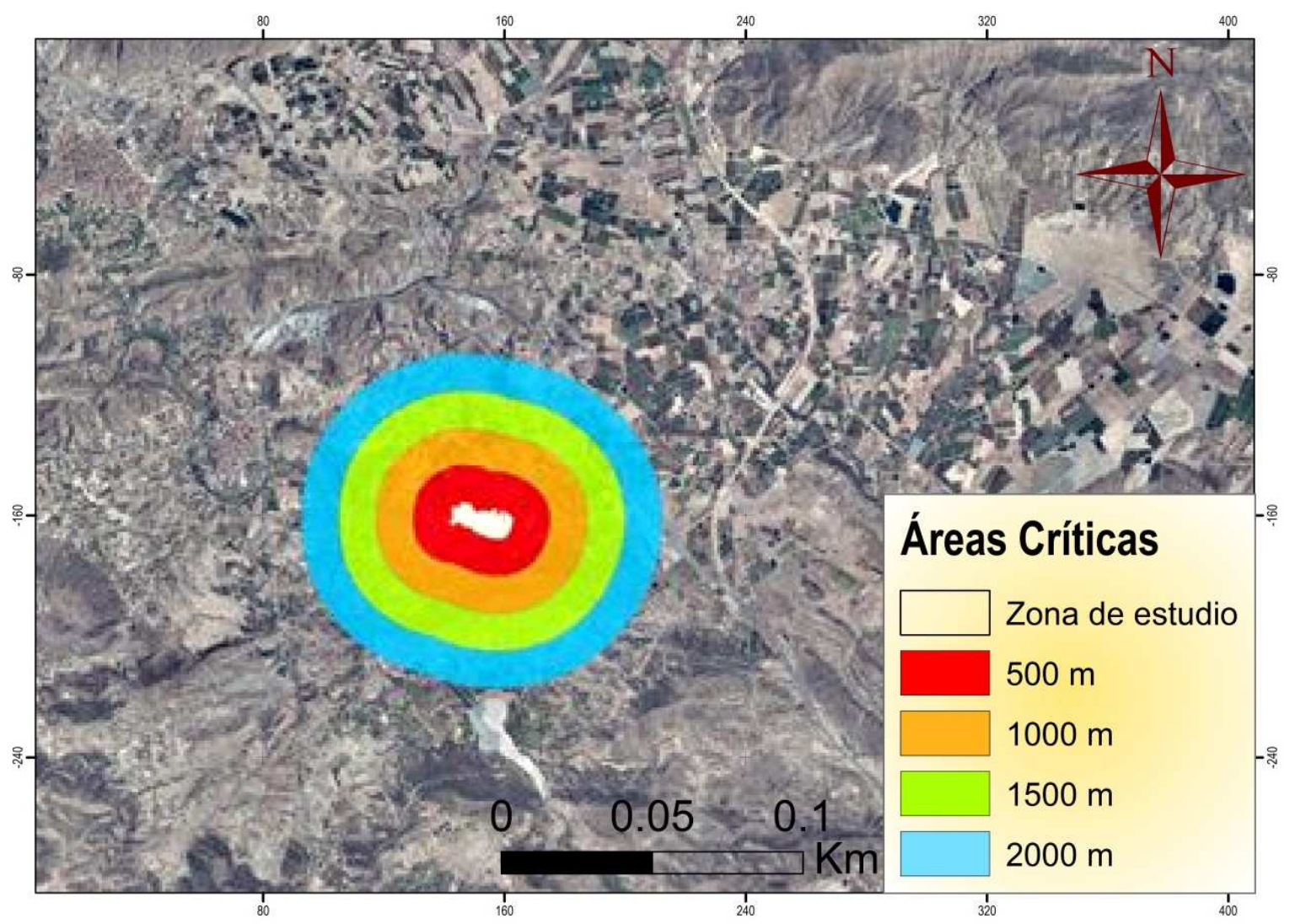

Figura 9. Distribución espacial de las áreas críticas en la emisión de ruido ambiental. Estudio de Impacto Ambiental (EsIA) de la Cantera Solana de San Ginés (Región de Murcia). Fuente: elaboración propia para Ambiental S.L.

\section{- Recortes de capas en un SIG}

En la mayoría de trabajos realizados con los SIG el análisis se circunscribe a un ámbito o zona de estudio concreta. En estos casos resulta conveniente limitar (recortar) todas las capas utilizadas en el proyecto SIG a los límites de la zona de estudio. Dicha tarea se realiza mediante la herramienta recortes, habitualmente denominada en los programas SIG como EXTRACT-CLIP. En dicha herramienta se incluye simplemente la capa a recortar (input layer) y la capa de la zona de estudio (clip layer) a cuyos límites se desea recortar la capa anterior. 
En la Figura 10 se muestran a modo de ejemplo las capas, en formato vectorial, de Masas de Agua Subterránea de las Confederaciones Hidrográficas del Segura, Júcar y Ebro recortadas exclusivamente a los límites de la Comunidad Valenciana.

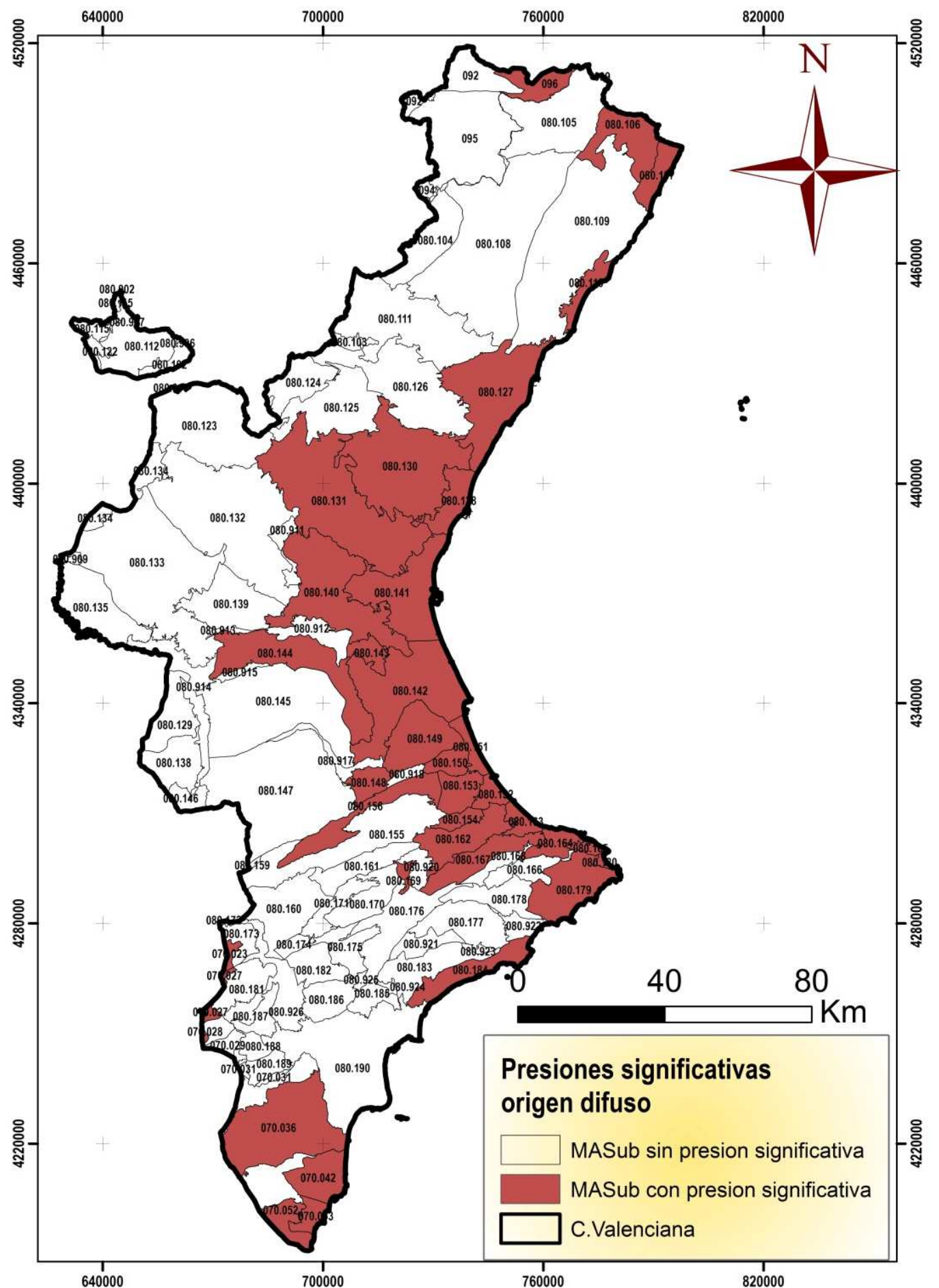

Figura 10. Masas de Agua Subterránea de la Comunidad Valenciana con presiones significativas por fuentes de contaminación difusa. Fuente: elaboración propia. 


\section{- Edición de figuras, esquemas, etc. con un SIG}

Actualmente, la mayoría de los programas SIG tienen incorporadas herramientas para editar esquemas y figuras pudiendo realizar fácilmente una composición de imágenes como la mostrada en la Figura 11.

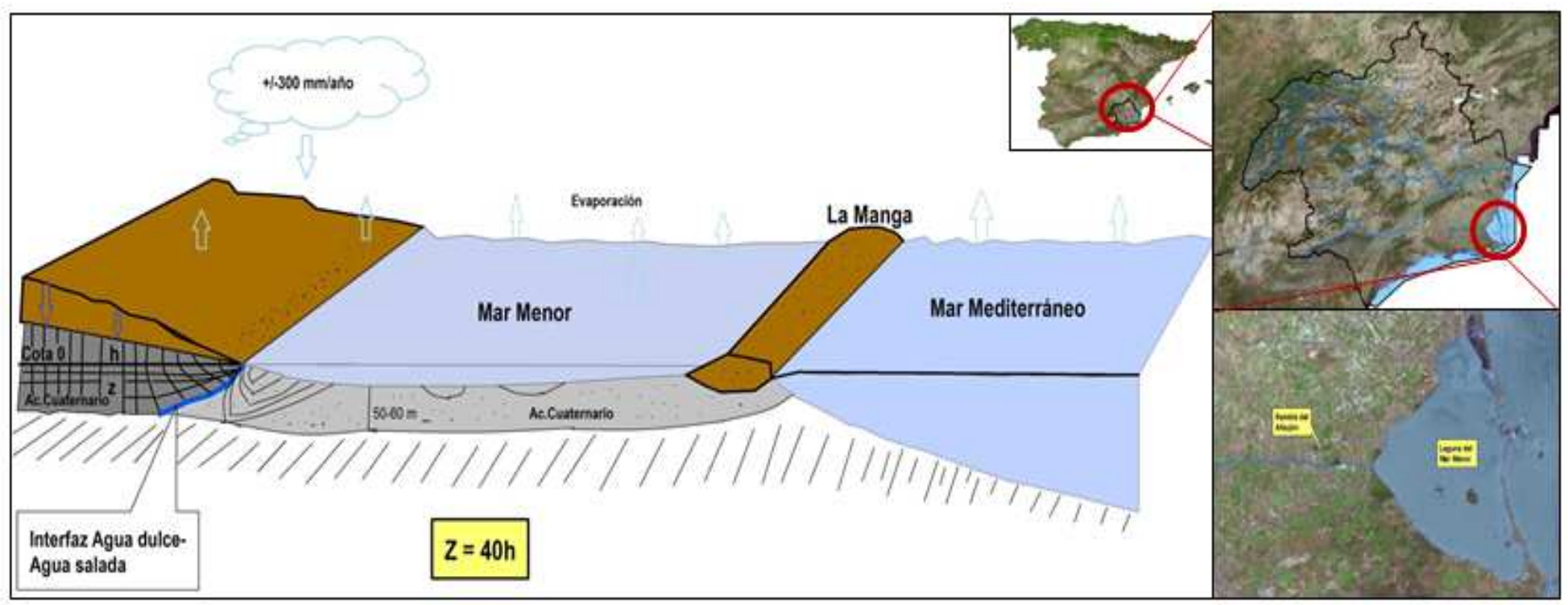

Figura 11. Composición de imágenes elaboradas en un SIG. Zona de estudio: Rambla del Albujón y Mar Menor (cuenca del Segura). Fuente: elaboración propia.

\section{PRINCIPALES SIG UTILIZADOS HOY EN DÍA}

Actualmente son numerosos los software SIG a descargar en un PC particular como cualquier otro programa. A continuación se indican someramente los más utilizados:

\section{1-Privativos (de pago)}

\section{- ArcGIS}

Producido y comercializado por ESRI (Environmental Systems Research Institute). Pese a ser privativo, se trata probablemente del software SIG más utilizado a nivel global debido a la potencia y sencillez que ofrecen sus herramientas.

Concretamente el genérico ArcGIS engloba diferentes aplicaciones que se pueden dividir en familias temáticas como ArcGIS Server, para la publicación y gestión web, ArcGIS Móvil para la captura y gestión de información en campo, y ArcGIS Desktop. La aplicación de ArcGIS para escritorio, incluye en sus últimas ediciones las herramientas ArcReader, ArcMap, ArcCatalog, ArcToolbox, ArcScene y ArcGlobe, además de diversas 
extensiones. ArcGIS for Desktop se distribuye comercialmente bajo tres niveles de licencias que son, en orden creciente de funcionalidades (y coste): ArcView, ArcEditor y Arclnfo.

Bibliografía recomendada para aprender a utilizar ArcGIS:

> Nivel básico: UAM (2011a); UAM (2011b); Puerta-Tuesta et al (2011); https:// doc.arcgis.com/es/arcgis-online/reference/shapefiles.htm.

$>$ Nivel intermedio: Puerta-Tuesta et al (2013).

$>$ Nivel avanzado: ESRI (2012).

Cómo descargar gratis ArcGIS for Desktop en mi PC: https://www.google.es/webhp? sourceid=chrome-instant\&ion=1\&espv=2\&ie=UTF-8\#q=como\%20descargar\%20arcgis\%20gratis.

\section{2-De Software libre (código abierto)}

\section{- GRASS (Geographic Resources Analysis Support System)}

Software SIG bajo licencia GPL (software libre). GRASS está disponible principalmente para plataformas UNI (GNU/Linux). Sin embargo, recientemente se han implementado versiones de este programa en el Sistema Operativo Microsoft Windows (Windows NT, Windows 2000, Windows XP, etc.).

Se trata con diferencia del programa SIG más potente existente en la actualidad. Ello es debido principalmente a:

- El lenguaje que utiliza el programa basado en librerías Cygwin, comandos (códigos), paquetes relacionados con $\mathrm{R}$, etc. Se trata en cierto modo de un lenguaje de programación en el que el usuario introduce consultas en las consolas o terminales de GRASS (interfaz del programa) y éstas devuelven resultados (mapas, gráficos, etc.). En la Figura 12 se muestra una pequeña consulta: 


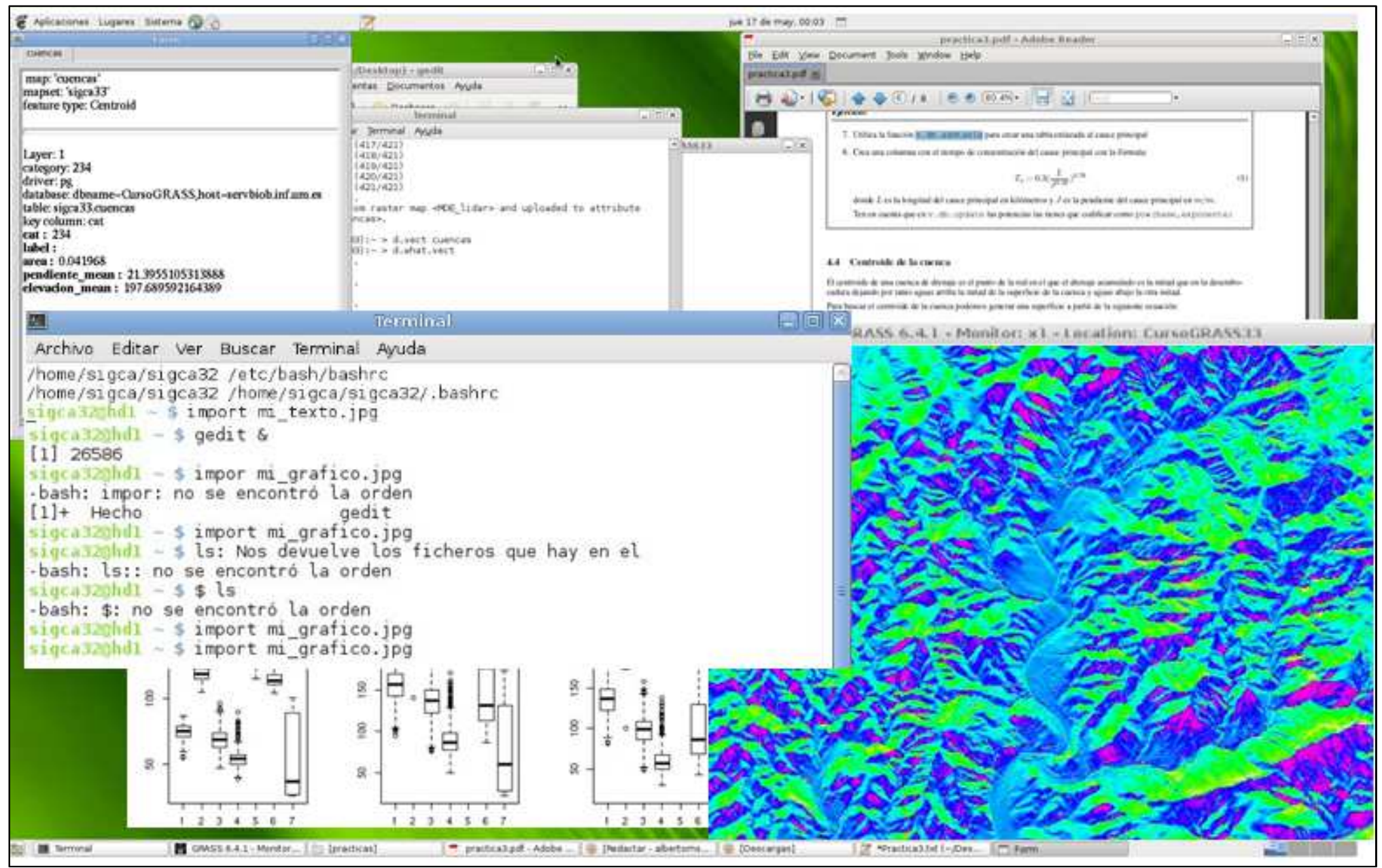

Figura 12. Terminales de GRASS versión 6.4.1 que devuelven el modelo digital de elevación del terreno (MDE). Fuente: elaboración propia.

$>$ Debido a que es un programa en código abierto y a que los diferentes usuarios del mismo (principalmente investigadores) pueden desarrollar sus propios paquetes en GRASS (al igual que sucede en el software R) existe actualmente una comunidad científica mundial que cuelga y publica en la red sus nuevos paquetes. De este modo, cualquier usuario puede implementarlos.

$>$ Al Sistema Operativo en el que tradicionalmente se ha desarrollado (Linux: es más potente que Windows).

Estas características dotan al programa de una complejidad considerable en comparación con el resto de SIG cuyas interfaces (más visuales e intuitivas) ofrecen un entorno más amigable para el usuario. Por ello, normalmente GRASS suele quedar más relegado al campo de la investigación e innovación en SIG, mientras que en la empresa privada y en la Administraciones Públicas se suele utilizar ArcGIS.

Bibliografía y enlaces recomendados para intentar aprender a utilizar GRASS:

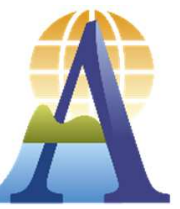


$>$ Nivel básico: Neteler (2005), Alonso-Sarría (2011).

> Nivel intermedio: Tutorial de GRASS 6.0 en castellano (http://web.archive.org/ web/20070928133454/http://www.gdf-hannover.de/lit_html/nutshell_v10_es/node2 .html).

> Nivel avanzado: GRASS Community "worldwide network of developers" (https: //grass.osgeo.org/support/community/).

Cómo descargar GRASS en mi PC: https://grass.osgeo.org/download/software/.

\section{- QGIS}

QGIS, anteriormente llamado también Quantum GIS, presenta una interfaz y funcionamiento muy similar a ArcGIS. Debido a su juventud (los primeros lanzamientos de QGIS se sitúan en el año 2002), a día de hoy es menos potente que los SIG tradicionales (ArcGIS y GRASS). No obstante, dado que se trata de un SIG en código abierto, en el futuro dicha situación probablemente se revierta.

En la Figura 13 se muestra la interfaz de QGIS con algunas capas en formato ráster, vectorial y servicios WMS.

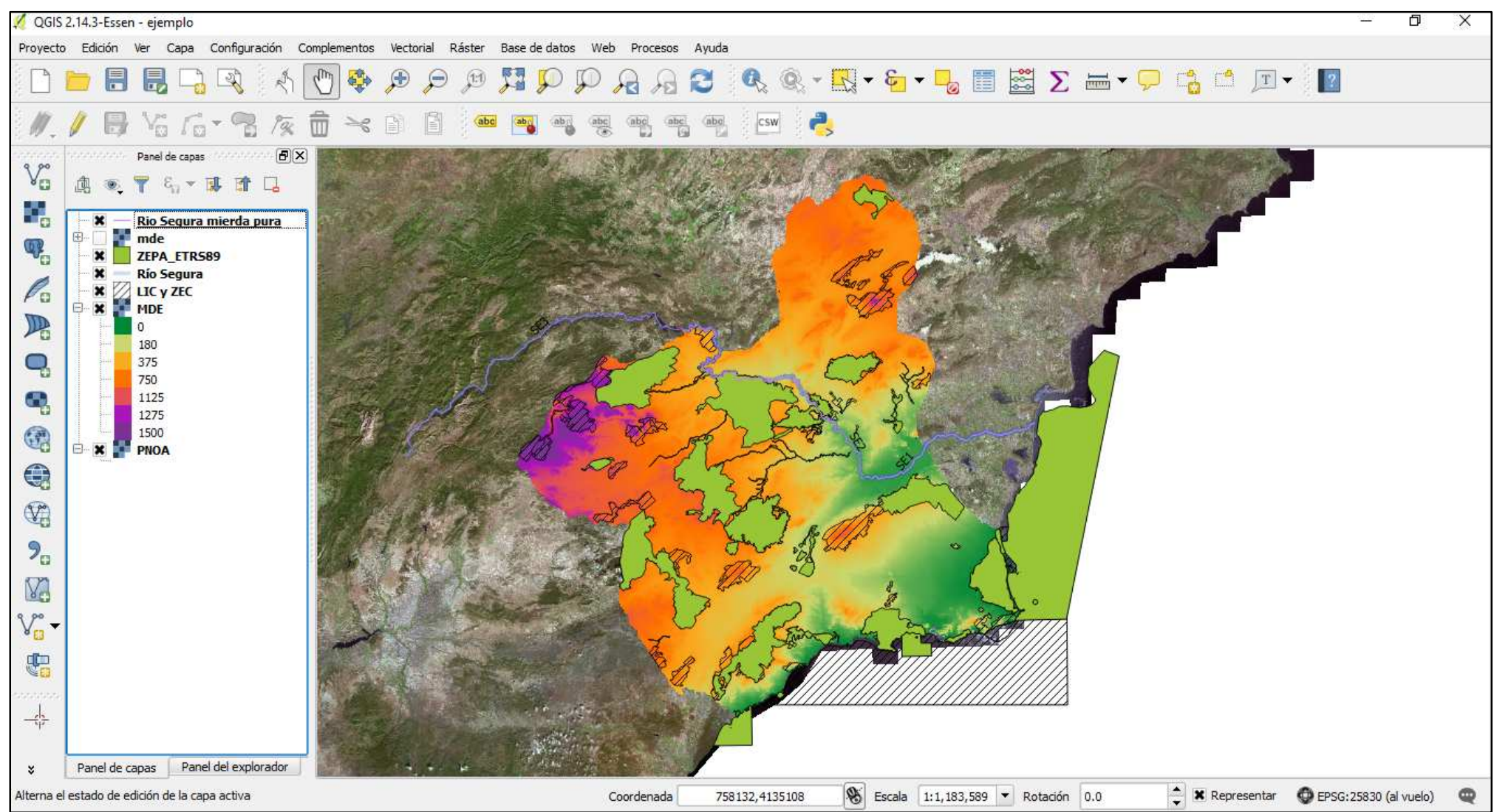


Figura 13. Interfaz de QGIS versión 2.14.3 mostrando capas en formato ráster (MDE), en vectorial (Río Segura, ZEPA_ETRS89, LIC y ZEC) y servicios WMS (ortofoto del PNOA). Zona de estudio: Región de Murcia. Fuente: elaboración propia.

Bibliografía recomendada para aprender a utilizar QGIS:

> Nivel básico: http://docs.qgis.org/2.14/en/docs/training_manual/ Y http://docs. qgis.org/2.14/pdf/.

$>$ Nivel intermedio: http://docs.qgis.org/2.14/en/docs/user_manual/.

$>$ Nivel avanzado: http://www.qgis.org/es/site/forusers/books/index.html.

Cómo descargar QGIS en mi PC: http://www.qgis.org/es/site/forusers/download.html.

\section{- GvSIG}

Este proyecto fue inicialmente impulsado por el gobierno regional de la Comunidad Valenciana (Generalidad Valenciana) de España. De hecho, las siglas gvSIG son la denominación "Generalitat Valenciana Sistema de Información Geográfica". Es menos potente que los SIG tradicionales (ArcGIS y GRASS).

Bibliografía recomendada para aprender a utilizar GvSIG:

$>$ http://www.gvsig.com/es/divulgacion/libros.

$>$ http://www.gvsig.com/es.

$>$ http://downloads.gvsig.org/download/gvsig-desktop/dists/2.2.0/docs/gvsig-2.2.0-doc1.0.0-es.pdf.

$>$ http://media.wix.com/ugd/1c299f_09f1926dba7945f997acd2a8f3d273c2.pdf.

Cómo descargar GvSIG en mi PC: http://www.gvsig.com/es/productos/gvsig-desktop/ descargas.

\section{- R y RStudio}

RStudio es un entorno de desarrollo integrado (IDE) para el lenguaje de programación en base R. Aunque la finalidad de R y RStudio se orienta principalmente a estadística y análisis de datos, en la actualidad la comunidad de desarrolladores de $R$ ha elaborado gran cantidad de paquetes (comandos, funciones, líneas de código, etc.) que posibilitan la implementación de los SIG en el entorno R. De hecho, a menudo los desarrolladores de GRASS conectan los paquetes del entorno GRASS con R.

Concretamente RStudio tiene la misión de proporcionar el entorno informático estadístico de $\mathrm{R}$, permitiendo un análisis y desarrollo para que cualquiera pueda analizar 
los datos con R. Actualmente RStudio se encuentra disponible para los Sistemas Operativos Windows, Mac y Linux. La interfaz de RStudio incluye una consola, es decir, un editor de sintaxis que apoya la ejecución del código, así como herramientas para el trazado, la depuración y la gestión del espacio de trabajo.

Al igual que sucede con GRASS, el aprendizaje de los SIG a través de la interfaz de RStudio probablemente entraña una mayor dificultad que mediante otros programas con interfaces más sencillas y visuales (como ArcGIS, QGIS, etc.). En la Figura 14 se muestra la interfaz de RStudio en la que he cargado capas ráster y vectoriales.

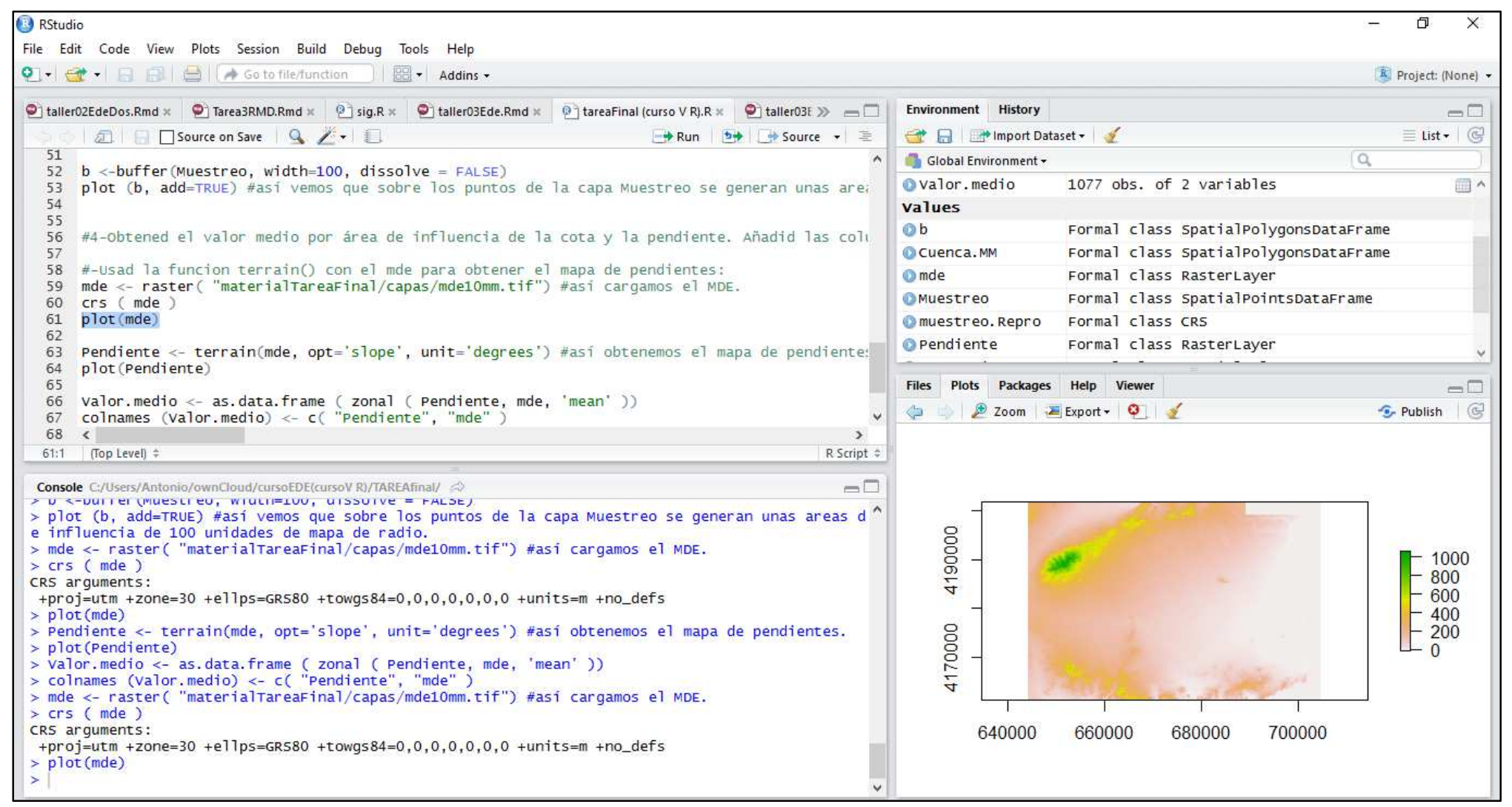

Figura 14. Interfaz de RStudio versión 1.0.44 mostrando el plot del Modelo Digital de Elevaciones (MDE). Zona de estudio: campo de Cartagena (Región de Murcia). Fuente: elaboración propia.

Bibliografía recomendada para aprender a utilizar paquetes SIG dentro de RStudio:

> Paquete Ráster en RStudio: Hijmans et al (2016).

$>$ Paquete rasterVis: Visualization Methods for Raster Data (https://cran.r-project. org/web/packages/rasterVis/index.html).

> Paquete Shapefiles: Read and Write ESRI Shapefiles (https://cran.r-project.org/ web/packages/shapefiles/index.html). 
$>$ Paquete Maptools: Tools for Reading and Handling Spatial Objects (https://cran. r-project.org/web/packages/maptools/index.html).

> Paquete RArcInfo: Functions to import data from Arc/Info V7.x binary coverages (https://cran.r-project.org/web/packages/RArclnfo/index.html).

> Paquete rLiDAR: LiDAR (Light Detection and Ranging) Data Processing and Visualization (https://cran.r-project.org/web/packages/rLiDAR/index.html).

> Paquete rgdal: Bindings for the Geospatial Data Abstraction Library (https://cran.r-project.org/web/packages/rgdal/index.html).

> Mapeo web con el paquete Leaflet para lenguaje R: http://amsantac.co/blog/es/ r/2015/08/11/leaflet-R-es.html.

> Paquete rgl: 3D Visualization Using OpenGL (https://cran.r-project.org/web/ packages/rgl/index.html).

Evidentemente para poder implementar los paquetes mostrados en la consola de RStudio, antes es necesario que el usuario entienda y maneje el citado programa. A continuación, se relacionan cuatro manuales de nivel básico:

$>$ Curso de Introducción a la Estadística. Tutorial 02: Estadística descriptiva con R (http://www.postdata-statistics.com/IntroEstadistica/Tutoriales/Tutorial-02.pdf). Manual muy ilustrativo y sencillo.

> Entorno de trabajo R. RStudio (http://www.um.es/ae/FEIR/10/).

$>$ User's Manual RStudio (http://www.r-tt.com/downloads/es/Recovery_Manual.pdf).

$>$ Manual básico para el tratamiento de datos de calidad del aire mediante el lenguaje estadístico R (http://www.openair-project.org/PDF/R_Openair aplicado_a_ calidad_del_aire.pdf).

Cómo descargar R y RStudio en mi PC:

$>$ Descarga de R. Se introduce en el buscador "late version $R$ ". A fecha de 09/11/2016 es la R-3.3.2 (para Windows): https://cran.r-project.org/bin/windows /base/.

$>$ Descarga de RStudio. Se introduce en el buscador "late version RStudio". A fecha de 09/11/2016 es la RStudio Desktop 1.0.44: https://www.rstudio.com/ products/rstudio/download/.

Nota: "aunque en la práctica el usuario utiliza R y RStudio desde la interfaz (consola) de RStudio, debemos recordar que R y RStudio son dos programas diferentes, por lo que 
el usuario debe realizar ambas descargas. En ocasiones el usuario cae en el error de creer que al haber descargado RStudio también descarga R. Para poder utilizar ambos programas desde la consola de RStudio debe existir compatibilidad entre las versiones de R y RStudio. Por ejemplo, la última versión de RStudio (la 1.0.44) sólo es compatible con la versión de R 2.11.1 o posteriores. En definitiva, para evitar este problema de posibles incompatibilidades es recomendable descargar cada 6 meses las últimas versiones de ambos programas, reemplazando lógicamente las descargadas previamente en nuestro PC. De este modo, podremos acceder a los nuevos paquetes introducidos por la comunidad de desarrolladores de R en las últimas versiones".

\section{BIBLIOGRAFÍA}

Alonso-Sarría, F. 2011. Tutorial de introducción a GRASS. 120 pp. Disponible en: http://www.um.es/geograf/sigmur/sigpdf/grass_tutorial.pdf

Alonso-Sarría, F. 2014. Sistemas de Información Geográfica. Temario de la asignatura (20132014). Universidad de Murcia. 245 pp. Disponible en: http://fobos.inf.um.es/alonso/SIGCCAA/temario.pdf

Ballari, D. 2006. Puesta en marcha y explotación de geoservicios del Open Geospatial Consortium: Curso teórico-práctico con tecnologías Open Source. WMS-Servidores de Mapas en Red. Universidad Politécnica de Madrid. 45 pp. Disponible en: https://imedea.uib-csic.es/gis/geoportal/doc/1-WMS-Curso_OGC.pdf.

BOE. 2014. Resolución de 21 de enero de 2014, de Parques Nacionales, por la que se publica el Acuerdo del Consejo de Ministros de 10 de enero de 2014 por el que se amplían los límites del Parque Nacional de las Tablas de Daimiel por incorporación de terrenos colindantes al mismo. BOE 23 (27 enero 2014), sec. I. Pág. 4955. Disponible en: https://www.boe.es/boe/dias/2014/01/27/pdfs/BOE-A-2014-785.pdf.

ESRI. 2012. Tutorial de 3D Analyst en Castellano. Versión ArcGIS10.0. ESRI (Environmental Systems Research Institute). 202 pp. Disponible en: http://help.arcgis.com/es/arcgisdesktop/10.0/pdf/tutorial_3d_analyst.pdf

Hijmans, R.J. et al. 2016. Package Ráster: Geographic Data Analysis and Modeling. Version 2.5-8. Repository CRAN. Disponible en: https://cran.r-project.org/web/packages/ raster/raster.pdf

Iniesto, M. y Núñez, A. 2014. Introducción a las Infraestructuras de Datos Espaciales. Ministerio de Fomento. Instituto Geográfico Nacional. Centro Nacional de Información Geográfica (CNIG). 418 pp. DOI: 10.7419/162.12.2014. ISBN: 162-14022-0. Disponible en: http://hdl.handle.net/2117/26164 
Jódar-Abellán, A., Albaladejo-García, J.A., y Fernández-Rodríguez, H. 2016. Análisis de la Evolución y Estado Actual del Parque Nacional Las Tablas de Daimiel (Cuenca Alta del Guadiana, España). 13ํEd. Congreso Nacional del Medio Ambiente (CONAMA). 81 pp. Disponible en: http://www.conama11.vsf.es/conama10/download/files/ conama2016/CT\%202016/1998971805.pdf.

Neteler, M. 2005. GRASS 6: Una guía de inicio (GRASS 6 in a nutshell). Open Source Geospatial '05 Conference. University of Minnesota, Minneapolis, MN, USA. 39 pp. Disponible en: http://grassbook.org/wp-content/uploads/neteler/osg05/neteler_ grass6_nutshell2005_spanish.pdf

Olaya, V. 2014. Sistemas de Información Geográfica. 854 pp. Disponible en: http://volaya.github.io/libro-sig/

Paruelo, J.M. 2007. Cartografía, Sistemas de Información Geográficos (SIG) y Teledetección. LART-FAUBA. 37 pp. Disponible en: http://es.slideshare.net/suelosyaguas/cap-clasesig-uba

Puerta-Tuesta, R., Rengifo-Trigozo, J., y Bravo-Morales, N. 2011. ArcGIS10-Básico. Universidad Nacional Agraria de la Selva (Perú). Facultad de Recursos Naturales Renovables. 148 pp. Disponible en: http://media.wix.com/ugd/1c299f_dda35 fe1f25c483691e2f020076f8dbc.pdf

Puerta-Tuesta, R., Rengifo-Trigozo, J., y Bravo-Morales, N. 2013. Manual de ArcGIS10-Nivel Intermedio. Universidad Nacional Agraria de la Selva (Perú). Facultad de Recursos Naturales Renovables. 117 pp. Disponible en: http://media.wix.com/ugd/1c299f_ 0d9d6a943d414ce685bdcc0f10ff756d.pdf

Sastre-Olmos, P. 2010. Sistemas de Información Geográfica (SIG). Técnicas básicas para estudios de biodiversidad. Instituto Geológico y Minero de España (IGME). 58 pp. Disponible en: http://media.wix.com/ugd/1c299f_c2bcafcbaa9c4cf7b68d1628b2f450 d0.pdf

UAM. 2011a. Tutorial (nivel básico) para la elaboración de mapas con ArcGIS. Universidad Autónoma de Madrid. 48 pp. Disponible en: http://biblioteca.uam.es/cartoteca/ documentos/CURSO_SIG_BASICO_I.pdf

UAM. 2011b. Tutorial de Servidores WMS (Web Map Service). Visualización de Cartografía disponible en los Servidores WMS en Sistemas de Información Geográfica (ArcGIS y gvSIG). Universidad Autónoma de Madrid. 30 pp. Disponible en: http://biblioteca.uam.es/cartoteca/documentos/Tutorial_WMS.pdf 


\title{
LECCIÓN 7.3: INFRAESTRUCTURAS DE DATOS ESPACIALES EN LOS SISTEMAS DE INFORMACIÓN GEOGRÁFICA
}

\author{
Antonio Jódar Abellán
}

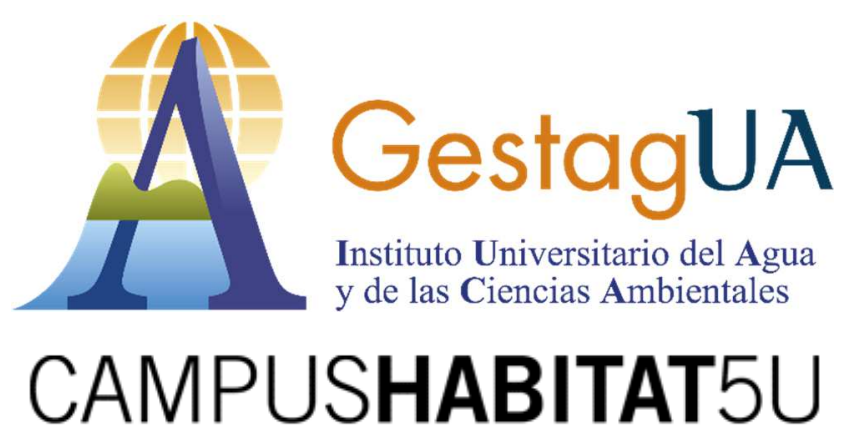




\section{INTRODUCCIÓN}

Tal y como se mencionó en la Lección 7.2-Tratamiento de la Información Espacial en Sistemas de Información Geográfica las "Infraestructuras de Datos Espaciales (IDE)" son en definitiva centros de descarga (bases de datos) a los que los usuarios recurren para descargar capas (en formato ráster, vectorial y/o direcciones URL de servicios web) de un modo gratuito.

Habitualmente las IDE cuelgan a disposición del público toda la información espacial que poseen para su descarga directa en archivos comprimidos (del tipo .zip, .rar, etc.). Sin embargo, en ocasiones, para la descarga de determinada información espacial las IDE exigen que los usuarios realicen una petición formal de la misma autentificándose y alegando los fines para los que ésta será utilizada (caso por ejemplo de ortofotos realizadas a elevada resolución y que incluyan bases militares pudiendo afectar a la seguridad nacional, etc.).

En esta última lección del Módulo 7: Herramientas Geográficas se incluyen algunas recomendaciones que el usuario debe tener en consideración antes de realizar una descarga masiva de datos espaciales, seguido de lo cual se muestran algunos ejemplos de IDE a nivel internacional, europeo, nacional y autonómico.

\section{CONSIDERACIONES PREVIAS A LA DESCARGA DE DATOS DE UNA IDE}

\section{1-Realizar todas las descargas de un mismo proyecto SIG en el mismo directorio}

Antes de comenzar la descarga de información espacial desde una IDE o base de datos, resulta conveniente que el usuario decida en qué directorio guardará dicha información. Recomendaciones:

El directorio (carpeta) debe poseer una ruta corta en nuestro PC, del tipo $\mathrm{C} /$ :BaseDatosX. Ello asegura que posteriormente nuestro programa SIG lea correctamente la información que guardemos en el directorio "BaseDatosX".

Para asegurar una lectura correcta desde el SIG es recomendable que el título de nuestro directorio no posea espacios. Ejemplo: BaseDatosX.

Anotar en un documento, bloc de notas, etc. la fecha de descarga de la información espacial procedente de la citada base de datos, así como el link de la misma. Ello es 
importante si en un futuro la IDE actualiza su información espacial y el usuario no recuerda la fecha en que descargó la versión previa de dicha información.

$>$ Una vez que el usuario ha descargado la información que necesita de la IDE, y la ha guardado en un directorio concreto, no debe "trasladar (cortar-pegar)" la información (las capas) contenidas en ese directorio a otro, puesto que en tal caso la visualización de dichas capas en nuestro proyecto SIG ya no será posible (Figura 1).

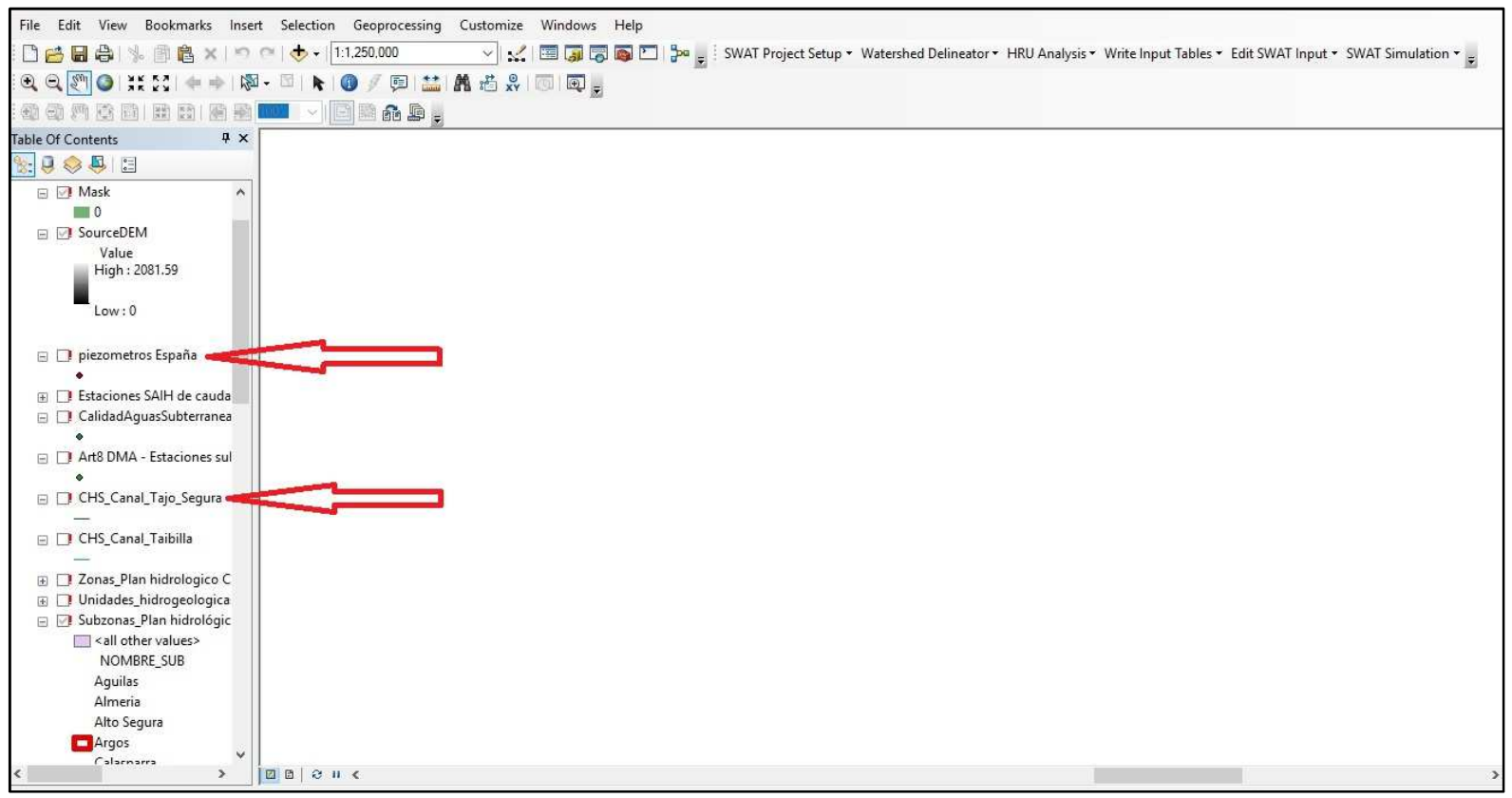

Figura 1. Interfaz de ArcGIS10.2.2 con las capas "caídas" al haberlas cambiado de directorio. Se observan unos signos de exclamación en color rojo con los que el programa advierte del fallo. Fuente: elaboración propia.

Esta última situación se soluciona elaborando un nuevo proyecto SIG en el que establezcamos la nueva ruta en la que se encuentran las capas que pretendemos cargar en la interfaz del SIG. No obstante, si el número de capas es considerable volver a cargarlas una a una nos hará perder tiempo.

\section{2-Establecer el directorio del Proyecto SIG}

La mayoría de programas SIG requieren que antes de empezar a trabajar con la propia interfaz del SIG establezcamos el directorio del Proyecto SIG. Sencillamente se trata de guardar ("Guardar como") nuestra interfaz del SIG en un directorio determinado (carpeta) y con un nombre que escojamos (el nombre del proyecto, por ejemplo: Pepe). 
Sin embargo, a diferencia de lo que ocurre con determinados programas como "Microsoft Word" o "Microsoft Excel" donde los ficheros pueden ser trasladados (copiados-pegados) entre diferentes carpetas, en los programas SIG, habitualmente, el proyecto queda inutilizado al realizar dicha operación.

\section{3-Establecer el Sistema de Coordenadas por defecto en el Proyecto SIG}

Por último, antes de cargar en nuestro proyecto SIG las capas descargadas desde la web de la IDE, es necesario establecer el "Sistema de Coordenadas por defecto que tendrá el proyecto" y por lo tanto todas las capas que en él carguemos. De este modo, en caso de que alguna de las capas cargadas posea un sistema de coordenadas diferente al establecido por el usuario en el proyecto SIG, el programa advertirá de dicha situación para que el usuario "reproyecte" esa capa.

Como resulta evidente el establecimiento de un mismo Sistema de Coordenadas para todas las capas del proyecto tiene por objeto que la superposición de las mismas sea exacta.

En España, desde 2015, la proyección escogida por defecto para todas las capas es la ETRS-1989/UTM Zone 30N (Figura 2).

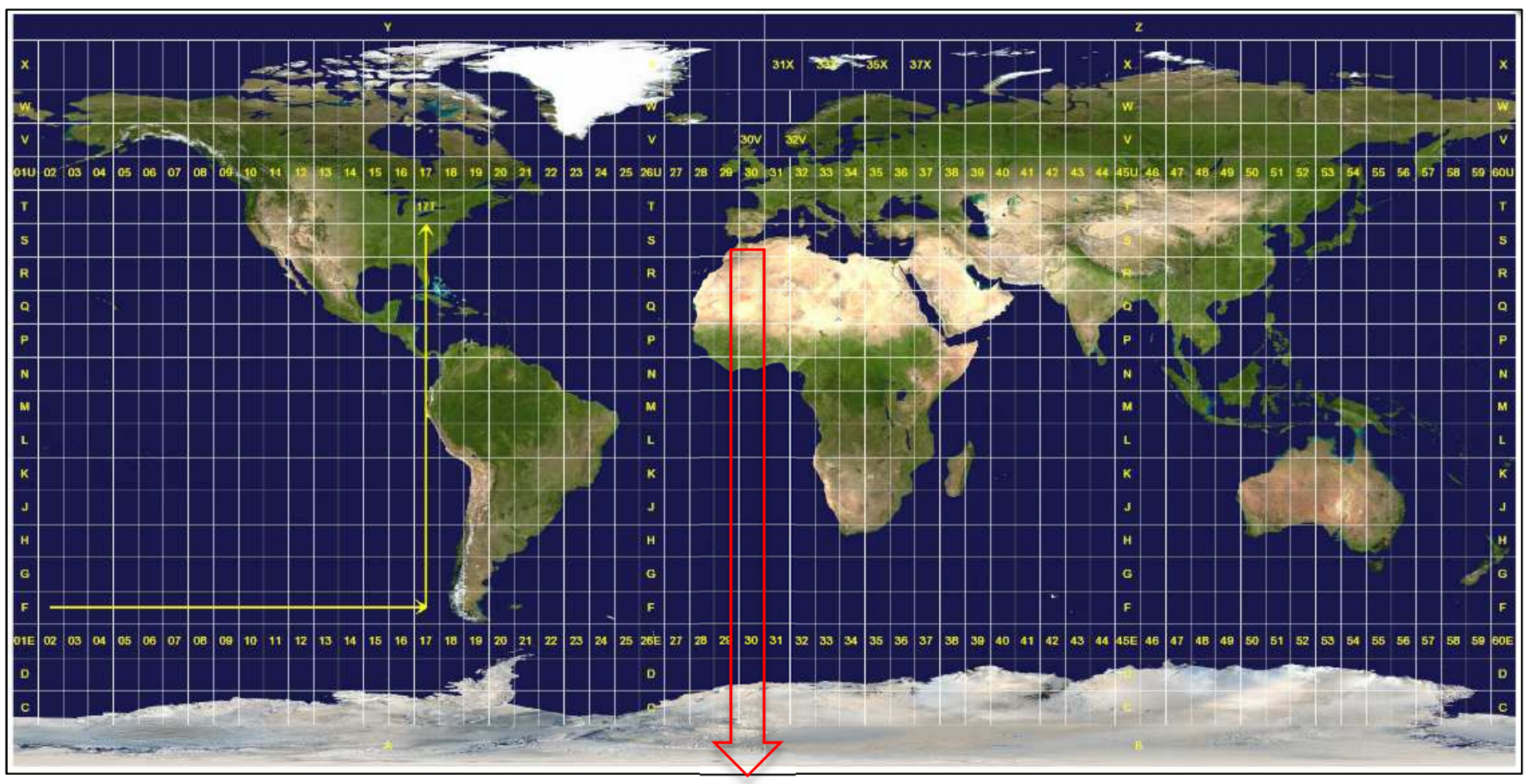




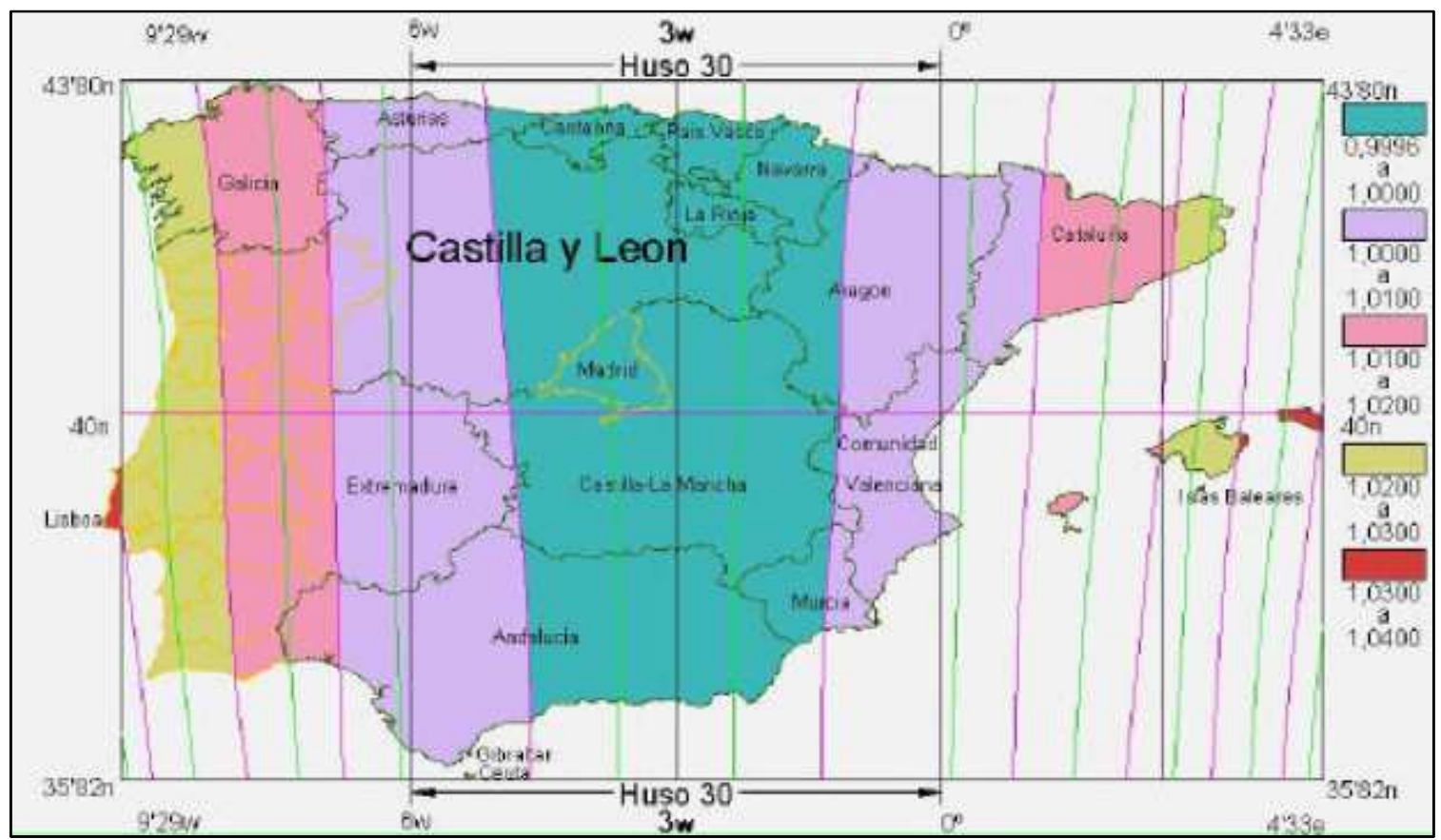

Figura 2. División del Globo en Zonas UTM (arriba). Península Ibérica: Zonas 29, 30 y 31 de izquierda a derecha (abajo). Canarias es la 28. Fuente: http://joanrocablog.com/?p=11560 y http://www.um.es/ geograf/sigmur/temariohtml/node8_ct.html.

Para una mayor comprensión sobre Sistemas de Referencia Espacial, Geodesia y Cartografía (es decir, Datums, Redes Geodésicas, Geoide, Elipsoide, Tipos de Proyecciones, la Proyección Universal Transverse Mercator, etc.) se remite a SastreOlmos (2010), Alonso-Sarría (2014) e IGN (2015).

\section{IDES A DIFERENTES NIVELES}

A continuación, se muestran, a modo de ejemplo, algunas Infraestructuras de Datos Espaciales (IDE) a nivel internacional, europeo, nacional y autonómico.

\section{1-IDEs a nivel internacional}

\section{-Base de datos DIVA-GIS}

La base de datos mundial DIVA-GIS permite la descarga gratuita de cartografía (coberturas de usos de suelo, tipos de suelo, MDE, áreas administrativas, demografía, etc.), principalmente en formato ráster y vectorial para los 194 países del planeta. Enlace: http://www.diva-gis.org/gdata. 
En la Figura 3, se muestran las capas del "Modelo Digital de Elevaciones (MDE)" y "Áreas Administrativas" para Cuba y Australia.
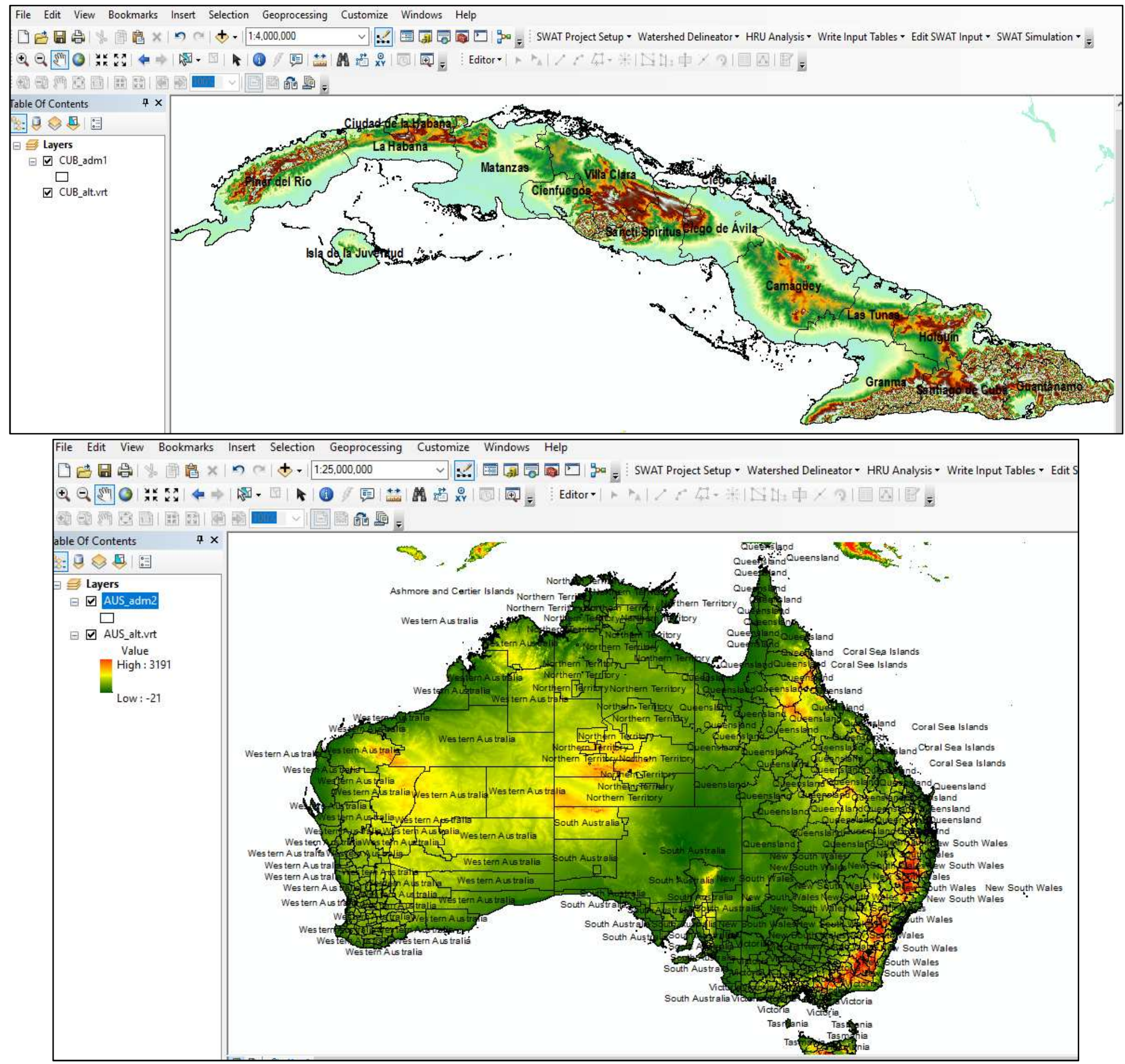

Figura 3. Interfaz de ArcGIS10.2.2 mostrando las capas MDE y Áreas Administrativas para Cuba (arriba) y Australia (abajo) propiedad de la base de datos mundial DIVA-GIS. Fuente: elaboración propia. 
Como se puede observar en la Figura 3, la sencillez del proceso y la cantidad de información obtenida son considerables. Simplemente, he descargado las citadas capas para Cuba y Australia y las he visualizado en el programa SIG. Destacar, además, que tras los archivos en formato vectorial, en este caso la capa de Áreas Administrativas, se encuentra la tabla de atributos con información de demografía, etc. para las diferentes regiones de ambos países.

\section{-Base de datos Harmonized World Soil Database}

En algunos casos, las Infraestructuras de Datos Espaciales o bases de datos están diseñadas para que el usuario las descargue directamente como una aplicación de escritorio en su propio PC. Dicha alternativa suele ser común en bases de datos mundiales con información a nivel de continente donde la descarga de cartografía de país en país sería demasiado lenta. Es el caso de la base de datos mundial de tipos de suelos "Harmonized World Soil Database $v$ 1.20" (Figura 4). Enlace: http://webarchive.iiasa.ac.at/Research/LUC/External-World-soil-database/HTML/.

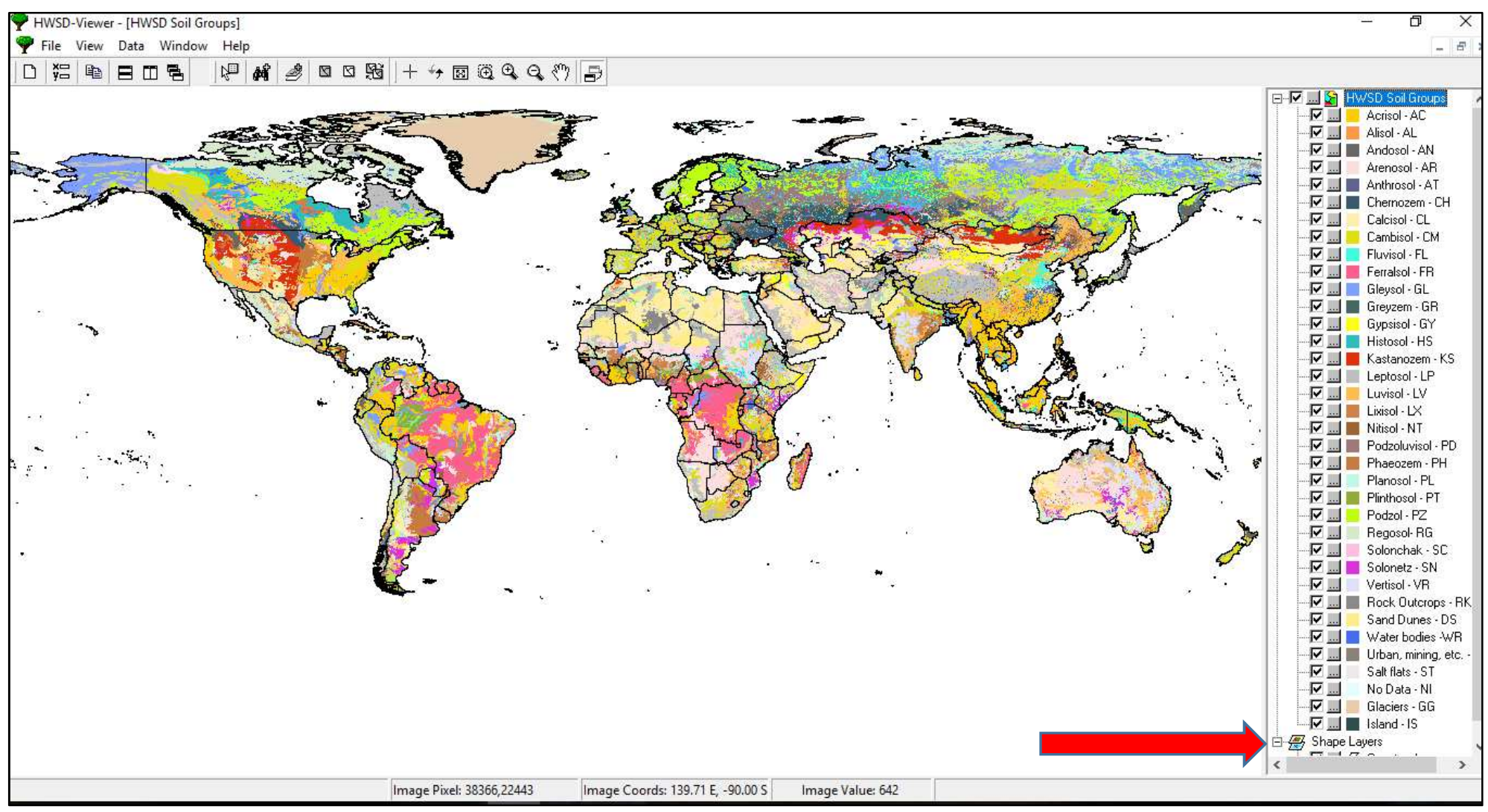

Figura 4. Aplicación de escritorio de la base de datos "Harmonized World Soil Database v 1.20". 
Destacar que habitualmente en este tipo de aplicaciones de escritorio el usuario puede cargar sus propias capas ráster o vectoriales (lo indico en la Figura 4 con la flecha roja).

\section{2-IDE a nivel europeo}

\section{-Base de datos Corine European soil database version 2}

A nivel europeo podemos mencionar por ejemplo la base de datos europea "Corine European soil type database version 2" creada en 2003 por la European Environment Agency. La escala operacional a la que se realizó es 1:1.000.000 (Figura 5). Enlace: http://www.eea.europa.eu/data-and-maps/data/soil-type.

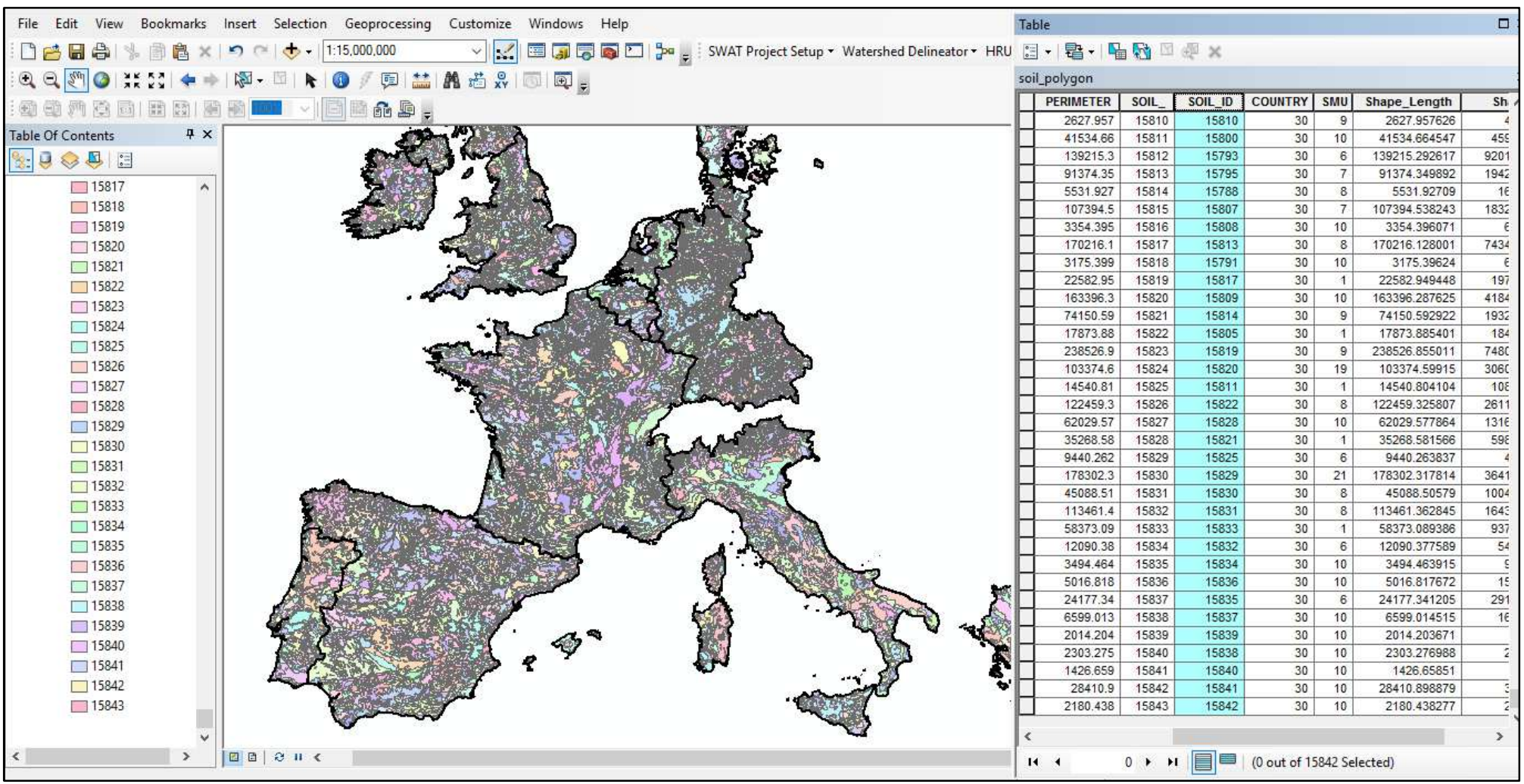

Figura 5. Interfaz de ArcGIS10.2.2 mostrando la capa de suelos de la base de datos "Corine European soil type database version 2". Fuente: elaboración propia.

En la Figura 5 se muestra la capa vectorial de suelos de la base de datos "Corine European soil type database version 2" junto con la tabla de atributos de la misma. Se observa cómo hay 15.843 identificadores de suelo, es decir, 15.843 lugares en Europa inventariados para esta base de datos. Ello no quiere decir que los tipos o clases de suelo sean 15.843 , ya que numerosas regiones presentan el mismo tipo de suelo. 
Con posterioridad la "Land Resource Management Unit of the Joint Research Centre of the European Commission" mejoró la resolución espacial y el no de países incluidos en la European Soil Database (ESDB). Las nuevas versiones están disponibles en: http://eusoils.jrc.ec.europa.eu/data.html.

\section{3-IDE a nivel nacional (España)}

\section{-Centro de Descargas del Instituto Geográfico Nacional}

El Centro de Descargas del Instituto Geográfico Nacional es probablemente la IDE más potente de toda España. Dispone de información espacial (capas en formato ráster y vectorial) a nivel de: Ortofotos del PNOA max.actualiad, Mapa Topográfico Nacional a escala 1:50.000 y 1:25.000, Usos del Suelo (capas de Corine Land Cover y Siose), Modelo Digital de Elevaciones a diferentes escalas (alguno de los cuales se ha realizado incluso con tecnología Lidar), Mapas Cartográficos, Mapas de Población, etc. El usuario puede descargar toda esta información seleccionando la división administrativa que desee (Comunidad Autónoma, Provincia o Municipio) y la Hoja del Mapa Topográfico Nacional a escala 1:50.000. Ello es debido a que dada la elevada resolución de los ficheros publicados por el IGN, el tamaño de los mismos también es considerable, razón por la que se hace necesario que el usuario haga una selección ("máscara") de la información que necesita. Enlace Centro de Descargas del Instituto Geográfico Nacional: http://centrodedescargas.cnig.es/CentroDescargas/buscadorCatalogo. do. Web oficial del IGN: http://www.ign.es/ign/main/index.do.

En las siguientes figuras, se muestra la interfaz de ArcGIS10.2.2 con diferentes capas procedentes del IGN y la elaboración propia de capas a partir de las primeras (caso del mapa de pendientes a partir del Modelo Digital de Elevaciones o MDE, y del mapa de subcuencas a partir del MDE junto con la red hidrográfica). Dado que en todas las figuras se selecciona la misma zona de estudio: cuenca alta del río Taibilla (en la cuenca hidrográfica del río Segura) ello nos indica el elevado conocimiento y el nivel de detalle que puede llegar a obtenerse con un SIG en una zona de trabajo determinada. 


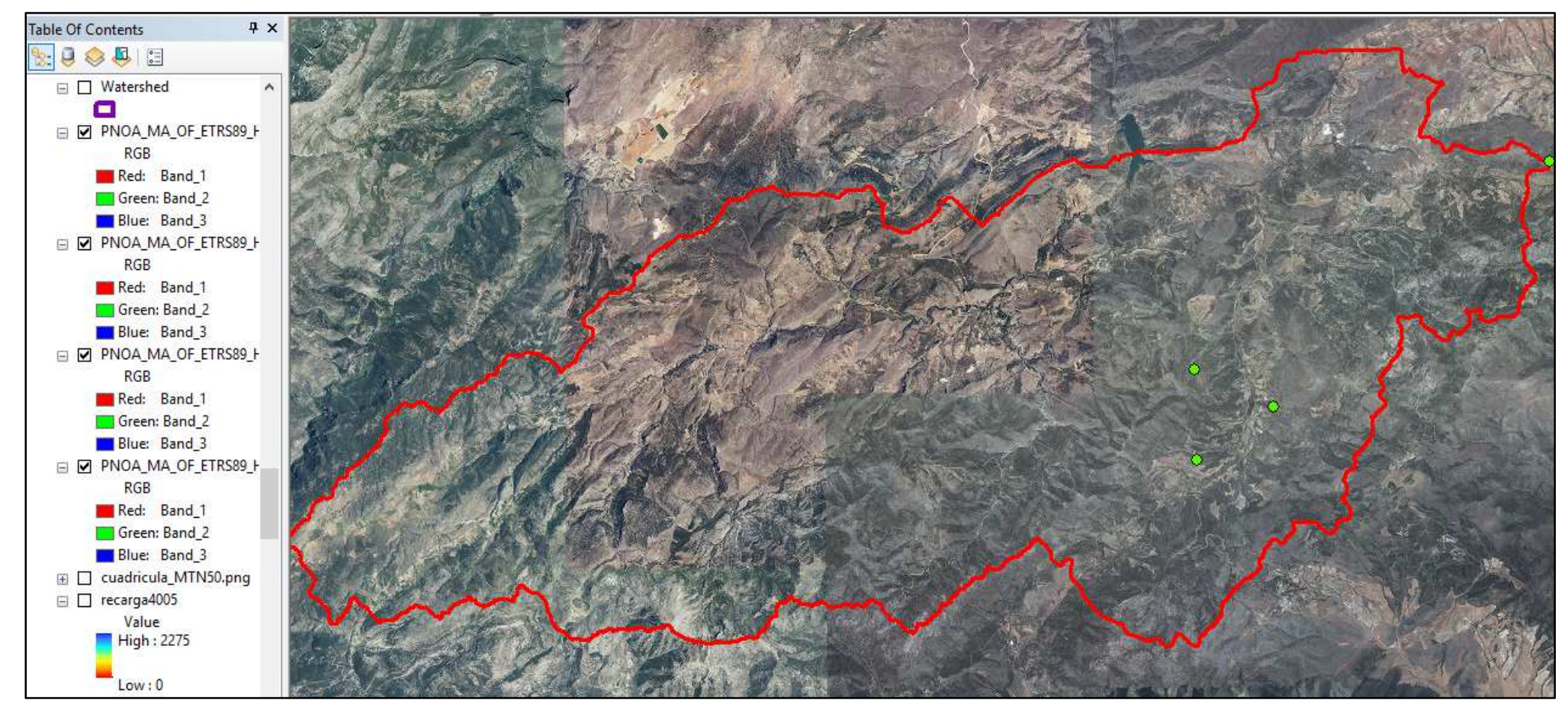

Figura 6. Ortofotos del PNOA max.actualidad descargadas para la cuenca alta del río Taibilla. Hojas del MTN50 seleccionadas: 0888, 0889, 0909 y 0910. Escala de representación 1:125.000. Fuente: elaboración propia a partir de capas IGN.

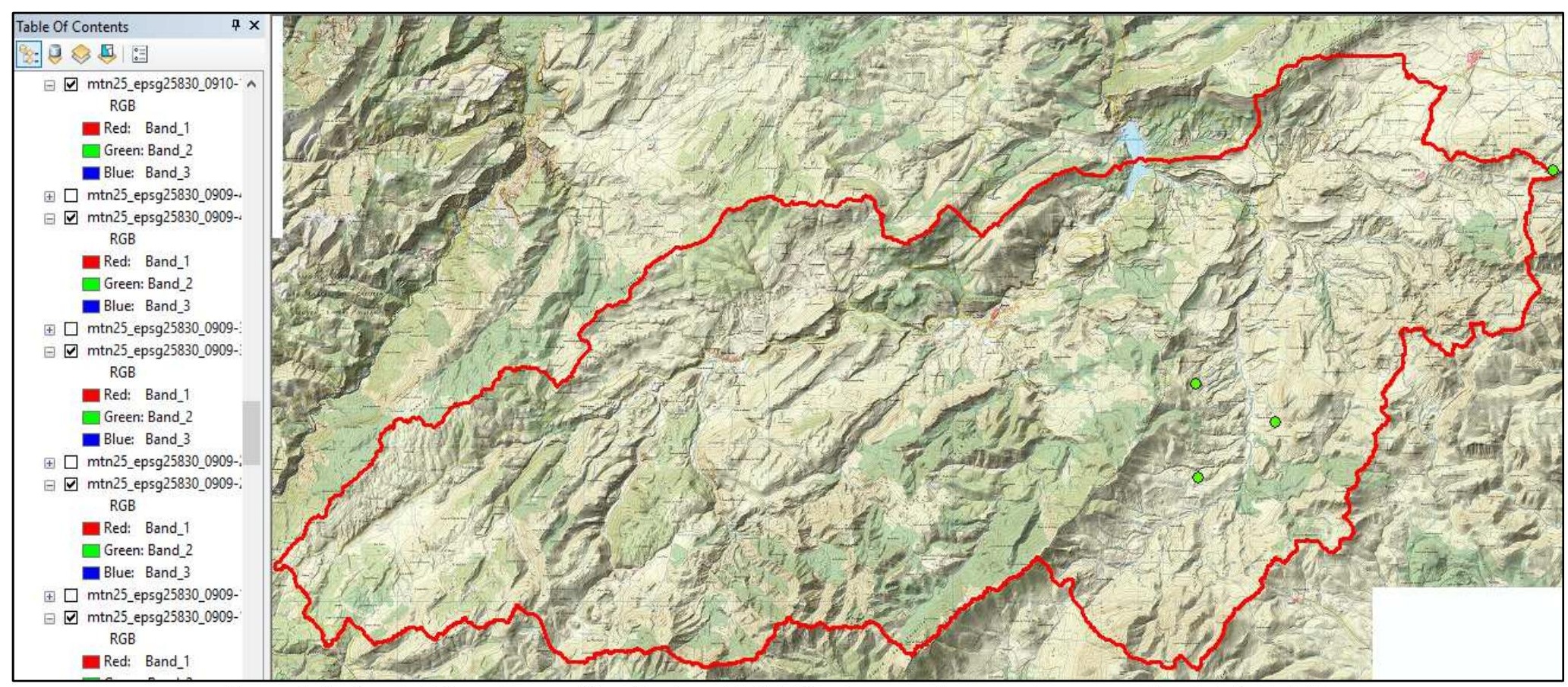

Figura 7. Hojas del Mapa Topográfico Nacional 1:25.000 descargadas para la cuenca alta del río Taibilla. Escala de representación 1:125.000. Fuente: elaboración propia a partir de capas IGN. 


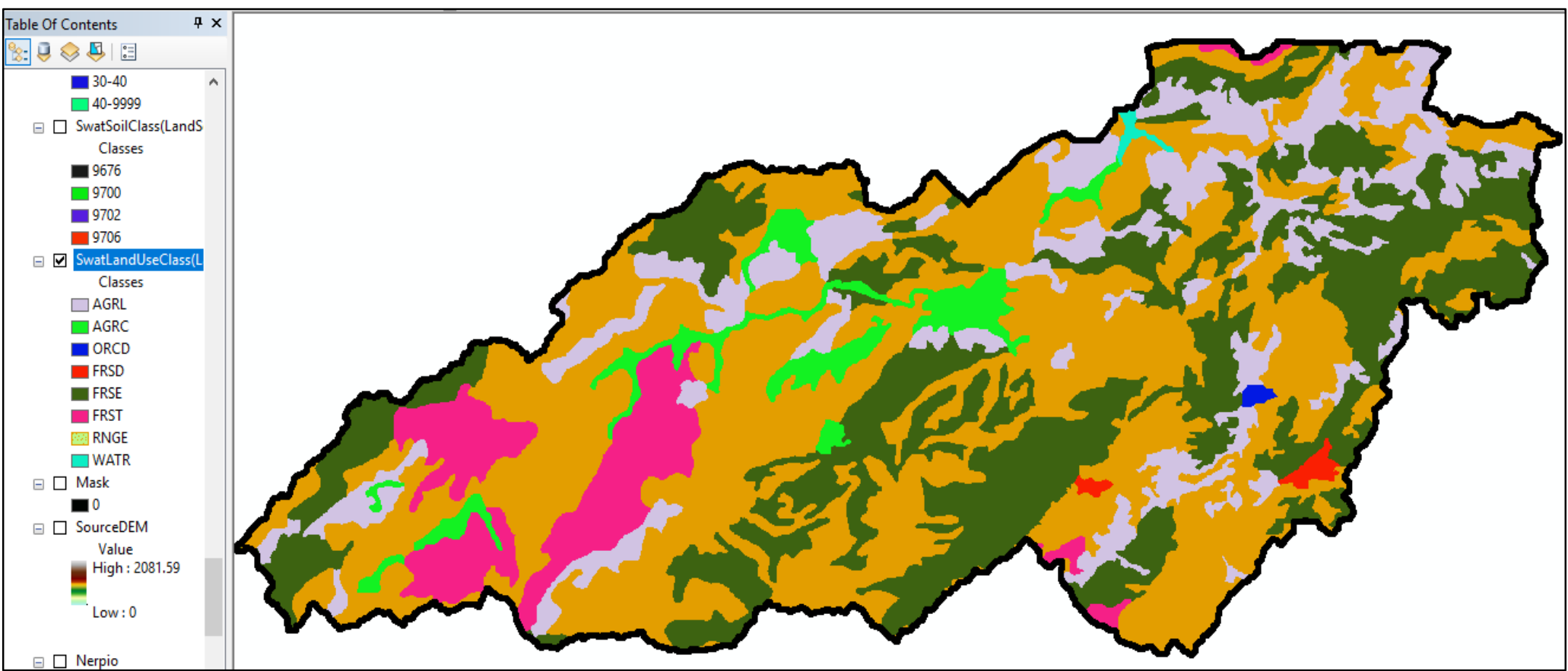

Figura 8. Clases de Usos del Suelo de Corine Land Cover 2006 recortados a la cuenca alta del río Taibilla. Escala de representación 1:125.000. Fuente: elaboración propia a partir de capas IGN.

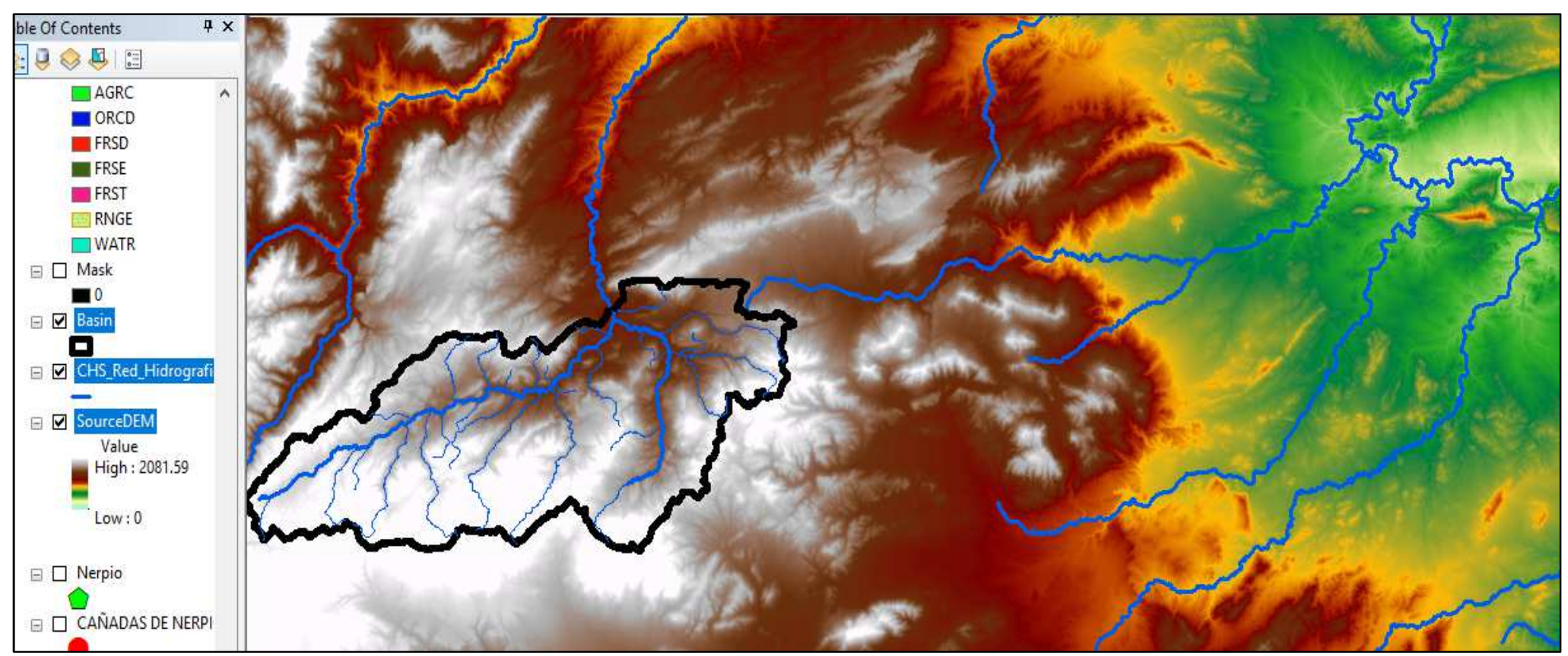

Figura 9. Modelo Digital de Elevaciones (MDE) elaborado para la cuenca del Segura con RStudio a partir de los MDE descargados de la web del IGN según el MTN50 (en RStudio se unifican dichas capas obteniendo un único MDE para toda la cuenca). Capa SHP de Red hidrográfica propiedad de la Confederación Hidrográfica del Segura (CHS) mostrando en la cuenca del Taibilla los cauces principales con un ancho de línea superior a la otorgada en los cauces secundarios. Fuente: elaboración propia a partir de capas IGN y CHS. 


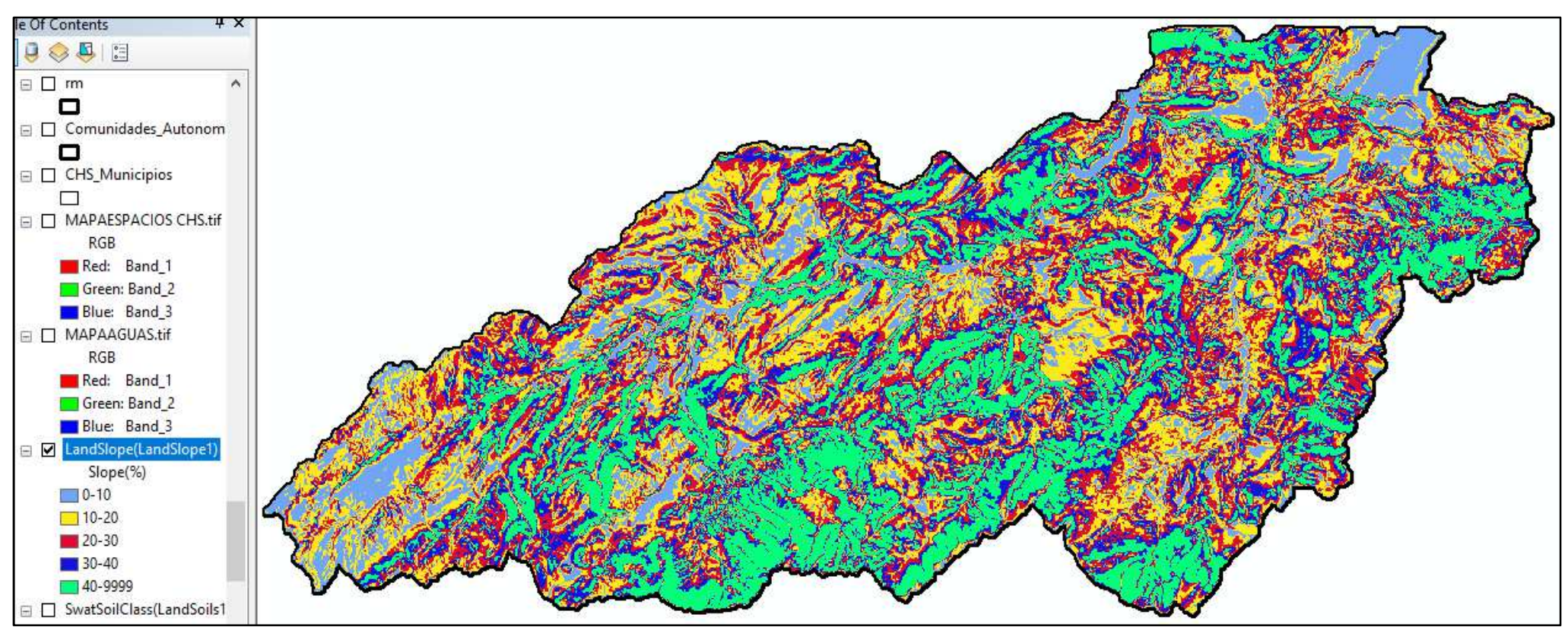

Figura 10. Capa de Pendientes elaborada para la cuenca alta del río Taibilla a partir del MDE anterior. Escala de representación 1:125.000. Fuente: elaboración propia.

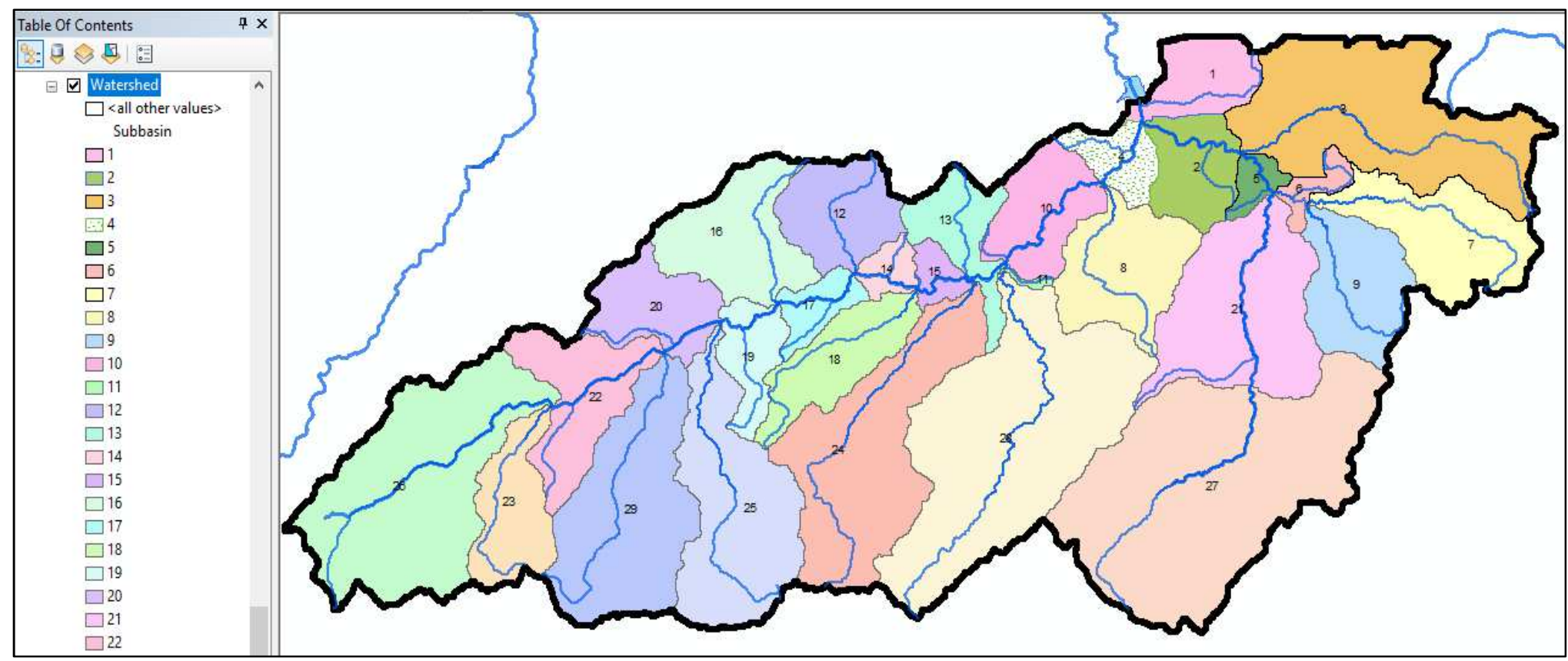

Figura 11. Capa vectorial de Subcuencas, de la cuenca alta del río Taibilla, elaborada a partir del MDE (ráster) +Red hidrográfica (vectorial). Escala de representación 1:125.000. Fuente: elaboración propia.

\section{-Geoportal IDEE}

En cuanto a los Servicios Web (WMS, WMTS, etc.), probablemente el más potente en España es el Geoportal de la Infraestructura de Datos Espaciales de España (IDEE). 
No obstante, debe recordarse que los WMS y WMTS son simplemente direcciones URL, es decir, imágenes que visualizamos en nuestro programa SIG, por lo que debe recurrirse a ellos como último recurso. Enlace: http://www.idee.es/web/guest/directorio-deservicios?p_p_id=DIRSRVIDEE_WAR_DIRSRVIDEEportlet_INSTANCE_q4BW\&p_p _lifecycle= $1 \& p \_p \_s t a t e=$ normal\&p_p_mode $=v i e w \& p \_p \_c o l \_i d=c o l u m n-1 \& p \_p \_c o l \_c o u n t=1 \&$ DIRSRVID EE_WAR_DIRSRVIDEEportlet_INSTANCE_q4BW_tipoServicio=WMS\&_DIRSRVIDEE_WAR_DIRSR VIDEEportlet_INSTANCE_q4BW_supertipo=OGC\&_DIRSRVIDEE_WAR_DIRSRVIDEEportlet_INST ANCE_q4BW_descSrv=VISUALIZACION\&_DIRSRVIDEE_WAR_DIRSRVIDEEportlet_INSTANCE_q4 BW_tipoAmbito=ESTATAL.

\section{4-IDE a nivel autonómico (Comunidad Valenciana)}

En España, son varias las Comunidades Autónomas que han elaborado una cartografía similar a la ya existente a nivel nacional, pero con una escala operacional menor (es decir, consiguiendo mayor resolución, un tamaño de celda menor en el caso de las capas ráster, etc.).

En el caso de la Comunidad Valenciana, y aludiendo al ámbito de los recursos hídricos, probablemente el centro de descarga de cartografía gratuita más potente es la propia "Confederación Hidrográfica del Júcar (CHJ)". En la web de dicho organismo se encuentra publicada cartografía en formato ráster, vectorial y servicios web (principalmente WMS) con escalas operacionales considerablemente reducidas. En la Figura 5 de la lección 7.2, se visualizaron algunas capas de la $\mathrm{CHJ}$. Enlace $\mathrm{CHJ}$ : http://aps.chj.es/down/html/descargas.html.

No obstante, en la Comunidad Valenciana, diversos organismos provinciales han conseguido disminuir la escala operacional de algunas capas ráster y vectoriales de confederación, como sucede por ejemplo en la Diputación Provincial de Alicante, donde el Área de Ciclo Hídrico, en el marco de determinados proyectos, ha elaborado capas vectoriales y ráster de piezometría, acuíferos, etc. a elevada resolución (reducido tamaño de pixel).

\section{ANTE TANTOS DATOS E INFORMACIÓN ¿DÓNDE BUSCO?}

La decisión a la hora de qué base de datos o centro de descarga consultar para encontrar los ficheros ráster y vectoriales deseados es de vital importancia. Dejando a un lado las cuestiones relacionadas con la temática de la información buscada (si buscamos capas vectoriales de tipos de suelo evidentemente buscaremos dichas capas en una base de datos de tipos de suelos), probablemente el principal criterio de 
búsqueda se encuentra relacionado con la escala de trabajo que necesitamos en nuestro estudio.

Así, por ejemplo, en un estudio de ámbito local a nivel de cuenca hidrográfica, municipio, provincia, comunidad autónoma, etc. no resultaría aconsejable buscar información espacial (ráster o vectorial) en bases de datos internacionales, ya que aunque las capas disponibles en las mismas ocupen nuestra zona de estudio, la resolución de las citadas capas probablemente sea limitada (escala operacional elevada del tipo 1:1.000.000). Dicha situación se muestra en la Figura 12.

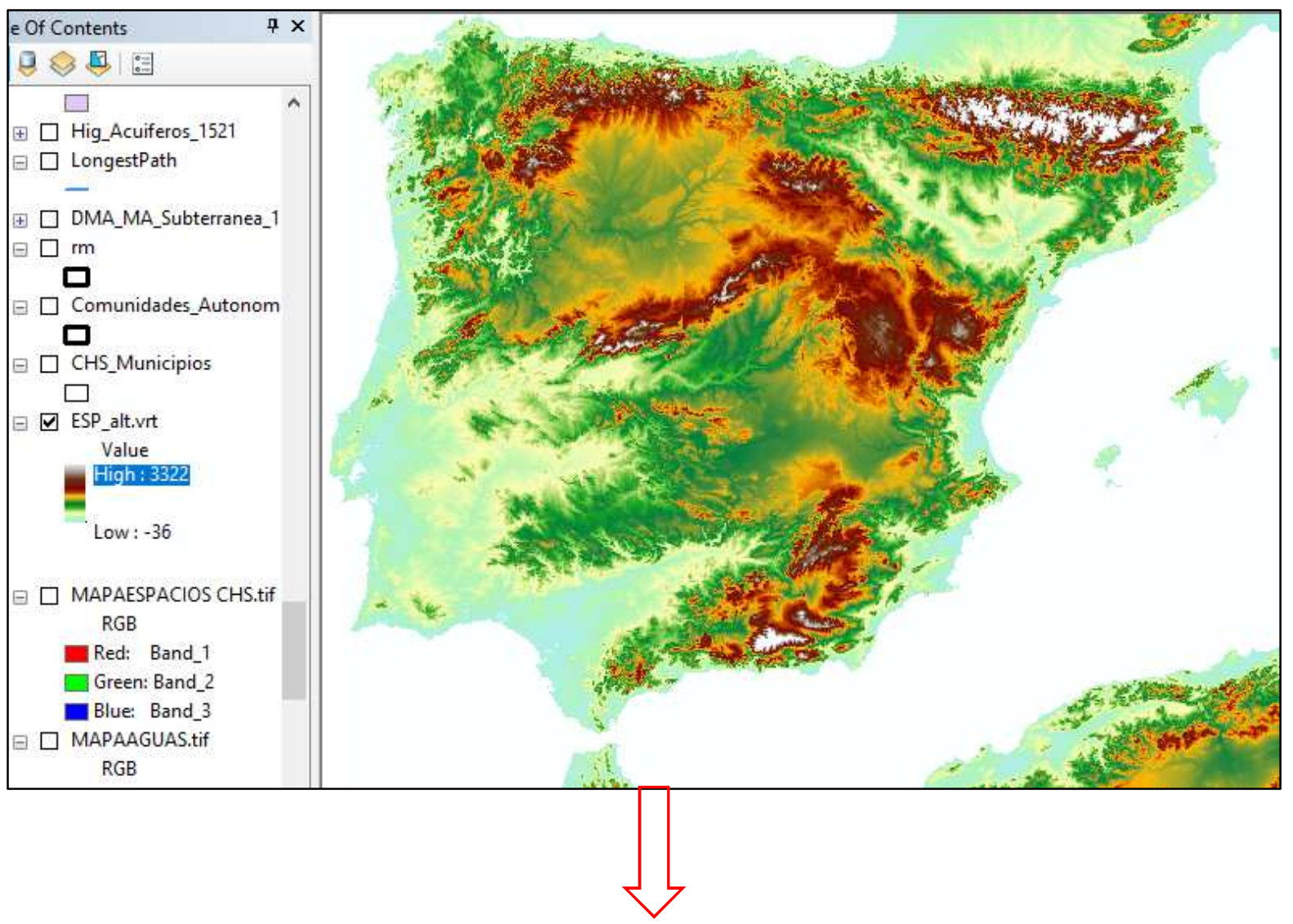

Disminuyendo la escala de representación a 1:800.000: 
vectorial) y servicios web a implementar en un SIG, junto con los principales software GIS y centros de descarga oficial (IDE) de la citada información espacial.

No obstante, corresponde a un nivel más especializado el tratamiento de las capas de entrada en un SIG en el que el usuario puede elaborar capas (mapas) diferentes a las anteriores. En el caso de los archivos ráster dicho tratamiento se puede realizar mediante operadores en Álgebra de Mapas, mientras que en formato vectorial suele recurrirse al geoprocesamiento de la información con operadores de lenguaje SQL (Structured Query Language). Quedan, así mismo, al margen de las presentes lecciones los fundamentos de la Teledetección, la rasterización o la vectorización (transformación de capas en formato ráster a vectorial y viceversa). Así mismo, actualmente la frontera del conocimiento y la innovación en cuanto a los SIG se localiza en revistas científicas JCR (Journal Citation Reports) clasificadas normalmente bajo las áreas de conocimiento del tipo GIS, Remote Sensing, Interpolation, Machine Learning, Soil Science, Environmental Sciences, etc.

Por último, cabe destacar que la utilización de los SIG no exime al usuario, técnico o especialista de recopilar información no digitalizada, puesto que en dicha circunstancia radica la principal limitación de los SIG. Concretamente, en determinadas zonas de estudio escasamente inventariadas/monitoreadas la información espacial digitalizada y disponible para ser incorporada en los SIG es limitada, motivo por el que el técnico o investigador se ve obligado a recurrir a capas/mapas nacionales, europeas e internacionales a menudo con escalas operacionales demasiado elevadas (del tipo 1:1.000.000). Es en dicha situación cuando cobra especial importancia la recopilación y lectura de bibliografía e informes derivados de proyectos realizados en la zona objeto de estudio. A partir de esta información espacial, digitalizada y no digitalizada, el técnico y/o investigador puede generar su propia base de datos para la zona en cuestión. Los SIG son por lo tanto un complemento, una ayuda que permite completar en parte las lagunas de información (datos) a las que se enfrentan habitualmente los usuarios, técnicos y especialistas del campo de las "ciencias que trabajan con datos espaciales". En cuanto a los recursos hídricos, la conexión de las herramientas SIG con los mismos es total, ya sea desde un punto de vista cuantitativo (hidrología superficial, subterránea y planificación hidrológica) o cualitativo (calidad de agua, depuración, reutilización, etc.). 


\section{BIBLIOGRAFÍA}

Alonso-Sarría, F. 2014. Sistemas de Información Geográfica. Temario de la asignatura (20132014). Universidad de Murcia. 245 pp. Disponible en: http://fobos.inf.um.es/alonso/SIGCCAA/temario.pdf

IGN (2015). Conceptos Cartográficos. Instituto Geográfico Nacional. Ministerio de Fomento.
Gobierno
de
España.
21
pp.
Disponible
en: http://media.wix.com/ugd/1c299f_84520011f894c2f21153f601422af7c8.pdf

Sastre-Olmos, P. 2010. Sistemas de Información Geográfica (SIG). Técnicas básicas para estudios de biodiversidad. Instituto Geológico y Minero de España (IGME). 58 pp. Disponible en: http://media.wix.com/ugd/1c299f_c2bcafcbaa9c4cf7b68d1628b2f450 d0.pdf 


\section{MÓDULO 8}

\section{HERRAMIENTAS ESTADÍSTICAS}




\title{
8.1. CONCEPTOS BÁSICOS EN ESTADÍSTICA APLICADA A LA GESTIÓN TERRITORIAL
}

\author{
Patricia Fernández Aracil
}

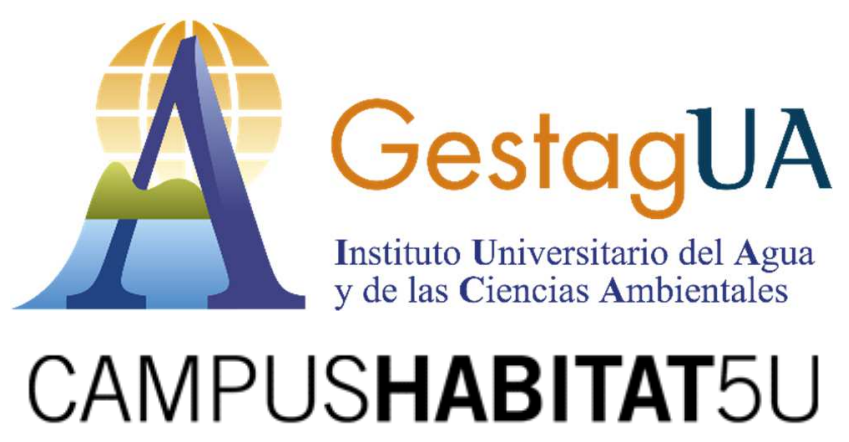




\section{INTRODUCCIÓN}

En el módulo 8 vamos a abordar algunas de las herramientas y fuentes estadísticas que pueden servir de utilidad a la hora de analizar el territorio, sus componentes y sus dinámicas.

\section{TIPO DE INFORMACIÓN}

Para analizar estadísticamente la realidad territorial del modo más fiel posible, debemos considerar tanto aquellas fuentes que proporcionen datos cuantitativos (reflejados por medio de números o métricas), como aquellas que ofrecen información cualitativa (variables categóricas o nominales). Igualmente, siempre tenemos la posibilidad de transformar las variables cualitativas en valores numéricos por medio de variables dicotómicas ficticias (más conocidas por su nombre en inglés: dummies). Efectivamente, son variables tontas, pues sólo pueden tomar los valores 0 ó 1, pero ello nos permite incluirlas en un análisis numérico.

Cuando nos disponemos a utilizar una variable categórica, hemos de tener presente que la transformación necesaria implica crear tantas variables ficticias (dummies) como categorías tiene la variable no métrica menos una.

Pongamos un ejemplo. Si queremos analizar si el tipo de gestión en la prestación de un servicio público afecta a otras determinadas variables y disponemos de tres tipos de gestión a considerar (directa, indirecta y otra), necesitaremos dos variables dicotómicas ficticias (D1 y D2) que las representen:

\begin{tabular}{|l|l|l|}
\hline Categoría & D1 & D2 \\
\hline Gestión directa & 1 & 0 \\
\hline Gestión indirecta & 0 & 1 \\
\hline Otro tipo de gestión & 0 & 0
\end{tabular}

\section{TIPOS DE FUENTES ESTADÍSTICAS}

En términos generales, hay dos tipos de fuentes estadísticas:

a) Registrales: aquellas procedentes de registros administrativos como (por ejemplo, las cifras oficiales de población de los municipios españoles extraídas de la revisión del padrón municipal, publicadas por el Instituto Nacional de Estadística).

b) Procedentes de encuestas o censos: cuando se obtienen por medio de preguntas tipificadas dirigidas a una muestra representativa de la población (por ejemplo, la encuesta de infraestructura y equipamientos 
locales publicada por el Ministerio de Hacienda y Administraciones Públicas).

Cabe tener presente que una labor que debe realizarse siempre por parte de quien trabaja los datos es valorar la fiabilidad de las fuentes estadísticas manejadas, estudiando con detenimiento:

a) La metodología.

b) Los procedimientos de control de calidad.

c) La coherencia de la información en sí misma, así como con otras fuentes.

\section{LA ESTRUCTURA DE LOS DATOS}

Antes de analizar unos datos que precisemos para nuestra labor -ya sea ésta académica, profesional o, simplemente, curiosidad- hemos de estructurarlos adecuadamente. En términos generales, las formas de estructurar los datos son tres $y$, para ejemplificarlo, utilizaremos datos referidos a los municipios de la provincia de Alicante cuya población es superior a los 100.000 habitantes:

a) Serie temporal. Si disponemos de una secuencia de valores distribuidos a lo largo de diferentes unidades temporales (año, mes, trimestre, etc.) para una misma unidad de análisis. En el ejemplo se observa la población del municipio de Alicante entre los años 2008-2013:

\begin{tabular}{|r|r|}
\hline Año & Población \\
\hline 2008 & 331.750 \\
\hline 2009 & 334.757 \\
\hline 2010 & 334.418 \\
\hline 2011 & 334.329 \\
\hline 2012 & 334.678 \\
\hline 2013 & 335.052 \\
\hline
\end{tabular}

b) Sección transversal o cruzada. Si disponemos de datos referidos a una misma unidad de tiempo, pero referidos a diversas unidades de análisis (países, municipios, empresas, entidades, etc.). En el ejemplo se observa la población de los municipios con más de 100.000 habitantes de la provincia de Alicante en el año 2013:

\section{Municipio Población}

\begin{tabular}{r|r|}
\hline Alicante/Alacant & 335.052 \\
\hline Elche/Elx & 230.224
\end{tabular}


c) Datos de panel o datos longitudinales de sección cruzada. Cuando se dispone de un conjunto de variables para un conjunto de unidades de análisis o secciones observadas a lo largo de diferentes unidades temporales. En el ejemplo se observa la población de los municipios con más de 100.000 habitantes de la provincia de Alicante entre los años 2008-2013:

\begin{tabular}{|r|r|r|} 
Municipio & Año & Población \\
\hline Alicante/Alacant & 2008 & 331.750 \\
\hline Elche/Elx & 2008 & 228.348 \\
\hline Torrevieja & 2008 & 101.381 \\
\hline Alicante/Alacant & 2009 & 334.757 \\
\hline Elche/Elx & 2009 & 230.112 \\
\hline Torrevieja & 2009 & 101.792 \\
\hline Alicante/Alacant & 2010 & 334.418 \\
\hline Elche/Elx & 2010 & 230.822 \\
\hline Torrevieja & 2010 & 101.091 \\
\hline Alicante/Alacant & 2011 & 334.329 \\
\hline Elche/Elx & 2011 & 230.354 \\
\hline Torrevieja & 2011 & 102.136 \\
\hline Alicante/Alacant & 2012 & 334.678 \\
\hline Elche/Elx & 2012 & 230.587 \\
\hline Torrevieja & 2012 & 103.720 \\
\hline Alicante/Alacant & 2013 & 335.052 \\
\hline Elche/Elx & 2013 & 230.224 \\
\hline Torrevieja & 2013 & 105.205 \\
\hline
\end{tabular}

\section{BIBLIOGRAFÍA}

Lévy Magin, J-P. y Varela Mallou, J. (2003). Análisis Multivariable para las Ciencias Sociales. Madrid: Pearson Prentice Hall.

Greene, William H. (1998). Análisis Econométrico. Madrid: Pearson Prentice Hall.

Pérez, C. (2007). Econometría básica: técnicas y herramientas. Madrid: Pearson Prentice Hall.

Pérez, C. (2008). Econometría avanzada: técnicas y herramientas. Madrid: Pearson Prentice Hall. 


\section{ENLACES}

Instituto Nacional de Estadística. Padrón. Población por municipios:

http://www.ine.es/inebmenu/mnu padron.htm

Ministerio de Hacienda y Administraciones Públicas. Encuesta de Infraestructura y Equipamientos Locales:

http://www.seap.minhap.gob.es/gl/web/areas/politica local/coop econom I ocal estado fondos europeos/eiel.html 


\title{
8.2. FUENTES ESTADÍSTICAS RELACIONADAS CON LA GESTIÓN TERRITORIAL
}

\author{
Patricia Fernández Aracil
}

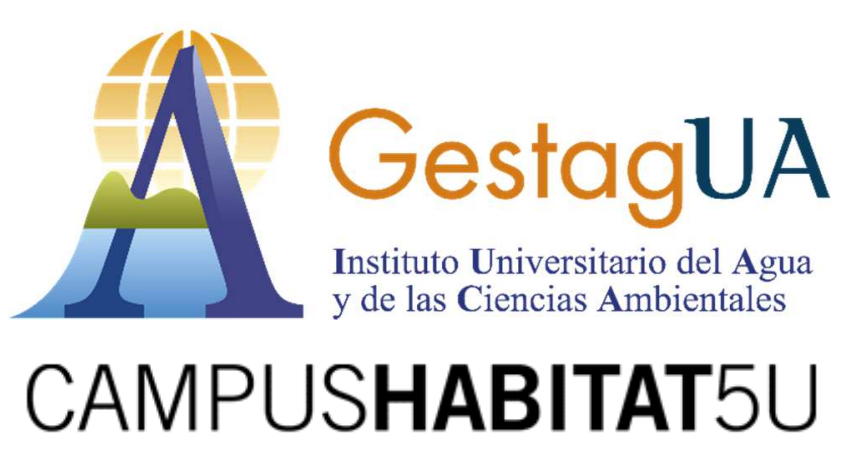




\section{INTRODUCCIÓN}

Al sumergirse en las fuentes estadísticas, hay un amplio mundo por descubrir, en continua actualización, del cual mencionaremos sólo algunos de sus fragmentos, especificando más detalles sobre las dos primeras fuentes estadísticas expuestas, que se encuentran inmersas en el Instituto Nacional de Estadística (INE, en adelante).

\section{EL NOMENCLÁTOR EN EL INE}

Las estadísticas territoriales referidas a la forma en la cual se asienta la población en los municipios, deben descender a una subdivisión de los mismos que, a pesar de no tener carácter oficial, resultan de mucha utilidad: las entidades singulares de población, así como sus núcleos y diseminados. Estas cifras pueden descargarse desde el Nomenclátor: población del padrón continuo por unidad poblacional, del INE.

Algunas definiciones previas respecto de esta fuente son:

a) Una entidad singular de población es cualquier área habitable del término municipal, habitada o excepcionalmente deshabitada, claramente diferenciada dentro del mismo, y que es conocida por una denominación específica que la identifica sin posibilidad de confusión.

b) Ninguna vivienda puede pertenecer simultáneamente a dos o más entidades singulares. Un municipio puede constar de una o varias entidades singulares de población. Si en un municipio no existen áreas habitables claramente diferenciadas, el municipio será considerado de entidad única.

c) Se considera núcleo de población a un conjunto de al menos diez edificaciones, que están formando calles, plazas y otras vías urbanas. Por excepción, el número de edificaciones podrá ser inferior a 10, siempre que la población que habita las mismas supere los 50 habitantes. Se incluyen en el núcleo aquellas edificaciones que, estando aisladas, distan menos de 200 metros de los límites exteriores del mencionado conjunto, con algunas excepciones.

d) Las edificaciones o viviendas de una entidad singular de población que no pueden ser incluidas en el concepto de núcleo se consideran en diseminado.

e) Una entidad singular de población puede tener uno o varios núcleos, o incluso ninguno, si toda ella se encuentra en diseminado. Ninguna vivienda puede pertenecer simultáneamente a dos o más núcleos, o a un núcleo y un diseminado. 
Seguidamente, veamos un ejemplo de lectura de los datos descargados desde esta fuente, a los cuales puede accederse siguiendo la ruta: INEbase / Demografía y población / Padrón. Población por municipios / Nomenclátor: Población del Padrón Continuo por Unidad Poblacional.

Desde la página de descarga de datos del Nomenclátor podemos descargar información a nivel provincial, municipal, etc., para uno o diversos años, en función de nuestros intereses y aplicando o no los sucesivos filtros que necesitemos antes de pulsar el botón de "Consultar selección". Para este ejemplo, procedemos a descargar el fichero del municipio "El Campello", ubicado en el litoral de la provincia de Alicante.

En el aparatado de "Búsqueda avanzada", según "Criterio geográfico", seleccionamos del primer desplegable la región "Comunitat Valenciana" y pulsamos "Cargar provincias". Seguidamente, en el desplegable de "Provincias", seleccionamos "Alicante/Alacant 03" y pulsamos "Cargar municipios". Si quisiéramos descargar todos los municipios de la provincia de Alicante, ya podíamos pulsar en "Consultar selección" sin seleccionar ningún municipio en concreto, obteniendo el fichero con las cifras de población desagregadas a nivel de entidad singular entre el año 2000 y la actualidad. Sin embargo, para este ejemplo, seleccionamos previamente el municipio de "Campello (el)", restringiendo nuestra descarga al año 2015 desde el desplegable final "Seleccione años".

La visualización del resultado, se observa en la página siguiente (Figura 1), donde es importante fijarse en los códigos de las unidades poblacionales:

- El código 000000 determina la población total del municipio.

- Los códigos establecidos por centenas (000100, 000200, etc.) determinan la población de cada entidad singular de población.

- Los códigos que aparecen después de aquellos establecidos por centenas, pero finalizan en sus respectivas unidades (000101, 000102, 000103, etc.) determinan la población de cada núcleo de población inserto en la entidad singular de población que determinan las centenas de su código.

- Los códigos que finalizan en 99 constituyen el diseminado de su respectiva entidad singular de población.

- Así, si nos fijamos en el código 000200 , observamos que su población total se corresponde con la suma dela población referida a los códigos 000201, 000202, 000203, 000204, 000205, 000206 y 000299; siendo el último código el referido a la población clasificada en diseminado de la entidad singular de población CAMPELLO (EL).

- Del mismo modo, la suma de la población de cada una de las entidades singulares del municipio (códigos definidos por centenas) constituye la población total del municipio. 
Nomenclátor: Población del Padrón Continuo por Unidad Poblacional a 1 de enero

\begin{tabular}{|c|c|c|}
\hline Provincia & Municipio & Unidad Poblacional \\
\hline 03 Alicante/Alacant & 050 Campello (el) & 000000 CAMPELLO (EL) \\
\hline 03 Alicante/Alacant & 050 Campello (el) & 000100 BALLESTERA \\
\hline 03 Alicante/Alacant & 050 Campello (el) & 000101 BALLESTERA \\
\hline 03 Alicante/Alacant & 050 Campello (el) & 000102 BONNY BARRIO \\
\hline 03 Alicante/Alacant & 050 Campello (el) & 000103 URBANIZACIÓN BONANZA \\
\hline 03 Alicante/Alacant & 050 Campello (el) & $000199^{\circ}$ DISEMINADO* \\
\hline 03 Alicante/Alacant & 050 Campello (el) & 000200 CAMPELLO (EL) \\
\hline 03 Alicante/Alacant & 050 Campello (el) & 000201 ALMADRABA (LA) \\
\hline 03 Alicante/Alacant & 050 Campello (el) & 000202 AMERADOR (L) \\
\hline 03 Alicante/Alacant & 050 Campello (el) & 000203 BANYETS (ELS) \\
\hline 03 Alicante/Alacant & 050 Campello (el) & 000204 CAMPELLO (EL) \\
\hline 03 Alicante/Alacant & 050 Campello (el) & 000205 PORCHA (LA) \\
\hline 03 Alicante/Alacant & 050 Campello (el) & 000206 PUEBLO ESPAÑOL \\
\hline 03 Alicante/Alacant & 050 Campello (el) & $000299^{\circ D I S E M I N A D O *}$ \\
\hline 03 Alicante/Alacant & 050 Campello (el) & 000300 COVETA FUMA \\
\hline 03 Alicante/Alacant & 050 Campello (el) & 000302 COVETA FUMA \\
\hline 03 Alicante/Alacant & 050 Campello (el) & 000400 PLAYA MUCHAVISTA \\
\hline 03 Alicante/Alacant & 050 Campello (el) & 000401 PLAYA MUCHAVISTA \\
\hline 03 Alicante/Alacant & 050 Campello (el) & 000500 CALA D'OR \\
\hline 03 Alicante/Alacant & 050 Campello (el) & 000501 CALA D'OR \\
\hline 03 Alicante/Alacant & 050 Campello (el) & 000600 MERCED (LA) \\
\hline 03 Alicante/Alacant & 050 Campello (el) & 000601 MERCED (LA) \\
\hline 03 Alicante/Alacant & 050 Campello (el) & 000700 VENTA LANUZA \\
\hline 03 Alicante/Alacant & 050 Campello (el) & 000701 VENTA LANUZA \\
\hline
\end{tabular}

Año 2015
Población total
78
78

\begin{tabular}{rrr} 
Hombres & \multicolumn{2}{c}{ Mujeres } \\
27356 & 13390 & 13966 \\
243 & 125 & 118 \\
2 & 2 & 0 \\
111 & 51 & 60 \\
110 & 62 & 48 \\
20 & 10 & 10 \\
18122 & 8861 & 9261 \\
1547 & 739 & 808 \\
650 & 333 & 317 \\
307 & 155 & 152 \\
15203 & 7412 & 7791 \\
23 & 9 & 14 \\
37 & 21 & 16 \\
355 & 192 & 163 \\
875 & 443 & 432 \\
875 & 443 & 432 \\
7297 & 3529 & 3768 \\
7297 & 3529 & 3768 \\
439 & 234 & 205 \\
439 & 234 & 205 \\
228 & 121 & 107 \\
228 & 121 & 107 \\
152 & 77 & 75 \\
152 & 77 & 75
\end{tabular}

Figura 1. Captura de los resultados obtenidos al buscar el municipio de Campello en el Nomenclátor del INE para el año 2015. Fuente:

http://www.ine.es/nomen2/index.do 
Tal y como sucede con el resto de estadísticas del INE, es posible exportar la información en ficheros Excel, CSV, etc.

\section{LAS ESTADÍSTICAS TERRITORIALES DEL INE}

Cuando nos interesa obtener información específica a nivel municipal, desde el INE se nos facilita el acceso a las estadísticas territoriales, que las encontraremos bien definidas en su página inicial mediante un mapa de colores (Figura 2).

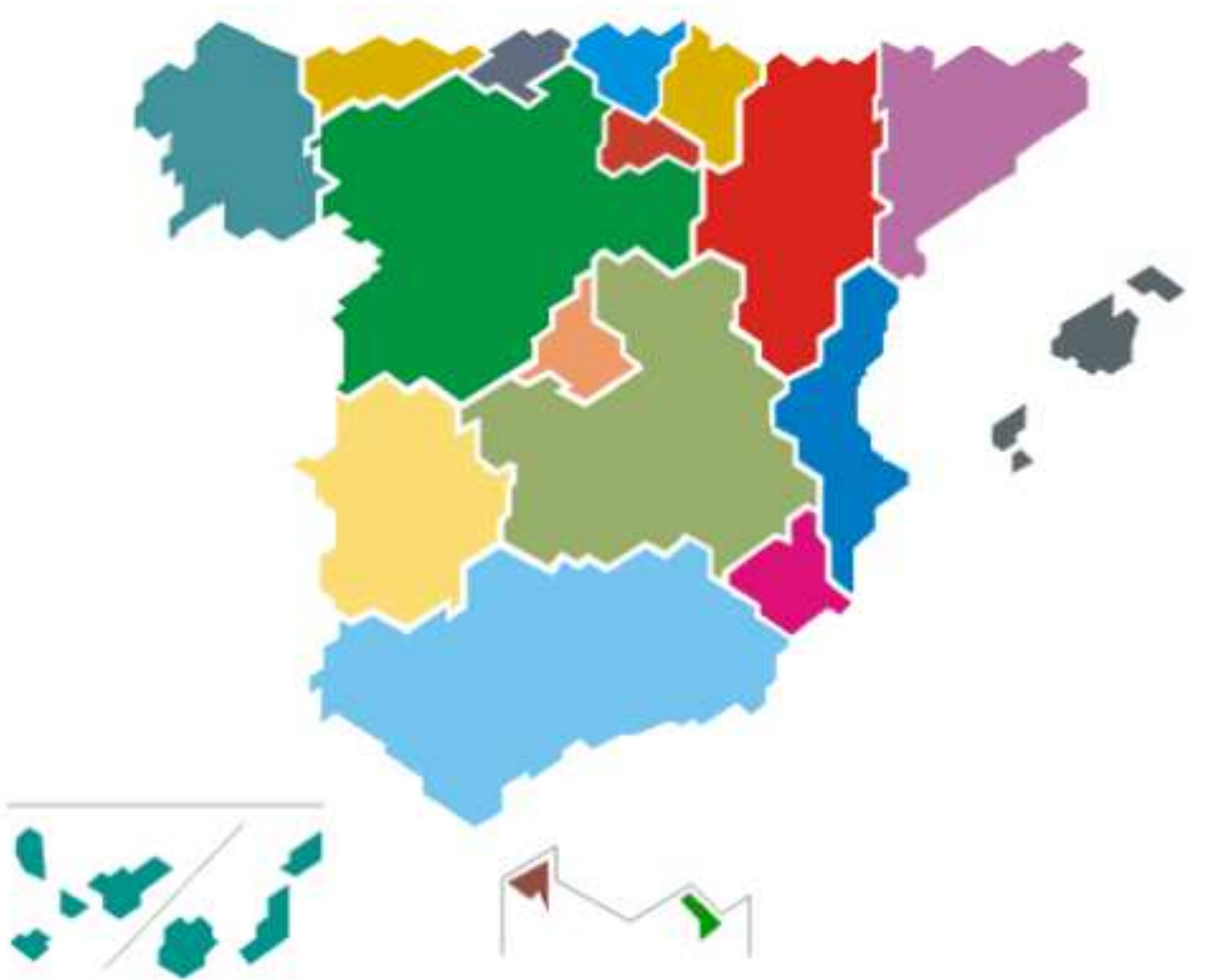

Figura 2. Mapa que identifica las estadísticas territoriales del INE. Fuente: http://www.ine.es/FichasWeb/Welcome.do

A modo de ejemplo, realizaremos la búsqueda del municipio de Benidorm; una vez estamos dentro de la página de búsqueda de estadísticas territoriales, seleccionamos en la parte superior del mapa el recuadro "Municipios". Podemos buscarlo escribiendo directamente su nombre en "Municipio a buscar", o bien, cargando la Comunidad Autónoma y provincia pertinentes.

Al seleccionar "Benidorm", pulsamos "Añadir" y el municipio se añade a un listado que aparece en la franja derecha de la página. Podemos consultar diversas áreas geográficas, sin embargo, el proceso se ralentiza a medida que añadimos datos a consultar. En la consulta ejemplificada, el resultado es el siguiente, tras pulsar en "Ir a la tabla de resultados" y exportar en formato Excel: 


\begin{tabular}{|c|c|c|}
\hline Municipios & Fecha & VALOR \\
\hline Padrón: Población Total & 2015 & 69.045 \\
\hline Padrón: Población Total (varones) & 2015 & 34.395 \\
\hline Padrón: Población Total (mujeres) & 2015 & 34.650 \\
\hline DIRCE. Número de empresas & 2016 & 5.326 \\
\hline DIRCE. Industria ( $n=$ empresas) & 2016 & 90 \\
\hline DIRCE. Construcción (no empresas) & 2016 & 533 \\
\hline $\begin{array}{l}\text { DIRCE. Comercio, transporte y hostelería ( } \mathrm{n} \text { - } \\
\text { empresas) }\end{array}$ & 2016 & 2.508 \\
\hline DIRCE. Total servicios ( $n$ o empresas) & 2016 & 2.195 \\
\hline - DIRCE. Información y comunicaciones ( $n$ - empresas) & 2016 & 67 \\
\hline $\begin{array}{l}\text { - DIRCE. Actividades financieras y de seguros (no } \\
\text { empresas) }\end{array}$ & 2016 & 101 \\
\hline - DIRCE. Actividades inmobiliarias (no empresas) & 2016 & 513 \\
\hline $\begin{array}{l}\text { - DIRCE. Actividades profesionales y técnicas ( } n \text { o } \\
\text { empresas) }\end{array}$ & 2016 & 779 \\
\hline $\begin{array}{l}\text { - DIRCE. Educación, sanidad y servicios sociales (no } \\
\text { empresas) }\end{array}$ & 2016 & 265 \\
\hline - DIRCE. Otros servicios personales ( $n-$ empresas) & 2016 & 470 \\
\hline Censo Agrario. Número de Explotaciones & 2009 & 44 \\
\hline Censo Agrario. Superficie agrícola & 2009 & 92,53 \\
\hline Censo Agrario. Unidades ganaderas totales & 2009 & 30,39 \\
\hline Censo 2011: Total viviendas familiares & 2011 & 58.011 \\
\hline Censo 2011: Total viviendas principales & 2011 & 27.912 \\
\hline Censo 2011: Viviendas secundarias & 2011 & 25.131 \\
\hline Censo 2011: Viviendas vacías & 2011 & 4.968 \\
\hline
\end{tabular}

Tabla 1. Resultado de las estadísticas territoriales del INE al buscar el municipio de Benidorm. Fuente: http://www.ine.es/FichasWeb/RegMunicipios.do 


\section{EL MINISTERIO DE FOMENTO}

Prácticamente todas las estadísticas extraídas desde el Ministerio de Fomento pueden resultar relevantes en la gestión territorial: construcción, movilidad, vivienda o transporte. Sin embargo, haremos aquí especial hincapié a las "Obras en edificación (visados de dirección de obra de los Colegios de Arquitectos Técnicos)", que se encuentran en el apartado dedicado a "Construcción".

Aquí podemos conocer, por ejemplo, el número de viviendas construidas a nivel nacional, regional o provincial, incluso desglosado mensualmente. Veamos el ejemplo para el caso de la provincia de Alicante (Figura 3):

\begin{tabular}{|c|c|c|c|c|c|}
\hline \multirow{4}{*}{ PERIODO } & \multicolumn{5}{|c|}{ OBRA NUEVA } \\
\hline & \multicolumn{3}{|c|}{ NÚMERO DE VIVIENDAS } & \multirow{2}{*}{\multicolumn{2}{|c|}{$\begin{array}{l}\text { SUPERFICIE MEDIA POR VIVIENDA } \\
\text { EDIFICIOS DE VIVIENDAS }\end{array}$}} \\
\hline & \multicolumn{2}{|c|}{ EDIFICIOS DE VIVIENDAS FAMILIARES } & \multirow{2}{*}{$\begin{array}{l}\text { EN OTROS } \\
\text { EDIFICIOS }\end{array}$} & & \\
\hline & UNIFAMILIAR & EN BLOQUE & & UNIFAMILIAR & EN BLOQUE \\
\hline 2015 & & 3,275 & 0 & 191 & 92 \\
\hline 2014 & & 1,717 & 0 & 204 & 96 \\
\hline 2013 & & 1,637 & 0 & 212 & 91 \\
\hline 2012 & & 949 & 0 & 226 & 89 \\
\hline 2011 & & 1,395 & 0 & 224 & 92 \\
\hline
\end{tabular}

Figura 3. Captura de los resultados obtenidos al buscar la provincia de Alicante en los visados de dirección de obra nueva del Ministerio de Fomento. Fuente:

http://www.fomento.gob.es/BE/?nivel=2\&orden=09000000

\section{EL MINISTERIO DE HACIENDA Y ADMINISTRACIONES PÚBLICAS}

Muchos son los datos relevantes que podemos encontrar en la central de información del Ministerio de Hacienda y Administraciones Públicas (MINHAP, en adelante), sin embargo, sólo mencionaremos algunos en esta ocasión.

En primer lugar, si deseamos conocer los presupuestos o liquidaciones de presupuestos de las corporaciones locales españolas, podemos pulsar la casilla denominada "Sistemas de financiación y deuda pública" (Figura 4). De estos presupuestos es de donde surge, en mayor medida, la gestión urbana y territorial municipal, tanto en lo relacionado con servicios públicos, como en cuanto a planificación urbana. 


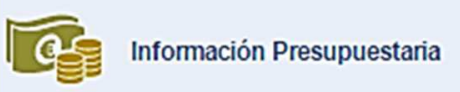

(3)) Impuestos proveedores

\section{(6)}

Sistemas de Financiación y

Deuda Pública

Inventario de Entes Públicos $\triangle 1$ Seguimiento de la Ley de

Estabilidad Presupuestaria

Estrategia de política fiscal

Coste de Personal y

Pensiones Públicas

Otra Información Económico-

Financiera

Figura 4. Central de información del MINHAP. Fuente: http://www.minhap.gob.es/esES/CDI/Paginas/centraldeinformacion.aspx

También resulta de mucho interés la información relativa a la Dirección General del Catastro, a la cual es preferible entrar desde su propio portal. Cabe destacar las series históricas referidas al suelo urbano o rústico, donde es posible extraer variables tales como la superficie edificada o el valor catastral con un nivel de desagregación que llega incluso al municipal.

Por último, cabe mencionar una de las fuentes estadísticas más recientes relacionada con la gestión de servicios públicos locales: el coste efectivo de los servicios de las entidades locales (CESEL).

Con la entrada en vigor de la Ley de Racionalización y Sostenibilidad de la Administración Local (Ley 27/2013, de 27 de diciembre), se introdujo el concepto de coste efectivo, así como la obligatoriedad de ser registrado para cada uno de los servicios prestados por las entidades locales. La información relativa al año 2014 es la primera que han facilitado las Entidades Locales, de acuerdo con los criterios de cálculo aprobados (Orden HAP/2075/2014 de 6 de noviembre de 2014).

Así, han proporcionado información sobre la forma de gestión de cada servicio y la composición del coste efectivo, total y desagregado, tanto si la gestión es directa pública (gastos de personal, corrientes, indirectos, amortización, arrendamientos y transferencias), directa empresarial (aprovisionamiento, gastos de personal, otros gastos de explotación, amortización de inmovilizado y otros gastos no financieros) o indirecta (contraprestaciones). Además, se publica un registro de las unidades físicas de referencia por servicio (número de puntos de luz 
de alumbrado público, producción anual de residuos, número total de viajeros en transporte público urbano, superficie urbanizada, etc.), así como de la composición de las entidades que son agrupaciones de otras.

Los servicios públicos para los cuales se dispone de la información son:

\begin{tabular}{|c|c|}
\hline $\begin{array}{l}\text { Aquellos cuya prestación es obligatoria } \\
\text { para los municipios }\end{array}$ & $\begin{array}{l}\text { Aquellos correspondientes a competencias } \\
\text { propias de los municipios }\end{array}$ \\
\hline Alumbrado público & $\begin{array}{l}\text { Urbanismo: planeamiento, gestión, ejecución } \\
\text { y disciplina urbanística }\end{array}$ \\
\hline Cementerio & Protección y gestión del Patrimonio histórico \\
\hline Recogida de residuos & $\begin{array}{l}\text { Promoción y gestión de la vivienda de } \\
\text { protección pública con criterios de } \\
\text { sostenibilidad financiera }\end{array}$ \\
\hline Limpieza viaria & Conservación y rehabilitación de la edificación \\
\hline $\begin{array}{l}\text { Abastecimiento domiciliario de agua } \\
\text { potable }\end{array}$ & Evacuación y tratamiento de aguas residuales \\
\hline Alcantarillado & $\begin{array}{l}\text { Infraestructura viaria y otros equipamientos } \\
\text { de titularidad de la entidad local }\end{array}$ \\
\hline Acceso a los núcleos de población & Policía local \\
\hline Pavimentación de las vías públicas & $\begin{array}{l}\text { Tráfico, estacionamiento de vehículos y } \\
\text { movilidad }\end{array}$ \\
\hline Parque público & $\begin{array}{l}\text { Información y promoción de la actividad } \\
\text { turística de interés y ámbito local }\end{array}$ \\
\hline Biblioteca pública & Ferias \\
\hline Tratamiento de residuos & Abastos, mercados, lonjas \\
\hline Protección civil & Comercio ambulante \\
\hline $\begin{array}{l}\text { Evaluación e información de situaciones de } \\
\text { necesidad social y la atención inmediata a } \\
\text { personas en situación o riesgo de exclusión } \\
\text { social }\end{array}$ & Protección de la salubridad pública \\
\hline Prevención y extinción de incendios & Actividades funerarias \\
\hline Instalaciones deportivas de uso público & Promoción del deporte \\
\hline Transporte colectivo urbano de viajeros & Instalaciones deportivas \\
\hline Medio ambiente urbano & Instalaciones de ocupación del tiempo libre \\
\hline $\begin{array}{l}\text { Medio ambiente urbano: Parques y } \\
\text { jardines públicos }\end{array}$ & Promoción de la cultura \\
\hline $\begin{array}{l}\text { Medio ambiente urbano: Gestión de los } \\
\text { residuos sólidos urbanos }\end{array}$ & Equipamientos culturales \\
\hline \multirow[t]{2}{*}{$\begin{array}{l}\text { Medio ambiente urbano: Protección contra } \\
\text { la contaminación acústica, lumínica y } \\
\text { atmosférica en las zonas urbanas }\end{array}$} & $\begin{array}{l}\text { Participar en la vigilancia del cumplimiento de } \\
\text { la escolaridad obligatoria }\end{array}$ \\
\hline & $\begin{array}{l}\text { Cooperar con las Administraciones educativas } \\
\text { correspondientes en la obtención de los }\end{array}$ \\
\hline
\end{tabular}




\begin{tabular}{|l||l|}
\hline $\begin{array}{l}\text { Aquellos cuya prestación es obligatoria } \\
\text { para los municipios }\end{array}$ & $\begin{array}{l}\text { Aquellos correspondientes a competencias } \\
\text { propias de los municipios }\end{array}$ \\
\hline & $\begin{array}{l}\text { solares necesarios para la construcción de } \\
\text { nuevos centros docentes }\end{array}$ \\
\hline & $\begin{array}{l}\text { Conservación, mantenimiento y vigilancia de } \\
\text { los edificios de titularidad local destinados a } \\
\text { centros públicos de educación infantil, de } \\
\text { educación primaria o de educación especial }\end{array}$ \\
\hline & $\begin{array}{l}\text { Promoción en su término municipal de la } \\
\text { participación de los ciudadanos en el uso } \\
\text { eficiente y sostenible de las tecnologías de la } \\
\text { información y las comunicaciones }\end{array}$ \\
\hline
\end{tabular}

Tabla 2. Servicios públicos para los cuales se muestra información en la fuente estadística del CESEL. Fuente:

https://serviciostelematicos.minhap.gob.es/Cesel/Consulta/Consulta.aspx

\section{LOS INSTITUTOS REGIONALES}

Cuando necesitamos información estadística más detallada a nivel espacial, podemos probar a recurrir a los portales estadísticos de las comunidades autónomas. Además, el INE centraliza los enlaces a cada uno de ellos a través de la ruta: "El INE / Organización estadística en España / La estadística de las CCAA".

En cada uno de los Estatutos de Autonomía se establece que la respectiva comunidad autónoma tiene competencia exclusiva sobre la estadística para los fines de la comunidad autónoma, estando presentes:

Andalucía

Aragón

Asturias, Principado de

Canarias

Cantabria

Castilla y León

Castilla-La Mancha

Cataluña

Comunitat Valenciana

Extremadura

Galicia

Balears, Illes

Madrid, Comunidad de 
Murcia, Región de

Navarra, Comunidad Foral de

País Vasco

Rioja, La

\section{OTRAS FUENTES ESTADÍSTICAS}

Si queremos hacer un análisis del territorio desde un enfoque empresarial, podemos acudir a la base de datos SABI: Sistema de Análisis de Balances Ibéricos. Se trata de una base de datos financiera con un total de un millón de empresas españolas con software de análisis financiero, estudios sectoriales, comparación de empresas españolas con portuguesas, ratios, actividades. Contiene una gran información sobre cada empresa con un gran nivel de detalle: información de contacto, balances, pérdidas y beneficios, precios, stocks, información financiera, marcas (sólo para empresas españolas), indicadores de fortaleza financiera directores, declaraciones originales/imágenes (sólo para empresas españolas), estructuras corporativas detalladas, estudios de mercado, noticias de negocios y empresas, mapas y análisis cartográficos, informes de auditoría (sólo para empresas españolas). Su único defecto es que requiere suscripción previo pago, no obstante, las universidades suelen facilitar el acceso a la comunidad universitaria para utilizar la información con fines académicos.

\section{ENLACES}

Instituto Nacional de Estadística:

http://www.ine.es/

Instituto Nacional de Estadística. Metodología del Nomenclátor: población del padrón continuo por unidad poblacional:

http://www.ine.es/nomen2/Metodologia.do

Instituto Nacional de Estadística Enlaces a las fuentes estadísticas de las comunidades autónomas:

http://www.ine.es/ss/Satellite?L=es ES\&c=Page \&cid=1254735904941\&p=12547359 04941\&pagename=INE\%2FINELayout 
Ministerio de Fomento. Información estadística:

https://www.fomento.gob.es/MFOM/LANG CASTELLANO/ATENCION CIUDADANO/I NFORMACION ESTADISTICA/

Ministerio de Hacienda y Administraciones Públicas. Central de información económico-financiera:

http://www.minhap.gob.es/es-ES/CDI/Paginas/centraldeinformacion.aspx

Ministerio de Hacienda y Administraciones Públicas. Dirección General del Catastro. Principales series históricas:

http://www.catastro.meh.es/esp/estadisticas 6.asp

Ministerio de Hacienda y Administraciones Públicas. Coste efectivo de los servicios de las entidades locales:

https://serviciostelematicos.minhap.gob.es/Cesel/Consulta/Consulta.aspx

Sistema de Análisis de Balances Ibéricos ( $\mathrm{SABI}$ ):

https://sabi.bvdinfo.com/version-2016112/home.serv?product=sabineo 


\title{
8.3. FUENTES ESTADÍSTICAS \\ RELACIONADAS CON EL AGUA
}

\author{
María José Moya Llamas
}

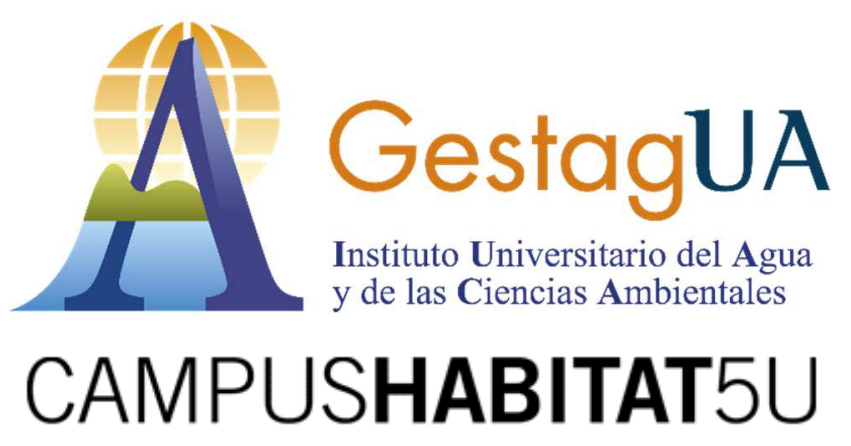




\section{INTRODUCCIÓN}

El agua es un recurso imprescindible para la vida humana y el medioambiente, pero también es un recurso escaso. El crecimiento de la población, su desigual reparto territorial, las actividades antropogénicas, entre otros, han supuesto una importante presión sobre el agua como recurso. Es necesario contar con instrumentos eficaces para su gestión. La información estadística es una herramienta necesaria para la gestión sostenible e integrada del agua.

El estudio estadístico del agua tiene como objetivo la descripción, evaluación y análisis de las disponibilidades y de los flujos en cantidades físicas que constituyen el llamado ciclo integral del agua, así como de las características de calidad de la misma, que a su vez repercuten en la cantidad disponible neta en los diferentes usos (Saralegui, J., 2008).

Una fuente estadística (statistical source/agency) es una entidad que recopila, procesa y distribuye datos estadísticos. Puede tratarse de entidades oficiales dedicadas a esta función (Eurostat, INE, Centro de Investigaciones Sociológicas (CIS), entidades oficiales no dedicadas específicamente a esta actividad (OCDE, ONU) o entidades privadas (asociaciones profesionales, etc.) (Montanyà, 2005).

Las fuentes estadísticas oficiales pueden constituir una base empírica muy importante en la generación de resultados. Éstas pueden ser recopiladas y distribuidas por unidades de gobierno locales a partir de registros administrativos o bien recopilarse a escala local y ser publicadas desde instancias administrativas superiores. Otra procedencia de las estadísticas oficiales son las encuestas, las cuales son el resultado de un trabajo coordinado a nivel nacional para la recopilación de datos que finalmente una agencia central reúne y distribuye de forma sistemática. (Corbetta, P., 2003).

\section{PRINCIPALES FUENTES ESTADÍSTICAS EN MATERIA DE AGUAS}

A continuación, se describen brevemente algunas de las fuentes estadísticas más relevantes en materia de aguas. 


\subsection{Fuentes estadísticas nacionales}

\subsubsection{Estatales}

\section{- INE}

El Instituto Nacional de Estadística (INE) es el organismo autónomo de carácter administrativo con personalidad jurídica y patrimonio propio adscrito al Ministerio de Economía y Competitividad encargado de coordinar todos los servicios estadísticos de la administración española. Es la principal fuente de datos estadísticos españoles. Dentro de la extensa temática del INE, en lo relativo a aguas cabe destacar:

- Encuesta sobre el Suministro y Saneamiento del Agua,

Esta encuesta tiene como principal objetivo proporcionar información de aquellas actividades relativas al ciclo integral del agua: captación, depuración, distribución, recogida y tratamiento de las aguas residuales.

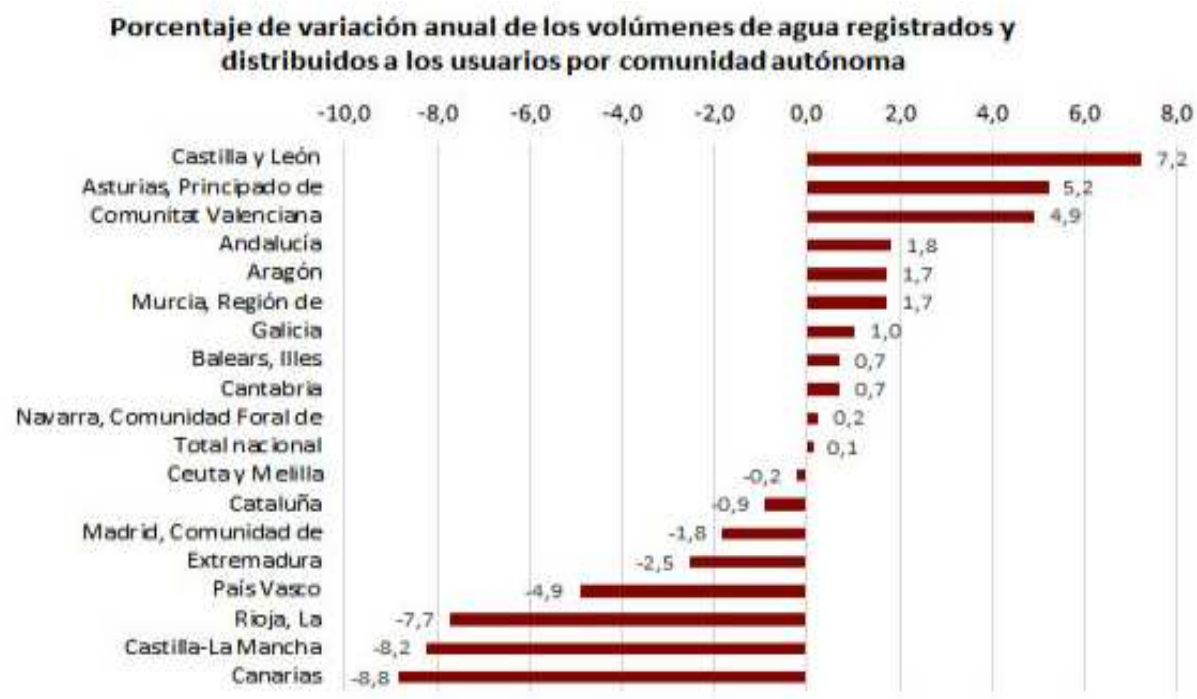

Figura 1. Extracto de la Encuesta sobre Suministro y Saneamiento de Agua. Año 2014

Esta publicación también recoge información sobre los distintos usos del agua, tanto en el sector agrario como en la industria. Se trata de una encuesta de periodicidad anual y cuyo ámbito abarca todo el territorio nacional. La publicación es de libre acceso a través de la página web del Instituto Nacional de Estadística.

- Encuesta sobre el Uso del Agua en el Sector Agrario,

El objeto de esta encuesta es cuantificar el volumen de agua utilizado para el riego por las comunidades de regantes, para en una segunda fase elevar dichos datos a la totalidad de la superficie de regadío de España con el fin 
de hacer una estimación de los volúmenes de agua de riego usados en todo el territorio nacional. Con carácter complementario esta encuesta estudia las variables económicas que conforman la actividad productiva de las comunidades de regantes. Su ámbito es el conjunto del territorio nacional y es de periodicidad anual.

Otras encuestas relevantes de este organismo son:

- Encuesta sobre el Uso del Agua en el Sector Industrial,

- Cuentas Satélites del Agua,

- Indicadores ambientales,

- Encuesta de Presupuestos Familiares.

\section{- AEAS}

La Asociación Española de Abastecimientos de Agua y Saneamiento, en colaboración con la Asociación Española de Empresas Gestoras de los Servicios de Agua a Poblaciones y los Ayuntamientos, realiza con carácter bienal una encuesta sobre Suministro de agua potable y saneamiento en España. Esta encuesta refleja indicadores relacionados con el ciclo integral del agua, incluyendo datos sobre el sector, abastecimiento, calidad del agua, saneamiento y gestión comercial.

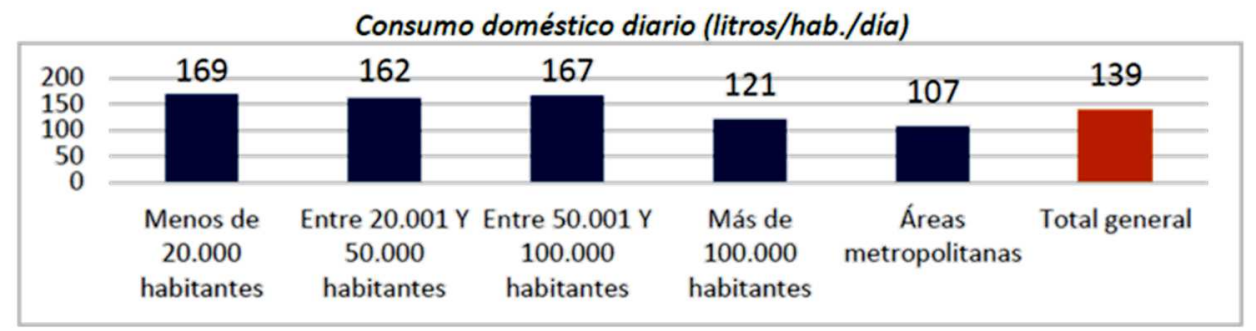

Figura 2. Consumo doméstico diario en España. Extracto del XIV Estudio Nacional de Suministro de Agua Potable y Saneamiento en España. Año 2016. AEAS.

\section{- Ministerio de Medio Ambiente y Medio Rural y Marino (MAGRAMA)}

Entre otras competencias, el MAGRAMA es el Departamento competente del Estado en materia de agua y medioambiente. Sus estadísticas en materia de aguas se centran en la evaluación de los recursos hídricos. Entre sus principales documentos estadísticos relacionados con el agua destacan:

- El Libro Digital del Agua. Recopilación de gran cantidad de información del estado de las masas de agua continentales subterráneas y superficiales, los recursos hídricos, las infraestructuras hidráulicas, los usos del agua y la calidad del agua. 
- Los Informes de Coyuntura. Se trata de informes periódicos que analizan la evolución reciente de los indicadores relativos al medio ambiente. El apartado de Aguas ofrece información sobre la situación actual y la evolución de las reservas hidráulicas y el llenado de los acuíferos.

- Boletines mensuales de Estadística (los cuales recogen datos pluviométricos mensuales),

- Boletines Hidrológicos semanales.

- El Anuario de Estadística.

- Agencia Estatal de Meteorología, la cual dispone de una base de datos que incluye series históricas de datos estadísticos en materia de precipitación.

\subsubsection{Fuentes autonómicas}

Las Comunidades Autónomas han asumido competencias en materia de estadística, creando sus respectivos institutos u oficinas de estadística. Los Índices anuarios estadísticos son de especial interés para la obtención de información a escala local que los datos en ellos reflejados generalmente se presentan por municipios. Algunos ejemplos de fuentes estadísticas procedentes de las CCAA son:

- El Instituto de Estadística de la Comunidad de Madrid,

- L'Institut d'Estadística de Catalunya

- El Instituto Valenciano de Estadística, entre otros.

Este último, por ejemplo, presenta la información estadística por temáticas. En materia de aguas, el apartado Territorio y Medioambiente supone una importante herramienta en cuanto a la distribución territorial del recurso, la pluviometría y los usos y calidad del agua.

\subsubsection{Fuentes locales}

Las corporaciones locales y ayuntamientos generalmente disponen de departamentos de estadística que editan publicaciones con datos agregados bien por temáticas o bien por territorio, los cuales se encuentran a disposición en los portales web de los respectivos ayuntamientos. De entre la información estadística que ofrecen destacan los Anuarios Estadísticos.

Las Mancomunidades, en el ejercicio de su función de coordinación de los diferentes municipios mancomunados, generalmente disponen de estadísticas 
relevantes en materia de aguas, tanto en lo referente al aprovechamiento y gestión del agua como en lo relativo a saneamiento, depuración e incluso reutilización.

\subsection{Fuentes estadísticas internacionales}

\section{- EUROSTAT}

La Oficina Europea de Estadística (EUROSTAT) es considerada la fuente de datos estadística europea más importante y ofrece información comparada de los distintos países que integran la Unión Europea. Pone a disposición datos macroeconómicos y también datos a nivel regional, los cuales se dividen en nueve áreas temáticas principales y treinta áreas subtemáticas. A continuación se acompaña un ejemplo de los datos estadísticos que ofrece EUROSTAT.

Tabla 1. Porcentaje de población conectada al menos a tratamiento secundario de aguas residuales (2003-2013) (\%). Fuente: EUROSTAT.

\begin{tabular}{|c|c|c|c|c|c|c|c|c|c|c|c|}
\hline & 2003 & 2004 & 2005 & 2006 & 2007 & 2008 & 2009 & 2010 & 2011 & 2012 & 2013 \\
\hline Belgium & 51.4 & 53.2 & 54.4 & 57.4 & 68.7 & 71.0 & 72.8 & 75.0 & 77.0 & 82.0 & 84.0 \\
\hline Bulgaria & 37.9 & 38.0 & 38.3 & 38.8 & 39.7 & 41.4 & 42.7 & 45.1 & 53.6 & 53.9 & 54.5 \\
\hline Czech Republic & 70.6 & 70.8 & 72.8 & 71.9 & 73.0 & 75.4 & 75.7 & 76.9 & 78.0 & 78.0 & 79.8 \\
\hline Denmark & : & & & : & & $:$ & 89.4 & 88.0 & 88.4 & 88.4 & 90.1 \\
\hline Germany & & 93.8 & 97.3 & : & 91.9 & & : & 95.3 & : & & \\
\hline Estonia & 70.0 & 71.0 & 73.0 & 73.0 & 73.5 & 79.5 & 79.5 & 78.3 & 81.1 & 81.2 & 82.1 \\
\hline Ireland & : & : & : & : & : & : & : & : & : & & \\
\hline Greece & : & : & : & : & 85.0 & : & 87.3 & 87.3 & 88.1 & 92.0 & \\
\hline Spain & : & : & : & 88.0 & : & 88.0 & : & 93.0 & & 94.8 & \\
\hline France & : & 79.5 & : & : & : & : & : & : & 56.1 & 56.1 & 55.4 \\
\hline Croatia & : & : & $:$ & : & $:$ & : & : & : & 27.0 & & \\
\hline Italy & $\vdots$ & $:$ & 93.6 & : & $\vdots$ & : & 83.0 & $:$ & : & : & \\
\hline Cyprus & 22.9 & 28.4 & 29.8 & : & : & : & : & : & : & : & \\
\hline Latvia & 68.3 & 64.3 & 63.8 & 62.9 & 60.9 & 54.3 & 60.9 & 58.1 & 63.9 & 66.0 & 67.2 \\
\hline Lithuania & 27.6 & : & : & : & : & : & : & : & & 63.1 & \\
\hline Luxembourg & 88.1 & & & & & & & 91.3 & 90.9 & 96.1 & 96.3 \\
\hline Hungary & 38.9 & 40.2 & 41.7 & 45.3 & 49.8 & 50.0 & 52.1 & 69.5 & 71.1 & 72.8 & 72.6 \\
\hline Malta & 16.1 & 13.3 & 13.2 & 9.3 & 8.4 & 14.8 & 15.2 & 6.6 & 93.2 & 93.1 & 92.9 \\
\hline Netherlands & 98.6 & 98.9 & 99.0 & 99.1 & : & 99.3 & & 99.4 & & 99.4 & \\
\hline Austria & & 88.9 & : & & $\vdots$ & 92.6 & & 93.9 & & 94.5 & \\
\hline Poland & 55.5 & 56.8 & 58.1 & 60.7 & 61.8 & 62.9 & 64.1 & 64.5 & 65.5 & 68.5 & 70.2 \\
\hline Portugal & 32.0 & & 42.6 & 37.0 & 51.0 & 52.0 & 55.8 & & & & \\
\hline Romania & : & 16.9 & 16.9 & & : & & & 22.0 & 31.0 & 32.7 & 35.5 \\
\hline Slovenia & 19.9 & 29.3 & 32.1 & 47.6 & 48.8 & 51.1 & 52.9 & 52.5 & 54.0 & 54.2 & 54.9 \\
\hline Slovakia & : & : & : & : & : & : & : & : & : & & \\
\hline Finland & & & : & & & $\because$ & $\because$ & 83.0 & 83.0 & 83.0 & 83.0 \\
\hline Sweden & 86.0 & 86.0 & 86.0 & 86.0 & 86.0 & 86.0 & 86.0 & 86.0 & 86.0 & 87.0 & 87.0 \\
\hline United Kingdom & & $:$ & : & $\therefore$ & $\therefore$ & 96.9 & 97.0 & 99.5 & $\vdots$ & $\therefore$ & \\
\hline Iceland & 1.0 & 1.0 & 2.0 & & & 2.0 & & & & & \\
\hline Norway & 55.4 & 56.2 & 58.0 & 58.6 & 58.5 & 58.8 & 59.3 & 59.2 & 61.4 & 62.6 & 62.6 \\
\hline Switzerland & . & $:$ & : & $:$ & $:$ & : & : & : & : & : & 98.0 \\
\hline Albania & - & & & & & & & 4.7 & 4.7 & 7.4 & 22.0 \\
\hline Serbia & 5.4 & 5.8 & 6.4 & 6.9 & 6.9 & 7.5 & 8.9 & 8.6 & 8.9 & 9.0 & 9.4 \\
\hline Turkey & 21.1 & 24.8 & & & 31.1 & 31.4 & 35.2 & 37.6 & & 42.0 & \\
\hline Bosnia and Herzegovina & 1.5 & 1.5 & 1.5 & 1.6 & 1.6 & 1.7 & 1.7 & 1.7 & 1.8 & 1.8 & 1.8 \\
\hline Kosovo & & & $\therefore$ & $:$ & 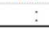 & $:$ & $:$ & : & 0.6 & 0.6 & 0.6 \\
\hline
\end{tabular}

En materia de aguas sus estadísticas abarcan:

- Los recursos hídricos (por año, promedio a largo plazo),

- Las extracciones (aguas dulces superficiales y las aguas subterráneas, otras fuentes),

- El uso del agua por grupo de actividad económica,

- las tasas de conexión a tratamiento de aguas residuales por tipo y nivel de tratamiento, 
- Infraestructuras de tratamiento de aguas residuales,

- Generación y disposición de lodos de depuradora,

- Generación de la contaminación marina producida por la fuente y su descarga por tipo de tratamiento.

- OCDE

La Organización para la Cooperación y el Desarrollo Económicos (OCDE) publica periódicamente estadísticas, entre las que destacan las de carácter medioambiental (OECD Environment Estatistics). En éstas se incluyen las siguientes bases de datos estadísticos relacionadas con el agua:

- Water,

- Water generation by sector,

- Green Growth Indicators,

- Environmental protection expenditure and revenues.

Así como las publicaciones:

- Environmental Performance of Agriculture in OECD countries since 1990: 6. Water (use and quality). Base de datos sobre calidad y uso del Agua en los países miembros de la OCDE.

- Sustainable Management of Water Resources in Agriculture. ISBN 97892-64-083455. OECD 2010.

- ONU

Dentro del programa denominado Workd Water Assessment Programe (WWAP) de la UNESCO cabe resaltar:

- Los informes monográficos periódicos en materia de aguas denominados The United Nations World Water Development Reports (WWDR), los cuales ofrecen un panorama global sobre el estado de los recursos de agua dulce del planeta. Basados en indicadores sobre el uso, la gestión y el estado de los recursos hídricos, su objetivo principal es proporcionar herramientas a los responsables de la toma de decisiones para la implementación del uso sostenible de los recursos hídricos.

- La publicación Cuentas y Estadísticas del Agua. División de Estadística de la ONU. Mayo de 2011. 
- OMS

- Bases de datos y estadísticas sobre agua, saneamiento y salud.

Esta base de datos incluye estimaciones de cobertura del suministro de agua y saneamiento, además de los datos de encuestas domiciliarias (MICS, DHS, censos, etc.) que se usaron para obtener tales estimados.

- UNICEF

- Dispone de una importante base de datos estadísticos denominada DevInfo. Entre las materias recogidas por Devinfo están agua, saneamiento y recursos medioambientales.

\section{- World Resources Institute}

El Instituto de Recursos Mundiales (WRI) es organización mundial de investigación no gubernamental que estudia la gestión sostenible de recursos naturales. Entre las cinco áreas objeto de estudio está el agua. Además de diferentes publicaciones centradas en el agua como recurso natural escaso y fuente de progreso, el apartado Maps \& Data de su página web ofrece interesantes gráficos y estadísticas al respecto.

\section{BIBLIOGRAFÍA}

Corbetta, Piergiorgio. (2003). Metodología y técnicas de investigación social (No. 303.1). McGraw-Hill.

Gil, J. S. (2008). Las encuestas del agua en el INE. Indice: Revista de estadística y sociedad, (28), 6-7.

Montanyà Lacambra, Rosa. (2005). Fuentes estadísticas y bibliotecas: estado de la cuestión. BiD: textos universitaris de biblioteconomia i documentació, núm. 15 (desembre). <http://bid.ub.edu/15monta2.htm>.

\section{ENLACES}

AEAS: http://www.aeas.es

AEMET: http://www.aemet.es

EUROSTAT: http://ec.europa.eu/eurostat/ 
HISPAGUA: http://hispagua.cedex.es/

INE: http://www.ine.es

MAGRAMA: http://www.magrama.gob.es/es/agua/estadisticas/

OCDE: http://www.oecd.org/

OMS: http://www.who.int/water_sanitation_health/database/es/

ONU: http://www.un.org/es/index.html

UNICEF: http://www.unicef.org/spanish/wash/index_statistics.html

World Resources Institute: http://www.wri.org/ 


\title{
8.4. TÉCNICAS DE ANÁLISIS
}

\author{
Patricia Fernández Aracil
}

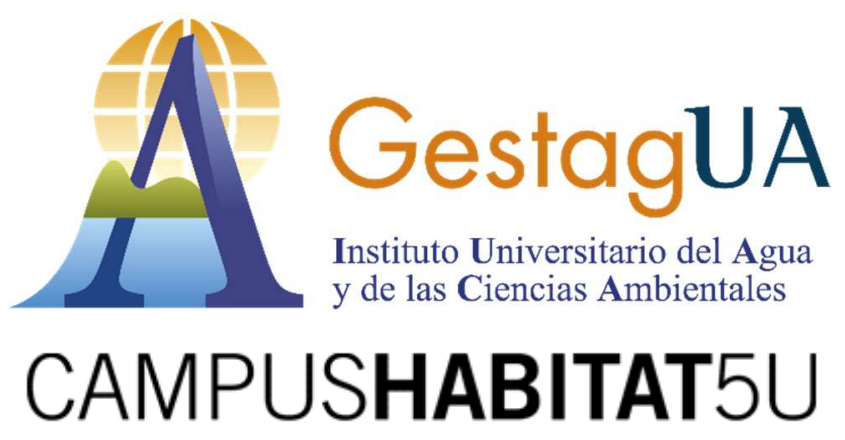




\section{INTRODUCCIÓN}

Toda investigación llevada a cabo mediante metodología cuantitativa debe sustentarse en un análisis empírico de datos para que las conclusiones extraídas sean válidas. La herramienta de análisis idónea vendrá determinada por los fines de la investigación en particular.

En este caso, haremos referencia al tratamiento de datos procedentes de fuentes estadísticas tales como las mencionadas en las lecciones anteriores, vinculadas con la ordenación territorial, la planificación urbanística, la gestión del agua o el enfoque integral de estas disciplinas.

Generalmente, los fenómenos que se desean estudiar se encuentran influidos por múltiples variables, por lo que las herramientas estadísticas más apropiadas para realizar dicho análisis empírico son las técnicas de análisis multivariante.

Sin embargo, la elección de una técnica de análisis no es una decisión sencilla, pues bajo la denominación de análisis multivariante se encuentra una gran diversidad de técnicas. Por ello, es muy importante comprender bien en qué consiste cada una de ellas, mientras que aquí esbozaremos las líneas generales que definen algunas de las más utilizadas, según lo explicado en Lévy y Varela (2003).

\section{TÉCNICAS DE ANÁLISIS DE LA DEPENDENCIA}

Las técnicas de análisis de la dependencia se aplican cuando una o más variables dependientes van a ser explicadas por un conjunto de variables independientes que actúan como predictores. Por ejemplo, si queremos analizar los factores que explican el desarrollo de un modelo urbano disperso, el porcentaje de viviendas unifamiliares construidas con respecto al total de viviendas podría ser nuestra variable dependiente, mientras que factores tales como el precio de los carburantes, el precio del suelo o el nivel económico de las familias constituirán las diferentes variables independientes.

El siguiente esquema puede ayudarnos en la elección de la técnica de análisis de la dependencia más apropiada: 


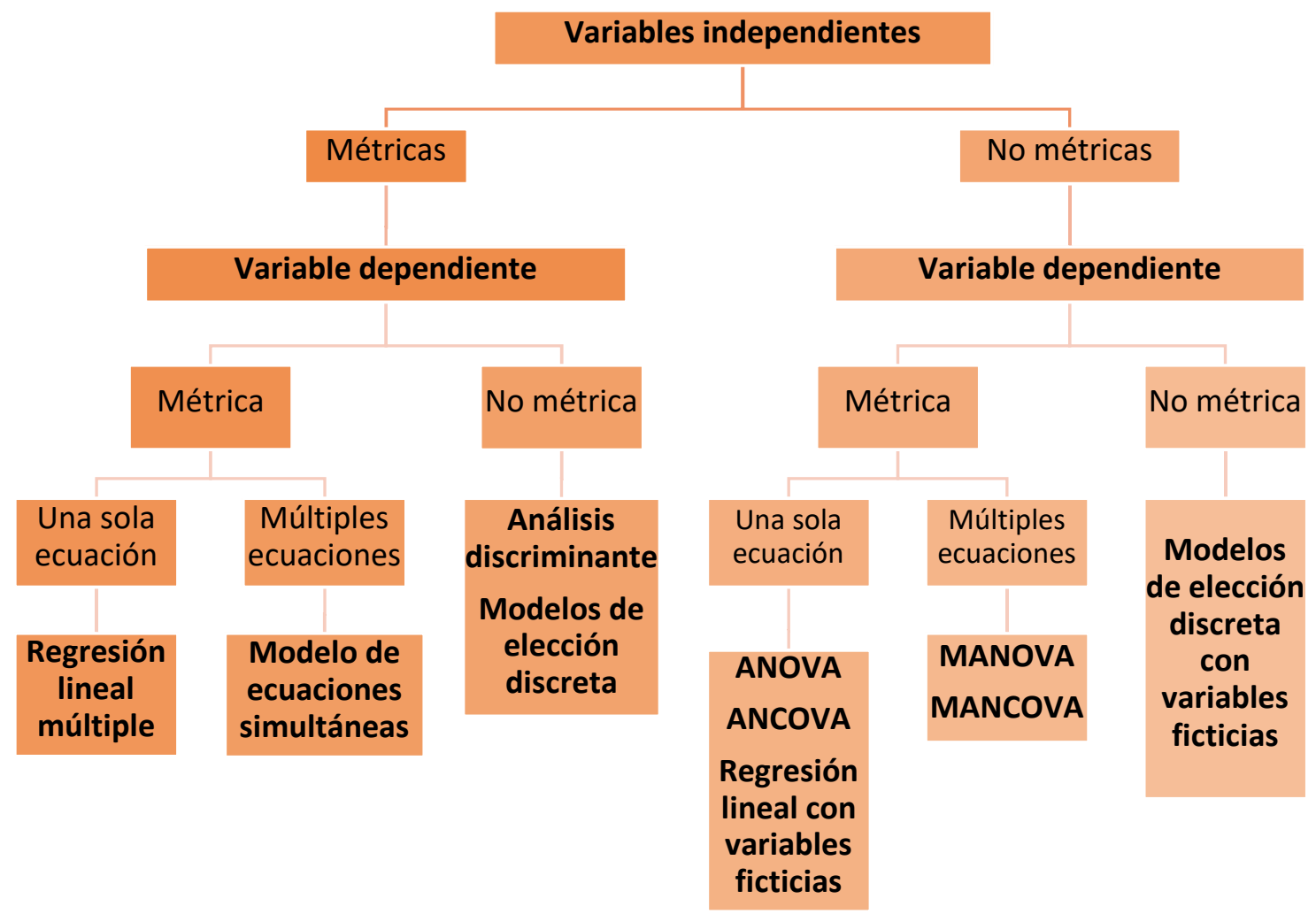

Figura 1. Criterios para escoger una técnica de análisis de la dependencia. Fuente:

Pérez, 2007.

\section{TÉCNICAS DE ANÁLISIS DE LA INTERDEPENDENCIA Y OTRAS}

Las técnicas de análisis de la interdependencia otorgan la misma consideración a todas las variables objeto de estudio, sin distinguir entre dependientes e independientes, y tienen como fin descubrir las interrelaciones y, en definitiva, la estructura subyacente en ellas. Son, por lo tanto, técnicas de clasificación, tales como: análisis factorial y por componentes principales, análisis de correspondencias, análisis de conglomerados, escalamiento multidimensional o análisis con clases latentes.

Otras técnicas, más novedosas que las anteriores, surgen para permitir un tratamiento más eficaz y eficiente de las ingentes cantidades de datos que se manejan en la actualidad. Por ejemplo, permiten clasificar y predecir simultáneamente: elección multicriterio discreta, análisis con redes neuronales o data mining. 


\section{REGRESIÓN LINEAL MÚLTIPLE}

Para finalizar esta lección, exponemos cómo resultaría una ecuación en su expresión más general tras plantear un análisis de regresión múltiple a un conjunto de datos que hayamos recopilado. El modo de obtener la citada ecuación pasaría por introducir la información en un programa de tratamiento estadístico de datos, como podría ser: $R$ (software libre), Stata, Eviews, SPSS o aquél que pueda estar a nuestra disposición. En los casos más sencillos, también nos puede servir una hoja de cálculo como Excel, por ejemplo.

Pongamos como ejemplo un modelo econométrico lineal, resultado de analizar un conjunto de datos de panel. La herramienta matemática para resolver numéricamente esta regresión lineal múltiple podría ser un análisis basado en la metodología de mínimos cuadrados ordinarios (MCO) o en mínimos cuadrados generalizados (MCG), por poner dos ejemplos. Sin embargo, esta decisión formaría parte de una fase posterior que conviene estudiar detenidamente, pues las variables han de cumplir, además, una serie de requisitos previos dependiendo de cada caso: normalidad, linealidad, homocedasticidad, etc. En el presente MOOC nos limitamos a plantear los aspectos más generales e introductorios.

Este ejemplo es una ecuación de tipo log-log, esto es, aplicando logaritmos naturales tanto a la variable dependiente, como a las variables independientes. La transformación logarítmica de todas las variables antes de realizar el cálculo posee ciertas ventajas como, por ejemplo, que los cambios en los logaritmos se corresponden aproximadamente con variaciones porcentuales o que la distribución empírica del logaritmo de la variable se dibuja más cercana a una distribución normal, característica que contribuye a cumplir con los requisitos previos de las variables y, por lo tanto, a evitar que las conclusiones sean espurias. Una regresión espuria sería algo erróneo, pues sería únicamente producto de la casualidad y no de relaciones causales que realmente existen.

$$
\log \left(Y_{x t}\right)=\beta_{0}+\beta_{i} \log \left(X_{x t_{i}}\right)+\varepsilon
$$


El significado de los símbolos es el que se sigue:

$\mathrm{Y}_{\mathrm{xt}}$ : variable dependiente o explicada

$\mathrm{X}_{\mathrm{xt}}$ : variables independientes o explicativas

$\beta_{0}$ : constante o intercepto

$\beta_{\mathrm{i}}$ : coeficientes estimados

$\varepsilon:$ parámetro de perturbación aleatoria o término de error

$\mathrm{x}$ : unidad espacial de análisis (país, región, provincia, municipio, calle, etc.)

t: unidad temporal de análisis (año, trimestre, mes, etc.)

Por medio de una ecuación como la reflejada en las líneas anteriores, obtendríamos una cuantificación de las elasticidades de la variable dependiente con respecto a cada una de las variables independientes. Esto es así gracias a haber aplicado previamente los logaritmos naturales y la traducción literal de cada coeficiente $\beta$ estimado sería como se sigue: el incremento de un $1 \%$ en la variable $X_{i}$ genera un incremento del $\beta_{i} \%$ en la variable $Y$, ceteris paribus, es decir, permaneciendo el resto de factores constantes.

\section{BIBLIOGRAFÍA}

Lévy Magin, J-P. y Varela Mallou, J. (2003). Análisis Multivariable para las Ciencias Sociales. Madrid: Pearson Prentice Hall.

Greene, William H. (1998). Análisis Econométrico. Madrid: Pearson Prentice Hall.

Pérez, C. (2007). Econometría básica: técnicas y herramientas. Madrid: Pearson Prentice Hall.

Pérez, C. (2008). Econometría avanzada: técnicas y herramientas. Madrid: Pearson Prentice Hall. 


\section{MÓDULO 9}

\section{LA PROTECCIÓN AMBIENTAL DEL RECURSO}




\title{
9.1. VERTIDOS INDIRECTOS A REDES DE SANEAMIENTO
}

\author{
Irene Sentana Gadea
}

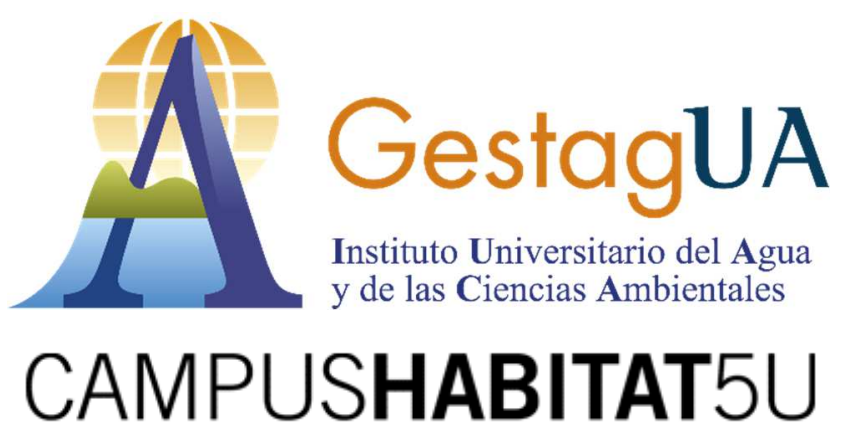




\section{INTRODUCCIÓN}

El Real Decreto 849/1986, de 11 de abril considera vertidos indirectos aquellos que se realizan en aguas superficiales a través de azarbes, redes de colectores de recogida de aguas residuales o de aguas pluviales, o por cualquier otro medio de desagüe, o cualquier otro elemento del dominio público hidráulico, así como los realizados en aguas subterráneas mediante filtración a través del suelo o del subsuelo.

En relación a las ramblas, tienen la doble consideración de vertidos directos (a aguas superficiales en las épocas en las que el cauce lleve agua, o al DPH en la época en las que el cauce esté seco) y de vertidos indirectos a subterráneas. Por tanto, como vertidos directos o indirectos deberán cumplir los límites de emisión más restrictivos de los dos casos. (MMA, 2007).

Además, el Reglamento del Dominio Público Hidráulico considera que los azarbes (canales de desagüe de riego) son vertidos indirectos.

Los vertidos con destino aguas superficiales a través de la red de alcantarillado o de colectores tiene como órgano competente en cuencas tanto intercomunitarias como intracomunitarias al órgano autonómico o local.

\section{VERTIDOS URBANOS O INDUSTRIALES CON SUSTANCIAS PELIGROSAS DE LA LISTA I}

La Directiva relativa a la protección de las aguas subterráneas contra la contaminación causada por determinadas sustancias peligrosas (80/68/CEE), en relación a los vertidos de aguas residuales, prohíbe el vertido directo de aguas residuales que contengan sustancias de la lista I de dicha directiva y obliga a establecer las medidas de protección adecuadas para impedir los vertidos indirectos de las mismas sustancias.

Dentro de las sustancias de la lista I se incluyen en la directiva 80/68/CEE las siguientes:

- Compuestos organohalogenados y sustancias que puedan originar compuestos semejantes en medio acuático.

- Compuestos organofosforados.

- Compuestos orgánicos de estaño. 
- Sustancias que posean un poder cancerígeno, mutágeno o teratógeno en el medio acuático o a través del mismo.

- Mercurio y compuestos de mercurio.

- Cadmio y compuestos de cadmio.

- Aceites minerales e hidrocarburos.

- Cianuros.

A su vez dicha directiva también limita la autorización de vertidos directos e indirectos en aguas con sustancias de la lista II, dependiendo de estudios hidrogeológicos, y la evaluación de riesgos que demuestren que medioambientalmente el vertido no produce contaminación de las aguas subterráneas. Entre los compuestos de la lista II se encuentran (tabla 1):

Tabla 1. Lista II. Directiva 80/68/CEE

\begin{tabular}{|c|c|c|c|c|c|c|}
\hline \multicolumn{7}{|c|}{ Metaloides y metales así como sus compuestos } \\
\hline Cinc & Cobre & Niquel & Cromo & Plomo & Selenio & Arsénico \\
\hline Antimonio & Molibdeno & Titanio & Estaño & Bario & Berilio & Boro \\
\hline Uranio & Vanadio & Cobalto & Talio & Telurio & Plata & \\
\hline \multicolumn{7}{|c|}{ Biocidas y sus derivados que no estén en la lista I } \\
\hline \multicolumn{7}{|c|}{$\begin{array}{l}\text { Sustancias que tenga un efecto perjudicial en el sabor y/olor de las aguas } \\
\text { subterráneas, así como los compuestos que puedan originar dichas sustancias en } \\
\text { las aguas, volviéndolas no aptas para el consumo humano }\end{array}$} \\
\hline \multicolumn{7}{|c|}{$\begin{array}{l}\text { Compuestos orgánicos de silicio tóxicos o persistentes y sustancias que puedan } \\
\text { originar dichos compuestos en las aguas, salvo aquellos que sean biológicamente } \\
\text { inocuos o que se transformen rápidamente en el agua en sustancias inocuas }\end{array}$} \\
\hline \multicolumn{7}{|c|}{ Compuestos inorgánicos de fosforo elemental } \\
\hline \multicolumn{7}{|c|}{ Fluoruros } \\
\hline \multicolumn{7}{|c|}{ Amoniaco y nitritos } \\
\hline
\end{tabular}

Como se puede observar un amplio abanico de sustancias de la lista II comprende metales y muchas de estas sustancias se producen principalmente en el ámbito industrial.

\section{VERTIDOS INDUSTRIALES A REDES DE SANEAMIENTO}

Las leyes que regulan el vertido de aguas industriales a la red de saneamiento en las diferentes Comunidades son similares, aunque los valores limite a veces cambian sustancialmente. A modo de ejemplo se muestra en la tabla 2, los parámetros físico químicos de la Comunidad de Madrid (Ley 10/1993, de 26 de octubre) junto con los establecidos por el Ayuntamiento de Alicante. Se establece 
que todos los vertidos a la red de alcantarillado deben ajustarse a la composición y las características fijadas por las Comunidades.

Según la Ordenanza de Gestión y Uso Eficiente del Agua en la Ciudad de Madrid de 31/05/2006, si el resultado de dicha caracterización indicará que se sobrepasan los límites establecidos en el anexo II del Decreto 57/2005 de la Consejería de Medio Ambiente y Ordenación del Territorio de la Comunidad de Madrid (tabla 2), la empresa solicitante del vertido a la red de saneamiento, deberá presentar un estudio de tratamiento previo ante el órgano ambiental competente del Ayuntamiento donde constarán como mínimo:

- caudal a tratar y proceso industrial que lo genera

- composición del agua bruta antes del tratamiento

- características del tratamiento de depuración propuesto

Tabla 2. Requisitos para vertidos a redes de alcantarillado establecidos por las administraciones locales competentes.

\begin{tabular}{|c|c|c|c|}
\hline Parámetro & Unidades & $\begin{array}{c}\text { Valores máximos } \\
\text { instantáneas. Ayto } \\
\text { Madrid }\end{array}$ & Ayto.Alicante $* 1$ \\
\hline Temperatura & ${ }^{\circ} \mathrm{C}$ & 40 & 50 \\
\hline pH & Ud de $\mathrm{pH}$ & $6-10$ & $5.5-9.5$ \\
\hline DBO5 & $\mathrm{mg} / \mathrm{L}$ & 1000 & 700 \\
\hline DQO & $\mathrm{mg} / \mathrm{L}$ & 1750 & 1300 \\
\hline Sólidos en Suspensión & $\mathrm{mg} / \mathrm{L}$ & 1000 & 1000 \\
\hline Aceites y grasas & $\mathrm{mg} / \mathrm{L}$ & 100 & 100 \\
\hline Cianuros totales & $\mathrm{mg} / \mathrm{L}$ & 5 & 1 \\
\hline Cloruros & $\mathrm{mg} / \mathrm{L}$ & 2000 & 1600 \\
\hline Conductividad & Us7CM2 & 7500 & 3800 \\
\hline Detergentes totales & $\mathrm{mg} / \mathrm{L}$ & 30 & 25 \\
\hline Fluoruros & $\mathrm{mg} / \mathrm{L}$ & 15 & 9 \\
\hline Sulfatos & $\mathrm{mg} / \mathrm{L}$ & 1000 & 1000 \\
\hline Sulfuros & $\mathrm{mg} / \mathrm{L}$ & 5 & 2 \\
\hline Toxicidad & Equitox $/ \mathrm{m}^{3}$ & 25 & 25 \\
\hline \multicolumn{4}{|c|}{ COMPUESTOS ORGANOHALOGENADOS } \\
\hline $\begin{array}{l}\text { Organohalogenados } \\
\text { adsorbibles (AOX) }\end{array}$ & $\mathrm{mg} \mathrm{Cl} / \mathrm{L}$ & 5 & \\
\hline THM (Totales) & $\mathrm{mg} / \mathrm{L}$ & 2.5 & \\
\hline \multicolumn{4}{|c|}{$\begin{array}{l}\text { HIDROCARBUROS PERSISTENTES Y SUSTANCIAS ORGÁNICAS TÓXICAS Y } \\
\text { BIOACUMULABLES }\end{array}$} \\
\hline $\begin{array}{l}\text { BTEX (Benceno tolueno } \\
\text { etilbenceno y xileno) }\end{array}$ & $\mathrm{mg} / \mathrm{L}$ & 1.5 & \\
\hline Fenoles totales & $\mathrm{mg} / \mathrm{L}$ & 2 & 2 \\
\hline $\begin{array}{l}\text { Hidrocarburos } \\
\text { aromáticos policíclicos } \\
\text { (PAH) }\end{array}$ & $\mathrm{mg} / \mathrm{L}$ & 1 & 1 Pesticidas \\
\hline Hidrocarburos totales & $\mathrm{mg} / \mathrm{L}$ & 20 & 25 \\
\hline Aluminio & $\mathrm{mg} / \mathrm{L}$ & 20 & 10 \\
\hline Arsenico & $\mathrm{mg} / \mathrm{L}$ & 1 & 1 \\
\hline Bario & $\mathrm{mg} / \mathrm{L}$ & 20 & 20 \\
\hline Boro & $\mathrm{mg} / \mathrm{L}$ & 3 & 3 \\
\hline Cadmio & $\mathrm{mg} / \mathrm{L}$ & 0.5 & 0.5 \\
\hline
\end{tabular}




\begin{tabular}{|c|c|c|c|}
\hline Cobre & $\mathrm{mg} / \mathrm{L}$ & 3 & 1 \\
\hline Cromo hexavalente & $\mathrm{mg} / \mathrm{L}$ & 1 & 0.6 \\
\hline Cromo total & $\mathrm{mg} / \mathrm{L}$ & 3 & 2 \\
\hline Estaño & $\mathrm{mg} / \mathrm{L}$ & 2 & \\
\hline Hierro & $\mathrm{mg} / \mathrm{L}$ & 10 & 10 \\
\hline Manganeso & $\mathrm{mg} / \mathrm{L}$ & 2 & 1 \\
\hline Mercurio & $\mathrm{mg} / \mathrm{L}$ & 0.1 & 0.1 \\
\hline Niquel & $\mathrm{mg} / \mathrm{L}$ & 5 & 4 \\
\hline Plata & $\mathrm{mg} / \mathrm{L}$ & 1 & \\
\hline Plomo & $\mathrm{mg} / \mathrm{L}$ & 1 & 0.6 \\
\hline Selenio & $\mathrm{mg} / \mathrm{L}$ & 1 & 1 \\
\hline Zinc & $\mathrm{mg} / \mathrm{L}$ & 3 & 5 \\
\hline Tóxicos metálicos & $\mathrm{mg} / \mathrm{L}$ & 5 & \\
\hline \multicolumn{4}{|c|}{ SUSTANCIAS QUE CONTRIBUYEN A LA EUTROFICACIÓN } \\
\hline Nitrógeno total & $\mathrm{mg} / \mathrm{L}$ & 125 & \\
\hline Nitrógeno-Amoniacal & $\mathrm{mg} \mathrm{N} / 1$ & & 65 \\
\hline Nitrógeno Kjendahl & $\mathrm{mg} \mathrm{N} / 1$ & & 75 \\
\hline
\end{tabular}

Para la consecución de los objetivos de vertido a alcantarillado, las industrias deben aplicar tratamientos avanzados a sus aguas de forma que reduzcan los contaminantes mayoritarios. Es tal la diversidad de industrias y los procesos que en sus instalaciones se realizan que no hay tratamientos estándar para todas, sino que cada una debe adaptarse a sus necesidades y cargas contaminantes que producen.

La eliminación de los contaminantes se puede hacer bien por métodos no destructivos (adsorción, desorción, extracción en fase líquida o tecnología de membranas) que permiten en la mayoría de los casos concentrar para luego eliminar mediante una destrucción química posterior, o por métodos destructivos (tratamientos biológicos, oxidación química).

Según Rodríguez-Fernández et al. (2006) existen los tratamientos convencionales que principalmente abarcan:

- Los tratamientos de eliminación de materia en suspensión (desbaste, sedimentación, flotación, filtración, coagulación- floculación)

- Tratamientos para la eliminación de materia orgánica disuelta (precipitación, procesos electroquímicos, intercambio iónico, adsorción, desinfección)

- Tratamientos biológicos (Procesos biológicos aerobios, anaerobios y proceso biológicos de eliminación de nitrógeno y fósforo)

Destacar los tratamientos de coagulación floculación y electrocoagulación, que se utilizan tanto en el tratamiento de aguas residuales urbanas como en el ámbito industrial, en empresas textiles, papeleras, de alimentación... para la selección de los tratamientos se requieren estudios previos para la selección del coagulante y de 
aquellos parámetros como $\mathrm{pH}$, dosis, etc., que afectan en los rendimientos de eliminación.

Los procesos electroquímicos se aplican muchas veces para la reducción de metales tóxicos presentes en las aguas.

Dentro de los tratamientos biológicos existe un amplio abanico de procesos como:

- Aerobios

- Proceso de fangos activados

- Procesos con biomasa soportada

- Anaerobios

- Reactores de contacto

- Reactor de manto de lodos y flujo ascendente (UASB)

- Filtro anaerobio

- Reactor anaerobio de lecho fluidizado

Los procesos de reducción de nitrógeno, son tratamientos biológicos en los que las bacterias autótrofas producen una nitrificación en presencia de oxígeno, y posteriormente mediante bacterias desnitrificantes se produce la eliminación de NO3- en un sistema anóxico.

La reducción de fósforo, se hacía tradicionalmente con adición de $\mathrm{Ca} 2+$, aunque también hay métodos para su eliminación biológica, en este proceso los microrganismos de la masa bacteriana en un ambiente pobre en oxígeno (anaerobio), no consumen fósforo debido a la presencia de ácido acético, pero si posteriormente se produce un sistema aerobio con aporte de oxígeno, dichos microorganismos consumen de forma rápida el fosforo, lo que permiten sedimentar y separar.

Estas tecnologías convencionales van muchas veces unidas a tecnologías emergentes para reducir aún más la producción de vertidos. Entre las principales tecnologías emergentes encontramos:

- Oxidación

- Procesos de membrana.

Dentro de los procesos de oxidación, se encuentra la oxidación química, donde se incluyen proceso de:

- Incineración

- Oxidación húmeda no catalítica 
- Oxidación húmeda catalítica

- Oxidación húmeda supercrítica

- Procesos avanzados de oxidación donde se generan radicales hidróxilos para interaccionar con compuestos orgánicos presentes en las aguas, los reactivos más comunes para generar estos radicales $\mathrm{HO}^{-}$son el ozono, el peróxido de hidrógeno, la radiación ultravioleta y la fotocatálisis. Entre los tratamientos avanzados se pueden destacar los siguientes:

- Ozonización en medio alcalino

- Ozonización con peróxido de hidrógeno

- Métodos de ozono-ultravioleta

- Peróxido de hidrógeno-catalizador

- Procesos fot-Fenton $\left(\mathrm{Fe}^{+2} / \mathrm{H}_{2} \mathrm{O}_{2} / \mathrm{UV}\right)$

- Oxidación avanzada con ultrasonidos (UA) $\left(\mathrm{O}_{3} /\right.$ US y $\mathrm{H}_{2} \mathrm{O}_{2} /$ US

- Métodos electroquímicos

- Oxidación catalítica $\left(\mathrm{O}_{3} /\right.$ Cat.)

- Proceso fotocatalíticos $\left(\mathrm{O}_{3} / \mathrm{TiO}^{2} / \mathrm{UV}\right.$ y $\left.\mathrm{H}_{2} \mathrm{O}_{2} / \mathrm{TiO}_{2} / \mathrm{UV}\right)$

En las últimas décadas los procesos de membrana han tenido un papel muy destacado, su principal ventana es que estos procesos se llevan a cabo a temperatura ambiente, son procesos sencillos y compactos y permiten separar contaminantes disueltos o dispersos en forma coloidal incluso a baja concentración. Su clasificación se puede hacer bien por el tipo de membranas, por la forma de filtración, pero una de la clasificación más habitual depende del tamaño del poro de la membrana dividiéndose entre:

- Microfiltración

- Ultrafiltración

- Nanofiltración

- Ósmosis inversa

Su principal inconveniente es el ensuciamiento de las membranas, esto requiere someterlas a limpiezas periódicas si se quieren mantener los caudales de tratamiento y el coste económico que implica la fuerza impulsora necesaria para el proceso, donde por lo general se requieren grandes aportes energéticos.

También se utilizan los procesos basados en la electrodiálisis con membranas, donde la incorporación de cargas eléctricas restringe el paso de iones presente en la disolución acuosa, en este caso en lugar de ser la fuerza impulsora la presión, es la diferencia de potencial eléctrico. 
A modo de ejemplo, en una industria cárnica, sus aguas se caracterizan por contener una elevada carga orgánica debido a la presencia de sangre, grasas, purines..., además de valores elevados de sólidos en suspensión, nitrógeno, fósforo y sal. Además, las aguas presentan fluctuaciones importantes de $\mathrm{pH}$ debido al uso en su proceso de ácidos y sosa como agentes de limpieza.

Entre las etapas del tratamiento se podría incluir están:

- Pretratamiento

- Desbaste de gruesos y finos

- Desengrasado mediante flotación

○ Homogenización

- Tratamientos biológicos posibles

- Proceso de lodos activos donde se incluyan proceso de desnitrificación

- Proceso con reactores biológicos secuenciales SBR, donde se combina en un mismo tanque el proceso de reacción, la aeración y la clarificación y soporta relativamente bien las fluctuaciones de caudal.

- Procesos anaerobios. Estos permiten realizar la disminución del contenido de materia orgánica y nitrógeno con un consumo energético menor que los procesos anteriores.

Como se ha venido mostrando en todo este tema, la reglamentación para el vertido debe ser cumplida de manera escrupulosa por el bien del medioambiente, pero no existen tratamientos únicos que permitan ser aplicados a todos los vertidos. En referencia a los vertidos industriales, convendrá hacer un estudio exhaustivo de la composición de los vertidos y analizar qué tratamientos son los correctos para cumplir las directivas que les sean de aplicación en cada caso.

\section{BIBLIOGRAFÍA}

Real Decreto 849/1986, de 11 de abril, por el que se aprueba el Reglamento del Dominio Público Hidráulico que desarrolla los títulos preliminares, I, IV, V, VI, VII y VIII del texto refundido de la Ley de Aguas, aprobado por el Real Decreto Legislativo $1 / 2001$, de 20 de julio y sus modificaciones.

MMA (2007). Ministerio de Medio Ambiente (2007). Manual para la gestión de vertidos. Madrid: Ministerio de Medio Ambiente. Recuperado de: http://www.magrama.gob.es/es/agua/publicaciones/Manual_para_la_gestion_de_ver tidos_tcm7-28966.pdf 
DECRETO 57/2005, de 30 de junio, por el que se revisan los Anexos de la Ley 10/1993, de 26 de octubre, sobre Vertidos Líquidos Industriales al Sistema Integral de Saneamiento.

http://www.defensa.gob.es/itoxdef/Galerias/documentacion/legislacion/ficher os/05-_DECRETO_57-2005_de_30_de_junioxrevision_Ley10-1993.pdf

Directiva del Consejo del 17 de diciembre de 1979 relativa a la protección de las aguas subterráneas contra la contaminación causada por determinadas sustancias peligrosas. 80/68/CEE.

Ordenanza de Gestión y Uso Eficiente del Agua en la Ciudad de Madrid. Marginal: ANM 2006\50. Tipo de Disposición: Ordenanzas municipales. Fecha de Disposición: $31 / 05 / 2006$. http://www.madrid.es/UnidadWeb/UGNormativas/Normativa/2006/Ficheros/ ANM200650.pdf

ORDENANZA DE VERTIDOS DEL SERVICIO MUNICIPAL DE ALCANTARILLADO. Texto aprobado, inicialmente, por el Pleno de 29 de septiembre de 2008, de cuya elevación a definitivo se dio cuenta al Pleno de 27 de marzo de 2009 PUBLICACIÓN: BOP: no 93, de 20 de mayo de 2009. Ayuntamiento de Alicante

Tratamientos avanzados de aguas residuales industriales. Rodríguez Fernández-Alba, Antonio; Letón García, Pedro; Rosal García, Roberto; Dorado Valiño, Miriam; Villar Fernández, Susana y San García, Juana Mạ. CITME, CEIM, Comunidad de Madrid. Madrid, 2006. 136 páginas Vigilancia tecnológica n 2 "Tratamientos avanzados de aguas residuales industriales". https://www.madrimasd.org/informacionidi/biblioteca/publicacion/doc/VT/VT2_Trata mientos_avanzados_de_aguas_residuales_industriales.pdf 


\title{
9.2. VERTIDOS DIRECTOS A AGUAS CONTINENTALES Y MARINAS
}

\author{
Pedro Varó Galvañ
}

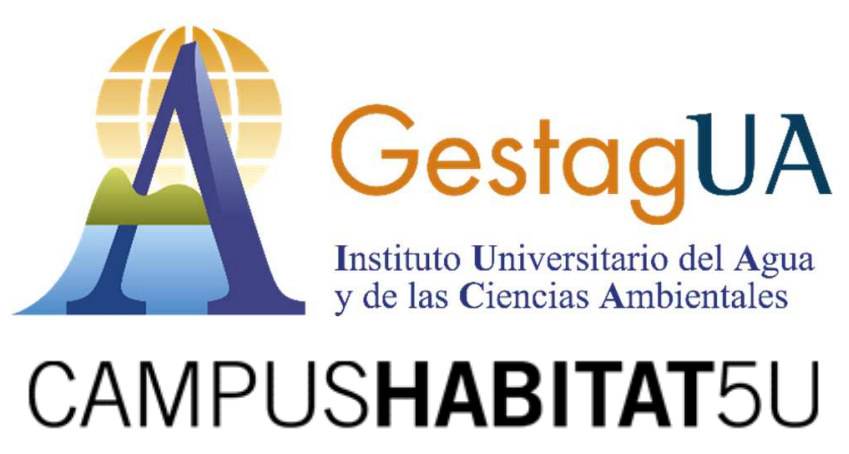




\section{INTRODUCCIÓN}

En base a lo dispuesto en el Real Decreto 817/2015, por el que se establecen los criterios de seguimiento y evaluación del estado de las aguas superficiales y las normas de calidad ambiental, se consideran:

Aguas continentales: todas las aguas en la superficie del suelo, y todas las aguas subterráneas situadas hacia tierra desde la línea que sirve de base para medir la anchura de las aguas territoriales.

Aguas costeras: las aguas superficiales situadas hacia tierra desde una línea cuya totalidad de puntos se encuentren a una distancia de una milla náutica mar adentro desde el punto más próximo de la línea de base que sirve para medir la anchura de las aguas territoriales y que se extienden, en su caso, hasta el límite exterior de las aguas de transición. $Y$ aguas de transición: masas de agua superficiales próximas a las desembocaduras de los ríos y que son parcialmente salinas como consecuencia de su proximidad a las aguas costeras, pero que reciben una notable influencia de flujos de agua dulce.

Se considera vertido directo la emisión directa de contaminantes a las aguas continentales o a cualquier otro elemento del DPH (dominio público hidráulico), así como la descarga de contaminantes en el agua subterránea mediante inyección sin percolación a través del suelo o del subsuelo.

Los vertidos directos a ramblas, tienen la doble consideración de vertidos directos (a aguas superficiales en las épocas en que el cauce lleve agua, o al DPH en la época en la que el cauce se encuentre seco) y de vertidos indirectos a subterráneas. (MMA, 2007).

Los tipos de vertido considerados a efectos de la gestión de vertidos son:

- vertidos urbanos y asimilables a urbanos.

- vertidos industriales con presencia de sustancias peligrosas I.

- vertidos industriales procedentes de piscifactorías.

- vertidos industriales procedentes de aguas de refrigeración.

- vertidos industriales procedentes de aguas de achique de actividades mineras.

- resto de vertidos industriales (sin presencia de sustancias peligrosas). 


\section{PARÁMETROS CARACTERÍSTICOS DE LA ACTIVIDAD GENERADORA DEL VERTIDO}

Los parámetros o sustancias que pueden contaminar las aguas son muchos, tanto de naturaleza física, química como biológica.

Se denomina parámetro característico de una determinada actividad generadora de vertido aquel qué en condiciones normales de funcionamiento de la actividad y de explotación de sus instalaciones de tratamiento, estará presente en el vertido. Por tanto, los parámetros característicos deben guardar una relación causa-efecto con el foco emisor del vertido.

Para cada vertido en particular debe estudiarse cuáles son sus parámetros característicos, aunque, con carácter general y tan solo a modo indicativo se puede establecer una cierta relación entre cada tipo de vertido y los parámetros o grupos de parámetros que deben figurar en sus autorizaciones de vertido:

- Vertidos Urbanos sin componente industrial: se establecerán valores límite de emisión exclusivamente para los parámetros típicamente generados por la contaminación doméstica, también conocidos como parámetros generales (condiciones de oxigenación y carga orgánica expresada como DBO y DQO, sólidos en suspensión y nutrientes expresados mediante las concentraciones de compuestos de nitrógeno y/o fósforo).

- Vertidos Industriales: se establecerán valores límite de emisión exclusivamente para los parámetros derivados de los diversos procesos industriales y actividades anejas que den lugar al vertido. Estos parámetros serán específicos de cada sector industrial y de cada proceso productivo. Hay que destacar que se deberán incluir además los propios de las aguas sanitarias procedentes de los aseos de la instalación, si éstas no se encuentran segregadas.

- Vertidos Urbanos con componente industrial: se establecerán valores límite de emisión para los parámetros generales de origen doméstico y además para los parámetros específicos de las actividades industriales recogidas por la red de colectores e incorporadas al vertido.

\section{VERTIDOS URBANOS Y ASIMILABLES A URBANOS SIN SUSTANCIAS PELIGROSAS}

Los parámetros característicos de la actividad, sus valores límite de emisión y métodos de medición de referencia para vertidos procedentes de plantas de 
tratamiento de aguas residuales urbanas provienen de la directiva 91/271/CEE transpuesta por el RDL 11/1995, el R.D 509/1996 y el R.D 2116/1998.

En función de la zona en la que se realice el vertido (normal, sensible o menos sensible) y del número de habitantes equivalentes de la aglomeración urbana, se exige un tipo de tratamiento. $Y$ para cada uno de los tipos de tratamiento la legislación exige determinados límites de emisión en concentración o en porcentaje de reducción (Tabla 1).

Tabla 1. Requisitos para vertidos

\begin{tabular}{|c|c|c|c|}
\hline \multicolumn{4}{|c|}{$\begin{array}{l}\text { VERTIDOS PROCEDENTES DE INSTALACIONES DE DEPURACIÓN DE AGUAS RESIDUALES } \\
\text { URBANAS MEDIANTE TRATAMIENTO SECUNDARIO (a) }\end{array}$} \\
\hline \multicolumn{2}{|l|}{ Parámetros } & Concentración & $\begin{array}{l}\text { Porcentaje mínimo de } \\
\text { reducción }(b)\end{array}$ \\
\hline \multicolumn{2}{|c|}{$\mathrm{DBO}_{5}$ (c) $\left(\right.$ a $20^{\circ} \mathrm{C}$ sin nitrificación) } & $25 \mathrm{mg} / \mathrm{l} \mathrm{O} 2$ & $70-90 \%$ \\
\hline \multicolumn{2}{|l|}{ DQO } & $125 \mathrm{mg} / 1 \mathrm{O}_{2}$ & $75 \%$ \\
\hline \multicolumn{2}{|c|}{ Total sólidos en suspensión } & $35 \mathrm{mg} / \mathrm{l}(\mathrm{d})$ & $90 \%(d)$ \\
\hline \multicolumn{4}{|c|}{$\begin{array}{l}\text { VERTIDOS PROCEDENTES DE INSTALACIONES DE DEPURACIÓN DE AGUAS RESIDUALES } \\
\text { URBANAS REALIZADOS EN ZONAS SENSIBLES }(*)\end{array}$} \\
\hline \multicolumn{2}{|l|}{ Parámetros } & Concentración & $\begin{array}{l}\text { Porcentaje mínimo de } \\
\text { reducción }(b)\end{array}$ \\
\hline \multirow[t]{2}{*}{ Fósforo total } & 10.000 a $100.000 \mathrm{~h}-\mathrm{e}$ & $2 \mathrm{mg} / \mathrm{l} \mathrm{P}$ & \multirow[t]{2}{*}{$80 \%$} \\
\hline & $>100.000 \mathrm{~h}-\mathrm{e}$ & $1 \mathrm{mg} / \mathrm{l} \mathrm{P}$ & \\
\hline \multirow{2}{*}{$\begin{array}{l}\text { Nitrógeno total (e) } \\
(\mathrm{mg} / \mathrm{l} \mathrm{N})\end{array}$} & 10.000 a 100.000 h-e & $15 \mathrm{mg} / \mathrm{l} \mathrm{N}(\mathrm{f})$ & \multirow[t]{2}{*}{$70-80 \%$} \\
\hline & $>100.000$ h-e & $10 \mathrm{mg} / \mathrm{l} \mathrm{N}$ & \\
\hline \multicolumn{4}{|c|}{$\begin{array}{l}\text { VERTIDOS PROCEDENTES DE INSTALACIONES DE DEPURACIÓN DE AGUAS RESIDUALES } \\
\text { URBANAS EN ZONAS DE ALTA MONTAÑA }(>1.500 \mathrm{~m})\end{array}$} \\
\hline \multicolumn{2}{|l|}{ Parámetros } & Concentración & $\begin{array}{l}\text { Porcentaje mínimo de } \\
\text { reducción }(b)\end{array}$ \\
\hline \multicolumn{2}{|c|}{$\mathrm{DBO}_{5}(\mathrm{c})\left(\mathrm{a} 20^{\circ} \mathrm{C} \sin\right.$ nitrificación) } & $25 \mathrm{mg} / 1 \mathrm{O}_{2}$ & $40 \%$ \\
\hline \multicolumn{2}{|l|}{$\mathrm{DQO}$} & $125 \mathrm{mg} / \mathrm{l} \mathrm{O} 2$ & $75 \%$ \\
\hline \multirow{2}{*}{$\begin{array}{l}\text { Total sólidos en } \\
\text { suspensión }\end{array}$} & $2.000-10.000$ h-e & $60 \mathrm{mg} / 1$ & $70 \%$ \\
\hline & $>10.000$ h-e & $35 \mathrm{mg} / \mathrm{l}$ & $90 \%$ \\
\hline
\end{tabular}

(a) O proceso equivalente. Se aplicará el valor de concentración o el porcentaje de reducción.

(b) Reducción relacionada con la carga del caudal de entrada.

(c) Este parámetro puede sustituirse por otro: carbono orgánico total (COT) o demanda total de oxígeno (DTO), si puede establecerse una correlación entre la $\mathrm{DBO}_{5}$ y el parámetro sustituto.

(d) Este requisito es optativo. Los análisis de vertidos procedentes de sistemas de depuración por lagunaje se llevarán a cabo sobre muestras filtradas; no obstante, la concentración de sólidos en suspensión en las muestras de agua sin filtrar no deberá superar los $150 \mathrm{mg} / \mathrm{l}$.

(e) Nitrógeno total equivalente a la suma del nitrógeno Kjeldahl total ( $\mathrm{N}$ orgánico y amoniacal), nitrógeno en forma de nitrato $\left(\mathrm{NO}_{3}\right)$ y nitrógeno en forma de nitrito $\left(\mathrm{NO}_{2}\right)$.

(f) Estos valores de concentración constituyen medias anuales según el punto 3 o del apartado A2 del Anexo III del RD. 509/1996. No obstante, los requisitos relativos al nitrógeno pueden comprobarse mediante medias diarias cuando se demuestre, que de conformidad con el apartado A1 del Anexo III, se obtiene el mismo nivel de protección. En ese caso la media diaria no deberá superar los $20 \mathrm{mg} / \mathrm{l}$ de Nitrógeno total para todas las muestras, cuando la temperatura del efluente del reactor biológico sea superior o igual a 12 ㄷ. En sustitución del requisito relativo a la temperatura, se podrá aplicar una limitación del tiempo de funcionamiento que tenga en cuenta las condiciones climáticas regionales. 
(*) Las Zonas sensibles de las cuencas intercomunitarias fueron declaradas por la Resolución de 25/5/1998 de la Secretaría de Estado de Aguas y Costas y revisadas por Resolución de 10/7/2006 de la Secretaría para el Territorio y la Biodiversidad.

Los requisitos para instalaciones individuales pueden no aplicarse si la reducción de la carga total de todas las instalaciones que vierten a la zona sensible es del: $75 \%$ para el $\mathrm{P}$ total y $75 \%$ para el $\mathrm{N}$ total.

En cuanto a los vertidos urbanos correspondientes a instalaciones de depuración inferiores a 2.000 h-e, la legislación determina que deberán recibir un "tratamiento adecuado". En este caso no se concreta el tipo de tratamiento ni límites de vertido asociados, solamente se exige que las aguas receptoras cumplan después del vertido los objetivos de calidad por usos y normas de calidad ambiental previstas para el medio receptor.

\section{ACTIVIDADES INDUSTRIALES CAUSANTES DE VERTIDOS}

La principal fuente de información para la determinación de los parámetros característicos y los límites de vertido para actividades industriales causantes de vertidos son los documentos de referencia sobre las Mejores Técnicas Disponibles (MTDs) asociadas a los sistemas y procesos productivos de cada una de las actividades industriales enumeradas en el Anexo I de la Directiva 96/61/CEE (IPPC). (MAGRAMA, 2016).

\section{BIBLIOGRAFÍA}

MMA (2007). Ministerio de Medio Ambiente (2007). Manual para la gestión de vertidos. Madrid: Ministerio de Medio Ambiente. Recuperado de: http://www.magrama.gob.es/es/agua/publicaciones/Manual_para_la_gestion_ de_vertidos_tcm7-28966.pdf

Real Decreto 817/2015, de 11 de septiembre, por el que se establecen los criterios de seguimiento y evaluación del estado de las aguas superficiales y las normas de calidad ambiental. Recuperado de: http://www.boe.es/boe/dias/2015/09/12/pdfs/BOE-A-2015-9806.pdf 


\section{ENLACES}

MAGRAMA (2016). Mejores técnicas disponibles. MTD. Recuperado de: http://www.magrama.gob.es/es/calidad-y-evaluacion-ambiental/temas/medioambiente-industrial/prevencion-y-control-integrados-de-la-contaminacionippc/mejores-tecnicas-disponibles-mtd/ 


\subsection{CONTAMINACIÓN Y PROTECCIÓN DE AGUAS SUBTERRÁNEAS}

José Miguel Andreu Rodes

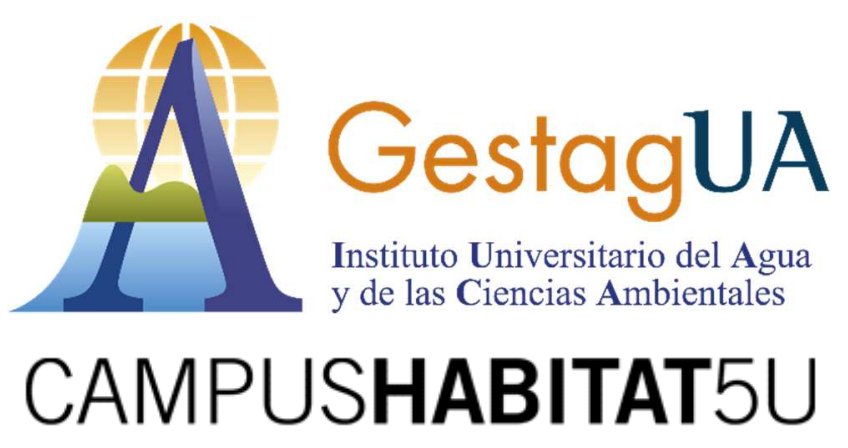




\section{INTRODUCCIÓN}

El desarrollo económico e industrial conlleva problemas de deterioro ambiental y contaminación. Frecuentemente vemos en los medios de comunicación noticias de contaminación atmosférica, de ríos y lagos o del mar, entre otros, por lo que la contaminación es uno de los principales problemas que tiene la sociedad en el siglo XXI. A pesar de que aguas subterráneas son más desconocidas y las noticias en los medios menos habituales, éstas también presentan problemas de contaminación. Así, en España se puede considerar como el principal problema de las aguas subterráneas, ya que se estima que uno de cada cuatro acuíferos relacionados con abastecimientos de pequeños municipios tiene problemas de contaminación por nitratos (nocivos para la salud y el medio ambiente). A continuación, se exponen algunas nociones básicas de contaminación de aguas subterráneas.

\section{2. ¿ES POSIBLE CONTAMINAR LAS AGUAS SUBTERRÁNEAS?}

Las aguas subterráneas que tienen los acuíferos entran de forma natural principalmente por terrenos permeables. Es por esas zonas permeables por donde también pueden entrar otras sustancias o contaminantes. No obstante, para que un contaminante entre en un acuífero debe ser capaz de atravesar la superficie del terreno. Para poder infiltrarse y adentrarse en el acuífero los contaminantes deben ser líquidos (en fase no acuosa) o estar disueltos en el agua.

Una vez en el acuífero tendrán que conseguir atravesar la zona no saturada (franja entre la superficie del terreno y el nivel del agua en el acuífero) hasta alcanzar la parte inferior denominada zona saturada en la que está el agua subterránea. Durante su circulación por la zona no saturada el flujo contaminante puede experimentar una serie de procesos físicos, químicos y biológicos que dificultan que el contaminante alcance la zona saturada. Entre estos procesos se pueden destacar:

- Retenciones físicas. Dependiendo de las características texturales del terreno se producen filtraciones y retenciones capilares

- Adsorción. La presencia de arcillas o materia orgánica favorece que ciertas sustancias queden adheridas a la superficie por fuerzas electrostáticas.

- Intercambio iónico. Igualmente se pueden producir intercambios de iones entre el contaminante y ciertos minerales (minerales de la arcilla, zeolitas carbón, humus, entre otros).

- Precipitación. Las variaciones de las condiciones fisicoquímicas del medio (temperatura, $\mathrm{pH}$, potencial redox) pueden dar lugar a la precipitación de ciertas sales y su retención en el medio. 
- Degradación y desintegración. Algunos contaminantes pueden descomponerse y desaparecer a lo largo del tiempo como las sustancias radiactivas, pesticidas o contaminantes orgánicos.

En definitiva, la zona no saturada actúa como una barrera natural que dificulta la progresión del contaminante hacia el acuífero, hasta el punto de que, si las cantidades infiltradas no superan esos procesos, el contaminante no llegaría a alcanzar la zona saturada y no contaminaría el agua subterránea. Además, también en la zona saturada existen mecanismos de dilución y dispersión como consecuencia del movimiento del contaminante en el acuífero, así como procesos de atenuación semejantes a los que se produjeron en la zona no saturada.

Todo ello apunta que la contaminación de las aguas subterráneas, no es tan fácil como la contaminación de las aguas superficiales. Sin embargo, sí es posible contaminarlas y existen numerosos ejemplos de contaminación en nuestros acuíferos.

\section{3. ¿QUÉ SE ENTIENDE POR CONTAMINACIÓN DE LAS AGUAS SUBTERRÁNEAS?}

Existen diferentes definiciones de contaminación, entre ellas se encuentra la que recoge la Ley del Agua, de forma que puede considerarse como "la acción y el efecto de introducir materias o formas de energía o inducir condiciones en el agua que, de modo directo o indirecto, impliquen una alteración perjudicial de su calidad en relación con los usos posteriores o con su función ecológica", lo que supone que se produzca una alteración de las características originales naturales que supongan un impacto negativo a los ecosistemas o afecte a su utilización posterior, todo ello como resultado de la actividad humana. Por tanto, quedan excluidas de esta definición aquellas aguas que, aunque presenten elevados niveles de ciertos elementos o sustancias, su origen sea natural.

\section{4. ¿CÓMO SE CONTAMINAN LAS AGUAS SUBTERRÁNEAS?}

Se denominan focos de contaminación a los lugares por donde los contaminantes son capaces de alcanzar las aguas subterráneas. Atendiendo a la extensión de estos focos de contaminación se puede hablar de:

- Contaminación puntual. Aquella que afectan a una zona muy concreta y perfectamente localizada. Así una posible fuga de los depósitos de una gasolinera, los lixiviados de un vertedero de residuos de extensión limitada o un accidente de tráfico con un derrame tóxico pueden ser considerados focos de contaminación 
puntual. Este tipo de contaminación es más intensa cerca del lugar donde se produce y disminuye a medida que nos alejamos del foco. La propagación del contaminante que alcance la zona saturada se realizará siguiendo la dirección del flujo del agua subterránea en ese lugar.

- Contaminación difusa. Cuando se produce en áreas de gran extensión en la que la contaminación está muy dispersa y no es fácil identificar un foco principal. Son ejemplos de este tipo de contaminación la causada por las actividades agrícolas debido al uso de pesticidas y fertilizantes, la relacionadas con las pérdidas de las redes de alcantarillado en las grandes ciudades o la explotación intensiva de los acuíferos costeros que provocan intrusión marina. Este tipo de contaminación suele ser preocupante, ya que muchas veces no es fácil de actuar contra la misma de manera directa, por lo que suele alargarse en el tiempo.

\section{5. ¿QUÉ ACTIVIDADES CONTAMINAN LAS AGUAS SUBTERRÁNEAS?}

Son muchas las actividades que pueden contaminar las aguas subterráneas, por lo que algunos autores han elaborado listas (Sánchez et al., 2002). A continuación, se presentan algunas de las principales:

- $\quad$ Actividades urbanas. Principalmente relacionadas con la acumulación de residuos sólidos en vertederos y el vertido de los efluentes líquidos.

Residuos sólidos urbanos. Los vertederos de residuos sólidos en superficie generan lixiviados por ellos mismos o por la lluvia que reciben. Si no se recogen y tratan adecuadamente pueden llegar a contaminar las aguas subterráneas con diversos tipos de contaminantes orgánicos e inorgánicos.

Aguas residuales. Los residuos líquidos de los núcleos urbanos constituyen una fuente potencial de contaminación de gran impacto, ya que suelen generarse grandes volúmenes de aguas grises que terminan retornando al medio natural. En los países desarrollados suelen ser tratados e integrados de nuevo al ciclo normal de utilización. La composición de las aguas residuales suele aportar muchos tipos de contaminantes como sales disueltas, detergentes, microorganismos, materia orgánica, medicamentos, etc.

- $\quad$ Actividades agrícolas y ganaderas. Las actividades agrícolas son una fuente de contaminación extensa capaces de afectar a grandes volúmenes de agua subterránea. Los principales problemas se asocian a los fertilizantes (compuestos nitrogenados, fósforo y potasio) y plaguicidas (fungicidas, insecticidas, bactericidas, etc.), los cuales pueden tener persistencia de varios años. Muchas veces la degradación de los productos que se utilizan como plaguicidas pueden resultar más tóxicos y persistentes que los productos originales aplicados. 
En cuanto a los residuos de los animales los principales problemas se asocian con las estabulaciones de grandes explotaciones, ya que pueden generar cantidades importantes de estiércol y purines. Su vertido y lixiviado incorporan compuestos nitrogenados, fosfatos, bacterias, cloruros, e incluso metales pesados a las aguas subterráneas.

- $\quad$ Actividades industriales y mineras. Dependiendo del tipo de actividad industrial se pueden generar efluentes muy variados con desigual toxicidad. Industrias como las papeleras, metalurgia, cerámica, curtidos, entre muchas otras, requieren de tratamiento de sus efluentes, ya que sus vertidos son altamente contaminantes al aportar diferentes elementos como metales pesados, sales y otras sustancias. También el tratamiento de los minerales o la infiltración del agua de lluvia en las escombreras, en el caso de las minas, son causantes de la contaminación de las aguas subterráneas.

- Otras actividades. Se recogen en este epígrafe, a título de ejemplo, algunas de las muchas actividades que también pueden ocasionar problemas de contaminación de las aguas subterráneas: la sobreexplotación de acuíferos que puede conllevar deterioros del agua o intrusión marina; el abandono incorrecto de pozos, ya que éstos actúan como vías preferenciales de entrada de la contaminación; la inyección de efluentes en el subsuelo; el transporte y almacenamiento de sustancias insalubres, nocivas y peligrosas ya que accidentes, fugas, negligencias de manipulación o mala praxis en su almacenamiento pueden ocasionar derrames y vertidos; o por último las propias infraestructuras como cementerios, campamentos, o carreteras pueden convertirse en focos de contaminación frente a las aguas subterráneas.

\section{6. ¿CÓMO PROTEGER LAS AGUAS SUBTERRÁNEAS FRENTE A LA CONTAMINACIÓN?}

Corregir la contaminación de las aguas subterráneas es una tarea difícil, cara y no siempre los métodos empleados ofrecen las garantías que el acuífero quede libre de contaminación, por eso la mejor forma de proteger las aguas subterráneas frente a la contaminación es evitar que ésta se produzca. Existen una serie de actuaciones de carácter preventivo que persiguen evitar que el agente contaminante llegue acuífero, y en el caso de que lo hicieran tratar de conseguir una disminución de su afección, estas actuaciones no son excluyentes unas de otras. Entre ellos se pueden destacar las siguientes:

Estudios de vulnerabilidad. El concepto de vulnerabilidad de un acuífero a la contaminación se aplica para expresar la sensibilidad de las aguas subterráneas a 
una alteración de su calidad original como consecuencia de las actividades humanas.

Existen dos tipos de vulnerabilidad, la vulnerabilidad intrínseca que depende de una serie de características propias del medio (desarrollo del suelo, características geológicas, hidrológicas, etc.) las cuales influyen en la accesibilidad hidráulica del contaminante al acuífero y de la capacidad de atenuación de la zona no saturada como resultado de la retención físico-química o de la reacción de los contaminantes con el terreno; y la vulnerabilidad específica en que además, la contaminación depende de las propiedades específicas del contaminante o grupo de contaminantes (comportamiento en el acuífero, movilidad, persistencia, entre otros).

Existen diversas metodologías que permiten mostrar la vulnerabilidad de las aguas subterráneas frente a la contaminación mediante representaciones cartográficas. Entre las más utilizadas se encuentran aquellas que a partir de un conjunto de parámetros seleccionados y la estimación de un índice de vulnerabilidad es posible delimitar o trazar áreas con diferente vulnerabilidad.

Perímetros de protección. Se trata de otra de las herramientas habitualmente utilizadas para la protección de aguas subterráneas. Se emplean para preservar la calidad de los manantiales y sondeos que se destinan para abastecimiento urbano. Su implementación consiste en la delimitación de un área del entorno de la captación. En ella se definen unas zonas ordenadas de mayor a menor riesgo (habitualmente entre 3 y 4 zonas) en la que se prohíben o restringen actividades e instalaciones que pudieran contaminar el agua subterránea, así como afectar los caudales destinados al abastecimiento de la población. Su delimitación requiere un buen conocimiento de las características del acuífero en el entorno de la captación así como de la propia obra.

Ordenación territorial de las actividades. Consistente en la planificación previa del uso del territorio en función de la información hidrogeológica básica y los estudios de vulnerabilidad de los acuíferos. Su aplicación ofrece garantías absolutas frente a la contaminación, de forma que aquellas actividades potencialmente contaminantes queden ubicadas fuera de los límites de acuíferos, o bien donde éstos se encuentren protegidos por la presencia de capas impermeables.

Toma de medidas y obras preventivas. Se incluyen aquí la toma de medidas adecuadas, el cuidado en las operaciones manejo y la realización de obras preventivas para evitar vertidos accidentales y fugas de contaminantes en las diferentes actividades. El almacenamiento de sustancias peligrosas en depósitos subterráneos, las actividades mineras, la construcción de infraestructuras, o la inyección en el subsuelo, entre otras, requieren de estudios de impacto ambiental en que se contemplan este tipo de actuaciones. 
Establecimiento de redes de vigilancia y control. Con ellas se podrá establecer un seguimiento espacial y temporal de la calidad y, por consiguiente, poder detectar la contaminación antes de que su expansión por el interior del acuífero sea muy grande. Además, estas redes pueden realizar seguimientos específicos de los agentes contaminantes concretos si se dispone de un inventario de actividades y focos contaminantes.

Concienciación y educación. Es esta otra herramienta para luchar contra la contaminación de las aguas subterráneas. Puede tener diferentes enfoques, desde campañas de información para que los agricultores adecuen las cantidades de fertilizantes a las necesarias, hasta la educación infantil para dar a conocer las aguas subterráneas y concienciar de la importancia de preservar su calidad natural.

\section{CONCLUSIONES}

Las aguas subterráneas constituyen un recurso de gran valor socioeconómico y medioambiental. Un tercio de la población española se abastece de aguas subterráneas, siendo ampliamente utilizadas en pequeños municipios. En la agricultura, aunque menos empleadas que las superficiales, también son muy importantes. Muchos de los ecosistemas naturales dependen de ella. El papel que juegan las aguas subterráneas puede verse afectado por la contaminación, por lo que es necesario protegerlas y preservarlas. Actualmente disponemos de herramientas que deben ser utilizadas para evitar su contaminación.

\section{BIBLIOGRAFÍA}

Fetter, C.W. (2008). Contaminant Hydrogeology. Waveland Press.

DIPUTACIÓN PROVINCIAL DE ALICANTE (2004). Mapa de vulnerabilidad de los acuíferos a la contaminación provincia de Alicante. Alicante.

López Geta, J.A., Fornés, J.M., Ramos, G. \& Villarroya, F. (2009). Las aguas subterráneas un recurso natural del subsuelo. Instituto Geológico y Minero de España \& Fundación Marcelino Botín, Madrid.

Llamas, M. R., Fornés, J.M., Hernández-Mora, N. \& Martínez Cortina, L. (2001) Aguas Subterráneas: Retos y Oportunidades. Fundación Marcelino Botín. MundiPrensa, Madrid.

Pulido-Bosch, A. (2007) Nociones de Hidrogeología para Ambientólogos. Serv. Publ. Universidad de Almería.

Sánchez González, A.M., Nieto, M, Obartí, J., Capdepón J.V., Belenguer, C.C. \& Foster, S. (2002). Guía para la delimitación e implantación de perímetros de 
protección de captaciones de aguas subterráneas para abastecimiento público. Dirección General de Obras Hidráulicas y Calidad de las Aguas. Ministerio de Medio Ambiente.

\section{ENLACES}

http://hidrologia.usal.es/hidro.htm

http://www.fao.org/docrep/W2598S/W2598S00.htm 


\title{
9.4. LOS HUMEDALES
}

\author{
Carlos Martín Cantarino
}

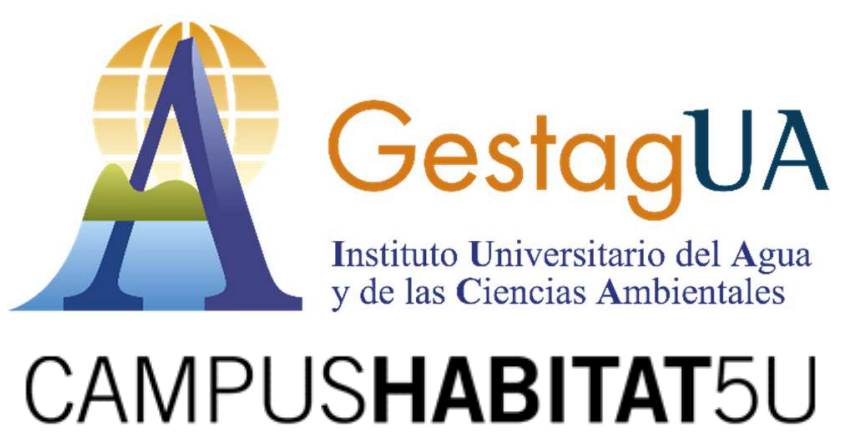




\section{INTRODUCCIÓN}

El agua es un recurso básico para la supervivencia del ser humano, para su economía y para el mantenimiento de su cultura.

El objetivo fundamental del tema es resaltar que toda masa de agua de las que obtenemos o a través de las cuales gestionamos el recurso hídrico no es simplemente una acumulación de $\mathrm{H}_{2} \mathrm{O}$ sino más bien forma parte de sistemas complejos, eco-sistemas, se trate de ríos, lagos, humedales, criptohumedales e incluso sistemas hidráulicos creados artificialmente por el ser humano. Que por el simple hecho de ser masas de agua dentro de la ecosfera (y no en el vacío), se hayan inscritas en el ciclo ecológico global del agua, y por ello sometidos a condicionantes físicos y biológicos, e inevitablemente son sistemas "vivos" y que, por tanto, como todo ecosistema, rinden servicios útiles a la sociedad, económicamente relevantes, en cualquiera de sus fases.

Es bien sabido que la mayor parte del agua existente en la ecosfera está en los ecosistemas oceánicos (alrededor del 96,5\%), y que los otros depósitos importantes de agua son el hielo de los casquetes polares $(1,8 \%)$ y las aguas subterráneas contenidas en la corteza terrestre o acuíferos (0,8\%). Un 0,001\% corresponderá al agua atmosférica, con lo que sólo poco más del 0,01\% correspondería a los sistemas de aguas superficiales continentales. Dado que las masas oceánicas o los casquetes polares son compartimentos hídricos difícilmente aprovechables como fuentes del recurso agua por el ser humano, podemos afirmar que los ecosistemas de aguas continentales representan el "cuello de botella" (como afirma Odum, 1971) del ciclo hídrico global desde el punto de vista de los intereses humanos.

En segundo lugar, se intenta mostrar que, por supuesto, estos sistemas deben ser "protegidos", tal como reza el título del módulo (de hecho han sido uno de los espacios emblemáticos del conservacionismo), pero no tanto en el sentido popular (y un tanto restrictivo) de la palabra ("librarlos de interferencias humanas"), sino el que resulta propio de todo recurso valioso que ofrece múltiples servicios sociales y cuya gestión resulta, por ello, compleja, es decir, en el de que los diferentes usos sociales deben planificarse teniendo en cuenta sus diversas e interdependientes utilidades, y no sólo una de ellas.

Y en tercer lugar que lo sistemas húmedos reales, por el interés que siempre han tenido para las sociedades humanas, son también, inevitablemente, producto 
de una historia de transformaciones antrópicas y, por ello, tienen una parte cultural, que debe ser considerada en su gestión si se intenta conservarlos y gestionarlos eficientemente. Para ello, analizar brevemente el ejemplo del llamado "Sistema de Zonas Húmedas del Sur de Alicante" puede ser muy ilustrativo.

\section{ECOSISTEMAS ACUÁTICOS Y ZONAS HÚMEDAS}

Podemos reconocer una gran diversidad de ecosistemas acuáticos continentales, desde los grandes ríos o lagos, hasta las pequeñas charcas temporales aparecidas después de las lluvias. Sin embargo, en un sentido estricto, la expresión "zonas húmedas" o "humedales", que no deja de ser una traducción poco satisfactoria del término inglés wetlands (Lévêque, 1996), hace referencia a ecosistemas intermedios entre las grandes masas de agua y los sistemas terrestres en los que el agua se drena fuera del sistema (Tiner, 1991; Lévêque, 1996). Los humedales son, pues sistemas ecotonales, una transición entre los ecosistemas terrestres y los plenamente acuáticos. Sin embargo, presentan características singulares, no meramente intermedias entre esos dos tipos de ecosistemas.

La definición de humedal (wetland) por parte del Convenio Ramsar es muy amplia: "los humedales son áreas de marisma, pantanos, turberas o agua, artificiales o naturales, permanentes o temporales, en las que el agua permenece estática o fluye, sea dulce, salobre o salada, incluyendo áreas de agua marina en las que la profundidad en marea baja no exceda de 6 metros". Otros documentos elaborados por el Comité Ramsar describen las zonas húmedas como "áreas en las que el agua es el factor principal que controla el ambiente y la vida animal y vegetal asociada. Aparecen donde la capa freática está en superficie o muy cerca de ella, o donde la tierra está cubierta por agua" (Ramsar, 2016).

La CE (Federal Register1982) y la EPA (Federal Register 1980) de EE.UU. definen zonas húmedas (wetlands) como aquellas áreas que están inundadas o saturadas por agua superficial o subterránea en una frecuencia y duración suficientes como para sostener, y que en condiciones normales sostienen, vegetación predominante típicamente adaptada a la vida en condiciones de suelo saturado de agua.

Como vemos, según varias definiciones usuales, la presencia de una biota (en especial, las plantas) capaz de vivir en suelos saturados de humedad (hidrófitos) es, pues, un rasgo identificador de todo humedal (Tiner, 1991). Esto es importante incluso a efectos legales, según se verá a continuación. 
Importa destacar que las zonas húmedas incluyen, pues, ecosistemas bastantes diferentes por sus rasgos biológicos, como las áreas pantanosas, las marismas, los almarjales y otras similares, incluyendo ecosistemas de aguas dulces, salobres o francamente saladas.

Dos rasgos resultan importantes para comprender la ecología de las zonas húmedas:

1. Los humedales son sistemas históricos, es decir, sometidos a procesos temporales de diferentes escalas. Por un lado, a escala geológica, vienen determinados por los procesos de subsidencia o por el descenso o aumento de los niveles marinos. Los aportes de sedimentos por parte de los cursos de agua temporales o permanentes que a ellos afluyen, en interacción con los mencionados procesos generales, pueden determinar una tendencia hacia la colmatación y aterramiento, algo general en albuferas costeras, en las que a veces los procesos de sucesión ecológica son muy evidentes incluso en períodos cortos de tiempo. A todo ello, desde luego, habrá que sumar la influencia de las actuaciones humanas a lo largo de la historia, como se verá más adelante (Rosselló i Verger, 1993).

2. Buena parte de los humedales son sistemas dinámicos, sometidos en mayor o menor medida a aportes de energía subsidiarias como corrientes, mareas, oleaje, etc. En cierta forma, muchos de los humedales resultan tan productivos a causa de estos aportes de energía que favorecen los procesos ecológicos (Odum, 1971; Odum y Sarmiento, 1997). Por tanto, el carácter dinámico de las zonas húmedas es parte importante de su ecología y d elos servicios ecosistémicos que prestan.

\section{LOS SERVICIOS ECOSISTÉMICOS DE LOS HUMEDALES}

Los humedales ocupan, como ya hemos mencionado, una proporción muy modesta de la superficie terrestre (alrededor del 3\%), pero su importancia va más allá debido a la multiplicidad de servicios ecosistémicos que prestan (Lugo et al., 1990). Mencionemos, entre los más relevantes: 
- Disipan la energía de las inundaciones. Situadas en zonas bajas o deprimidas, pueden recibir buena parte de las aguas de avenida, evitando que afecten a otras áreas (Bullock y Acreman, 2003).

- Son un importante sumidero de carbono, especialmente por el alto contenido en carbono orgánico de sus suelos. Se estima que, en promedio, los suelos de un humedal contiene $72 \mathrm{hg} / \mathrm{m}^{2}$, la cifra más alta de cualquier tipo de ecosistema. Debido a ello, aunque los humedales representen, como decíamos, sólo alrededor de un $3 \%$ de la superficie total de la Tierra, se estima que retienen un $12 \%$ del carbón orgánico mundial. Ello les otorga un papel destacado en el ciclo global del carbono y, por tanto, en las tendencias de cambio climático recientes (Lugo et al., 1990)

- Recargan los acuíferos. Según situaciones concretas, los humedales mantienen un equilibrio por filtración entre las capas subterráneas y las masas de agua superficiales (Bullock y Acreman, 2003).

- Depuran las aguas afluentes, bien por actuar como simple trampa física de los sedimentos y nutrientes acarreados, (en lo cual desempeñan un papel importante los gradientes de salinidad habituales en estos sistemas) como por el papel activo de flora y fauna (biodepuración). Por ejemplo, se estima que la vegetación de un humedal puede absorben entre 20 y $50 \mathrm{~kg}$ de nitrógeno por hectárea y año (Lévêque, 1996). Esta alta capacidad de biodepuración debe comprenderse también como resultado de la alta productividad primaria del sistema, como se comentará más adelante.

- Tienen una notable capacidad de denitrificación, es decir, de transformación de nitratos $\mathrm{o}$ amonio en $\mathrm{N}_{2}$ inerte que escapa a la atmósfera. Siendo el aporte excesivo de nitrógeno una de las principales causas de contaminación y de eutrofización de los sistemas acuáticos, la capacidad denitrificadora de las comunidades bacterianas de las zonas húmedas, estimada entre 0,5-1 Tm por hectárea y año (Lévêque, 1996), representa uno de los factores biodepuradores más importantes dentro del ciclo del nitrógeno a nivel global.

- Quizás la característica ecológica más destacable de los humedales sea su alta productividad primaria, que se encuentra entre las más altas de la ecosfera. Así, dependiendo del tipo de humedal de que se trate, la productividad puede llegar a las 10.000 Kilocalorías por Ha y año, e incluso en ciertas condiciones a las $25.000 \mathrm{Kcal} / \mathrm{Ha}$-año (Odum y Sarmiento, 1997). Esta alta productividad viene ligada a unos niveles muy altos de biodiversidad, entre los que tiene especial relevancia la de aves. Por todo ello, los humedales proporcionan recursos biológicos muy importantes (a través de la caza, pesca, marisqueo, recolección de fibras y materiales vegetales como cañizo, junco, enea, plantas barrilleras, etc.), al tiempo que les dota de un alto valor conservacionista. 
- En el caso de humedales conectados con el mar (albuferas, estuarios) dicha alta productividad y sus características de abrigo convierte a estos ecosistemas en zonas muy importantes de cría o crecimiento de juveniles de especies marinas costeras, de tal forma que muchas poblaciones marinas de interés pesquero dependen de la presencia o no de dichos refugios de cría. Casos típicos son los peces mugílidos, doradas, lubinas, determinados crustáceos, etc.

Todo sumado, resulta evidente, según los estudios más rigurosos, que los beneficios económicos, directos e indirectos, de las zonas húmedas resultan muy superiores a los que podrían obtenerse del espacio que ocupan si se desecaran y pusiera en cultivo. A nivel mundial, se estima que los servicios aportados por los humedales a la Humanidad pueden valorarse en al menos 4.9 billones de dólares US (Millenium Ecosystem Assessment, 2005; Ramsar, 2016).

\section{LA INFLUENCIA HUMANA EN LA ECOLOGÍA DE LOS HUMEDALES}

Precisamente por las altas productividades biológicas de los humedales, y por sus importantes servicios ecológicos, las sociedades humanas han tenido históricamente una vinculación importante con estos sistemas. Y precisamente por ello, escasos sistemas húmedos han estado libres de la modificación humana, a veces desde épocas bien antiguas, de tal forma que su configuración y valores en un momento dado (y esto es algo que cualquier plan de gestión o conservación debe tener presente) dependen en buena medida de tales transformaciones antrópicas.

Una cierta alteración se ha debido, desde los mismos orígenes de la especie humana, a la caza y pesca más o menos intensiva y a la extracción de materias primas vegetales (cañas, enea, etc.).

Más importante puede haber sido, en ocasiones, la alteración de los ciclos hídricos como consecuencia del desvío de caudales hacia la agricultura. También, y sobre todo en épocas más recientes, la utilización directa o indirecta de los humedales para la descarga de residuos y contaminantes.

También ha sido frecuente considerarlos como espacios improductivos y fuente de enfermedades por lo que en especial en Europa a partir del siglo XVIII ha sido una política común el intentar su desecación y puesta en cultivo (bonificación). Ejemplos históricos fue la bonificación de los Fenlands, en Inglaterra (iniciada ya en el s. XVII, pero con avances significativos sólo en los s. XVIII y XIX), las marismas Pontinas (agri Pontini) en Italia (inicios del s. XX) o la colonización de los humedales del Bajo Segura 
mediante las Pías Fundaciones del cardenal Belluga (inicios del siglo XVIII, con intervenciones posteriores hasta el mismo s. XX).

En otros casos, sin embargo, la intervención humana se ha dirigido a intentar mantener el humedal y sus recursos piscícolas y cinegéticos, aun en contra de los procesos naturales que tendían a la colmatación y las albuferas de Valencia y de Elche, en las que se construyeron canales para aportar agua al humedal desde los ríos Turia y Segura, respectivamente, ya desde la Edad Media.

También en ocasiones se transformaron profundamente las características ecológicas de las zonas húmedas con el fin de promover o intensificar la producción de cierto recurso concreto. Ejemplos típicos son la transformación en salinas o la conversión de zonas húmedas temporales en permanentes, mediante un aporte de caudales, para favorecer la explotación cinegética y piscícola.

Todos estos tipos de alteración de las zonas húmedas, que pueden haber actuado conjuntamente, en partes distintas de un mismo sistema o sucesivamente en diferentes épocas, hace que la estructura y funcionamiento actuales de cada humedal resulte ya inseparable de dicha historia de transformaciones antrópicas. $\mathrm{E}$ igualmente, entre los servicios y funciones proporcionados por las zonas húmedas debe considerarse también su valor como depositario del patrimonio cultural de los pueblos que los han configurado, tanto en lo que se refiere a aspectos materiales (infraestructuras hidráulicas, construcciones tradicionales, artesanías ligadas al sistema, etc.) como inmateriales (costumbres, conocimientos, habilidades, etc.).

\section{LA PROTECCIÓN Y GESTIÓN DE LOS HUMEDALES: UNA NECESIDAD SOCIEOCONÓMICA}

La mencionada tendencia a la desecación de humedales, que llega con fuerza hasta el segundo tercio del siglo $\mathrm{XX}$, y su degradación por contaminación, alteraciones de los aportes hídricos, etc., así como la creciente conciencia del valor de estos ecosistemas para la fauna (especialmente de aves acuáticas) y flora, promovieron que estos ecosistemas estuvieron entre los más emblemáticos de los incipientes movimientos conservacionistas a partir de 1960s.

Un hito importante lo marcó el Convenio de Ramsar, aprobado en la ciudad iraní de ese nombre el 2 de febrero de 1971. Desde entonces, el 2 de febrero de cada año se celebra el todo el mundo el Día Internacional de los Humedales. El Convenio 
planteó un primer listado de humedales de importancia internacional que ha ido aumentando con el tiempo. Actualmente la Lista Ramsar incluye casi 3.000 humedales de todo el mundo, 74 de ellos en España. El Convenio establece el compromiso de las partes firmantes de promover la conservación y el buen estado de los humedales. Para ello, y desde un principio, la estrategia Ramsar, teniendo en cuenta su generalizada antropización, se basó en promover el llamado "uso racional" (wise use) de tales sistemas, más que la eliminación de interferencias antrópicas.

Destaquemos que algunas legislaciones (y puede comprobarse que es una tendencia generalizada, en la línea Ramsar) imponen la protección de cualquiera zona húmeda por el hecho de serlo, como la ley 11/94, de la Generalitat Valenciana, de Espacios Naturales Protegidos.

Con todo, la degradación o destrucción de los humedales continúa en todo el planeta, por las más variadas razones (Millenium Ecosystem Assessment, 2005; Ramsar, 2016).. Buena parte del problema radica, desde luego, en decidir, qué es el uso racional de sus servicios. Sin duda, como afirma Lévêque (1995), para ello se deben tener en cuenta los múltiples servicios que proporciona, y no sólo algunos de ellos. $\mathrm{Y}$, desde luego, considerarlos como sistemas interactivos, de transición, con una variabilidad espacio-temporal a varias escalas que forma parte de su funcionalismo y en la que el sentido histórico e integrador debe ser dominante.

\section{LOS HUMEDALES EN EL ÁMBITO SEMIÁRIDO DEL SE IBÉRICO: EL CASO DEL SISTEMA DE ZONAS HÚMEDAS DEL SUR DE ALICANTE}

Las zonas húmedas en condiciones áridas o semiáridas tienen un significado especial. Normalmente se originan como consecuencia del aporte de agua, vía ríos o, desde áreas geográficas con mayores disponibilidades hídricas. Evidentemente, y aún en mayor medida que en otros ámbitos, tales humedales están muy transformados y hasta determinados por la actividad humana. En el caso del SE ibérico, se ha comprobado que buena parte de su importante diversidad faunística depende, de hecho, más que de los hábitats naturales, de los sistemas húmedos o riparios transformados o construidos por el ser humano (Varela et al., 2011).

El Ilamado actualmente "Sistema de Zonas Húmedas del Sur de Alicante", situado en el ámbito del SE ibérico semiárido, caracterizado por precipitaciones anuales medias inferiores a $350 \mathrm{~mm}$, es seguramente un caso paradigmático. Está integrado por tres parques naturales y algunas otras zonas húmedas más pequeñas. 
Los tres parques, declarados zonas protegidas por la administración valenciana en la década de los 80 del siglo XX, están acogidos a la Convención Ramsar y son Lugares de Interés Comunitario (LIC) y Zonas de Especial Protección para las Aves (ZEPA), por lo que forman parte de la Red Natura 2000 de la Unión Europea.

Su importancia ecológica es notable, en especial por la riqueza de su fauna de aves, pero también por el interés de su vegetación, que cuenta con notables endemismos botánicos ligados especialmente a las formaciones halófilas (propias de medios ricos en sal). Desde un punto de vista faunístico, cabe destacar que este Sistema se considera esencial para la supervivencia europea de dos especies de anátidas amenazadas: la cerceta pardilla (Marmaronetta angustirostris) y la malvasía blanca (Oxyura leucocephala).

Describamos muy brevemente las características de estos tres Parques Naturales:

- El Parque Natural de El Hondo de Elche y Crevillent está formado, en el $80 \%$ de su superficie, por dos grandes embalses de riego construidos en el segundo tercio del siglo XX por la Compañía de Riegos de Levante para almacenar y regular caudales impulsados desde el río Segura y canales de aguas sobrantes de la huerta de la Vega Baja. Se trata, pues, de aguas dulces de riego, aunque la degradación reciente de la cuenca del río Segura, de cuya cola se toman estos caudales, ha hecho que en los últimos años las aguas alcances con frecuencia valores de salinidad bastante elevados. A ello se suma también niveles de contaminación temporalmente altos. El restante $20 \%$ de la superficie lo constituyen una serie de charcas creadas en el último tercio del siglo XX sobre antiguos saladares para la explotación cinegética y piscícola. Obtienen sus aguas, en general salobres, de manantiales locales o de sobrantes del regadío inutilizables para usos agrícolas.

- El Parque Natural de las Salinas de Santa Pola se instala sobre la antigua Albufera de Elche, espacio mantenido desde la Edad Media por los señores feudales de esta población mediante una conducción de aguas desde el río Segura y las sobrantes del regadío de su huerta. De esta forma se mantenía su rentable explotación pesquera contra la tendencia natural al aterramiento (Martín Cantarino, 2014). Sin embargo, a principios del siglo XX empezó la transformación del espacio en explotaciones salineras. Forma parte también del Parque un cinturón periférico de antiguos saladares convertido en charcas permanentes dedicadas a la explotación cinegético-piscícola en el último tercio 
del siglo XX, de la misma forma que en el cercano P.N. de El Hondo. Sus aguas provienen también de manantiales locales o de sobrantes del regadío.

- El Parque Natural de las Lagunas de La Mata y Torrevieja está formado por dos grandes cubetas endorreicas tradicionalmente sin conexión con el mar y cuya desecación natural en verano permitía la explotación de la sal precipitada. Sin embargo, a partir del s. XIX el sistema de las dos lagunas se conectó con el mar mediante acequias artificiales para aumentar la producción salinera y desde entonces cuentan con lámina de agua permanente. Incluso en los años 1970 s se empezó a incorporar un caudal hipersalino procedente de una mina de sal gema situada a varios kilómetros de distancia.

Vemos pues que el Sistema de Zonas Húmedas del Sur de Alicante, de gran valor conservacionista, presenta en realidad un funcionalismo muy complejo y muy determinado por las profundas transformaciones antrópicas, algunas de fechas muy recientes. Podemos considerar, por ello, que el funcionamiento hidrológico y ecológico del Sistema se basa actualmente en las actividades económicas que lo han configurado, que determinan su hidrología (en buena parte dependiente de bombeos) y sin las cuales no podría mantenerse por sí mismo, sean éstas la actividad agraria, la explotación salinera o la caza y la pesca.

El no haber tenido en cuenta suficientemente esta situación llevó a que la imposición en los años 1980s de las figuras de protección ecológica desencadenara un estado de conflictividad entre los diferentes stakeholders locales y la administración ambiental.

Aunque desde un principio se reconoció que las actividades humanas podrían ser compatibles con la conservación de los ecosistemas, el hecho es que tales actividades no se consideraron, al menos plenamente, en todas sus consecuencias, como lo que realmente son: no algo meramente "compatible", sino como elemento básico de su funcionamiento ecológico actual.

En realidad, la falta de visión integrada podía detectarse en la carencia de análisis de los componentes históricos del modelado del sistema, así como en la escasa información existente $y$, consecuentemente, la falta de gestión y promoción de la parte cultural del sistema (usos y tradiciones, riqueza de elementos hidráulicos históricos, etc.). De ahí que, frente a los procesos de decadencia de las formas tradicionales de gestión, la crisis agrícola, la degradación del sistema hídrico del Segura, (del que depende el Sistema), el envejecimiento de la población local, etc., apenas se propusieran medidas proactivas; más bien, el modelo de gestión se basó en prohibir o limitar las actividades consideradas negativas para los elementos 
faunísticos o botánicos, desde una visión reduccionista. De ahí el estallido recurrente de conflictos, en ocasiones virulentos, cuando tales limitaciones ambientales obstaculizaban los usos tradicionales, y la decadencia paulatina de la calidad ambiental de los ecosistemas (Martín Cantarino, 2010).

En los últimos años se han puesto en marcha algunas iniciativas más integradoras. La promoción del ecoturismo, por ejemplo, insuficientemente desarrollado aún en el Sistema (en buena parte por las limitaciones al respecto impuestas por los Planes Rectores de Uso y Gestión), podría ser, adecuadamente regulado, un factor para promover sinergias entre los valores ambientales y los servicios de todo tipo que proporciona actualmente el ecosistema.

En cualquier caso, y como colofón, destaquemos que, dada la complejidad del Sistema, cualquier gestión que no sea capaz de integrar los múltiples usos y servicios del mismo, con el potencial que tal multiplicidad tiene cara a la sostenibilidad del mismo, estará abocada al fracaso.

\section{CONCLUSIONES}

- La gestión integrada y realista del agua requiere considerar las masas de agua como ecosistemas, como sistemas complejos, controlados en parte por procesos biológicos, que son productores de servicios socioeconómicos múltiples

- Dentro de los ecosistemas acuáticos de interés para el ser humano, los humedales o zonas húmedas tienen un especial valor. Debemos considerarlos como ecosistemas de transición o ecotonos. y son dinámicos.

- los humedales se encuentran entre los ecosistemas más productivos del planeta y generan beneficios muy variados: biodepuración, control de avenidas, recursos cinegéticos y piscícolas, mantenimiento de la biodiversidad, turismo, educación, etc.

- los humedales no son sólo un ecosistema natural, sino sistemas complejos cuya estructura y función actuales, y por tanto sus servicios, dependen normalmente de una larga historia de usos y transformaciones humanas. los aspectos culturales forman parte esencial de su ecología

- la conservación y gestión de los humedales requiere considerarlos como sistemas eco-culturales, de usos múltiples y, por tanto, manejar de forma integrada sus conflictos de uso. 


\section{BIBLIOGRAFÍA}

Bullock, A.; Acreman, M. 2003. The role of wetlands in the hydrological cycle. Hydrology and Earth System Sciences 7(3): 358-389.

Lévêque, C. 1996. Écosystèmes aquatiques. Hachette, Paris.

Lugo, A.E.; Brown, S.; Brinson, M.M. Concepts in wetland ecology. En: Lugo, A.E.; Brinson, M.M.; Brown, S. (Eds.): Forested Wetlands, pp.: 53-85. Elsevier Science Publishers, Amsterdam.

Martín Cantarino, C. 2010. Environmental conflicts and conflict management: some lessons from the WADI experience at El Hondo Nature Pak (South-Eastern Spain). En: Scapini, F. y Ciampi, G. (Eds.): Coastal water bodies: nature and culture conflicts in the Mediterranean. Pp.: 61-78. Springer, Dordrecht.

Martín Cantarino, C. 2014. "El acequia que don Manuel mandó facer": la importancia del conocimiento histórico para la comprensión y gestión del "Sistema de Zonas Húmedas del Sur de Alicante". En: Sanchis-Ibor, C.; PalauSalvador, G. Mangue Alférez, I.; Martínez-Sanmartín, L.P. (Eds.) Irrigation, Society, Landscape. Tribute to Thomas F. Glick, pp.: 254-273. València, Universitat Politècnica de València.

(descargable en: doi: http://dx.doi.org/10.4995/ISL2014.2014.163)

Millenium Ecosystem Assessment. 2005. Ecosystems and human well-being: wetlands and water. Synthesis. World Resources Institute, Washington, EE.UU.

Odum, E. P. 1971. Fundamentals of Ecology, 3a ed. Saunders Company, Philadelphia, EE.UU..

Odum, E.P; Sarmiento, F.O. 1997. Ecología. El puente entre ciencia y sociedad. McGraw-Hill- Interamericana., México.

Ramsar, 2016: An Introduction to the Ramsar Convention on Wetlands. 5a Ed. Ramsar Handbooks. Ramsar Convention Secretariat, Gland, Suiza.

Rosselló i Verger, V. 1993. Albuferas mediterráneas. Cuadernos de Geografía, 53: 35-64.

Tiner, R.W. 1991. The concept of a hydrophyte for wetland identification. BioScience 41(4): 236-247.

Valera, F.; Díaz-Paniagua, C.; Garrido-García, J.A.; Manrique, J.; Pleguezuelos, J.M. y Suárez, F. 2011. History and adaptation stories of the vertebrate fauna of southern Spain's semi-arid habitats. Journal of Arid Environments, 75: 1342-1351. 


\section{ENLACES}

- Sitio oficial del Convenio Ramsar: http://www.ramsar.org/

- Página del Ministerio de Agricultura y Pesca, Alimentación y Medio Ambiente dedicada a los Humedales:

http://www.mapama.gob.es/es/biodiversidad/temas/ecosistemas-y-

conectividad/conservacion-de-humedales/

- Páginas de la Generalitat Valenciana dedicadas a los parques naturales del Sistema de Zonas Húmedas del Sur de Alicante:

www.parquesnaturales.gva.es/web/pn-el-fondo www.parquesnaturales.gva.es/web/pn-salines-de-santa-pola www.parquesnaturales.gva.es/web/pn-lagunas-de-la-mata-torrevieja 


\section{MÓDULO 10}

EVALUACIÓN DE PROYECTOS 


\title{
10.1. CONCEPTOS BÁSICOS
}

\author{
Armando Ortuño Padilla
}

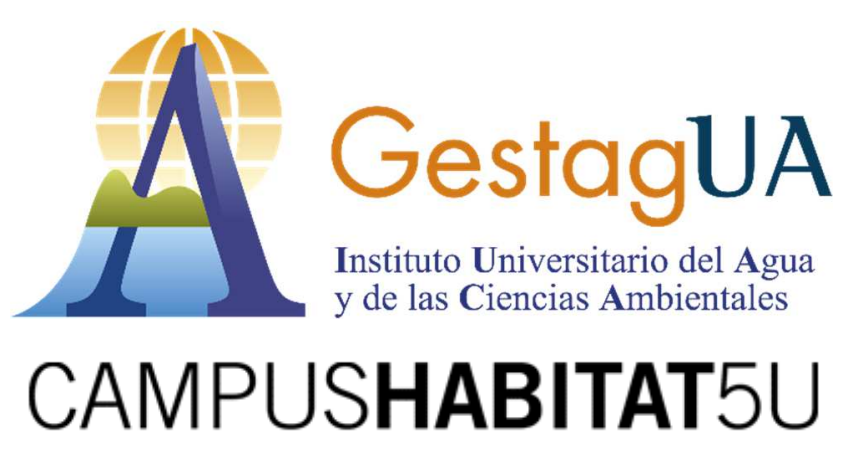




\section{INTRODUCCIÓN}

¿Cómo saber cuándo una infraestructura es positiva para la sociedad? ¿son siempre buenas porque generan empleo y riqueza? ¿Hasta qué punto hay que ejecutar infraestructuras? ¿Quién la tiene que financiar: el sector público, el privado o entre ambos?

En este epígrafe introductorio se va a hacer un repaso a los criterios que nos permiten evaluar cuándo las infraestructuras deben ejecutarse y quién debe financiarlas. El método habitualmente empleado para realizar esta evaluación económica de proyectos es el Análisis Coste-Beneficio.

Se define como la suma de ingresos menos los costes que experimenta la infraestructura a lo largo del periodo en que se encuentra operativa (vida útil). Como ingresos o beneficios generados se podrían citar:

- Los puramente monetarios como los cánones, tasas, peajes, etc. ingresados por la empresa o sociedad que gestiona la infraestructura (operador).

- Los que repercuten directamente en el bienestar de la sociedad pero cuyo valor monetario no es ingresado directamente por el operador. En todo caso, estos beneficios se traducen a euros para que se pueda medir el impacto económico de los ingresos totales sobre la sociedad.

Como costes habría que considerar fundamentalmente:

- Expropiación de terrenos.

- Ejecución de la obra.

- Explotación y conservación: personal, mantenimiento de la maquinaria, de la propia infraestructura, etc.

El ejemplo de la ejecución de una autopista de peaje es muy clarificador al respecto. En la siguiente lección se especificará el caso de las obras hidráulicas. Supongamos que se quiere ejecutar una autopista de peaje. Veamos qué partidas configuran los ingresos y los costes:

Ingresos:

- Peaje por los vehículos que transitan por ella.

- Reducción de la congestión porque al ejecutarse una nueva carretera se descongestionan otras carreteras del entorno.

- Reducción de accidentes porque el tráfico se hace más fluido en toda la red de carreteras del entorno. 
- Reducción del ruido para los residentes porque se ha reducido el tráfico en las carreteras urbanas debido a que el tráfico se ha desviado hacia la autopista.

- Reducción de emisiones de gases de efecto invernadero, etc.

Costes:

- Expropiación de terrenos por donde va a discurrir la autopista.

- Ejecución de la autopista.

- Costes de mantenimiento de la propia autopista: reasfaltado, correcta señalización, etc.

- Costes de personal: el propio equipo gestor de la Autopista, los operarios en los puestos de control de acceso y salida al peaje, etc.

Según se ha señalado, estos ingresos y costes se deben computar a lo largo de la vida útil de la infraestructura; habitualmente se considera un periodo de 30 años.

Como el alumno puede deducir, tanto los ingresos como los costes responden a estimaciones, siendo muy complicadas las estimaciones de demanda o ingresos: ¿cómo saber en este caso cuántos coches van a circular por mi autopista? Existen modelos matemáticos que nos ayudan a calcularlos, pero los errores siguen siendo muy sustanciales en muchas ocasiones.

Una vez detectados los ingresos y costes que tendría nuestra infraestructura, el paso siguiente es realizar esa diferencia para el conjunto de la vida útil de modo que un resultado positivo nos indicará que la infraestructura es socialmente rentable y, por tanto, se aconseja su ejecución, o negativo, en cuyo caso no se recomienda su ejecución.

El indicador que nos mide esta diferencia entre ingresos y costes es el Valor Actual Neto o VAN, y representa una cantidad en euros.

En realidad, a la hora evaluar inversiones no sólo se analiza si una infraestructura es positiva o no como se ha comentado, sino que se deben analizar varias alternativas para definir cuál de ellas es la que arroja un mayor valor del VAN, que será la que finalmente escojamos.

En el caso de la Autopista, podríamos analizar también qué pasaría si, en lugar de una construir una autopista, ejecutamos un tren de alta velocidad o simplemente mejoramos los servicios de autocares existentes entre las dos ciudades a conectar (observemos que en este último caso no habría que ejecutar ningún tipo de 
infraestructura ni pagar expropiaciones, solamente aparecerían costes de mantenimiento de la maquinaria -autocares- $y$ de personal -equipo gestor de la empresa y conductores-).

Para finalizar con esta introducción, resta discutir quién y cuándo debe financiar la infraestructura.

En este sentido, se debe hacer una distinción entre los dos tipos de Análisis coste-beneficio existentes:

- El Análisis coste beneficio social, que es exactamente el que se acaba de explicar.

- El Análisis coste-beneficio financiero o empresarial, que se diferencia en esencia del social en que en la parte de ingresos sólo se tienen en cuenta los ingresos monetarios.

Esto se hace así porque lo que se mide es si para el sector privado -una empresa-, sería rentable la ejecución de la infraestructura, ya que los ingresos no monetarios (reducción de los accidentes, congestión, etc.) no son facturados por la empresa; es decir, la empresa sólo cobra el peaje de los vehículos.

Así, y para dilucidar quién ha de sufragar la infraestructura, se deben tener en cuenta las siguientes posibilidades:

1. El Análisis Coste-Beneficio social es negativo. Como se ha dicho, no se aconseja ejecutar la infraestructura.

2. El Análisis Coste-Beneficio social es positivo. Se recomienda ejecutar la alternativa con mayor del VAN.

3. El Análisis Coste-Beneficio empresarial es positivo. Puesto que una empresa conseguiría beneficios por sí misma, no se debe financiar con fondos públicos.

4. El Análisis Coste-Beneficio empresarial es negativo. Se debe financiar con fondos públicos parcialmente hasta la cantidad económica que permita que la empresa consigue un beneficio razonable.

Por lo tanto, en el ejemplo de la Autopista:

- Si el Análisis Coste-Beneficio social es negativo, no se recomendará que se ejecute.

- Si el Análisis Coste-Beneficio social es positivo y es la alternativa con mayor VAN, se recomienda su ejecución.

- Si el Análisis Coste-Beneficio empresarial es positivo, es decir, que con los ingresos del peaje se rebasan todos los costes: expropiación, ejecución, 
mantenimiento, conservación, etc. no se financiará la infraestructura con dinero público.

- Si el Análisis Coste-Beneficio empresarial es negativo, es decir, los ingresos por peaje no compensan la totalidad de los costes, las administraciones públicas financiarán parte de esos costes hasta que el empresario consiga un beneficio razonable.

\section{BIBLIOGRAFÍA}

- De Rus (2008): Análisis coste-beneficio: evaluación económica de políticas y proyectos de inversión. Editorial Ariel.

- Comisión Europea. "Guide to Cost-Benefit Analysis of investment projects (Economic appraisal for Cohesion Policy, 2014-2020)". Directorate General Regional Policy, 2015.

\section{ENLACES}

- http://ec.europa.eu/regional_policy/sources/docgener/studies/pdf/cba_guide.p df

- http://www.magrama.gob.es/es/

- http://ec.europa.eu/dgs/regional_policy/index_es.htm 


\title{
10.2. EVALUACIÓN SOCIAL, FINANCIERA Y ANÁLISIS DE RIESGOS
}

\author{
Armando Ortuño Padilla
}

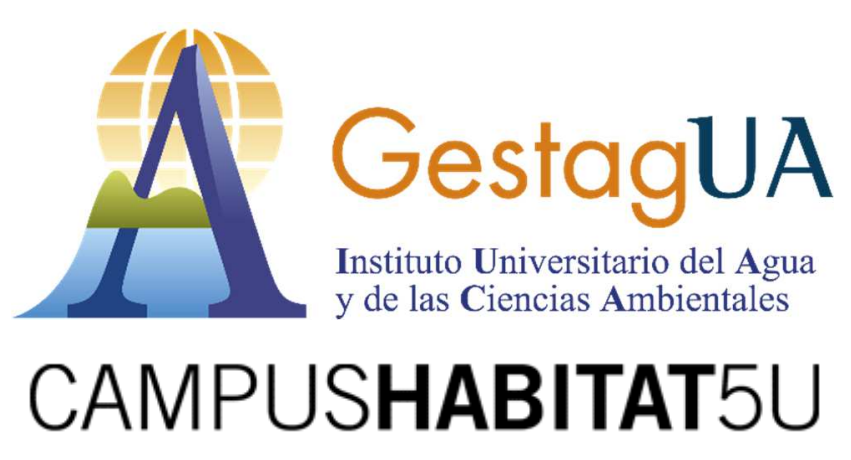




\section{INTRODUCCIÓN}

Anteriormente se ha descrito la metodología para evaluar los proyectos de inversión de infraestructuras diferenciando entre el Análisis coste-beneficio social y financiero.

En esta lección nos centraremos en los proyectos de infraestructuras que relacionados con la gestión del agua. En este marco se pueden citar como los más relevantes:

- Acueductos o trasvases para la conducción de agua hasta las zonas de demanda.

- Redes de abastecimiento de agua para una ciudad.

- Redes de alcantarillado.

- Depuradoras.

- Embalses y presas.

- Sistemas de regadío

- Desaladoras

- Obras frente a grandes avenidas e inundaciones.

El ejemplo en el que nos vamos a centrar consiste en la ejecución de una depuradora de aguas residuales en el entorno de una ciudad.

\section{ANÁLISIS COSTE-BENEFICIO DE UNA DEPURADORA DE AGUAS RESIDUALES}

Como primer paso, para llevar a cabo el Análisis coste-beneficio social habrá que considerar para cada alternativa los siguientes costes:

- Redacción del proyecto.

- Ejecución y mantenimiento de la/s depuradora/s a lo largo de la vida útil del proyecto, es decir, 30 años, incluyendo el coste de las expropiaciones.

- Equipamiento y maquinaria.

- Personal técnico especializado.

- Supervisión mientras se ejecuta la obra.

- Publicidad.

- Contingencias (imprevistos).

Como ingresos, computarían los siguientes:

- Los pagos efectuados por las familias conectadas a la nueva red de saneamiento y depuración. Normalmente, se trata de que esos costes por 
familia, que se establecen por metro cúbico de agua vertida a la red de cada vivienda, no superen el $3 \%$ de la media de los ingresos familiares de la ciudad o el país para que puedan ser soportados por los ciudadanos.

- Mejora de la calidad del agua del río a su paso por la ciudad de modo que sus habitantes podrán disfrutar de la ribera del río como nueva zona de ocio y esparcimiento.

- Ahorro para los ciudadanos que quedarán conectados con la red saneamiento y depuración ya que no tendrán que seguir manteniendo sus fosas sépticas.

En el análisis financiero, se mantendrían todos los costes, pero, respecto de los ingresos, solamente se mantendrían los correspondientes al volumen de agua vertido a la red de saneamiento y depuración por parte de las viviendas, de forma que no computarían el resto de beneficios ya que no serán ingresados por el operador: mejora de calidad del agua del río y supresión de fosas sépticas.

Como se comentó previamente, para que el proyecto sea rentable socialmente, la suma total de ingresos menos costes del Análisis coste-beneficio social ha de ser positiva (VAN positivo).

Si es así, el paso siguiente es analizar el resultado del Análisis coste-beneficio empresarial. Este resultado será habitualmente negativo puesto que, como se ha dicho, las tasas máximas en muchos casos no permiten superar el 3\% de la renta familiar, por lo que no cubrirán la totalidad de costes. De este modo, la infraestructura deberá contar con financiación desde el sector público.

\section{ANÁLISIS DE RIESGOS}

Un último punto relacionado con la metodología del Análisis coste-beneficio hace referencia al análisis de riesgos, es decir, qué ocurriría si la estimación realizada sobre la demanda de metros cúbicos tratados fuera muy superior a la real o bien que los costes de ejecución fueran muy superiores a los estimados.

Estos errores en las estimaciones son muy habituales, incluso con los costes de expropiación de los terrenos. Para ello, se lleva a cabo un análisis de sensibilidad o de riesgos en el que se barajan diferentes hipótesis relativas a las estimaciones de las partidas más importantes tanto de ingresos como de costes. 
Así, en este proyecto es habitual que, en la parte de costes, los relativos a ejecución puedan incrementarse significativamente, mientras que, en la parte de ingresos, las variaciones más significativas provengan de la reducción tanto de las tarifas como del volumen tratado por la depuradora.

En este análisis de sensibilidad, se estima cuánto tendrían que incrementarse o reducirse cada una de partidas por separado para que el proyecto ya no fuera rentable social: resultado del Análisis coste-beneficio social (VAN) igual a cero.

Con ello, se apreciará cuál de estas partidas es la que más riesgo entraña para que el proyecto ya no sea rentable socialmente, lo que llevará a vigilar especialmente la estimación de esa partida para conseguir esa rentabilidad social.

\section{BIBLIOGRAFÍA}

- De Rus (2008): Análisis coste-beneficio: evaluación económica de políticas y proyectos de inversión. Editorial Ariel.

- Comisión Europea. "Guide to Cost-Benefit Analysis of investment projects (Economic appraisal for Cohesion Policy, 2014-2020)". Directorate General Regional Policy, 2015.

\section{ENLACES}

- http://ec.europa.eu/regional_policy/sources/docgener/studies/pdf/cba_guide.p df

- http://www.magrama.gob.es/es/

- http://ec.europa.eu/dgs/regional_policy/index_es.htm 


\subsection{ANÁLISIS DEL IMPACTO SOCIAL}

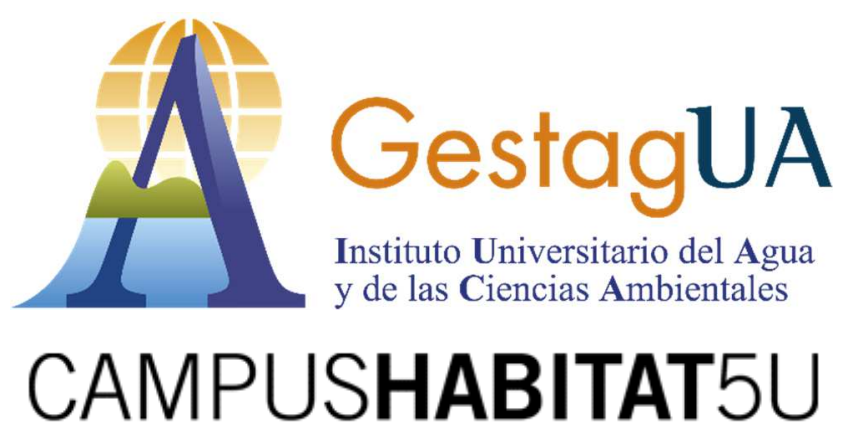




\section{INTRODUCCIÓN}

Toda acción antrópica genera un impacto en el entorno. A partir de la Revolución Industrial, la capacidad que los seres humanos poseían de transformar su ambiente creció de forma exponencial. Gran parte de esos cambios han sido consecuencia de las grandes obras de ingeniería que han modificado la faz terrestre a una velocidad y con una potencia sin precedentes.

Hasta hace poco tiempo, no se tenían en cuenta los impactos que estas acciones ocasionaban sobre la naturaleza. Para la cultura occidental, estas obras eran ejemplos del proyecto histórico de dominación de la naturaleza por parte de la humanidad. Cuando se comenzó a percibir sus efectos negativos, fueron interpretados como costes colaterales que se debían pagar para propiciar el progreso. Así, durante buena parte del siglo pasado, proyectos de intervención en el medio ambiente (en adelante PIM) se interpretaron como instrumentos privilegiados para el desarrollo regional. Por ejemplo, la construcción de grandes represas se entendía como una oportunidad para poner nuevas tierras en regadío, aumentar la producción y las rentas campesinas y asegurar el alimento para una población en rápido crecimiento. Las grandes represas también servían para controlar los flujos de los ríos, reduciendo las catastróficas pérdidas económicas y humanas que las inundaciones ocasionaban. La energía hidroeléctrica generada alimentaba las nuevas industrias y ciudades que surgían como consecuencia del desarrollo. Esta energía, calificada como limpia, ayudaba a limitar la dependencia del país de fuentes energéticas foráneas. Por último, la gran cantidad de mano de obra que se empleaba en la construcción de las represas se consideraba un instrumento privilegiado para paliar el azote del desempleo.

Esa visión excesivamente optimista, antropocéntrica y economicista de los PIM comenzó a cuestionarse a partir de los años ochenta del siglo pasado. Los fracasos de numerosos megaproyectos, el fuerte rechazo que despertaban entre las poblaciones afectadas, la desigual distribución de sus costes y beneficios y el surgimiento de una conciencia ecologista fomentaron la oposición a los PIM. En definitiva, el reconocimiento de los impactos socioambientales de las grandes intervenciones en el territorio comenzó a cuestionar la legitimidad de esos proyectos (Burdge, 2004a, Taylor, 2004).

Una de las herramientas habituales para la mejora de la sostenibilidad de los PIM son los procesos de evaluación de impacto ambiental (EIA en adelante). Las tendencias normativas a nivel global, marcadas por los países más avanzados y sensibilizados con los problemas ambientales (Estados Unidos, Canadá o Australia, 
por ejemplo), han ido reconociendo la necesidad de incluir, conocer y evaluar los aspectos sociales, como también los ambientales propiamente dichos.

Las Evaluaciones de Impacto Social (EIS en adelante) representan una evolución de las EIA. Bien se pueden presentar como una aportación dentro de las EIA para cumplimentarlos con el análisis de los efectos sociales de los PIM, o bien las EIS pueden tener una naturaleza independiente para remarcar los efectos que los PIM ocasionan sobre las poblaciones humanas afectadas.

En todo caso, las EIS estudian los efectos que los PIM ocasionan sobre las personas, con el objetivo de maximizar sus consecuencias positivas y eliminar, mitigar, disminuir o compensar sus efectos negativos.

Así la propuesta de EIS que se presenta en este capítulo no se limita a la identificación de impactos, sino que avanza hacia su incorporación en los diseños y primeras fases de PIM, bien para proponer su no ejecución si los efectos negativos sobre el bienestar general superasen a los efectos positivos o bien incorporando modificaciones en los proyectos que aumentasen sus consecuencias positivas.

Esta aportación se justifica por:

- La importancia de la gestión de los impactos sociales de los proyectos para las empresas promotoras, para los actores políticos relacionados con los procesos de toma de decisiones y para las comunidades locales que arrostran una parte importante de los efectos que los proyectos generan en sus territorios.

- El contexto sociopolítico de las PIM.

- El aumento de megaproyectos.

- Las políticas neoextractivistas de los gobiernos latinoamericanos en la primera década del siglo XXI.

- La capacidad de la tecnología de modificar territorios y estilos de vida.

- La emergencia de movimientos sociales glocales.

- El aumento de los conflictos ambientales.

\section{OBJETIVO}

Este trabajo presenta como principal objetivo ofrecer a los investigadores, profesionales, docentes y alumnos universitarios del ámbito latinoamericano interesados en las evaluaciones de impacto social (EIS) una introducción que les acerque su diseño, ejercicio y enseñanza. 
Se entiende por impacto social las consecuencias que para las poblaciones humanas tienes cualquier acción pública y privada que altere las maneras en las que la gente vive, trabaja, juega, se relaciona con los otros, se organiza para satisfacer sus necesidades y en general se comportan como miembros de una sociedad. El término también incluye los impactos culturales relacionados con los cambios en normas, valores y creencias que guían y racionalizan el conocimiento de las personas de sí mismas y de su sociedad.

\section{HISTORIA DEL E.I.S.}

El estudio específico de los riesgos e impactos sociales (evaluación de impactos sociales o EIS), nació como disciplina en el marco de la EIA. Catton and Dunlap (1978), centran la atención en la condición social de la crisis ambiental de fin de siglo XX. El de Finsterbusch (Finsterbusch and Wolf 1977) puede considerarse el primer trabajo de sistematización teórica y metodológica de la EIS. Estos primeros trabajos, como en el caso de la EIA, también tienen como denominador común las dificultades de integración de la EIS en la EIA, y los defectos de la "contabilidad social" en los proyectos (du Pisani and Sandham 2006, p. 707).

Se ejerce la autocrítica desde la propia disciplina, al señalar la necesidad de construcción teórica y especificación metodológica: los déficits de integración analítica ambiental-social en los proyectos de intervención y, en los casos en que se consideran los aspectos sociales, los déficits técnico-metodológicos de su diagnóstico y análisis.

El desarrollo normativo internacional en el marco de la EIA impulsa la EIS; desde los años 1980 se convierte en una prolífica área de trabajo, especialmente en el ámbito anglosajon y en los países donde las exigencias legales para con los proyectos son mayores. En los últimos años, el incremento en la producción académica, y también la expansión en el ejercicio profesional en la EIA y la EIS, señalan el creciente interés en el mundo científico y de los negocios por el análisis de riesgos e impactos.

\section{CONCEPTOS}

A.- Definición de Evaluación de Impacto Social: la evaluación del impacto social comprende los procesos de análisis, seguimiento y gestión de las consecuencias 
sociales voluntarias e involuntarias, tanto positivas como negativas, de las intervenciones planeadas (políticas, programas, planes, proyectos), así como cualquier proceso de cambio social invocado por dichas intervenciones. Su objetivo primario es producir un entorno biofísico y humano más sostenible y equitativo (Vanclay, 2004).

B.- Definición de impacto: Se entiende por impacto el efecto de un cambio. Esta definición tiene la virtud de su sencillez y el defecto de su simplicidad. Si la aplicamos a la evaluación de impactos, puede ser mejorada teniendo en cuenta el entorno en donde se produce el impacto. Así el enfoque contextual hace referencia a la reacción que se establece entre un estímulo externo y un elemento situado al interior del sistema. Para entender el impacto no es suficiente conocer el estímulo externo y el elemento afectado. Es imprescindible conocer el entorno en el que se sitúa el elemento afectado. Con un ejemplo se puede entender mejor esta idea. El impacto de una represa sobre un grupo indígena depende además del tipo de represa del entorno ambiental, económico, social, político y cultural en el que se sitúa esa población. Por ejemplo, la calidad de las instituciones democráticas del país donde se construye la obra altera la intensidad y la calidad del impacto. En países con alta calidad democrática, los derechos de los grupos indígenas son salvaguardados por la legislación y, además, ésta es aplicada. En países con baja calidad democrática, estas leyes pueden no existir o si existen pueden encontrarse ante muchas dificultades en su aplicación. Así, el impacto está condicionado por la naturaleza de la intervención, las características del elemento afectado y por el entorno donde acontece la interacción entre fuerza/elemento.

C.- Definición de impacto social: se entiende por impacto social a los impactos tal y como son experimentados por las personas (a nivel individual o de grupo) ya sea en un sentido físico o corpóreo o en un sentido congnitivo o perceptivo. Por lo tanto, los impactos son siempre socialmente construidos -además de tener una naturaleza física o positivista.

De una forma más sistematizada, Vanklay (2004) propone que los impactos sociales son efectos de un cambio sobre:

1.- la forma de vida de las personas - es decir, cómo viven, trabajan, juegan e interactúan unas con otras en el quehacer cotidiano;

2.- su cultura - esto es, sus creencias, costumbres, valores e idiomas o dialectos compartidos;

3.- su comunidad - su cohesión, estabilidad, carácter, servicios e instalaciones; 
4.- sus sistemas políticos - el grado al que las personas pueden participar en las decisiones que afectan sus vidas, el nivel de democratización que está teniendo lugar y los recursos suministrados para ese fin;

5.- su entorno - la calidad del aire y el agua que utiliza la población; I disponibilidad y calidad de los alimentos que consume; el nivel de peligro o riesgo, polvo y ruido al que está expuesta; la idoneidad del saneamiento, su seguridad física y su acceso a y control sobre los recursos;

6.- su salud y bienestar - la salud es un estado de bienestar total desde el punto de vista físico, mental, social y espiritual, y no solamente la ausencia de enfermedad;

7.- sus derechos tanto personales como a la propiedad - especialmente si las personas se ven económicamente afectadas o no o experimentan desventajas personales que pueden incluir la violación de sus libertades civiles;

8.- sus temores y aspiraciones - sus percepciones acerca de su propia seguridad, sus temores acerca del futuro de su comunidad y sus aspiraciones tanto en lo que respecta a su propio futuro como al de sus hijos.

\section{ESQUEMAS DE IMPACTOS SOCIOAMBIENTALES}

Las anteriores definiciones de impacto y de impacto social no están libres de discusión cuando el analista o investigador se enfrenta a evaluar impactos de grandes obras o intervenciones que afectan tanto al orden ecológico como al social. Una obra de infraestructura hidráulica genera cambios directamente sobre el ámbito de lo social. Una depuradora mejora la salud y la calidad de vida de los usuarios, esferas que entran directamente en el área de lo social. Al mismo tiempo, hay efectos sobre el medio ambiente que terminan derivando en efectos sobre lo social. Así una represa puede alterar la vida de la fauna piscícola, con un efecto sobre la cantidad de peces de una especie determinada que puede ser la fuente principal de alimento o de la actividad pesquera-comercial de una comunidad de pescadores ribereños. De esta forma, un impacto ambiental deriva en un impacto social al afectar la intervención a los servicios ecosistémicos. Según el informe de Evaluación de los Ecosistemas del Milenio (Reid et al., 2005), se entiende por servicio ecosistémico todos los beneficios que las poblaciones humanas obtienen de los ecosistemas.

Para entender mejor esta doble vía de impactos podemos emplear en modelo analítico Slootweg, Vanclay y van Schooten M (2001) introduciendo un cambio, donde su modelo sitúa la variable "filtro del paisaje" se debe sustituir por servicios ecosistémicos. 


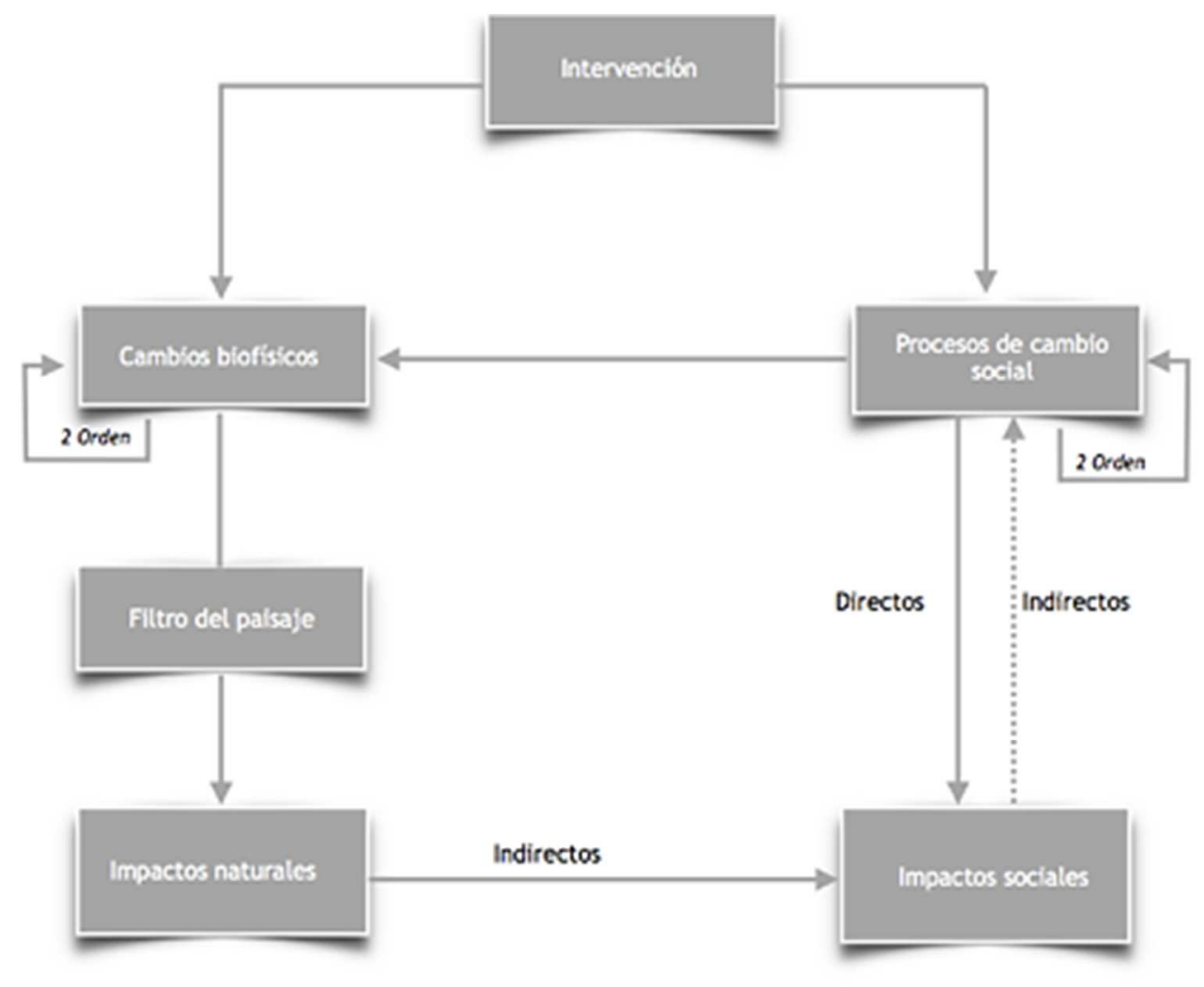

Fuente: Elaboradón propa a partir de Slootweg. Vandisy and van Schooten (2011)

\section{LOS TIPOS DE EIS}

En relación a la función y finalidad de las EIS, resulta interesante revisar la distinción entre Social Impact Statement y Social Impact Management. El primer enfoque se pone en marcha una vez el proyecto se ha diseñado, concentra su trabajo en los impactos directos ocasionados por la PIM y tiene como principal objetivo su aprobación por parte de las autoridades competentes. El segundo enfoque, Social Impact Management, entiende la EIS como un instrumento orientado a fortalecer el proceso de toma de decisiones relacionadas con el diseño, ejecución y manejo del proyecto. Este enfoque pretende contribuir al risk management de la PIM en cuanto que se orienta a la reducción de costes económicos, sociales y ambientales tanto de aquellos que recaen sobre las empresas o instituciones impulsoras de la PIM como sobre las comunidades locales afectadas. Enfatiza que la EIS debe incorporarse desde el inicio como una herramienta del diseño, y acompañar al proyecto como una pieza importante en su gestión y su seguimiento. Este enfoque amplía el concepto de proyecto más allá de la obra o intervención al estudiarlo en todas las fases de su ciclo y al entenderlo 
como un proceso social y no solo como un ejercicio técnico (Burdge y Johnson, 2004: 15-20).

En consecuencia, en la propuesta de Social Impact Management cobra especial relevancia las dimensiones contextual, longitudinal y relacional de los efectos socioambientales derivados de la PIM. Desde este enfoque se estudia, por lo tanto:

a) los impactos durante todo el ciclo del proyecto, incluyendo la gestión posterior a su construcción y sus efectos a largo plazo (longitudinal);

b) la interacción entre los cambios ambientales y sociales (relacional), así como

c) el análisis de los contextos locales, socio-culturales e institucionales donde se ejecuta el proyecto (contextual).

\section{FASES DEL EIS}

A.- SCOPING. Los objetivos de esta primera fase son:

a) la identificación de los principales problemas en relación con el PIM. Una mirada general al proyecto que sirva de introducción al caso;

y b) la revisión bibliográfica de casos de estudio similares en contextos socioambientales similares. Si se han encontrado EIS previos que identifican un conjunto de impactos, estos se emplearán como un primer listado de impactos sobre los que levantar las subsiguientes fases de la investigación.

Junto a esta tarea, se presenta el marco de referencia, las variables claves a considerar, el área geográfica afectada y otras áreas de impacto secundario, la unidad de análisis y los métodos de análisis y medición de impactos, los stakeholders o partes y grupos de interés afectados positiva y negativamente por el proyecto.

El análisis de stakeholders requiere un apartado de especial tratamiento. Si entendemos que los impactos son las percepciones del cambio tal y como son sentidos por los afectados e interesados (stakeholders), la identificación y evaluación de los impactos pasa por identificar todos los grupos de interés para recabar sus opiniones y percepciones sobre los efectos de la intervención sobre ellos y sus comunidades y territorios. Con sus opiniones y las de expertos debe construirse una lista final de impactos que se sumará al primer listado obtenido por la revisión bibliográfica y que será evaluado en la fase correspondiente.

Asimismo, el análisis de los stakeholders requiere no solo su identificación sino también su cualificación con respecto al proyecto. Resulta imprescindible conocer 
dos variables analíticas: vulnerabilidad e influencia. Se entiende por vulnerabilidad, la probabilidad de que un determinado grupo o individuo sufra las consecuencias negativas de un PIM. Esta mayor probabilidad está condiciona por factores estructurales -que posicionan a los sujetos y grupos en una situación de vulnerabilidad- y por los capitales (ambientales, económicos, sociales y culturales) que posean. Se entiende por influencia, como la capacidad de intervenir en el proceso de toma de decisiones relacionado con el proyecto y de defender sus intereses y valores.

A la hora de evaluar los impactos, se debe tener en cuenta sobre quién recaen (vulnerabilidad) y qué capacidad (influencia) poseen para evitar el efecto negativo del impacto.

B.- PROFILING. Esta segunda fase consiste en el llevar a cabo el inventariado y descripción del estado o situación de la comunidad anterior al impacto.

Una EIS tiene como fin predecir y evaluar los futuros efectos que la PIM provocaría en la sociedad de acogida. Por ello, es prioritario conocer la comunidad en estado 0 , es decir antes de que sea impactada y posteriormente identificar los posibles cambios que la PIM ocasionaría en esa comunidad. En otras palabras, proporciona la información básica para comparar los cambios que el proyecto ocasionará. Esta fase consiste en la recogida de información sobre la comunidad en el estado de pre-impacto para proporcionar las estimaciones primarias (inputs) en los modelos de predicción y estimación de efectos. Las áreas en las que se divide el estudio de la comunidad son:

- Análisis demográfico

- Análisis socioterritorial

- Análisis socioeconómico

- Análisis estructuras políticas e institucionales locales y supralocales

- Análisis del sistema normativo-cultural

C.- IDENTIFICACION Y EVALUACIÓN DE IMPACTOS. Esta tercera fase se convierte en parte central de las EIS. Consiste en identificar de forma apriorística los efectos que un PIM va a ejercer en un futuro sobre las personas de un determinado territorio.

El proceso de detección de posibles impactos se nutre de tres fuentes de información:

a) La revisión de la literatura especializada. Se obtiene de la fase de scoping. El objetivo es identificar un listado primario de impactos a partir de casos de 
estudio que identifiquen los impactos sociales provocados por intervenciones similares en contextos similares.

b) Entrevistas realizadas a los actores stakeholders. El objetivo es que los entrevistados identifiquen qué impactos ocasionaría la intervención en su territorio y sobre su comunidad. De esta forma se consigue un listado más contextualizado de impactos.

c) A estas dos fuentes de información, se añade el juicio de los investigadores y expertos, que aportan su experiencia y conocimiento, dado que algunos impactos pueden aparecer en las fases finales o incluso una vez finalizado la actuación o pueden estar ocultos por ser difícilmente percibibles por su naturaleza compleja o ajena al conocimiento de los stakeholders.

Por lo tanto, las subfases de este paso son las siguientes

a) Construcción de un listado final de impactos obtenido uniendo el primer listado de impactos (ver fase de scoping) y un segundo listado obtenido de la identificación que realicen los stakeholders a los que se les suma la opinión de los expertos y del equipo que dirija el EIS -a partir de sus conocimientos y experiencias en la materia.

b) Construcción de una check-list con cada uno de los impactos que actúan sobre las esferas inventariadas. El objetivo es identificar qué impactos afecta a qué área social.

c) Evaluación de los impactos en diferentes escalas. No es suficiente con identificar los impactos. Los efectos deben ser evaluados y cualificados. En este sentido, se deben seleccionar unas categorías cualificadoras de impactos que estarán en función del tipo de proyecto, de la comunidad o stakehodler afectado (con criterios de vulnerabilidad e influencia) y del contexto. Así, una vez identificados cada uno de los impactos, se establece una serie de criterios analíticos que permitiesen a los entrevistados valorar la importancia atribuida a cada uno de los mismos.

A continuación se lista algunos de los criterios empleados más frecuentemente en la evaluación de los impactos:

Criterio 1. Naturaleza ¿El impacto es positivo o negativo, bien para el entrevistado o bien para el conjunto de la comunidad o para el proyecto/empresa

Criterio 2. Intensidad ¿Qué intensidad o fuerza se percibe el impacto?

Criterio 3. Extensión ¿Cuál es la extensión del impacto en cuanto a zona afectada y distancia del sujeto con respecto a la zona de afectación? Criterio 4. Ciclo del Proyecto ¿En qué fase del ciclo del proyecto se comienza a percibir el impacto?

Criterio 5. Persistencia ¿Cuál es la duración del efecto de este impacto: Fugaz, Temporal, Permanente

Criterio 6. Reversibilidad ¿El impacto es reversible o irreversible?

Criterio 7. Vulnerabilidad ¿Sobre qué grupos vulnerables cae el impacto? 
Criterio 8. Influencia ¿Qué grado de influencia tiene el stakeholder ante el impacto?

A partir de todos esos datos, se está en disposición de realizar diversos análisis encaminados a identificar los impactos positivos y negativos, su intensidad, urgencia de actuación, etc. Esta información alimenta la siguiente fase que es la de formulación de alternativas

\section{D.- FORMULACIÓN DE ALTERNATIVAS y EVALUACIÓN DE LAS ALTERNATIVAS.}

El potencial de disminución de impactos es la principal tarea de los EIS. Por lo tanto, esta fase debería incluirse en los primeros pasos del diseño del proyecto o PIM. A partir de la información proporcionada por la fase anterior, se debe proceder a:

1) Evaluar la pertinencia social del proyecto. Si los impactos sociales negativos fuesen muy graves y permanente, el EIS debería dar una evaluación negativa y proponer el no desarrollo/ejecución del proyecto.

2) Si los efectos negativos pueden ser eliminados, reducidos/mitigados o compensados hay que establecer talleres participativos para realizar propuestas de modificación del proyecto. De ahí la conveniencia/obligatoriedad de que la EIS sea realizada en la fase de diseño del PIM. Temas como la localización del proyecto, el tipo de tecnología, la forma en que se implementen las decisiones, o la disponibilidad de la fuerza de trabajo son entendidas como ventanas de actuación sobre las que se puede establecer un conjunto de medidas alternativas.

3) La incorporación de estas alternativas al proyecto, al modificarlo obliga por tanto a volver a evaluar el efecto socio-ambiental de las mismas.

E.- SEGUIMIENTO, MITIGACIÓN Y GESTIÓN. Se refiere a la vigilancia y monitorización en la aplicación de los resultados del EIS a lo largo de la ejecución del proyecto.

F.- AUDITORÍA O EVALUACIÓN EXPOST. Se refiere a la evaluación completa del proyecto de desarrollo y a la producción de un informe final que sirva para posteriores experiencias como bibliografía de caso.

\section{BIBLIOGRAFÍA}

Aledo-Tur, A., \& Domínguez-Gómez, J. A. (2016). Social Impact Assessment (SIA) from a multidimensional paradigmatic perspective: challenges and opportunities. Journal of Environmental Management. 
Becker, D., Harris, C., McLaughlin, W. and Nielsen, E., 2003. A participatory approach to social impact assessment: the interactive community forum. Environmental Impact Assessment Review, 23(3), 367-382.

Becker, H., 2001. Social impact assessment. European Journal of Operational Research, 128(2), 311-321.

Bornmann, L., 2013. What is societal impact of research and how can it be assessed? A literature survey. Journal of the American Society for Information Science and Technology, 64(2), 217-233.

Craig, D., 1990. Social impact assessment: politically oriented approaches and applications, Environmental Impact Assessment Review, 10(1/2), 37-55.

Esteves, A., Franks, D., and Vanclay, F., 2012. Social impact assessment: the state of the art. Impact Assessment and Project Appraisal, 30(1), 34-42.

Reid, W. V., Mooney, H. A., Cropper, A., Capistrano, D., Carpenter, S. R., Chopra, K., \& Kasperson, R. (2005). Evaluación de los ecosistemas del milenio. Informe de síntesis. Washington, US, RRF.

Ross, H., McGee, T., 2006. Conceptual frameworks for SIA revisited: a cumulative effects study on lead contamination and economic change. Impact Assessment and Project Appraisal,, vol. 24, no 2, 139-149.

Van Schooten, M., Vanclay, F., and Slootweg, R., 2003. Conceptualising social change processes and social impacts. In H. Becker \& F. Vanclay (Eds.), The international handbook of social impact assessment. Cheltenham, UK: Edward Elgar.

Vanklay, F. (2004). Principios internacionales de la evaluación de impacto social. Asociación Internacional de Evaluación del Impacto (IAIA) Universidad de Tasmania. EUA. Traducción al español: PREVAL: Programa para el Fortalecimiento de la Capacidad de S\&E de los proyectos FIDA en América Latina y el Caribe. Traductora: Susana Carrera Risco.

Ziller A., 2012. The new social impact assessment handbook: a practice guide. Australia Street Company.

\section{ENLACES}

Documental "El Canal de la Discordia": cuando el control y gestión del Canal de Panamá pasó al estado panameño a finales de 1999, el gobierno comenzó a preparar un plan para su modernización. Este plan incluía la construcción de nuevas esclusas para que pudieran atravesarlo un mayor número de barcos y que admitiese los nuevos buques Post-Panamax de gran tamaño. El proyecto de Ampliación del Canal se ha seleccionado como ejemplo paradigmático de Grandes Obras Públicas (GOP) por su impacto ambiental, económico y social. Este caso de estudio nos servirá para reflexionar sobre las relaciones que existen entre desigualdad, desarrollo y medio ambiente. http://hdl.handle.net/10045/12324 